
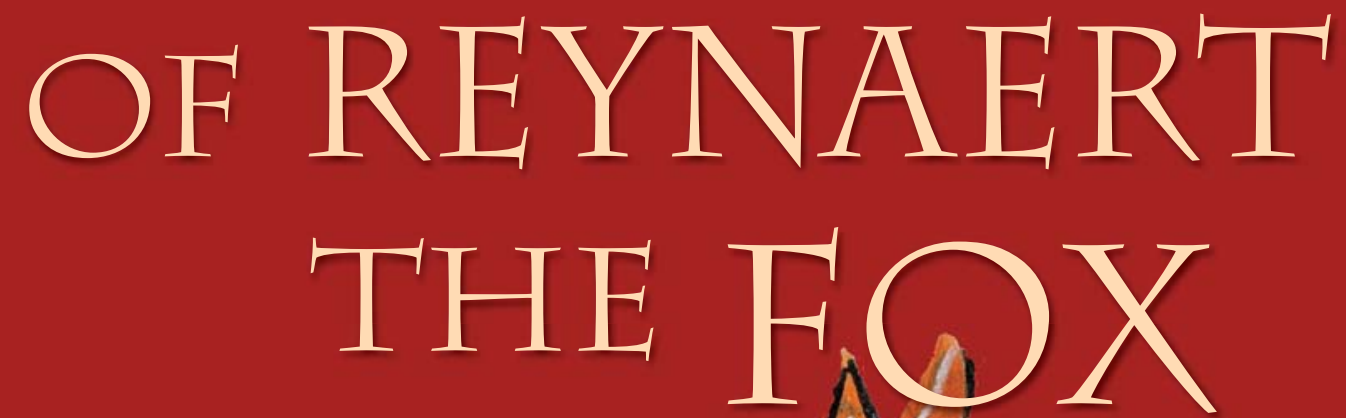

Iext and Facing Iranslation

of the Middle Dutch

Beast Epic 
Of Reynaert the Fox 


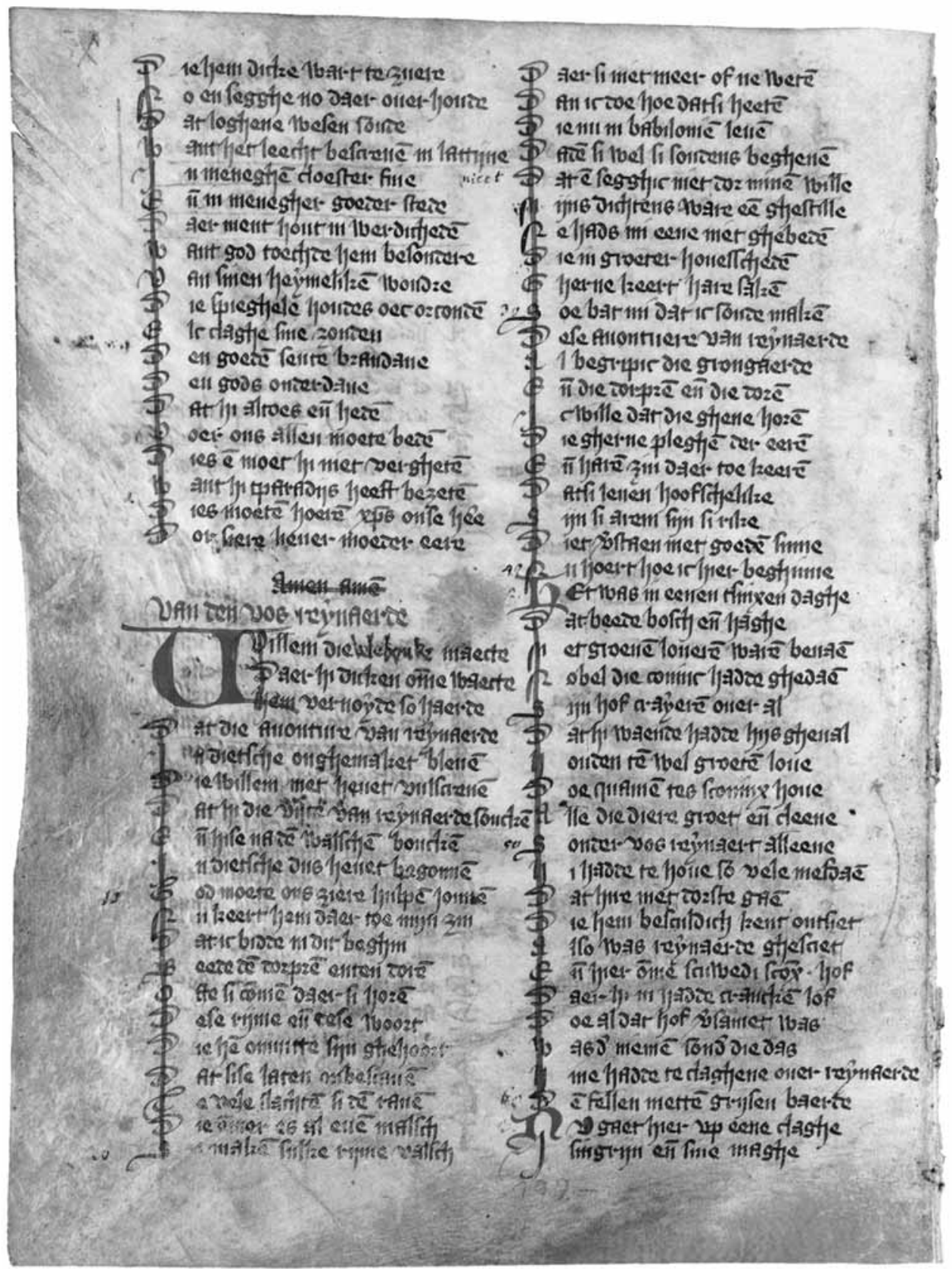




\section{Of Reynaert the Fox}

Text and Facing Translation of the Middle Dutch Beast Epic

VAN DEN VOS REYNAERDE

Edited with an introduction, notes and glossary by André Bouwman and Bart Besamusca

Translated by Thea Summerfield

Includes a chapter on Middle Dutch by Matthias Hüning and Ulrike Vogl

AMSTERDAM UNIVERSITY PRESS 
The production of this book was made possible by Hendrik Muller's Vaderlandsch Fonds en NLPVF (Foundation for the Production and Translation of Dutch Literature)

Cover: Kok Korpershoek, Amsterdam, the Netherlands

Front cover: detail from Chester Beatty Library, Dublin, Ms. 61 (psalterium, Flanders, s. XIII-2, border decoration f. 61r: Reynaert and Cuwaert cf. 11. 144-48). (C) Chester Beatty Library.

Back cover: fox. (C) Jochum Kole, Heerenveen, the Netherlands

Lay-out: $V_{3}$ Services, Baarn, the Netherlands

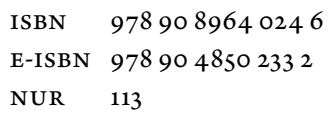

(C) Besamusca, Bouwman, Summerfield/Amsterdam University Press, 2009

All rights reserved. Without limiting the rights under copyright reserved above, no part of this book may be reproduced, stored in or introduced into a retrieval system, or transmitted, in any form or by any means (electronic, mechanical, photocopying, recording or otherwise) without the written permission of both the copyright owner and the author of the book. 


\section{Table of contents}

Acknowledgements 7

Introduction 9

1. Literary tradition 9

2. The author 14

3. The text 17 3.1 The prologue 17

3.2 The plot 18

3.3 Words and deeds 19

3.4 Literary space 23

3.5 Justice and its perversion 24

4. The audience 28

5. Transmission and reception 34

About the translation $\quad 41$

Text, translation and notes $\quad 41$

Editorial principles $\quad 247$

Middle Dutch - A short introduction 257

1. Middle Dutch diversity 257

1.1 Differences between dialects 259

2. Spelling and pronunciation 260

3. Grammatical structures 263

3.1 Morphology 263

3.1.1 Declension 263

3.1.2 Plural formation 266

3.1.3 Conjugation 267 
3.2 Syntax 268

3.2.1 Word order 268

3.2.2 Passive voice and impersonal constructions 269

3.2.3 Negation 270

Further reading $\quad 273$

1. Editions 273

2. Research 274

3. Middle Dutch 277

Index of proper names 279

Glossary 283

Word index (semantic fields) $\quad 347$

Bibliography 357

List of illustrations $\quad 367$

Contributors 368 


\section{Acknowledgements}

Our plan to publish an edition and facing translation of Van den vos Reynaerde for nonDutch readers dates back to the first half of the 199os. But years went by, and it was not until the end of 2004 that we found the time one needs to carry out such a project. At that time, we were also happy to meet in Maria Vlaar an enthusiastic representative of the Foundation for the Production and Translation of Dutch Literature (NLPVF). This organization has financed the translation.

The structure of this book has benefited from the example of several predecessors. Adriaan J. Barnouw - translator of many Dutch texts (among them Van den vos Reynaerde) - published an edition of the Middle Dutch legend Beatrijs for foreign students as early as 1914, which includes a grammar and a glossary. The idea to add an extensive glossary to our edition and translation took shape while using Wendelin Foerster's Wörterbuch zu Kristian von Troyes' sämtliche Werken (5th ed. 1973), later also The Earliest Branches of the Roman de Renart (2001), edited by R. Anthony Lodge and Kenneth Varty.

Thanks are due to our German colleagues Matthias Hüning and Ulrike Vogl, who contributed a chapter on Middle Dutch. Their introduction to Middle Dutch diversity, spelling, pronunciation and grammatical structures enhances the practical value of this volume considerably.

We owe the greatest debt to Thea Summerfield, who skilfully translated Van den vos Reynaerde and our accompanying texts into English. We thank her for the close and harmonious cooperation during the last two years. We cherish the memories of our monthly, all-day-long sessions in which the three of us discussed the exact meaning of hundreds of Middle Dutch lines and their English equivalents.

Finally, we should like to extend our gratitude to colleagues who graciously helped us with this edition.Douglas Kelly commented on the English translation of Van den vos Reynaerde; Peter Field did the same for the Introduction. Keith Busby, Karina van Dalen-Oskam, Marijke Mooijaart and Peter Raedts gave useful advice.

May this edition attract new readers to the undisputed masterpiece of Middle Dutch literature! We welcome all suggestions for improvement. 

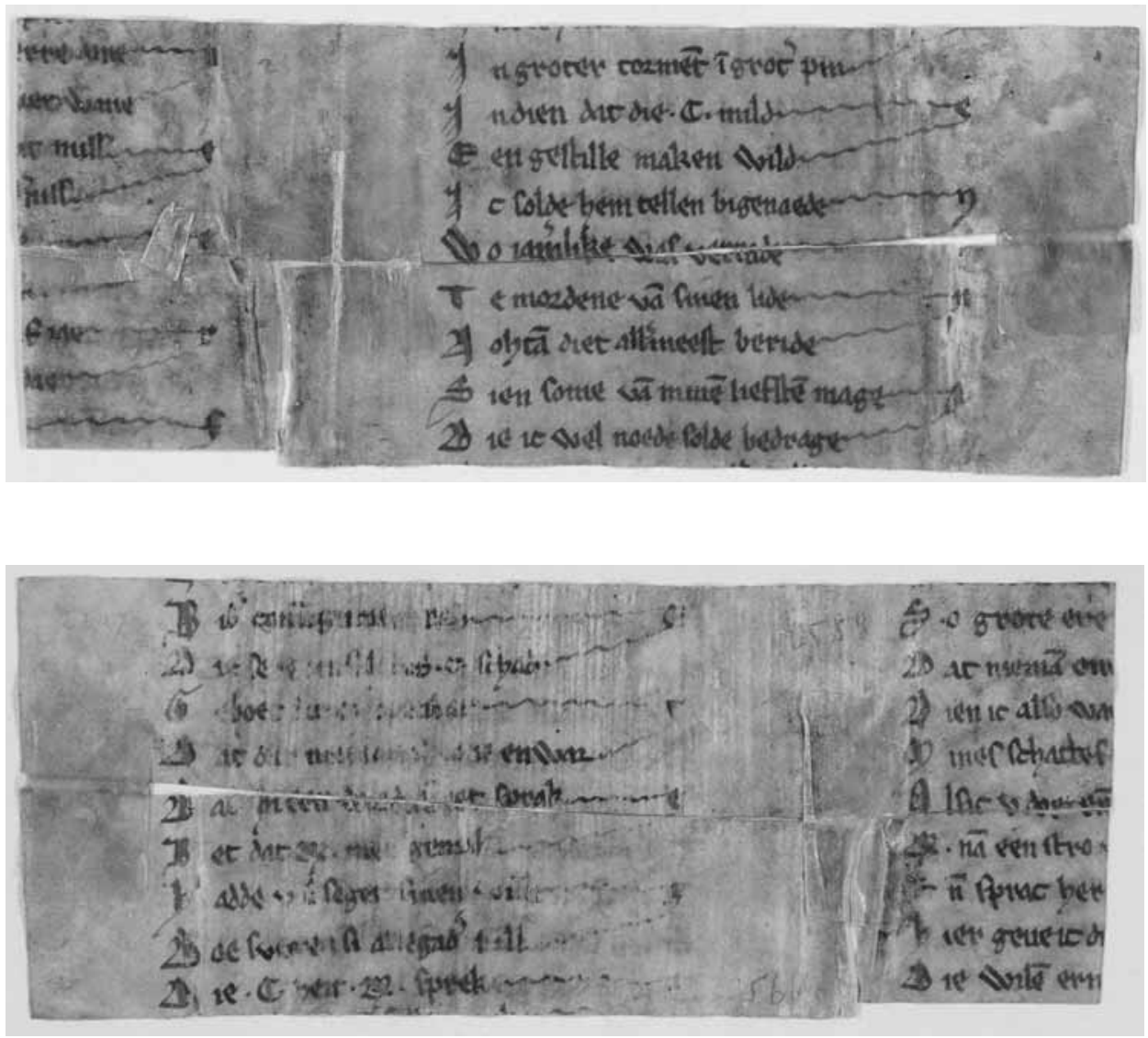


\section{Introduction}

If the Times Literary Supplement were to ask its readers which works they considered to be supreme masterpieces of medieval literature, what would be the result? No doubt the Chanson de Roland would figure prominently, as would the Arthurian romances by Chrétien de Troyes. In all probability Sir Gawain and the Green Knight, Wolfram von Eschenbach's Parzival and Gottfried von Strassburg's Tristan would also be listed. In addition, Dutch readers of the TLS would be certain to make a case for Van den vos Reynaerde (literally: 'Of Reynaert the Fox'). This Middle Dutch beast epic is famous among specialists, but is hardly known outside the Netherlands and Belgium as a result of the language barrier.

The present edition of Van den vos Reynaerde with its translation into English on facing pages hopes to bridge the gap between this thirteenth-century text and non-Dutch readers. They are likely to find it as fresh and entertaining as it was when it was first written. It will enable them to get acquainted with, for example, the author's composition technique, his lively style, his preference for striking descriptive details, his wit and his deeply cynical outlook on life. Text and translation are accompanied by explanatory notes (to be found at the bottom of the page). A glossary, short introduction to Middle Dutch and suggestions for further reading conclude this volume. First, however, this introduction will discuss the literary tradition of the medieval beast epic and facts known about the author. It will also provide a brief summary and note major features of the tale, the implied audience and the transmission and reception of the work.

\section{Literary tradition}

Our knowledge of medieval beast literature in western Europe is almost entirely limited to those stories that were written down, initially in Latin, later also in the vernacular languages.' No doubt stories about animals will also have been passed down by word

1 For an introduction in English based on recent research into nine centuries of Reynaert literature, see Varty 2000; for an introduction in Dutch, see Janssens \& Van Daele 2001. 
of mouth, but very little is known about this oral tradition. This makes it difficult to determine the relationship between the oral transmission of tales and written, literary culture or the extent to which the two traditions are rooted in popular and (Latin) scholarly cultures. Vehement debates about the origins of the western European beast epic have been the result.

As early as the nineteenth century the so-called 'folklorists' looked for the answer in folk poetry about animals that either had not been preserved, or had not been recorded until a much later date. This type of poetry was initially regarded by Jacob Grimm as an animal saga, already known by the Germanic tribes, which had developed independently from the classical fables. Later, Leopold Sudre was an exponent of the idea that orally disseminated medieval folk tales featuring animals were based in part on classical fables and Latin monastic poetry. The 'Aesopists', on the other hand, detected the direct examples of the Latin and vernacular beast epics from the twelfth and thirteenth centuries in these early medieval written animal stories. ${ }^{2}$

Lucien Foulet has shown convincingly that the authors of the earliest Old French Renart narratives did, in fact, frequently derive material directly from the Ysengrimus, a Middle Latin beast epic named after the wolf who, in confrontations with the cunning fox Reinardus, is continually worsted. The author of the Ysengrimus, too, creatively recycled a considerable amount of material from classical fables, so that the supposed dependence on folk tales is doubtful, to say the least. ${ }^{3}$ Although the last word has not yet been said (or written) about the early history of the Roman de Renart and the Ysengrimus, these narratives are clearly essential to a proper understanding of the tradition of which Van den vos Reynaerde forms part. The author of this Middle Dutch beast epic, 'Willem', was familiar with at least part of the Old French corpus of texts and used it in the course of his composition. The Flemish poet was by no means exceptional in this. Nearly all medieval beast literature, both in Latin and in the vernacular, made creative use of existing texts.

The literary tradition to which Van den vos Reynaerde belongs, is ultimately, by way of various medieval stepping-stones, based on the Greek fable of the sick lion, ascribed to Aesop. It may well be that Willem did not know this fable in its original form. Nevertheless knowledge of this oldest of all sources is useful. As the paraphrase below shows, a number of motifs in Van den vos Reynaerde have a long and venerable ancestry:

The lion had become old and lay sick in his den. All the animals visited their king, except the fox. Then the wolf took the opportunity to blacken the fox's reputation with the lion: the fox was said to despise the ruler of all animals

2 For the theories formulated by folklorists and Aesopists, see Grimm 1834; Sudre 1893; Foulet 1914.

3 For a discussion of the dependence of the Ysengrimus on classical fables, see Mann 1988. 
and had not come to see the king for that reason. At that moment the fox appeared; he had just managed to overhear to wolf's last words. The lion roared at him, but the fox asked for permission to say something in his defence and said: 'Which of all your visitors has done as much for you as I have? I traversed the whole world in search of a medicine for you - and now I have found it.' The lion commanded him to name the medicine at once. Then the fox said: 'You must flay a living wolf and wrap yourself in the skin while it is still warm.' And when the wolf lay there suffering, the fox laughed and said: 'Rulers should not be angered but be incited to good deeds.' The fable teaches that every sin brings its own punishment. ${ }^{4}$

This fable underwent a number of changes in the western European tradition. The most significant one is that King Lion's illness was gradually replaced by the proclamation of a court day as the reason for the animals to gather. ${ }^{5}$ In the course of the Middle Ages this motif was developed in ever more voluminous writings. In the Middle Latin Ysengrimus, written just before 1150 in Ghent, the court day episode numbers some twelve hundred lines (book III), the Old French Le Plaid ('The Trial') has just under seventeen hundred, Van den vos Reynaerde has double that amount, and in Reynaerts historie ('The History of Reynaert'), the fifteenth-century Middle Dutch adaptation and continuation of Van den vos Reynaerde, this number is doubled again. From the Ysengrimus onwards the animals in the stories are not only the characteristic representatives of their kind, but also individuals. They are given fixed proper names: the wolf is called Ysengrimus, Ysengrin, Ysingrijn, the fox Reinardus, Renart, Reynaert. In addition situations and customs from the contemporary, real world are interpolated and sometimes satirized. It will not be accidental that the monk who wrote the Middle Latin Ysengrimus for a monastic audience, regularly presents the greedy wolf as an abbot and bishop. In Le Plaid and Van den vos Reynaerde the setting is that of a feudal, chivalric society: the wolf and the fox have become barons.

The title Roman de Renart refers to a complex of Old French stories called 'branches', rather than a single text. They have as their subject matter the conflicts between the fox Renart and his arch-enemy Ysengrin the wolf and the other animals in King Noble's realm. The oldest surviving story was probably written about 1175 by Pierre de SaintCloud (referred to as 'Perrot'; see p. 15) and relates the origin of the feud: the adultery between Renart and Ysengrin's wife Hersent, and later Renart's rape of Hersent,

4 The paraphrase of the fable of the sick lion is based on a German translation (Schnur 1985, p. 111) of the Greek text (Perry 1952, Aes. 258).

5 Changes in the fable of the sick lion in the western European tradition are discussed in Graf 1920, pp. 13-25; Bartelinck 1977; Goossens 1996b. 
which led to legal proceedings at the court of King Noble. ${ }^{6}$ This story must have been instantly successful, for between 1175 and 1180 six other narratives about Renart were written by different authors, up to 1205 there were another eleven, and even in the first half of the thirteenth century several more appeared. These Renart branches at first functioned independently (even though they responded to one another), but soon they were collected in compilations. Fourteen complete manuscript compilations are extant, as well as nineteen fragments and manuscripts containing one or more branches, dating mainly from the thirteenth and fourteenth centuries. Research into the Roman de Renart was long aimed at reconstruction: of the sources, or of the original texts, and of the Ur-compilation on which the compilation codices are based. In the past few decades more attention has been paid to the diversity of the literary and manuscript forms of the extant branches. ${ }^{8}$

Editions of the compilation manuscripts $\mathrm{A}, \mathrm{B}$ and $\mathrm{C}$ are available. ${ }^{9}$ The most usual numbering of the branches is the one adopted in the edition by Ernest Martin. It is based on the sequence of the stories as they appear in manuscript A rather than on the date of composition. Le Plaid, also known as Le Jugement ('The Judgement') is branch I here. In this verse narrative - a sequel to branch II-Va - the fox Renart faces criminal charges by Ysengrin and Chantecler and is summoned three times. Sentenced to be hanged, he begs for mercy; he promises to better his life and to undertake a journey to the Holy Land. Moved by pity King Noble relents. However, as soon as Renart has left the court as a pilgrim, he maltreats Coart the hare and mocks the king. All the courtiers pursue the fox, who manages to reach Maupertuis in the nick of time.

It is not surprising that, when writing Van den vos Reynaerde, it was this branch I that Willem took as an example. From a literary point of view Le Plaid is one of the most attractive stories of the Roman de Renart, and, probably for that reason, the one surviving in the largest number of manuscripts. The story was also rewritten repeatedly by Old French poets. In Le duel judiciaire (branch VI) the fox stands trial once again for his crimes. This time this results in a judicial duel with Ysengrin, which Renart loses. In Renart médecin (branch $\mathrm{X}$ ) the fox is summoned by orders of the king, at first by the dog Roonel, later by Brichemer the stag, but in both cases the mission fails through

6 For an edition of the earliest branches (II-Va), see Lodge and Varty 2001.

7 For research into the Roman de Renart, see Jauss 1959 ; Flinn 1963; Bossuat 1967; De Combarieu \& Subrenat 1987 (motif and character indices); Nieboer \& Verhulsdonck 1988; Varty 1998 (bibliography).

8 For examples of the 'récriture' and 'mouvance' of Renart-branches, see Varty 1988-1991 and Scheidegger 1989.

9 For an edition of the Roman de Renart according to compilation manuscript A, see Martin 1882-1887; according to ms. B, see Roques 1948-1963; according to ms C, see Fukumoto, Harano \& Suzuki 1983-1985. For translations based on the edition by Martin (ms. A): Jauss-Meyer 1965 (German); Dufournet \& Méline 1985 (French); Owen 1994 (English). For French translations based on the Roques edition (ms. B), see Toesca 1979; Rey Flaud \& Eskénazi 1982. 
Renart's doing. Not until Renart hears that Noble has fallen ill does he travel to the king's court with Grinbert. There he poses as a doctor and of course knows exactly how the king can be cured: by making him sweat heavily in Ysengrin's skin. It is sometimes difficult to see whether the author has conceived of a new story or presents a new version of an existing story. In two Roman de Renart manuscripts (B and H) Le Plaid contains a passage of approximately a hundred and thirty lines in which Renart's conviction and reconciliation with the king has been completely rewritten. This version particularly distinguishes itself by the detailed account of the barons' consultation that precedes the death sentence and by the role played by Grinbert, here presented as his nephew's saviour. ${ }^{10}$

The Middle Dutch author sticks to the broad outlines of the plot of his original, but in the details he goes his own way entirely. This means that, when plots are compared, the suspense factor in these stories no longer lies in the question if the fox will manage to keep out of the clutches of the king and his courtiers, but rather how that is achieved. This applies to us, the modern readers, and must also have been true for Willem's audience, in so far as it was familiar with other animal stories (see pp. 31-33). In comparison with Le Plaid and the other branches set during a court day, Van den vos Reynaerde distinguishes itself in particular by the superior manner of the Flemish fox's escape from execution. In Le Plaid King Noble takes pity on the fox and pardons him, which may be generous, but is hardly convincing from a psychological point of view. In Willem's poem the fox plays on Nobel's greed by weaving a brilliant concoction of lies. He misleads the king with the story of his unhappy childhood and by casually mentioning a treasure and a conspiracy to kill King Nobel. Even Reynaert's own relatives are said to have been involved in that plot. Next he gives a detailed description of the place where the treasure is to be found, which is confirmed by Cuwaert the hare, capping the deception by the tale of his excommunication which will enable him to flee the court as a pilgrim. A mere promise of profit - and nothing more substantial - is sufficient ground for Nobel to be reconciled with Reynaert. The French king may have been sentimental, the Flemish king proves to be immoral. This is also the reason why the reputation of the court is tarnished far worse at the end of Willem's poem than it is in Le Plaid.

Willem may have known the Ysengrimus, which was probably written in Ghent in 1148-1149, in other words, in roughly the same location as where, a century later, Van den vos Reynaerde was composed." In this cleverly compiled Latin poem of more than

10 For the rewritten passage in branch I in mss B and $\mathrm{H}$, compare lines 1339-1478 in the Roques edition (1948-1963) to lines 1313-1418 in the edition by Martin 1882-1887.

11 For an edition of the Ysengrimus (Latin text and English translation and commentary), see Mann 1987. A verse translation in Dutch was published in Van Mierlo 1946; see also the more recent prose translation by Nieuwenhuis (1997). 
6,500 lines, divided into seven books, the greedy wolf takes centre stage. The best supporting role for a male character is for the fox, his enemy and evil counsellor. Their confrontations are primarily verbal in character, with Reinardus' illusory reality dominating that of the wolf. As a result Ysengrimus allows himself to be manipulated and, back in the real world, is severely punished for his credulity. He is repeatedly seriously wounded, is flayed to cure the sick king and is eventually torn apart by a herd of wild pigs. ${ }^{12}$

The literary tradition of writings about animals comprises not only the narrative, fictional beast epic - including the fable ${ }^{13}$ - but also scientific writings about animals. In both categories animals are described not for their own sake, but to transmit a deeper meaning. Whereas in the beast epic the animals are authorial creations, meant to provide a moralising representation of human life, animals in Latin bestiaries or 'books of beasts' are seen as natural phenomena, in accordance with the medieval view that the created, transitory world refers to God's real, eternal world. ${ }^{14}$ The outer characteristics and behaviour of the animals is interpreted allegorically. In this way they provide medieval mankind with lessons about God and the devil, about heaven and hell, about virtue and sin. In works on natural history - as in De naturis rerum by Thomas of Cantimpré, translated and adapted by the thirteenth-century Flemish author Jacob van Maerlant in his Der naturen bloeme - there is more emphasis on zoological knowledge. Information of this kind was not usually, however, the result of personal observation, but was derived from such authorities as the philosopher Aristotle (384-322 BC), who in the Middle Ages was seen as the greatest scholar of all time, Pliny (23/24-79), the Roman military commander, procurator and writer, and the archbishop and encyclopedist Isidore of Seville (ca. 565-636). ${ }^{15}$

\section{The author}

In Van den vos Reynaerde we meet a self-confident poet. He uses the first line of the prologue to state his name, Willem, and the title of an earlier work, Madocke: he is Willem die Madocke maecte ('Willem who made Madock'). At the end of the poem he again incorporates his first name by means of an acrostic, using the first letter of each of the last nine lines: BI WILLEME (3461-69). The two references to his name will have served to recommend the work to his audience; however, for the modern reader

12 For a survey of the Latin beast epic in the Middle Ages, see Knapp 1979; Ziolkowski 1993.

13 For a discussion of Middle Dutch fables, see Wackers 1993; Schippers 1995; Schippers 1999.

14 For an English translation of a Latin bestiary, see White 1980.

15 Bestiaries and encyclopedias (among them Maerlant's Der naturen bloeme) are discussed in Wackers 1986, section 2.3; Bouwman 1993b; Wackers 2001; Wackers 2005. 
they remain obscure. No poem called Madocke has come down to us and of the author we know nothing more than can be deduced from the text of Van den vos Reynaerde itself. For example, the poem's language shows that Willem came from East Flanders. ${ }^{16}$ He must have been well-educated and widely read, was familiar with Old French beast narratives, which provided material and inspiration, and was well-informed about legal procedures. He may have been a monk with considerable experience in worldly affairs. ${ }^{17}$

A few lines down a second author is mentioned in the prologue: 'Arnout' (6). $\mathrm{He}$ is said to have failed to complete or write one or more stories about Reynaert. Initially critics assumed a joint authorship and Arnout was seen as the writer who had started Van den vos Reynaerde but had not been able to complete it. Willem was supposed to have rewritten the section composed by his predecessor (approximately up to the conviction) and to have completed it by adding the section on Reynaert's reconciliation, revenge and escape.$^{18}$ Later, however, a greater appreciation of the unity displayed by the composition of the poem led to the view, now generally held, that the poem was the work of a single author: Willem. The similar ways in which the Old French sources were used in the first and second sections of Van den vos Reynaerde would seem to confirm this opinion. ${ }^{19}$

This conclusion obviously requires a different explanation for the second name. Some scholars associate Arnout with the prologue of Willem's most important Old French source, Le Plaid, in which an anonymous author mentions a certain 'Perrot' who is supposed to have 'forgotten' to record the story of Reynaert's trial. ${ }^{20}$ Others hold it to be an invented name, made up for the sake of creating ambiguity or as an oblique hint at the Middle Dutch, thirteenth-century Arthurian Roman van Walewein, as this romance was written by two authors (Penninc and Pieter Vostaert). ${ }^{21}$ It has also been suggested that Arnout is the author of a Flemish translation of the Old French beast narrative to which Le Plaid is a sequel. ${ }^{22}$

Van den vos Reynaerde must have been written after the composition of Le Plaid, for which, as we saw earlier, a date of composition is assumed of 1179 , and before 1279 , the

16 For a discussion of the author's East Flemish origin on the basis of linguistic forms, see Muller 1917, chapter III; Gysseling 1966/67.

17 Various historical persons have been suggested. Van Daele 2005 pleaded the case of the Cistercian lay brother Willem van Boudelo (died July 1261). However, conclusive evidence is lacking.

18 For arguments in favour of joint authorship, see Muller 1944, pp. 14-24.

19 For arguments in favour of single authorship, see Van Mierlo 1942; Arendt 1965. On implications of the adaptation technique for the question of authorship, see Bouwman 1991, pp. 418-420.

20 On Arnout as an Old French author (Perrot), see Van Mierlo 1942; Arendt 1965, pp. 3-6; Bouwman 1991, pp. 45-47.

21 For arguments that Arnout is an invented name, cf. Hellinga 1957, pp. 18-20 and Lulofs 1983, p. 200.

22 For Arnout as the Flemish translator of 'branch II-Va', see Delbouille 1929, pp. 46-47. 
last year in which Reynardus vulpes, the Latin translation of Van den vos Reynaerde, can have been written (see p. 36). There have been several attempts at narrowing down this broad estimate with its margin of one hundred years by reading the poem to a greater or lesser degree as a roman à clef. Maurits Gysseling discerned allusions to historical events from the last years of the reign of Philip of Alsace, Count of Flanders (1168-1191), on the basis of which he dates the work before 1191. Leopold Peeters, on the other hand, wanted to assign a date of around 1260, as several passages were considered by him to refer to the struggle between two noble dynasties, the Dampierre and the Avesnes families, about the succession in Flanders and Hainault. ${ }^{23}$

A certain consensus has formed around the latter date, although on different grounds. It appears that Willem made use of an Old French compilation, the original version of which is dated after 1205. Aspects of his versification technique have also led to a date of around or just after the middle of the thirteenth century. ${ }^{24} \mathrm{In}$ addition there are several Middle Dutch works that allude to Van den vos Reynaerde. Jacob van Maerlant, for example, announces in his Rijmbijbel (completed in 1271) in connection with the truth value of his poem: dit nes niet madox droem / noch reinard noch arturs boerden ('this is not Madoc's dream, nor a wild story about Reinard or Artur'), perhaps referring to the story about Madoc mentioned in the first line of Van den vos Reynaerde. Here, Maerlant shows his contempt for the fictitious lies in Van den vos Reynaerde and other stories, which would seem to have been written reasonably recently. ${ }^{25}$

Positioning Willem in East Flanders does not automatically provide us with a clue as to the region where the poem originated. As is evident from the oeuvre of the Flemish author Maerlant, whose works were commissioned by patrons in the county of Holland, the author of Van den vos Reynaerde might have written for people in a region other than East Flanders. However, the Flemish origin of the work is confirmed by the author's use of place-names, such as 'Abstale' (802), 'Belsele' (2097), 'Elmare' (373 ff.), 'Hijfte' (2262-63), 'Hulsterloe' (2575 ff.), 'Kriekepit' (2578 ff.), 'Leye' (2640) and 'Waes' (2257). These toponyms from the Ghent area indicate that the work's primary audience must have been familiar with the geography of East Flanders (see also p. 28 and the Index of proper names). ${ }^{26}$

23 See for the early date Gysseling 1975; for the date around 1260, see Peeters 1973/74.

24 For a date in the third quarter of the thirteenth century, see Bouwman 1991, pp. 418-420 (on the basis of the Old French compilation); Van den Berg 1983, p. 224 (versification); Janssens 1991, pp. 174-175 (allusions; collected in Van Oostrom 1983).

25 Maerlant's Rijmbijbel (Gysseling 1983), lines 34.813-14.

26 On toponyms, see Teirlinck 1910-1912; Van Daele 1994. 


\section{The text}

\subsection{The Prologue}

In his prologue (1-40) Willem addresses 'peasants and fools' (13), urging them with considerable force to leave his text alone, as they will not understand it anyway (1124). A few lines further down the poet makes clear that his work is intended for those who know how to appreciate it $(34,39)$ : Ic wille dat dieghene horen [...] Diet verstaen met goeden sinne ('I wish it to be heard by those ... who will understand it properly'). But how is Willem's poem to be understood? ${ }^{27}$

A similar authorial attitude is found in Esopet. In the prologue to this late thirteenth or early fourteenth-century Middle Dutch collection of fables the author also discusses the way in which the work should be understood. The anonymous Esopet poet points out to his audience that, although his fables may not be a direct representation of the real world, they none the less contain truth:

Ic sal u hier exemple maken

Van beesten recht of si spraken.

Maer merket ende hoert

Meer die redene dan die woert.

Ontdoet elc wort, ghi vinter in

Redene ende goeden $\sin .^{28}$

(I shall provide an example for you here of animals, as if they could speak. But mark and listen to the meaning rather than the words. Unlock each word, you'll find in it reason and a good meaning.)

Whereas in the fables, a fictional tale of limited size is closely connected with an explicitly formulated moral, the story in a full-blown beast epic such as Van den vos Reynaerde rises to a higher plane, while the moral meaning remains implicit. And yet Willem's desire that the audience may verstaen met goede sinne this new work of his is not far removed from the advice that they should discover the goeden sin in Esopet, or rather, it is its result. The readers and listeners of Van den vos Reynaerde, too, should first see through the 'lies' of the tale (that animals can speak and behave like human beings) before finding the deeper meaning of that story. ${ }^{29}$

27 For a study of prologues in Middle Dutch texts, see Sonnemans 1995.

28 Esopet; Stuiveling 1965, lines 17-22.

29 See for a discussion of the truth value and meaning of beast narratives, Wackers 1986, pp. 12-38. 


\subsection{The plot}

Court day - At Whitsun King Nobel holds court. The lion sends for his subjects and everyone appears, with the exception of the fox Reynaert. Ysingrijn the wolf, the dog Cortoys and Pancer the beaver charge the absent baron before the king with rape, theft and physical abuse respectively. Reynaert's case is taken up by his nephew, Grimbeert the badger. The latter's eloquent defence is interrupted by the arrival of the cock Cantecleer, followed by a bier. Cantecleer accuses the fox of the multiple murders of his children; the dead body on the bier - it is his daughter Coppe - is the latest proof of Reynaert's crimes. The king decides, in particular on the grounds of this last complaint, to summon the fox. (41-496)

First summons - Bruun the bear departs as the king's messenger to Manpertuus, the fox's fortress, but fails in his task. Blinded by the desire for honey that Reynaert has promised him, he gets stuck in a half-split oak in the yard of the villager Lamfroyt. Before managing to escape, he is severely maltreated by the quickly assembled villagers. Badly injured and with nothing to show for his pains, he returns to the king's court. (497-1042)

Second summons - The king's next messenger, Tybeert the cat, is hardly more successful. Eager to have mice for his dinner, Tybeert allows himself to be led by Reynaert to a priest's barn. There he walks into a snare that had been prepared for the fox. The cat's loud cries wake the priest and his family, who give him a severe beating. He barely manages to extricate himself and flee. Blind in one eye he arrives at court. (1043-1358)

Third summons - After the second failed summons, King Nobel sends Grimbeert as his messenger. The badger persuades the accused to accompany him to the court. On the way there the fox confesses his sins to his nephew, as a result of which countless crimes come to light. He especially dwells extensively and full of malicious delight on his bad behaviour towards Ysingrijn. He recounts how the wolf, as a result of the fox's actions, got stuck in a priest's barn and later fell off a beam in the roof of a house and on each occasion was badly beaten. It is clear that Reynaert's contrition is not sincere, for when they pass the garden of a convent, the fox tries to grab a cockerel. His confessor indignantly calls him to order. (1359-1752)

Conviction and reconciliation - At court, Reynaert is tried and sentenced to death. Before being led to the gallows, the fox asks permission to make a public confession. Initially he describes how he came to live a life of sin. However, in a subtle way he works round to an (invented) story about a treasure and a conspiracy on the king's life. The wolf, bear and cat, as well as Grimbeert and Reynaert's own father are said to have made every effort to dethrone Nobel and to put Bruun on the throne. The conspiracy was foiled only because Reynaert managed to steal his father's treasure, which would have financed the rising. There is no one present at court to contradict this tale: Ysingrijn, Bruun and Ty- 
beert are erecting the gallows somewhere else, Grimbeert has in the meantime left the court together with Reynaert's relatives, and Reynaert $S r$ is said to have died. In fear of his life, but especially eager to get his hands on the treasure, King Nobel believes Reynaert's words. In addition, the queen points out that Reynaert is accusing his own relatives. His story must, therefore, be true. The king promises to pardon Reynaert in exchange for the treasure. The fox describes the place where he has buried it: near the spring Kriekeputte, not far from Hulsterloe. Nobel is not entirely happy about it all, and asks the fox to come with him to dig up the treasure. Knowing that there is no such thing, Reynaert thinks up a new lie. He declares that three years earlier he was excommunicated by the pope and that it is now high time for him to travel to Rome to have the ban lifted. From there he will journey on to the Holy Land. In the course of the official reconciliation with Reynaert the king refrains from mentioning the treasure and the excommunication to his subjects, merely stating that the fox is about to go on a pilgrimage. (1753-2795)

Revenge and flight - On their return from the field where they have erected the gallows, the bear and the wolf are imprisoned. The fox has a scrip - a special bag for pilgrims - cut from the skin on Bruun's back. Ysingrijn and his wife suffer in a similar way when they are made to provide shoes made of wolf's skin for the fox's journey. In this way Reynaert revenges himself on his opponents. King Nobel orders Belin the ram, his court chaplain, to hand over the pilgrim's attributes to Reynaert during a church ceremony. Before leaving with all the accoutrements needed by a pilgrim, the fox persuades Belin and Cuwaert the hare to accompany him a little way on his pilgrimage. As soon as he arrives at his home Manpertuus, he kills Cuwaert and sends Belin, who was waiting outside, back to the court with a letter in Reynaert's bag. He advises the ram to say that he, Belin, is the author of the letter. This is what Belin does. However, when the letter proves to be nothing but Cuwaert's bloody head, Belin has unwittingly made himself responsible for the murder of the hare. Reynaert's deception is unmistakable. Nobel, humiliated, utters a terrible roar. His position has become precarious, for by his own fault he has become embroiled with his two mightiest barons. The leopard Fyrapeel manages to reconcile the king with Bruun and Ysingrijn: the bear and the wolf are allowed, in exchange for their loyalty, to pursue and kill all members and descendants of Belin's and Reynaert's families till the end of time. Peace appears to have been restored. (2796-3469)

\subsection{Words and deeds}

The action in Van den vos Reynaerde consists mainly of conflict situations in which characters are pitted against one another. The conflicts are caused by Reynaert. In his encounters with Cuwaert, with Canticleer and his children, with Ysingrijn in the priest's barn and on the roof beam of a house, with Cuwaert and Belin at Manpertuus, 
he is always the aggressor. In the confrontation with Bruun and Tybeert as the king's messengers as well as with King Nobel himself, he responds to the court community that wishes to make him toe the line. Each time the fox manages to exploit the weaknesses of his opponents and to turn the situation to his own advantage by tricking them in an ingenious way.

The tricks follow more or less the same pattern. Reynaert greets his opponent with a great deal of flattery. In passing he mentions something that arouses a strong desire: honey, mice, a treasure, being literate. The opponent gets excited and flatters the fox, even promising him something in return for the coveted object or skill. Having made the deal, Reynaert leads his future victim to the trap. The opponent enters the trap, spurred on by Reynaert, with the result that he is humiliated and maltreated. Reynaert's confrontations with the representatives of the court community in particular run along the lines of this pattern, albeit that in the final, ultimate confrontation a number of motifs return at an abstract level: the king is led only in his mind's eye to the wilderness of Kriekeputte, where the so-called treasure is said to have been buried. $\mathrm{He}$ also suffers only symbolically from the usual taunts and maltreatment. Nevertheless the 'letter' that Reynaert gives Belin the ram for King Nobel, and the latter's desperate roar when he sees through Reynaert's deception and faces his own disgrace, leave little to the imagination. ${ }^{30}$

The author succeeds in varying the presentation of the tricks in a subtle way. At the beginning of the poem it is a character, Canticleer, who describes the way in which Reynaert misled him and killed and devoured the larger part of his feathered offspring. The people listening to Van den vos Reynaerde are as much part of the audience as the assembled animals at the king's court. Next the audience is informed at considerable length by the narrator about the two tricks that the fox plays on his victims Bruun and Tybeert, the king's messengers. In his confession Reynaert adopts the role of narrator and tells Grimbeert - and by implication the poem's readers or listeners - in great detail of two tricks played on Ysingrijn.

When, after his conviction, the fox addresses the court, the information known by the audience of Van den vos Reynaerde no longer corresponds to what Reynaert's animal audience knows: the former now see through the fox much more clearly than the latter group does. Now two tricks are revealed simultaneously - although at different levels. Reynaert tells the animals at the king's court of the trick by which he managed to end the conspiracy: the theft of the treasure. However, in the meantime the readers or listeners of Van den vos Reynaerde realize, as a result of the narrator's intervention,

30 The tricks used by the fox to manipulate appearance and reality during a confrontation with the opponent in the Roman de Renart have been discussed by Jauss 1959, p. 212. This idea was applied to Van den vos Reynaerde by Arendt who analyses the structure and action of the tricks (Arendt 1965, pp. 149-207). For some modification of Arendt's analysis, see Bouwman 1991, pp. 402-405. 
that in fact a very different trick is in the process of being developed here, one which will enable Reynaert to mislead the king and save his own skin. That trick, too, is centred on the treasure. ${ }^{31}$

A characteristic aspect of the tricks in Van den vos Reynaerde is their extremely verbal nature. The fox paints with pretty words (scone tale, according to the narrator in line 1075) a picture of a world as his opponents would have it, but which deviates drastically from the events that are about to take place. Even when Reynaert mocks his victims, he exploits the gap between rhetoric and reality. ${ }^{32}$ We see this for example in the following cases. Bruun has managed to pull himself free of the half-split oak and has escaped the villagers by jumping into the river. A fair way downstream he drifts to the river bank, where Reynaert sees him lying on the sand, badly hurt. The fox mocks Bruun by pretending that he does not recognize him and mistakes him for a priest, cynically taking the bear's bloody head and paws for the skull cap and gloves of an abbot or prior (94151). Also, when Tybeert is caught by the throat in the snare, which is threatening to throttle him, he screams loudly. On that occasion Reynaert compliments the cat on the melodious way he is 'singing at the dinner table' (1218-19).

This process of renewed interpretation and narration is central to the structure of Van den vos Reynaerde (see p. 22-23). Earlier events in the story are described again by a particular character, most often by the fox, but also by other animals. Its function is always the same: the character in question presents a biased version of events that have been related earlier, as it were rewrites history along the lines of his own desires and interests, and thus characterizes himself. We see this, for example, when Reynaert chases a cockerel near a convent, but is stopped by Grimbeert. The narrator next tells us that the fox, continuing on his way, keeps looking back, licking his chops. This sinful action, about which he is quite rightly rebuked by Grimbeert, is turned by Reynaert into a pious action: he reproaches his confessor for disturbing his prayers for the salvation of the souls of all his feathered victims from the nunnery's garden (1726-44).

After Reynaert has left Nobel's court as a pilgrim, he takes Cuwaert and Belin along to Manpertuus. While the ram waits outside, the fox takes Cuwaert into his den. Once there he grabs the hare by the throat - who in mortal fear calls for Belin - and kills him. When Belin, full of suspicion, asks Reynaert why Cuwaert called out to him, the fox reinterprets the actual events here, too (3222-47). The audience, aware of what really happened, sees through the deception in these words. Similarly, from the very beginning Grimbeert presents Reynaert's theft of a sausage and his (first) attempt on Cuwaert's life as the confiscation of stolen goods and the chastisement of a stupid pupil by his

31 For a discussion of the different forms in which the tricks are presented, see Bouwman 1993a, p. 38.

32 According to Mann 1987, pp. 58-77 speculating on the discrepancy between words and deeds is already a prominent theme in Ysengrimus. Cf. also Wackers 1994. 
master (99-169, 247-62). Grimbeert's evocation of the fox as a pious hermit who is doing penance for his sins is unmasked as a lie in retrospect when Canticleer's story shows that Reynaert, disguised as a hermit, has misled the cock and in this way has succeeded in devouring many of his children (263-81,315-420). The characters thus try to manipulate the fictional reality of the poem by means of their verbal skills. ${ }^{33}$

The poem's audience is given the opportunity to gauge the gap between appearance and reality. It is regularly given more information than the characters receive by means of the narrator's commentary on events in the story and the fox's 'asides'. This enables them to see Reynaert's words in perspective. The procedure is presented emphatically in the episode of the First Summons, where readers and listeners are confronted for the first time with one of the fox's tricks, and for that reason are not yet used to Reynaert's intentions and way with words (542-46, 623-26, 634-43, 903-8). It also happens in other episodes, for example when Reynaert has been convicted and resorts to a complex trick (2034-49, 2164-78, 2227-38).

In other words, the author plays a sophisticated game with his audience. Sometimes he involves them in the story, at other times he sets them thinking about what has happened. In this way he alternately creates involvement and distance. On the one hand Reynaert impresses not only King Nobel's court, but also the readers or listeners of the beast epic with his ingenious fabrications; on the other hand the narrator encourages the audience by means of his asides to see through the 'lies' of the story, so that they 'will understand it properly' (verstaen met goeden sinne; 39$).{ }^{34}$

Willem's poem does not contain any reports of historical events; there is only the made-up story. The audience knows from the outset that the happenings in this beast epic have never taken place, indeed, that they never could take place (as is the case, of course, in many fictional accounts). That is why every 'attempt' by the narrator to forge a link with (historical) reality has an ironic effect (see, for example, 293-301, 3016-21). This also happens when the animals in direct speech set the scene for their fictional actions in contemporary Flanders. For example, when a cock claims to have been shown a pilgrim's scrip and mantle by Reynaert that have come from the priory at Elmare (367-374), the tale's implied audience from East Flanders will think of the nearby priory of that name, but it will also realize that no pilgrim's attributes are handed over to foxes there.

Perhaps the anthropomorphism in Van den vos Reynaerde, i.e. making animals act and speak like human beings and using objects intended for use by humans, should be explained in a similar way. The clash of animal and human components is likely to elicit at least a smile - about a fox wearing four(!) shoes, for example (2852-2934) - but with

33 On the subject of new interpretations and newly recounted events by the story's characters, see Bouw$\operatorname{man} 1998$.

34 For further examples and the narrator's ironic comments on Reynaert's feigned distress, see 289798 and 2990-94. 
the laugh comes the realization of the impossibility of the representation. This realization may even be a condition for the comic effect.

At moments of verbal high tension the author and his Reynaert character seem to coincide in their roles of 'narrator/tempter'. Both create a contrast between reality and appearance, create 'fiction', both 'lie' in their attempts to convince their audiences. Willem is certainly not unsympathetic in his description of Reynaert's tricks. Nevertheless an appreciation of the esthetic perfection of Reynaert's verbal skills does not necessarily imply a positive evaluation of his actions. This is evident from the negative epithet $f e l$ (wicked, vicious) that is frequently used by both the narrator and other characters when referring to the fox: Reynaert, den fellen (60), dat felle dier (88), die felle ghebuere (344), diefelle (614) etc. Moreover, the author seems to be just as critical of the fox's behaviour as he is of that of the fox's opponents (see p. 24-27).

\subsection{Literary space}

Willem regularly makes his characters, and Reynaert in particular, refer to real places. Thus the narrative space in his poem acquires a sense of actuality for his audience, while at the same time the author creates an ironic effect, as was suggested earlier. In his fabrications, the fox uses a multitude of well-known place names to enhance the truth of his tale. ${ }^{35}$ The Flemish names evoke a sense of proximity, whereas place-names like Aachen and Paris (2630-31) broaden the perspective to 'far away'. This is not to say, however, that the story is set in a realistic, historic landscape. It is a tell-tale sign that the narrator himself refrains from any kind of realistic topography. He never, or almost never, provides exact locations for the places that are really important - particularly King Nobel's court and Manpertuus, Reynaert's den (a literary place-name!). There is little point, therefore, in tracing Bruun's journey on a map of thirteenth-century Flanders, for example, as has at times been tried in traditional place-name research (which considered the stream that Bruun jumps into in order to escape from the villagers to be the river Scheldt). Rather than real geography, we are dealing in Van den vos Reynaerde with a literary space. ${ }^{36}$

The author consistently situates the conflicts between the court animals and Reynaert in two distinctive landscapes: the well-ordered world of the court as opposed to the trackless wilderness. Nobel's landscape is a protected area, a fenced-in park filled with the softness of spring and a blissful peace (41-43, 322-39), a space characterised by straight roads (1314-17, 1702-3, 1747-50). The landscape in which Reynaert lives

35 For a survey of the traditional research into the place-names, see Teirlinck 1910-1912; Van Daele 1994, pp. 7-175.

36 For literary approaches to the question of space, see Arendt 1965, pp. 73-148; Van Daele 1994, pp. 217542; for modifications, see Bouwman 1991, pp. 392-396; Bouwman 1996. 
is complex and threatening for the court animals: mountainous, with dark woods and desolate, wild regions; there are no paved roads, at best crooked paths (502-12, $632-33,881-87,891)$. In a number of respects the moral lapses of the court animals in their conflict with the fox are represented spatially, as crossing the line from the wellorganised world of the court and/or entering the wilderness. To mention a few examples: Canticleer ventures with his children bueten mure, outside the walls (393), Bruun reaches the half-split oak with honey along a crooked path (632-33), Tybeert only regains the rechte strate, the straight road leading back to the court, after his beating at the village priest's house (1314-17), King Nobel is sent by the fox to the terrifying Kriekeputte wilderness to get hold of the treasure (2572-2697). When Reynaert plans to pounce on one of the convent's cocks, he is also said to be buter rechter vaert, 'beside the straight road' (1694) - only a short time after he had promised his confessor Grimbeert to better his life 'and to point the right way / to all those he would see stray' (1682-83).

The conclusion of the confrontations often takes place in an in-between area where human beings live: the village (and, to a lesser degree, the convent). The inhabitants of the village are presented as rough, coarse and ugly, and as a group behave with hostility towards the court animals. It is to this uncourtly place that Reynaert leads his victims, where they are beaten up and reduced to whining animals, stripped of all courtly ideals and without the power of speech (644-849, 1163-1317, 1508-1604, 1610-45). For Reynaert the village is part of his hunting ground; for the court animals it belongs to the wilderness.

The 'park and wilderness' landscape described in Van den vos Reynaerde is, therefore, to a certain extent a psychological landscape. The appreciation of the scenery is determined from a court perspective: the parks have a positive meaning, the wildernesses a negative one. However, for Reynaert it is exactly the other way round: when, at the end of the story, he departs for good with his family, he extols the virtues of a new wilderness where they will be able to hunt to their heart's content (3153-65, 3317-29).

\subsection{Justice and its perversion}

The action in Van den vos Reynaerde develops within a legal framework: against the fox, continuously in conflict with the other animals, criminal proceedings are initiated at the court of King Nobel..$^{37}$ The story begins with the assembly of the court at Whitsun, presided over by the king. The fox's victims or - in the case of Cuwaert and Coppe

37 The legal aspects of Van den vos Reynaerde have been compared to real legal practice in the thirteenth century, partly on the basis of Van Caenegem 1954 and 1956, by legal historians. See Hermesdorf 1955; Jacoby 1970; Van Dievoet 1975; Van den Brink \& Van Herwaarden 1977. 
- their relatives bring charges against the fox. The accused is not present and is defended by a relative, but to no avail. Reynaert is summoned. Not until after the third summons does the fox appear at court. He is tried and sentenced to death by the barons. However, he manages to persuade the king to pardon him and thus escapes execution. Even so, he is incorrigible and revenges himself on his enemies. One might expect that in a plot of this kind the trial would be central. Nothing could be further from the truth, however: the whole trial is described, one might even say dismissed, in less than twenty lines (1868-84). The story is only half-way through when the legal proceedings against the fox are concluded! We can hardly, therefore, consider the extensive fabricated story spun by Reynaert at the king's court as an oratio judicialis, a legal speech in the strict sense of the word..$^{38} \mathrm{After}$ all, Reynaert's speech does not start until after the verdict has been read and the executioners are on their way to prepare the gallows. It may be concluded that, despite the legal narrative framework, the poet of Van den vos Reynaerde finds other aspects of his text more important. ${ }^{39}$

Of greater significance than Reynaert's legal trial is the moral 'trial' with which Willem presents his audience. In that trial it is not just Reynaert who is indicted, but also, or rather in particular, his opponents. In much the same way as the king urged his barons to judge Reynaert (1879-84), the poet wishes to induce the audience to judge his characters, placed as they are on opposite sides of a conflict. The weightiest conflict in Van den vos Reynaerde, between the fox and the king, causes new, feudal conflicts. They undermine the relationship between Nobel and his vassals, and thus the court community itself.

It is striking in this context that initially the king asks his barons' advice before taking any legal step and also acts upon their counsel (466-81, 1000-16, 1328-31). Even when Reynaert appears at court, feudal harmony still reigns there. After a proper trial the fox is sentenced to death by the highest barons, who have been urged to do so by the king (1868-84). However, when the fox appears to be the owner of a huge treasure, Nobel's interests no longer coincide with those of his barons. That at once marks the end of any proper legal procedures. The king leads Reynaert out of the circle of courtiers for private discussion (2491-95). He is reconciled with Reynaert without asking his barons' advice and without telling them that he stands to gain a treasure. For the first time in the story the court has become internally divided in a conflict with the fox. Fissures appear in the fabric of the feudal order.

When Reynaert appears at court, he presents himself as the king's loyal servant and - without mentioning any names - accuses a number of courtiers of being false (1786-

38 On the notion that Reynaert's pack of lies is not an oratio judicialis, see Bouwman 1991, pp. 278-281.

39 The point of view that the legal aspects have a literary as well as a historical context was suggested by Heeroma 1971 and Bouwman 1991, pp. 360-367 and 397-402. This section is based on that discussion. 
92). At first the fox's accusations seem little more than empty slander and are dismissed resolutely by Nobel as such (1796-1801). However, the invented conflict between the king and his barons becomes reality when, eager to believe the existence of a treasure and a conspiracy, the king withdraws his protection from the alleged conspirators Bruun and Ysingrijn and, without a trial, has them taken prisoner and maltreated. This is a felony and a very serious breach of the king's obligations as liege lord. The king now enters into a feud with his most important vassals. In the end Nobel manages to resolve this internal conflict only by committing more injustices.

As part of the reconciliation it is determined that Bruun and Ysingrijn and their relatives will be allowed to hunt and kill Belin, Reynaert and the clans to which they belong for all eternity. In issuing this decree the king once again - and this time irrevocably - breaks his obligations towards his vassals. Nobel now keeps the peace by excluding Belin and Reynaert and their relations from the peace; he denies these vassals their right to protection and delivers them to the mercies of wolves and bears, 'from now until Doomsday' (3443). The feudal order, for the safeguarding of which Reynaert was tried and convicted, has now been suspended. In actual fact the court ceases to exist as an orderly society, a community where predator and prey might live together in peace.

It is no accident that an eschatological dimension opens up here. In the encounter with Reynaert, the satanic tempter, each opponent separately falls from grace and eventually the court community as a whole is degraded from paradise to wilderness. Reynaert has experienced that process too, or so he says, after his conviction in a public confession (2070-78). The fox describes his mild behaviour towards the lambs as the blissful state of paradise, and his killing of a lamb as the beginning of his 'fall'. Willem alludes here to the well-known verses in the Bible where the prophet Isaiah describes the future messianic peace (in fact in terms of the lost paradise from Genesis):

Habitat lupus cum agno et pardus cum hedo accubabit vitulus et leo et ovis simul morabuntur et puer parvulus minabit eos; vitulus et ursus pascentur simul requiescent catuli eorum et leo quasi bos comedet paleas. ${ }^{40}$

The wolf shall dwell with the lamb: and the leopard shall lie down with the kid: the calf and the lion, and the sheep shall abide together, and a little child shall lead them. The calf and the bear shall feed: their young ones shall rest together: and the lion shall eat straw like the ox.

The final passage of Van den vos Reynaerde - where the leopard tries to reconcile the lion with the wolf and the bear by delivering to them the ram and his descendants - is, in this 
view, a cynical reversal of the biblical vision of peace. By doubling the 'paradise lost' motif, the author indicates that the court community now follows in Reynaert's footsteps. This insight is confirmed in yet other ways.

Fyrapeel explains to the king why Belin the ram has forfeited his life: 'he has admitted himself that he betrayed Cuwaert' (3418-19). These words cannot but remind one of Reynaert's words to Hermeline: 'The king acknowledged that Cuwaert was the first to accuse us falsely before him' (3108-10). Belin, like Cuwaert, is made a peace offering, a means of compensation in a reconcilation between third parties. Here, as was the case when Reynaert reported the king's decision to Hermeline, the audience may distinguish truth and untruth in what Fyrapeel says. It knows that Cuwaert did not treat Reynaert treacherously; it also knows that Belin was not the cause of Cuwaert's demise. But in the same way that Reynaert puts a very wide interpretation on the king's command to honour him (2780-83), the leopard understands Belin's confession that he has written the letter in a purely metaphorical way. This cross-current strengthens the audience's realization that in the end the actions of the court community are not hugely different from Reynaert's actions.

The wilderness encroaches on the court where predator and prey used to live harmoniously. Looking back from the end of Van den vos Reynaerde, we see that the theme of the lost paradise is also mirrored in the fable of which Reynaert reminds his listeners to illustrate how undesirable the usurpation of Nobel's throne by Bruun would have been (2299-2325). In this fable the frogs exchange their freedom entirely through their own fault for the tyranny of King Stork, 'who killed and devoured them wherever he found them, both in the water and in the field' (2311-13). In Reynaert's view, Bruun is like this devouring stork. Willem's audience knows that Reynaert is lying about the bear's role. But that same audience also knows after the bitter denouement of the story that Nobel, Bruun and Ysingrijn themselves are applicants for the role of King Stork when the sovereign has granted the wolf and the bear the right to persecute some of his subjects: 'In the field or in the woods, they will all be at your disposal and you may kill them as much as you like' (3444-46).

Van den vos Reynaerde is a story of animals that are wicked and stupid, and of one animal that is wicked and devious. Its readers and listeners must surely have admired the ingenuity of Reynaert's tricks. However, it is unlikely that their admiration prevented them from arriving at a moral judgement of the fox's behaviour. After all, the story is about animals and it is always someone else who is deceived. The story contains no character with whom the audience can effortlessly identify. In this respect Van den vos Reynaerde resembles the fable to which it indirectly owes its existence: its audience and readers are made to see in a mirror how to avoid 'beastly' behaviour themselves. 


\section{The audience}

Earlier we saw that Van den vos Reynaerde was probably written in the third quarter of the thirteenth century, for an audience and/or readership likely to have enjoyed the fact that the action is situated by the characters themselves in the Flemish landscape. For example, the convent where Reynaert is said to have acquired his pilgrim's attributes and where Ysingrijn is said to have rung the bells is called Elmare $(373,1483$, 1493), which was the name of a priory of Saint Peter's Abbey near Ghent. Also, the wolf and the fox are said to have sworn an oath of allegiance under a tree near Belsele (2097), and Reynaert claims that the conspirators gathered between Hijfte and Ghent (2263). There can be no doubt, therefore, that the implied audience of Van den vos Reynaerde is East Flemish. However, the poem contains no information - not even in the prologue - that allows a more precise identification of the person(s) for whom it was intended. Scholars of necessity have to make the best of indirect and often ambiguous data.

According to an old hypothesis Van den vos Reynaerde was written for a bourgeois audience. Its didactic tenor was thought to suit the mentality and cultural emancipation of the patricians in Flemish towns like Ghent and Bruges, which had enjoyed a marked economic boom in the twelfth and thirteenth centuries and had also gained in political influence. In addition, it has been observed that this urban elite seems to be the only social group that is not satirized in Willem's poem, whereas the aristocracy, clergy and country people are severely criticized and mocked. From this point of view Reynaert can be seen as a freedom-loving individualist whose quick-wittedness brings about the fall of the antiquated feudal system. King Nobel is considered as more or less mirroring the count of Flanders. ${ }^{4}$

However, other critics have argued that within the narrative reality of the text Reynaert should be regarded as belonging to the high aristocracy (like Bruun and Ysingrijn, for example) and is a criminal rather than a trickster by medieval standards. In their view Van den vos Reynaerde was written for a court audience, as has also been argued for the Old French Roman de Renart. In that case the story was not inspired by bourgeois resentment, but either by aristocratic self-mockery, or by a real concern for the decline of feudal society. The conflict of King Nobel with his vassal Reynaert might then mirror the tensions present among the Flemish aristocracy in the thirteenth century. The lower aristocracy had lost a sizeable part of its freedom and power in its dealings with the count. The count, moreover, was not only liege lord, he was also a vassal of the king of France. The two Flemish countesses, Johanna and her sister Margareta had to deal with liege lords (Philip Augustus, Louis VIII and IX) who aimed to limit the independence

41 For arguments in favour of a bourgeois interest in Middle Dutch literature, see Jonckbloet 1852, pp. $122-123$. 
of their mighty vassal as much as lay within their power, making clever use of the conflicts between the count and the aristocracy and the urban patricians. There is some evidence that the aristocratic Dampierre family was familiar with Van den vos Reynaerde. ${ }^{42}$

Various compromises have been proposed. It is not impossible, for example, that, as is suggested in lines 26-31 of the prologue, Van den vos Reynaerde had an aristocratic patron, but was listened to by a bourgeois audience. It should also be taken into account that the urban elite of the thirteenth century consisted of several layers, as the aristocracy by birth had mixed to a considerable degree with the more socially successful members of the bourgeoisie. The possibility that vernacular literature was aimed at different social communities as its intended audience has also been suggested. In that case the text will have appealed to both the bourgeois elite in the towns and the court aristocracy. ${ }^{43}$

It is tempting to scan the text for details which might be made to fit the reality of the time and in particular the political situation in Flanders. In an extreme form we see this in attempts to read Van den vos Reynaerde as a roman à clef(see p. 16). Another approach is to detect connections with contemporary literature - which, of course, may also have implications for determining the primary audience of the beast narrative. In this context it is striking that Van den vos Reynaerde pays far more detailed attention to the conflict between Reynaert and his liege lord Nobel than does the Old French Le Plaid. It is possible that the author plays here with a topical theme from contemporary chivalric romance.

In Old French and Middle Dutch Charlemagne epics dating from the period 11701260, the antagonism between king and vassal is a major theme. The feudal order is maintained by powerful and loyal vassals like Guillaume d'Orange. However, in a number of texts internal tensions threaten the court community, because the king treats one of his loyal vassals unjustly. In a number of so-called 'traitor epics' the king is bribed or driven to do so by a malicious traitor who falsely accuses the loyal vassal of having devised a plot to murder the king, which he only just managed to foil, or so the traitor pretends. In the 'epics of revolt' (works like the Old French Renaut de Montauban and the Middle Dutch adaptation of this text, Renout van Montalbaen) the king through his own malice causes the loyal vassals to rebel and to go into forced exile. Only at the end of the tale are king and vassal reconciled and traitors vanquished. Then,

42 A court audience was argued by Van Oostrom 1983. On the Dampierre milieu, see Bouwman 1991, pp. 65-66 (n. 34), 425-426 (n.194-195), and cf. Van Daele 1998, p. 139.

43 See Pleij 1983 and Van Hoecke 1987, who regard the rise of a Flemish literature as an endeavour by the counts to increase their prestige with the French king, their liege lord. On the multifunctionality of Middle Dutch texts, see Prevenier 1994; Besamusca 1998 studies the Moriaen, a Middle Dutch Arthurian romance, from this point of view. Cf. also Wackers $2000 a$ and Van Oostrom 2006, pp. 227-72. 
too, the feudal order is restored with God's help. Possibly well-known patterns from Charlemagne epics are reversed in Van den vos Reynaerde. The fox may then be seen as a (triumphant!) traitor who manages to persuade King Nobel to take his two loyal vassals, Bruun the bear and Ysingrijn the wolf, prisoner and to maltreat them by telling a brilliantly fabricated story of a conspiracy and of an equally imaginary treasure. Alternatively, Reynaert can be seen as a rebel vassal who is not reconciled with the king, but deliberately and successfully leaves the court community, preferring voluntary exile.

The implied audience of Van den vos Reynaerde must also have been familiar with a range of animal stories. In the prologue the author regrets that die avonture van Reynaerde (4) had not yet been made in Dutch. It is only after several tens of lines that the tale appears to be about a fox, when it is said that all animals come to King Nobel's court day, 'except for Reynaert the fox alone' (50). Between the appearance of Nobel die coninc (44) and the first reference to his status as a lion, there are more than 1800 lines: Voert sprac Reynaert: 'Coninc lyoen' (1833) ('Reynaert continued: "King Lion”'). When Ysingrijn is introduced, it is again not stated what kind of animal he is. The audience is informed of this only much later, when Reynaert confesses to his nephew Grimbeert his crimes against Ysingrijn among much else. On that occasion he mentions that it was his doing that the villagers noticed 'that there was caught in the priest's larder a wolf' (1574-75). The author clearly did not think it necessary to mention the kind of animal concerned when he introduced these characters; he assumed that the audience would already be familiar with them from other stories. Where one passage from the fox's confession is concerned, such foreknowledge can be demonstrated. ${ }^{44}$

In Bruges, around 1275, the Reynardus vulpes was written, a translation of Van den vos Reynaerde in Latin verse (see above). The author of this work, Balduinus Iuvenis, is a representative of the earliest audience ever to hear or read Willem's poem. In the course of his perusal of the Flemish beast narrative Balduinus came across a passage in the episode of the fox's confession in which Reynaert declares that he has deceived the wolf on many occasions:

'Sint dedic hem meerren scamp
up thijs, daer icken leerde visschen,
daer hi niene conste ontwisschen.
Hi ontfincker meneghen slach' (1504-7).

(Later I caused him more disgrace on the ice, when I taught him to fish in a place where he could not escape. There he received a severe hiding.)

44 Our discussion of intertextuality is based primarily on Bouwman 1998, which also contains a concise survey of story elements in Van den vos Reynaerde with parallels in other beast narratives. 
The fox refers here to a story about a fishing expedition on the ice, which existed independently from Van den vos Reynaerde. The oldest versions are found in the Latin Ysengrimus (ca. 1150) and in branch III (Les Poissons, ca. 1178) of the Roman de Renart. In his Reynardus vulpes Balduinus extended the passage from his exemplar from four to sixteen Latin lines (663-78). However, the details of the interpolation were not of his own devising; too many narrative elements which are lacking in Van den vos Reynaerde are found in the version of the story from the Ysengrimus and branch III to make that likely. As Balduinus could not possibly know from the four Middle Dutch lines what Ysingrijn was fishing with, and why he could not escape (the wolf had followed the fox's advice one night and had hung his tail in a hole in the ice which froze over during the night), he must have been familiar with another story about the wintry fishing expedition, from which he could derive material for his interpolation. ${ }^{45}$

Like Balduinus, the implied audience of Van den vos Reynaerde (assuming it was familiar with contemporary literature) also knew a version of 'the fishing expedition on the ice' as well as other beast narratives to which the text alludes. Willem's poem refers in passing to various episodes which are lacking from its Old French source Le Plaid. These episodes must have been known in the thirteenth century as independent narratives. Some of these literary cross-currents may well have enhanced the appreciation of some characters' manipulative speeches by those among the audience who were acquainted with these narratives.

Grimbeert vigorously defends his absent uncle against the charges that have been brought against him. He blackens the reputation of Ysingrijn, Reynaert's chief opponent, by dwelling on the cases when the wolf treated the fox badly. On one of those occasions the wolf is said to have taken advantage shamelessly of Reynaert's courage. After the fox had thrown fish down from a cart to Ysingrijn, who was following at a safe distance, all Reynaert was offered as his share of the plunder by the greedy wolf were the bones of one single fish (206-16). This story of the fox and the cart loaded with fish is found outside Willem's beast narrative in two branches of the Roman de Renart, dating from ca. 1178. The oldest version features as part of branch III. Renart shams dead when he sees a fish cart approaching. The merchants throw him on to the cart, with the intention of skinning the dead body at a later stage and selling the pelt. While the cart rattles along, Renart gorges himself on fish. Eventually the fox jumps down off the cart, with garlands of eels around his body, and taunts the merchants. A later version of his story is found in branch XIV ( $L a$ Queue - Primaut), in which Renart tells the tale of his success in the fish cart to the wolf Primaut, one of Ysengrin's brothers. Primaut then also lies down in the middle of the road shamming dead when

45 See for the episode of the fishing expedition on the ice in Reynardus vulpes, with a Dutch translation, Huygens 1968, pp. 86-87. 
a fish cart approaches, but this time the merchants are on their guard and give the wolf a merciless beating.

Grimbeert's story does not agree with the two Old French versions. One might assume that a story is referred to here which has been lost. However, another explanation is also worth considering. This particular fish cart version is Willem's own invention, and a variation on well-known versions not unlike the story of the stolen ham which Grimbeert is going to produce next as an example of a deception practised by Ysingrijn (217-29). In the same way as the fox goes to great lengths to procure the ham for Ysingrijn and is rewarded on that occasion with the string that it hung from, Reynaert throws fish down from the cart to the wolf, who leaves just one single fish' bones (214). The Middle Dutch author has Grimbeert twist the well-known versions of 'the fox and the fish cart' so that his uncle will be acquitted. That is the function of the link. Those among the audience who know the French versions will see through the procedure, and will reach the conclusion that Grimbeert is lying.

Based on its prior knowledge of beast narratives the story's public will have been able to estimate the extent to which characters in Van den vos Reynaerde re-interpret and twist older stories. That is an essential aspect of the retelling of events from branch II-Va by Ysingrijn, Grimbeert and Reynaert respectively. This oldest branch of the Roman de Renart, which was probably written around 1175, relates the beginning of the conflict between the fox and wolf. After a number of adventures that did not go well for the fox, Renart accidentally enters the den of the she-wolf Hersent, who has recently given birth to a number of cubs. Renart's claim that her husband Ysengrin has been telling everyone that the fox is in love with her makes Hersent so angry that she turns the allegation into action and commits adultery. Ysengrin hears what has happened from the cubs, who have been befouled by the fox and called sons of a whore. The wolf is furious with his wife, who realizes that Renart has deceived her. When they hunt the fox, Hersent runs ahead in her eagerness, gets stuck in one of the entrances to the fox's den, and is subsequently raped by Renart, an action witnessed from a distance by her husband who arrives a little later. Ysengrin charges the fox at King Noble's court with rape, keeping quiet in the meantime about the earlier adultery. However, the fox is not sentenced, but it is decided that Renart is to swear his innocence on the bones of a saint. Ysengrin decides to take the law into his own hands, and devises an ambush. On the appointed day Renart is to swear on the teeth of the mastiff Roonel, who is told to feign death. Then, as soon as he has gripped the fox with his jaws, a pack of dogs will pounce on the fox. However, the fox notices the deception and manages to escape just in time.

If the audience of Van den vos Reynaerde is familiar with the events in these branches, it will understand why the wolf, in making his complaint, not only remains silent about the adultery between the she-wolf and the fox, but deliberately mentions the 
rape of Hersint and the maltreatment of the cubs in one breath, suggesting in so doing that the two crimes took place in the wolf's lair (thus obviating the need to explain that Hersint was raped in the fox's den, which, from a legal point of view, would be suspicious). The listener sees through Ysingrijn's pretence at astonishment when he states that Reynaert was to swear his innocence with an oath and continues: 'as the relics were brought, he changed his mind, and escaped us in his stronghold' (83-85). After all, it was not Reynaert's wily character, but the ambush with Roonel and the other mastiffs that made the fox decide to run for it. The audience, armed as it is with its knowledge of other stories, also understands that Grimbeert ignores the rape and stresses the adultery, which he re-interprets as proof of a courtly love affair of more than seven years standing between Reynaert and Haersint (234-46). Reynaert, too, alludes in his confession and at court to the adulterous relationship (1648-69, 1970-92), which makes sense only if it is assumed that the audience already knew the popular story about it.

How do these literary cross-currents affect our ideas about the primary audience of Van den vos Reynaerde? As the beast narratives that Willem takes to be common knowledge are not extant in Middle Dutch, but only in Old French, a bilingual audience must be assumed in Flanders. The fact that it knows that Nobel die coninc is a lion, shows familiarity with the Old French literary tradition in which King Lion is called Noble for the first time (see branche II-Va). The fact that in Willem's poem the small dog Cortoys 'complained to the king in French' (100), a complaint that is clearly understood perfectly by the courtiers, as Tybeert's and Grimbeert's reactions show, is also indicative of familiarity with bilingualism among the primary listeners of Van den vos Reynaerde. This also furthers our understanding of the reason why Willem did not limit himself to making a translation when he turned Le Plaid into Dutch (see also the prologue, line $4 \mathrm{ff}$.), but instead wrote a reworked narrative with a brilliant ending in literary competition with his French colleagues. After the fox's conviction the Old French author concludes his story using about two hundred lines. However, from this point onwards Willem adds another 1500 lines or so, almost doubling the poem in size, focusing on Reynaert's escape from his sentence by means of an elaborate and ingenious collection of lies. A bilingual audience will no doubt have enjoyed the competitive spirit (see p. 13). This seems an additional argument to regard the patricians of Ghent as the implied audience, as the Flemish-speaking urban elite learned French in childhood to facilitate contacts in adult life with commercial partners and the high aristocracy. 


\section{Transmission and reception}

Van den vos Reynaerde is extant more or less complete in two Middle Dutch manuscripts containing several texts. The codices are known among scholars by the names of the places where they used to be kept: the Comburg manuscript and the Dyck manuscript. In addition fragments of three other manuscripts have been found. When after several centuries the codices had lost their original function, bookbinders used strips or leaves from these volumes in the bindings of printed books, from which they were retrieved in later centuries. Reynaert scholars refer to these fragments as the Darmstadt, Rotterdam and Brussels fragments, according to the cities where they are kept. The five sources are frequently referred to simply by the letters A, F, E, G and J.

The first manuscript (A) was discovered at the end of the eighteenth century in the library of the Ritterstift Comburg near Schwäbisch Hall in Baden-Württemberg (now Stuttgart, Württembergische Landesbibliothek, Cod. poet. et phil. $2^{\circ} 22$ ). It is a composite manuscript, assembled around 1540, that consists of six parts, all of which were produced in East Flanders (probably in Ghent) within a span of forty years (ca. 1380-1420) by ten different scribes. The volume numbers 346 parchment folios $(267 \times 195 \mathrm{~mm})$ and contains some fifty different texts, among them Die Rose by a certain Heinric, poems by Jacob van Maerlant, Van Sente Brandane, sections from Jan van Boendale's Der leken spieghel, and the Rijmkroniek van Vlaanderen. The beast epic Van den vos Reynaerde, in total 3469 lines - on folios $192 \mathrm{v}^{\circ} \mathrm{a}-213 \mathrm{r}^{\circ} \mathrm{b}$ - is part of the fourth manuscript, numbering 56 folios (179-234). It was copied at the beginning of the fifteenth century by scribe $E$ with two columns of 42 lines per page in a Textualis, the usual formal bookscript. ${ }^{46}$ The present edition is based on the text in this manuscript. ${ }^{47}$

The second complete manuscript (F) was not discovered until a century later, in 1907, again in a German aristocratic library, this time of Schloss Dyck near Neuss in Rheinland-Westfalen. The manuscript numbers 124 parchment folios (294/6x211 mm), written in two columns of 40 lines per page in a Textualis. It was probably produced in the period 1330-1360 in Nedersticht or the eastern part of the county of Holland. Van den vos Reynaerde numbers 3393 lines, covering folios $102 \mathrm{r}^{\circ} \mathrm{b}-123 \mathrm{r}^{\circ} \mathrm{b}$, following Jacob van Maerlant's encyclopedia Der naturen bloeme. Since 1991 it has been kept in the Universitätsbibliothek Münster under shelfmark Ms. N.R. $381 .^{48}$

46 Derolez 2006 distinguishes six basic types of gothic script: Textualis, Semitextualis, Cursiva antiquior, Cursiva, Hybrida, Semihybrida.

47 On ms. A (Comburg, now Stuttgart), see Brinkman \& Schenkel 1997, pp. 9-111; cf. also Deschamps 1972, nr. 21; De Vos 1991.

48 On ms. F (Dyck, now Münster), see Muller 1908; Deschamps 1972, nr. 22; Overgaauw 1992; Overgaauw 1996. 
The fragment of the third manuscript (E) - known since 1889 and now kept in Darmstadt, Hessische Landes- und Hochschulbibliothek under shelfmark Hs. 3321 - consists of a cropped and damaged parchment bifolium (now 216x148 $\mathrm{mm}$ ), written with two columns of 36 lines per page in a Textualis. The manuscript from which the fragment originates must have been written in what is now the Dutch province of Limburg in the last quarter of the thirteenth century. The text comprises 287 lines, corresponding to lines 2588-2722, 3017-3158 in this edition. ${ }^{49}$

The fragments of the fourth manuscript (G) were presented in 1933 by Erik von Scherling, an antiquarian bookdealer in Leiden, to the codicologist Willem de Vreese, who acquired them for the Gemeentebibliotheek (Public Library) in Rotterdam, where they are kept under shelfmark $96 \mathrm{~B} 5$ (olim $14 \mathrm{G}$ 8). It consists of two and three strips of parchment, cut from two bifolia, filled with a single column of ca. 24 lines per page in a Textualis in an unusual lay-out: the last letter of each pair of rhyming words has been written only once (in the right margin at some distance from the rest of the text, at the level of the first rhyme word) and has been connected with the two rhyme words by wavy lines. This fourth manuscript was probably produced in the period 1260-128o, in the area around Geldern-Kleef, now in Germany. This makes it the oldest known source of Van den vos Reynaerde. The text numbers 63 partly damaged lines, which correspond to lines 2186-94, 2209-17, 2556-64, 2579-87, 3123-29, 3147-52, 3274-80, 3299-3305 in this edition..$^{50}$

In 1971 fragments of a fifth Reynaert manuscript $(\mathrm{J})$ were discovered in Brussels. Glued together with other fragments, they were used in the upper and lower covers of the binding of a printed book from the first half of the sixteenth century (now Brussels, Koninklijke Bibliotheek, ms. IV 774). It concerns six cropped paper folios (now $170 x 110 \mathrm{~mm}$ ), written in a single column of $30 / 33$ lines per page in a Cursiva, the cursive gothic bookscript. The manuscript to which the leaves originally belonged was produced in the first quarter of the fifteenth century in East Flanders. The text comprises 369 lines, roughly corresponding to lines 577-641, 830-91, 956-1023, 1465-1523, 1706-66, 2079-2142 in this edition..$^{51}$

Van den vos Reynaerde must have been a popular text in the medieval Low Countries. This is indicated by the fact that it survives in five manuscripts, a relatively large number for a narrative work - at least by Dutch standards - from a number of different regions (Flanders, the county of Holland, Limburg, Geldern/Kleef), but also that a fellow author was twice inspired by Willem's work. ${ }^{52}$

49 On fragment E (Darmstadt), see Martin 1889; Gysseling 1980, nr. 30; Staub \& Sänger 1991.

50 On fragment G (Rotterdam), see Muller 1940, pp. 204-9; Gysseling 1980, nr. 29. For fragment G as the remains of a minstrel's manuscript, see Besamusca 1987; this hypothesis was rejected in Gumbert 1989, pp. 117-19.

51 On fragment J (Brussels), see Deschamps 1975; Deschamps \& Mulder 1998.

52 For a general survey, see Janssens \& Van Daele 2001. 
It was probably in Bruges that an author who called himself Balduinus Iuvenis wrote a Latin adaptation. He dedicated his Reynardus vulpes to Jan van Vlaanderen (12501291), son of the Flemish count Gwijde van Dampierre and prior of the chapter of SintDonaas in Bruges. Balduinus begins as follows: Fabula Reynardi, sicut reor agnita multis teutonice scripta, metrificata sonet ('may the history of Reynaert, known as I think to many in Dutch, now sound in Latin verse'). The poem was written between 12721279, but has been preserved only in a rather corrupt printed edition, produced in the workshop of Ketelaer and De Leempt in 1473 or 1474 in Utrecht, which is extant in two copies: Deventer, Stads- or Atheneumbibliotheek, Inc. VIII C 8 (4) and Mainz, Priesterseminar, Ms. 165 (8). Balduinus integrally adopted the narrative structure of Van den vos Reynaerde and often stayed close to the Flemish text with his choice of words. However, he definitely also added emphases that are entirely his own, mainly by means of abbreviations and moralisations, and placed himself in the Latin literary tradition. The Reynardus vulpes was - and still is - used mainly by literary historians as an early source (L) of Van den vos Reynaerde..$^{53}$

Reynaerts historie, a poem of some 7800 lines, was written at least a century and a half later. In its first part the unknown Flemish poet follows Van den vos Reynaerde fairly accurately. However, in his version the fox does not flee into the wilderness, but stays at Mapertuus, while King Nobel extends the court day because of his reconciliation with Bruun and Ysegrim. A sequel of about 4300 lines has been added here, in which more charges are brought against Reynaert. At Nobel's court the fox defends himself against the accusations with the help of his clan. The trial ends in a judicial duel between Reynaert and Ysegrim, which the fox manages to decide in his favour. King Nobel next presents him with a high position in his realm. The text has been preserved in two manuscripts. The 'Brussels' manuscript (B), acquired in 1836 by the Koninklijke Bibliotheek in Brussels, where it is kept under shelfmark 14601, was produced around 1470 in the northern Low Countries, possibly in Utrecht, by a scribe who, according to two acrostics (in B 7805-7794) is called Claes van Aken. ${ }^{54}$ The fragments (C), formerly in the possession of Hendrik van Wijn, were acquired by the Koninklijke Bibliotheek of The Hague in 1834, and are now kept under shelfmark 75 B 7. According to the colophon, these 'the Hague' fragments are the remnants of a manuscript that was produced

53 For a description of the incunabulum containing Reynardus vulpes, see Campbell 1874, nr. 978; ILC 1862. A diplomatic edition based on the Deventer copy was made by Hellinga 1952. A critical edition based on the same Deventer copy was made by Huygens 1968. For a study of the adaptation techniques used, see Jonkers 1985. For a survey of the status quaestionis and suggestions for further research, see Engels 1996a, 1996b.

54 For a description of ms. B (Brussels), see Deschamps 1972, nr. 23a. The text is available in a facsimile edition (De Keyser 1938), a diplomatic edition (Hellinga 1952) and the critical edition by Wackers (2002), which replaces two nineteenth-century editions (Willems 1836; Martin 1874). For an edition of the Middle Dutch text with a German translation, see Schlusemann and Wackers 2005. 
in Holland in 1477. The text numbers 1055 lines, corresponding to B $6755-7793 .{ }^{55}$ Reynaerts historie was long studied primarily as a 'textual link': on the one hand as an adaptation and, consequently, a source of Van den vos Reynaerde, on the other hand as an exemplar of the printed editions by Leeu, Caxton and others (see below). Only in the past few decades has literary appreciation of the text begun.

The verse text of Reynaerts historie was printed (probably unchanged) between 1487 and 1490 by Gheraert Leeu in Antwerp, illustrated with woodcuts, divided into chapters by Hinrek van Alckmer, and provided with summarizing chapter headings and prose moralisations. ${ }^{56}$ Only seven leaves of this verse incunabulum (D) have survived (including four woodcuts), which are now kept in the University Library of Cambridge under shelfmark Inc. 4 F 6.2 (3367). The text corresponds to lines B 1513-88, 1639$55,1753-72,1780-890 .{ }^{57}$ Hinrek van Alckmer's name occurs in the prologue to a Lower German adaptation of the verse incunabulum, Reynke de vos (R). The only complete copy of this edition, printed in Lübeck in 1498, which also has woodcuts, chapter headings and prose moralisations, is kept in the Herzog August-Bibliothek in Wolfenbüttel (shelfmark 32. / 4 Poet. rar.). ${ }^{58}$ It should be noted that the text of Reynke de vos does not derive directly from $\mathrm{D}$, but from a now lost Dutch printed edition.

As Reynke de vos, the poem made a triumphant conquest of Europe, now documented in great detail by Hubertus Menke in his international Reynaert bibliography. ${ }^{59}$ The Low German text was reprinted up to 1660 , translated into High German in 1544 and into Danish in 1555. Publications in Swedish and Icelandic were based on the Danish edition, while the High German translation was reprinted no fewer than twenty-one times up to 1617. It spawned a number of subgroups, among them a set of seven Latin printed texts (1567-1612). On the basis of Gottsched's High German prose translation of Reynke de vos from 1752, Goethe composed his famous adaptation in hexameters: Reineke Fuchs, In zwölf Gesängen (1794). This poem established a tradition of its own, with translations into many languages.

A Middle Dutch prose adaptation of Reynaerts historie had already been printed by Gheraert Leeu in Gouda in 1479 and by Jacob Jacobsz. van der Meer in Delft in

55 For a description of fragment C (The Hague), see Deschamps 1972, nr. 23b. For a diplomatic edition of the text, see Hellinga 1952.

56 For a survey of the printed Dutch Reynaert tradition from the 15th to 19th century, see Wackers 2000 (in English).

57 For a description of verse incunabulum D, see Campbell 1874-189o, 2nd Suppl., nr. 977a; ILC 1861. For a reconstruction, see Naar de letter 1972, pp. 31-39. The D text is available in a facsimile edition (Breul 1927) and a diplomatic edition (Hellinga 1952).

58 The text of Reynke de vos is available in a facsimile edition (Sodmann 1976) and in an edition that includes a corresponding selection from the Middle Dutch versions (Goossens 1983a). For the sources of Reynke de vos, see Witton 1980.

59 See Menke 1992. 
1485 as Die historie van Reynaert die vos (Pg, Pd). Two copies are extant of the text that was printed in Gouda: The Hague, Koninklijke Bibliotheek, Inc. 169 G 98, and London, British Library, Inc. Grenville 10495. Of the book printed in Delft a single copy is extant: San Marino, Huntington Library, 100244 (PR 8873-5).$^{60}$ Two years after Leeu, William Caxton printed The history of reynaerd the fox (1481) in Westminster, translated by himself from a 'copye whiche was in dutche' (W); this is the beginning of an English Reynaert tradition that encompasses three centuries. It is likely that Pg was not the first printed prose Reynaert, as neither Pd nor W appear to derive directly from Pg. The prose editions share a division into chapters with summarizing headings, but lack the moralisations and the woodcuts that grace the rhymed version. ${ }^{61}$

The so-called Reynaert chapbooks produced in the Low Countries can be divided into three groups. ${ }^{62}$ These are the sixteenth-century luxury publications by Plantijn $\left(\mathrm{H}_{1564}, \mathrm{H}_{1566}\right)$, the chapbooks from the northern parts of the Low Countries ( $\mathrm{Hn}$ : $16^{\text {th }}-18^{\text {th }}$ century) and those from the southern Low Countries (Hz: $17^{\text {th }}-20^{\text {th }}$ century). ${ }^{63}$ Various printed editions must have been lost; some are known only because they are referred to somewhere, or are hypothetical. Each of the three groups is in its own way based on a reconstructed printed edition $(\mathrm{H})$, for which material is believed to have been derived from the tradition of both $\mathrm{D}$ (prologue and illustrations) and $\mathrm{P}$ (prose text). ${ }^{64}$ The adaptation techniques used in the chapbooks - abbreviation, simplification, moralisation, alteration of offensive passages (a frequent phenomenon in printed texts in the Southern Low Countries which were subject to ecclesiastical censure) - have proved rewarding objects of research. ${ }^{65}$

The rediscovery at the beginning of the nineteenth century of the medieval manuscripts containing Van den vos Reynaerde in combination with the fascination with the past that Romanticism had aroused, created an immense interest in the Reynaert material. In the newly formed state of Belgium (dominated by a French-speaking elite) this

60 For a description of the printed editions in prose Pg and Pd, see Campbell 1874, nos. 976 and 977; ILC 1859, 1860. The text of Pg, based on the copy in The Hague, is available in a diplomatic edition (Hellinga 1952 and Rijns 2007); for variants in Pd as compared to Pg, see Rijns 2007.

61 For the printing history of the prose adaptations, see Hellinga 1965; Vriesema 1980; Witton 1980; Goossens 1983 (woodcuts); Schlusemann 1991.

62 For a bibliography of the so-called Reynaert chapbooks, see Verzandvoort \& Wackers 1983; Menke 1992.

63 The text of a number of chapbooks has been published. For H1564, see Martin 1876, Rijns 2007; for H1566, see Sabbe and Willems 1924, Rijns 2007; for Hn1589, see Rijns 2007; for Hn, ca. 1780, see Merlijn 1975; for Hz, 1651, see Rijns 2007; for Hz, ca. 1700, see Verzandvoort and Wackers 1988, Rijns 2007. Rijns 2007 provides diplomatic and synoptic editions of the sources between $1479(\mathrm{Pg})$ and $1700(\mathrm{~Hz})$.

64 On the relationships among the Reynaert chapbooks, see Naar de letter 1972, pp. 70-82; Goossens 1981.

65 For an analysis of adaptation techniques in Reynaert chapbooks, see Goossens 1988; Wackers \& Verzandvoort 1989. 
interest was further strengthened by the 'flamingants', a Flemish emancipatory movement that drew upon the cultural achievements of their medieval ancestors to demand equal rights. Editions of the Middle Dutch texts, as well as a large number of modern adaptations for the entertainment of both adult and young readers were the result. ${ }^{66} \mathrm{In}$ Dutch literary histories, Van den vos Reynaerde now takes pride of place.

66 For a survey of adaptations of Van den vos Reynaerde from the 19th and 2oth centuries, see Goossens 1988; for an analysis of these texts, see Van Daele 1990, Goossens 1996a. 


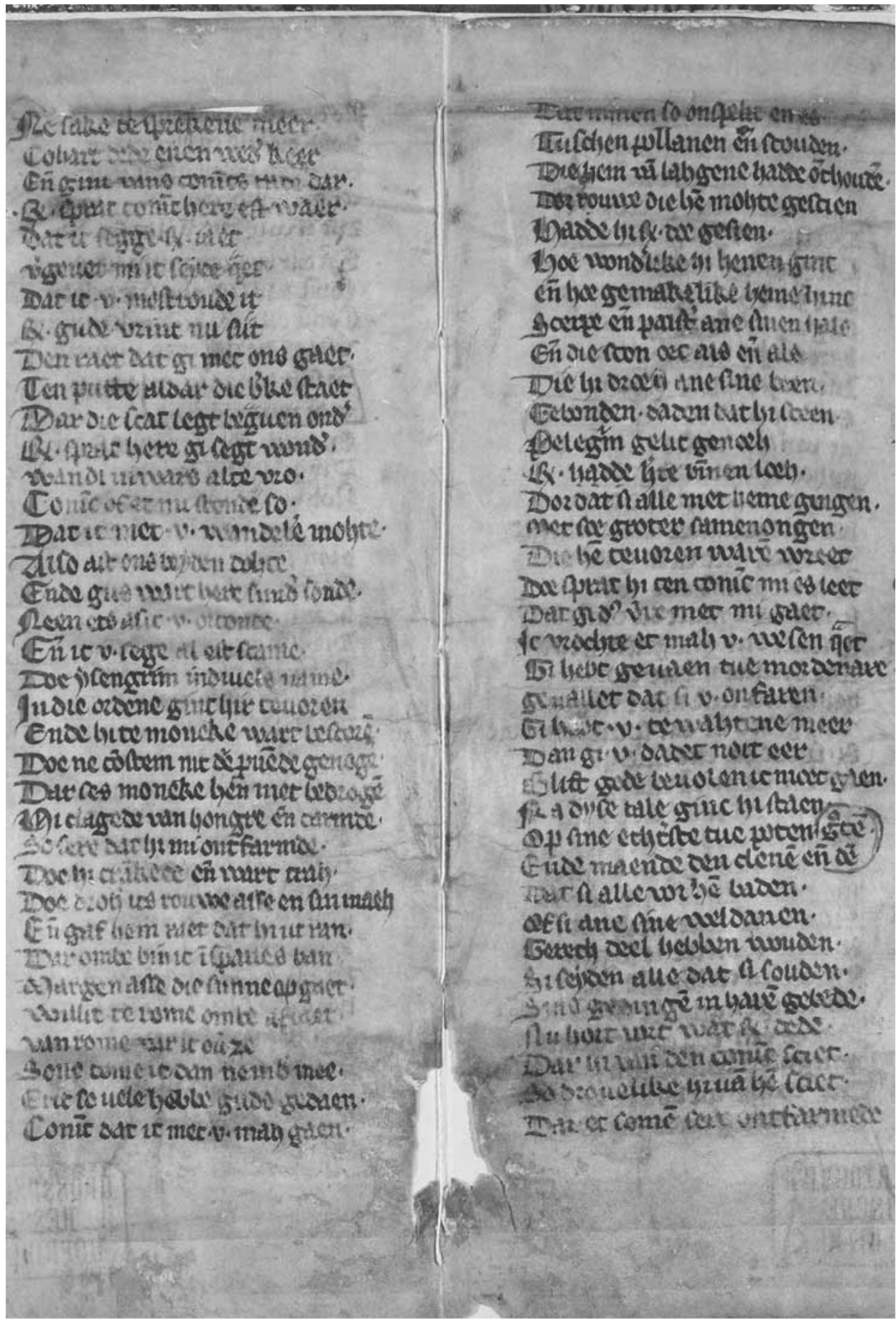




\section{Text, translation and notes}

About the translation - The English translation of Willem's Van den vos Reynaerde aims to present readers who are not familiar with Middle Dutch with a narrative that may be enjoyed in its own right, while it follows at the same time the Middle Dutch text as closely as is reasonably possible. Lines are kept parallel, unless this would result in distorted grammar and style, but any lack of parallelism never extends beyond two or three lines. Thus readers of the translation will find it easy to refer to the original text. Tenses in medieval - including Middle Dutch - texts tend to sway between present and past. These alternations have mostly been preserved in the translation as they rarely hinder comprehension. The anthropomorphic animals are referred to by pronouns usually reserved for human beings. For the names of the animals one form is used consistently in the translation; this is the form listed as headword in the Index of proper names.

Thea Summerfield 
Willem die Madocke maecte,

daer hi dicken omme waecte,

hem vernoyde so haerde

dat die avonture van Reynaerde

5

in Dietsche onghemaket bleven

- die Arnout niet hevet vulscreven -

dat hi die vijte dede soucken

ende hise na den Walschen boucken

in Dietsche dus hevet begonnen.

10

God moete ons ziere hulpen jonnen!

$\mathrm{Nu}$ keert hem daertoe mijn zin

dat ic bidde in dit beghin

beede den dorpren enten doren,

ofte si commen daer si horen

15 dese rijme ende dese woort

(die hem onnutte sijn ghehoort),

dat sise laten onbescaven.

Te vele slachten si den raven,

die emmer es al even malsch.

Si maken sulke rijme valsch,

daer si niet meer of ne weten

dan ic doe hoe dat si heeten

$[192 \mathrm{vb}]$

die nu in Babilonien leven.

Daden si wel, si soudens begheven.

25 Dat en segghic niet dor minen wille.

Mijns dichtens ware een ghestille, ne hads mi eene niet ghebeden

die in groeter hovesscheden

1 A Middle Dutch story about Madoc has not come down to us, but there are strong indications that a work with this title did at one time exist. Willem's earlier tale probably told of a dream that Madoc had, as seems to be suggested in Maerlant's Rijmbijbel (cf. p. 16). Madoc is sometimes considered to have been a story about a seafarer's adventures.

6 It has been suggested that Van den vos Reynaerde was written by two poets and that Willem completed Arnout's unfinished work. However, serious objections may be raised to this notion of joint authorship. Assuming that the name was not an invention, it seems probable, also in view of the emphatic Walsch-Dietsch (French-Dutch) contrast in the lines before and after the name, that Arnout was a French Renart poet (cf. p. 15).

13 dorpren ('peasants') refers to non-courtly persons. 


\section{Prologue}

Willem who made Madocke, which often kept him awake, was so extremely annoyed that the tales of Reynaert

5 - which Arnout has not finished remained unwritten in Dutch that he had the life looked for and, following the French books, he began it in Dutch as follows. May God favour us with his help!

Now I am of a mind to urge at this beginning both peasants and fools whenever they happen to hear

15 the rhyme and these words (which are wasted on them), that they leave them unchanged. They too much resemble the raven who always thinks he knows it all. They claim that many verses are untrue which they know no more about than I know what the people are called who now live in Babylon. If they were sensible, they would give up.

I am not saying this for myself.

I would not have written this poem if a certain lady had not asked me who likes to conduct her affairs

23 Babilonien ('Babylon') is used here in a hyperbolic comparison to indicate a proverbially distant, foreign place. It may well be the case that the oblique reference to biblical Babylon, the scene of linguistic 'babel', is intentional. Genesis 11 describes how building the tower of Babel led to the rise of multiple languages and the resulting confusion and incomprehension among people.

26 Literally the Middle Dutch phrase reads: 'my poetry writing would only be silence'. 26-31 Willem claims to have written his verse romance at the request of a courtly lady, whom he does not, however, name. It is usually assumed that, rather than having a real, existing person in mind, the poet parodied the medieval custom of dedicating writings to the nobility, and especially to noble women. 
gherne keert hare saken.

30 Soe bat mi dat ic soude maken dese avontuere van Reynaerde.

Al begripic die grongaerde ende die dorpren ende die doren, ic wille dat dieghene horen

35 die gherne pleghen der eeren ende haren zin daertoe keeren dat si leven hoofschelike, sijn si arem, sijn si rike, diet verstaen met goeden sinne.

$40 \quad$ Nu hoert hoe ic hier beghinne!

Het was in eenen tsinxendaghe dat beede bosch ende haghe met groenen loveren waren bevaen. Nobel die coninc hadde ghedaen

45 sijn hof crayeren overal, dat hi waende, hadde hijs gheval, houden ten wel groeten love. Doe quamen tes sconinx hove alle die diere, groet ende cleene,

50 sonder vos Reynaert alleene. Hi hadde te hove so vele mesdaen dat hire niet dorste gaen. Die hem besculdich kent, ontsiet. Also was Reynaerde ghesciet 55 ende hieromme scuwedi sconinx hof, daer hi in hadde crancken lof. Doe al dat hof versamet was, was daer niemen, sonder die das, hi ne hadde te claghene over Reynaerde,

42-48 The initially harmonious atmosphere is evoked by means of a so-called 'Natureingang': it is spring and trees and hedgerows are covered in green leaves (see also 322-26). The 
in a very courtly manner.

30 She asked me to make this story about Reynaert.

Although I denounce the nit-pickers and the peasants and the fools, I wish it to be heard by those

35 who like to act honourably and put their minds to living in a courtly way, whether they be poor or rich, and who will understand it properly.

$40 \quad$ Nowhear how I begin!

\section{King Nobel holds court}

It was on a day at Whitsuntide when trees and shrubbery alike were dressed all over with green leaves.

Nobel the King had had his court-day proclaimed everywhere, which, he thought, - all being well would greatly increase his fame. Then came to the king's court all the animals, large and small, except for Reynaert the fox alone. He had behaved so badly at court that he did not dare go. Whoever is knowingly guilty, is afraid. This was the case with Reynaert and that is why he avoided the king's court where his esteem was low. When the entire court had gathered there was nobody, except the badger, who did not have some reason for complaining of 
60 den fellen metten grijsen baerde.

$\mathrm{Nu}$ gaet hier up eene claghe.

Isingrijn ende sine maghe

ghinghen voer den coninc staen.

[193ra]

Ysengrijn begonste saen

65 ende sprac: 'Coninc heere,

dor hu edelheit ende dor hu eere

ende dor recht ende dor ghenade,

ontfaerme hu miere scade

die mi Reynaert heeft ghedaen,

70 daer ic af dicken hebbe ontfaen

groeten lachter ende verlies.

Voer al dandre ontfaerme hu dies

dat hi mijn wijf hevet verhoert

ende mine kindre so mesvoert

dat hise beseekede daer si laghen, datter twee noint ne saghen

ende si worden staerblent.

Nochtan hoendi mi sent.

Het was sint so verre comen

80 datter eenen dach af was ghenomen

ende Reynaerd soude hebben ghedaen

sine onsculde. Ende also saen

alse die heleghe waren brocht,

was hi andersins bedocht

85 ende ontfoer ons in sine veste.

Heere, dit kennen noch die beste

die te hove zijn commen hier.

Mi hevet Reynaert, dat felle dier,

62-71 In the course of the court day Ysingrijn the wolf, supported by his relatives, brings charges against Reynaert. Medieval feudal society initially lacked a strong, central source of authority. The authorities usually prosecuted only after the injured party had made a formal complaint. See also the 'complaint' made by Cortoys, and by Pancer/Cuwaert and Cantecleer later in the story.

72-77 In branch II of the Roman de Renart (Martin 1882-1887, 1027-1396) the fox finds himself in the wolves' lair by accident. After Haersint, the she-wolf, has agreed to have sexual intercourse with Reynaert, the latter urinates on her cubs and leaves the lair. Once her husband has returned, the she-wolf tries to convince him without much success that she has been raped. A few days later the two wolves chase the fox. When the she-wolf gets stuck in the 
60 Reynaert, the scoundrel with the grey beard.

Now a charge is made against him.

Ysingrijn and his relatives

took up their positions before the king.

Ysingrijn began at once

65 and said: 'My Lord King,

for the sake of your nobility and of your honour,

and for the sake of justice and of mercy,

take pity on the harm

inflicted upon me by Reynaert,

through whom I have often incurred

great humiliation and loss.

Take pity especially because

he has had his way with my wife

and has maltreated my children so badly

75 that, by pissing on them where they lay,

two of them lost their sight

and are now totally blind.

In addition he later disgraced me.

It had by then come to such a pass

80 that a day had been appointed

when Reynaert should swear

his innocence in court. But as soon

as the relics were brought,

he changed his mind

85 and escaped us in his stronghold.

My lord, this is well known among the highest

of those who have come here to court.

Reynaert, that vicious animal,

narrow entrance to the fox's den, she is raped, in full view of the approaching wolf, by Renart who has left his den by another exit. Ysingrijn's complaint concerns the rape; for obvious reasons he remains silent about his wife's adultery (cf. pp. 32-33).

73 verhoert is ambiguous; apart from meaning 'raped', it refers to sexual fulfilment.

79-85 Reynaert's escape when about to swear his innocence is seen in a different light when the story of Ysingrijn's devious plan, recounted in branch Va of the Roman de Renart, is taken into account (Martin 1882-1887, 1091-1272). There the fox flees because he discovers just in time that the holy relics on which he was to swear were in fact the teeth of the dog Roonel, who was shamming death. The wolf's biased version of events clearly demonstrates that he is dissembling (cf. p. 33). 
so vele te leede ghedaen,

9o ic weet wel al sonder waen:

al ware al tlaken paerkement

dat men maket nu te Ghent, inne ghescreeft niet daeran.

Dies zwijghics nochtan,

95 neware mijns wives lachter

ne mach niet bliven achter, no onversweghen no onghewroken.'

Doe Ysengrijn dit hadde ghesproken, stont up een hondekijn, hiet Cortoys,

100 ende claghede den coninc in Francsoys

hoet so arem was wijleneere

dat alles goets en hadde meere

in eenen winter, in eene vorst,

dan alleene eene worst

105 ende hem Reynaert, die felle man,

die selve worst stal ende nam.

Tybeert die cater die wart gram.

Aldus hi sine tale began

ende spranc midden in den rinc

ende seide: 'Heere coninc,

dordat ghi Reynaerde zijt onhout,

so en es hier jonc no hout,

hi ne hebbe te wroughene jeghen hu.

Dat Cortoys claghet nu,

115 dats over menich jaer ghesciet.

Die worst was mine, al en claghic niet.

Ic hadse bi miere lust ghewonnen

daer ic bi nachte quam gheronnen

omme bejach in eene molen,

120 daer ic die worst in hadde ghestolen

eenen slapenden molenman.

Hadder Cortoys yewet an,

97 no onversweghen: onversweghen may be a scribal error for versweghen, but it could also be argued that this is a slip of the tongue on Ysingrijn's part ("nor not hushed up").

107 Tybeert die cater: although the text specifies that Tybeert is a male cat or tomcat, we translate 'cater' as 'cat', in accordance with usual practice. 
has done me so much harm;

go I am quite convinced:

if all the cloth now made in Ghent

were parchment, I should not have

enough to describe it all.

That is why I prefer to be silent about it,

95 but my wife's disgrace

must neither be overlooked,

nor not hushed up, nor remain without revenge.'

When Ysingrijn had spoken thus

a small dog stood up, called Cortoys,

100 and complained to the king in French

how a while ago it had been so poor

that it had had nothing left

one winter when there was a frost

except for one sausage

105 and that Reynaert, the scoundrel, had stolen that very sausage from him.

Tybeert the cat was roused to fury.

This is how he began his speech

and he jumped into the middle of the circle

110 and he said: 'My Lord King,

because you bear Reynaert ill will

there is no one here, young nor old,

or he has something to charge him with before you.

What Cortoys is complaining of now

115 happened many a year ago.

The sausage was mine, but I don't complain.

I had got hold of it craftily

when one night, looking for something to bag,

I went into a mill

120 where I stole the sausage

from a sleeping miller.

If Cortoys profited by it at all

107-25 Tybeert argues that Cortoys' complaint is not admissible: the sausage belonged to the cat, who in his turn had stolen it from a sleeping miller. As the miller was traditionally renowned for sexual prowess in the Middle Ages, the sausage may have ambiguous implications.

117 lust is ambiguous, meaning both 'clever trick' as well as 'lust'. 
dan was bi niemene dan bi mi.

Hets recht dat omberecht zi

125 die claghe die Cortoys doet.'

Pancer de bever sprac: 'Dinct hu goet,

Tybeert, dat men die claghe ombeere?

Reynaert es een recht mordeneere

ende een trekere ende een dief.

130 Hi ne heeft oec niemene so lief, no den coninc, minen heere, hi ne wilde dat hi lijf ende eere verlore, mochtire an winnen een vet morzeel van eere hinnen.

135 Wat sechdi van eere laghe? En dedi ghistren in den daghe eene die meeste overdaet an Cuwaerde den hase, die hier staet, die noyt eenich dier ghedede?

140 Want hi hem binnen sconinx vrede ende binnen des coninx gheleede ghelovede te leerne sinen crede ende soudene maken capelaen.

Doe dedine sitten gaen

145 vaste tusschen sine beene.

Doe begonsten si overeene spellen ende lesen beede ende lude te zinghene crede. Mi gheviel dat ic te dien tijden

150 ter selver stede soude lijden. Doe hoerdic haerre beeder sanc ende maecte daerwaert minen ganc met eere arde snelre vaerde. Doe vandic daer meester Reynaerde, 155 die ziere lessen hadde begheven

\footnotetext{
140-41 King Nobel has proclaimed peace, which meant that his subjects were not allowed to carry weapons or to pursue old feuds. Reynaert's attempt on Cuwaert's life is, therefore, also a breach of the king's peace. This undermines Nobel's authority, as Pancer the beaver remarks at the end of his speech (165-69).

142-48 It has been suggested that the expressions maken capelaen ('make chaplain') and
} 
this was entirely my doing.

It would only be right to dismiss

the complaint that Cortoys makes.'

Pancer the beaver spoke: 'Do you think it right, Tybeert, that the complaint should be dismissed?

Reynaert really is a murderer and a cheat and a thief.

Also, there is nobody he likes so much, not even my lord the king, that he would not wish him to lose life and honour if that might get him a succulent bite of a chicken.

135 And a trap, what do you say of that? Did he not yesterday, in broad daylight, perpetrate one of the worst crimes ever committed by any animal against Cuwaert the hare, standing here?

140 For at a time when the king's peace and safe conduct have been proclaimed, he promised to teach him the creed and to make him chaplain. Then he made him sit tightly between his legs. Together they began to practice spelling and reading and to sing the creed loudly. It so happened that at this moment

150 I passed that place.

Then I heard them singing together and went in that direction, at a great speed.

Then I found master Reynaert there

155 who had finished

zingen crede ('sing the creed') should be read as scabrous allusions to masturbation and sexual intercourse respectively. If this is correct, Reynaert and Cuwaert committed the sin that should not be named in the Middle Ages (the crimen nefandum): homosexual love. See in this context also 144-45. This interpretation is supported by a marginal decoration, depicting a very frightened hare with a bloodied bottom, holding a book (cf. Meuwese 2006). 
die hi tevoren up hadde gheheven, ende diende van sinen houden spelen ende hadde Coewaerde bi der kelen ende soude hem thoeft af hebben ghenomen

160 waer ic hem niet te hulpen comen bi avontueren in dien stonden. Siet hier noch die verssche wonden ende die teekine, heere coninc, die Coewaert van hem ontfinc.

165 Laetti dit bliven onghewroken, dat hu verde dus es tebroken, ghi ne wreket als huwe mannen wijsen, men saelt huwen kindren mesprijsen hiernaer over wel menich jaer.'

170 'Bi Gode, Pancer, ghi secht waer,' sprac Ysengrijn daer hi stoet. 'Heere, waer Reynaerd doot, het waer ons goet, also behoude mi God mijn leven. Neware wert hem dit vergheven, 175 hi sal noch hoenen binnen eere maent sulken dies niet ne bewaent.' Doe spranc up Grinbert die das, die Reynaerts broedersone was, met eere verbolghenlike tale:

180 'Heere Ysengrijn, men weet dat wale ende hets een hout bijspel: viants mont seit selden wel. Verstaet, neemt miere talen goem: ic wilde, hi hinghe an eenen boem

185 bi ziere kelen als een dief die andren heeft ghedaen meest grief.

162-64 The person bringing the charge can strengthen his case by supplying evidence. That is why Pancer points to his relative Cuwaert's fresh wounds. A well-known example from Germanic legal practice is the complaint with the dead man: the victim's body is brought to the court of law by his relatives and is shown when the charge is made. This is also the reason why Cantecleer will bring his daughter Coppe's dead body to the court on a bier (283-90).

177-282 In his plea for the defence Grimbeert the badger first proposes a reconciliation between the fox and Ysingrijn, Reynaert's most powerful enemy. He argues that this is the 
his earlier lesson

and was up to his old tricks

and he had Cuwaert by the throat

and would have bitten his head off

160 if I had not accidentally

come to his aid at that moment.

See here the fresh wounds

as evidence, lord king,

which Cuwaert sustained by his doing.

165 If you leave unpunished in this way

the disturbance of your peace, ignoring the verdict of your barons, it will be held against your children for many years to come.'

170 'By God, Pancer, what you say is true,' said Ysingrijn from where he stood. 'Lord, it would be a good thing for us all if Reynaert were dead, so help me God.

But if he is pardoned for this,

175 he is sure to trick within a month those of us who are not prepared for it.'

Then Grimbeert the badger jumped up, who was Reynaert's brother's son, and spoke these angry words:

180 'Lord Ysingrijn, as everyone surely knows and it is an old saying: Sweet words rarely fall from the enemy's mouth. Listen, pay attention to my words:

I would wish that the one who

185 has caused the other most grief were hanged by the neck from a tree like a thief.

more appropriate as in his view the wolf has caused Reynaert more harm than the other way around (177-202). When this clever counter-accusation is called a lie (203-4), Grimbeert takes the time to support his claim (205-32), after which he disproves the actual charges made against the fox. He interprets the rape as adultery between courtly lovers, the theft of the sausage as the confiscation of stolen goods, and dismisses the attack on Cuwaert as a master's chastisement of a recalcitrant pupil (233-62). Finally Reynaert is depicted as a redeemed sinner who now lives the life of a hermit and fasts $(263-82)$. For the first time in the story the problem of the relationship between rhetoric and reality is raised (cf. pp. 21-22). 
Heere Ysengrijn, wildi angaen soendinc ende dat ontfaen, daertoe willic helpen gherne.

190 Mijn oem en saelt hem oec niet wernen.

Entie meest andren heeft mesdaen

sal den andren in baten staen van minen oem ende van hu. Al comt hi niet claghen nu, 195 ware mijn oem wel te hove ende stonde in sconinx love, heere Ysengrijn, als ghi doet, en soude den coninc niet dincken goet ende ghi ne bleves heden onbegrepen,

200 dat ghi sijn vel so hebt ghenepen so dicwile met huwen scerpen tanden, dat hi niet ne conde ghehanden.' Ysengrijn sprac: 'Hebdi gheleert an huwen oem dus lieghen apeert?'

205 'In hebbe daeran niet gheloghen. Ghi hebt minen oem bedroghen arde dicke in menegher wijsen. Ghi mesleettene van den pladijse die hi hu warp van der kerren, 210 doe ghi hem volghet van verren ende ghi die beste pladijse uplaset, daer ghi hu ane hadt versadet. Ghi ne gaeft hem no goet no quaet, sonder alleene eenen pladijsengraet

215 dat ghi hem te jeghen brocht, dordat ghine niet en mocht. Sint hoendine van eenen bake die vet was ende van goeder smake, dien ghi leit in huwen muzeele.

187-88 Grimbeert suggests that the wolf should make a promise of reconciliation and accept a similar promise on the fox's part.

208-16 In branch III of the Roman de Renart the fox shams death in the middle of the road when a cart with a load of fish approaches. When he has been tossed on to the cart on account of his valuable pelt, he makes a meal of the fish (Martin 1882-1887, 1-164). Grimbeert twists 
Lord Ysingrijn, should you wish

to agree to a settlement,

I will be pleased to assist.

190 My uncle will not make objections either.

And whoever is the worst miscreant, whether it be my uncle or you, he will owe the other party compensation.

Even though he is not now appearing to make a complaint,

195 if my uncle's standing at court was high and if he enjoyed the king's favour

- as you do, Lord Ysingrijn -

the king would not approve of it

and you would not escape punishment this time

200 for having ravaged his skin

so often with your sharp teeth, while he had no way of taking revenge.'

Ysingrijn spoke: 'Have you learned from your uncle to lie so blatantly?'

205 - 'I have not told any lies.

You have deceived my uncle very often and in many different ways.

You cheated him when he threw you

the plaice from the cart,

210 while you followed him at a distance

and picked up the best plaice

with which you satisfied your hunger.

You gave him nothing at all,

except for the bones of one single plaice,

215 which you offered him

because you did not fancy them any more.

Later you cheated him with a side of bacon

that had much fat on it and was very tasty,

which you took between your jaws.

this story in such a way that it makes Ysingrijn appear in a bad light. In the badger's version Reynaert is in the wolf's company. In the same way as the wolf owes his success in appropriating a ham to the fox, showing his gratitude by leaving nothing but the string from which it was hung (217-19), he here devours the plaice that Reynaert throws down to him from the cart, leaving nothing but the bones of one single fish (cf. p. 31-32). 
Doe Reynaert heesschede zijn deele, andwoerdi hem in scerne:

"Hu deel willic hu gheven gherne,

Reynaert, scone jonghelinc!

Die wisse daer die bake an hinc,

225 becnause, so es so vet."

Reynaerde waes lettel te bet

dat hi den goeden bake ghewan

in sulker zorghen, dattene een man

vinc ende warpene in sinen zac.

230 Dese pine ende dit onghemac

hevet hi leden dor Ysengrijne

ende ondert waerven meer dan ic hu rijme.

[194ra]

Ghi heeren, dinct hu dit ghenouch?

Nochtan om meer onghevouch

235 dat hi claghet om sijn wijf,

die Reynaerde hevet al haer lijf

ghemint; so doet hi hare.

Al ne makeden zijt niet mare,

ic dart wel segghen over waer

240 dat langher es dan VII jaer

dat Reynaert hevet hare trauwe.

Omdat Haersint, die scone vrouwe,

dor minne ende dor quade zede

Reynaert sinen wille dede,

245 wattan? So was sciere ghenesen.

Wat talen mach daeromme wesen?

Nu maket heere Cuwaert, die hase, eene claghe van eere blase.

Of hi den credo niet wel en las,

250 Reynaerd, die zijn meester was, mochte hi sinen clerc niet blauwen?

Dat ware onrecht, entrauwen.

217-29 After the distorted story of the theft of the fish Grimbeert relates a shortened version of the theft of the ham in branch V of the Roman de Renart (Martin 1882-1887, 1-148). In this way the badger emphasizes once again the greed and malice of the wolf, who broke the agreement to share the booty and fobbed Reynaert off with the string for hanging the side of bacon. 236 al haer lijf is ambiguous; it means both 'all her life' and 'with all her body'. Cf. also 1978, 1988. 
When Reynaert demanded his share,

you mocked him and said:

"I should like to give you your share,

Reynaert, my dear young man!

The string from which the bacon was hung,

225 chew on it, it is very greasy."

Reynaert was little better off

for having got hold of the fine side of bacon,

with the risk that someone

would catch him and toss him into his bag.

230 This grief and this trouble

he suffered through Ysingrijn's doing

and a hunderd times more than I am telling you.

My lords, don't you think this is enough?

It is the more disgraceful

235 that he complains of his wife

who has loved Reynaert

all her life, and he her.

Even though they did not make it known,

I dare declare as the truth

240 that for more than seven years

Reynaert has had her faithful devotion.

If a beautiful woman like Haersint

accommodated Reynaert

on account of her love and lecherous habits,

245 so what? She soon got over it.

Why bother wasting words on it?

Now Lord Cuwaert, the hare, is turning a trifle into a complaint.

If he failed to read the creed as he should,

250 why should not Reynaert, his master,

be allowed to beat his pupil?

Surely, that would not be right.

243 Manuscript $\mathrm{F}$ reads dur hoveschede instead of dor quade zede. The reading in the Comburg manuscript makes sense: by saying that the she-wolf loved Reynaert as she lacks decency, Grimbeert implies that he disapproves of Haersint's behaviour, hoping in this way to impress the king favourably. Nevertheless the reading in F fits the context better: after all, Grimbeert means to argue that the fox and the she-wolf are courtly lovers.

245 This line is ambiguous; it means both 'she soon got over it' and 'she soon reached a climax'. 
Cortoys claghet om eene worst die hi verloes in eene vorst.

255 Die claghe ware bet verholen: ende hoerdi dat so was ghestolen? Male quesite male perdite: over recht wert men qualike quite dat men hevet qualic ghewonnen.

260 Wie sal Reynaerde dat verjonnen of hi ghestolen goet ghinc an? Niemen die recht versceeden can. Reynaert es een gherecht man. Sint dat die coninc sinen ban

265 hevet gheboden ende sinen vrede, so weetic wel dat hi ne dede dinc negheene dan of hi ware hermite ofte clusenare. Naest siere huut draecht hi een hare.

270 Binnen desen naesten jare so ne hat hi vleesch, no wilt no tam.

Dat seidi die ghistren danen quam. Malcroys hevet hi begheven, sinen casteel, ende hevet upheven

275 eene cluse daer hi leghet in. Ander bejach no ander ghewin so wanic wel dat hi ne hevet dan karitate die men hem ghevet. Bleec es hi ende magher van pinen.

280 Hongher, dorst, scerpe karijnen doghet hi voer sine zonden.' Recht te desen selven stonden, doe Grimbert stont in dese tale, saghen si van berghe te dale

285 Canticler commen ghevaren, ende brochte up eene bare eene doode hinne ende hiet Coppe,

257 Garbled Latin for 'male quaesita male perdita', literally: 'badly acquired, badly lost goods', or 'stolen goods never thrive'. 
Cortoys complains of a sausage

that he lost in a frost.

255 The charge had better not been made:

didn't you hear that it had been stolen?

Male quesite male perdite:

It is right to lose in an unlawful way

that which has been acquired by unlawful means.

260 Who will blame Reynaert

for confiscating stolen goods?

Surely no one conversant with the law.

Reynaert is a law abiding man.

Since the king proclaimed his peace

265 on pain of punishment,

I know for a fact

that he behaved no worse than

if he were a hermit or a recluse.

Next to his skin he wears a hair shirt.

270 Within the past year he ate no meat, neither of wild nor tame animals.

So someone said who yesterday came from there.

He has left Malcroys,

his castle, and has built a cell

275 where he now lives.

He surely has no other possessions

or income

than the alms given him.

Pale he is and thin with doing penance.

280 Hunger, thirst, sharp chastisement

he suffers for his sins.'

Just at that moment

while Grimbeert thus stood pleading,

they saw Canticleer

285 coming down the hill,

who on a bier brought

a dead hen called Coppe;

273 Malcroys, i.e. evil hole, is one of Reynaert's fortresses, but it is not his strongest. See also the note to line 512 . 
die Reynaert hadde bi den croppe

hoeft ende hals afghebeten.

290 Dit moeste nu de coninc weten.

Canteclere quam voer de bare gaende,

sine vederen zeere slaende.

In wederzijden van der baren

ghinc een hane wijde mare.

295 Die een hane hiet Cantaert, daer wijlen na gheheeten waert

Vrauwe Alenten goeden hane.

Die ander hiet, na minen wane, die goede hane Crayant,

300 die scoenste hane die men vant tusschen Portaengen ende Polane.

Elkerlijc van desen hanen

drouch eene berrende stallicht, dat lanc was ende richt.

305 Dat waren Coppen broeders twee, die riepen: 'O wy' ende 'wee'.

Om haerre sustre Coppen doot

dreven si claghe ende jammer groot.

Pinte ende Sproete droughen die bare.

310 Hem was te moede zware van haerre suster die si hadden verloren.

Men mocht arde verre horen

haerre tweer carminghe.

Dus sijn si commen int ghedinghe.

315 Canticler spranc in den rijnc

ende seide: 'Heere coninc,

dor God ende dor ghenade, nu ontfaermet miere scaden

die mi Reynaert heeft ghedaen

ende minen kinderen die hier staen

ende seere hebben haren onwille.

293-301 Cantaert is so famous that Lady Alente at one time named her cock after him. It is not impossible that historic persons (a noble lady and her lover?) are alluded to here, but part of the joke is also the interplay between fiction and reality. Cantaert is a fictional cock and owes his fame entirely to the story's author. In other words, in Willem's poem a 'cock' 
Reynaert had bitten her head and neck off by the throat.

290 This the king had to know. Canticleer walked in front of the bier, beating his wings vehemently. On either side of the bier walked a cock of renown.

295 One was called Cantaert, whose name was in the past given to Lady Alente's noble cock. The other one was, if I am right, the noble cock Crayant, the handsomest cock one might find between Brittany and Poland.

Each of these cocks carried a lighted candle that was tall and straight.

305 They were Coppe's two brothers, crying 'woe' and 'welaway'.

For their sister Coppe's death they loudly complained and lamented. Pinte and Sproete carried the bier.

310 They were deeply saddened by the loss of their sister.

From a very large distance their joint lamentations might be heard. In this manner they arrived at the court.

315 Canticleer jumped into the circle and said: 'Lord King, for God's sake and the sake of mercy, take pity on my distress, caused by Reynaert on me

320 and on my children who are standing here greatly aggrieved.

is named after a cock made famous by Willem's poem ... The other cock (just as much a literary creation) is called Crayant, na minen wane, 'if I am right', the narrator says, as if he is not quite sure and as if this cock really exists and struts around outside the poem, somewhere between Brittany and Poland. 
Ten ingane van aprille, doe die winter was vergaen ende men siet die bloumen staen

325 over al die velde groene, doe was ic fier ende coene van minen groten gheslachte. Ic hadde jongher zonen achte ende jongher dochtren zevene,

330 dien wel lusten te levene, die mi Roede die vroede hadde brocht tenen broede. $S i$ waren alle vet ende staerc ende ghinghen in een scone paerc,

335 dat was beloken in eenen muere. Hierbinnen stoet eene scuere daer vele honden toe hoorden. Dat si menich dier fel scoorden, dies waren mine kindre onvervaert.

340 Dit benijdde dus Reynaert dat siere waren so vaste binnen dat hire negheen conste ghewinnen. Hoe dicken ghinc hi om den muere, Reynaert, die felle ghebuere, 345 ende leide om ons sine laghen! Alsene dan die honde saghen, liepen si na met haerre cracht. Eene waerf wart hi up de gracht bi avontueren daer belopen,

350 dat ic hem sach een deel becoepen sine diefte ende sinen roef, dat hem die pelse zeere stoef. Noch ontquam hi bi baraten.

Dattene God moete verwaten!

355 Doe waerwi zijns langhe quijte. Sint quam hi als een hermijte,

322-420 The image of the enclosed, safe yard in springtime repeats the harmonious beginning of the tale (41-47) and contrasts sharply with the cruel conclusion of Cantecleer's story. By producing a proclamation of peace with the king's seal appended and by posing as a pious 
In early April

when winter was gone away

and the flowers were seen

325 in all the green fields,

then I took pride and joy

in my large offspring.

I had eight young sons

and seven young daughters

330 that were full of life and which the sensible hen Roede

had given me in one brood.

They were all plump and strong

and walked about in a fair courtyard

335 enclosed by a wall.

Inside it was a barn

where many dogs were kept.

As they cruelly tore apart many a beast, my children felt no fear.

340 Reynaert could not bear the thought that they were so safe in there that he was unable to grab one.

How often did he walk around the wall, Reynaert, that vicious neighbour,

345 and set his traps for us!

Whenever the dogs spotted him

they pursued him with all their might.

One day when they caught up with him

by accident, near the ditch,

350 I saw how he paid to some extent

for his thieving and robbing:

the hairs of his pelt went flying about.

Even so he escaped by a ruse.

May God put a curse on him!

355 Then, for a long time, he did not trouble us.

Later he appeared dressed as a hermit,

hermit (and pilgrim, which seems mutually exclusive), Reynaert lured the credulous cock and his children to the area outside the fence and killed one of them. Eventually the predatory fox made eleven victims. (See for the spatial aspects of the episode, pp. 23-24). 
Reynaerd, die mordadeghe dief, ende brochte mi zeghele ende brief te lesene, heere coninc,

360 daer hu seghele ane hinc.

Doe ic die letteren began lesen, dochte mi daeran ghescreven dat ghi haddet coninclike over alle huwen rike

365 alle dieren gheboden vrede ende oec allen voghelen mede. Oec brochte hi mi ander niemare ende seide dat hi ware een begheven clusenare

370 ende hi hadde ghedaen vele zware voer sine zonden meneghe pine.

Hi toechde mi palster ende slavine, die hi brochte van der Elmare, daeronder eene scerpe hare.

375 Doe sprac hi: "Heere Cantecleer, nu mooghdi wel vorwaertmeer van mi sonder hoede leven. Ic hebbe bi der stolen vergheven al vleesch ende vleeschsmout.

380 Ic bem voertmeer so hout, ic moet miere zielen telen. Gode willic hu bevelen; ic ga daer ic hebbe te doene. Ic hebbe middach ende noene 385 ende priemen te segghene van den daghe." Doe nam hi neven eere haghe

361-66 The cock thinks that the sealed proclamation reads that King Noble has proclaimed his peace. The fact that he does not express himself with greater certainty indicates that he lacks sufficient proficiency as a reader. Cantecleer meant to ascertain whether he and his family had nothing more to fear, but his reading ability fell short of a proper understanding of the text. Could it be that he only recognized a few (Latin?) words?

373 Elmare was a monastery between Aardenburg and Biervliet, near present-day Waterland-Oudeman. Founded in 1144, it was a priory of St Peter's Abbey in Ghent from the thirteenth century onwards. For reasons unknown Willem considers this monastery important: later in the story Elmare is referred to again (cf. 1483 and 1493).

378 Reynaert underpins his story by claiming that he has had his oath to refrain from meat 
Reynaert, the murdering villain, and brought me a sealed writ to read, Lord King,

360 to which your seal was appended.

When I began to read the letters

I took them to signify

that you, by your royal power,

had declared in your entire kingdom

365 peace to all the animals

and to all the birds as well.

He also brought me other news

and said that he had entered

a reclusive order

370 and that he had often and most severely

done penance for his sins.

He showed me his pilgrim's staff and mantle

that he had brought from Elmare Priory,

a rough hair shirt underneath.

375 Then he said: "Lord Canticleer,

from now on you will be able to live

without having to protect yourself from me.

I have sworn on the stole

to abstain from eating all meat and dripping.

380 I am so old now

that I must look after my soul.

I commend you to God's care;

I go where duty calls me.

I am still to recite the daily Hours

385 of sext, nones, and prime today."

Then, along a hedge

and fat confirmed by a priest. The latter is said to have put the stole, the long shawl worn over his surplice, on Reynaert's head.

384-85 Reynaert lists a few of the liturgical hours in the wrong order. The Divine Office or Liturgy of the Hours is a set of daily prayers, said every twenty-four hours and divided into eight canonical hours (although in practice not always at three-hour intervals): matins (prayers said at midnight), lauds (at dawn), the four minor offices in the daytime: prime, terce, sext and none (originally prayers said at six, nine and twelve, and at three in the afternoon), vespers (evensong at sundown) and compline (the evening prayer before retiring). The fact that Reynaert's incorrect list fails to arouse Cantecleer's suspicions, indicates that the cock is no better acquainted with ecclesiastical life than the fox. 
sinen wech; te dien ghesceede

ghinc hi lesen sinen crede.

Ic wart blide ende onvervaert

390 ende ghinc te minen kindren waert

ende was so wel al sonder hoede

dat ic al met minen broede

sonder zorghe ghinc buten muere.

Daer gheviel mi quade avontuere,

395 want Reynaert, die felle saghe,

was ghecropen dor de haghe

ende hadde ons die porte ondergaen.

Doe wart miere kindre saen

een ghepronden huten ghetale;

400 dat leide Reynaert in sine male.

[195ra]

Quade avontuere mi doe nakede, want sint dat hise smakede in sinen ghiereghen mont, ne conste ons wachtre no onse hont

405 no bewachten no bescaermen.

Heere, dat laet hu ontfaermen:

Reynaert leide sine laghe

beede bi nachte ende bi daghe

ende roefde emmer mine kindre.

410 So vele es tghetal $n u$ mindre dant ghewone was te zine dat die XV kindre mine sijn ghedeghen al tote vieren;

so zuver heefse die onghiere

415 Reynaert in sinen mont verslonden.

Noch ghistren wart hem metten honden

ontjaghet Coppe die mare,

die hier leghet up dese bare.

Dit claghic hu met groeten zeere.

420 Ontfaremt hu mijns, wel soete heere!'

Die coninc sprac: 'Grimbeert die das,

416-37 As Cantecleer is able to support his complaint legally against Reynaert by showing Coppe's body, legal proceedings must now follow. The cock's story has made it abundantly clear that Reynaert has in no way bettered his life. Grimbeert, who finds his plea invalidated, 
he went his way that time, reciting the creed.

I was glad and free from fear

390 and went to my children and was so completely off my guard that, with all my brood, I went outside the wall without a care. There it was that disaster befell me, 395 for Reynaert, that evil piece of work, had crept through the hedge and had cut off our way to the gate. Then one of my children was rapidly taken from the group;

400 Reynaert led it into his stomach.

Evil events awaited me then, for when he had had a taste of her with his greedy mouth, neither guards nor our dogs

405 were able to shield or protect us. Lord, may this arouse your pity: Reynaert set his traps both by night and by day and continually robbed me of my children.

410 Their number is now so diminished from what it used to be that my fifteen children are now reduced to four; so thoroughly has that cruel Reynaert

415 devoured them with his maw. It was only yesterday that the dogs, chasing him, retrieved Coppe of great repute who is lying here on this bier. With great distress I bring this charge before you.

420 Take pity on me, dear Lord!'

The king said: 'Grimbeert the badger, 
hu oem, die clusenare was, hi hevet ghedaen so goede carine!

Levic een jaer, het sal hem scinen!

425 Nu hoert hier, Canticleer, wat sal der talen meer?

$\mathrm{Hu}$ dochter leghet al hier versleghen.

God moet haerre zielen pleghen.

Wi ne moghense niet langher houden

430 - God moeter al ghewouden ende sullen onse vygelyen zinghen.

Daerna sullen wise bringhen, den lichame, ter eerden met eeren. Dan sullen wi met desen heeren

435 ons beraden ende bespreken hoe wi best ghewreken an Reynaerde dese moort.' Doe hi ghesprac dese woort, beval hi jonghe ende houden

440 dat si vygelyen zinghen souden.

Dat hi gheboet, was sciere ghedaen.

Doe mochte men horen aneslaen ende beghinnen harde ho dat placebo domino

445 ende die verse die daertoe horen. Ic seit oec in waren worden, neware oec ware ons te lanc, wie daer der zielen vers zanc ende wie die zielenlesse las.

450 Doe die vygelye ghehent was, doe leide men Coppen in dat graf, dat bi engiene ghemaect was,

438-49 Noble gives orders for the officium defunctorum, the office for the dead, to be held (cf. the Rituale Romanum, Tit. VI, Cap. IV, dating prior to Vaticanum II). It concerns a wake (cf. vygelyen, 440), during which a prescribed series of texts and prayers was sung and recited for the soul of the deceased, spread over three liturgical hours: vespers, matins and lauds. The office begins with the antiphone 'placebo domino in regione vivorum' ('I will please the Lord in the land of the living'). These and other antiphones, short hymns, precede and follow the recitation of various psalms (cf. der zielen vers, 448); during matins three times three readings from the Book of Job (cf. die zielen lesse, 449) alternate with sung responses. 
your uncle, who was a hermit, certainly kept up his fast!

Give me a year and I'll show him!

425 Now listen, Canticleer,

what more is there to say?

Your daughter lies here murdered.

May God have mercy on her soul.

We cannot keep it here any longer

$430-$ it is now at God's command -

and we shall sing the vigil mass.

Afterwards we shall commit the body

to the earth honourably.

Next we shall take counsel

with these lords and discuss

how best to take revenge on

Reynaert for this murder.'

Having spoken these words

he ordered young and old

440 to sing the vigil mass.

What he ordered was done at once.

Then one could hear

how the placebo domino

was begun very loudly

445 as well as the verses following.

If it would not take too long

I would certainly also have mentioned

who sang the antiphones there

and who read the lesson.

450 When the vigil had ended

Coppe was laid in the grave

that had been made with ingenuity

446-49 For the first time in the story the narrator positions himself firmly as a commentator on the story. Using the pronoun 'I', he informs his public that he has shortened his account somewhat to avoid long-windedness. For other passages where the narrator addresses the public, using the personal pronoun 'I' to comment on his story, see $298,648,806,1756$, 1873-74, 2176-78, 2546-47, 2921-26, 3016-21, 3433. The narrator also guides the tale's reception by addressing his public directly, as in $702,872,2833-34,2885-88$. Questions serve to involve the public in the action, as in $647,689,747,753,961,1075,2548,2926$. He draws its attention with the formula $\mathrm{Nu}$ hoert $(877,970,1430,2164,2238,2799,2841,2849,2899,3049,3317)$ or Nuverneemt (2227). 
onder die linde in een gras.

Van maerbersteene slecht was

455 die saerc die daerup lach.

Die letteren die men daeran sach,

deden an tgraf bekinnen

wie daer lach begraven binnen.

Dus spraken die boucstave

460 an den zaerc up den grave:

'Hier leghet Coppe begraven,

die so wale conste scraven,

die Reynaert die vos verbeet

ende haren gheslachte was te wreet.'

$465 \mathrm{Nu}$ leghet Coppe onder mouden.

Die coninc sprac tsinen houden

dat si hem alle bespraken

hoe si alrebest ghewraken

dese groete overdade.

470 Doe waren si alle te rade

dat si daer den coninc rieden,

dat hine dan soude ombieden

dat hi te hove soude comen,

no dor scaden no dor vromen

475 ne lette, hi ne quame int ghedinghe,

ende men Brune van dien dinghe

die bodscap soude laden.

Dies was die coninc sciere beraden,

dat hi dus sprac te Bruun den beere:

480 'Heere Bruun, dit segghic voer dit heere,

dat ghi dese bodscap doet.

Oec biddic hu dat ghi zijt vroet,

dat ghi hu wacht van baraet;

[195va]

Reynaert es fel ende quaet.

485 Hi sal hu smeeken ende lieghen.

Mach hi, hi sal hu bedrieghen

met valschen woorden ende met sconen.

462 Literally: 'who was so good at scratching'. The word scraven has sexual overtones.

466-78 King Nobel does not decide unilaterally what legal action needs to be taken. He

sends for his barons who agree that Reynaert must be summoned to court for criminal 
under the lime tree in a patch of grass.

Of polished marble was

455 the stone on it.

The letters that one saw on it

made it clear

who lay buried there.

This is what the letters

460 on the gravestone read:

'Here lies Coppe,

who ever joyfully ranged free,

bitten to death by Reynaert the fox

who did her family cruel injury.'

465 Coppe now lies under the soil.

The king said to his councillors

that they should discuss among themselves

how best to avenge

this great crime.

470 Then they all agreed

in their advice to the king

that he should order him

to come to court,

and that nothing, good or bad,

475 should prevent his attendance at the trial,

and that Bruun should be the one

to be charged with the message.

On this matter the king took a decision without delay,

addressing Bruun the bear therefore as follows:

480 'Lord Bruun, I say this before this assembly, that you must take the message.

Also, I urge you to act wisely, and to beware of deceit;

Reynaert is wicked and mischievous.

485 He will flatter you, and tell lies.

If he can, he will hoodwink you

with false and fine words.

prosecution, and that Bruun the bear is to deliver the summons. The king complies with their decision (cf. also 165-69, 432-37). Decisions are taken in feudal harmony during the trial and conviction. It is after the conviction that tensions arise (cf. p. 25). 
Mach hi, bi Gode, hi sal hu honen.'

'Heere,' seit hi, 'laet hu castyen!

490 So moete mi God vermalendyen

of mi Reynaert so sal honen,

inne saelt hem wederlonen,

dat hijs an den dulsten zi.

$\mathrm{Nu}$ ne zorghet niet om mi.'

495 Nu neemt hi orlof ende hi sal naken

Daer hi zeere sal mesraken!

$\mathrm{Nu}$ es Brune up die vaert

ende hevet in ziere herten onwaert

ende het dochte hem overdaet

500 dat yement soude sijn so quaet

ende dat hem Reynaert hoenen soude.

Dort doncker van eenen woude quam hi gheloepen dor eene wostine

daer Reynaert hadde de pade sine

505 ghesleghen crom ende menichfoude, also als hi huten woude hadde gheloepen om sijn bejach.

Beneden der woestinen lach een berch oech ende lanc.

510 Daer moeste Bruun sinen ganc te middewaerde over maken, sal hi te Manpertus gheraken.

Reynaerd hadde so menich huus, maer die casteel Manpertus

515 dat was die beste van sinen borghen.

495-96 The narrator comments that Bruun will meet a bad end. In this way, after Nobel's earlier warning that Bruun must beware of the wicked fox's tricks (482-88), he heightens the suspense for his public. Rather than asking themselves whether or not the bear is going to be duped, they will have wondered how this is going to happen. Various comments by the narrator in what follows $(611,638-43,1075-80,2164-78,3295)$ and explicit asides by Reynaert (62326, 2034-49) serve the same function (cf. p. 22).

502-12 By describing Bruun's journey through a variety of landscapes the narrator indicates 
By God, he will disgrace you if he can.'

'My Lord,' said he, 'stop these admonitions!

490 May God's curse be upon me if Reynaert disgraces me in such a way

that I shall not be able to repay in kind, making him look silly.

Do not worry on my account.'

495 Now he takes his leave and will arrive in a place where he will encounter much misfortune!

\section{First summons}

Now Bruun is on his way

and he considers it unlikely in his heart

and it seemed to him absurd

500 that anyone would be so wicked

and that Reynaert would disgrace him.

Through the darkness of a forest

he made his way through a wasteland

where Reynaert had made his tracks

505 crooked and manifold, each time when he had left the forest

to go hunting.

On the other side of the wasteland

was a mountain, high and broad.

510 Bruun had to make his way

across it in the middle

to reach Manpertuus.

Reynaert had very many residences,

but the castle of Manpertuus

515 was the best of his strongholds.

that the bear now enters a different world. He leaves the ordered world of the court and enters the trackless wilderness where Reynaert is lord and master. Here and elsewhere, the spatial transition also clearly implies a moral lapse (cf. pp. 23-24).

512 In the Roman de Renart, Renart's strongest fortress is sometimes called Maupertuis in addition to Malpertuis. It is likely that the scribe of the Comburg manuscript (or a predecessor) took the third letter of the word for an $-n$. Like Malcroys the name means 'evil hole'. 
Daer trac hi in als hi in zorghen ende in noede was bevaen.

$\mathrm{Nu}$ es Brune die beere ghegaen dat hi te Manpertuus es comen,

520 daer hi de porte hevet vernomen daer Reynaerd hute plach te gane. Doe ghinc hi voer die barbecane sitten over sinen staert ende sprac: 'Sidi in huus, Reynaert?

525 Ic bem Bruun, des coninx bode. Die hevet ghezworen bi sinen Gode, $[195 \mathrm{vb}]$ ne comdi niet ten ghedinghe ende ic hu niet voer mi bringhe, recht te nemene ende te ghevene

530 ende in vreden voert te levene, hi doet hu breken ende raden. Reynaerd, doet dat ic hu rade ende gaet met mi te hove waert.' Dit verhoerde al nu Reynaert,

535 die voer in sine poerte lach, daer hi vele te ligghene plach dor waremhede van der zonnen. Bi der tale die Bruun heeft begonnen bekenden altehant Reynaert

540 ende tart bet te dale waert in sine donckerste haghedochte. Menichfout was zijn ghedochte hoe hi vonde sulken raet daer hi Bruun, den fellen vraet, 545 te scherne mede mochte driven ende selve bi ziere eeren bliven.

522 The barbecane ('barbican') is a barricade which forms the outer defence of the castle. 531 breken ende raden: to break someone's bones and subsequently place him on a wheel. 547-622 Reynaert misleads Bruun by stressing the futility of his journey, saying that he would have gone to King Nobel's court day anyway, if only he had not eaten far too much of some new kind of food. Bruun reacts immediately. On his arrival the bear had addressed Reynaert formally (Sidi in huus? 524), as befits his role as the king's messenger. But now that his craving has been aroused, he forgets his official role and changes to an informal mode of address (wat haetstu, 562). The bear is no longer master of himself, as is also clear from 
That is where he went when he was afraid and found himself in dire straits.

Now Bruun has walked so far that he has arrived at Manpertuus,

520 where he spotted the gate where Reynaert customarily went out. Then, in front of the barbican, he sat down on his tail and said: 'Are you at home, Reynaert?

525 It's me, Bruun, the messenger of the king who has sworn this oath by his God: if you do not come to the trial and if I fail to bring you with me to subject yourself to the law

530 and to live in peace in the future, he shall have you broken on the wheel.

Reynaert, do as I advise, and come with me to court.' All this was heard by Reynaert, 535 who was lying just inside his porch, as he often did on account of the warmth of the sun. By the words that Bruun had begun to speak Reynaert recognized him at once

540 and he withdrew further into the darkest part of his den. Many thoughts went through his mind how to devise a plan by means of which he might

545 trick Bruun, the greedy glutton, without loss of honour to himself.

the fact that he addresses Reynaert as neve, 'nephew' (581), which does not refer to a family relationship, but to Bruun's intention to be on good terms with Reynaert. As Reynaert deliberately pretends to be unaware of what Bruun is trying to do (585, 588-91, 595, 601), Bruun gets increasingly worked up. A similar kind of dynamics is found in the superlatives by which the quantities of honey to be supplied or consumed are indicated (592-93, 598$600,602-4,619,637)$. Reynaert's hyperbolic language serves the purpose of provocation, while Bruun's is coloured by greed and boastfulness. On the structure of Reynaert's tricks, see also p. 20. 
Doe sprac Reynaert overlanc:

'Huwes goets raets hebbet danc, heere Bruun, wel soete vrient.

550 Hi hevet hu qualic ghedient die hu beriet desen ganc ende hu desen berch lanc over te loepene dede bestaen. Ic soude te hove sijn ghegaen,

555 al haddet ghi mi niet gheraden, maer mi es den buuc so gheladen ende in so utermaten wijse met eere vremder niewer spise, ic vruchte in sal niet moghen gaen.

560 Inne mach sitten no ghestaen; ic bem so utermaten zat.' 'Reynaert, wat haetstu, wat?' 'Heere Brune, ic hat crancke have. Arem man dannes gheen grave;

565 dat mooghdi bi mi wel weten. Wi aerme liede, wi moeten heten, hadden wijs raet, dat wi node haten. Goeder versscher honichraten hebbic couver arde groet.

570 Die moetic heten dor den noet, als ic hel niet mach ghewinnen. Nochtan als icse hebbe binnen, hebbicker af pine ende onghemac.' Dit hoerde Brune ende sprac:

575 'Helpe, lieve vos Reynaert, hebdi honich dus onwaert? Honich es een soete spijse die ic voer alle gherechten prijse ende voer alle gherechten minne.

580 Reynaerd, helpt mi dat ics ghewinne. Edele Reynaert, soete neve, also langhe als ic sal leven willic hu daeromme minnen. Reynaerd, helpt mi dat ics ghewinne.'

585 'Ghewinnen, Bruun? Ghi hout hu spot!' 
Then Reynaert said after a long time:

'Many thanks for your good advice,

Lord Bruun, dear friend.

550 He did you a disservice, the person who suggested that you make this journey and had you cross this mountain range. I would have gone to court,

555 even if you had not advised me to do so, but my stomach is so full and in such an excessive way with some strange new food that I fear that I shall not be able to go.

560 I can neither sit nor stand, I am so extremely full.'

- 'Reynaert, what did you eat? what?'

- 'Lord Bruun, I have eaten poor quality food.

A poor man is no count,

565 that is obvious when you look at me.

We poor people have to eat things that, if we had the choice, we would never eat.

Good, fresh honeycombs

I have in stock aplenty.

570 Those I must eat out of necessity when I cannot get anything else.

But when I have swallowed them, I suffer pain and discomfort as a result.'

Bruun heard this and said:

575 'Help, my dear fox Reynaert, do you despise honey so much?

Honey is delicious food, which I appreciate above all other dishes and love more than any other dish.

580 Reynaert, help me get it.

Noble Reynaert, dear nephew, so long as I live I shall love you for it.

Reynaert, help me get it.'

$585 \quad-$ 'Get it, Bruun? You must be joking!' 
'In doe, Reynaert, so waer ic zot, hildic spot met hu, neen ic niet.'

Reynaert sprac: 'Bruun, mochtijs yet?

Of ghi honich moghet heten,

590 bi huwer trauwen, laet mi weten.

Mochtijs yet, ic souts hu saden.

Ic saels hu so vele beraden, ghi ne hatet niet met hu tienen, waendic hu hulde daermet verdienen.'

595 'Met mi tienen? Hoe mach dat wesen?

Reynaert, hout huwen mont van desen ende sijts seker ende ghewes: haddic al thonich dat nu es tusschen hier ende Portegale,

$600 \quad$ ic haet al up teenen male.'

Reynaerd sprac: 'Bruun, wat sechdi?

Een dorper, heet Lamfroit, woent hier bi, hevet honich so vele tewaren, ghi ne hatet niet in VII jaren.

605 Dat soudic hu gheven in hu ghewout, heere Brune, wildi mi wesen hout ende voer mi dinghen te hove.'

Doe quam Brune ende ghinc gheloven ende sekerde Reynaerde dat:

610 wildine honichs maken zat - des hi cume ombiten sal hi wilde wesen overal ghestade vrient ende goet gheselle. Hieromme louch Reynaert die felle

615 ende sprac: 'Bruun, heelt mare, verghave God dat mi nu ware also bereet een goet gheval alse hu dit honich wesen sal, al wildijs hebben VII hamen.'

620 Dese woort sijn hem bequame, Bruun, ende daden hem so sochte, hi louch dat hi nemmee ne mochte.

611 Understatement, meaning that he will not eat anything at all. 
- 'I am not, Reynaert, I'd be a fool to joke with you, no, not me.'

Reynaert said: 'Bruun, would you like some of it? If you want to eat honey,

590 on your word of honour, let me know.

If you want some, I could make you eat your fill.

I shall give you so much

that ten of you would not be able to eat it

if in that way I would earn your loyal support.'

$595-$ - Ten of us? How can that be?

Reynaert, say no more about this

and know for certain and a fact:

if I had all the honey

between here and Portugal,

$600 \quad$ I would eat it all up in one go.'

Reynaert said: 'Bruun, what's that you're saying?

A villager, who is called Lamfroyt, lives near here, and he has so much honey, truly, that you could not eat it in seven years.

605 I would put it at your disposal, provided, Lord Bruun, that you are prepared to take my side and plead for me at court.'

Then Bruun solemnly promised and assured Reynaert

610 that if the latter was prepared to stuff him with honey - of which he will hardly have a taste he would be willing, in all circumstances, to prove a loyal friend and good companion. This amused that scoundrel Reynaert,

615 and he said: 'Bruun, hero of renown, if only God were to afford me as much happiness as this honey will give you, even if you wanted seven barrels of it.'

620 These words pleased Bruun much, and he found them so agreeable that he laughed himself silly. 
Doe peinsde Reynaerd daer hi stoet:

'Bruun, es mine avonture goet,

625 ic wane hu daer noch heden laten

daer ghi sult lachen te maten.'

$\mathrm{Na}$ dit peinsen ghinc Reynaert huut

ende sprac al overluut:

'Oem Bruun, gheselle, willecome!

630 Het staet so: suldi hebben vrome, hier ne mach zijn gheen langher staen.

Volghet $\mathrm{mi}$; ic sal voeren gaen.

Wi houden desen crommen pat.

Ghi sult noch heden werden zat,

635 saelt na minen wille gaen.

Ghi sult noch heden hebben sonder waen

also vele als ghi moghet ghedraghen.'

Reynaert meende van groten slaghen;

dit was dat hi hem beriet.

640 Die keytijf Bruun ne wiste niet waer hem Reynaerd die tale keerde, die hem honich stelen leerde dat hi wel seere sal becoepen.

Al sprekende quam dus gheloepen

645 Reynaert met sinen gheselle Brune tote Lamfroits bi den tune.

Wildi horen van Lamfreyde?

Dat was, eist waer so men mi seide, een temmerman van goeden love,

650 ende hadde bi sinen hove eene eecke brocht huten woude

die hi ontwee clieven soude

ende hadde twee wegghen daerin ghesleghen, also temmermans noch pleghen.

655 Die eecke was ontdaen wel wijde.

Des was Reynaert arde blide.

Te Brunen sprac hi ende louch:

'Siet hier hu grote ghevouch,

626 Understatement, meaning that he will not find anything to laugh about at all.

629 By addressing Bruun as 'uncle' Reynaert follows the example of the bear, who earlier 
Then Reynaert thought to himself:

'Bruun, if all goes well for me,

625 I think I'll leave you even today

in a place where you will not laugh much.'

Having thought this, Reynaert went outside

and said loudly:

'Uncle Bruun, dear friend, welcome!

630 The matter is this: if you wish to profit

we should not stay here any longer.

Follow me; I'll lead the way.

We follow this crooked path.

You will have your fill today

635 if all goes as I wish.

Without doubt, this very day you will get

as much as you can bear.'

Reynaert meant a severe beating;

that was what he had in mind for him.

640 Bruun the dunce did not get

the meaning of Reynaert's words,

who was teaching him to steal honey

that he will pay for dearly.

Talking in this way Reynaert

645 arrived with his companion Bruun

at the fence around Lamfroyt's house.

Do you want to hear about Lamfroyt?

He was - if it is true what people told me a carpenter of good repute,

650 and had brought to his yard an oak tree from the forest that he intended to split in two and in which he had knocked two wedges, as carpenters do to this day.

655 The oak had been split open very wide.

That pleased Reyneart greatly.

Laughing, he said to Bruun:

'See here your heart's desire,

called him 'nephew' (581). At the same time their hierarchical positions are highlighted: the bear is mightier than the fox. 
Brune, ende nemet wel goem.

660 Hier in desen selven boem es honichs utermaten vele. Prouft of ghijs in huwe kele ende in huwen buuc moghet bringhen. Nochtan suldi hu selven dwinghen:

665 al dincket hu goet die honichraten, hetet te zeden ende te maten, dat ghi hu selven niet verdervet. Ic ware ontheert ende onthervet, wel soete oem, mesquame hu yet.'

670 Brune sprac: 'Reynaert, ne sorghet niet. Waendi dat ic bem onvroet?

Mate es tallen spele goet.'

'Ghi secht waer,' sprac Reynaerd. 'Waeromme bem ic oec vervaert?

675 Gaet toe ende crupet daerin.' Reynaert peinsde om zijn ghewin ende Brune liet hem so verdoren dat hi thoeft over die horen ende die twee voerdere voete instac.

680 Ende Reynaert poghede dat hi brac die wegghen beede huter eecken, die daertevoren ghinc so smeeken. Bruun bleef ghevanghen in den boem. $\mathrm{Nu}$ hevet de neve sinen oem

685 in boesheden bracht met sulker achte dat hi met liste no met crachte in gheere wijs ne can ontgaen ende bi den hoefde staet ghevaen. Wat raeddi Brunen te doene?

690 Dat hi was sterc ende coene sal hem niet ghehelpen moghen. Hi sach wel, hi was bedroghen. $\mathrm{Hi}$ began briesschen ende dulen. Hi was ghegrepen bi zier mulen

672 The bear is quite able to quote the proverb about moderation (a peculiarly courtly virtue), but he does not know how to apply it in what follows. In a subtle way the author has 
Bruun. Now take note.

660 Here in this very tree

there is an exceptional amount of honey.

Try to get it down your throat

and into your stomach.

But you will have to control yourself:

665 however tasty you think the honeycombs, mind your manners and eat moderately, so it does not disagree with you.

I would be disgraced and dishonoured, dearest uncle, if any mishap befell you.'

670 Bruun said: 'Reynaert, don't worry.

Do you take me for a fool?

Moderation in everything.'

'What you say is true,' said Reynaert.

'Anyway, why should I worry?

675 Go, and get inside.'

Reynaert pondered his good luck and Bruun allowed himself to be fooled to such an extent that he inserted his head, ears and all, as well as his two front paws.

680 And Reynaert did his utmost to wrench the two wedges out of the oak he who had earlier talked so smoothly. Bruun ended up caught in the tree. Now the nephew has caused his uncle

685 such problems with his devious plans that, neither by ingenuity nor by force, is there an escape for him in any way, and he is held captive by the head.

What would you advise Bruun to do?

690 That he was strong and brave will not be any help to him now. He realized that he had been duped. He started to howl and to growl.

He had got trapped with his muzzle

already been playing with the moderation-immoderation alternation before this $(557,561$, $626,661,666)$. 
695 so vaste ende bi den voeten voren, al dat hi pijnde, was verloren.

Hi ne waende nemmermeer ontgaen.

Van verren was Reynaert ghestaen

ende sach commen Lamfreyde,

700

die up sinen hals brochte beide

een scaerpe haex ende eene baerde.

Hier mooghdi horen van Reynaerde,

hoe hi sinen oem ghinc rampineeren:

'Oem Brune, vaste gaet mineeren!

705 Hier comt Lamfroyt ende sal hu scijncken.

Haddi gheten, so souddi drincken!'

$\mathrm{Na}$ der talen so ghinc Reynaert

weder te sinen casteele waert,

sonder orlof. Ende mettien

710 hevet Lamfroyt den beere versien

ende vernam dat hi was ghevaen.

Doe ne was daer gheen langher staen.

Hi liep wech metter haest

daer hi die hulpe wiste naest,

715 daer dat naeste dorp stont, ende dede hem allen cont dat daer stont ghevaen een beere.

Doe volchde hem een mekel heere:

int dorp ne bleef man no wijf.

720 Den beere te nemene sijn lijf

liept al dat loepen mochte.

Sulc was die eenen bessem brochte,

sulc eenen vleghel, sulc een rake,

sulc quam gheloepen met eenen stake,

725 so si quamen van haren werke.

Selve die pape van der kerke

brochte eenen cruusstaf,

die hem de coster noede gaf.

Die coster drouch eene vane

705-6 Preparing and pouring or drinking beverages is a sarcastic reference to inflicting or experiencing physical abuse (see also 1955, 2173-78 and 2801). Making sauces (1216) also belongs to this type of 'special treat' metaphors. 
695 and front paws so tightly

that all his efforts were in vain.

He thought he'd never escape.

Reynaert stood at a distance

and saw Lamfroyt coming,

700 who carried on his shoulder both

a sharp hatchet and a battle axe.

Here you may hear of Reynaert

and how he began to mock his uncle:

'Uncle Bruun, tuck in!

705 Here comes Lamfroyt, ready to pour.

Having eaten one should drink!'

Having said this, Reynaert

returned to his castle,

without taking leave. And just then

710 Lamfroyt saw the bear

and noticed that he had got trapped.

He did not hesitate for a moment.

He hurriedly made his way

to where he knew help was at hand

715 in the nearest village,

and told everyone

that a bear stood trapped.

Then a huge army followed him:

in the village neither man nor woman stayed behind.

720 To take the bear's life

all who could walk came along.

One brought a broom,

another a flail; one brought a pitchfork,

another came running with a stick,

725 just as they left their work.

Even the priest from the church

brought a staff with a crucifix,

which the verger had reluctantly given him.

The verger carried a church banner

722-30 The weapons carried by the villagers are ludicrous. They want to attack the bear with objects used in the home and in the fields. In this context it is not surprising that the priest intends to attack Bruun with a crucifix. 
730 mede te stekene ende te slane.

Des spapen wijf, vrauwe Julocke, quam gheloepen met haren rocke, daer so omme hadde ghesponnen.

Voer hem allen quam gheronnen

735 Lamfroyt met eere scerper haex.

Al hadde Brune lettel ghemaex,

hi ontsach meer ongheval

ende sette al jeghen al, doe hi dat gheruchte hoorde.

740 Hi spranc up sodat hem scorde van sinen aensichte al die huut. Al brochte Brune dat hoeft huut met aerbeide ende met pinen, nochtan liet hi daer van den zinen

745 eene oere ende beede sine lier. Nye maecte God so leelic dier! Hoe mochte hi zeerre sijn mesrocht? Al haddi thoeft hutebrocht, eer hi die voete conde ghewinnen

750 blever alle die claeuwen binnen ende sine twee anscoen beede. Dus gherochte hi huut met leede. Hoe mochte hi zijn ontheert meer?

Die voete waren hem so zeer

755 dat hi tloepen niet conste ghedoghen. Dat bloet liep hem over die hoghen, dat hi niet wel conste ghesien. Hi ne dorste bliven no vlien. $\mathrm{Hi}$ sach suut onder die zonne

760 Lamfroyt commen gheronnen; daerna die priester, die heere, hi quam gheloepen vele zeere; daerna die coster metter vane; daerna alle die prochiane,

731 Priests were forbidden to enter into a sexual relationship, although the reality was often different in the Middle Ages. This means that officially the pape who has a wife (or concubine) and children (cf.1171 and 1236) lives in sin. It is likely that he enjoyed considerable sexual favours, 
730 with which to hit and to prod.

The priest's wife, Lady Julocke,

came running up with her distaff

with which she had been spinning.

In front of them all ran

735 Lamfroyt with a sharp axe.

Even though Bruun was not very comfortable,

he feared more misery

and made a tremendous effort

when he heard the noise.

740 He jumped up, so that

all the skin was torn from his face.

Although Bruun extricated his head

with a great deal of trouble,

he nevertheless lost in the process

745 one ear and both his cheeks.

Never did God create such a hideous animal!

How could he possibly fare worse?

Even though he had pulled out his head,

before he could free his paws

750 his nails as well as

his two gloves stayed behind.

In this way he got out with great pain.

How could he have been more dishonoured?

His feet hurt so badly

755 that he could not bear to walk.

Blood ran into his eyes,

so that he could not see properly.

He dared neither stay nor flee.

Under the sun, from the south, he saw

760 Lamfroyt come running up,

followed by the priest, that worthy,

who came running fast;

after him the verger with the banner;

and after him all the parishioners,

as Julocke's name characterizes her as a temptress: ju lokke* literally means 'you I tempt'.

751 With the reference to the two gloves, the skin on Bruun's paws is meant.

$75^{8}$ The point here is that Bruun is paralyzed by fear. 
765 die houde lieden metten jonghen.

Daerna quam up haren stap ghespronghen

sulke quene die van houden

cume eenen tant hadde behouden.

Wie so wille, wachte hem dies:

770 die scade hevet of verlies

ende groet ongheval,

over hem so willet al!

Dit sceen arem man Brunen wel.

Sulc dreechdem nu an sijn vel

775 die des ghesweghen hadde stille, hadde Bruun ghestaen tsinen wille.

Dit was beneden eere riviere

dat Brune, onsalichst alre diere, van meneghen dorper was beringhet.

780 Doe was daer lettel ghedinghet.

Hem naecte groet onghemac:

die een slouch, die ander stac,

die een slouch, die ander warp.

Lamfroyt was hem alrescaerpst.

785 Een hiet Lottram Lancvoet;

hi drouch eenen verhoernden cloet

ende stacken emmer na dat hoghe.

Vrauwe Vulmaerte scerpe loghe

ghinckene koken met eenen stave.

790 Abelquac ende mijn vrauwe Bave

laghen beede onder die voete

ende streden beede om eene cloete.

Ludmoer metter langher nese

drouch eenen loedwapper an een pese

795 ende ghincker met al ommezwinghen.

Ludolf metten crommen vingheren

dede hem alles tevoren,

want hi was best gheboren,

777-819 The way Bruun is maltreated is a parody on skirmishes during battle in medieval narratives. A famous example is the Chanson de Roland, in which the rearguard of Charlemagne's army is ambushed near Roncevaux. In one episode the narrator explains at great length how the Frankish commander Roland and his companions Gerin, Gerer, Sansun, Anseïs, Engeler, Oton, Berenger and Margariz exert themselves in the first few fights with the Saracens (cf. Segre \& Tys- 
765 old people as well as young.

Next there came, leaning on a stick, many an old hag with barely a tooth left in her mouth from old age. If you're interested, pay heed to this:

770 he who suffers harm or loss and great distress is everyone's butt!

Poor Bruun soon found this out.

Many were after his skin

775 who would have kept very quiet

if Bruun could have done as he wished.

It was on the bank of a river that Bruun, most miserable of all animals, was surrounded by many villagers.

780 Little was said at that time.

Great discomfort was in store for him:

some hit him, others stabbed him, some hit him, others threw things at him.

Lamfroyt caused him the sharpest pain.

785 Lottram Lancvoet, as one man was called, carried a stick with horn cladding which he constantly aimed at his eye.

Lady Vulmaerte wielded a stick until the pain made him piss himself.

790 Abelquac and my Lady Bave both lay on the ground and together fought for one of his balls.

Ludmoer with the long nose was carrying a lead ball on a cord

795 and was swinging it around. Ludolf with the crooked fingers set an example to all of them, for he was of the highest birth,

sens 2003, laisse XCVI-CIV). The participants in the fight in Van den vos Reynaerde are no knights, but villagers with comical and suggestive names. Moreover, their weapons and their actions they try to put out one of Bruun's eyes and fight over one of his testicles - are totally unchivalric. By this kind of uncourtly struggle Bruun, wholeft the court as a confident hero, is made ridiculous. 788-89 Literally: 'Lady Vulmaerte boiled sharp lye / for him with a stick'. 
sonder Lamfroy alleene.

800 Hughelijn metten crommen beene was zijn vader, dat weet men wale, ende was gheboren van Abstale ende was sone vrauwe Ogernen, eens houtmakigghe van lanternen.

805 Ander wijf ende ander man, meer dan ic ghenomen can, daden Brunen groet onghemac, sodat hem zijn bloet huutlac. Brune ontfinc al sulc payment

810 als hem elc gaf daeromtrent. Die pape liet den cruusstaf ghedichte slaen, slach in slach, ende die coster metter vane ghinc hem vastelike ane.

815 Lamfroyt quam ter selver wijlen met eere scerper bijlen ende slouchene tusschen hals ende hoeft, dat Brune wart zeere verdoeft, dat hi verspranc van den slaghe

820 tusschen der riviere enter haghe in eenen trop van houden wiven ende warper een ghetal van viven in die riviere die daer liep, die wel wijt was ende diep.

825 Des papen wijf wasser eene.

Des was spapen bliscap cleene. Doe hi zijn wijf sach in die vliet, doe ne luste hem langher niet Bruun te stekene no te slane.

830 Hi riep: 'Siet, edele prochiane, ghindre vloot vrauwe Julocke beede met spillen ende met rocke. $\mathrm{Nu}$ toe, die haer helpen mach! Ic gheve hem jaer ende dach

826-36 Bruun owes his escape entirely to the fact that in his anguished state he pushes five women into the river. When the priest sees that Julocke is one of them, he abuses the clerical 
with the sole exception of Lamfroyt.

800 Hughelijn with the crooked legs was his father, as is well-known, and was born in Abstale and he was the son of Lady Ogerne, who mended lanterns for a living.

$805 \quad$ Other men and women more than I can name, caused Bruun great distress, so that he lost much blood. Bruun was on the receiving end

810 from every side. The priest brought down the staff and crucifix ceaselessly upon him, blow upon blow, and the verger with the banner attacked him with gusto.

815 Lamfroyt approached at that moment with a sharp axe and hit him between neck and head;

Bruun was so dazed that he jumped aside because of the blow,

820 between the river and the hedge, into the middle of a group of old women, and pushed five of them into the river that ran there and that was quite wide and deep.

825 The priest's wife was one of them. That little pleased the priest.

When he saw his wife in the river he was no longer interested in stabbing or hitting Bruun.

830 He shouted: 'Look, worthy parishioners, there floats Lady Julocke with her spindle and her distaff.

Whoever can help her, go!

I will give him for a year and a day

means of obtaining grace by promising the villagers pardons for sins (yet to be committed) in return for getting his wife back onto dry land. 
835 vul pardoen ende aflaet van alre sondeliker daet.' Beede man ende wijf lieten den aermen keytijf Brune ligghen over doot

840 ende ghinghen daer die pape gheboot, beede met stringhen ende met haken. Die wijle dat si die vrauwe huut traken, so quam Brune in die riviere ende ontswam hem allen sciere.

845 Die dorperen waren alle gram: si saghen dat hem Brune ontswam, dat si hem niet mochten volghen. Upt ouver stonden si verbolghen ende ghinghen na hem rampineren.

850 Bruun die lach in die ryviere daer hi vant den meesten stroem. Al dryvende bat hi dat God den boem moeste verdrouven ende verwaten daer hi zijn hoere in hadde ghelaten

855 ende beede sine lier. Voert vloucte hi dat felle dier, den boesen vos Reynaerde, diene met sinen brunen baerde so diepe in die eecke dede crupen.

860 Daerna Lamfroyt van der stupen daer hi hem so leede dede. In aldustanen ghebede lach Brune also langhe wijle dat hi wel een halve mile

865 van der stede was ghedreven daer die dorpers waren bleven. $\mathrm{Hi}$ was verpijnet ende moede ende ondercommen van den bloede, sodat hi hadde crancke vaert.

870 Doe zwam hi te lande waert

860 The stupen, the stocks or pillory, refers to the half-split oak in which Bruun is caught with his head and paws. 
835 a full pardon and absolution

for all his sinful actions.'

Man and wife both

left the miserable creature

Bruun lying there for dead

840 and went where the priest told them

to go with ropes and with hooks.

While they pulled the woman out,

Bruun reached the river

and quickly swam away from them all.

845 All the villagers were angry:

they saw that Bruun swam away from them,

so that they could not follow him.

They stood on the river bank, incensed, and started to hurl abuse at him.

850 Bruun was lying in the river where the current was strongest for him.

Floating along, he prayed that God

would curse and damn the tree

in which he had left his ear

855 and both his cheeks.

Next he cursed that vicious animal,

the wicked fox Reynaert,

who, with his brown beard,

had so deeply made him dive into that oak.

860 Next Lamfroyt, on account of the stocks

by means of which he had suffered so.

Engaged in prayers of this nature

Bruun floated for such a long time

that he had drifted at least half a mile

865 from the place

where the villagers had been left behind.

He was exhausted and tired

and weakened by loss of blood, causing him to make slow progress.

870 Then he swam towards the land

862 ghebede is an ironic euphemism for curses. 
ende croep ligghen in dat hoever.

Ghi ne saghet noint droever

gheen dier no gheenen man!

Hi lach jammerlic ende stan

875 ende slouch met beede sinen lancken.

Des mochte hi al Reynaerde dancken.

$\mathrm{Nu}$ hoert wat Reynaert heeft ghedaen!

Hi hadde een vet hoen ghevaen

bi Lamfroyts an der heyden

880 eer hi danen was versceiden.

Hi hadt up eenen berch ghedreghen

verre huut allen weghen,

daer het eenlic was ghenouch.

Dat was wel zijn ghevouch,

885 dordat daer was niemens ganc

ende hi dor niemens bedwanc

sine proye dorste rumen.

Doe hi dat hoen toten plumen

hadde gheleit in sine male,

890 doe ghinc hi neder te dale

eenen verholenliken pat.

Hi was utermaten zat.

Dat weder was scone ende heet.

Hi hadde gheloepen dat hem dat zweet

895 nederliep neven die liere.

Daeromme liep hi ter riviere, dordat hi hem vercoelen soude.

In bliscap arde menichfoude was sijn herte doe bevaen.

900 Hi hopede wel al sonder waen

dat Lamfroyt hadde den beere versleghen

ende hine thuuswaert hadde ghedreghen.

Doe sprac hi: 'Hets mi wel ghevaren.

Die mi te hove meest soude daren,

905 die hebbic doot in desen daghe.

875 Bruun is shaking because he is out of breath.

903-8 Reynaert's monologue provides important information about his intentions. He had planned to kill the bear in such a way that he could not be held accountable. He intended to remove a redoubtable opponent through Lamfroyt, which would have enabled him to insist 
and crawled up on the bank to lie down there.

You never saw a more pitiable

animal or human being!

He lay there moaning woefully,

875 shaking with both his sides.

He had Reynaert to thank for it all.

Now hear what Reynaert did!

He had caught a plump chicken

in the field near Lamfroyt's house

880 before going on his way.

He had carried it to a hill,

far from any road,

where it was completely deserted.

That was what he wanted,

885 because no one went there

and he would not be forced by any one

to give up his prey.

When he had led the chicken

into his stomach, except for the feathers,

890 he went down the hill

along a secret track.

He was extremely full.

The weather was fine and hot.

He had been running until the sweat

895 ran down his cheeks.

That is why he went to the river,

so that he might cool off.

His heart was filled

with very great joy for many reasons.

900 He felt pretty sure

that Lamfroyt had killed the bear

and had dragged it to his house.

Then he said: 'It went well for me.

The one who would harm me most at court

905 has been killed today through my doing.

later at court that he knew nothing of the summons. However, it immediately becomes clear that Reynaert's plan has come to nothing: Bruun is still alive. The narrator thus sheds an ironic light on Reynaert's plans and character. 
Nochtan wanic sonder claghe ende sonder wanconst bliven. Ic mach te rechte bliscap driven.' Doe Reynaert was in dese tale,

910 sach hi nederwaert te dale ende vernam Bruun daer hi lach. Enten eersten als hine sach, hadde hijs rauwe ende toren. Daer die bliscap was tevoren, 915 daer lach $n u$ thoren ende nijt ende sprac: 'Vermalendijt, Lamfroyt, moet dijn herte sijn! Du best dulre dan een zwijn, Lamfroyt, ergher putensone!

920 Lettel eeren bestu ghewone. Hoe es di dese beere ontgaen, die di tevoren was ghevaen? Hoe menich morseel leghet deran, dat gherne hetet menich man.

925 O wy, Lamfroyt, verscroven druut, hoe rikelike een beerehuut heefstu heden verloren, die di ghewonnen was tevoren!' Dit scelden hevet Reynaert ghelaten

930 ende ghinc neder bi der straten dor te siene hoet Bruun stoet. Doe hine sach ligghen al een bloet ende ziec ende onghesont, den aermen beere, te dier stont

935 - Dat sach Reynaert arde gherne doe bescalt hine te sinen scherne: 'Siere priester, dieu vo saut! Kendi Reynaert, den rybaut? Wildine scauwen, so siettene hier, 940 den roden scalc, den fellen ghier.

930 The strate ('road') offers a contrast with the secret track that the fox used earlier (891). 936-51 When Reynaert's tricks have been successful, he mocks his victims, a common feature of beast tales. This also happens in Bruun's case, whose impending beating was earlier compared to a drinking bout (704-6). Here he is likened to a cleric on account of the lack of 
And yet I do not expect

to be charged or suspected.

I have every reason to be glad.'

While speaking these words

910 Reynaert looked down

and saw Bruun lying there.

And as soon as he saw him,

he felt sad and angry.

His earlier joy

915 now gave way to fury and irritation

and he said: 'Damned,

Lamfroyt, you deserve to be!

You have less sense than a pig,

Lamfroyt, horrible son of a whore!

920 Even a little respect is too much for you.

How did this bear escape you,

which earlier had been caught for you?

There are many delicious morsels on it

which many would like to eat.

925 Dear me, Lamfroyt, useless fellow, what a precious bearskin

did you lose today

which earlier had been won for you!'

Reynaert stopped his abuse

930 and went down to the road to see how Bruun was doing.

When he saw him lying there, the poor bear, covered in blood injured and in a bad state,

935 - Reynaert took pleasure in seeing it he taunted him for his amusement:

'My lord priest, Dieu vos saut!

Do you know the villain Reynaert?

If you want to see him, then you see him here,

940 the red scoundrel, the wicked glutton.

skin on his scalp and skinless paws. His head injury is compared by Reynaert to a skull cap and an outsize tonsure, while the wounds on his paws are associated by the fox with discarded gloves (cf. p. 21).

937 Old French dieu vos saut means: 'may God protect you'. 
Seght mi priester, soete vrient, bi den Heere dien ghi dient, in wat ordinen wildi hu doen, dat ghi draghet roeden capproen?

945 So weder sidi abd so pryhore? $[198 \mathrm{rb}]$ Hi ghinc hu arde na den hore die hu dese crune hevet bescoren! Ghi hebt huwen top verloren, ghi hebt hu anscoen afghedaen:

950 ic wane ghi wilt zinghen gaen van huwen complete dat ghetijde.'

Dit hoerde Brune ende wart omblijde, want hi ne const doe niet ghewreken. Hem so dochte sijn herte breken

955 ende slouch weder in die riviere. Hi ne wilde van den fellen diere nemmeer hoeren die tale. Hi liet hem neder daer te dale metten strome dryven tehant

960 ende ghinc ligghen up dat zant. Hoe sal nu Brune te hove comen? Al mocht hem al de weerelt vromen, hi ne ghinghe niet over sine voete. Hi was ghenoopt so onsoete

965 in die eecke, daer hi tevoren van tween voeten hadde verloren alle die claeuwen ende dat vel, hi ne conste niet ghepeinsen wel hoe hi best ten coninc gaet.

970 Nu hoert hoe hi die vaert bestaet! Hi zat over sine hamen ende began met groter scamen rutsen over sinen staert. Ende als hi dus moede waert,

950-51 For the liturgical hours, see the note to lines 384-85. 954 In other words: he could no longer stand it.

961-81 After the painful escape from the half-split oak, the beating by the villagers and Reynaert's cruel taunts, Bruun's humiliation is still not over. His front paws lack skin and 
Tell me, priest, dear friend, by the Lord that you serve, which Order do you intend to join, as you are wearing a red hat?

945 Are you an abbot or prior?

Whoever gave you this tonsure sheared very close to your ears! You have lost the hair on your crown, you have taken off your gloves:

950 I take it that you intend to sing the Hour of compline.'

Bruun heard this and was not amused, for he could not at that moment take revenge. It seemed to him his heart would break

955 and he plunged back into the river.

He no longer wanted to hear the words of that vicious animal. He let himself float downriver on the current at once

960 and lay down on the sandy riverbank.

How is Bruun to reach the court now?

Nothing in the world would induce him to go on foot. He had been caught in the oak

965 so painfully - where earlier he had lost from his two paws all the nails as well as the skin that he was at a loss how best to go to the king.

970 Now hear how he undertakes the journey!

He sat on his behind and began, feeling very ashamed, to move himself forward on his tail. And if, doing this, he became tired,

claws, so that once he has crawled out of the water, he can only move in unorthodox fashion, by sliding on his tail and rolling over and over from his back to his stomach. This is how he approaches the court, where some wonder what (not: who) it is that comes spinning down the road. 
975 so wentelde hi dan eene wile.

Dus dreef hi meer dan eene mile eer hi tes coninx hove quam.

Doe men Brune vernam in derre wijs van verren comen, 980 wart ghetwifelt van hem zomen wat daer quam ghewentelt zoe. Dien coninc wart de herte onvroe, die Brune bekende tehant, ende seide: 'Dit es mijn serjant,

985 Brune; hem es dat hoeft so roet, hi es ghewont toter doot.

Ay God, wie heeftene so mesmaect?'

Binnen desen so was Brune ghenaect dat hi den coninc claghen mochte.

990 Hi stan ende versuchte onzochte ende sprac: 'Coninc, edel heere, wreket mi dor hu selves eere over Reynaerde, dat felle dier, die mi mine scone lier met ziere lust verliesen dede ende daertoe mine hoere mede ende hevet mi ghemaect als ghi siet.' Die coninc sprac: 'Of ic dit niet ne wreke, so moetic zijn verdoomt!'

1000 Ende hierna so hevet hi ghenoomt alle die hoechste bi namen ende ontboet dat si quamen allegader an sinen raet ende rieden hoe dese daet

1005 best werde gherecht tes conincs eere.

Doe rieden die meeste heeren dat menne twee waerven daghen soude, Reynaerde, of die coninc woude, ende horen tale ende wedertale.

1010 Oec seiden si, si wilden wale

1009 tale ende wedertale: literally: 'tale and countertale', here: charge and defence. 
975 he would roll for a while.

He did this for more than a mile

before reaching the king's court.

When Bruun's approach

in this manner was spotted from a distance,

980 some could not make out what it was

that came rolling there.

The king, who recognized Bruun at once,

felt very sad at heart

and said: 'This is my servant,

985 Bruun; his head is so red

that he must be mortally injured.

Dear God, who has maltreated him so?'

Meanwhile Bruun had come so near

that he could complain to the king.

990 He moaned and sighed loudly

and said: 'King, noble lord,

revenge me for the sake of your own honour

on Reynaert, that vicious animal

who, with his nasty trick,

995 has made me lose my fair cheeks

and my ear to boot,

and has made me as you see me.'

The king said: 'May I be damned

if I don't avenge this!'

1000

And afterwards he called

all the mightiest lords by name

and ordered them all to attend his council

and to advise him how this deed

might best be dealt with by law

1005 in accordance with the king's honour.

Then the highest in the land suggested

that Reynaert should be summoned a second time, if the king agreed,

so that both sides of the story might be heard.

1010 They also said that they would like 
dat Tybeert die cater van desen tote Reynaerde bode soude wesen.

Al ware hi cranc, hi ware vroet.

Dese raet dinct den coninc goet.

1015 Doe sprac die coninc: 'Heere Tybeert, gaet wech. Eer ghi wederkeert, besiet dat Reynaert met hu come.

Dese heeren segghen some, al es Reynaert andren dieren fel,

1020 hi gheloevet hu so wel dat hi gherne doet huwen raet. Ne comt hi niet, hets hem quaet. Men salne drie waerven daghen te lachtre alle sinen maghen.

1025 Gaet Tybeert, dit secht hem.' 'Ay heere,' sprac Tybeert, 'ic bem een arem wicht, een cleene dier. Heere Brune, die staerc was ende fier, ne conste Reynaert niet ghewinnen.

1030 In welker wijs salics beghinnen?'

Doe sprac die coninc: 'Heere Tybeert, ghi zijt wijs ende wel gheleert.

Al sidi niet groet, nochtan hets menich die met luste can

1035 dat werken ende met goeden rade dat hi met crachte niet ne dade. Gaet, doet sciere mijn ghebod.' Tybeert sprac: 'Nu helpe mi God dat het mi moete wel vergaen.

1040 Ic sal eene vaert bestaen die mi doet zwaer in minen moet. God ghevere mi af al goet!'

1023-24 According to medieval legal procedures an accused had to be summoned three times before he could be sentenced in absentia. By staying away the accused showed that he had a bad conscience and wished to stay out of the clutches of the law. 
Tybeert the cat to be the messenger to Reynaert.

Although he was weak, he was clever. The king thought this good advice.

1015 Then the king said: 'Lord Tybeert, on your way. Make sure, before you return, that Reynaert comes with you.

Some of these lords say that, although Reynaert is hostile towards

1020 other animals, he trusts you so much that he will do as you tell him.

If he fails to appear, he will be the worse for it.

He will be summoned a third time, to the disgrace of all his relatives.

1025 Go, Tybeert, tell him this.'

'Please, lord,' Tybeert said, 'I am a poor creature, a small animal.

Lord Bruun, who was strong and brave could not get the better of Reynaert.

$1030 \quad$ How am I to tackle this?'

Then the king said: 'Lord Tybeert, you are wise and experienced.

You may not be big, yet often many with cunning and discretion

1035 reach results that with violence they would not. Go, quickly do as I tell you.' Tybeert said: 'Now may God help me, that it will end well for me.

1040 I must undertake a journey that presses heavily on me. God give that I may fare well!' 
$\mathrm{Nu}$ moet Tybeert doen die vaert, die zeere es drouve ende vervaert.

1045 Ende als hi up den wech quam, sach hi van verren ende vernam

Sente Martins voghel, ende quam ghevloghen.

Doe wart Tybeert vroe ende in hoghen ende riep an: 'Sente Martins voghel,

1049a keer herwaert dinen vlogel,

1050 nu vliech te miere rechter hant!'

Die voghel vloech daer hi vant een haghe daer hi in wilde lijden ende vloech Tybeert ter luchter zijden.

Dit teekin ende dit ghemoet

1055 dochte Tybeert niet wesen goet. Hadde hi ghesien den voghel lijden scone ter rechter zijden, so waende hi hebben goet gheval.

$\mathrm{Nu}$ was hi dies onthopet al.

1060 Nochtan maecte hi hem selven moet ende gheliet hem, als menich doet, bet dan hem te moede was. Dus liep hi henen sinen pas, tes hi quam te Manpertus

1065 ende vant Reynaerde in zijn huus alleene staen verweendelike. Tybeert sprac: 'God die rike moete hu goeden avont gheven.

Die coninc dreecht hu an hu leven, 1070 ne comdi niet te hove met mi.' Reynaert sprac: 'Tybeert, helet vry, [199ra] neve, ghi zijt mi willecome. God gheve hu eere ende vrome. Bi Gode, dat jan ic hu wale!'

1043-59 According to medieval superstition it was bad luck to be passed on one's left by a Saint Martin's bird. The frightened cat has, therefore, been warned. In the Middle Ages the left had negative connotations, a result of biblical influence. It is not known which bird is 


\section{Second summons}

Now Tybeert has to undertake the journey, feeling very anxious and fearful.

1045 And when he had started on his road, he saw and noticed from a distance a Saint Martin's bird, which came flying towards him.

This made Tybeert glad and cheerful and he called out: 'Saint Martin's bird,

1049 a wend your wing this way,

1050 now fly along my right hand side!'

The bird flew to where it found a bush into which it wished to go and flew along Tybeert's left hand side. This omen and this encounter

1055 did not seem good news to Tybeert. If he had seen the bird pass him nicely on his right, he would have imagined himself in luck. Now he had lost all hope of success.

1060 Nevertheless he pulled himself together and pretended - as many do to be more confident than he felt. And so he walked on at a steady pace until he reached Manpertuus

1065 and found Reynaert at home, standing there full of confidence.

Tybeert said: 'May the Almighty God give you a good evening. The king is threatening to take your life 1070 if you do not come to court with me.' Reynaert said: 'Tybeert, noble hero, nephew, you are welcome here. God give you honour and prosperity. By God, that would I wish for you!' hen harrier. The bird was probably associated with impurity and deadly danger. 
1075 Wat coste Reynaerde scone tale?

Al seghet sine tonghe wale, sine herte die es binnen fel. Dit wert Tybeerde ghetoghet wel eer die lijne wert ghelesen

1080 ten hende. Ende met desen sprac Reynaert: 'Neve, ic wille dat ghi tavont herberghe hebt met mi ende morghen willen wi metten daghe te hove waert sonder saghe.

1085 In hebbe oec onder alle mine maghe niement, Tybeert, daer ic mi nu bet up verlate dan up hu. Hier was commen Bruun de vraet. Hi toechde mi so fel ghelaet ende dochte mi so overstaerc dat ic omme dusent maerc den wech met hem niet hadde bestaen. Dat sal ic met hu, al sonder waen, maerghin metter dagheraet.'

1095 Tybeert sprac: 'Hets beteren raet ende het dinct mi beter ghedaen dat wi noch tavont te hove gaen dan wi tote morghin beiden.

Die mane scijnet an der heiden

1100 also claer alse die dach.

Ic wane, niemen ne sach beter tijt tote onser vaert.' 'Neen, lieve neve,' sprac Reynaert, 'sulc mochte ons dages ghemoeten, 1105 hi soude ons quedden ende groeten, die ons nemmermee dade goet,

1079-80 These lines mean literally: 'before the line has been read to the end'. Possibly lijne suggests a string of prayer beads.

1081-1158 After the first summons the day has advanced. Tybeert already wishes Reynaert 'good evening' (goeden avont, 1068) and intends to return at once with the fox to the king's court. Reynaert, however, wishes to wait until the next morning and offers Tybeert hospitality, which means that a meal will have to be eaten. When Tybeert himself mentions the evening meal (110910), Reynaert answers that all he has in the house is honey, knowing that cats do not like honey. 
1075 What does the smooth talking cost Reynaert?

Even though his tongue speaks fine words,

within his heart he is wicked.

This will become clear to Tybeert

before the story has been read

1080 to its conclusion. And then

Reynaert said: 'Nephew, I want you

to be my guest tonight,

and tomorrow, at light of day,

we will go to court without further ado.

1085 After all, among all my relatives

I have no one, Tybeert, in whom

I put more trust than I do in you.

Bruun the glutton came here.

He had such an aggressive attitude

1090 and I considered him so immensely strong

that I would not for a thousand marks

have walked along the way with him.

But I will with you, definitely,

tomorrow morning at dawn.'

1095 Tybeert said: 'It is more advisable

and it seems better to me

if we went to court this evening

than waiting until tomorrow.

The moon is shining on the heath

1100 as brightly as if it were day.

I think that no one could find

a better time for our journey.'

'No, dear nephew,' Reynaert said,

'Those who, if met during the day,

1105 would address and greet us,

would most certainly not treat us well

By means of these clever manipulations Reynaert induces the cat to name his favourite food himself (fat mice). In turn, this provides an opening for suggesting that the guest's food should be procured elsewhere. Reynaert's proposition - in which the number of mice in the priest's barn is of a hyperbolic size (1123-26) - is met by Tybeert in equally exaggerated terms (1134-41, 1149-50, 1155-56). The fox increases Tybeert's excitement by pretending not to understand his enthusiasm (1121-22, 1131-32, 1142, 1147). On the structure of Reynaert's tricks, see also p. 20.

1091 A marc is a gold or silver coin. 
quame hi snachts in ons ghemoet.

Ghi moet herberghen tavont met mi.'

Tybeert sprac: 'Wat souden wy

1110 eten, Reynaert, of ic hier bleve?'

'Daeromme zorghe ic, lieve neve.

Hier es der spijsen quaden tijt.

Ghi mocht heten, begheerdijt,

een stic van eere honichraten,

1115 die bequamelic es utermaten.

Wat sechdi, moochdi shonichs yet?'

Tybeert sprac: 'Mi ne roukes niet.

Reynaert, hebdi niet in huus?

Gavedi mi eene vette muus,

1120 daermede liet ic hu ghewaert.'

'Eene vette muus,' sprac Reynaert, 'soete Tybeert, wat sechdi?

Hier woent noch een pape bi;

een scuere staet noch an sijn huus,

1125 daer in es meneghe vette muus.

Ic waense niet ghedroughe een waghen, so dicken hoere ic den pape claghen dat sine dryven huten huuse.'

'Reynaert, zijn daer so vette muse?

1130 Verghave God, waer ic nu daer.'

'Tybeert,' seit hi, 'sechdi waer?

Wildi muse?' 'Of icse wille?

Reynaert, doet dies een ghestille.

Ic minne muse voer alle saken.

1135 Weetti niet dat muse smaken

bet dan eenich venisoen?

Wildi minen wille doen

dat ghi mi leet daer si zijn,

daermede mochti die hulde mijn

1140 hebben, al haddi minen vadre

doot ende mijn gheslachte algadre.'

Reynaert sprac: 'Neve, houddi hu spot?'

'Neen ic, Reynaert, also helpe mi God.'

'Weet God, Tybeert, wistic dat,

1145 ghi soutter sijn noch tavont sat.' 
if they met us at night.

You must stay and be my guest tonight.'

Tybeert said: 'What would we

1110 eat, Reynaert, if I stayed here?'

'That is what worries me, dear nephew.

Food is scarce here at the moment.

You might, if you like, eat a piece of honeycomb,

1115 which is quite delicious.

What do you say, you like honey perhaps?'

Tybeert said: 'I don't care for it.

Reynaert, don't you have anything else in your house?

If you gave me a fat mouse,

1120 I would be content with that.'

'A fat mouse,' Reynaert said, 'sweet Tybeert, what are you saying?

Now near here lives a priest;

a barn is built against his house

1125 in which there are many fat mice.

I believe they would not fit into a cart, so often do I hear the priest complain

that they are driving him from house and home.'

- 'Reynaert, are there really such fat mice there?

1130 God give that I was there now.'

'Tybeert,' he said, 'Is this true?

Do you want mice?' - 'Do I want them?

Reynaert, be silent about it.

I love mice above anything.

1135 Don't you know that mice taste

better than any kind of game?

If you are willing to do as I wish

by leading me to the place where they are,

you would be assured of my friendship,

1140 even if you were the murderer

of my father and all my kin.'

Reynaert said: 'Nephew, are you joking?'

- 'Not me, Reynaert, so help me God.'

- 'God is my witness, Tybeert: if I was sure of that

1145 you would eat your fill there even tonight.' 
'Sat, Reynaert? Dat ware vele!'

'Tybeert, dat sechdi thuwen spele.'

'In doe, Reynaert, bi miere wet.

Haddic een muus ende waer so vet,

1150 in gaefse niet omme eenen busant.'

'Tybeert, gaet met mi tehant.

Ic leede hu daer ter selver stat

daer icker hu sal maken zat,

eer ic nemmermeer van hu sceede.'

1155 'Ja ic, Reynaert, up die gheleede

ghinghe ic met hu te Mompelier.'

[199va]

'So gaen wi dan. Wi sijn hier

al te langhe,' sprac Reynaert.

Doe so namen si up die vaert,

1160 Tybeert ende sijn oem Reynaert, ende liepen daer si loepen wilden dat si nye toghel uphilden eer si quamen tes papen scuere, die met eenen erdinen muere

1165 al omme ende omme was beloken, daer Reynaert in was tebroken des ander daghes daertevoren, doe die pape hadde verloren eenen hane, die hi hem nam.

1170 Hieromme was tornich ende gram des papen sone Martinet, ende hadde voer dat gat gheset een strec den vos mede te vane. Dus gherne wrake hi den hane.

1175 Dit wiste Reynaert, dat felle dier, ende sprac: 'Neve Tybeert, hier crupet in dit selve gat.

Ne weset traghe no lat.

Gaet al omme ende omme gripen.

1156 In the Middle Ages Montpellier in the south of France was the place to study medicine. It was a widely known town, mentioned by Tybeert because it is far away.

1171 Martinet is the result of a forbidden relationship. He is the son of a priest, someone not allowed to enter into a sexual relationship with a woman (see also the note to 731 ). His 
- 'My fill, Reynaert? That would be nice!'

- 'Tybeert, you are only saying this in jest.'

- 'I am not, Reynaert, by my faith.

If I had a mouse, and if it was fat,

1150 I would not part with it for a piece of gold.'

- 'Tybeert, come with me straightaway.

I shall lead you to this place

where I shall make you get your fill

before I ever leave your side again.'

1155 - 'Yes, Reynaert, with that assurance

I would even go with you to Montpellier.'

- 'Well, then, let's go. We have been here

too long already,' Reynaert said.

Then they set out on their journey,

1160 Tybeert and his uncle Reynaert, and ran where they wanted to run, with unbridled speed, until they reached the priest's barn, which had been enclosed

1165 all round with an earthen wall, which Reynaert had broken into the day before when the priest had lost a cock, which the fox had taken from him.

1170 For this reason the priest's son Martinet was fuming and irate, and before the hole he had set a snare to catch the fox. So badly did he want to avenge the cock.

1175 Reynaert, that evil animal, knew this, and said: 'Nephew Tybeert, crawl through this hole here. Don't dawdle or be slow.

Grab everything about and around you.

name is reminiscent of the Saint Martin's bird that gave a first indication of Tybeert's impending misfortune (1047) brought about by the priest's son. He is the one who discovers the cat in the snare, wakes the people in the house, and throws the stone that puts out Tybeert's eye. 
1180 Hoert hoe die muse pipen!

Keert weder huut als ghi zijt sat.

Ic sal hier bliven voer dit gat ende sal hu hier buten beiden.

Wi ne moghen niet tavont sceiden.

1185 Morghin gaen wi te hove waert.

Tybeert, siet dat ghi niet en spaert.

Gaet heten ende laet ons keeren

te miere herberghen met eeren.

Mijn wijf sal ons wel ontfaen.'

1190 'Willic te desen gate ingaen?

Wat sechdi, Reynaert, eist hu raet?

Die papen connen vele baraet,

ic besteecse arde noode.'

'O wy, Tybeert, twi sidi bloode?

1195 Wanen quam huwer herten desen wanc?'

Tybeert scaemde hem ende spranc

daer hi vant groet ongherec,

want eer hijt wiste, was hem een strec

omme sinen hals arde vast.

1200 Dus hoende Reynaert sinen gast!

Alse Tybeert gheware wart

des strecs, wart hi vervaert

ende spranc voert. Dat strec liep toe.

Tybeert moeste roupen doe

1205 ende wroughede hem selven dor den noot.

Hi makede een gheroup so groot

met eenen jammerliken ghelate

dat Reynaert hoerde up der strate

buten, daer hi alleene stoet,

1210 ende riep: 'Vindise goet,

die muse, Tybeert, ende vet?

Wiste nu dat Martinet,

1190-99 Once arrived at the hole in the wall around the priest's barn, Tybeert hesitates despite his greedy appetite. The delay in the action serves to heighten the suspense: is Tybeert going to discover the danger that is in store for him after all? However, Reynaert overcomes Tybeert's suspicions by accusing him of cowardice. Ashamed of himself the cat jumps through the hole, and gets caught in the snare. The same procedure is used to an even more marked degree in the case of the deception of King Nobel (cf. 2200, 2514-17, 2623-35). 
1180 Hear how the mice are squeaking!

Come outside again when you've had enough.

I shall stay by this hole and shall wait for you here outside.

We must stay together tonight.

1185 Tomorrow we will go to court.

Tybeert, take care not to be slow.

Go and eat and let us return

to my hospitable dwelling, as is fitting.

My wife will receive us gladly.'

1190 - 'Should I go in through this hole?

What do you say, Reynaert, is that your advice?

Priests are cunning;

I don't like to cross them.'

- 'Oh dear, Tybeert, why are you such a coward?

1195 What caused this change of heart?'

Tybeert was ashamed of himself and jumped

into a place where he experienced great misery,

because, before he knew it, a snare

was very tight around his neck.

1200 In this way Reynaert deceived his guest!

When Tybert became aware

of the snare, he took fright

and jumped forward. The snare pulled tight.

Tybeert then had to scream

1205 and betrayed himself by his distress.

He uttered such loud screams

and cried out so pitifully

that Reynaert heard it in the street,

outside, where he stood by himself,

1210 and he shouted: 'Are the mice to your liking,

Tybeert, and are they fat?

If only Martinet knew

1200 By stating that Reynaert disgraces his guest, the narrator shows disapproval of the fox's behaviour. Reynaert violates the rules governing hospitality in order to get rid of Tybeert (cf. 1108, 1187-89).

1210-25 As was the case where it concerned Bruun, Reynaert rejoices in Tybeert's suffering when his scheme has worked. The sauce (1216) refers to the physical abuse at Martinet's hands (see note to lines 705-6). 
dat ghi ter taflen satet

ende dit wiltbraet dus hatet,

1215 dat ghi verteert, in weet hoe, hi sauder hu saeuse maken toe.

So hovesch een cnape es Martinet!

Tybeert, ghi singhet in lanc so bet.

Pleecht men tes coninx hove des?

1220 Verghave God, die gheweldich es, dat, Tybeert, daer met hu ware

Ysingrijn die mordenare

in sulker bliscap als ghi zijt!

Dus heeft Reynaert groot delijt

1225 dor Tybeerts ongheval.

Ende Tybeert stont ende ghal

so lude dat Martinet ontspranc.

Martinet riep: 'Ha ha, God danc!

Ter goeder tijt heeft nu ghestaen

1230 mijn strec: ic hebber met ghevaen

den hoenredief na minen wane.

$\mathrm{Nu}$ toe, ghelden wi hem den hane!'

Met desen wart hi toten viere

ende ontstac eenen stroewisch sciere

1235 ende wecte moedre ende vadre

ende die kindre allegadre

ende riep: 'Nu toe, hi es ghevaen!'

Doe mochte men sien porren saen

alle die in dien huus waren.

1240 Selve die pape ne wilde niet sparen, quam hute sinen bedde moedernaect.

Martinet hi was gheraect

tote Tybeert ende riep: 'Hijs hier!'

Die pape spranc an dat vier

1245 ende ghegreep zijns wijfs rocke.

Een offerkeersse nam vrouwe Julocke

1236 The scandalous relationship in which the priest is engaged with Julocke has, as we find here, led to more children. This may well be mentioned to discredit the priest even more. 1245-49 In this scene Willem alludes to the motif of the mundus inversus, the world turned upside down. The priest and his wife each reach for objects (the distaff and the church candle) which are part of their partner's daily business: Julocke carries the heavy candle, and the priest 
that you were at table

and eating this game in this way

- how you can stomach it I don't know -

he would make you a sauce with it.

Such a well-mannered boy is Martinet!

Tybeert, you are singing better all the time.

Is that customary at the king's court?

1220

If only it had pleased the almighty God

that that criminal Ysingrijn

had been with you, Tybeert,

and as full of joy as you are!'

In this way Reynaert delights

1225 in Tybeert's mishap.

And Tybeert stood screaming

so loudly that Martinet woke up.

Martinet shouted: 'Ha, ha, thank God!

My snare was set at the right time:

1230 it seems to me that I have caught the chicken thief with it.

Let's go now and settle the score for the cock!'

At once he moved to the fire and quickly lit a wisp of straw,

1235 and woke his mother and father and all the children

and shouted: 'Let's go, he's caught!'

Then all those who were in the house

could be seen to shift themselves immediately.

1240 The priest himself, not wishing to stay behind,

left his bed as naked as the day he was born.

Martinet had reached Tybeert

and shouted: 'He is here!'

The priest jumped towards the fire

1245 and grabbed his wife's distaff.

Lady Julocke took a church candle

runs out wielding the distaff, an object strongly associated with femininity and, in the hands of a man, with a marked lack of masculinity. A little later Julocke says that she would have been quite prepared to give up the alms money of a whole year to have prevented the priest's injury, again assuming her husband's role (1272-75). The comic role reversal is concluded with the image of Julocke carrying her injured husband to his bed in her arms when, like a woman, he has fainted. 
ende ontstacse metter haest.

Die pape liep Tybeert naest

ende ghincken metten rocke slaen.

1250 Doe moeste Tybeert daer ontfaen

wel meneghen slach alineen.

Die pape stont, als hem wel sceen, al naect ende slouch slach in slach up Tybeert die voer hem lach.

1255 Daer ne spaerdene haer negheen. Martinet ghegreep eenen steen ende warp Tybeert een hoghe huut.

Die pape stont al bloeter huut ende hief up eenen groeten slach.

1260 Alse Tybeert dat ghesach, dat hi emmer sterven soude, doe dedi een deel als die boude, dat dien pape verghinc te scanden. Beede met claeuwen ende met tanden

1265 dedi hem pant, alsoet wel scheen, ende spranc dien pape tusschen die been in die burse al sonder naet, daer men dien beyaert mede slaet. Dat dinc viel neder up den vloer.

1270 Die vrauwe was zeerich ende zwoer bi der zielen van haren vader, si ne wilde wel om algader die offerande van eenen jare dat niet den pape ghevallen ware

1275 dit vernoy ende dese scame. So sprac: 'In sleets duvels name moete dit strec sijn gheset! Siet, lieve neve Martinet, dit was van huwes vader ghewande.

1280 Siet hier mijn scade ende mijn scande

1260-69 As was the case during the first summons, it is the sensuality of the relationship between the priest and Julocke which enables the messenger to save himself. Because Tybeert, fearing for his life, jumps up into the priest's crutch and tears off a testicle, all members of the family stop maltreating the cat and concentrate on the priest. This enables Tybeert to 
and hastily lit it.

The priest went towards Tybeert

and started to hit him with the distaff.

1250 Then Tybeert had to accept

many blows in a short time.

The priest stood, as all could see, completely naked and, blow upon blow,

hit Tybeert lying before him.

1255 Nobody spared themselves there.

Martinet picked up a stone

and threw it at Tybeert, which cost him an eye.

The priest stood dressed only in his skin

and raised his arms for a mighty blow.

1260 When Tybeert realised

that he was sure to die,

he summoned the little courage he had,

which led to dishonour for the priest.

With both his claws and his teeth

1265 did he injure him, as was obvious,

and jumped up between the priest's legs,

at the purse that has no seam,

with which the bells are rung.

The thing fell down on to the floor.

1270 The wife was distressed and swore

by her father's soul

that she would gladly have given

the alms of an entire year

for the priest not to have suffered

1275 this sorrow and this shame.

She said: 'In the name of the hideous devil

this snare must have been set!

See, my dear Martinet,

this was part of your father's tools.

1280 See here my loss and my shame

tear the snare apart with his teeth and escape (1308-16).

1276-83 Julocke regrets the priest's loss, fearing he will become impotent and unable to satisfy her sexual needs. Once again the priest's forbidden relationship is highlighted.

1278 Julocke's use of the word neve expresses intimacy. See also 3075. 
emmermeer voert in allen stonden.

Al ghenase hi van der wonden, hi blivet den soeten spele mat.'

Reynaert stont noch doe voer tgat.

1285 Doe hi dese tale hoerde, hi louch dat hem bachten scorde ende hem crakede die taverne. Doe sprac hi te sinen scherne: 'Swijghet, Julocke, soete vrouwe, 1290 ende laet zijncken desen rauwe ende laet bliven huwen toren! Wattan, al hevet hu heere verloren eenen van den clippelen zinen? Al te min so sal hi pinen!

1295 Laet bliven dese tale achtre. Gheneset de pape, en es gheen lachtre dat hi ludet met eere clocken!' Dus troeste Reynaert vrauwe Julocken, die haer arde zeere mesliet.

1300 Die pape mochte langher niet ghestaen; hi viel in ommacht. Doe hiefsene up met haerre cracht ende drouchene recht te bedde waert. Hierbinnen keerde Reynaert

1305 alleene ter herberghen waert ende liet Tybeert zeere vervaert ende in zorghen van der doot. $\mathrm{Al}$ was Tybeerts zorghe groet, doe hise alle onledich sach 1310 over dien pape, die daer lach ghewont, doe ghinc hi hem pinen so dat hi metten tanden zine die pese midden beet ontwee. Doe ne wildi letten nemmee 1315 ende spranc weder hute ten gate ende dede hem up die rechte strate,

1288-97 Rey'naert's taunts are not limited to his victim Tybeert. Julocke, too, is comforted sarcastically by the fox on account of her lamentations. According to the fox her husband will 
for ever and a day.

Even if he recovers of his injuries,

he still won't be up to our sweet game.'

Reynaert was still standing before the hole.

1285 When he heard these words, he laughed until his belly nearly burst and a fart cracked from his backside.

Then he said, mockingly:

'Be silent, Julocke, dear lady,

1290 and restrain these lamentations

and put a stop to your distress!

What does it matter that your lord has lost

one of his clappers?

The less he will need to exert himself!

1295 Be quiet about this.

If the priest recovers, it will be no dishonour

that he rings with one bell!'

In this way Reynaert comforted Lady Julocke, who carried on very noisily.

1300 The priest could no longer

stand; he fainted.

Then she lifted him up with a great effort

and carried him straight to bed.

Meanwhile Reynaert returned

1305 to his dwelling alone,

leaving Tybeert in great anguish

and mortal fear.

Even though Tybeert's worries were great,

when he saw that all were occupied

1310 with the priest who was lying there

injured, he made such an effort

that with his teeth

he bit the cord in two.

Then he did not hesitate for a moment

1315 and jumped back out of the hole

and took the straight road

be capable of performing satisfactorily in bed with just one testicle. In the course of the first summons Bruun was mocked twice. 
die tes conincx waert ghelach.

Eer hi daer quam, so waest dach

ende die zonne begonste rijsen.

1320 In eens arems ziecs wijsen quam Tybeert in thof gheronnen, die tes papen hadde ghewonnen dat hi langhe claghen mach.

Alse die coninc dit versach,

1325 dat hi hadde dat hoeghe verloren, doe mochte men vreeselike horen den coninc dreeghen den dief Reynaert.

Die coninc doe niet langher ne spaert, hi ne riep sine baroene te rade

1330 ende vraechde wat hi best dade jeghen Reynaerts overdaet.

Doe wart ghindre menich raet hoe men Reynaert ter redenen brochte, die dese overdaet wrochte.

1335 Doe sprac Grimbeert die das, die Reynaerts broedersone was: 'Ghi heeren, ghi hebt meneghen raet. Al ware mijn oem noch also quaet, sal men vry recht voertdraghen,

1340 men salne drie waerven daghen, also men doet eenen vryen man. Ende en comt hi niet dan, so es hi sculdich alre dinc daer hi af voer den coninc

1345 van desen heeren es beclaghet.' 'Wie wildi, Grimbeert, dattene daghet?' sprac de coninc. 'Wie es hier die sijn hoeghe ofte sijn lier wille setten in avontueren

1350 omme eene felle creatuere? Ic wane hier niemene en es so zot.' Grimbeert sprac: 'So helpe mi God! Siet mi hier; ic bem so coene

1340-45 According to the medieval law of litigation Reynaert can be sentenced in absentia if 
that led to the king's court.

Before he arrived there, it was day

and the sun began to rise.

1320 Pitiful and weak, Tybeert came running into the court; at the priest's house he had gained something he might long complain of. When the king noticed

1325 that he had lost an eye, the king could be heard to threaten that criminal Reynaert fearfully. The king then lost no time in summoning his barons to council

1330 and he asked what he might best do as regards Reynaert's offence.

Then many a proposal was made how Reynaert, who had perpetrated this offence, should be made to see reason.

1335 Then Grimbeert the badger, who was Reynaert's brother's son, said: 'My lords, you have given much advice. Even if my uncle were twice as bad, if the law for the free is to be maintained, 1340 he will have to be summoned three times, as is done where it concerns a free man. And if he fails to appear then, he will be found guilty of everything of which he has been accused

1345 by these lords before the king.' 'Who, according to you, Grimbeert, should serve the summons?' said the king. 'Which of those present is willing to risk his eye or cheek

1350 for a fiendish creature? I reckon that no one here is fool enough.' Grimbeert said: 'So help me God! Look at me here, I am so brave he also fails to respond to the third summons without a lawful excuse. See the note to 1023-24. 
dat ic wel dar bestaen te doene

1355 dese bodscap, ghebiedijt.'

'Grimbeert, gaet wech ende zijt

vroet ende wacht hu jeghen mesval.'

Grimbert sprac: 'Coninc heere, ic sal.'

Dus gaet Grimbeert te Manpertuus.

1360 Als hire quam, vant hi in huus

sinen oem ende vrauwe Ermelijnen,

die bi haren welpekijnen

laghen in die haghedochte.

Ende ten eersten dat Grimbeert mochte,

1365 groette hi sinen oem ende ziere moyen.

$[200 v b]$

Hi sprac: 'En sal hu niet vernoyen

des onrechts daer ghi in zijt?

Dincket hu noch niet wesen tijt

dat ghi trect, oem Reynaert,

1370 tote des conincs hove waert, daer ghi wel zeere zijt beclaghet?

Ghi zijt III waerven ghedaghet.

Vermerrendi maerghin den dach, so zorghic dat hu ne mach

1375 negheene ghenade me ghescien.

Ghi sult in den derden daghe sien

huwen casteel bestormen, Manpertuus.

Ghi sult gherecht sien voer hu huus

eene galghe ofte een rat.

1380 Over waer segghic hu dat:

beede hu kindre ende hu wijf

1364-1406 Grimbeert's announcement that ignoring this third summons will result in the storming of Manpertuus after three days and the death of Reynaert with his wife and children is in accordance with medieval law. Three days after the final summons has been served the breaker of the peace is declared an outlaw. The fox seems impressed by these arguments and states that he will follow Grimbeert to the king's court (1399-1506). When, at the end of the story, Reynaert has fled with his family to a new wilderness (3140-65, 3317-29), the reader may wonder why he did not do this as soon as Grimbeert issued his summons. One explanation might be that 
that I dare take

1355 this message, if you tell me to.'

- 'Grimbeert, be on your way and act

cautiously and beware of mishaps.'

Grimbeert said: 'Lord King, so I shall.'

\section{Third summons}

And so Grimbeert goes to Manpertuus.

1360 When he arrived there, he found

his uncle and Lady Hermeline at home,

lying with their cubs

in their den.

And as soon as Grimbeert could,

1365 he greeted his uncle and his aunt.

He said: 'Are you not worried

about your present uncertain legal position?

Don't you think it time yet,

uncle Reynaert, to go

1370 on your way to the king's court

where serious accusations are made against you?

You have been summoned three times.

If you fail to appear tomorrow,

I fear that you will not find

1375 any mercy anymore.

On the third day you will find

your castle Manpertuus stormed.

You will see in front of your house

a gallows or wheel erected.

1380 I assure you of this:

both your children and your wife

Reynaert goes to court to defend the interests of his clan (small predators), but that explanation does not fit the facts. After all, Reynaert's lies and bad behaviour at court and later at Manpertuus result in himself and all his relatives being made outlaws. There is, of course, a narrative explanation: if Willem does not let the fox go to court, the story will reach an abrupt and untimely end. Moreover, it later becomes clear that Reynaert has sought the confrontation with the court deliberately, as maybe deduced from his admission in 2042-49. It would seem that Reynaert had already decided to go to the king's court before Grimbeert's arrival, but does not tell him this. 
sullen verliesen haer lijf

lachterlike, al sonder waen.

Ghi ne moghet selve niet ontgaen.

1385 Daeromme es hu de beste raet

dat ghi met mi te hove gaet.

Hets messelic hoet ghevallen mach:

hu es dicken up eenen dach

vremder avontueren ghevallen

1390 dan ghi noch, quite van hem allen, met des conincx orlove maerghin sciet huten hove.'

Reynaert seide: 'Ghi secht waer.

Nochtan, Grimbeert, comme ic daer

1395 onder des conincs ghesinde, dat ic binnen den hove vinde es up mi verbolghen al.

Quame ic danen, het ware gheval.

Nochtan dinct mi beter wesen

1400 - Ghenese of ic mach ghenesen -

dat ic met hu te hove vare

dan het al verloren ware:

casteel, kindre ende wijf

ende daertoe mijns selves lijf.

1405 In mach den coninc niet ontgaen.

Alse ghi wilt, so willic gaen.

Hoert,' seit hi, 'vrauwe Hermelijne,

ic bevele hu die kindre mine,

dat ghire wale pleghet nu.

1410 Voer alle dandre bevelic hu

minen zone Reynaerdine.

Hem staen wel de gaerdeline

in zine muulkine overal.

Ic hope dat hi mi slachten sal.

1415 Hier es Rossel, een scone dief, die hebbic nochtan harde lief, ja, als yement sine kindre doet. Al eist dat ic nu van hier moet, ic salt mi nemen arde na, updat ic mach, dat ic ontga. 
will most certainly lose their lives

in a dishonourable way.

You will not escape yourself.

1385 Therefore your best advice is

to come with me to court.

It is uncertain how it will end:

you have many a day

had stranger things happen to you

1390 than leaving, acquitted of all accusations,

the court tomorrow

with the king's approval.'

Reynaert said: 'You are right.

Nevertheless, Grimbeert, when I join there

1395 the king's retinue, everyone I shall meet at court bears me a grudge.

To get away from there would be real luck.

Even so, I think it better

1400 - however it will end for me -

that I should go to court with you

than that all should be lost:

castle, children and wife,

and my own life as well.

1405 I cannot escape the king.

If you wish, I shall go.

Listen,' he said, 'Lady Hermeline,

I entrust my children to you,

that you may take good care of them.

1410 Especially I entrust to you

my son Reynardijn.

The whiskers on his little muzzle

suit him well.

I hope that he will take after me.

1415 Here is Rossel, a fine scoundrel, whom I love dearly nevertheless, yes, as much as anyone loves his children.

Even though I must leave here

I shall do the best I can,

1420 if it is within my powers, to escape. 
Grimbeert, neve, God moet hu lonen.'

Met hoofschen woorden ende met sconen

nam Reynaert an de sine orlof

ende ruumde sijns selves hof.

1425 Ay, hoe drouve bleef vrauwe Hermeline

ende hare cleene welpekine,

doe Reynaert sciet huut Manpertuus

ende hi hof liet ende huus

aldus omberaden staen.

1430 Nu hoert wat Reynaert heeft ghedaen

teerst dat hi quam an der heyden!

Hi sprac te Grimbeerte ende zeide:

'Grimbert, scouwet, soete neve,

van zorghen suchtic ende beve.

1434 a Ic ga in vresen vander doet.

$1434 \mathrm{~b}$ Mijn berouwenisse is so groet

1434 c van sonden die ik hebbe gedaen.

1435 Lieve neve, ic wille gaen

1437 te biechten hier te di:

hier nes ander pape bi.

Hebbic mine biechte ghedaen,

1440 hoe so die saken sijn vergaen,

mine ziele sal te claerre wesen.'

Grimbeert andwoerde na desen:

'Oem, wildi te biechten gaen,

so moetti dan verloven saen

1445 alle diefte ende allen roef,

of en diet hu niet een loef.'

1421 It is strange that Reynaert, having just said these words to his wife, suddenly addresses Grimbeert. Why does he abruptly thank the badger? It is likely that something went wrong at some stage in the textual history of the Comburg redaction. In the original work the fox will probably have continued speaking to Hermeline, as he does in other redactions.

1430-1691 The author uses the fox's confession to refer from the main story to existing beast narratives and side stories, thus creating a kind of collage. Here follows a survey of the sins Reynaert confesses: he deceived Bruun (1463-64) as well as Tybeert (1465-67), kidnapped and killed Canticleer's children (1468-72), sneered at the king and queen (1473-77), and tricked Ysingrijn the wolf on many occasions: about their family relationship (1482), as a monk at Elmare (1483-98), with a tonsure (1499-1503), on the ice (1504-7), with the priest of Bloys (1508-1605), at a trapdoor (1606-45), with his wife Haersint (1648-69). Within the reality of the narrative this confession serves two important functions. By making the fox refer to events that (are supposed to) have occurred at an earlier stage of the story or in well-known 
Grimbeert, nephew, may God reward you.'

With courtly and with fine words

Reynaert took leave of his family and departed from his own residence.

1425 Oh, how sadly did Lady Hermeline and her little cubs stay behind, when Reynaert left Manpertuus, leaving home and estate entirely unprotected.

1430 Now hear what Reynaert did as soon as he reached the heath! He addressed Grimbeert and said: 'Grimbeert, look, dear nephew, I sigh and tremble with anxiety.

1434a I am in fear of my life.

1434 b My remorse concerning the sins

$1434 \mathrm{C}$ that I have committed is so great.

1435 Dear nephew, I wish

1437 to confess them here to you:

there is no one else near here to act as priest. Once I have made my confession, 1440 whatever may befall, my soul will be that much cleaner.'

Grimbeert answered to this: 'Uncle, if you want to go to confession you must abjure immediately

1445 all thieving and stealing, otherwise it will do you no good at all.'

beast narratives, the author provides his public with additional information. Partly on the basis of this confession, readers and listeners are thus able to see that Reynaert's claims later in the story are a pack of lies (1820-32, 2095-2105, 2706-16). At the same time the fox throws light on his character by the nature of his confession. Two 'sins' in particular are dwelled on at great length, with Reynaert rendering the dialogues between himself and the characters involved in direct speech (1508-1645). By recounting these adventures, which are at odds with the confession framework on account of their length and wealth of detail, the fox may well be suspected of glorying in his wicked ways.

1433-38 Reynaert claims to be in periculum mortis, in mortal fear of his life. That is a valid reason for making a confession. As there is no priest anywhere near, the fox wishes to confess his sins to the badger. This kind of lay confession was allowed in exceptional circumstances. As becomes clear from what follows, Reynaert lies when he says that he feels perfect contrition (contritio). 
'Dat weet ic wel,' sprac Reynaert.

'Grimbeert, nu hoert haerwaert

ende vandet mi gheraden.

1450 Siet, ic comme hu te ghenaden van allegader mire mesdaet.

$\mathrm{Nu}$ hoert, Grimbeert, ende verstaet:

confiteor pater, mater,

dat ic den otter ende den cater

1455 ende alle diere hebbe mesdaen.

Daeraf willic mi in biechten dwaen.'

Grimbeert sprac: 'Oem, walschedi?

Of ghi yet wilt, spreect jeghen mi

in Dietsche, dat ict mach verstaen.'

1460 Doe sprac Reynaert: 'Ic hebbe mesdaen

jeghen alle diere die leven.

Bidt Gode dat hijt mi moete vergheven.

Ic dede minen oem Brune

al bloedich maken sine crune.

1465 Tybeert dede ic muse vaen

daer ickene zeere dede slaen

tes papen huus, daer hi spranc int strec.

Ic hebbe ghedaen groet ongherec

Canticleer ende sine kindre:

1470 waren si meerre ofte mindre,

dicken makedicse los.

Dor recht beclaghet hi den vos.

Die coninc en es mi oec niet ontgaen.

Ic hebbe hem toren oec ghedaen

1475 ende mesprijs der coninghinne, dat si spade sullen verwinnen

also vele eeren van mi.

Oec hebbic, dat segghic di,

Grimbeert, mee liede bedroghen

1480 dan ic di soude ghesegghen moghen.

1452-59 The standard formula to begin a confession is: 'Confiteor, pater, peccavi' ('I confess, father, for I have sinned'). Reynaert corrupts the Latin and continues in the vernacular. The badger holds the corrupt Latin for French. Both animals are treated ironically here. 
'I am well aware of it,' Reynaert said.

'Grimbeert, now listen carefully

and advise me, please.

1450 See, I come to you for absolution

for all my offences.

Listen, now, Grimbeert, and take note:

Confiteor pater, mater,

that I have wronged

1455 the otter and the cat and every animal.

Of that I desire to cleanse myself through confession.'

Grimbeert said: 'Uncle, are you speaking French?

If you please, speak to me

in Dutch, so I can understand it.'

1460 Then Reynaert said: 'I have misbehaved

towards all living animals.

Pray God that he may pardon me.

I caused my uncle Bruun

to end up with a very bloody crown.

1465 I induced Tybeert to catch mice

where I had him badly beaten,

at the priest's house, where he jumped into the snare.

I have caused Canticleer

and his children much grief:

1470 whether there were many or few,

often I made away with them.

He is right to accuse the fox for it.

Nor did the king escape me.

I caused him distress

1475 and the queen such great shame

that it will be a long time

before they get as much honour from me.

Also I have - I am telling you,

Grimbeert - cheated more persons

1480 than I could tell you.

1473-77 After Reynaert has admitted his cruel treatment of Bruun, Tybeert and Canticleer, he confesses a heinous deed against Nobel and his wife. What event the fox is alluding to is not altogether clear. Perhaps Reynaert is thinking of his rape of the queen, described in branch Ia of the Roman de Renart. Cf. Martin 1882-1887, 1783-1800. 
Ende Ysengrijn, dat verstaet, hiet ic oem dor baraet.

Ic maectene moonc ter Elmaren, daer wi beede begheven waren.

1485 Dat wart hem al te zeere te pinen.

Ic dede hem an die clockelijnen

binden beede sine voete.

Dat luden wart hem doe so soete

dat hijt emmer wilde leeren.

1490 Dat verghinc hem tonneeren, want hi luudde so utermaten

dat alle die ghinghen bi der straten

ende waren binnen der Elmare, waenden dat die duvel ware

1495 ende liepen daer si luden hoerden. Eer hi doe conste in corten woerden ghespreken "Ic wille mi begheven," hadsi hem na ghenomen tleven. Sint dedic hem crune gheven.

1500 Hem maechs ghedincken al zijn leven, dat weetic wel over waer.

Ic dede hem afbernen dat haer, sodat hem die zwaerde cramp. Sint dedic hem meerren scamp

1505 up thijs, daer icken leerde visschen, daer hi niene conste ontwisschen. Hi ontfincker meneghen slach. Sint leeddickene up eenen dach

1481-82 The fact that Reynaert calls the wolf 'uncle' is a feature found in many branches of the Roman de Renart. The animals are supposed to be related and the wolf is considered to be superior in status to the fox. The fox addresses Ysingrijn in this way to win his confidence. Even though the wolf is deceived time and time again, he continues to believe in his pseudonephew's sincerity.

1483-98 It is likely that Willem put together the succinct story of the wolf who has joined a monastic order and, tied to the bell rope, rings the bells and is maltreated, from narrative elements found in various branches of the Roman de Renart. In a number of Old French narratives an animal is made a monk, and other tales refer to the ringing of the bells. It is only in branch VIII of the Roman de Renart that the two elements occur together: Ysingrijn is made a monk and is maltreated after having rung the bells. Cf. Martin 1882-1887, 119-134. On the monastery of Elmare, see the note to 373 . 
And Ysingrijn, understand me well,

I called uncle for a deception.

I made him a monk in Elmare

which we had both entered.

1485 That led to a painful time for him.

I had him tie his two feet

to the bell ropes.

Ringing the bells he liked so much then

that he was eager to practice it.

1490 That caused him great shame,

for he rang the bells so loudly

that all who were walking outside in the street

and all who were inside Elmare

thought that it was the devil

1495 and ran to where they heard the bells ringing.

Then, before he could quickly say

"I want to enter the order",

they had just about taken his life.

Subsequently I gave him a tonsure.

1500 He will remember it all his life,

I am sure of that.

I burned away his hair

as a result of which his scalp shrivelled up.

Later I caused him more disgrace

1505 on the ice, where I taught him to fish

in a place where he could not escape.

There he received a severe hiding.

At a later time I took him one day

1499-1503 Reynaert refers to an adventure told in branch III of the Roman de Renart (cf. Martin 1882-1887, 165-372). There the fox persuades the hungry wolf that he can have an abundance of delicious eels to eat if he decides to become a monk. When Ysingrijn declares that he wants to join the order, the fox gives him a tonsure by scalding him with boiling water, causing the skin to peel off his scalp.

1504-7 The story of the fishing expedition on the ice features in several branches of the Roman de Renart. In branch III the adventure immediately follows the tale of the tonsure (cf. Martin $1882-1887,373-510$ ). One winter the fox makes the wolf believe that he can catch fish by hanging his tail, with a bucket tied to its end, in a hole in the ice. The next morning the wolf finds his tail frozen fast in the ice. He is assaulted by a passing nobleman and his pack of dogs (cf.pp. 30-31).

1508-1605 The story of Ysingrijn's misfortune in the barn of the priest of the (unknown) 
tote des papen van Bloys.

1510 In al dat lant van Vermendoys

so en woende gheen pape riker.

Die selve pape hadde eenen spijker

daer menich vet bake in lach.

Des haddic dicken goet ghelach.

1515 Onder dien spijker haddic een gat

verholenlike ghemaect. In dat,

daer dedic Ysingrijn incrupen.

Daer vant hi rentvleesch in cupen

ende baken hanghende vele.

1520 Des vleesch dedi dor sine kele

so vele gheliden utermaten.

Als hi weder huten gate

waende keeren huter noet,

hem was dien leeden buuc so groet

1525 dat hi beclaghede zijn ghewin.

Daer hi was commen ongherich in, ne condi sat niet commen huut.

Ic liep, ic maecte groet gheluut

int dorp ende maecte groet gherochte.

1530 Nu hoert wat ic daer toebrochte.

Ic liep aldaer die pape zat

te ziere taflen ende hat.

Die pape hadde eenen cappoen,

$[201 v b]$

dat was dat alrebeste hoen

1535 dat men in al dat lant vant.

Hi was ghewent al toter hant.

Dien prandic in minen mont

voer die tafle daer hi stont, aldaert die pape toesach.

1540 Doe riep die pape: "Nu vanc, slach!

village of Bloys consists of two parts. First the tale is told how the wolf, having entered the barn through a gap, gobbled up so much meat that he got stuck on trying to leave. Next Reynaert led the villagers to Ysingrijn by stealing the priest's cock. For the second story Willem may have made use of the Ysengrimus, in which, by stealing a cock, the fox leads a priest and the congregation to the wolf, who at that moment is stuck in the ice by his tail (cf. Mann 1987, book 1, 529, and book 2, 158). Just how false Reynaert's feelings of remorse are, is evident from 
to the priest of Blois.

1510 In the entire region of Vermendois

there was not a richer priest.

This particular priest had a larder

where many sides of good bacon were stored.

I often had a good taste of them.

1515 Under the larder I had made a hole

in a hidden place. Into that hole,

that is where I made Ysengrijn crawl in.

There he found beef in barrels

and many sides of bacon hanging up.

1520 He bolted down an enormous

amount of meat.

When he thought to return

to safety back through the hole,

his damn belly had become so big

1525 that he regretted what he had gained.

The place he had entered hungry

he could not leave now he was full.

I ran away; I made a lot of noise

in the village and made a great racket.

1530 Now hear how I brought that about.

I went to where the priest

was at table, eating his dinner.

The priest had a capon,

it was the very best chicken

1535 to be found anywhere in the region.

It was quite used to being hand fed.

That one I grabbed with my mouth

while it stood before the table, before the priest's eyes.

1540 Then the priest shouted: "Quick, grab him, hit him!

the obvious pleasure with which he describes the way the wolf is attacked.

1510 Vermendois is a county in Northern France that belonged for some time (1156-1186) to the county of Flanders. It has been suggested that the lant van Vermendoys is a concise reference to the area of Oostkerke, between Bruges and Sluis, where the abbey of St.-Quentin (located in the county of Vermendois) had certain possessions.

1527 What is meant here is that the wolf has got stuck. 
Helpe! Wie sach dit wonder nye?

Die vos comt daer ic toezye

ende roeft mi in mijn huus.

So helpe mi Sancta Spiritus.

1545 Te wers hem dat hire quam!"

Dat tafelmes hi upnam

ende stac de tafle dat so vloech

verre boven mi arde hoech

in middenwaerde up den vloer.

1550 Hi vloucte zeere ende zwoer

ende hi riep lude "Slach!" ende "Va!"

Ende ic voeren ende hi na.

Sijn tafelmes haddi verheven

ende brochte mi ghedreven

1555 up Ysingrijn daer hi stont.

Ic hadde dat hoen in minen mont, dat arde groet was ende zwaer.

Dat so moestic laten daer, waest mi leet ofte lief.

1560 Doe riep die pape: "Ay, heere dief, ghi moet den roef hier laten!”

Hi riep ende ic ghinc miere straten danen, daer ic wesen woude.

Alse die pape upheffen soude

1565 dat hoen, sach hi Ysingrine.

Doe naecte hem eene grote pine.

Hi warpene int hoeghe metten messe.

Den pape volchden si zesse, die alle met groeten staven quamen.

1570 Ende als si Ysingrijn vernamen, doe maecten si een groet gheluut ende die ghebuere quamen huut ende maecten grote niemare manlic andren, dat daer ware

1575 in spapen spijker een wulf ghevaen, [202ra] die hem selven hadde ghevaen bi den buke in dat gat.

1544 The priest invokes the Holy Spirit in corrupt Latin: 'Sancta Spiritus' instead of 
Help! Whoever saw a marvel like this?

Even as I watch that fox comes in

and robs me in my house.

So help me Sancta Spiritus.

1545 It will be the worse for him for coming here!"

He grabbed the table knife

and knocked against the table so that

it flew high over my head

and came down in the middle of the floor.

1550 He swore heavily and raged

and shouted loudly "Hit him!" and "Grab him!"

And I was off and he after me.

His table knife he held up high

and he chased me

1555 to where Ysingrijn was standing.

In my mouth I had the chicken

which was very big and heavy.

I had to leave it there, whether I wanted to or not.

$1560 \quad$ Then the priest shouted: "There, sir thief, you have to leave your spoils behind here!"

He shouted and I made off and went on my way.

When the priest was about to pick up

1565 the chicken, he spotted Ysingrijn.

Then great trouble was in store for him.

The priest threw the knife, hitting him in the eye.

Six men followed the priest, who all came carrying big clubs.

1570 And when they saw Ysingrijn

they made a lot of noise

and the neighbours came out of their houses

and told one another about the big news

that there was caught

1575 in the priest's larder a wolf

that had got itself trapped

by its belly in the hole.

'Spiritus Sanctus', thus highlighting his virtual illiteracy. 
Als die ghebuere ghevreescheden dat, liepen si dat wonder bescauwen.

1580 Aldaer wart Ysingrijn teblauwen, sodat hem ghinc al huten spele, want hi ontfincker arde vele groete slaghe ende groete worpe.

Dus quamen die kindre van den dorpe

1585 ende verbonden hem die hoghen. Het stont hem so, hi moest ghedoghen. So zeere slouchsi ende staken dat sine huten gate traken. Doe ghedoghedi vele onghevals.

1590 Ende bonden hem an sinen hals eenen steen ende lietene gaen ende lietene dien honden saen, diene ghinghen bassen ende jaghen. Oec diende men hem met groten slaghen

1595 so langhe dat hi ghelove was. Doe viel hi neder up dat gras of hi ware al steendoot. Doe was dier kindre bliscap groot. Ghindre was groete niemare.

1600 Si namene ende leidene up eene bare ende droughene met groten ghehuke over steene ende over struke. Buten dien dorpe in eene gracht bleef hi ligghende al dien nacht.

1605 Inne weet hoe hi danen voer. Sint verwervic dat hi mi zwoer sine hulde een jaer al omtrent. Dat dedi up sulc convent dat icken soude maken hoenre sat.

1610 Doe leeddickene in eene stat daer ic hem dede te verstane dat twee hinnen ende eenen hane in een groet huus an eere straten

1602 This is the waste land outside the village.

1606-45 The story of Ysingrijn's failed chicken theft from a house where the wolf falls off a roof beam as a result of Reynaert's machinations, is an adventure not found anywhere in the Roman de 
When the neighbours heard that they came to see that marvel.

1580 There Ysingrijn was beaten, so that it was no fun for him at all, for he received many hard blows there and big stones that were thrown at him. Then the children from the village came along 1585 and blindfolded him.

He had little choice, he had to allow it. So violently did they beat and stab him that they managed to pull him out of the hole. Then he had to suffer a great deal of misery.

1590 And they tied a stone to his neck and let him go and at once set the dogs on him, that barked at him and chased him.

He was also treated to severe beatings

1595 for such a long time that he became exhausted. Then he fell down on the grass as if he were as dead as a stone. Then the children were overjoyed. There was much excitement all round.

1600 They picked him up and laid him on a bier and carried him with much clamour across a stony and scrubby waste land. Outside the village in a ditch he lay all that night.

1605 I don't know how he got away from there.

Afterwards I managed to make him swear his friendship for an entire year. He did this on condition that I would stuff him with chickens.

1610 Then I led him to a place where I told him that, in a large house along the road, two hens and a cock

Renart. Willem probably composed this story, basing himself on traditional story elements like the nocturnal break-in and the entrapped burglar betraying his presence by the noise he makes. 1607 sine hulde refers to Ysingrijn's loyalty as a vassal. 
up eenen aenbalke saten,

1615 recht teere valdore bi.

Daer dedic Ysingrijn bi mi

up dat huus clemmen boven.

$[202 \mathrm{rb}]$

Ic seide, ic wilde hem gheloven, wildi crupen in die valdore,

1620 dat hire soude vinden vore van vetten hoenren sijn ghevouch. Ter valdore ghinc hi ende louch ende croep daerin met vare ende began tasten harenthare.

1625 Hi taste ende als hi niet en vant, sprac hi: "Neve, hets hier bewant te zorghen, ic ne vinder niet." Ic sprac: "Oem, wats hu ghesciet? Cruupter een lettel bet in!

1630 Men moet wel pijnen om ghewin. Ic hebse wech diere saten voren." Dus so liet hi hem verdoren, dat hi die hoenre te verre sochte. Ic sach dat icken hoenen mochte

1635 ende hortene so dat hi voer van daerboven up den vloer ende gaf eenen groeten val, dat si ontspronghen overal die in dien huse sliepen.

1640 Die bi den viere laghen, si riepen, daer ware in huus si ne wisten wat ghevallen voer dat vyergat.

Si worden up ende ontstaken lecht.

Doe sine daer saghen echt,

1645 wart hi ghewont toter doot.

Ic hebben brocht in menegher noot, meer dan ic ghesegghen mochte. Nochtan, al dat ic nye ghewrochte

1648-69 Reynaert had sexual intercourse with the she-wolf twice: the first time she committed adultery, the second time he raped her (see note to 72-77). The fox's confession concerns the adultery, which, as he states in cryptic terms (1654-55), he would like to repeat 
were sitting on a roof beam

1615 right next to a trapdoor.

There I made Ysingrijn climb with me

up to the top of that house.

I said that I assured him that

if he would crawl in through the trapdoor,

1620 he would find just inside

as many fat hens as he liked.

Laughing he went to the trapdoor

and carefully crawled through

and began to grope around here and there.

1625 He groped around and when he did not find anything

he said: "Nephew, I fear there is something

wrong, I can find nothing here."

I said: "Uncle, what's up with you?

Crawl a little further in!

1630 One needs to take trouble to succeed.

I have taken away the ones sitting at the front."

In this way he let himself be fooled

and looked for the chickens too far off.

I saw that I could play a nasty trick on him

1635 and pushed him so that he fell

from up there on to the floor

and his fall was so loud

that everyone woke up

who was asleep in the house.

1640 Those who were lying by the fire shouted

that something in the house, they did not know what,

had dropped in front of the fireplace.

They got up and made light.

When they next saw him there,

1645 he was given mortal injuries.

I have brought great trouble on him, more than I can say.

But all the things that I ever perpetrated

some time. This makes it clear once again that Reynaert's confession is insincere. The badger reacts like a serious confessor, not as someone secretly enjoying the story in all its details. His serious attitude is evident from his admonitions in 1678-87. 
jeghen hem, so ne roucke ic niet

1650 so zeere, als dat ic verriet vrauwe Yswenden, sijn scone wijf, die hi liever hadde dan sijns selfs lijf.

God die moet mi vergheven.

Haer dedic dat mi liever ware bleven

1655 te doene dant es ghedaen.'

Grimbeert sprac: 'Of ghi wilt gaen

claerliken te biechten tote $\mathrm{mi}$

ende zijn van huwen zonden vry,

so suldi spreken ombedect.

[202va]

1660 In weet waerwaert ghi dit trect:

"Ic hebbe jeghen sijn wijf mesdaen."

Oem, dat en can ic niet verstaen, waer ghi dese tale keert.'

Reynaert sprac: 'Neve Grimbeert,

1665 ware dat hoofschede groot

of ic hadde gheseit al bloot:

"Ic hebbe gheslapen bi miere moyen"?

Ghi zijt mijn maech, hu souts vernoyen

seidic eeneghe dorperheit.

1670 Grimbeert, nu hebbic hu gheseit

al dat mi mach ghedincken nu.

Gheeft mi aflaet, dat biddic hu,

ende settet mi dat hu dinct goet.'

Grimbeert was wijs ende vroet

1675 ende brac een rijs van eere haghe

ende gaffer mede XL slaghe

over alle sine mesdaden.

Daerna, in gherechten raden,

riet hi hem goet te wesene

1680 ende te wakene ende te lesene

ende te vastene ende te vierne

ende te weghe waert te stierne

alle die hi buten weghe saghe

1654-55 Reynaert's comment is ambiguous. He seems to be saying that he did something to the she-wolf that he would sooner not have done, but his words can also be taken to mean that he would prefer still having to do what he is referring to, rather than having already accomplished it. 
against him I do not regret so much

1650 as the fact that I betrayed him with

Lady Haersint, his beautiful wife, whom he loved more than his own life.

May God forgive me!

With her I did something I like having to do better

1655 than having done it.'

Grimbeert said: 'If you want to

confess sincerely to me

and be free from your sins,

you must speak openly.

1660 I do not know what you mean with:

"I have behaved badly towards his wife".

Uncle, I do not understand

what you mean with these words.'

Reynaert said: 'Nephew Grimbeert,

1665 would it be very civilised

if I had bluntly said:

"I have slept with my aunt"?

You are my relative, it would disturb you

if I used a coarse expression.

1670 Grimbeert, now I have told you

all that I can remember at present.

Give me absolution, I pray you,

and set me the penance that you think fitting.'

Grimbeert was wise and sensible

1675 and broke a twig off a bush

and gave Reynaert forty stripes with it

for all his transgressions.

Afterwards he urgently

advised him to be good

1680 and to wake and to pray

and to fast and to attend

and to point the right way

to all those he would see stray

1675-76 The forty stripes or blows which the fox has had administered by Grimbeert are in accordance with ecclesiastical usage, based on the Bible (Deut. 25, 3 and 2 Cor. 11, 24).

1681 te vierne means to observe holy days. 
ende hi voert alle sine daghe

1685 behendelike soude gheneeren.

Hierna so dedi hem verzweeren

beede roven ende stelen.

$\mathrm{Nu}$ moet hi siere sielen pleghen,

Reynaert, bi Grimbeerts rade,

1690 ende ghinc te hove up ghenade.

$\mathrm{Nu}$ es die biechte ghedaen.

Die heeren hebben den wech bestaen

tote des conincs hove waert.

$\mathrm{Nu}$ was buter rechter vaert

1695 dien si te gane hadden begonnen

een pryoreit van zwarten nonnen,

daer meneghe gans ende menich hoen,

meneghe hinne, menich cappoen

plaghen te weedene buten muere.

1700 Dit wiste die felle creatuere,

die onghetrauwe Reynaert,

ende sprac: 'Te ghenen hove waert

$[202 \mathrm{vb}]$

so leghet onse rechte strate.'

Met dusdanen barate

1705 leedde hi Grimbeert bi der scueren, daer die hoenre buten muere ghinghen weeden harenthare.

Den hoenre wart Reynaert gheware.

Sine oghen begonden omme te ghane.

1710 Buten den andren ghinc een hane

die arde vet was ende jonc.

Daerna gaf Reynaert eenen spronc, sodat dien hane die plumen stoven.

Grimbeert sprac: 'Oem, ghi dinct mi doven!

1715 Onsalich man, wat wildi doen?

Wildi noch om een hoen

in alle die groete zonden slaen

daer ghi te biechten af zijt ghegaen?

1694-1748 Reynaert attempts to steal one of the convent's chickens but is stopped just in time by Grimbeert, who reprimands him severely. The narrator leaves no doubt about Reynaert's evil intentions (1700-7). The fox strays from the straight and narrow 
and for the rest of his days

1685 to make an honest living.

After this he made him abjure

both robbing and stealing.

Now Reynaert has to look after his soul

following Grimbeert's advice,

1690 and he went to court in the hope of mercy.

Now the confession is over.

The two lords went on their way

to the king's court.

Now beside the straight road

1695 they had started out on, there was a priory of black nuns

where many a goose and many chickens,

many a hen, many capons

used to range for food outside the walls.

1700 The scoundrel knew this, that devious Reynaert, and said: 'Towards that court the straight road leads us.' With this deception

1705 he led Grimbeert to the barn, where, outside the walls, the hens were pecking here and there. Reynaert noticed the hens. His eyes began to rove around.

1710 At a distance from the others walked a cockerel that was very fat and young. Reynaert leapt in its direction, scattering the cockerel's feathers.

Grimbeert said: 'Uncle, I think you're mad!

1715 Misguided man, what are you doing?

Do you want for the sake of a chicken

to lapse into all the great sins

which you have just confessed?

immediately after his confession (cf. 1694, 1747 and p. 23-24) and is clearly, therefore, a hypocrite.

1702 hove refers to the convent's garden. 
Dat moet hu wel zeere rauwen!'

1720 Reynaert sprac: 'Bi rechter trauwen, ic hads vergheten, lieve neve. Bidt Gode dat hijt mi vergheve.

Het ne ghesciet mi nemmermeer.'

Doe daden si eenen wederkeer

1725 over eene smale brugghe.

Hoe dicken sach Reynaert achter rugghe weder daer die hoenre ghinghen!

Hi ne conste hem niet bedwinghen, hi ne moeste ziere zeden pleghen.

1730 Al hadde men hem thoeft afghesleghen, het ware ten hoenren waert ghevloghen also verre alst hadde ghemoghen.

Grimbeert sach dit ghelaet ende seide: 'Onreyne vraet,

1735 dat hu dat hoghe so ommegaet!' Reynaert andwoerde: 'Ghi doet quaet dat ghi mine herte so verseert ende mine bede dus verstorbeert. Laet mi doch lesen II paternoster

1740 der hoenre zielen van den cloester ende den gansen te ghenaden, die ic dicken hebbe verraden, die ic desen heleghen nonnen met miere lust af hebbe ghewonnen.'

1745 Grimbeert balch, newaer Reynaert hadde emmer zine oghen achterwaert, tes si quamen ter rechter straten die si tevoren hadden gelaten.

1750 Daer keerde si te hove waert

1749 ende arde zeere beefde Reynaert, doe hi began den hove naken, daer hi waende seere mesraken.

1744 lust is ambiguous, meaning both clever trick and physical desire. 
That you will regret dearly!'

1720 Reynaert said: 'In all truth, I had forgotten it, dear nephew. Pray God he may forgive it me. It shall never happen again.'

Then they turned back

1725 across a narrow bridge.

How often did Reynaert look back to where the chickens were! He could not restrain himself, he had to follow his instincts.

1730 Even if they had knocked off his head, it would have flown to the hens, as far as it possibly could.

Grimbeert noticed this behaviour and said: 'Filthy glutton,

1735 for having such a roving eye!'

Reynaert answered: 'You are doing wrong by hurting my feelings so and by disturbing my prayer.

Allow me to recite two pater nosters

1740 for the salvation of the souls of the convent's hens and geese, which I have frequently attacked and which I have often caught by tricking these pious nuns.'

1745 Grimbeert was angry, but Reynaert kept looking back, until they arrived at the straight road that they earlier had left.

1750 There they turned towards the court

1749 and Reynaert trembled very much when he approached the court where, he feared, he would fare very badly. 
Doe in sconinx hof was vernomen dat Reynaert ware te hove comen

1755 met Grimbeerde den das, ic wane daer niemene ne was so arem no van so crancken maghen, hi ne ghereedde hem up een claghen. Dit was al jeghen Reynaerde.

1760 Nochtan dedials die onvervaerde, hoe so hem te moede was, ende hi sprac te Grimbeerte den das: 'Leedet ons die hoechste strate.' Reynaerd ghinc in dien ghelate 1765 ende in also bouden ghebare ghelijc of hi sconinx sone ware ende hi niet en hadde mesdaen. Boudeliken ghinc hi staen voer Nobele dien coninc

1770 ende sprac: 'God die alle dinc gheboet, hi gheve hu, coninc heere, langhe bliscap ende eere!

Ic groet hu, coninc, ende hebbe recht. En hadde nye coninc eenen knecht

1775 so ghetrauwe jeghen hem als ic oyt was ende bem. Dat es dicken worden anschijn. Nochtan die sulke die hier zijn, souden mi nochtan gherne roven 1780 huwer hulden, wilde ghi hem gheloven. Maer neen, ghi niet. God moete hu lonen! Het ne betaemt niet der cronen dat si den scalken ende den fellen te lichte gheloven dat si vertellen. 1785 Nochtan willics Gode claghen: dier es te vele in onsen daghen

1773-95 Reynaert pretends to be one of the king's loyal vassals. The adoption of this stance is connected with the trick which he later uses to deceive Nobel. In the same way as Bruun and Ysin- 


\section{Conviction and reconciliation}

When it became known at the king's court

that Reynaert had arrived at court

1755 with Grimbeert the badger,

I reckon there was no one

- however poor or of inferior family -

who did not prepare himself for a complaint.

All this was aimed at Reynaert.

1760 Nevertheless he acted as if he had nothing to fear, whatever his real feelings, and he said to Grimbeert the badger:

'Lead us along the high street.'

Reynaert presented an attitude

1765 and such bold behaviour

that it looked as if he were the king's son

and had done nothing wrong at all.

Boldly he took up his position

in front of Nobel the king

1770 and said: 'God who has created

everything, may he give you, Lord King,

enduring joy and honour!

I greet you, king, as is only right.

Never did a king have a servant

1775 as loyal towards him

as I am and have ever been.

This has often become clear.

Yet some of those who are here

would with pleasure rob me

1780 of your favour, if you were willing to believe them.

But no, not you. God reward you!

It is not fitting for crowned heads

to put credence too lightly

in tales told by false counsellors and villains.

1785 Yet I wish to complain of this to God:

there are in this day and age too many plotters

grijn are deluded by promises of honey and mice, the fox will make Nobel believe that he has escaped a conspiracy and that it is Reynaert, his most devoted servant, whom he has to thank for it. 
der scalke die wroughen connen,

die $n u$ ter rechter hant hebben ghewonnen

overal in rike hove.

1790 Dien sal men niet gheloven.

Die scalcheit es hem binnen gheboren, dat si den goeden lieden doen toren.

Dat wreke God up haer leven

ende moete hem eewelike gheven

1795 al sulken loen als si zijn waert!'

Die coninc sprac: 'O wy, Reynaert!

O wy, Reynaert, onreyne quaet, wat condi al scone ghelaet!

Dat en can hu niet ghehelpen een caf.

$1800 \quad$ Nu comt huwes smeekens af.

In werde bi smeekene niet hu vrient.

Hets waer, ghi sout mi hebben ghedient

van eere saken in den woude,

daer ghi qualic in hebt ghehouden

1805 die eede die ic hadde ghezworen.'

'O wy, wat hebbic al verloren!'

sprac Canticleer, die daer stont.

Die coninc sprac: 'Hout huwen mont,

heere Canticleer, nu laet mi spreken;

1810 laet mi antwoerden sinen treken.

Ay, heere dief Reynaert, dat ghi mi lief hebt ende waert, dat hebdi sonder huwe pine mine boden laten anschine:

1815 arem man Tybeert, heere Brune, die noch bloedich es zijn crune! Ic ne sal hu niet scelden; ic waent hu kele sal ontghelden noch heden al up eene wijle.'

1820 'Nomine patrum, christum filye!' sprac Reynaert, 'of mijn heere Brune noch al bloedich es die crune,

1820 After Nobel's furious reaction Reynaert begins his answer with a garbled formula used when making the sign of the cross (here to ward off approaching evil): In nomine Patris, 
capable of making false accusations

who now have gained the upper hand everywhere at powerful courts.

1790 They should not be believed.

Villainy is their nature; as a result they cause all good people distress.

May God revenge it upon their lives and may $\mathrm{He}$ give them in eternity

1795 such reward as they deserve!'

The king said: 'Woe upon you, Reynaert!

Woe, Reynaert, foul piece of evil, what a fine front you put on!

That will not help you one bit now.

1800 Stop your flattery now.

Flattery won't make me your friend.

The truth is that you should have served me concerning a certain affair in the wood, whereas you did not keep

1805 to the peace that I had proclaimed.'

- 'Alas, to think of all I have lost!'

said Cantecleer, who was standing there.

The king said: 'Hold your tongue,

Lord Canticleer, now let me speak;

1810 let me respond to his nasty tricks.

Well, Lord villain Reynaert, that you love and respect me, this you have shown without much trouble to my messengers:

1815 poor Tybeert and Lord Bruun

whose crown is still covered in blood!

I shall not find fault about it with you;

I suspect that your throat will suffer for it even today, before long.'

$1820 \quad$ 'Nomine patrum, christum filye!'

Reynaert said, 'If my Lord Bruun's crown

is still bloody all over,

et Filii, et Spiritus Sancti ('in the name of the Father, the Son and the Holy Ghost'). The fox's words mean something like 'in the name of the Fathers and Christ the Son'. 
1822a her coninc, wat bestaet mi dat?

$1822 \mathrm{~b}$ Of hi Lamfreits honich at

$1822 \mathrm{C}$ ende hem die dorper laster dede,

$1822 \mathrm{~d}$ noch heft Brune so grote lede.

Was hi teblauwen of versproken, waer hi goet, hi ware ghewroken

1825 eer hi noint vloe int water. Banderzijde: Tybeert die cater, dien ic herberghede ende ontfinc, of hi hute om stelen ghinc tes papen sonder minen raet

1830 ende hem die pape dede quaet, bi Gode, soudic dat ontghelden? So mochtic mijn gheluc wel scelden!' Voert sprac Reynaert: 'Coninc lyoen, wien twifelt des, ghi ne moghet doen

1835 dat ghi ghebiet over mi? Hoe groot mine sake zi, ghi moghet mi vromen ende scaden. Wildi mi zieden ofte braden ofte hanghen ofte blenden, 1840 ic ne mach hu niet ontwenden. Alle diere zijn in hu bedwanc. Ghi zijt groet ende ic bem cranc. Mine hulp es cleene ende dhuwe groet. Bi Gode, al slouchdi mi doot, 1845 dat ware eene crancke wrake.' Recht in dese selve sprake doe spranc up Belin de ram ende sine hye, die met hem quam; dat was dame Hawy.

1850 Belin sprac: 'Gawy alle voert met onser claghen.' Bruun spranc up met sinen maghen ende Tybeert die felle

1845 Reynaert means that if he were to be executed, this would be retribution unworthy of a mighty king.

1846-85 Having listed the plaintiffs who have the fox taken prisoner in the king's presence (1846-67), the narrator summarizes the account of Reynaert's trial and conviction 
1822a Lord King, what's that to me?

$1822 \mathrm{~b}$ Even if he did eat Lamfroyt's honey

$1822 \mathrm{C}$ and even if those peasants did beat him up,

$1822 \mathrm{~d}$ surely Bruun is big and strong enough.

When he was beaten or ridiculed, he should, had he been brave, have revenged himself

1825 before finally escaping into the water.

And then: that Tybeert the cat, whom I received hospitably,

went out stealing

at the priest's house against my advice

1830 and was badly treated by the priest,

by God! am I to suffer for it?

Then I can really say goodbye to my luck!'

Reynaert continued: 'King Lion, who doubts that you can do

1835 whatever you command with me?

However strong my case,

you can make or break me.

Whether you want to boil or roast

or hang or blind me,

1840 I cannot escape you.

All animals are in your power.

You are mighty and I am weak.

I get little support and you get much.

By God, if you put me to death,

1845 that would be a poor revenge.'

Just as this was being said

Belin the ram jumped up

and his ewe that accompanied him;

that was Lady Hawy.

1850 Belin said: 'Let all of us

present our charges.'

Bruun jumped up with his relatives

and nasty Tybeert

in a few lines (1868-85, and see pp. 24-25). This summary will be followed by an extensive description of Reynaert's escape from execution, which numbers more than four hundred lines (2052-2490). In this way the emphasis is on the lies with which the fox will gain Nobel's favour. 
ende Ysingrijn sijn gheselle,

1855 Fortadent dat everzwijn

ende die raven Tiselijn,

Pancer die bever, och Bruneel,

dat watervar, dat butseel, ende dat eencoren, heere Rosseel,

1860 die wesel, mijn vrauwe Fine,

- Cantecleer ende die kindre zine

makeden groten vederslach -

dat foret Cleenebejach,

liepen alle in dese scare.

1865 Alle dese ghinghen openbare

voer haren heere den coninc staen

ende daden Reynaerde vaen.

$\mathrm{Nu}$ ghinct ghindre up een playdieren.

Nye hoerde man van dieren

1870 so scone tale als nu es hier

tusschen Reynaerde ende dandre dier

$[203 \mathrm{vb}]$

1871 a orconde denghenen die dat horden!

$1871 \mathrm{~b}$ Soudic die tale entie worden

voertbringhen die men brochte daer,

het ware mi pijnlic ende zwaer.

Daeromme corte ic hu de woort.

1875 Die beste redenen ghinghen daer voort.

Die claghen die de dieren ontbonden, proufden si met goeden orconden, als si sculdich waren te doene.

Die coninc dreef die hoeghe baroene

1880 te vonnesse van Reynaerts saken.

Doe wijsden si dat men soude maken

eene galghe, sterc ende vast,

ende men Reynaerde den fellen gast

daeran hinghe bi ziere kelen.

1885 Nu gaet Reynaerde al huten spele!

Doe Reynaert verordeelt was,

1886-1914 Grimbeert leaves the court with Reynaert's relatives; they disagree with the verdict of the death sentence (1886-93). If a conflict with this group were to arise, this would certainly undermine Nobel's position, as he is dependent on his vassals. However, a death sentence has been pronounced that cannot easily be ignored by Nobel, who, although he 
and Ysingrijn his companion,

1855 Fortadent the boar

and Tiecelin the raven,

Pancer the beaver, as well as Bruneel,

the bittern, that shapeless bag,

and the squirrel, Lord Rosseel,

1860 the weasel, my Lady Fine,

- Cantecleer and his children

wildly flapped their wings -,

the ferret Cleenebejach,

they all joined the crowd.

1865 All of them took up their positions

before their lord the king and had Reynaert taken prisoner.

Now the pleading started there. Never did anyone hear animals

1870 utter such eloquent words as they did here

in the case between Reynaert and the other animals,

$1871 \mathrm{a}$ as witnessed by those who heard it!

$1871 \mathrm{~b}$ If I had to report the speeches and the words

that were presented there,

it would be difficult and troublesome for me.

That is why I shall shorten the tale for you.

1875 The best arguments were brought forward there.

The charges that the animals presented

were supported by reliable witnesses,

as was expected of them.

The king urged the mighty barons

1880 to pronounce the verdict in Reynaert's case.

Then they passed as their judgement

that a gallows should be made, strong and solid,

and that Reynaert, that felonious fellow,

was to be hanged from it by his throat.

1885 Now the game is up for Reynaert!

When Reynaert had been sentenced,

administers justice and presides over the court of law, can pass no judgement: he is bound to pass sentence as his vassals wijsen, 'advise' (165-69). Facing this dilemma, the king - called arde vroet, 'very perceptive' (1894) - makes a veiled attempt at postponing the execution. In a pseudo-reproachful tone he addresses the executioners Ysingrijn and Bruun thus: 'how slow 
orlof nam Grimbeert die das met Reynaerts naeste maghen: si ne consten niet verdraghen

1890 no si ne consten niet ghedoghen, dat men Reynaerde voer haren oghen soude hanghen alse eenen dief. Nochtan waest hem somen lief. Die coninc, hi was arde vroet.

1895 Doe hi mercte ende verstoet dat so menich jonghelinc met Grimbeerte huten hove ghinc, die Reynaerde na bestoet, doe peinsdi in sinen moet:

1900 'Hier mach inloepen andren raet.

Al es Reynaert selve quaet, hi hevet meneghen goeden maech.' Doe sprac hi: 'Twi sidi traech, Ysingrijn ende heere Bruun?

1905 Reynaerde es cont menich tuun ende hets den avonde bi. Hier es Reynaert; ontsprinct hi, comt hi III voete huter noot, sinen lust die es so groot

1910 ende hi weet so meneghen keer, hi ne wert ghevanghen tsjaermeer.

Sal men hanghen, twi ne doet ment dan?

Eer men nu ghereeden can eene galghe, so eist nacht.'

1915 Ysingrijn was wel bedacht ende sprac: 'Hier es een galghe bi.' Ende mettien woerde versuchte hi. Doe sprac die cater, heere Tybeert: 'Heere Ysingrijn, hu es verzeert

you are (1903-4); surely you can see it is nearly evening and Reynaert is so familiar with the terrain that he would not be caught for a considerable time if he escaped (1905-11); if Reynaert is to hang, why don't you get on with it; it is now too late to hang him' (1913-14). The time of day is important as death sentences had to be executed before sun down. Nobel's indirect way of addressing the executioners is a tactical move according to this interpretation. For the first time in the story the king's interests and the interests of the barons do not 
Grimbeert the badger took his leave with Reynaert's next of kin: they could neither bear to see

1890 nor could they accept that Reynaert should before their eyes be hanged like a thief. Yet some it suited very well. The king now, he was very perceptive.

1895 When he noticed and realized that many a youngster who was closely related to Reynaert left the court with Grimbeert, he thought to himself:

1900 'Here something else needs to be considered. Even if Reynaert himself is wicked, he has many a good relative.' Then he said: 'Why do you dawdle, Ysingrijn and Lord Bruun?

1905 Reynaert is familiar with many hedgerows and it is nearly evening. Here we have Reynaert; if he escapes, if he manages to get three feet of freedom, his cunning is so great

1910 and he knows so many byways that he will never be caught in a year. If he is to hang, why is it not done? Before a gallows can be got ready now, it will be night.'

1915 Ysingrijn had a thought and said: 'There is a gallows near here.' And with these words he sighed.

Then the cat, Lord Tybeert, spoke: 'Lord Ysingrijn, your heart

run completely parallel (see p. 25).

1905 The king means that Reynaert is acquainted with numerous hedgerows in which to hide.

1906 The second day, which started with Tybeert's return to court (cf. 1318-19) was spent delivering the third summons and with Reynart's trial and death sentence at court. Now it is nearly evening. 
1920 hu herte, in wanconst hu niet. Nochtan Reynaert diet al beriet ende selve medeghinc daer men huwe twee broeders hinc, Rumen ende Wijdelancken.

1925 Hets tijt, wildijs hem dancken. Waerdi goet, het ware ghedaen, hi ne ware noch niet onverdaen.' Ysingrijn sprac tote Tybeert: 'Wat ghi ons algader leert!

1930 Ne ghebrake ons niet een strop, langhe heden wist zijn crop wat zijn achterhende mochte weghen.' Reynaerd, die langhe hadde ghesweghen, sprac: 'Ghi heeren, cort mine pine.

1935 Tybeert heeft eene vaste lijne, die hi bejaghede, an sine kele, daer hi vernoys hadde vele int huus daer hi den pape beet, die voer hem stont al sonder cleet.

1940 Her Ysingrijn, nu maect hu voren; ende sidi nu daertoe vercoren, ende ghi, Brune, dat ghi sult dooden Reynaert huwen neve, den fellen roden!'

Doe so sprac die coninc saen:

1945 'Doet Tybeerte medegaen.

Hi mach clemmen. Hi mach de lijne updraghen sonder huwe pijne. Tybeert, gaet voren ende maect ghereet.

Dat ghi yet let, dats mi leet.'

1950 Doe sprac Ysingrijn tote Brune:

'So helpe mi de cloestercrune

1923-27 At Reynaert's instigation two of the wolf's brothers have in the past been hanged. A story of this kind is not found in the Roman de Renart. It is not clear whether Willem is alluding to a story not known today, or whether he invented the hanging.

1929 Ysingrijn means that Tybeert is talking nonsense.

1943 The intimation of friendly intimacy, neve, contrasts sharply with the characterization of Reynaert as a scoundrel.

1944 In redactions other than Comburg it is not the king but Reynaert who tells Tybeert 
1920 is troubled, I shall not hold it against you.

Yet it was Reynaert who had thought it all out

and went along himself

to where they hanged your two brothers,

Rumen and Wijdelancken.

1925 It's time that you thank him for it.

If you were strong, it would be over by now,

he would no longer be alive.'

Ysingrijn said to Tybeert:

'What would we do without your advice!

1930 If we weren't short of a noose,

his throat would long ago have known

what his behind weighs.'

Reynaert, who had long been silent, said: 'You lords, shorten my anguish.

1935 Tybeert has a strong rope

around his throat, which he acquired

where he had much to endure

in the house where he bit the priest

who stood before him without any clothes.

1940 Lord Ysingrijn, make haste now;

after all you have been appointed,

and you, Bruun, that you should kill

Reynaert, your nephew, the red scoundrel!'

Then the king spoke at once:

1945 'Let Tybeert go along.

He can climb. He can take the rope

to the top without the difficulty it would cause you.

Tybeert, hurry and get it ready.

It pains me to see you so slow.'

1950 Then Ysingrijn said to Bruun:

'May the tonsure

to accompany Bruun and Ysingrijn. The wolf's late and inadequate reaction (1953-54) suggests that the redaction in which the fox is the sole speaker is probably closer to the original. It is also primarily in Reynaert's interest that the cat - whom he will accuse a little later - leaves the scene.

1951-52 The wolf swears on his tonsure. This is reminiscent of one of his earlier mishaps. Reynaert scalded his scalp with boiling water, thus making the skin come off (see note to 1499-1503). 
die boven up mijn hoeft staet, in hoerde nye so goeden raet alse Reynaert selve ghevet hier.

1955 Hem langhet omme cloesterbier.

$\mathrm{Nu}$ gaen wi voeren ende bruwen hem!'

Bruun sprac: 'Neve Tybeert, nem

die lijne. Du salt medeloepen.

Reynaert die salt nu becoepen,

1960 mijn scone liere ende dine hoghe.

Ghawi ende hanghene so hoghe

dats lachter hebben al sine vrient.'

'Ghawi, hi heves wel verdient,'

sprac Tybeert ende nam de lijne.

1965 Hi ne dede nye so lieve pine.

$\mathrm{Nu}$ waren die drie heeren ghereet

1966a die Reynaerde hadden harde leit.

Dat was die wulf ende Tybeert

ende der Bruun, die hadde gheleert

honich stelen te zinen scaden.

1970 Ysingrijn was so beraden, eer hi van den hove sciet, hi ne wilde des laten niet, hi ne vermaende nichten ende neven ende alle die binnen den hove bleven,

1975 beede ghebuere ende gaste, dat si Reynaerde hilden vaste. Vrauwe Arsenden, zinen wive, beval hi bi haren live dat so stonde bi Reynaerde

1980 ende soene name bi den baerde ende van hem niet ne sciede, no dor goet no dor miede, no dor niet no dor noet,

1955 By way of revenge for his tonsure, Ysingrijn suggests brewing monastic beer, a metaphor indicating the preparation of physical abuse (Reynaert will be hanged). In 2173-78 the narrator returns to the brewing metaphor. In 2801 the raven calls Reynaert master butler. Cf. also the note to 705-06.

1977-92 Ysingrijn is described in ironic terms here. By using ambiguous phrases, he inadvertently gives the impression of conducting a marriage between his wife and the fox: he asks her 
on top of my head help me;

I never heard such good advice

as Reynaert gives here himself.

1955 He has a fancy for the monks' beer.

Let us hurry now and brew it for him!'

Bruun said: 'Nephew Tybeert, take

the rope. You shall come along.

Reynaert will now pay

1960 for my fine cheeks and your eye.

Let's go and hang him so high

that all his friends will be disgraced.'

'Let's go, he has certainly deserved it,'

Tybeert said, and took the rope.

1965 Never did he exert himself with more pleasure.

Now the three lords,

1966a who hated Reynaert intensely, were ready.

These were the wolf and Tybeert

and Lord Bruun, who had learned

to his cost to steal honey.

1970 Ysingrijn was so determined

that, before leaving the court,

he insisted on urging that

his nieces and nephews

and all those who remained at court

1975 - both acquaintances and strangers should keep Reynaert prisoner.

Lady Haersint, his wife,

he ordered on her life

to stand at Reynaert's side

1980 and to take him by his beard

and never to part from him,

not for goods and not for riches,

not for better and not for worse,

to stay with Reynaert for better and for worse until death will part them (1981-84). Reynaert realizes this and continues the ambiguity by hinting that he did not rape the she-wolf, but that she committed adultery. For that reason he does not need to ask forgiveness from her; asking her husband's forgiveness suffices. That is why Reynaert asks for half ghenade, 'half mercy' (1987). 1978 bi haren live is ambiguous, meaning 'on her life' or 'with her lover', in other words: Reynaert. Cf. 236, 1988. 
no dor zorghe van der doot.

1985 Reynaert andwoerde in corten woorden, dat alle die daer waren horden: 'Heere Ysingrijn, half ghenade! Al ware hu lief mijn grote scade ende al brincdi mi in vernoye,

1990 ic weet wel: soude mijn moye te rechte ghedincken ouder daet, so ne dade mi nemmermeer quaet.

Maer her Ysingrijn, soete oem, ghi neemt huwes neven crancken goem,

1995 ende heere Brune ende heere Tybeert, dat ghi mi dus hebt onneert! Ghi drie, ghi hebbet ghedaen al dat men mi ontliven sal. Daertoe hebdi ghemaket

2000 dat sowie die mi ghenaket, sceldet mi dief of hevet leet. Daeromme moetti, God weet, gheonneert werden alle drie, ghi ne haest dat ghescie

2005 al dat ghi begaert te doene. Mi es dat herte noch also coene; ic dar wel sterven eene waerf. Ne wart mijn vader doe hi staerf van alle sinen zonden vry?

2010 Gaet, ghereet die galghe! Of ghi een twint $n u$ langher niet ne spaert, of varen moetti inderwaert alle huwe voete ende huwe been!' Doe sprac Ysingrijn: 'Ameen.'

2015 'Amen,' sprac Brune, 'ende hinderwaert moet hi varen die langher spaert.' Tybeert sprac: 'Nu haesten wy.' Ende mettien woerde spronghen zi ende liepen voert arde blide 2020 ende pijnden hem ten strijde 1988 This line is ambiguous. Reynaert appears to be saying 'even if you love my downfall', but 
nor even for fear of death.

1985 Reynaert answered quickly with words that all assembled there heard: 'Lord Ysingrijn, have half mercy on me!

Even if you love my downfall and even though you lead me into trouble,

1990 I know for certain that, if my aunt were to remember past actions in all honesty, she would never harm me. Really, Lord Ysingrijn, dear uncle, you take bad care of your nephew,

1995 as do Lord Bruun and Lord Tybeert, for having disgraced me so!

You three, you are completely responsible for it that they shall kill me.

Moreover, you have ensured

2000 that anyone who approaches me abuses me for a thief or hates me. For that reason, God is my witness, may all three of you be dishonoured if you don't make haste

2005 to do all that you plan.

My heart knows no fear at all;

I have to die at some time.

Was not my father, when he died, free of all sins?

2010 Go, prepare the gallows! Either you don't delay one moment longer, or you may go to hell as fast as your feet and legs can carry you.'

Then Ysingrijn said: 'Amen.'

2015 'Amen,' Bruun said, 'and may he go to hell who delays any longer.'

Tybeert said: 'Let's hurry now.'

And with these words they jumped up and ran away with great joy

2020 and competed with one another 
te springhene over meneghen tuun, Ysingrijn ende heere Bruun.

Tybeert volchde hem naer; hem was die voet een lettel zwaer

2025 van der lijnen die hi drouch. Nochtan was hi rasch ghenouch; dat dede hem al die goede wille. Reynaert stont ende zweech al stille ende sach sine viande loepen

2030 die hem dat strec an waenden cnoepen. 'Maer het sal bliven,' sprac Reynaert, die staet ende scauwet daerwaert ende si springhen ende si keeren. Hi peinsde: 'Deus, wat joncheeren!

2035 Nu laetse springhen ende loepen. Levic, si sullent noch becoepen, hare overdaet ende hare scampye, mi ne ghebreke reynaerdye.

Nochtanne zijn si mi

2040 liever verre danne bi, dieghene die ic meest ontsach. $\mathrm{Nu}$ willic prouven dat ic mach te hove bringhen een baraet dat ic voer de dagheraet

2045 in groter zorghen vant te nacht. Hevet mine lust sulke cracht alsic noch hope dat so doet, al es hi lustich ende vroet, ic wane den coninc noch verdoren.'

2050 Die coninc dede blasen eenen horen ende hiet Reynaerde huutwaert leeden. Reynaert sprac: 'Laet teerst ghereeden die galghe daer ic an hanghen sal. Ende daerbinnen so sal ic al 2055 den volcke mine biechte conden

2039-49 Reynaert's monologue informs the tale's audience of his intentions. His devious plan requires that his three adversaries leave the court. The plan he has concocted is targeted at the king. The indications of time suggest that his plan took shape during the night that ended so badly for Tybeert, that is, even before Grimbeert's arrival. 
in jumping over many a hedgerow,

Ysingrijn and Lord Bruun.

Tybeert followed them at a distance;

he found walking somewhat heavy going

2025 because of the rope he carried.

Nevertheless he was quick enough;

that was because he was in such a good mood.

Reynaert stood there and was silent

as he watched his enemies walk away

2030 who thought to put the noose round him.

'But that will not happen,' said Reynaert,

who stands and watches them

as they jump this way and that.

He thought: 'Deus, what silly youngsters!

2035 Let them jump and run now.

If I survive, they will pay

for their arrogance and their abuse,

if my foxy tricks don't fail me.

Nevertheless I prefer to see

2040 in the distance, rather than close by,

those that I feared most.

Now I want to try to

to present the court with a plan

that I thought up before dawn

2045 in great anguish in the night.

If my ruse works as well

as I hope it will,

then, however clever and quick-witted he is,

I expect to be able to deceive the king.'

2050 The king gave orders for a horn to be blown and had Reynaert led out.

Reynaert said: 'First let be prepared

the gallows on which I shall hang.

And meanwhile I shall

2055 publicly make my confession

2051 huutwaer leeden means 'lead out, forth', i.e. from the court to the gallows.

2054-60 Reynaert announces a public confession to ensure forgiveness for his sins, which is also meant to avoid that other animals are accused falsely of his crimes after his death. Nobel cannot refuse his prisoner this. The way is now clear for Reynaert's fabrications. 
in verlanessen van minen zonden.

Hets beter dat al tfolc verstaet

mine diefte ende mine ondaet, dan si namaels eeneghen man

2060 mine overdaet teghen an.'

Die coninc sprac: 'Nu segghet dan.'

Reynaert stont als een drouve man

ende sach al omme harenthare.

Daer so sprac hi al openbare:

2065 'Helpe,' seit hi, 'Dominus!

nu en es hier niemen in dit huus,

no vrient no viant, ic ne bem

een deel mesdadich jeghen hem.

Nochtan horet alle, ghi heeren.

2070 Laet wijsen ende leeren

hoe ic, Reynaert, aermijnc,

eerst an die boesheit vinc.

In allen tijden spade ende vroe, was ic een hovesch kint noch doe.

2075 Doe men mi spaende van der mammen, ghinc ic spelen metten lammen dor te hoerne dat ghebleet, sodat ic een verbeet.

Ten eersten lapedic dat bloet.

2080 Het smaecte so wel, het was so goet, dat ic dat vleesch mede ontgan.

Daer leerdic leckernie an

so vele dat ic ghinc ten gheeten

int wout daer icse hoerde bleeten.

2085 Daer verbeet ic hoekine twee.

So dedic des derdes daghes mee

ende ic wart bouder ende coene

ende verbeet haenden ende hoene

ende gansen daer icse vant.

2090 Doe mi bloedich wert mijn tant,

2065 Dominus: the Lord God.

2070-76 Reynaert explains how he came to live a life of sin. The fact that Reynaert as a 'child' played with lambs, is reminiscent of the vision of the future as described in the Bible 
so that my sins may be forgiven.

It is better that all here present

should hear of my thieving and my crimes

than that they should later charge another

2060 with my misdeeds.'

The king said: 'Well then, speak.'

Reynaert stood there, a picture of misery, and looked all around him. Then he spoke, clearly audible:

2065 'Help me,' said he, 'Dominus!

Now there is no one here in this place, neither friend nor foe, whom I have not wronged in one way or another.

Nevertheless listen all of you, my lords.

2070 Let it become clear to you

how I, Reynaert, poor creature, first began my wicked ways.

At all times, night and day, I was a well-behaved child.

2075 When I was weaned from the breast

I went to play with the lambs

so as to hear them bleat, until I bit one to death.

For the first time I lapped up the blood.

2080 It tasted so good, it was so nice that I also tried the flesh.

That taught me to appreciate good food so much that I went to the goats in the woods where I heard them bleating.

2085 There I bit to death two kids.

This I also did on the third day and I became ever bolder and braver and killed ducks and chickens and geese wherever I came across them.

2090 When I had developed a taste for blood

in the Book of Isaiah $(11,6-7)$. On the arrival of the Messiah, the peace of paradise will be restored, and the wolf will lie with the lamb (see pp. 26-27). 
was ic so fel ende so wreet dat ic zuver up verbeet al dat ic vant ende wat mi dochte dat mi bequam ende dat ic vermochte.

2095 Daerna quam ic ende Ysingrine te wintre in eenen couden rijme bi Belsele onder eenen boem. Hi rekende dat hi ware mijn oem ende began eene sibbe tellen.

2100 Aldaer worden wi ghesellen. Dat mach mi te rechte rauwen! Daer gheloofden wi bi trauwen recht gheselscap manlic andren. Doe begonsten wi tegader wandelen.

2105 Hi stal tgroete ende ic dat cleene. Dat wi bejaechden wart ghemeene. Ende als wi deelen souden doe, ic was in hueghen ende vroe, mochtic mijn deel hebben half.

2110 Alse Ysingrijn bejaghede een calf of eenen weder of eenen ram, so grongierdi ende maecte hem gram ende toechde mi een ghelaet dat so zuer was ende so quaet

2115 dat hi mi daermet van hem verdreef ende hem mijn deel algader bleef. Nochtan hachtic niet van dien. So menich waerven hebbic versien, alse wi een groete proye lagheden 2120 die ic ende mijn oem bejagheden, eenen osse of eenen bake, doe ghinc hi sitten met ghemake met sinen wive vrauwe Harsenden

2095-99 While under Ysingrijn's influence - who calculated that they were related - Reynaert is supposed to have been persuaded to join the wolf as 'partners in crime'. The fox gives a skewed presentation of the facts. As his earlier confession and other stories show, it was the fox who made the wolf believe that they were related. See note to 1481-82.

2104-38 Earlier, in the distorted tale of the theft of the fish (cf. note to 208-16) and his version of the theft of the side of bacon (see note to 217-29), Grimbeert stressed the wolf's gluttony. 
I became so fierce and cruel that I bit to death everything I met and that I thought would agree with me and that I could handle.

$2095 \quad$ Next I met Ysingrijn one winter during a cold spell near Belsele under a tree.

He calculated that he was my uncle and began to point out our kinship.

2100 That is where we became partners.

I have every reason to regret it!

There we swore on our word of honour

loyal friendship to one another.

Next we began to roam around together.

2105 He stole the big ones and I the little ones.

All that we caught was common property.

But when we came to share,

I was very pleased indeed

if I received half of my share.

2110 When Ysingrijn caught a calf, or a wether or a ram,

he would growl and become ferocious

and I would be shown such

disagreeable and mean behaviour

2115 that he scared me off with it

and that my share fell to him altogether.

However, that did not bother me.

So many times I found,

when we had been lying in wait for a large prey

2120 that my uncle and I then caught,

an ox or a pig,

that he would sit down at his ease

with his wife Lady Haersint

Reynaert continues along these lines. In the same way that Grimbeert earlier said that the fox was only given the fish bones and the string from the side of bacon as his share, Reynaert now says that he had to be satisfied with a rib that had been gnawed bare by the wolf's cubs. However, although Reynaert did not get his proper share of the loot, this did not really matter as he is very fond of his uncle and anyway, he is exceedingly rich .... Slowly but surely the clever fox has worked round to the introduction of the treasure (2134-38). 
ende met sinen VII kindren.

2125 So ne mochtic cume deene hebben

van den alremintsten rebben

die sine kindre hadden ghecnaghet.

Dus nauwe hebbic mi bejaghet.

Nochtan dat was mi lettel noot.

2130 Ne waer dat mijn zin so groot

die lieve drouch te minen oem, die mijns nemet crancken goem, ic hadde ghewonnen wel tetene. Coninc, dit doe ic hu te wetene:

2135 ic hebbe noch selver ende gout dat al es in mier ghewout so vele dat cume een waghen te VII waerven soude ghedraghen!' Alse die coninc dit verhoerde,

2140 gaf hi Reynaerde felle andwoerde: 'Reynaert, wanen quam hu die scat?' Reynaert andwoerde: 'Ic segghu dat. Wijldijt weten also ict weet, no dor lief no dor leet

2145 so ne salt danne bliven verholen. Coninc, dien scat was bestolen. $\mathrm{Ne}$ waer hi oec ghestolen niet, daer ware die moert bi ghesciet an hu lijf, in rechter trauwen,

2150 dat alle huwen vrienden mochte rauwen.'

Die coninghinne wart vervaert ende sprac: 'O wy, lieve Reynaert! O wy, Reynaert, o wy, o wy! O wy, Reynaert, wat sechdi?

2155 Ic mane hu bi der selver vaert dat ghi $n u$ ons secht, Reynaert, die hu ziele varen sal, dat ghi ons secht de waerheit al openbare ende brinct voort

2139-63 The treasure - the size of which is sketched by Reynart in superlatives (2137-38) - appears to have been stolen and to be at the same the financial means of funding a conspiracy to murder King Nobel. This arouses reactions from the royal couple. Nobel shows 
and his seven children.

2125 Then I would be allowed at most

one of the tiniest ribs

that his children had gnawed bare.

This is how little it yielded me.

And yet I did not really mind it.

2130 If I had not felt so much

affection for my uncle,

- who hardly cares for me -

I could have had enough to eat.

King, this I want you to know:

2135 I still have silver and gold

that is entirely at my disposal

in such great quantities that a cart going seven times

round would barely be able to transport it.'

When the king heard this,

2140 he gave Reynaert a sharp answer:

'Reynaert, how did you come by this treasure?'

Reynaert answered: 'I'll tell you about it.

If you wish to know what I know,

neither for love nor for hate

2145 shall it remain hidden.

King, that treasure was stolen.

But if it had not been stolen,

it would have been used for the murderous

attack on your life, on my word of honour,

2150 that would greatly grieve all your friends.'

The queen became upset

and said: 'Alas, my dear Reynaert!

Alas, Reynaert, alas, alas!

Alas, Reynaert, what are you saying?

2155 I urge you, by nothing less

than the journey that your soul will undertake,

that you tell us this instant, Reynaert,

the whole truth

publicly, and inform us

an interest in the treasure. The queen fears for her husband's life; anxiously she encourages

Reynaert to speak freely.

2144 The phrase means 'for nothing in the world'. 
2160 of ghi weet van eenegher moort of eenen mordeliken raet die jeghen minen heere gaet. Dat laet hier openbare horen.' $\mathrm{Nu}$ hoert hoe Reynaert sal verdoren

2165 den coninc entie coninghinne [205va] ende hi bewerven sal met zinne des coninx vrienscap ende sine hulde ende hi, buten haerre sculde, Brune ende Ysingrijn beede

2170 uphief in groter onghereede ende in veeten ende in ongheval jeghen den coninc bringhen sal! Die heeren, die nu waren so fier dat si Reynaerde waenden bier

2175 te sinen lachtre hebben ghebrauwen. Ic wane wel in rechter trauwen dat hi sal weder mede blanden dien si sullen drincken met scanden! In eenen ghelate met drouven zinne

2180 sprac Reynaert: 'Edele coninghinne, al haddi mi nu niet ghemaent, ic bem een die sterven waent. In laet niet ligghen up mijn ziele. Ende waert so dat mi gheviele, 2185 mi stonder omme in de helle te sine daer die torment es entie pine! Indien dat die coninc milde een ghestille maken wilde, ic soude segghen met ghenaden

2190 hoe jammerlike hi was verraden te mordene van zinen lieden. Nochtan diet alremeest berieden, sijn som van minen liefsten maghen,

2164-78 The narrator draws his public's attention: Nu hoert ('Now hear'). He announces that Reynaert will deceive Nobel and his wife and will cause a conflict between them and Bruun and Ysingrijn. This informs the public even at this early stage of the course events will take. The narrator's comments accentuate Reynaert's cunning.

2180-2208 Reynaert answers the queen that he wishes to speak freely about the murder plot 
2160 if you know of any attempt at murder or of a plan with intent to murder that concerns my husband.

Let us hear it here in this assembly.'

Now hear how Reynaert will delude

2165 the king and queen and how, in an ingenious way, he will gain the king's friendship and favour, and how he, through no fault of their own, will cause Bruun and Ysingrijn both

2170 great difficulties and how he will create hardship for them and a feud with the king! These lords, they were now very proud because they thought to have brewed

2175 Reynaert some beer to his disgrace. However, I truly believe that he in his turn will brew them mead that they will drink to their shame!

With a face expressing sadness

2180 Reynaert said: 'Noble queen, even if you had not pressed me at this moment, I am one who expects to die.

I do not want to burden my soul with it. And if I did so accidentally,

2185 hell would await me for it where there is torment and pain!

If the noble king would cause it to be quiet, I would, with his permission, relate

2190 how dreadfully he was betrayed by his subjects with a plan for his murder.

Yet the worst conspirators are some of my dearest relatives,

even though a number of his own relatives are implicated. He states that he accuses them only for fear of going to hell. King Nobel is touched by this but still hesitates. He seeks confirmation and asks Reynaert sechstu mi waer? ('are you telling the truth?' 2200), using the familiar form of address (see also note to 547-622). Reynaert stresses that he speaks the truth; after all, he is about to die (minelanghe vaert, 'my long journey',2207) and has to be mindful of the salvation of his soul. 
2195 ne daet die zorghe van der hellen, daer men seit dat si in quellen die hier sterven ende moort weten, si ne bringhense voort.' Dien coninc wart die herte zwaer

2200 ende sprac: 'Reynaerd, sechstu mi waer?' 'Waer?' sprac Reynaert, 'vraechdi mi des?

Ja ne weet ghi wel hoet met mi es?

Ne bewaent niet, edel coninc, al bem ic een aermijnc,

2205 hoe mochtic sulke moert ghetemen?

Waendi dat ic wille nemen eene loghene up mine langhe vaert?

Entrauwen, neen ic!' sprac Reynaert.

$\mathrm{Bi}$ der coninghinnen rade,

2210 die zeere ontsach des sconinx scade, gheboet die coninc openbare dat daer niemen so coene en ware dat hi een wordekijn yet sprake tote dien dat Reynaert met ghemake

2215 hadde vulseit al sinen wille.

Doe zweghen si allegader stille.

Die coninc hiet Reynaerde spreken.

Reynaert was van fellen treken.

Hem dochte scone zijn gheval.

2220 Hi sprac: 'Nu zwighet overal, nadien dat es den coninc lief. Ic sal hu lesen sonder brief die verraderen openbare, sodat ic niemene en spare

2225 dien ic te wroughene sculdich bem.

Dies lachter hevet, scaems hem!'

$\mathrm{Nu}$ verneemt allegader

2197 Hier: that is, on earth.

2211 The king raises his voice as he is speaking in an official capacity.

2222 lesen sonder brief means to recite by heart and accurately.

2227-38 The narrator's comments ensure that the audience is informed of Reynaert's plan to accuse his father and Grimbeert of treason. Precisely by assigning complicity to his own relatives in 
whom I would in no way accuse

2195 if it was not for the fear of hell, where - it is said - all those suffer who die here and know of a murder and do not reveal it.'

The king's heart sank

2200 and he said: 'Reynaert, are you telling me the truth?' 'The truth?' said Reynaert, 'are you asking me that?

Surely you know how it is with me?

Don't you wonder, noble king, how even a poor creature like me

2205 could bear such an outrage?

Do you think I would want to burden myself with a lie on my long journey?

Truly, not me!' Reynaert said.

On the advice of the queen,

2210 who feared that the king should come to harm, the king loudly proclaimed that no one should be so bold as to utter so much as a single word until Reynaert had been able at his leisure

2215 to have his say, as it pleased him. Then all kept very silent. The king told Reynaert to speak. Reynaert was full of low tricks. It seemed to him that his luck was great.

2220 He said: 'Now be silent, all of you, because the king wishes it.

I shall describe without written record the traitors to you in this assembly in such a way that I shall spare no one

2225 whom I ought to accuse.

Whoever is thus disgraced, should be ashamed!'

Now hear all of you

the murder plot - something unheard of in medieval feudal society - Reynaert strengthens the truth value of his accusations (2233-37 and cf. 2518-27). When a little later he lies to the king and queen, the tale's listeners know more than the royal couple. In this way the sense of Reynaert's cleverness is strengthened. See also the note to 2164-78. Grimbeert is absent and subsequentlyit is revealed that Reynaert's father has died (2481-83); neither can, therefore, contradict the charges. 
hoe Reynaerd sinen erdschen vader

met verradenessen sal bedragen

2230

ende eenen van sinen liefsten maghen;

dat was Grimberte den das,

die hem hout van herten was!

Dat dede Reynaert ommedat, dat hi wilde dat men te bat

2235 sinen woerden gheloeven soude van sinen vianden, of hi woude die verranesse tyen an.

$\mathrm{Nu}$ hoert hoe hi dies began!

Reynaert sprac: 'Wilen teer stonden

2240 hadde mine heere mijn vader vonden

des coninx Hermeliken scat

in eene verholnen stat.

Doe mijn vader hadde vonden

den scat, wart hi in corten stonden

2245 so overdadich ende so fier

dat hi veronweerde alle dier

die sine ghenote tevoren waren.

Hi dede Tyberte den kater varen

in Arttinen, dat wilde lant,

2250 aldaer hi Brunen den beere vant.

Hi ontboet Brune grote Gods houde

ende hi in Vlaendren commen soude

ende hi coninc wilde wesen.

Bruun wart vro van desen:

2255 hi hadt meneghen dach begaert.

Daer maecte hi hem te Vlaendren waert

ende quam in Waes, int soete lant,

daer hi minen vader vant.

Mijn vader ontboet Grimbeerte den wysen

2228 erdschen vader: his own father, as opposed to the heavenly father of all mankind.

2241 Reynaert arouses the king's greed by referring to the treasure of King $(\mathrm{H})$ ermeli(n)c (cf. also 2564). It concerns the legendary, fourth-century Gothic sovereign Ermanric from Germanic heroic legend. He is supposed to have possessed an enormous, now lost treasure, and, according to local legend, built the fortress of Ghent.

2243-76 Reynaert describes the conspiracy, which his father is said to have devised and financed. In his story, the five animals swear that they will crown Bruun in Aachen. That places the bear in the capital of the Roman Empire and on Charlemagne's throne. The 
how Reynaert will accuse

his own father of treason

2230

as well as one of his dearest relatives;

that was Grimbeert the badger,

who was very fond of him!

Reynaert did this as

he intended that

2235 his words about his enemies

should be the more credited

when he accused them of treason.

Now hear how he began this!

Reynaert said: 'Once upon a time

2240

my lord and father had found

the treasure of King Ermelinc

in a hidden place.

After my father had found the treasure,

he became, in no time at all,

2245 so overconfident and so proud

that he looked down on all the animals

who earlier had been his equals.

He had Tybeert the cat travel

to the Ardennes, that wild region,

2250 where he met Bruun the bear.

He wished Bruun Godspeed,

and he invited him to come to Flanders,

and would he like to become king.

Bruun was glad of this:

2255 he had wanted it for a long time.

Then he went to Flanders

and arrived in Waes, that lovely region,

where he met my father.

My father sent for reliable Grimbeert

theme of treason in Van den vos Reynaerde is reminiscent of similar themes in Charlemagne epics, in which traitors temporarily manage to manipulate the king by means of bribes or false accusations in such a way that he treats a loyal vassal unjustly. However, eventually feudal order is restored. The point of the joke is that Reynaert pretends that there are traitors at work in King Nobel's court and that he himself is the loyal vassal, whereas the reality is exactly the other way around: it is Reynaert who will prove to be the (successful) traitor, while the so-called traitors are Nobel's loyal vassals. In addition the feudal order will have disappeared for good at the end of the story (cf. 1770-95, 2486-90, 3399-3410, 3436-51 and see pp. 25-26). 
2260 ende Ysingrijn den grijsen;

Tybeert die kater was die vijfste;

ende quamen teenen dorpe, hiet Hijfte.

Tusschen Hijfte ende Ghend

hilden si haer paerlement

2265 in eere belokenre nacht.

Daer quamen si bi sduvels cracht

ende bi sduvels ghewelt

ende zwoeren daer an twoeste velt

alle vive des coninx doot.

2270 Nu hoert wonder alle groot:

si swoeren op Ysegrims crune,

2270 a alle vive, dat si Brune

$2270 \mathrm{~b}$ souden bringe op den stoel tAken

$2270 \mathrm{c}$ endesouden geweldich coninc maken.

2270d Wat si noch overeendraghen: wilde yement van sconincx maghen dat wedersegghen, mijn vader soude met sinen selvere, met zinen goude

2275 so denghenen steken achtre dat sijs souden hebben lachtre.

Dit weetic ende segghe hu hoe.

Eens morghins arde vroe gheviel dat mijn neve die das

2280 van wine een lettel droncken was ende lyet in verholnen rade minen wive, miere vrauwen Hermelinen, ende al van pointe te pointe seide daer si liepen an die heyde.

2285 Mijn wijf es eene vremde vrouwe ende gaf Grimberte hare trauwe dat verholen bliven soude. Ten eersten dat so quam ten woude daer ic was ende so mi vant,

2290 so telde zoet mi tehant. Newaer het was al stillekine.

Oec seide zoet bi sulken lijcteekine

2270a Another reminder that the fox scalded the skin off Ysingrijn's scalp with boiling water. See the notes to 1499-1503 and 1951-52. 
2260 and grey Ysingrijn;

Tybeert the cat was the fifth and they came to a village called Hijfte.

Between Hijfte en Ghent

they held their council

2265 on a dark night.

There they gathered through the devil's power

and the devil's might

and swore there in the waste land

all five to the king's death.

$2270 \quad$ Now hear a great marvel:

they swore on Ysingrijn's tonsure,

2270a all five of them, that they would

$2270 \mathrm{~b}$ get Bruun on the throne in Aachen

$2270 \mathrm{C}$ and would make him a mighty king.

2270d They also agreed to the following:

if any of the king's relatives

was to object, my father would

with his silver and with his gold

2275 oppose them to such an extent

that they would be disgraced.

That I know and I shall tell you how.

One morning, very early, it so happened that my nephew the badger

2280 was a little drunk with wine and he confided in good faith in my wife, Lady Hermeline, and told her all about it, detail by detail, as they were walking on the heath.

2285 My wife, who is a special lady, gave Grimbeert her promise that it would remain a secret. As soon as she reached the wood where I was and she met me,

2290 she told it me at once. But she did it in secret.

Also she told it me with such evidence 
dat ict kende so waer

dat mi alle mine haer

2295 upwaert stonden van groten vare.

Mine herte wart mi openbare

also caut als een hijs.

Dies zijt seker ende wijs.

Die pude wijlen waren vry

2300 ende oec so beclaechden hem zij

dat si waren sonder bedwanc.

Ende si maecten een ghemanc

ende so groet ghecray up Gode

dat hi hem gave, bi sinen ghebode,

2305 eenen coninc diese dwonghe.

Dies baden die houde entie jonghe

met groten ghecraye, met groten ghelude.

God ghehoerde die pude

teenen tijde van den jare

2310 ende sende hem den coninc hodevare,

diese verbeet ende verslant

in allen landen daer hise vant,

beede in water ende in velt.

Daer hise vant in sine ghewelt,

2315 hi dede hem emmer onghenade.

Doe claechden si; het was te spade.

Het was te spade, ic secht hu twy:

sij die voren waren vry,

sullen sonder wederkeer

2320 sijn eyghin bliven emmermeer

ende leven eewelike in vare

van den coninc hodevare.

Ghi heeren, aerme ende rike,

ic vruchte oec diesghelike

2325 dat nu van hu soude ghevallen.

Doe droughic zorghe voer ons allen.

Dus hebbic ghezorghet voer hu;

2299-2322 The story of the frogs who want to be ruled was known in the Middle Ages both in the vernacular and in Latin in the form of an Aesopian fable. It cannot be determined whether Willem used the Middle Dutch Esopet or the Middle Latin tradition. In most versions of the Aesopian fable the frogs do not find themselves having to cope with a stork, but 
that I was so convinced of the truth

that all my hairs

2295 stood upright for great fear.

My heart truly became

as cold as ice.

Take good heed of the following.

The frogs used to be free

2300 and yet they complained

that they had no one with authority over them.

And they got together

and sent up a loud croaking to God

to give them, by his command,

2305 a king who would have power over them.

This begged the old ones and the young ones

with loud croaking, with a loud noise.

God heard the frogs

at a certain time of year

2310 and sent them king stork, who killed and devoured them

wherever he found them, both in the water and in the field.

Where he could get them in his power,

2315 he was always merciless towards them.

Then they complained; it was too late.

It was too late, I'll tell you why:

they who used to be free

will irreversibly

2320 be subjected to him for ever more

and live eternally in fear

of king stork.

You, my lords, poor and rich,

I feared something similar

2325 might befall you now.

Then I took the care of all of us upon myself.

Thus I have looked after you;

with a snake. Reynaert uses the fable to illustrate that Nobel's good kingship is preferable to the cruel regime of anti-king Bruun, who would terrorize his subjects as the stork did the frogs. Towards the end of Van den vos Reynaerde the implications are that the fable may be reinterpreted as heralding Nobel's new regime, in which only the fittest survive. 
dies dancti mi lettel nu!

Ic kenne Brunen valsch ende quaet

2330 ende vul van alre overdaet.

Ic peinsde, worde hi onse heere,

dat ontvruchtic arde zeere,

dat wi alle waren verloren.

Ic kende den coninc welgheboren

2335 ende soete ende goedertiere

ende ghenadich allen dieren.

Het dochte mi bi allen dinghen

eene quade manghelinghe,

die ons ne mochte comen

2340 noch theeren noch te vromen.

Hieromme peinsdic ende poghede.

Mine herte grote zorghe ghedoghede

hoe so erghe eene zake,

dat so ghescort worde ende brake

2345 mijns vaders bosen raet,

die eenen dorper, eenen vraet, coninc ende heere maken waende.

Emmer badic Gode ende maende

dat hi den coninc, minen heere,

2350 behilde sine warelteere.

Bedi ic kenne wel dat:

behilde mijn vader sinen scat, si souden wel des raets ghetelen onder hem ende sinen ghespelen,

2355 dat die coninc worde verstoten. In diepen ghepeinse ende in groten was ic dicken, hoe ic dat soude vinden waer die scat lach die mijn vader hadde vonden.

2360 Ic wachte nauwe tallen stonden minen vader ende leide laghen in meneghen bosch, in meneghe haghen, beede in velde ende in woude.

Waer mijn vader, die lusteghe houde,

2365 henentrac ende henenliep, was het droghe, was het diep, 
and for this you give me little thanks now!

I know Bruun as false and malicious

2330 and full of violence.

I thought: if he becomes our lord,

then I fear very much

that we would all be lost.

I knew the king as noble

2335 and gentle and kind-hearted

and merciful towards all animals.

It seemed to me in all respects

a poor exchange,

which could bring us

2340 neither honour nor profit.

This I pondered and thought.

I was extremely concerned

how such a terrible business

might be thwarted

2345 and my father's evil plan frustrated, who intended to make a peasant, a glutton, king and lord.

Incessantly I prayed to God and begged

that he might allow the king, my lord,

2350 to retain his dominion.

For I was fully aware of the following:

if my father kept his treasure,

he and his accomplices would be sure

to execute the plan

2355 so that the king would be overthrown.

Deeply immersed in many thoughts

I often found myself, wondering how

I might find out where the treasure

lay hidden that my father had found.

2360 I kept a close guard at all times

on my father and lay in wait

in many a wood, in many a hedgerow,

both in the field and in the wood.

Wherever my crafty old father

2365 went or walked,

whether it was dry or marshy, 
waest bi nachte, waest bi daghe, ic was emmer in die laghe.

Waest bi daghe, waest bi nachte,

2370 ic was emmer in die wachte.

Up eene stont gheviel daernare dat ic mi decte met groten vare ende lach ghestrect neven dheerde ende van den scatte die ic begheerde

2375 gherne yewer hadde vernomen.

Doe saghic minen vader comen hute eenen hole gheloepen.

Doe began ic ten scatte hopen, bi den barate als ic hem sach

2380 dryven, als ic hu segghen mach. Want hi huten holle quam, sach ic wel, ende vernam dat hi ommesach ende merkedi of hem yemene ware bi.

2385 Ende als hi niemene en sach, doe queddi den sconen dach ende stoppede dat hol met sande ende maectet ghelijc den andren lande. Dat ic dit sach, ne wiste hi niet.

2390 Doe saghic, eer hi danen sciet, dat hi den steert liet medegaen daer sine vote hadden ghestaen ende decte sijn spore metter mouden. Daer leerdic an den vroeden houden

2395 een lettel meesterlike liste die ic tevoren niet ne wiste. Aldus voer mijn vader danen ten dorpe waert, daer die hanen ende die vette hinnen waren.

2400 Teerst dat ic mi durste baren, spranc ic up ende liep ten hole. In wilde niet langher zijn in dole ende ic gheraecter doe tehant. Sciere scraefdic up dat zant met minen voeten ende croep in. 
whether it was by night or by day,

I was ever spying on him.

Whether by day or by night,

2370 I was ever watchful.

Then, one time it so happened

that I covered myself with large ferns

and lay flat on the earth

and would dearly have known something

2375 about the treasure that I coveted.

Then I saw my father

emerge from a hole.

Then I began to have hopes of the treasure

as a result of the wily way

2380 in which he behaved, as I shall tell you.

For when he came out of the hole,

I watched carefully, and noticed

that he looked around to see

if anyone was near.

2385 And when he did not see anyone, he greeted the light of day

and stopped up the hole with sand, making it even with the ground around it. That I saw this, he did not realize.

2390 Then I saw, before he left that place, that he dragged his tail across where his feet had been, and covered his tracks with earth. There I learned from my cunning old father

2395 a masterly little trick that I did not know before.

In this way my father went away from there, in the direction of the village, where the cocks and the plump hens were.

As soon as I dared show myself

I jumped up and went to the hole.

I did not wish to be in uncertainty any longer

and I got there fast.

Quickly I scratched away the sand with my paws and crawled in. 
Aldaer vandic groet ghewin.

Daer vandic selver ende goud.

Hier nes niemen nu so houd dies nye so vele tegader sach!

2410 Doe ne spaerdic nacht no dach, ic en ghinc trecken ende draghen sonder karre ende waghen over dach ende over nacht met algader miere cracht.

2415 Mi halp mijn wijf, vrouwe Hermeline.

Des dogheden wi grote pine eer wi den overgroeten scat brochten in een ander gat, daer hi bet lach tonsen ghelaghe.

2420 Wij droughene onder eenen haghe in een hol verholenlike.

Doe was ic van scatte rike. $\mathrm{Nu}$ hoert wat si hierbinnen daden die den coninc hadden verraden.

2425 Brune die beere sendde huut verholenlike zijn saluut achter lande ende omboet al denghenen rijcheit groet die dienen wilden omme tsout.

2430 Hi beloofde hem selver ende gout te ghevene met milder hant. Mijn vader liep in al dat lant ende drouch des Brunen brieve. Hoe lettel wiste hi dat de dieve 2435 te sinen scatte waren gheraect, dies hem so quite hadden ghemaect. En ware die scat niet ontgonnen, hi hadder met die stat van Lonnen altegader moghen coepen.

2440 Dus wan hi an zijn ommeloepen! Doe mijn vader al omme ende omme tusschen dier Elve entier Zomme

2442 This is the Lower German area. 
There I found great booty.

There I found silver and gold.

There is no one present here, however old,

who ever saw so much together!

2410 Then I did not hesitate one moment,

I started dragging and carrying

without a cart or wagon,

both by day and by night,

with all the power that I had.

2415 My wife, Lady Hermeline, helped me.

We had to give ourselves great trouble

before we had taken the enormous treasure

to a different hole,

where it was better within our reach.

2420 We carried it to a hole under a bush

without being noticed.

Then I was in the possession of the treasure.

Now hear what those who had

betrayed the king, did in the meantime.

2425 Bruun the bear sent

his salutation secretly

through the land and promised

great riches to all

who would serve him for pay.

2430 He promised to dole out to them

silver and gold generously.

My father traversed the entire country

with the writs from Bruun.

Little did he know that the thieves

2435 had got to his treasure, of which they had relieved him.

If the treasure had not been made away with, he would have been able to buy the entire city of London with it.

2440 So much did he profit by all his running around!

When my father had crossed

all the land between the Elbe and the Somme 
hadde gheloepen al dat lant ende hi meneghen coenen serjant

2445 hadde ghewonnen met sinen goude, die hem te hulpen commen soude alse die zomer quame int lant, keerde mijn vader daer hi vant Brune entie ghesellen zine.

2450 Doe teldi die groete pine ende die menichfoudeghe zorghe die hi voer de hoghe borghe int lant van Sassen hadde leden, daer die jagheren hadden gheleden

2455 alle daghe met haren honden, die hem vervaerden te meneghen stonden.

Dit telde hi te spele algader.

Daerna so toghede mijn vader brieve die Brunen wel bequamen,

2460 daer XIIC al bi namen sheere Ysingrijns maghe in stonden, met scerpen claeuwen, met diepen monden, sonder die catren ende die baren die alle in Bruuns souden waren,

2465 ende die vosse metten dassen van Doringhen ende van Sassen. Dese hadden alle ghezworen: indien dat men hem tevoren van XX daghen ghave haer sout,

2470 si souden Brunen met ghewout seker wesen tsinen ghebode.

Dit benam ic al, danct Gode! Doe mijn vader hadde ghedaen sine bodscap, hi soude gaen

2475 ende scauwen zinen scat. Ende als hi quam ter selver stat daer hine ghelaten hadde tevoren, was die scat al verloren ende sijn hol was uptebroken.

2480 Wat holpe vele hieraf ghesproken?

Doe mijn vader dat vernam, 
in all directions

and had enlisted many a brave soldier

2445 with his gold,

who would come to his aid

once it was summer,

my father returned to where

he found Bruun and his companions.

2450 Then he told them of the great troubles

and the many dangers

that he had experienced

before the high fortresses in the land of Saxony,

where the hunters had passed

2455 every day with their dogs

which had terrified him many times.

All this he said quite casually.

Afterwards my father produced

lists that were much to Bruun's liking,

2460 which contained twelve hundred

named relatives of Lord Ysingrijn,

with sharp claws, with huge maws,

quite apart from the cats and the bears,

all of whom were in Bruun's pay,

2465 and the foxes and the badgers

from Thuringia and from Saxony.

All of them had sworn

that if they were paid

twenty days' wages in advance,

2470 they would, according to their powers, be sure to obey Bruun's orders.

All this I put a stop to, thank God!

When my father had delivered

his message, he wanted to go

2475 and have a look at his treasure.

And when he arrived in the same place

as where he had left it earlier,

the treasure was completely gone

and his hole broken open.

$2480 \quad$ What use is it to dwell on it?

When my father saw it, 
wart hi zeerich ende gram, dat hi van torne hem selven hinc. Dus bleef achter Brunen dinc

2485 bi miere behendichede al.

Nu meerct hier mijn ongheval:

heere Ysingrine ende Brune de vraet hebben nu den nauwen raet metten coninc openbare

2490 ende arem man Reynaerd es die blare!'

Die coninc entie coninghinne, die beede hopeden ten ghewinne, si leedden Reynaerde buten te rade ende baden hem dat hi wel dade

2495 ende hi hem wijsde sinen scat. Ende alse Reynaerd horde dat, sprac hi: 'Soudic hu wijsen mijn goet, heere coninc, die mi hanghen doet?

So waer ic huut minen zinne!'

2500 'Neen, Reynaert,' sprac die coninghinne, 'mine heere sal hu laten leven [207va] ende sal hu vriendelike vergheven allegader sinen evelen moet ende ghi sult voert meer sijn vroet

2505 ende goet ende ghetrauwe.' Reynaerd sprac: 'Dit doe ic, vrauwe, indien dat mi de coninc nu vaste ghelove hier voer hu dat hi mi gheve sine hulde 2510 ende hi al mine sculde wille vergheven ende ommedat so willic hem wijsen den scat, den coninc, aldaer hi leghet.' Die coninc sprac: 'Ic ware ontweghet, 2515 wildic Reynaerde vele gheloven.

2491-2541 The moment when the king and queen take Reynaert aside and ask him to show them the treasure (2491-95) is of paramount importance for the story. Blinded by their greed the royal couple opts for private (financial) gain. In this way it becomes evident that the community of the court no longer presents a united front to the fox. Reynaert has succeeded in creating a schism (see pp. 25-26). The fox subsequently leads the conversation in a 
he became so miserable and angry

that he hanged himself from sheer frustration.

And so Bruun's plan came to nothing,

2485 entirely as a result of my cunning.

Now observe my ill luck:

Lord Ysingrijn and Bruun the glutton

now clearly are the king's

trusted counsellors,

2490 and poor Reynaert is the scapegoat!'

The king and the queen, both of whom hoped to profit, took Reynaert apart to discuss the matter and asked him if he would be so good

2495 as to show his treasure to them. And when Reynaert heard this, he said: 'Would I show my property to you, Lord King, who is having me hanged?

Then I would be out of my mind!'

2500 'No, Reynaert,' said the queen, 'my lord will let you live and will benevolently forgive and forget the ill feeling that he felt towards you, while you shall henceforth be sensible

2505 and virtuous and loyal.'

Reynaert said: 'That I will, my lady, if the king firmly promises me now in your presence

that he will give me his support

2510 and that he will forgive me all I am guilty of; and in return I will show the king where the treasure is kept.'

The king said: 'I'd be misled 2515 if I believed all that Reynaert is saying.

subtle way towards a deal: mercy in exchange for the treasure (2496-99, 2506-10). The king, who still mistrusts the fox (2514-17), allows himself to be persuaded by his wife (2500-5, 2518-27, 2528-33). Nevertheless Nobel threatens to persecute Reynaert's descendants for ever if the fox should persist in his wicked ways (2534-37). 
Hem es dat stelen ende dat roven ende dat lieghen gheboren int been.' Die coninghinne sprac: 'Heere, neen! Ghi moghet Reynaerde gheloven wel.

2520 Al was hi hier tevoren fel, hi nes nu niet dat hi was.

Ghi hebt ghehoert hoe hi den das ende sinen vader hevet bedreghen met morde, die hi wel beteghen

2525 mochte hebben andren dieren, wildi meer zijn argertieren ofte fel ofte onghetrauwe.' Doe sprac die coninc: 'Gentel vrauwe, al waendic dat mi soude scaden,

2530 eist dat ghijt mi dorret raden, so willict laten up hu ghenent dese vorworde ende dit covent up Reynaerts trauwe staen. Newaer ic segghe hem sonder waen:

2535 doet hi meer eerchede, alle die hem ten tienden lede sijn belanc, sullent becoepen.' Reynaerd sach den coninc beloepen ende wart blide in sinen moet

2540 ende sprac: 'Heere, ic ware onvroet, ne gheloofdic hu niet also.'

Doe nam die coninc een stro ende vergaf Reynaerde algader die wanconst van sinen vader

2545 ende zijns selves mesdaet toe. Al was Reynaert blide doe, dat en dinct mi gheen wonder wesen! Ja ne was hi van der doot ghenesen? Doe Reynaert quite was ghelaten, 2550 was hi blide utermaten ende sprac: 'Coninc, edel heere,

2542-45 By handing him a straw, Nobel forgives Reynaert's sins. It concerns a symbolic legal procedure, the festucatio or halminghe, during which the straw was thrown down or broken 
For him stealing and robbing and lying is second nature.' The queen said: 'My lord, no! You may certainly believe Reynaert.

2520 Even though he was wicked before, he is no longer what he used to be. You have heard how he accused the badger and his father of a plot to kill you, which he might easily

2525 have attributed to other animals, if he meant to persist in being wicked and mean or disloyal.' Then the king said: 'Noble lady, even if I thought that it would harm me,

2530 if you dare advise me to do it, then I will, on your responsibility, let this agreement and this covenant depend on Reynaert's loyalty. But I shall be blunt with him:

2535 if he perpetrates wicked deeds again, all those related to him to the tenth degree will suffer for it.'

Reynaert noticed that the king was swayed and rejoiced inwardly,

2540 and said: 'Lord, I would be unwise if I did not promise you that.'

Then the king picked up a straw and fully forgave Reynaert his father's enmity

2545 as well as his own crimes. That Reynaert was very pleased then does not seem a marvel to me! Had he not just escaped a certain death? When Reynaert had been pardoned, 2550 he was overjoyed and said: 'King, noble lord,

as a sign of the complete exoneration of all guilt. The official reconciliation, witnessed by the assembled court, is to follow at a later stage (2764-95). 
God moete hu loenen al die eere die ghi mi doet ende mijn vrauwe. Ic secht hu wel bi miere trauwe

2555 dat ghi mi vele eeren doet, so groet eere ende so groet goet dat niemen nes onder die zonne dien ic also wale jonne mijns scats ende miere trauwen

2560 als ic hu doe ende miere vrauwen.' Reynaert nam een stroe voer hem ende sprac: 'Heere coninc, nem. Hier gheve ic di up den scat die wijlen Ermelinc besat.'

2565 Die coninc ontfinc dat stroe ende dancte Reynaerde zoe als quansijs: 'Dese maect mi heere.' Reynaerts herte louch so zeere dat ment wel na an hem vernam,

2570 doe die coninc so gheorsam algader was te sinen wille. Reynaert sprac: 'Heere, zwighet stille; merket waer mine redene gaet. Int oesthende van Vlaendren staet

2575 een bosch, ende heet Hulsterloe. Coninc, ghi moghet wesen vroe, mochti onthouden dit: een borne, heet Kriekepit, gaet zuutwest niet verre danen.

2580 Heere coninc, ghi ne dorst niet wanen dat ic hu de waerheit yet messe. Dats een de meeste wildernesse die men hevet in eenich rike.

2561-65 The festucatio is doubled here, as Reynaert transfers his treasure symbolically by using a straw.

2572 Literally $z$ wighet stille means 'be silent'.

2574-93 The fox gives precise indications where the treasure is to be found. In the forest of Hulsterloe, a historically identifiable place, Kriekeputte is to be found, according to Reynaert. At the time of writing this was probably an existing spring. Reynaert uses these realistic toponyms to impress the reliability of his story upon his audience. For Willem's audience the references to realistic locations will have served to enhance the dramatic irony of the episode (see p. 22). The 
may God reward you for all the honour

you and my lady do me.

I assure you on my pledge of loyalty

2555 that you do me a great honour, so much honour and so much favour

that there is no one under the sun

to whom I so willingly surrender

my treasure and my loyalty

2560 as I do to you and my lady.'

Reynaert held up a straw

and said: 'Lord King, take it.

I herewith hand over to you the treasure

which earlier was in Ermelinc's possession.'

2565 The king received the straw

and thanked Reynaert

as if he meant to say: 'This makes me its master.'

In his heart Reynaert laughed so much

that it almost showed,

2570 when the king so obediently

did entirely as he wished.

Reynaert said: 'Lord, listen;

mind what I have to say.

In the east of Flanders there is

2575 a wood, which is called Hulsterloe.

King, you will be pleased

to remember this:

a spring, called Kriekeputte,

runs towards the southwest not far from there.

2580 Lord King, you need not fear

that I tell you anything less than the truth.

It is one of the wildest regions

that can be found in any realm.

fox characterizes the place as a dismal area, which shows a striking resemblance to the cursed place described in the Bible in the Book of Isaiah $(34,10-12)$, which is prophesied to lie waste for generations and through which no one shall ever pass. It is said there that the cormorant and the bittern possess it, while the owl and the raven shall dwell in it, and that it has no rulers. By Reynaert's location of his treasure in this very similar locus terribilis and his intention to make the king go there ( $2597 \mathrm{ff}$.), the story's audience is warned in a subtle way of Nobel's impending downfall. The delightful place described at the beginning of the poem (41-43) proves to be an illusion; the gruesome surroundings of Kriekeputte are Nobel's wretched reality (see p.24). 
Ic segghe hu oec ghewaerlike

2585 dat somwijlen es een half jaer

[208ra]

dat toten borne commet daer

no weder man no wijf

no creature die hevet lijf,

sonder die hule entie scuvuut

2590 die daer nestelen in dat cruut, of eenich ander voghelijn

dat elwaer gherne wilde zijn

ende daer $b i$ avontuere lijdet.

Ende daerin leghet mijn scat ghehidet.

2595 Verstaet wel, ditte es hu nutte:

die stede heetet Kriekeputte.

Ghi sult daer gaen ende mijn vrauwe.

Ne wetet oec niemene so ghetrauwe

die ghi sult laten wesen hu bode.

2600 Verstaet mi wel, coninc, dor Gode, maer gaet daer selve ende alse ghi

dien selven putte commet bi, ghi sult vinden jonghe baerken.

Heere coninc, dit suldi maerken:

2605 die alrenaest den putte staet, coninc, tote dier baerken gaet.

Daer leghet die scat onder begraven.

Daer suldi delven ende scraven

een lettel mos in deene zijde.

2610 Daer suldi vinden menich ghesmide van goude, rijkelijc ende scone.

Daer suldi vinden die crone

die Ermelijnc die coninc drouch

ende ander chierheit ghenouch:

2615 edele steene, guldin waerc;

men cocht niet omme dusent maerc.

Ay coninc, als ghi hebt dat goet,

hoe dicken suldi peinsen in huwen moet:

"Ay Reynaert, ghetrauwe vos,

2589 There has been considerably debate about the word scuvuut. It is usually translated as 'night owl'. This makes little sense, however, as the owl is already mentioned in the same 
I also tell you truthfully

2585 that sometimes for as long as half a year

neither man nor woman

comes to that spring,

nor any living creature

except the owl and the jay

2590 who have their nests there in the bushes,

or any other little bird

that would prefer to be somewhere else

and has alighted there by chance.

And that is where my treasure lies hidden.

2595 Listen well, this is to your advantage:

the place is called Kriekeputte.

You must go there and my lady.

Do not consider anyone trustworthy enough

to have him go in your stead.

2600 Take good note, king, in God's name, just go there yourself and when you

get to the pool in question,

you will see young birch trees.

Lord King, this you should note:

2605 go to that birch

which is nearest the pool, king.

The treasure lies buried under it.

There you must dig and scratch away

a little moss on one side.

2610 There you will find many pieces of jewellery

set in gold, costly and beautiful.

There you will find the crown

that King Ermelinc wore

and many other precious objects:

2615 gems, goldsmiths' work;

it could not be bought for a thousand marks.

Ah, king, once you have these goods,

how often you will think to yourself:

"Ah, Reynaert, faithful fox,

line. With the translation 'jay', like the crow and the raven a thief and a scoundrel, we follow Van Gasse 1993. 
2620 die hier grouves in dit mos

desen scat bi dijnre lust, God gheve di goet waer du best."'

Doe andwoerde die coninc saen:

'Reynaert, sal ic die vaert bestaen,

2625 ghi moet zijn mede in die vaert.

Ende ghi moet ons, Reynaert, helpen den scat ontdelven.

Ic ne wane bi mi selven

aldaer nemmermeer gheraken.

2630 Ic hebbe ghehoort nomen Aken ende Parijs. Eist daer yet na?

Ende also als ic versta, so smeekedi, Reynaert, ende roomt.

Kriekeputte dat ghi hier noomt,

2635 wanic es een gheveinsde name.'

Dit was Reynaerde ombequame ende verbalch hem ende seide: 'Ja, ja, coninc, ghi zijter also na alse van Colne tote meye.

2640 Waendi dat ic hu die Leye wille wijsen in die flume Jordane? Ic sal hu wel toeghen, dat ic wane, orconde ghenouch al openbare.' Lude riep hi: 'Cuwaert, comt hare!

2645 Comet voer den coninc, Cuwaert.' Die diere saghen dese vaert; hem allen wonderde wat daer ware. Cuwaert die ghinc met vare; hem wonderde wat die coninc woude.

2650 Reynaert sprac: 'Cuwaert, hebdi coude? Ghi bevet. Zijt blide al sonder vaer ende secht minen heere den coninc waer. Dies manic hu bi der trauwen die ghi ver Genten miere vrauwen

2654a ende hem selven sculdich sijt.'

2654b Doe sprac Cuwart: 'Vermaledijt

$2654 \mathrm{C}$ so moetic werden, al wistic wel

2654d dat micosten soude mijn vel, 
2620 who buried under this moss here

this treasure with all your cunning,

God be with you wherever you are."

Then the king answered at once:

'Reynaert, if I were to undertake the journey,

2625 you must come along.

And you, Reynaert, must

help us dig up the treasure.

I don't think that by myself

I shall ever get there.

2630 I have heard Aachen mentioned

and Paris. Is it near there?

But I fancy, Reynaert, that

you are trying to curry favour, and are bluffing.

Kriekeputte, that you mention here,

2635 is, I reckon, a made-up name.'

This irritated Reynaert

and it annoyed him and he said: 'Yes, yes,

king, you are as close

as Cologne is to the month of May.

2640 Do you think I want to make you believe that the Leie is the river Jordan?

I will soon give you, so I expect, plenty of evidence quite openly.'

Loudly he shouted: 'Cuwaert, come here!

2645 Come before the king, Cuwaert.'

The animals saw him move;

they all wondered what it meant.

Cuwaert went with trepidation;

he wondered what the king wanted.

2650 Reynaert said: 'Cuwaert, are you cold?

You are trembling. Cheer up, don't be afraid

and tell my lord the king the truth.

I urge you to do this by the loyalty

that you owe to my Lady Gente

2654a and to himself.'

2654 b Then Cuwaert said: 'I may be damned,

$2654 \mathrm{C}$ even if I knew for certain

$2654 \mathrm{~d}$ that it would cost me my life, 


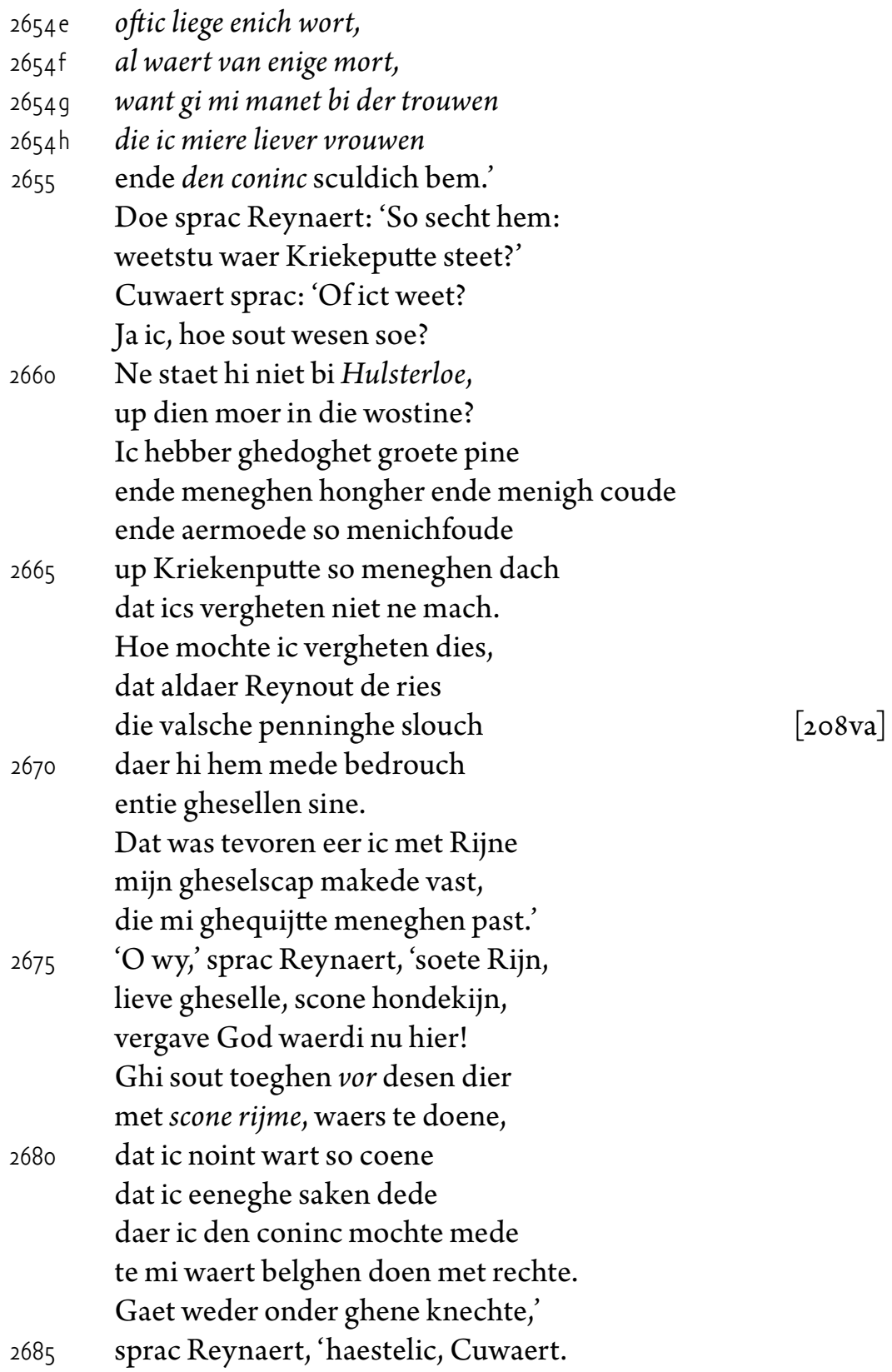

2662-74 The hare probably gives a truthful report of past events. Having stated that near Kriekeputte he suffered hunger, cold and poverty, he names two animals: Reynout the counterfeiter (a dog?) and the small dog Rijn, who turns out to be a poet. It is unclear whether 
2654e if I lie a single word,

$2654 \mathrm{f}$ even if it concerned some crime or other,

$2654 \mathrm{~g}$ since you urge me to do this by the loyalty

$2654 \mathrm{~h}$ that I owe my dear lady

2655 as well as the king.'

Then Reynaert said: 'Well, tell him:

do you know where Kriekeputte is?'

Cuwaert said: 'Do I know that?

Yes, of course, how could I not?

2660 Isn't it near Hulsterloe, near that swamp in the waste land?

I have endured great suffering there, and much hunger and often cold and constant poverty

2665 in Kriekeputte, for so many days, that I cannot forget it.

How could I forget this:

that unscrupulous Reynout made the counterfeit money there

2670 with which he earned a living for himself and his accomplices. That was before I became firm friends with Rijn, who often payed my school fees for me.'

2675 'Alas,' said Reynaert, 'darling Rijn, dear friend, handsome little dog, God give you were here now!

You would show before these animals in fine verse, if necessary,

2680 that I never was so bold as to do anything by which I might justly arouse the king's wrath against me. Go back to the servants again,' 2685 said Reynaert, 'and hurry, Cuwaert.

the author alludes to a beast narrative that is no longer extant, or to real persons and events. Cuwaert's statement that counterfeiters dwelled near Kriekeputte is tendentious in light of Reynaert's imaginary treasure. 
Mijn heere de coninc ne heeft thuwaert

gheene sake te sprekene meer.'

Cuwaert dede eenen wederkeer

ende ghinc van sconincx rade daer.

2690 Reynaert sprac: 'Coninc, eist waer

dat ic seide?' 'Reynaert, jaet.

Verghevet mi, ic dede quaet

dat ic hu mestroude yet.

Reynaert, goede vrient, nu siet

2695 den raet dat ghi met ons gaet ten putte aldaer dien berke staet daer die scat leghet begraven onder.'

Reynaert sprac: 'Ghi secht wonder.

Waendi, in waers arde vro,

2700 coninc, oft mi stonde also

dat ic met hu wandelen mochte

also als ons beeden dochte

ende ghi, heere, waert al sonder zonde?

Neent, het es also ic hu orconde

2705 ende ict hu segghe, al eist scame.

Doe Ysingrijn in sduvels name

in de ordine ghinc hier tevoren

ende hi te moonke wart bescoren,

doe ne conste hem de provende niet ghenoughen

2710 daer VI moonke hem bi bedroughen.

Hi claghede van honghere ende carmede

so zeere dats mi ontfaermede.

Doe hi carmede ende wart traech,

doe haddics rauwe als een zijn maech

2715 ende gaf hem raet dat hi ontran.

Daeromme bem ic in spaeus ban.

Maerghin als die zonne upgaet,

willic te Roeme om aflaet.

Van Roeme willic overzee;

2720 danen ne keeric nemmermee

2706-16 Reynaert gives a new twist to the story of how the wolf entered a monastery and was given a tonsure (see notes to 1499-1503, 1951-52 and 2270a). Reynaert is supposed to have incited the hungry monk Ysingrijn to leave the monastery, and it is for this that he is now under a papal ban. His excommunication is invented by the fox to prevent having to 
My lord the king has nothing further

to discuss with you.'

Cuwaert went back

and left the king's council there.

2690 Reynaert said: 'King, is it true

what I told you?' - 'Reynaert, it is.

Forgive me, it was wrong of me

to mistrust you somewhat.

Reynaert, good friend, now consider

2695 the proposal to come with us

to the pool where the birch tree stands

under which the treasure lies buried.'

Reynaert said: 'What you say is remarkable.

Don't you think I would not be overjoyed,

2700 king, if I were in a position

to go along with you,

as both of us should like,

without you, lord, committing a sin?

No, it is as I shall openly declare

2705 and tell you, even though it is disgraceful.

When Ysingrijn in the devil's name

entered an order some time ago

and his crown was shaved on becoming a monk,

he found that the rations on which six monks lived

2710 were not enough for him.

He complained of hunger and moaned

so much that I took pity on him.

When he moaned and got weaker

it distressed me, being his relative,

2715 and I advised him to run away.

That is why I have been excommunicated by the pope.

Tomorrow as the sun rises

I intend to go to Rome for an indulgence.

From Rome I want to go to the Holy Land;

2720 from there I shall certainly not return

accompany the king to Kriekeputte, where it will soon become obvious that there is no treasure.

2706 In the devil's name implies insincerity.

2719 overzee: literally 'overseas', that is, across the Mediterranean to the Holy Land. 
eer ic so vele hebbe ghedaen, coninc, dat ic met hu mach gaen thuwer eeren ende thuwer vromen, of ic te lande wedercome.

2725 Het ware een onscone dinc, souddi, heere coninc, maken huwe wandelinghe met eenen verwatenen ballinghe als ic nu bem, God betere mi!'

2730 Die coninc sprac: 'Reynaert, zidi yet langhe verbannen?' Doe sprac Reynaert: 'Ja ic, hets III jaer dat ic wart voer den deken Hermanne in vullen zeinde tebannen.'

2735 Die coninc sprac: 'Reynaert, nadat ghi zijt tebannen, men souts mi doen verwijt, Reynaert, liet ic hu met mi wandelen. Ic sal Cuwaerde ofte eenen andren toten scatte doen gaen met $\mathrm{mi}$

2740 ende ic rade hu, Reynaert, dat ghi niet ne laet, ghi ne vaert dat ghi hu van den banne claert.' 'So ne doe ic,' sprac Reynaert. 'Ic ga morghin te Rome waert, 2745 gaet na den wille mijn.' Die coninc sprac: 'Ghi dinct mi zijn bevaen in arde goeden dinghen. God jonne hu dat ghijt moet vulbringhen, Reynaert, alse hu ende mi

2750 ende ons allen nutte zi.'

Doe dese tale was ghedaen, doe ghinc Nobel die coninc staen up eene hoghe stage van steene,

2725-34 According to Reynaert he was sentenced by the full ecclesiastical court, where his excommunication was imposed by deacon Herman. This means that the fox has incurred a major excommunication or anathema: he has been cursed and is excluded totally from the ecclesiastical community. It is not known if there is a historical person associated with the deacon. On account of the excommunication the fox not only has to go to Rome - the pope is the only person who can absolve from excommunication - he also cannot possibly accompany Nobel before 
until I have done so much,

king, that I can associate with you

to your honour and advantage,

if I return to this country.

2725 It would not be very nice,

Lord King, if you should

go about with

someone who has been excommunicated

as I am now, God help me!'

2730 The king said: 'Reynaert, have you been

under a ban for a long time?' Then Reynaert said:

'Certainly, it has been three years since

I was banished in the presence of deacon Herman

and the full ecclesiastical court.'

2735 The king said: 'Reynaert, as you have been put

under a ban, I would be reproached, Reynaert,

for allowing you to associate with me.

I shall make Cuwaert or someone else

go to the treasure with me

2740 and I advise you, Reynaert,

do not fail to depart

so that you may have the ban lifted.'

'I will not fail to do so,' said Reynaert.

'I shall go to Rome tomorrow,

2745 if it goes as I have planned.'

The king said: 'You appear to be

full of very good intentions.

God give that you may achieve this,

Reynaert, for the sake of you and me

$2750 \quad$ and everybody else.'

When this conversation had ended,

King Nobel went to stand upon

a high stone stage,

departing to retrieve the treasure. Any contact with a banned person was strictly forbidden. 2751-95 Before the assembled court, Nobel pardons the fox (2777-79). The king twists Reynaert's account of his excommunication and the resulting journey to the pope in Rome. The king remains silent about Reynaert's excommunication, but tells the animals that, as part of the reconciliation, Reynaert is going on a pilgrimage for the expiation of his sins (2787-95). He also does not mention that in reality he has promised to pardon the fox in return for a treasure. 
daer hi up plach te stane alleene

2755 als hi sat in zijn hof te dinghe.

Die dieren saten teenen ringhe

al omme ende omme in dat gras,

nadien dat elc gheboren was.

Reynaerd stont bi der coninghinne,

2759a die hi te recht wel mochte mynnen.

2760 'Bidt voer mi, edele vrauwe, dat ic hu met lieve wederscauwe.'

Soe sprac: 'Die Heere daert al an staet,

doe hu van zonden vul aflaet.'

Die coninc entie coninghinne

2765 ghinghen met eenen bliden zinne

voer haer diere aerme ende rike.

Die coninc, die sprac vriendelike:

'Reynaert es hier commen te hove

ende wille, dies ic Gode love,

2770 hem betren met al zinen zinnen.

Ende mijn vrauwe de coninghinne

hevet so vele ghebeden voer hem

dat ic zijn vrient worden bem

ende hi versoent es jeghen $\mathrm{mi}$

2775 ende ic hem hebbe ghegheven vry beede lijf ende lede.

Reynaerde ghebiedic vullen vrede.

Anderwaerf ghebiedic hem vrede

ende derde waerven mede,

2780 ende ghebiede hu allen bi huwen live

dat ghi Reynaerde ende zinen wive

ende zinen kindren eere doet, waer si commen in hu ghemoet,

sijt bi nachte, zijt bi daghe.

2785 In wille meer gheene claghe van Reynaerts dinghen horen.

Al was hi rouckeloes hiervoren,

2768-86 Nobel announces that he is reconciled with Reynaert. He has quashed the fox's conviction and has pardoned him. However, there is something wrong here: the king arranges the reconciliation for himself alone. Although Reynaert has been charged by a 
where he normally only stood

2755 when he presided over a lawsuit at his court.

The animals sat in a circle

round about in the grass,

each according to his birth.

Reynaert stood near the queen,

2759 a to whom he had every reason to be grateful.

2760 - 'Pray for me, noble lady, that I may safely see you again.'

She said: 'May the Lord who rules everything, give you full absolution for your sins.'

The king and the queen

2765 took up their positions full of good cheer

before the animals, poor and rich.

The king said graciously:

'Reynaert has come to our court here, and intends, for which I praise God,

2770 to mend his ways wholeheartedly.

And my lady the queen

has taken his part to such an extent

that I have become his friend

and he is reconciled with me

2775 and I have given him the free use

of his body and his limbs.

I proclaim full peace for Reynaert.

Once more I command peace for him, and also a third time,

2780 and I order all of you, at the peril of your lives,

to honour Reynaert and his wife

and his children,

wherever you meet them,

whether it be by night or by day.

2785 I do not wish to hear

any more complaints about Reynaert's actions.

Even though he was callous in the past,

number of animals, none of them receives satisfaction for having suffered proven wrongs.

Impelled by his craving for the treasure, Nobel acts selfishly (see pp. 25-26).

2775-76 This means that Reynaert has been discharged from prosecution. 
hi wille hem betren, ic segghe hu hoe:

Reynaert wille maerghin vroe

2790 palster ende scerpe ontfaen

ende wille te Roeme gaen

ende van Rome danen wille hi overzee

ende dan commen nemmermee

eer hi heeft vul af laet

2795 van alre zondeliker daet.'

[209rb]

Dese tale hevet Tyselijn vernomen

ende vloech danen dat hi es comen

ende hi vant die III ghesellen.

$\mathrm{Nu}$ hoert wat hi hem sal tellen!

$2800 \quad H i$ sprac: 'Keytive, wat doedi hier?

Reynaert es meester bottelgier

int hof ende moghende utermaten.

Die coninc heeftene quite ghelaten van alle sinen mesdaden

2805 ende ghi zijt alle III verraden.'

Isingrijn began andwoerden

te Tieceline met corten woerden:

'Ic wane ghi lieghet, heere raven.'

Mettien woerde began hi scaven

2810 ende Brune die volchde mede.

Si ghinghen recken hare lede

loepende tes coninx waert.

Tybeert bleef zeere vervaert

ende hi bleef sittende up die galghe.

2815 Hi was van sinen ruwen balghe

in zorghen so groet utermaten

dat hi gherne wille laten

sine oeghe varen over niet

die hi in spapen scuere liet,

2820 indien dat hi verzoent ware.

2801 meester bottelgier: 'master butler.' In other words: 'Reynaert calls the shots at court'. 
he intends to better his life, I shall tell you how:

Reynaert will early tomorrow morning

2790 receive the pilgrim's staff and scrip

and will go to Rome

and from Rome across the sea

and will certainly not return

before he has been given complete absolution

2795 for all his sins.'

\section{Revenge and flight}

Tiecelin heard these words

and he flew to where he had come from

and he found the three friends.

Now hear what he will tell them!

2800 He said: 'Wretches, what are you doing here?

Reynaert is master butler at court and extremely powerful.

The king has pardoned him

of all his crimes

2805 and all three of you have been betrayed.'

Ysingrijn turned on Tiecelyn

and gave a curt reply:

'I reckon you're lying, Lord Raven.'

With these words he ran off

2810 and Bruun followed suit.

They went as fast as their legs

could carry them towards the king's court.

Tybeert stayed behind, very frightened, and he stayed where he sat on top of the gallows.

2815 He was so extremely worried

about saving his skin

that he was quite prepared

to leave his eye unavenged

that he had lost in the priest's barn,

2820 if he might be reconciled with Reynaert.

2815 sinen ruwen balghe: literally: 'his rough pelt'. 
Hi ne wiste wat doen van vare dan hi ghinc sitten up die micke. $\mathrm{Hi}$ claechde vele ende arde dicke, dat hi Reynaerde ye bekinde.

2825 Isingrijn quam met groeten gheninde ghedronghen voer de coninghinne ende sprac met eenen fellen zinne te Reynaert waert so verre dat die coninc wart al erre

2830 ende hiet Ysingrine vaen ende Brune. Alsoe saen worden si ghevanghen ende ghebonden. Ghi ne saghet nye verwoedde honden doen meer lachters dan men hem dede,

2835 Ysingrine ende Brunen mede!

Men voerese als leede gaste.

Men bantse beede daer so vaste

dat si binnen eere nacht met gheenrande cracht

2840 een let niet en mochten roeren. $\mathrm{Nu}$ hoert hoe hise voert sal voeren, Reynaert, die hem was te wreet! Hi dede dat men Brunen sneet van sinen rugghe een velspot af,

2845 dat men hem teere scerpen gaf, voets lanc ende voets breet.

$\mathrm{Nu}$ ware Reynaert al ghereet, haddi IV verssche scoen.

$\mathrm{Nu}$ hoert wat hi sal doen,

2850 hoe hi sal IV scoen ghewinnen! Hi ruunde toter coninghinnen: 'Vrauwe, ic bem hu peelgrijn. Hier es mijn oem, Ysingrijn. Hi hevet IV vaste scoen.

2825-40 Bruun and Ysingrijn are taken prisoner without a trial and are badly maltreated. The king perverts the law.

2841-96 Nobel has announced that, as part of the reconciliation, Reynaert will undertake a pilgrimage. The fox (who himself had not mentioned a pilgrimage explicitly) uses this new development to revenge himself on his enemies. At Reynaert's suggestion the 
He was so scared that he knew nothing better to do than to sit on the pole.

He deeply regretted all the time that he had ever got to know Reynaert.

Ysingrijn pushed his way very roughly to a place before the queen and uttered with a fierce demeanour such coarse accusations of Reynaert that the king was roused to great anger

2830 and had Ysingrijn taken prisoner and Bruun too. Straightaway they were apprehended and tied up.

You never saw rabid dogs more deeply humiliated than they did them,

2835 Ysingrijn and Bruun also! They were treated like hateful foes. They were tied up so tightly there that the entire night they were unable to move

2840 so much as a single limb.

Now hear what more he will do to them, Reynaert, who treated them very cruelly! He got them to cut from Bruun's back a piece of skin

2845 that was given him by way of a scrip, a foot long and a foot broad. Now Reynaert would be quite ready, provided he had four new shoes.

Now hear what he will do, 2850 how he will obtain four shoes! He whispered to the queen: 'Lady, I am your pilgrim.

Here is my uncle, Ysingrijn. He has four stout shoes.

prisoners, as well as Haersint, are partly flayed to provide Reynaert with suitable attributes for his journey. In a creative way the author of Van den vos Reynaerde makes use here of a well-known motif from the literary tradition: the wolf who, on the fox's advice, has to give up his skin to cure the sick king lion (see pp. 10-11). 
2855 Helpt mi dat icse an mach doen.

Ic neme hu ziele in mine plecht.

Het es peelgrins recht

dat hi ghedincket in sine ghebeden

al tgoet dat men hem noyt dede.

2860 Ghi moghet hu ziele an mi scoyen.

Doet Haersenden, miere moyen, gheven twee van haren scoen.

Dit moghedi wel met eeren doen:

so blivet thuus in haer ghemac.'

2865 Gherne die coninghinne sprac:

'Reynaert, ghi ne mochtes niet onbaren,

ghi ne hebt scoen: ghi moetet varen

huten lande in des Gods ghewout,

over berghe ende int wout

2870 ende terden struke ende steene.

Dinen aerbeit wert niet cleene;

hets dijn noet dattu hebs scoen.

Ic wilre gherne mijn macht toe doen.

Die Ysingrijns waren hu wel ghemicke:

2875 si zijn so vaste ende so dicke

die Ysingrijn draghet ende zijn wijf.

Al sout hem gaen an haer lijf,

elkerlijc moet hu gheven twee scoen

daer ghi hu vaert mede moet doen.'

2880 Dus hevet die valsche peelgrijn

beworven dat dher Ysingrijn

al toten knien hevet verloren

van beede sine voeten voren

dat vel algader toten claeuwen.

2885 Ghi ne saecht noint voghel braeuwen

die stilre hilt al sine leden

dan Ysingrijn de zine dede,

doe men so jammerlike ontscoyde

dat hem dat bloet ten teen afvloyde!

2885-87 To tame and train a newly caught falcon it would have its eyes 'seeled': 'Seeling consisted of putting one neat stitch through the lower eyelids with a linen thread and tying the ends over the head (or [...] stitching through the upper lids and tying under the beak'). This was commonly done before transportation by the merchants, so as to keep the birds 
2855 Help me, so I can put them on.

I shall take your soul into my care.

It is a pilgrim's duty

to remember in his prayers

all the good that was ever done for him.

2860 You may benefit your soul by giving me shoes.

Have Haersint, my aunt, give two of her shoes.

You may do this in all decency:

she will stay quietly at home.'

2865 Full of good will the queen spoke:

'Reynaert, you should not lack

shoes: you have to travel

in foreign lands, in God's care,

across mountains and through woods,

2870 and over stumps and stones.

Yours is not an easy task,

so that it is necessary for you to have shoes.

I will be pleased to use my influence to get them.

Ysingrijn's would suit you well:

2875 they are very strong and robust,

the ones that Ysingrijn and his wife wear.

Even if it cost them their lives,

each of them must give you two shoes

with which you will be able to make your journey.'

2880 In this way did the false pilgrim

achieve that Lord Ysingrijn

lost the skin of both his front paws

from his knees

all the way down to his nails.

2885 You never saw a bird having its eyelids

stitched together make less of a stir

than Ysingrijn moved his limbs

when he was divested so pitifully of his shoes

that the blood ran down from his toes!

calmer' (Cummins 1988, 200). It is not clear whether the narrator means here that the wolf tries to keep as still as possible to avoid even more pain, or that he resists vehemently. In the second case the author's comment is ironic. 
2890 Doe Ysingrijn ontscoyt was, moeste gaen ligghen up dat gras vrauwe Hersvint die wulfinne met eenen wel drouven zinne ende liet haer afdoen dat vel

2895 ende die claeuwen also wel bachten van beede haren voeten. Dese daet dede wel soeten Reynaerde sinen drouven moet. $\mathrm{Nu}$ hoert wat claghen hi noch doet!

2900 'Moye,' seit hi, 'moye, in hoe meneghen vernoye hebdi dor minen wille ghewesen! Dats mi al leet, sonder van desen eist mi lief. Ic segghe hu twi.

2905 Ghi zijt, des ghelovet mi, een die liefste van minen maghen. Bedi sal ic hu scoen andraghen. God weet dats al huwe bate. Ghi sult an hoghen aflate 2910 deelen ende an al dat perdoen, lieve moye, dat ic in hu scoen sal bejaghen overzee.' Vrauwe Hersvinden was so wee dat so cume mochte spreken:

2915 'Ay, Reynaert, God moete mi wreken dat ghi over ons siet huwen wille!' Ysingrijn balch ende zweech stille ende zijn gheselle Brune, neware hem was te moede arde zware.

2920 Si laghen ghebonden ende ghewont. Hadde oec doe ter selver stont [210ra] Tybeert die cater ghewesen daer,

2897-98 What is meant here is that Reynaert was in a very good mood. Cf. also the note to 2990-94.

2899-2912 In accordance with his earlier behaviour towards the animals that he tricked, Reynaert again taunts his victim: he pretends that he will give the she-wolf a share in the indulgences he will acquire, as he will be wearing the shoes she 'gave' him on his pilgrimage. He also calls Haersint moye ('aunt', 2900, 2911) and one of his favourite relatives (maghen, 2906), 
2890 When Ysingrijn had been unshoed,

Lady Haersint, the she-wolf, had to lie down on the grass, looking very sad, and had the skin stripped off

2895 as well as the nails of her back feet. This action was balm to

Reynaert's distressed mood.

Now hear how he proceeds to lament!

2900 'Aunt,' he said, 'aunt, how much misery you have had to endure on my account! I am very sorry, but in this case it pleases me. I shall tell you why.

2905 You are, I asssure you, one of my dearest relatives.

For that reason I will wear your shoes.

God knows you will benefit by it.

You will share in the papal indulgences

2910 and in the full pardon, dear aunt, that I will acquire in your shoes in the Holy Land.'

Lady Haersint was in so much pain that she could hardly speak:

2915 'Oh, Reynaert, may God avenge me for you imposing your will on us!'

Ysingrijn was furious and remained silent, like his companion Bruun, but they were utterly despondent.

2920 They lay bound and injured. If at that time Tybeert the cat had been there,

thus alluding once again to the supposed family relationship between himself and his 'uncle' Ysingrijn. By admitting that she has had much to bear from him, the fox probably refers to their adultery and her rape (see pp. 32-33).

2920-25 Reynaert has cruelly revenged himself on his opponents and if the opportunity had presented itself, he would have treated Tybeert in a similar manner. Reynaert's unlimited thirst for revenge provides a sharp contrast with his appearance as a penitent pilgrim. 
ic dar wel segghen over waer:

hi hadde so vele ghedaen tevoren,

2925 hi ne waers niet bleven sonder toren!

Wat helpt dat ict hu maecte lanc?

Des ander daghes voer de zonneupganc

dede Reynaert zijn scoen smaren, die Ysingrijns tevoren waren

2930 ende zijns wijfs vrauwe Hersenden, ende hadse vaste ghedaen benden om zine voeten ende ghinc daer hi vant den coninc ende zijn wijf die coninghinne.

2935 Hi sprac met eenen soeten zinne: 'Heere, God gheve hu goeden dach ende mier vrauwen, die ic mach prijs gheven met rechte. $\mathrm{Nu}$ doet Reynaert gheven, huwen knechte,

2940 palster ende scerpe ende laet mi gaen.'

Doe dede die coninc haesten saen den capelaen, Belin de ram.

Ende als hi bi den coninc quam, sprac die coninc: 'Hier es

2945 dese peelgrijn; leest hem een gheles ende ghevet hem scaerpe ende staf.' Belin den coninc andwoerde gaf: 'Heere, in dar des doen niet. Reynaert hevet selve beghiet

2950 dat hi es in spaeus ban.' Die coninc sprac: 'Belin, wats dan?

2927 At the crack of dawn on the third day Reynaert prepares himself for his departure as a pilgrim. This means that the fox's mendacious story, his pardon as well as the imprisonment and maltreatment of Bruun and the two wolves took place on the evening of the second day.

2941-84 In accordance with medieval tradition Nobel wants to have the attributes for the pilgrimage consecrated before they are handed to Reynaert (cf. the 'Benedictio peregrinorum ad loca sancta prodeuntium' in the Rituale Romanum, Tit. VIII, Cap. XI, dating prior to Vaticanum II). However, Reynaert has incurred a major excommunication which excludes him from all sacraments. It is for this reason that Belin initially objects to the king's request (how the ram knows that the fox has been excommunicated is not explained). As Nobel wishes to hide the true reason for this reconciliation with the fox - the treasure - it is in his 
I dare say this with certainty: he had earlier done so much

2925 that he would not have escaped distress!

What use would it serve if I told you more?

The next day before dawn

Reynaert had his shoes greased

which earlier had belonged to Ysingrijn

2930 and his wife Lady Haersint, and had them tied securely round his feet and went to where he found the king and his wife the queen.

2935 He said gently: 'Lord, may God grant you a good day and my lady, whom I have every reason to praise.

Now let Reynaert, your servant, be given

2940 staff and scrip and let me depart.'

Then the king made

the chaplain, Belin the ram, come hastily. And when he arrived before the king, the king said: 'Here is

2945 this pilgrim; read him a lesson and give him scrip and staff.'

Belin answered the king:

'Lord, I am not allowed to do this.

Reynaert himself has admitted

2950 that he is under a papal ban.' The king said: 'Belin, so what?

best interests to present Reynaert as a pilgrim who wishes to atone for his sins as a form of reconciliation. For that reason he finds Belin's objection about Reynaert's excommunication irksome. The king finds a way out by referring to a certain master Jufroet, who is said to teach that a sinner feeling perfect contrition may have the guilt of mortal sin removed purely by the intention of confessing his sins and undertaking a pilgrimage to the Holy Land (in other words, prior to departure and without intercession of the Church). It is not clear which theologian Nobel has in mind here. It has been suggested that the Benedictine abbot Goffridus Vindociniensis (ca. 1070-1132), who wrote about confession, is meant. Another possibility is that Willem had Geoffrey Ridel in mind, the theological adviser of King Henry II of England (1154-1189), who was excommunicated repeatedly.

2945 gheles: a text from the Bible or a prayer. 
Meester Jufroet doet ons verstaen: hadde een man alleene ghedaen also vele zonden alse alle die leven

2955 ende wildi aercheit al begheven ende te biechten gaen ende penitencie daeraf ontfaen, dat hi overzee wille varen, hi mochte hem wel selve claren.'

2960 Belin sprac ten coninc echt: 'Ic en doere toe crom no recht van gheesteliker dinc altoes, ghi ne wilt mi quiten scadeloes jeghen bisscop ende jeghen den deken.'

2965 Die coninc sprac: 'In VIII weken so ne wane ic hu bidden so vele. Oec haddic liever dat huwe kele hinghe dan ic hu heden bat.' Ende alse Belin hoerde dat, 2970 dat die coninc balch te hem waert, wart Belin so vervaert dat hi beefde van vare ende ghinc ghereeden zine autare ende began zinghen ende lesen

2975 al dat hem goet dochte wesen. Doe Belin die capelaen oemoedelike hadde ghedaen dat ghetijde van den daghe, doe hinc hi an zine craghe 2980 eene scaerpe van Bruuns velle. Oec gaf hi den fellen gheselle den palster in de hant daerbi, te zinen ghevoughe. Doe was hi al ghereet te ziere vaert.

2985 Doe sach hi ten coninc waert. Hem liepen die gheveinsde tranen neder neven zine granen alse oft hi jammerlike in sine herte van rauwen hadde grote smerte. 
Master Jufroet teaches us:

if a man had committed all on his own

as many sins as all living people together,

2955 and if he wanted to renounce his wicked ways

and go to confession

and accept as a penitence

to go to the Holy Land,

he might still be absolved.'

2960 Then Belin said to the king:

'I will in no way

perform any kind of religious rite, unless you are prepared to clear me

with the bishop and with the deacon.'

2965 The king said: 'In the next eight weeks

I don't expect to ask this much of you.

And also I would sooner see you hanged

than ask you for anything today.'

And when Belin heard

2970 that the king was angry with him,

Belin became so frightened

that he trembled with fear

and went to prepare his altar

and began to sing and read

2975 all that he considered suitable.

When Belin the chaplain

had meekly performed the service

proper to that time of day,

he hung around Reynaert's neck

2980 a scrip made of Bruun's skin.

He also gave the scoundrel the staff in his hand with it, for his use. Then he was fully prepared for his journey.

2985 Then he looked at the king.

The bogus tears ran down

along his whiskers

as if in his heart he was terribly upset

and suffering great distress. 
2990 Dit was bedi ende anders niet dat hi hem allen die hi daer liet niet hadde beraden al sulke pine alse Brunen ende Ysingrine, haddet moghen ghevallen!

2995 Nochtan stont hi ende bat hem allen dat si over hem bidden souden also ghetrauwelike alsi wouden dat hi over hem allen bade.

Dat orlof nemen dochte hem spade,

3000 want hi gherne danen ware. $\mathrm{Hi}$ was altoes zeere in vare als die hem selven sculdich weet. Doe sprac die coninc: 'Mi es leet, Reynaert, dat ghi dus haestich zijt.'

3005 'Neen, heere, het es tijt!

Men sal gheene weldaet sparen.

Huwen orlof, ic wille varen.'

Die coninc sprac: 'Gods orlof.'

Doe gheboet die coninc al dat hof met Reynaerde huutwaert te ghane, sonder alleene die ghevane.

$\mathrm{Nu}$ wart Reynaert peelgrijn, ende zijn oem Ysingrijn ende Brune die ligghen ghebonden

3015 ende ziec van zeeren wonden. Mi dinct ende ic wane des, dat niement so onspellic es tusschen Pollanen ende Scouden, die hem van lachene hadde onthouden dor rauwe die hem mochte ghescien, hadde hi Reynaerde doe ghesien! Hoe wonderlic hi henenghinc ende hoe ghemackelic dat hem hinc

2990-94 Reynaert is crying mock tears (gheveinsde tranen, 2986). He pretends to be very sad now that the time of his departure as a pilgrim aproaches (cf. also 3051-52). The narrator addresses his public with the ironic comment that Reynaert is crying purely because he is disappointed that he has not succeeded in harming more courtiers than just Bruun and Ysingrijn. Cf. also the note to 2897-98 and below. 
2990 This was for no other reason

than that he had not caused as much harm

to all those he left behind

as he had to Bruun and Ysingrijn,

if that had been possible!

2995 Nevertheless, standing there, he requested them all

to pray for him

as sincerely as they wished

him to pray for all of them.

The farewells took too long to his mind,

3000 for he was eager to get away from there.

He was constantly afraid,

because he was aware of his guilt.

Then the king said: 'I regret,

Reynaert, that you are in such a hurry.'

$3005-$ 'No, lord, it is time!

One should not put off a good deed.

With your permission, I wish to depart.'

The king said: 'Go with God.'

Then the king ordered the entire court

3010 to accompany Reynaert outside, with the exception of the prisoners.

Now Reynaert has turned pilgrim

and his uncle Ysingrijn

and Bruun lie tied up

3015 and suffering from painful wounds.

I am convinced that

there is no one so downhearted

between Poland and Schouwen

because of a disaster that had befallen him,

3020 or he would have laughed

on seeing Reynaert then!

How amazing his departure was

and how naturally did

3016-21 In this aside the narrator makes a distinction between the here-and-now of the fictional action and the doe (then, 3021) of the story. His public realizes that it cannot participate in the story, and cannot see the ludicrously attired fox anymore than the most miserable person between Poland and Schouwen can see him. The two regions symbolize the extreme east (Poland) and west (Schouwen was an island in the county of Zeeland). 
scaerpe ende palster omme den hals

3025 ende die scoen als ende als die hi drouch an zine been ghebonden, sodat hi sceen een peelgrijn licht ghenouch! Reynaerts herte binnen louch,

3030 dordat si alle met hem ghinghen met so groter zameninghen die hem tevoren waren wreet. Doe sprac hi: 'Coninc, mi es leet dat ghi so verre met mi gaet.

3035 Ic vruchte het mach hu wesen quaet. Ghi hebt ghevaen II mordenaren. Ghevalt dat si hu ontvaren, ghi hebt hu te wachtene meer dan ghi noint hadt eer.

3040 Blijft ghesont ende laet mi gaen.'

$\mathrm{Na}$ dese tale ghinc hi staen up sine II achterste voeten ende maende die diere, cleene ende grote, dat si alle voer hem baden, 3045 of si alle an sine weldaden recht deel nemen wouden. Si seiden alle dat si souden $[210 v b]$ sijns ghedincken in haer ghebede. Nu hoert voert wat Reynaert dede!

3050 Daer hi van den coninc sciet, so drouvelic hi hem gheliet dat hem somen zeere ontfaremde. Cuwaert den haze hi becaremde: 'O wy, Cuwaert, sullen wi sceeden?

3055 Of God wilt, ghi sult mi gheleeden ende mijn vrient Belin de ram.

3049-3138 The false pilgrim manages to lure two tame animals from the court to Manpertuus, where Reynaert is to say farewell to his wife and children. Cuwaert the hare enters the den at Reynaert's request to help comfort the fox's wife. Cuwaert does, indeed, offer solace, but does so physically rather than verbally: the fox takes him by the throat and kills him. Reynaert's confrontations with Cuwaert show how the story will develop: evil will reign supreme. At the time of their first encounter Reynaert's tuition as a pseudo- 
the scrip and staff hang around his neck

3025 and did he wear all the shoes

that he had tied around his legs,

so that he might quite easily

have been taken for a pilgrim!

Reynaert laughed in his heart,

3030 because all those who went with him

in such a large gathering

had earlier been ill-disposed towards him.

Then he said: 'King, it worries me

to have you come with me so far.

3035 I fear that it may do you harm.

You have caught two criminals.

If it should be so that they escape,

you will have to be on your guard

more than ever before.

3040 Take care and let me go.'

After these words he raised himself

on his two back legs

and urged all the animals, small and large,

to pray for him,

3045 if they all wished to profit

by his good works.

They all said that they would

remember him in their prayers.

Now hear what Reynaert did next!

3050 When he took leave of the king,

he pretended to be so sad

that some took great pity on him.

He moaned to Cuwaert the hare:

'Alas, Cuwaert, must we part?

3055 God willing, you will accompany me

with my friend Belin the ram.

cleric had not yet had the desired result; on the contrary, the failed murder attempt was one of the charges that led to the institution of legal proceedings. However, by the end of the story, Reynaert, this time in the guise of a false pilgrim, has conquered all problems. He does not let the hare escape a second time once he has it in his den. Belin the ram is waiting outside; his services will be abused by Reynaert to let Nobel know that he has been deceived. 
Ghi twee, ghi ne daedt mi noint gram.

Ghi moet mi bet voertbringhen.

Ghi zijt van zoeter wandelinghen

3060 ende onberoupen ende goedertieren

ende ombeclaghet van allen dieren.

Ghestade es huwer beeder zede, als ic doe ten tijden dede

als ic clusenare was.

3065 Hebdi lovere ende gras, ghi ne doet negheenen heesch noch om broet no om vleesch noch om sonderlinghe spijse.' Met aldusghedanen prijse

3070 hevet Reynaert dese II verdoort, dat si met hem ghinghen voort totedat hi quam voer zijn huus ende voer de porte van Manpertuus. Alse Reynaert voer de porte quam,

3075 doe sprac hi: 'Belin, neve ram, ghi moet alleene buten staen. Ic moet in mine veste gaen; Cuaert sal ingaen met mi. Heere Belin, bidt hem dat hi

3080 troeste wel vrauwe Hermelinen met haren cleenen welpkinen, als ic orlof an hem neme.' Belin sprac: 'Ic bids heme dat hise alleene troeste wale.'

3085 Reynaert ghinc met scoenre tale so smeeken ende losengieren in so menegher manieren dat hi bi barate brochte Cuwaerde in sine haghedochte.

3090 Als si in dat hol quamen, Cuaert ende Reynaert tsamen, doe vonden si vrauwe Hermelinen met haren cleenen welpkinen.

3075 neve: the form of address is used as a sign of friendship. See also 1278. 
You two, you never gave me cause for anger.

You must see me on my way.

You are agreeable company

3060 and of good repute and kindhearted and none of the animals complains of you.

Steady is the way you both live, just as I did in the time when I was a hermit.

3065 So long as you have leaves and grass, you do not hanker at all after bread or meat or dainty food.' With praise like this

3070 has Reynaert misled the two, so that they accompanied him until he arrived at his house and before the gate of Manpertuus.

When Reynaert arrived at the gate

3075 he said: 'Belin, cousin ram, you must wait here outside by yourself. I must go into my fortress; Cuwaert will come in with me. Lord Belin, impress upon him that he 3080 offers suitable comfort to Lady Hermeline and her little cubs, when I say goodbye to them.' Belin said: 'I appeal to him to comfort every one of them.'

3085 Talking smoothly, Reynaert wheedled and cajoled so much and in so many ways that he deceived Cuwaert into coming with him into his den.

3090 When they entered the hole, Cuwaert and Reynaert together, they found Lady Hermeline there with her small cubs. 
Die was in zorghen ende in vare,

3095 want so waent dat Reynaert ware verhanghen. Ende so vernam dat hi weder thuuswaert quam ende palster ende scerpe drouch; dit dochte haer wonders ghenouch.

3100 So was blide ende sprac saen: 'Reynaert, hoe sidi ontgaen?'

3101 a Reynart sprac: 'Ic was gevaen,

$3101 \mathrm{~b}$ mar die coninc hi lijt mi gaen.

Ic bem worden peelgrijn.

Heere Brune ende heere Ysengrijn

sijn worden ghisele over mi.

3105 Die coninc hevet, danc hebbe hi, Cuaerde ghegheven in rechter zoene al onsen wille mede te doene.

Die coninc die lyede das dat Cuaert die eerste was

3110 die ons verriet jeghen hem. Ende bi der trauwen die ic bem sculdich hu, vrauwe Hermeline: Cuaerde naket eene groete pine. Ic bem up hem met rechte gram!'

3115 Ende alse dat Cuaert vernam, keerdi hem omme ende waende vlien, maer dat ne conste hem niet ghescien, want Reynaert hadde hem ondergaen die porte ende ghegreepene saen

3120 bi der kelen mordadelike. Ende Cuaert riep ghenadelike: 'Helpt mi, Belin! Waer sidi?

Dese peelgrijn verbijt mi!'

Dat roupen was sciere ghedaen,

3125 bedi Reynaert hadde saen

3101a-3110 Reynaert answers Hermeline's question with a number of half-truths. It is right that he has become a pilgrim, but in actual fact he pretended to have been excommunicated and needing to go to the pope. The bear and wolf really have been caught, but the information that they have offered themselves as hostages so that Reynaert might go on a pilgrimage, is false. Earlier the king had ordained on pain of death that the fox and his family 
She was worried and afraid,

3095 for she thought that Reynaert

had been hanged. And then she saw

that he came home again

and was carrying staff and scrip;

it struck her as a great marvel.

3100 She was glad and said at once:

'Reynaert, how did you escape?'

3101 a Reynaert said: 'I was caught,

$3101 \mathrm{~b}$ but the king let me go.

I have become a pilgrim.

Lord Bruun and Lord Ysingrijn

have become hostages for me.

3105 The king has - thanks be to him -

presented Cuwaert as lawful peace offering,

to do with as we please.

The king acknowledged

that Cuwaert was the first

3110 to accuse us falsely before him.

And by the loyalty that I owe

you, Lady Hermeline:

Cuwaert awaits grievous punishment.

I have every reason to be angry with him!'

3115 And when Cuwaert heard that, he turned round and wanted to flee, but he could not do it for Reynaert had cut off the way to the gate and seized him at once

3120 by the throat with murderous intent.

And Cuwaert shouted pitifully:

'Help me, Belin! Where are you?

This pilgrim is biting me to death!'

The shouting soon ceased,

3125 for Reynaert had straightaway

should be honoured (2780-84), which in Reynaert's interpretation means that the king has made a gift of Cuwaert to the fox and his family. Cuwaert's earlier mention of the counterfeiters at Kriekeputte (2667-71) is blown up by Reynaert to a betrayal of his case. Reynaert's cryptic account results in dramatic irony: the audience knows more than does Hermeline. This is amusing and accentuates the perversion of Reynaert's verbal skills. 
sine kele ontwee ghebeten.

Doe sprac Reynaert: 'Nu gaen wi heten

desen goeden vetten hase.'

Die welpine liepen ten ase

3130 ende ghinghen heten al ghemeene.

Haren rauwe was wel cleene

dat Cuaert hadde verloren tlijf.

Ermeline, Reynaerts wijf,

hat dat vleesch ende dranc dat bloet.

3135 Ay, hoe dicke bat so goets

den coninc, die dor sine doghet

die cleene welpkine hadde verhoghet

so wel met eenen goeden male.

Reynaert sprac: 'Hi jans hu wale.

3140 Ic weet wel, moet die coninc leven,

hi soude ons gherne ghiften gheven

die hi selve niet ne woude

hebben om VII maerc van goude.'

'Wat ghiften es dat?' sprac Hermeline.

3145 Reynaert sprac: 'Hets eene lijne

ende eene vorst ende twee micken.

Maer maghic, ic sal hem ontscricken,

hopic, eer lijden daghen twee,

dat ic omme zijn daghen mee

3150 ne gave dan hi omme tmijn.'

Soe sprac: 'Reynaert, wat mach dat zijn?'

Reynaert sprac: 'Vrauwe, ic secht hu.

Ic weet een wildernesse nu

van langhen haghen ende van heede

3155 ende die so nes niet onghereede

van goeden ligghene ende van spijsen.

Daer wonen hoenre ende pertrijsen

ende menegherande vogheline.

3134 As Cuwaert, according to Reynaert, had been delivered to him as lawful peace offering (in rechter zoene, 3106), this line appears to associate the consumption of the dead hare in a suggestive way with Christ's death on the cross, presented during the Last Supper as a sacrifice and celebrated as such in the Catholic mass (through the consecration and consumption of bread and wine in which Christ's broken body and spilled blood are substantially present). 3130-99 Reynaert realizes that King Nobel will exact revenge when he finds out that he has 
bitten his throat asunder.

Then Reynaert said: 'Now let us eat

of this good, fat hare.'

The cubs ran to the food

3130 and started to eat together.

They did not in the least regret

that Cuwaert had lost his life.

Hermeline, Reynaert's wife, ate of the flesh and drank the blood.

3135 Ah, how often did she wish the king

well, who, in his generosity,

had so delighted the little cubs

with a delicious meal.

Reynaert said: 'He is very pleased for you.

3140 I am sure that if the king lives,

he would gladly give us a present

that he himself would not like to

receive for seven gold marks.'

'What gift is that?' said Hermeline.

3145 Reynaert said: 'It is a rope

with a crossbeam and two poles.

But if I can, I hope to escape him

before two days are past,

so that I need care for his summons no more

3150 than he does for mine.'

She said: 'Reynaert, what does this mean?'

Reynaert said: 'Lady, I shall tell you.

I can think of a wilderness

with high bushes and heather,

3155 and where there is no lack

of suitable resting places and food.

Fowls and partridges live there

and all kinds of small birds.

been deceived (3140-50 and cf. 1372-84, 2534-37, 3319-20, 3420-24, 3447-51). That is why Reynaert will depart for a new wilderness with his family, out of reach of Nobel's court (cf. 3317-29). 3145-46 It concerns the constituent parts of a gallows.

3152-64 The fox presents the landscape to his wife as a paradise. This holds true only from a predator's perspective, for other animals risk their lives there. For the world of the court such a landscape is a locus terribilis (cf. the note to 2574-93). 
Wildi doen, vrauwe Ermeline,

3160 dat ghi gaen wilt met mi daer?

Wi moghen daer wonen VII jaer

(willen wi), wandelen onder die scade

ende hebben daer groete ghenade, eer wi worden daer bespiet.

3165 Al seidic meer, in loghe niet.'

'Ay, Reynaert,' sprac vrauwe Hermeline,

'dit dinct mi wesen eene pine

die algader ware verloren.

$\mathrm{Nu}$ hebdi dit lant verzworen

3170 in te wonen nemmermee,

eer ghi comt overzee;

ende hebt palster ende scerpe ontfaen.'

Reynaert andwoerde vele saen:

'So meer ghezworen, so meer verloren.

3175 Mi seide een goet man hier tevoren

in rade dat hi mi riet:

bedwongene trauwe ne diedet niet.

Al vuldade ic dese vaert, en holpe mi niet,' sprac Reynaert.

3180 'In waers een ey niet te bat.

Ic hebbe den coninc eenen scat belovet die mi es onghereet, ende als hi des de waerheit weet ende hi bi mi es bedroghen,

3185 dat ic hem al hebbe gheloghen, so sal hi mi haten vele meere dan hi noint dede eere.

Daerbi peinsic in minen moet:

dat varen es mi also goet

3190 alse dit bliven,' sprac Reynaert.

'Ende Godsat hebbe mijn rode baert, ghedoe hoe ic ghedoe,

of mi troestet mee daertoe

no die cater no die das,

3195 no Bruun, die na mijn oem was,

3180 The literal meaning of ey is 'egg'. 
Will you agree, Lady Hermeline,

3160 to go there with me?

We can live there for seven years,

if we like, walk in the shadow

and do very well there,

before we would be found out.

3165 If I said more about it, I would not lie.'

'Oh, Reynaert,' Lady Hermeline said, 'this seems to me

altogether a waste of effort.

You have just forsworn this land,

3170 never to live in it again,

until you return from the Holy Land,

and you have received the staff and scrip.'

Reynaert answered at once:

'The more you swear, the more you lose.

3175 A wise man once told me when he gave me some advice:

under duress a promise means nothing.

If I were to accomplish this journey, it would not help me,' said Reynaert.

3180 'It would not benefit me one bit.

I have promised the king a treasure which I do not possess, and once he knows the truth about it and how he has been deceived by me,

3185 and that I have told him a pack of lies, he will hate me far more than he ever did before.

That is why I think that going away will benefit me as much

3190 as staying,' said Reynaert.

'And may my red beard be damned, whatever my circumstances, if I should ever be persuaded again by the cat or the badger 3195 or by dear uncle Bruun, 
no dor ghewin no dor scade, dat ic in sconinx ghenade ne comme, dat ic leve lancst! Ic hebbe leden so meneghen anxt.'

3200 So zeere balch die ram Belijn dat Cuaert, die gheselle zijn, in dat hol so langhe merrede. Hi riep als die hem zeere errede: 'Cuaert, lates den duvel wouden!

3205 Hoe langhe sal hu daer Reynaert houden?

Twi ne comdi huut ende laet ons gaen?'

Alse Reynaert dit hadde verstaen, doe ghinc hi hute tote Beline ende sprac al stillekine:

$3210 \quad$ 'Ay heere, twi so belghedi? Al sprac Cuwaert jeghen mi ende jeghen ziere moyen, waeromme mach hu dus vernoyen? Cuaert dede mi verstaen,

3215 ghi moghet wel sachte voeren gaen, $[211 \mathrm{vb}]$ ne wildi hier niet langher zijn. Hi moet hier merren een lettelkijn met siere moyen Hermelinen ende met haren welpkinen,

3220 die seere weenen ende mesbaren omdat ic hem sal ontfaren.' Belin sprac: 'Nu secht mi, heere Reynaert, wat hebdi Cuaerde te leede ghedaen?

3225 Also als ic conste verstaen, so riep hi arde hulpe up mi.' Reynaert sprac: 'Wat sechdi? Belin, God moete hu beraden! Ic segghe hu wat wi doe daden.

3230 Doe ic in huus gheganghen quam ende Ermeline an mi vernam dat ic wilde varen overzee, ten eersten wart haer so wee dat so langhe in ommacht lach. 
or by the prospect of profit or loss

to surrender myself to the king's

mercy, as long as I live!

I have suffered so many fears.'

3200

The ram Belin became very angry

that Cuwaert, his companion, tarried so long in that hole.

Very annoyed, he shouted:

'Cuwaert, let the devil see to it!

3205 How long is Reynaert going to keep you there?

Why don't you come out so we can go?'

When Reynaert had heard this,

he went outside to Belin

and said softly:

3210 'Ah, lord, why are you annoyed?

If Cuwaert spoke with me

and with his aunt, why should that irritate you so?

Cuwaert gave me to understand

3215 that you may go ahead slowly, if you no longer wish to stay here.

He has to remain here just a little while

longer with his aunt Hermeline

and with her cubs,

3220 who are weeping and wailing loudly

because I shall leave them.'

Belin said: 'Now tell me,

Lord Reynaert, what wrong have you

done to Cuwaert?

3225 In so far as I could hear it, he called me urgently to come to his rescue.'

Reynaert said: 'What are you saying?

Belin, may God help you!

I shall tell you what we were doing then.

3230 As I entered my house

and Hermeline heard from me

that I intended to go to the Holy Land,

she was at once so overcome

that she lay unconscious for a long time. 
3235 Ende alse Cuaert dat ghesach, doe riep hi: "Bellijn, helet vry, com hare, ende helpt mi miere moyen laven; so es in ommacht!"

Dat riep hi met groeter cracht.

3240 Dit waren die woerde ende niet hel.' 'Entrauwen, ic verstont oec wel dat Cuaert dreef groet mesbare. Ic waende hem yet mesvallen ware.' Reynaert sprac: 'Belin, neent niet.

3245 Mi ware liever mesquame yet minen kindren of minen wive dan mijns neven Cuwaerts live.' Reynaert sprac: 'Vernaemdi yet dat mi de coninc ghistren hiet

3250 voer arde vele hoeghe liede, als ic huten lande sciede, dat ic hem een paer lettren screve? Suldijt hem draghen, Belin neve? Het es ghescreven ende al ghereet.'

3255 Belin sprac: 'Ende ic ne weet. Reynaert, wistic hu ghedichte dat ghetrauwe ware, ghi mochtet lichte ghebidden dat ict den coninc droughe, haddic eeneghe dinc

3260 daer icse mochte in steken.'

Reynaert sprac: 'Hu ne sal niet ghebreken.

Eer des coninx lettren hier bleven, ic soude hu dese scerpe eer gheven, heere Belin, die ic draghe

3265 ende hanghense an huwe craghe ende des conincs lettren daerin. Ghi sulter af hebben groet ghewin, des conincs danc ende groet eere. Ghi sult den coninc minen heere

3270 harde willecomme zijn.'

Dit loofde mijn heere Belijn.

Reynaert ghinc in die aghedochte ende keerde weder ende brochte 
3235 And when Cuwaert saw this, he called: "Belin, noble hero, come here and help me rouse my aunt. She has fainted!" That is what he shouted as loudly as he could.

3240 These were his words and nothing else.'

- 'Truly, I clearly also heard Cuwaert wailing loudly. I thought something awful had happened to him.'

Reynaert said: 'Belin, no, certainly not.

3245 I would sooner that something happened to my children or to my wife than to my cousin Cuwaert's life.'

Reynaert said: 'Did you happen to hear that the king asked me yesterday

3250 in the presence of very many nobles to write him a letter when I left the country? Would you take it to him, cousin Belin? It has been written and is quite finished.'

3255 Belin said: 'I don't really know. Reynaert, if I knew that your writing was trustworthy, you would not need to press me to take it to the king, if I had something

3260 to put it in.'

Reynaert said: 'You will lack for nothing.

Rather than that the letter to the king should stay here, I would give you this scrip, Lord Belin, that I wear, 3265 and hang it round your neck, with the letter to the king in it. You will reap great benefit from it, the king's gratitude and much honour. You will be most welcome 3270 with my lord the king.' This my Lord Belin promised to do.

Reynaert went back into his hole and returned and brought 
sinen vrient Beline jeghen

3275 dat hoeft van Cuaerde ghedreghen, in die scerpe ghesteken, ende hinc bi sinen quaden treken die scerpe Belin an den hals; ende beval hem als ende hals

3280 dat hi die lettren niet ne soude besien, of hi gherne woude den coninc teenen vrienden maken. Ende seide hem dat die lettren staken in die scerpe verholenlike

3285 ende of hi wesen wilde rike ende sinen heere den coninc hadde lief, dat hi seide dat desen brief bi hem alleene ware ghescreven ende hiere raet toe hadde ghegheven.

3290 Die coninc souts hem weten danc. Dat hoerde Belin ende spranc van der stede daer hi up stoet meer dan eenen halven voet, so blide was hi van der dinc,

3295 die hem te toerne sint verghinc! Doe sprac Belin: 'Reynaert heere, nu weet ic wel dat ghi doet eere $m i$ selven ende die zijn int hof. Men saels $m i$ spreken groeten lof,

3300 als men weet dat ic can dichten met sconen woerden ende met lichten, al si dat ics niet ne can.

Men seit dicken: hets menich man groete eere ghesciet, dat hem God jonste, 3305 van dinghen die hi lettel conste.' Hierna sprac Belin: 'Reynaert, wats hu raet? Wille Cuaert met mi weder te hove gaen?' 'Neen hi,' sprac Reynaert, 'hi sal hu saen 3310 volghen bi desen selven pade. Hi ne hevet noch negheene stade. $\mathrm{Nu}$ gaet voren met ghemake. 
his friend Belin

3275 Cuwaert's head, inserted into the scrip, and hung, evil minded as ever, the scrip round Belin's neck and strongly impressed upon him

3280 that he should not look at the letter if he wished to befriend the king. And he told him that the letter had been put deep down in the scrip

3285 and if he wanted to do well and if he loved his lord the king, then he had to say that this letter had been written by himself alone and that it had been his idea.

3290 The king would be very grateful to him. Belin heard this and jumped up from the place where he stood more than half a foot, so glad was he about this affair

3295 that later turned out so badly for him!

Then Belin said: 'Lord Reynaert, now I am certain that you honour me and the members of the court. I shall be praised highly

3300 when it becomes known that I can write with fine and plain words, even though I cannot really. It is often said: many acquire great honour - bestowed on them by God 3305 through skills they barely master.' Then Belin said: 'Reynaert, what do you advise? Should Cuwaert return with me to court?' 'No,' said Reynaert, 'he will speedily

3310 follow by the same route. He hasn't got time for it yet. Now go ahead and take it slowly. 
Ic sal Cuaerde sulke sake ontdecken, die noch es verholen.'

3315 'Reynaert, so blivet Gode volen,' sprac Belin ende dede hem up de vaert.

Nu hoert wat hi doet, Reynaert!

Hi keerde in sine haghedochte ende sprac: 'Hier naect ons gherochte,

3320 bliven wi hier, ende grote pine. Ghereet hu, vrauwe Hermeline, ende mine kindre also algader. Volghet mi; ic bem hu vader. Ende pinen wi ons dat wi ontfaren.'

3325 Doe ne was daer gheen langher sparen. Si daden hem alle up die vaert: Ermeline ende heere Reynaert ende hare jonghe welpkine; dese anevaerden die woestine.

$3330 \mathrm{Nu}$ hevet Belin die ram soe gheloepen dat hi quam te hove een lettel na middach. Als die coninc Belin ghesach, die de scerpe wederbrochte

3335 daer Brune die beere so onsochte tevoren omme was ghedaen, doe sprac hi te Belin saen: 'Heere Belin, wanen comedi? Waer es Reynaert? Hoe comt dat hi

3340 dese scerpe niet met hem draghet?' Belin sprac: 'Coninc, ic maghet hu segghen also ict weet. Doe Reynaert al was ghereet ende hi den casteel rumen soude, 3345 doe seide hi mi dat hi hu woude een paer lettren, coninc vry, senden ende doe bat hi mi

3313-14 Reynaert's words are ambiguous. He states that he will reveal a secret to Cuwaert, but his words may also mean that he will reveal a secret to the king by means of the hare (i.e. that there is no treasure). 
I shall make Cuwaert reveal something that as yet is hidden.'

3315 'Reynaert, may God keep you,' said Belin and went on his way.

Now hear what Reynaert does!

He returned to his den and said: 'Problems are in store for us

3320 if we stay here, and much misery. Get you ready, Lady Hermeline, and all my children, too. Follow me, I am your father. And let us make every effort to escape.'

3325 Then they did not delay any longer. They all went on their way: Hermeline and Lord Reynaert and their young cubs; they departed for the waste land.

3330 Now Belin the ram has made such good speed that he reached the court shortly after noon. When the king saw Belin, who returned the scrip

3335 for which Bruun the bear had earlier been maltreated so, he said to Belin immediately: 'Lord Belin, where are you coming from? Where is Reynaert? How come that he 3340 does not have this scrip with him?' Belin said: 'King, I shall tell it you as I understand it. When Reynaert was quite ready and was about to leave his fortress, 3345 he told me that he wanted to send you, noble king, a letter and then he asked me to deliver it out of affection for you. 
dat icse droughe dor huwe lieve.

3350 Ic seide meer dan VII brieve soudic dor huwen wille draghen.

Doe ne conste Reynaert niet bejaghen daer ic de brieve in draghen mochte. Dese scerpe hi mi brochte

3355 ende die lettren daerin ghesteken. Coninc, ghi ne horet noint spreken van betren dichtre dan ic bem.

Dese lettren dichte ic hem, gaet mi te goede of te quade.

3360 Dese lettren dichte ic bi minen rade, aldus ghemaect ende ghescreven.' Doe hiet hem die coninc gheven den brief Botsaerde sinen clerc. Dat was hi die ant werc

3365 bet conste dan yement die daer was. Botsaert plach emmer dat hi las die lettren die te hove quamen. Bruneel ende hi die namen die scerpe van den halse Belijns,

3370 die bi der dompheit zijns hiertoe hadde gheseit so verre dat hi snieme sal werden erre. Die scerpe ontfinc Botsaert de clerc. Doe moeste bliken Reynaerts werc, 3375 alse hi dat hoeft voerttrac, Botsaert, ende sach dat: 'Helpe, wat lettren zijn dit? Heere coninc, bi miere wit, dit es dat hoeft van Cuaerde!

3380 O wach, dat ghi noint Reynaerde, coninc, ghetrauwet so verre!' Doe mochte men drouve sien ende erre dien coninc entie coninghinne.

3362-68 It is not clear what kind of animals Botsaert the clerk and Bruneel are supposed to be. Were these characters familiar to Willem's public? It has been suggested that Botsaert might be a monkey or a boar; Bruneel is said to have been an ass. 
I declared that for your sake I would gladly

3350 carry more than seven letters.

Then Reynaert was unable to find anything

in which I might carry the letter.

He brought me this scrip

with the letter put inside it.

3355 King, you never heard speak

of a better writer than I am.

This letter I wrote for him,

whatever may befall me.

This letter I composed to the best of my ability,

3360 thus drawn up and put in writing.'

Then the king ordered him to give

the letter to Botsaert his clerk.

He was better at that job

than anyone who was present there.

3365 Botsaert always used to read

the letters that arrived at court.

Bruneel and he lifted

the scrip from around Belin's neck,

who, in his stupidity,

3370 had been saying so much

that he will soon regret it.

Botsaert the clerk received the scrip.

Then Reynaert's doing had to come to light,

as soon as Botsaert drew out

3375 the head and saw it:

'Help, what kind of a letter is this?

Lord King, by my faith,

this is Cuwaert's head!

Ah, woe, king, that you ever

$3380 \quad$ put so much trust in Reynaert!

Then the king and queen

could be seen to be sad and angry.

The king stood there deeply affected

3372-80 Earlier in the story Reynaert had mocked and teased his victims Bruun, Tybeert and Haersint verbally. The lion, however, is made a fool of in a non-verbal manner by Reynaert when Cuwaert's head is pulled from the bag. 
Die coninc stont in drouven zinne

3385 ende slouch zijn hoeft neder.

Overlanc hief hijt weder

up ende begonste werpen huut

een dat vreeselicste gheluut

dat noint van diere ghehoort waert.

3390 Ghene dieren waren vervaert.

Doe spranc voert Fyrapeel, die lubaert. Hi was een deel des coninx maech; hi mocht wel doen.

Hi sprac: 'Heere coninc lyoen,

3395 twi drijfdi dus groet onghevouch?

Ghi mesliet hu ghenouch, al ware de coninghinne doot.

Doet wel ende wijsheit groot ende slaect huwen rauwe een deel.'

3400 Die coninc sprac: 'Heere Fierapeel, mi hevet een quaet wicht so verre bedroghen dat ics bem erre, ende int strec gheleet bi barate, dat ic recht mi selven hate

3405 ende ic mine eere hebbe verloren.

Die mine vriende waren tevoren, die stoute heere Brune ende heere Ysingrijn, die rovet mi een valsch peelgrijn. Dat gaet miere herten na so zeere

3410 dat het gaen sal an mine eere ende an mijn leven, het es recht!' Doe sprac Fyrapeel echt:

'Es ghedaen mesdaet, men saelt zoenen.

Men sal den wulf enten beere doen comen

3415 ende vrauwe Hersenden also wel ende betren hem hare mesdaet snel ende over haren toren ende over hare pine versoenen metten ram Beline, nadat hi selve heeft ghelyet

3412-21 Nobel has wronged his mightiest vassals. According to Fyrapeel this calls for a reconciliation (3412). However, in the leopard's cynical mental world this does not apply to 
and hung his head.

3385 After a long time he lifted it again and began to raise the most terrifying sound that any animal was ever heard to make.

The animals there were afraid.

3390 Then forward sprang Fyrapeel, the leopard. He was a distant relative of the king; he was allowed to do so. He said: 'Lord King Lion, why are you making such a row?

3395 You are letting yourself go in a way as if the queen had died.

Behave properly and sensibly and modify your distress somewhat.' The king said: 'Lord Fyrapeel,

3400 I have been so terribly misled by a scoundrel that I am beside myself, and I have been trapped by a trick so that I now have every reason to hate myself and I have lost my honour.

3405 A false pilgrim robbed me of those who were my friends before, bold Lord Bruun and Lord Ysingrijn.

It make me very sad at heart that it will cost me my honour

3410 and my life, and rightly so!'

Then Fyrapeel spoke again: 'Where wrong has been done, peace must be sought. The wolf and the bear will be sent for, as will Lady Haersint

3415 and they will straightaway be compensated for the wrong done to them and for the distress and the pain they suffered by offering them the ram Belin, since he has admitted himself that he betrayed Cuwaert.

all animals. Belin, too, has - to Fyrapeel's mind at least - done wrong, but the ram has to pay for it with his life. At Nobel's court only the powerful will now survive: the law of the jungle. 
3420 dat hi Cuaerde verriet.

Hi heeft mesdaen, hi moet becoepen.

Ende daerna sullen wi alle loepen

na Reynaerde ende sulne vanghen

ende sullen sine kele hanghen

3425 sonder vonnesse, hets recht!'

Doe andwoerde die coninc hecht:

'O wy, heere Fyrapeel,

mochte dit ghescien, so ware een deel

ghesocht den rauwe die mi slaet.'

$3430 \quad$ Fyrapeel sprac: 'Heere, jaet.

Ic wille gaen maken die zoene.'

Doe ghinc Fyrapeel die coene

daer hi die ghevanghene vant.

Ic wane dat hise teerst ontbant!

3435 Ende daerna sprac hi: 'Ghi heeren beede, ic bringhe hu vrede ende gheleede.

Mine heere de coninc groet hu

ende hem berauwet zeere nu

dat hi jeghen hu heeft mesdaen.

3440 Hi biet hu soene, wildijt ontfaen,

wie so blide si ofte gram.

Hi wille hu gheven Belin den ram

ende alle sheere Belins maghe

van nu toten domsdaghe.

3445 Eist int velt, eist int wout,

hebse alle in hu ghewout

ende ghise ghewilleghelike verbit.

Die coninc ontbiet hu voer al dit:

dat ghi sonder eeneghe mesdaet

3423 The last line in the Dyck mansucript agrees with line 3423 in the redaction of the Comburg codex. This is one reason why the end of the Comburg redaction has been considered to be not original. However, this opinion now seems untenable. It is more likely that the last lines of the original poem are lacking from the Dyck redaction. See also the note to 3461-69.

3439-46 The leopard tries to reconcile the lion with the wolf and the bear by surrendering the ram and all its relatives to them for all eternity. This is reminiscent of the Messianic peace described in the Book of Isaiah (11, 6-7): 'And the wolf shall dwell with the lamb: and the leopard shall lie down with the kid: and the calf and the lion, and the sheep shall abide together, and a little child shall lead them. And the calf and the bear shall feed: their young ones shall rest together: and the lion shall eat straw like the ox.' However, the four predators 
3420 He has done wrong, he will pay for it.

And next we shall all go

after Reynaert and catch him

and hang him by the throat

without a trial, it's lawful!'

3425 Then the king answered to this:

'Well, Lord Fyrapeel,

if this could be done, then part

of the distress that I suffer would be alleviated.'

Fyrapeel said: 'Lord, certainly.

3430 I shall go and effect the reconciliation.'

Then brave Fyrapeel

went to where he found the captives.

I assume that he freed them first!

And then he said: 'You lords, both of you,

3435 I bring you peace and safe conduct.

My lord the king greets you

and now deeply regrets

the harm that he has done you.

He offers to recompense you, if you will agree,

3440 whatever anyone else may think.

He wants to give you Belin the ram

and all Lord Belin's relatives

from now until Doomsday.

In the field or in the woods,

3445 they will all be at your disposal

and you may kill them as much as you like.

The king especially wants you to know this:

that you may, without committing any crime,

harm and torment Reynaert

that are peaceful in Isaiah, agree in Willem's poem that they are justified in tearing apart the ram and his descendants till kingdom come. This is a cynical reversal, which indicates that in Nobel's world evil will reign for ever. At the leopard's proposal the king is reconciled with his highest vassals by infringing the rights of other vassals permanently. This spells the end of Nobel's feudal order (see pp. 25-27). Possibly there is another biblical motif which resonates here. Cuwaert and Belin function as the two goats from the Book of Leviticus, which are sacrificed on the day of atonement by the priest of the temple for the sins of the Jewish people. The first (Cuwaert) is killed in the temple (Manpertuus). The second, the actual scapegoat (Belin), is sent, laden with the iniquities of the people, into the wilderness to perish there (Lev. 16, 20-23). 
3450 Reynaerde moghet toren ende quaet doen ende alle zine maghen, waer so ghise moghet belaghen.

Dese twee groete vriheden wille hu die coninc gheven heden

3455 te vryen leene eewelike. Ende hierbinnen wilt die coninc rike dat ghi hem zweert vaste hulde. Hi ne wille oec bi sinen sculde nemmermeer jeghen hu mesdoen.

3460 Dit biedt hu de coninc lyoen.

Dit neemt ende leeft met ghenaden.

B i Gode, ic dart hu wel raden!'

I singrijn sprac toten beere:

'W at sechdire toe, Brune heere?'

3465 - 'I $c$ hebbe liever in de rijsere

$\mathbf{L}$ igghen dan hier in dysere.

$\mathbf{L}$ aet ons toten coninc gaen

E nde sinen pays daer ontfaen.'

$\mathbf{M}$ et Fyrapeel dat si ghinghen

E nde maecten pays van allen dinghen.

3461-69 The acrostichon BI WILLEME agrees with the information in the first line of the poem: its author is Willem. This is an argument in favour of the view that the end of the poem in the Comburg redaction is original. 
3450 and all his relatives,

wherever you can waylay them.

These two great liberties

does the king wish to bestow on you today

to be at your free disposal for all eternity.

3455 And in connection with this the mighty king wants you to do homage to him.

He will never again

knowingly wrong you.

This is what King Lion offers you.

3460 Accept it, and you will live in his favour.

B y God, I would certainly recommend it!'

Y singrijn said to the bear:

'W hat do you say, Lord Bruun?'

- 'I prefer lying in the bushes to

3465 L ying here, clapped in irons.

$\mathbf{L}$ et us go to the king and

E nter into his peace.'

M oving along with Fyrapeel, they

E nded by making peace all round. 
$D$ aningè toone meir beorved)

\& ñogfertion time

2. ae was cerenc mut tíme

\& ti muc yretcreap maccte vate

D ic mu gequit hate menig ê wat

- ví Gpuac v2 frecte upn

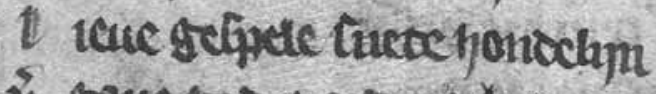

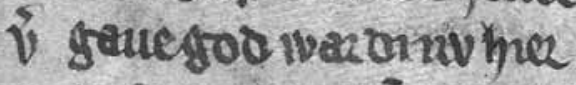

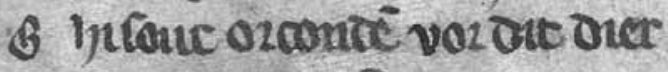

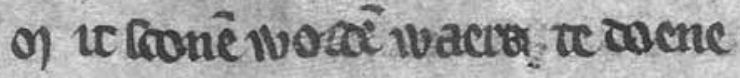

$D$ rtic nowe ne was to cocue

- at iccuige fake tece

- axucé.cómodhtemic

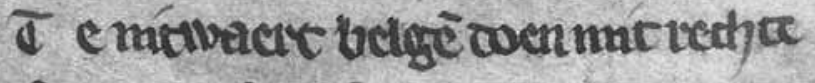

6 ace necó onó grone lanedjte

A prac zu nacticlike anvait

of ma here aica. mhete tailit

\&) egecur ori te Greike mect

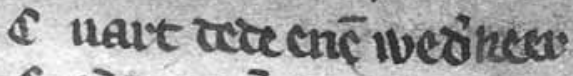

E ìgrar vá corránx vete car u2 gुmac. cò hereut waet 


\section{Editorial principles}

This edition of Van den vos Reynaerde is based on the redaction in the Comburg manuscript (Stuttgart, Württembergische Landesbibliothek, Cod. poet. et phil. ${ }^{\circ}{ }^{22}$ ). This codex consists of six parts; Van den vos Reynaerde is found in the fourth. It was written by scribe $\mathrm{E}$, and runs from line 22, halfway down folio 192va, to line 3 on folio $213 \mathrm{rb}$. Wherever a new column begins in the manuscript, a folio and column number is stated in the right hand margin of the edited Middle Dutch text.

There are two reasons why the Comburg redaction was preferred to the redaction in the Dyck manuscript (Münster, Universitätsbibliotheek, Ms. N.R. 381), even though the latter probably predates Comburg by more than half a century (see p. 34). First, the Dyck redaction is a copy of a Flemish exemplar, but written by a scribe from the county of Holland. This has resulted in many inconsistencies in word forms and spelling. By contrast the Comburg redaction is a regular Flemish copy in which the original word forms and spelling have been kept relatively intact (cf. Muller 1917, p. 47). A second reason is that the younger Comburg redaction appears to have preserved the original ending - including the acrostic BI WILLEME (lines 3461-69) ) - whereas Dyck probably has an abbreviated version of the conclusion (cf. Bouwman 1991, pp. 369-371, Van Daele 1996).

A colour facsimile, published by Janssens [a.o.] 1991, was used for the transcription. Here a critical edition of the Comburg text is presented, which implies a certain amount of editorial intervention. All modifications are accounted for below.

1. All abbreviations have been silently expanded. For a discussion of the abbreviation marks used by scribe E, see Brinkman \& Schenkel 1997, pp. 105-6.

2. No punctuation has been used in the manuscript. In the edited text modern punctuation marks have been added.

3. Sentences, proper names and the names of deities begin with a capital letter in the edited text. Roman numerals have also been rendered in capitals, but without the points that are used in the manuscript before and after the number. All capital letters were added by the editors. The rubricated capitals at the beginning of every line have not been indicated in the edited text. Comburg scribe E structured his text 
by using initials and paragraph signs in red paint; in the edited text these have also been ignored. Painted initials (one line in height) are found in lines 41, 61, 135, 149, 177, 233, 263, 283, 315, 361, 421, 441, 465, 497, 547, 575, 601, 627, 647, 707, 739, 778, 805, $837,877,909,929,961,1015,1043,1142,1233,1285,1335,1359,1393,1427,1533,1567,1603$, $1691,1753,1811,1847,1868,1886,1918,1966,1985,2041,2061,2139,2179,2227,2278,2389$, 2423, 2447, 2473, 2491, 2549, 2565, 2617, 2717, 2751, 2796, 2842, 2890, 2926, 2952, 2976, 3012 , 3074, 3090, 3124, 3152, 3166, 3200, 3248, 3272, 3296, 3330, 3374, 3426. The rubricated capitals directly following the painted initials have similarly been ignored, except in lines 135, 647 and 2926, where VV has been rendered as W. The same procedure has been applied to the painted initial V ( 3 lines in height) and rubricated capital V in line 1. Paragraph signs are found at the beginning of lines 126, 170, 203, 205, 247, 375, 562, 893, 1054, 1109, 2209, 2500, 2806, 3390.

4. The story has been subdivided by the editors into seven episodes: Prologue, King Noble Holds Court, First Summons, Second Summons, Third Summons, Conviction and Reconciliation, Revenge and Flight. In the edition these divisions are marked by white lines not found in the manuscript.

5. The spelling of $u / v$ and $i / j$ has been adapted in accordance with modern usage. No distinction has been made between the different forms of $r$ and $s$.

6. For the sake of clarity several words that were written as separate forms in the manuscript have been contracted in the edition, or, conversely, words written as compounds in the manuscript have been separated in the edition. Our guide here has been the Middelnederlandsch handwoordenboek (Verdam 1932). The contractions concern combinations of a preposition and a verb (as in af bernen, 'burn off'), compound adverbs (daer na, hier omme) and conjunctions (om dat) as well as compound nouns (cloester bier). Words have been separated when personal pronouns or particles have been joined on to preceding words without resulting in clisis, reduction or assimilation (see pp. 261-262). This is the case particularly when pronouns are followed by a negative particle (ghine), when followed by the first person singular of the past tense of a number of strong verbs (as in lietic, hietic) and in combinations with a conjunction (datsi, datso). The following cases, arranged alphabetically, have been modified: achter hende (1932), achter waert (1746), af bernen (1502), af doen (2894), af ghebeten (289), af ghedaen (949), af ghesleghen (1730), af vloyde (2889), al daer (2100, 2250, 2406, 2513, 2629, 2668, 2696), al daert (1539), al gader (1272, 1929, 2116, 2414, 2457, $2543,2571,2884,3168,3322)$, al gadre (1141), al in een (1251), alden ghenen (2428), aldus ghedanen (3069), alle gader (1003, 1451, 2216, 2227, 2503), alle gadre (1236), alre best (468), alre beste (1534), alre meest (2192), alre mintsten (2126), alre naest (2605), alre scaerpst (784), alsi (3302), alsmen (3300), alsomen (1341), alte gader (2439), alte hant (539), an draghen (2907), ander sins (84), ane slaen (442), ane vaerden (3329), bander zijde (1826), beere huut (926), biden $(688,942)$, bider (1705, 2654g), bouc stave (459), 
broeder sone $(178,1336)$, cleene beiach (1863), clocke lijnen (1486), cloester bier (1955), cloester crune (1951), cruus staf $(727,811)$, daer af $(1456,2957)$, daer an $(93,205,362$, $455,1884)$, daer bi $(2982,3188)$, daer binnen (2054), daer boven (1636), daer in (653, $675,1623,2594,3266,3354)$, daer mede $(1120,1139)$, daer met $(594,2115)$, daer na (432, $761,763,764,766,860,1678,1712,2095,2458,3420,3434)$, daer nare (2371), daer omme $(246,583,896,1111,1385,1874,2002,2716)$, daer omtrent (810), daer onder (374), daer te voren $(682,1167)$, daer toe $(11,36,189,445,996,1404,1941,1999,3193)$, daer up (456), daer waert $(152,2032)$, daermen $(1268,1923,2196)$, dan nes $(564)$, datmen $(92,127,259$, $1881,1891,1998$, 2234, 2468, 2843, 2845, 2859), datsi (22, 37, 338, 440, 467, 471, 842, 847, 1002, 1162, 1476, 1638, 1783, 1784, 1792, 1976, 2174, 2301, 2838, 2996, 3037, 3044, 3047, $3071,3468)$, datso $(256,1547,1558,1896,1979,2047,2114,2288,2344,2914,3234)$, datso wie (2000), den ghenen (1871a, 2275), der an (923), dieden (2424), die ghene (34, 2041), diemen $(278,300,455,1872,2583)$, dies ghelike $(2324)$, doemen $(978,2075,2888)$, doene $(828,3325)$, doetment (1912), dor dat $(111,216,885,897)$, dor datsi (3030), een coren (1859), en trauwen $(252,3241)$, ga wy (1850), gha wi (1963), ghine (167, 199, 213, 593, 604, $872,1384,1834,2004,2580,2741,2833,2866,2867,2885,2963,3057,3066,3355)$, godweet (2908), ha wy (1849), haddemen (1730), haer sint (242), haer waert (1448), haren thare $(1624,1707,2063)$, henen liep $(2365)$, henen trac (2365), hier af (2480), hier binnen $(336,1304,2423,3455)$, hier na $(1000,1686,3306)$, hier naer $(169)$, hier omme $(55,614$, 1170, 2341), hier toe (3370), hier voren (2787), hietic (1482), hine (59, 113, 130, 132, 277, 475, 697, 758, 953, 956, 963, 968, 1329, 1728, 1729, 1758, 1911, 1927, 1965, 1972, 1973, 2821, 2925, 3311, 3457), hoemen (1333), hoenre dief (1231), honich raten $(568,665,1114)$, hout makigghe (804), hulster loe (2575), hute brocht (748), huut lac (808), huut traken (842), huut waert (2051,3010), in crupen (1517), in dien (2187, 2468, 2507, 2820), in gaen (1190, $3078)$, in gane (322), in loepen (1900), in ne (93), in stac (679), iu locken (1298), jane (2202, 2548), krieke . pit (2578), krieke putte (2596, 2634, 2657), krieken putte (2665), lanc voet (785), leidemen (451), lietic (1120, 2737), maerber steene (454), mede gaen (1945, 2391), mede ghinc (1922), mede loepen (1958), merke di (2383), midden waerde (1549), mine $(1117,2038)$, mochtemen $(442,1238,1326,3381)$, moeder naect $(1241)$, molen man (121), na dat $(2735,3418)$, na dien $(2221,2758)$, ne gheen $(342,1255)$, ne gheene (267, $1375,3311)$, ne gheenen (3066), ne waer $(1745,2291)$, ne ware $(95,174,447)$, neder waert (910), neenic (1143), nochtauont (1097, 1145), oest hende (2574), offer keersse (1246), om dat $(242,3221)$, omme loepen (2440), omme dat (2233, 2511), omme sach (2383), omme zwinghen (795), onder commen (868), over al (45, 612, 1413, 1638, 1789, 2220), over een draghen (2271), over eene (146), over groeten (2417), over lanc (3385), over luut (628), over see (2719), over zee (2792, 2912, 2958, 3171,3232), over staerc (1090), pater noster (1739), pladijsen graet (214), puten sone (919), salic (2054), salmen (1339, 1790, 1912), secht di (1122), sine (1272, 1641, 1889, 1890, 2198), sielen lesse (449), slouch si (1587), so dat (740, 808, 869, 1503, 1581, 1713, 2078, 2224, 3027), somen (648), sone (271, 1649, 
1992, 2125, 2145, 2743, 2966), staer blent (77), steen doot (1597), stroe wisch (1234), tafel mes $(1546,1553)$, te bannen $(2734,2736)$, te blauwen $(1580,1823)$, te broken $(166,1166)$, te gader (2104, 2409), te hant (959, 983, 1151, 2290, 2403), te voren $(156,797,914,922$, 928, 965, 1748, 2247, 2396, 2468, 2477, 2520, 2672, 2707, 2924, 2929, 3032, 3175, 3336, 3405), te waren (603), thu waert (2686), thuus waert (902, 3097), toe brochte (1530), toe sach (1539), toe zye (1542), tote dat (3072), tsinxen daghe (41), twine (1912, 3206), up dat (1420), up draghen (1947), up gaet (2717), up heffen (1564), up heven (274), up hief (2170), up hilden (1162), up laset (211), up waert (2295), up te broken (2479), vanden (819), verbeetic (2085), vleesch smout (379), voert bringhen $(1872,3059)$, voert draghen (1339), voert meer (380), voert trac (3374), vor waert meer (376), vyer gat (1642), waer omme $(674,3213)$, waer waert (1660), waer wi (355), warelt eere (2350), water var (1858), wasic (2074), watsi (2271, 2423), weder brochte (3334), weder come (2724), weder keert (1016), weder lonen (492), weder segghen (2273), weder scauwe (2761), weder tale (1009), weder zijden (293), weetic (1447, 1501, 2277, 3297), wel gheboren (2334), wijlen eere (101), wine (429, 1184), zonne up ganc (2927), zuut west (2579).

7. In lines where the manuscript text does not make sense or contradicts other story elements, the edited text indicates that corrections have been made (printed in italics). All such instances are accounted for separately below, briefly stating reasons, insofar as possible, why a reading is incorrect, but also how it occurred during the transmission of the text. It is inevitable that a scribe should make mistakes: in the process of reading the manuscript he was copying (his exemplar); when recalling a passage just read (the dictée intérieure); during the writing process itself; and when searching the exemplar for the last word or line copied. The following errors are connected with these actions: reading errors (misreading of letters, abbreviations, words, word divisions); optical contamination, i.e. influence of one or more words from a previous or following line, a gloss etc.; memory errors; scribal errors (resulting in omitted or repeated letters, misspellings etc.); and continuation errors (homœoteleuton or eyeskip, resulting either in omission or repetition). For a survey of these 'mechanical' errors see Vinaver 1939 and Greetham 1994 and in particular Duinhoven 1975 (in Dutch). The method of textual criticism followed here does not aim to present a reconstruction of the thirteenth-century original; rather, it aspires to correct the obvious errors in the Comburg redaction, with the help of the variants in the sources predating 1500 . In those cases where Comburg (A) presents an intelligible reading, nothing has been changed, even though some redactions may have an older reading. The sources have been indicated by the sigla commonly used in Reynaert research (see pp. 34-36). Triple rhyme and assonance did not lead to critical adaptation of the text, nor did impure rhyme; however, orphan rhyme did (1049, 1966, 2759). The spelling of words and lines derived from other sources were not modified to fit the Comburg redaction, nor were they adapted in any other way. All added lines, twenty-six in total, are supplemen- 
tary to the line numbering based on Comburg (1-3469), and are marked as $a, b, c$ etc. Thus consulting the synoptic edition of the Reynaert sources published by Hellinga (1952) can present no difficulties. In the list of corrections a number of typographical signs are used:

* hypothetical word or form of which the existence is inferred

$>$ becomes

$<$ from

1 Madocke: as in F, (B) - A vele bouke (on erasure), probably the correction of the story title Madocke, by ca. 1400 almost certainly obscure.

6 Arnout: as in F-A willem. The person named in this line is not the author of Van den vos Reynaerde, but a predecessor, possibly a French poet of a Renart story (cf. Bouwman 1991, pp. 44-47).

7 dede: as in F, (B) - A van reynaerde, possibly an explanatory gloss on vijte (in A's exemplar), taken as a correction of dede (cf. Lulofs 1983, p. 297).

238 makeden - A reads makedent, scribal error caused by - $t$ in $z i j t$.

258 over recht - A has Onrecht; probably erroneous reading of *ou' recht; cf. F Mit rechte and $\mathrm{B}$ Mit recht.

303 drouch: cf. F, B (Droech) - A Droucht, scribal error.

305 Dat: cf. F (Dit), B (Die) - A Daer, possibly reading error of dat > *dar. There are four, not six, children (cf. lines 412-13).

320 minen kinderen: as in F, (B) - A mine sustren. Canticleer, the father, is speaking here.

332 tenen: as in $\mathrm{F},(\mathrm{L})$ - A te dien, resulting from the substitution of a numeral (regarded as an indefinite article) by a definite article.

344 Reynaert: as in F, B - A Want reynaert. A conjunction in combination with ende $(245)$ is ungrammatical. For an alternative explanation (want is an intrusive gloss on 343, meaning 'a wall made of wattle and daub') see Lulofs 1983, p. 299.

353 Noch ontquam: cf. F Nochtan quam .../ Dane, B Nochtant ontquam and L Sed tamen euasit - A Nochtan quam, resulting from reading error (with incorrect word division) *Nochontquam $>{ }^{*}$ Nochont quam.

378 stolen: as in $\mathrm{F}-\mathrm{A}$ scole, resulting from reading error $t>c$.

$410 n u$ : A has $m i$, reading error, possibly influenced by mindre (optical contamination).

436 best: as in F-A ons best. Because of the direct object dese moort in line 437, wreken cannot be a reflexive verb.

450 vygelye: singular on account of finite verb was - A vygelyen.

454 slecht was: A reads die slecht was, which obstructs the necessary link between lines 454 and 456 (cf. also F 440-41). 
456-55 Order of the lines by analogy with $F$, on account of the necessary link between lines 455 and 457 - A probably has an uncorrected continuation error here.

457 deden: cf. F - A dede (singular), adapted by the scribe on account of the transposed lines. He took Die saerc for the subject, instead of the plural form Die letteren.

502 Dort doncker: cf. F Durt donkerste, B Door dat doncker, L per opaca ruit nomorum vicinaque silue - A Dor den keer, a result of a reading error (with erroneous word division; cf. Lulofs 1983, p. 301).

535 voer in: $\mathrm{cf}$. F vore in and $\mathrm{L}$ iacet in porta; line 540 implies that the fox already lay partly in his den - A voer.

579 ende: $\mathrm{cf}$. F, B - A ende icse, subclause with contraction, taken by the scribe as a defective main clause and adapted accordingly.

$\mathbf{6 4 8}$ was, eist waer: $\mathrm{cf}$. B ist wair dat men my seit - A waer was eist.

786 verhoernden cloet: F, cf. L contum cornutum - A verboerden cloet. Possible reading error and understood as raised (high).

802 Abstale: cf. F Absdale - A Abscale, resulting from reading error of ${ }^{*} t>c$.

812 ghedichte: as in F, cf. B dicke - A ghestichte, result of a reading error?

848 Upt ouver: cf. F Op den oeuer - A Upt touver may be the result of dittography (caused by 'dictee intérieure': uptouver); cf. Muller 1944, p. 142 (1. 846).

$915 n u$ : as in $\mathrm{F},(\mathrm{B})$ - A in, reading error.

944 draghet: as in F, (B) - A draghen, reading error or memory lapse.

993 dier: as in F, B - A diet, reading error $r>t$.

996 hoere: cf. F luchter ore, L Aurem me leuam; singular on account of line 745 - A hoeren.

1004 ende rieden: as in $\mathrm{F}-\mathrm{A}$ doe rieden si, resulting from optical contamination caused by line 1006 .

1049a keer herwaert dinen vlogel: as in $\mathrm{B},(\mathrm{F}, \mathrm{L})$ - In A this line is missing as a result of a continuation error.

1088 vraet: as in $\mathrm{F}, \mathrm{B}-\mathrm{A}$ braet, reading error of $v>b$.

1104 dages: as in F, (B), as opposed to the meeting at night in line 1107 - A daer.

1276 In: as in F - A int, scribal error, possibly as the result of incorrectly remembered *in sleets.

1390 quite: cf. B quijt - A qijite, scribal error.

1415 Rossel, een: cf. F roseel een, $\mathrm{L}$ roscellus - A rollel ende, reading error of long $s>l$ and possibly also of ${ }^{*} e n e(n)>e n(d e)$.

1433 scouwet: as in $\mathrm{F}$ - A scone wel, reading error (with erroneous word division).

1434-37 Cf. F, (B, L) - Continuation error in A: as a result of eyeskip from van zorghen (1434) and van sonden (1434C), at the beginning of the last line copied, three lines have been left out. In order to supplement the resulting orphan rhyme, an extra line was invented: A 1436 Nu hoert mine redene saen (cf. Muller 1917, p. 241 and Lulofs 1983, p. 304). 
1451 mire mesdaet: as in F - A minen mesdaden, a result of memory lapse (influenced by the previous couplet).

1467 strec: as in F - A net, a result of a memory lapse? contradicts lines 1173, 1298 etc. 1506 niene: as in $\mathrm{F}$ - A mi niet.

1509 Bloys: as in D, (F) - A vimbloys, A van vimbloys may be the result of dittography (caused by optical contamination): *van van bloys.

1527 sat: as in F, B (L) - lacking in A; as a result the contrast with ongherich (1526) remains implicit.

1540 vanc: as in $\mathrm{F},(\mathrm{B})$ - A vant, reading error of $c>t$.

1543 mijn: as in F, B, (L) - A mijns, scribal error (or relict of *mijns selves?; cf. L propria ... domo).

1592 dien: A diene, optical contamination caused by the first word in line 1593.

1635 hortene: as in F, (B) - A hoendene, influenced by hoenen in line 1634 (optical contamination); cf. also Bouwman 1991, p. 196-97.

1642 vyergat: cf. F hemel gat, D valdore gat - A vyuer gat, scribal error.

1737 verseert: as in J - A versmaet; was the scribe influenced by the four preceding rhymes here?

1743 die ic: as in F, B, (L) - A Dien, reading error: $i c>n$.

1748 die si tevoren hadden gelaten: as in F, B - A doe began hem drouue ghelaten, see below under 1750-49.

1750-49 Order of the lines by analogy with $\mathrm{F}$ and $\mathrm{B}$, also in view of the link with lines 1751-52 - When in the exemplar of A the original line 1748 was left out through a continuation error, an orphan rhyme and a defective link were the result. These problems were solved by the scribe who transposed lines 1750 and 1749 , and invented a new line (1748), an amplification of line 1749.

1779 souden: as in F, B, D; plural (cf. line 1778) - A soude.

$1788 n u$ : as in $\mathrm{F}-\mathrm{A}$ niet, reading error, $n u>{ }^{*} n z=n$ (iet).

1822a-d In F, (B) - Continuation error in A as a result of eyeskip. From noch (in 1822 and $1822 \mathrm{~d}$ ), the first word of the line copied last, the scribe missed four lines (all clearly dependent on lines from the Old French source; cf. Muller 1917, p. 269, and Bouwman 1991, p. 491).

1836 sake: as in B (F); singular (cf. zi) - A saken.

1855 Fortadent: cf. F Foret adent - A Forcondet. In neither of the two redactions the significance of the boar's name (Strong-with the-tooth, Strongtooth) was understood; see for the conjecture Bouwman 1991, pp. 224-25.

1856 Tiselijn: as in F - A tyocelijn, scribal error.

1860 wesel, mijn: as in $\mathrm{F},(\mathrm{B}, \mathrm{D}, \mathrm{L})$ - A weline die.

1871a-b orconde denghenen die dat horden! / Soudic die tale entie worden: as in F, with an alteration according to $\mathrm{P}$ (F Orconden gingen); cf. also L - In A the two lines are 
missing, making lines 1872-73 unintelligible (cf. Bouwman 1991, p. 228).

1966a die Reynaerde hadden harde leit: as in $\mathrm{F}$ - in A this line is missing, probably as the result of a continuation error.

$2011 n u$ : A mi, incompatible with the intransitive verb sparen; caused by reading error.

2075 mammen: as in F, B - A mannen, reading error, probably as result of abbreviated form *manen (preserved in $\mathrm{F}$ and $\mathrm{B}$ ).

2097 Belsele: as in F - A besele scribal error (cf. Muller 1944, p. 110 and Van Daele 1994, p. 46 and 466 , note 758 ).

$2156 n u$ : A $m i$, as a second direct object (beside ons) incompatible with the verb secht; result of reading error.

2207 eene: $\mathrm{cf}$. F - A eeene, scribal error (dittography).

2229 bedragen: as in F, B - A bedrieghen, incompatible with the prepositional construction Met verradenessen. The scribe misread bedragen, i.e. 'accuse' or interpreted it as (a form of) bedriegen.

2230 maghen: cf. F, B - A maghen lieghen. A new rhyme word has been added to fit the change of rhyme in line 2229.

2241 Hermeliken: cf. F hermerikes - A heymeliken, in view of A 2564 ermelinc reading error of *hermeliken.

2243 Doe: cf. B, P - A, F Die, reading error; the line was regarded as an adjectival clause with stat (2242).

2270a-d The four lines, copied from F, do not feature in A, but cannot be missed. The direct object $D a t$ of weder segghen (2273), i.e. 'reject', by the king's relatives, cannot refer to the secret plot to murder the king in lines 2268-69, in which they are not involved. It can only refer to what follows publicly: Bruun's proclamation as king (cf. Bouwman 1991, pp. 276-78).

2311 verslant: as in $\mathrm{F}, \mathrm{B}-\mathrm{A}$ verslanc, reading error: $t>c$.

2334 kende den coninc: as in F, B (L), i.e. unlike Reynaert's experiences with Bruun (2329-30) - A kennen so, possibly a reading error of ${ }^{*}$ kendeden co. $>{ }^{*}$ kenden so.

2342 ghedoghede: $\mathrm{cf} . \mathrm{F}, \mathrm{B}-\mathrm{A}$ ende ghedoghede, the conjunction shows that the noun zorghe was regarded as a finite verb (and grote as an adjunct with herte).

2392 vote hadden: $\mathrm{cf}$. F, (B) voete - A vore hadde; vore reading error of * vote.

2403 gheraecter: $\mathrm{cf}$. F - A gheraecte.

2433 brieve: as in F, B - A baniere, hardly compatible with the secrecy expressed in lines 2425-27.

2434 dieve: as in F, B - A diere, sounds odd from the mouth of a fox.

2510 hi al mine sculde: as in $\mathrm{F},(\mathrm{B}, \mathrm{L})$ - A bruun alle mine onsculde, makes no sense. Possibly a gloss reminiscent of lines 594, 606 .

$\mathbf{2 5 2 6}$ argertieren: A erroneously reads argentieren. 
2537 belanc: as in $\mathrm{F}$ - A belanct, scribal error caused by sullent.

2592 elwaer: as in F, (E) - A daer waert, possibly a reading error of *el waer $>$ *d' waer. However, this adverb of direction is incompatible with the verb $z$ ijn ('to be').

$2593 b i$ : as in $\mathrm{F}, \mathrm{E}-\mathrm{A} h i$, reading error: $b>h$.

2594 ghehidet: as in F, E - A ghehidelt, scribal error.

2628 wane: as in $\mathrm{F}-\mathrm{A}$ wanen, corrupt.

2645 voer den: as in F, (E, B) - A voert, does not make sense.

2653-55 Lines a-h have been supplemented from F - Continuation error in A: by eyeskip from vrouwen (in lines 2654 and $2654 \mathrm{~h}$ ), the final word of the line last copied, eight lines were lost in a preliminary phase of A. In a subsequent scribal phase the surrounding lines have been adjusted. 2653 manic: as in F, E, (B) - A maent hi. 2654 ver Genten: as in F, (E) - A zijt sculdich. 2655 den coninc: cf. F - A die ic den coninc. Cf. Bouwman 1991, pp. 290-93.

2660 Hulsterloe: as in F, (B, E) and cf. line 2575 - A hulst ter loe.

2678 vor: as in $\mathrm{E}, \mathrm{F},(\mathrm{B})$ - A wee, does not make sense.

2679 scone rijme: $\mathrm{cf}$. $\mathrm{B},(\mathrm{E}),(\mathrm{L})$ - A huwen sone rijne, reading error.

2696 berke: as in E, (B), (L), and cf. lines 2601-07 - A burne.

2734 tebannen: cf. F gedaen te banne - A wart te bannen, before the past participle the finite verb from line 2732 is repeated (because of the subclause having main clause word order?).

2759a die hi te recht wel mochte mynnen: as in B - in A, a line is missing. More attractive and probably more original than A 2759-67 is F 2731-35: Nv hort hoe hier sal beginnen / Die coninc spreken coninclike / Mine dire arm ende rike / Beyde luttel ende groet / Mine baroene ende mine genoet. (Now listen how here the king will begin to speak in kingly fashion: 'My animals poor and rich, both small and large, my barons and my equal.')

2796 Tyselijn: cf. F necelijn < *tiecelijn, (B, L), and cf. line 1856 - A cirlin.

2812 tes: cf. F, B (ten) - A des.

$\mathbf{2 8 2 9}$ coninc: as in F, B - A cominc, scribal error (dittography).

2866 onbaren: as in F - A ombeeren, does not rhyme with varen (2867).

$\mathbf{2 8 8 3}$ van: as in $\mathrm{F}, \mathrm{B}-\mathrm{A}$ ende.

2928-29 smaren: as in $\mathrm{F},(\mathrm{B}, \mathrm{L})$ - A snoeren, semantic doubling in relation to lines 2931-32. tevoren waren: as in F, (B) - A waren tevoren. As a result of a memory lapse, a transposition within the line occurred in the exemplar of $A$. The new rhyme word voren (and the information in lines 2931-32) caused the scribe of A to make the reading error (or correction?) smaren $>$ snoeren.

2997 alsi wouden: as in F, (B) - A als hi woude.

3020 dor: as in E - A die, scribal error caused by Die (3019); optical contamination. 3101a-b Reynart sprac: 'Ic was gevaen, mar die coninc hi lijt mi gaen.': as in E, (B, L) - Continuation error in A (and F): as a result of eyeskip from ontgaen (3101) and gaen 
(3101b), the final word of the last line copied, the scribe skipped two lines (which are indispensable because of lines 3103-04).

3129 ase: as in $\mathrm{F}$ - A base, reading error for *hase.

3135 bat: as in E, F, (B) - A dancte, incomprehensible in combination with goets.

3177 bedwongene: as in F, B - A Bedi ne gheene, reading error (with incorrect word division) of ${ }^{*}$ bedwonghene.

3236 Bellijn: as in F, B - A lude, is grammatically correct, but hardly fits the context: Cuwaert has called Belin's name (line 3122) and it is clear that the ram has heard him, as line 3226 shows. Reynaert tries to twist some of Cuwaert's words (cf. Lulofs 1983, p. 313). 3239 Dat: as in F, (B) - A Doe, reading error influenced by A 3236 Doe riep hi (optical contamination).

3245 liever mesquame: as in F, (B) - A leet mesquame hem, lines 3246-47 do not fit; the scribe did not read any further and began to 'correct' the text, writing leet for lieuer and added hem.

3296-3300 Belin / Reynaert / $\mathrm{mi} / \mathrm{mi}$ / ic can: as in F, B, G, (L); on the basis of lines 3302-05 it must be Belin who is speaking, but in A the fox speaks. 3296 Belin: 'Reynaert - A reynaert belin. 3298 mi - A hu. 3299 mi - A hu. 3300 ic can - A ghi coont.

3325 daer: cf. (F) - A daer doe, caused by the beginning of the line Doe ne (added during the 'dictée intérieure'?).

3390 Fyrapeel: as in B, (F, L) - A Syrapeel, where $f$ was taken for the (long) s. Also in lines 3399, 3411, 3426, 3429, 3431, 3468.

3421-20 Order of the lines by analogy of $F, B$ and ( $L$ ) - In A, line 3421 serves as the justification to persecute Reynaert, but the line functions better as an excuse for victimizing Belin (cf. Lulofs 1983, p. 314).

3439 soene: as in $\mathrm{P},(\mathrm{B})$ - in $\mathrm{A}$ this direct object is missing.

3452 vriheden: as in $\mathrm{B}, \mathrm{P}-\mathrm{A}$ vreden, reading error or corruption due to 'dictee intérieure'.

3464 Ic: - A adds who is speaking: brune sprac ic (not necessary because of the direct address in line 3463).

3465 Ligghen dan hier: A reads Dan hier te ligghene (transposition within the line caused by a memory lapse?); in dysere: A reads int ysere (caused error during dictee intérieure?). Reconstruction of the acrostic according to Mrs H.A. De Vreese-Kroon (cf. Muller 1927, pp. 52-53). 


\section{Middle Dutch - A short introduction}

\section{Matthias Hüning \& Ulrike Vogl}

Middle Dutch is the term used for the language varieties spoken between approximately 1150 and 1500 in the territory covered nowadays by the Netherlands and Flanders, the part of modern Belgium, where Flemish - the southern variety of the Dutch spoken in the Netherlands - is spoken. At that time there was no standard variety of Dutch, 'Middle Dutch' does not, therefore, refer to one specific language: it is a collective term used to designate several dialects spoken over several centuries. This implies a huge variation in the grammatical structure, the pronunciation and the spelling of Middle Dutch. Middle Dutch thus consisted mainly of spoken varieties, but the surviving texts show that, during the Middle Ages, it was also increasingly used as a written language.

Contemporaries usually called their own language Dietsch or Duutsch - as in the beginning of Van den vos Reynaerde (4-5) - which means 'the language of the people' (lingua theodisca) as opposed to Latin or French, which were the dominant languages of writing, of administration and of the nobility, science, and the church at that time. While we have only a few text fragments in Old Dutch, a large number of Middle Dutch texts has survived. Van den vos Reynaerde is an early example of a literary text in Middle Dutch.

\section{Middle Dutch diversity}

Within Middle Dutch we can distinguish five large dialect groups: Flemish (including Zealandic), sometimes subdivided into West and East Flemish, was spoken in the modern region of West and East Flanders (Ghent, Bruges, Courtray); Brabantian was the language of the area covered by the modern Dutch province of North Brabant and the Belgian provinces of Brabant and Antwerp; Hollandic was mainly used in the present day provinces of North and South Holland and parts of Utrecht, while the people in Limburg (now a part of the Netherlands and Belgium) communicated in the Limburgish dialect. The final dialect group - East Middle Dutch - was spoken in the area of the modern provinces of Gelderland, Overijssel, Drenthe and parts of Groningen. 


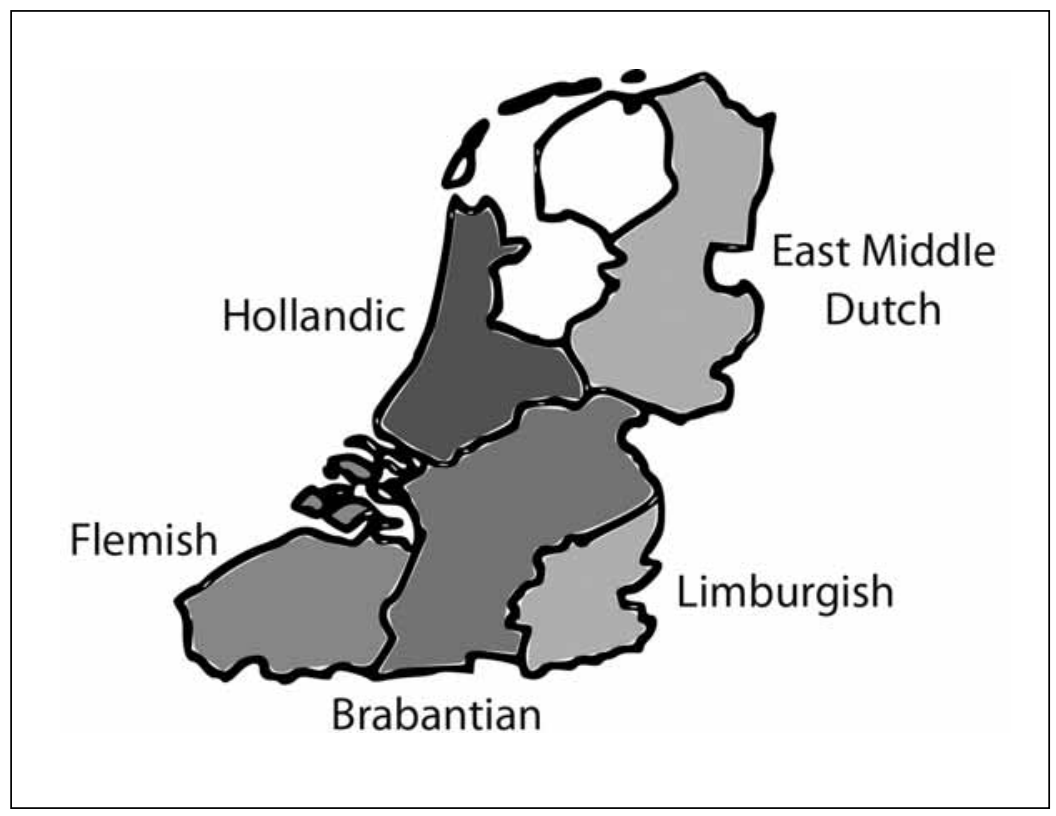

Fig. 1: The Middle Dutch dialectal groups

The last two of the Middle Dutch dialects mentioned above, Limburgish and East Middle Dutch, show features, respectively, of Middle High German and Middle Low German, since these two areas border directly onto the German language area. While East Middle Dutch consists of Low Saxon dialects, the other Middle Dutch dialect groups belong to the Franconian dialects. Finally, there is the present-day province of Friesland (cf. the white area in fig. 1) where, in the Middle Ages, Old Frisian dialects were spoken; Frisian is viewed as a separate language.

Identifying dialect features in a particular text starts in those texts whose place and time of origin are known. Local administrative and judicial documents are particularly suitable for this, as they are mostly written in the local dialect and because they are dated. Unfortunately not all surviving texts have a clearly identifiable place of origin. A single manuscript can often show features of several dialects. One reason for this can be that the scribe may speak a different dialect and so allows features of his own dialect to slip in, as it were, or even that he is making a conscious adaptation of the text into his own dialect. A further possibility is that words are borrowed from another dialect for the sake of preserving a rhyme. Or it can simply be the influence of Flemish-Brabantian tradition - in the thirteenth and fourteenth centuries the cultural and literary centre of gravity lay in Flanders. Sometimes marked dialect features are consciously avoided, for example if the text is directed at a wider audience. 
The date of origin of texts can also often be difficult to establish. Literary texts in particular, which are very often copies of copies of copies, show archaic characteristics alongside newer features from the same dialect; dialects too, of course, change with the passage of time.

Some features can spread to another dialect region, and there displace other characteristics which in turn sometimes even disappear completely. The responsibility for these changes is shared between increasing mobility and advancing urbanisation. As travelling became easier and towns grew, there was increasing contact with other dialects or even foreign languages. The need for a unified language arose. The invention of printing (ca. 1450) also led to an avoidance of dialect idiosyncrasies, because the texts were now addressed to a wider public. That is one of the first steps in the direction towards the development of a standard language.

\subsection{Differences between dialects}

Dialects can differ in several respects. On the lexical level, for example, one dialect may have a different word for the same concept, or the same word may have a different meaning in another dialect. Sometimes the texts themselves include explicit comments on differences in word usage, as Maerlant's comment (in Der naturen bloeme, around 1270) on the various names for a hedgehog shows: Een eghel heet ment in Dietscher tale, in Vlaemsche een heertse, dat wetic wale (= 'In (northern) Dutch it is called an eghel, but a heertse in Flemish, that I know well').

On the morphological level - i.e. inflection and word formation - variations can arise in the use of different affixes. For example, for female designations the suffixes -inne and -es (gravinne, abdesse = 'countess', 'abbess') are generally used, whereas -egge and -nede (spinnegge, vriendnede = 'spinster', 'friend') are a distinctly Flemish feature. In Brabantian we can also find the suffix-erse (burgersche, hooierse = 'citizen', 'haymaker'). The suffix -ster (melcster = 'milkmaid') only arises north of the great rivers Rhine and Meuse. Differences at the syntactic level - i.e. word order - have, unfortunately, hardly been investigated.

The greatest differences between dialects are of course to be found in the areas of spelling and pronunciation, at the phonological level. For example, a typical feature of Flemish is the unexpected presence or absence of the letter $h$ - at the start of words beginning with a vowel. We frequently find this phenomenon in the Flemish manuscript Van den vos Reynaerde [VdvR], a poem also of Flemish origin, which is edited here: hute (1241), haex (701) for ute, aex (= 'out', 'axe, hatchet') and ondert (232), oech (509) for hondert, hooch (= 'hundred', 'high').

Important features of the Hollandic dialect are the relics from Old Dutch shown in the combination-ft-for-cht-(gecoft, after instead of gekocht, achter = 'bought', 'behind'), 
and the diminutive forms using-gen or -gien (huysgen = 'little house'). Limburgish and eastern dialects still preserve the combination old instead of oud (wolde, solde instead of woude, soude = 'would', 'should'), and in Brabantian texts there is often an $o$ instead of $u$ (dos, vrocht $=$ 'thus', 'fruit').'

\section{Spelling and pronunciation}

The spelling of Middle Dutch texts differs greatly from Modern Dutch spelling. Since there was no spelling tradition, writers had to rely on the Latin spelling system and to suit it to their own needs. Middle Dutch spelling is usually characterized as more phonetic and less systematic, compared to the Modern Dutch system.

The spelling is more phonetic because it is largely guided by the sound, i.e. the pronunciation. In Middle Dutch texts we find forms like hant, lant, daet, hi vint (= 'hand', 'land', 'deed', 'he finds'), all spelled with a $-t$ because that is the sound one hears. In contrast, Modern Dutch spells the nouns with a $-d$ (hand, land, daad) because of a principle of uniformity: singular and plural forms are spelled the same - hand-handen, land-landen, daad-daden - despite the difference in pronunciation. ${ }^{2}$ Similarly, modern verb forms like $h i j$ vindt keep the $-d$ of the verbal stem although one does not hear it. The modern spelling uses a principle of analogy in these cases: the verbal stem should remain identifiable in the different forms of a verb and the regular ending $t$ is added for the 3 rd person singular (komen/hij kom-t, vinden/hij vind- $t=$ 'to come/he comes, to find/he finds'). Middle Dutch, however, does not care for these analogical relations, its speakers write a $-t$ whenever they hear it (hi vint).

Apart from these deviations with respect to modern Dutch there are also of course a great many variants within Middle Dutch itself. In the various writing centres (like scriptoria and chancelleries) the spelling conventions employed could often be quite divergent, and would also continue to change over time. An example of this can be seen in the spelling of long vowels. In very early texts these were still represented by a single letter, which can lead to confusion with the short vowels. In slightly later texts we often find -e- used as a sign of length, or sometimes an -i-: jaer (115) or jair (= 'year'). The modern habit of doubling the vowel (jaar) arises in the fifteenth century.

Because of the absence of a standard language, dialect differences are particularly liable to show up in texts. Even within a single text inconsistencies are common.

1 We cannot go into any details here; for a more extensive survey of dialect features see, for example, Van der Wal \& Van Bree (1992: chapter 5).

2 Dutch (like German, but unlike English) has final devoicing: voiced occlusives like /d/ are pronounced unvoiced (as $[t]$ ) at the end of a word or syllable. 
This may not be so surprising in literary texts, since, after all, the surviving texts are mostly copies carried out in turn by a series of scribes. However, in official texts too, even though written by a single writer, we can often find different forms for the same word.

Punctuation, scarce as it is in Middle Dutch manuscripts, does not correspond with modern practice. For example, a full stop may be added at the end of a line of verse, even if the sentence runs on to the next line. If rhyming texts are written continuously (scriptura continua, fairly uncommon anyway), the lines of verse are separated from each other by full stops. Full stops are also used to identify Roman numerals and to distinguish them from the ordinary letters, as in Ende gaffer mede.XL. slaghe (1676 = 'and gave (Reynaert) forty lashes with it'). ${ }^{3}$

In Middle Dutch we may find a number of features which still occur in modern Dutch but which today are only accepted in the spoken language and not in writing. The most obvious of these are phenomena known as assimilation, clisis and reduction. ${ }^{4}$

Assimilation - The term assimilation means 'making the same', i.e. the adaptation of a sound to its surroundings. This occurs mainly at word boundaries or between parts of words. For example, the word ontbieden (= 'to summon') is often pronounced as [ombi:den]. In this case, the $/ \mathrm{n} /$ assimilates to the $/ \mathrm{b} /$ by being pronounced with both lips and therefore sounds like an $/ \mathrm{m} /$. However, despite this pronunciation, the spelling of ontbieden never changes in modern Dutch. Yet, in Middle Dutch we can often also find this word written as ombiden or ombieden (472).

The mutual influence of Auslaut (final sound) and Anlaut (initial sound) in spelling can also be seen to affect consecutive words, i.e. at word boundaries. For example: $o p$ die (= 'on the') is often spelled as optie, where the voiced /d/ has lost its voicing under the influence of the unvoiced /p/.

This example also shows us that word division in Middle Dutch texts is not as fixed as in modern Dutch. Unstressed particles especially (i.e. words which primarily have a grammatical meaning, like articles, prepositions, pronouns etc.) are often written attached to the start of the following word (as in biderschepenen wille = "with agreement of the jurors', teseggene: 'to say').

Clisis - A phenomenon which is closely related to this is known as clisis. Here, too, we are concerned with two or more words being written together, but now this involves the loss of sounds. Weakly stressed words - mostly particles - attach themselves to a

3 However, in this edition of Van den vos Reynaerde the full stops marking Roman numerals are not retained.

4 In the Glossary, cases of assimilation, reduction and clisis have all been marked with '(clis.)'. 
strongly stressed word at the expense of part of their sound. Depending on whether the inclination (process of clisis) appears at the start or end of the word this is called proclisis and enclisis respectively. Examples of proclisis are: darme man $<$ die arme man (= 'the poor man') or, from $V d v R$, teerst dat $<$ te eerst dat (1431, = 'as soon as'). Examples of enclisis are: $m o e t t i<$ moet ghi $(1444$, = 'you must'); sechdi $<$ seecht ghi $(135$, = 'do you say'); dedine < dede hi hem (144, = 'he made him')

Such enclitic forms occur very frequently in Middle Dutch texts and can sometimes be ambiguous. For example, the form hoordi can be from hoort ghi (= 'do you hear'), hoordet ghi ('did you hear'), hoorde hi (= 'did he hear'), or in exceptional cases even from hore di ('= (I) hear you'). The correct interpretation can only be deduced from the context.

Reduction - Another feature which we find in Middle Dutch spelling is known as reduction, which manifests itself primarily in unstressed syllables, and is closely related to assimilation. Within this term we include the disappearance of sounds and the shortening of vowels or their weakening to an unstressed /e/ - the so-called schwa [ə].

Depending where the sound disappears from, we refer to it as procope (loss at the start of the word: as in ebben instead of hebben, = 'to have'), syncope (loss in the middle of a word, as in hooft instead of hovet, = 'head'), or apocope (loss at the end of a word, as in nach and vrou instead of nacht (= 'night') and vrouwe (= 'woman')). Apocope of a final schwa (as in vrou < vrouwe and ic heb $<$ ic hebbe = 'I have') is particularly common in Middle Dutch, and it is closely connected to the reduction of case endings and the accompanying loss of inflection.

Epenthesis - Not only do sounds disappear, sometimes an extra one creeps in. This phenomenon is called epenthesis and we find it, for example, in a word like arm (= 'poor') which is often pronounced as arem. Unlike modern Dutch where a clearly heard epenthetic sjwa [arəm] is regarded as sloppy, in Middle Dutch it is also reflected in the spelling; see, for instance, in $\operatorname{VdvR}$, arem $(38,101)$ and waremhede $(537,=$ 'warmth').

No matter how varied Middle Dutch spelling might be, it is still an important means of helping us to understand the pronunciation. In general a difference in the spelling reflects a difference in the sound. Alongside this, the rhymes can sometimes be of great value in the search for the correct phonological realisation of the characters. We should bear in mind, though, that any reconstruction of the pronunciation is always speculative. Our pronunciation of Middle Dutch is certainly not 'correct' (i.e. authentic): it is very close to current normal Dutch pronunciation and it is heavily influenced by it. To give one example: we know for certain that Middle Dutch -ij- was not yet a diph- 
thong but was still a long monophthong. That is why we always give the same pronunciation to Middle Dutch -ij- as in pijn, and -ie- as in sien, viz. a long [i:]. Yet these two sounds never rhyme with each other in Middle Dutch, nor do they generally alternate in individual words. This suggests that -ie- must actually have represented a different pronunciation from that given by $-i j$ - There must have been a difference which we can no longer grasp. ${ }^{5}$

\section{Grammatical structures}

One of the most striking differences between Middle Dutch and Modern Dutch is the fact that Middle Dutch (like modern German) still exhibits a fully-fledged case system. Nouns, adjectives, articles, pronouns, and numerals are inflected according to their function in the sentence, in other words, they change their form to conform to the 'case' in which they are being used. This morphologically coded case system eventually got lost. A residue is found in modern Dutch idiomatic expressions like de heer des huizes [genitive] (= 'landlord; boss'), but by and large it had disappeared in the seventeenth century.

Just like the other members of the Germanic language family, Dutch has the accent on the first main syllable. The final syllables which become weakened as a consequence of this are often reduced, or lost entirely. This can also be observed in Middle Dutch. The loss of case endings during the three centuries covered by Middle Dutch meant that the function of the constituents had to be rendered in a different way. A more fixed word order and the use of prepositions slowly took over this task. For example, a construction with the preposition van replaced the earlier genitive ending (as in des vaders huis $>$ het huis van de vader = 'the father's house, the house of the father'). Of course the change took place gradually, and the two alternatives were used alongside each other for a long time.

\subsection{Morphology}

3.1.1 Declension - The case system of Middle Dutch comprises four cases. The first case (nominative) can be used for the subject, the nominal part of the predicate or an addressed person. The second case (genitive) expresses a possessive relationship. The

5 It is, of course, beyond the scope of this introduction to give a survey of the different spelling variations and the corresponding sound values. For more details see Van Loey (1976) (in Dutch). Van Kerckvoorde (1993) provides an introduction to the phonetic system of Middle Dutch. 
function as indirect object is indicated by a form in the third case (dative), whereas a direct object takes the fourth case (accusative). Verbs, adjectives and prepositions are often bound to a particular case. So, for example, the verb pleghen governs a noun in the genitive, as in pleghen der eeren ( $35,=$ 'to practise honour - to act honourably'), as does the adjective werdich (as in werdich enechs prijs = 'worthy of some praise'). The dative is used, for example, with the verb slachten, as, for example, in slachten si den raven (18, = 'they resemble the raven') or with the preposition met (as in met luder sprake = 'with a loud voice').

The four cases are morphologically coded, i.e. they are marked by case endings on nouns and adjectives. Middle Dutch nouns can be subdivided into two large groups: the strong nouns and the weak nouns. Nouns ending in $-e$ in the nominative singular usually belong to the group with the weak inflection; a consonantal ending in this case indicates strong inflection for the word (but there are exceptions to this general rule). Just like the nouns, personal names are also inflected: male names can follow the strong or the weak inflection, whereas female names usually change form in line with the weak inflection. Compare for instance Reynaert sprac (2650, = 'R. spoke'; nominative) with Also was Reynaerde ghesciet (54, = 'this had happened to R.'; dative). Furthermore, the inflection is determined by the gender of the noun, where we need to distinguish between masculine, feminine and neuter words. The first two have merged in modern Dutch to form a single group, the so-called 'de-words'. Dictionaries of Middle Dutch often mention two genders for a noun, which usually reflects regional and/or temporal variation. Finally, the number of the noun is important in determining the correct inflectional form. We distinguish between singular and plural.

To illustrate the (early) Middle Dutch case system, we present the declension patterns of the nouns gast (= 'guest'), mensche (= 'human'), hof (= 'court'), herte (= 'heart'), daet (= 'deed'), and siele (= 'soul'), listed here side by side with the definite article - which emerged from the demonstrative pronoun - and the adjective goet $(=$ 'good').

\begin{tabular}{|ll|l|l|l|}
\hline Masculine & & strong & weak \\
\hline Sg. & Nom. & die goede & gast & mensche \\
& Gen. & des goets/goeden & gast(e)s & menschen \\
& Dat. & dien goeden & gaste & mensche \\
& Acc. & dien goeden & gast & mensche \\
Pl. & Nom. & die goede & gaste & menschen \\
& Gen. & der goeder & gaste & menschen \\
& Dat. & dien goeden & gasten & menschen \\
& Acc. & die goede & gaste & menschen \\
\hline
\end{tabular}




\begin{tabular}{|ll|l|l|l|}
\hline Neuter & & strong & weak \\
\hline Sg. & Nom. & dat goede & hof & herte \\
& Gen. & des goets/goeden & hoves & herten \\
& Dat. & dien goeden & hove & herte \\
& Acc. & dat goede & hof & herte \\
Pl. $\quad$ hom. & die goede & hove & herten \\
& Gen. & der goeder & hove & herten \\
& Dat. & dien goeden & hoven & herten \\
\hline & Acc. & die goede & hove & weak \\
\hline Feminine & & strong & siele \\
\hline Sg. & Nom. & die goede & daet & siele(n) \\
& Gen. & der goeter & daet / dade & siele(n) \\
& Dat. & der goeder & daet / dade & siele \\
Acc. & die goede & daet & sielen \\
Pl. Nom. & die goede & dade & sielen \\
& Gen. & der goeder & dade & sielen \\
& Dat. & dien goeden & daden \\
& Acc. & die goede & dade & sielen \\
\hline
\end{tabular}

Table I: Declension patterns in Middle Dutch ${ }^{6}$

The case, gender and number of the article, demonstrative pronoun and adjective depend on the noun with which they form a syntactic constituent. In some circumstances, however, the adjective is uninflected. Just as in modern Dutch, the adjective used predicatively is used in its basic form, as in die ridder es goet (= 'the knight is good'), as opposed to its attributive use in die goede ridder ('the good knight'). In the typical Middle Dutch feature of post-positioning, where the adjective immediately follows the noun, it does not change form, as in die ridder goet (= 'the knight good'), die vrouwe vroet $(=$ 'the woman wise'). Adjectives used independently are treated either as nouns or as adjectives, and can accordingly also be inflected in either way.

The infinitive form of the verb too gets the dative $-e$ ending if it is preceded by the particle te, as in te sprekene (= 'to speak'), te segghene (= 'to say').

Personal pronouns in modern Dutch show different forms for the use as subject and as object (like wij vs. ons (= 'we' vs. 'us'). In Middle Dutch they still have a full inflectional paradigm. 


\begin{tabular}{|l|l|l|l|l|}
\hline & $\mathbf{I}^{\text {st }}$ person & & $\mathbf{2}^{\text {nd }}$ person & \\
\hline & sg. & pl. & sg. & pl. \\
\hline Nom. & ic & wi & du & ghi \\
\hline Gen. & mijns & onser & dijn & uwer, uw(es) \\
\hline Dat. & mi & ons & di & u \\
\hline Acc. & mi & ons & di & u \\
\hline
\end{tabular}

\begin{tabular}{|l|l|l|l|l|}
\hline & $\mathbf{3}^{\text {rd }}$ person & & & \\
\hline & masc. sg. & fem. sg. & neut. sg. & pl. \\
\hline Nom. & hi, -i & si, -se & het, - (e)t & si, -se \\
Gen. & sijns, -(e)s & haer, -ere, -er, -re & $-(e) s$ & haer, -ere, -er, -re \\
Dat. & hem, -em, -en & haer, -ere, -er, -re & hem, -em & hem, hen, -en \\
Acc. & hem, -ene, -ne, & haer, -se & het, - (e)t & hem, hen, -se \\
& $-e n$ & & & \\
\hline
\end{tabular}

Table 2: Personal pronouns in Middle Dutch ${ }^{7}$

In the second person the plural forms of the personal pronoun can also be used for singular referents. The use of the plural form then signals politeness. The pronoun $g h i(=$ 'you'), for example, can indicate the plural as well as the singular. However, for the singular there is also the pronoun $d u$ (= 'thou'), which is only used occasionally and even then is often not used consistently, as, for example, in Du oude geck, God moet bederven $u$ lijf (= 'Thou old fool, God rot your body'). This pronoun is mostly a sign of intimacy cf. Reynaert, wat haetstu (562, = 'R., what did you eat?') - or a lower social level for the person addressed. It also often occurs in situations of contempt or anger, as in Vermalendijt, Lamfroyt, moet dijn herte sijn! Du best dulre dan een zwijn (916-18, = 'Damned, L., you deserve to be! You have less sense than a pig').

Enclisis is very common with personal pronouns. The third person forms in particular have several enclitic variants (printed in italics in table 2), which are used very frequently; see, for example, doe dedine [<deed hi hem] sitten gaen $(144$, = 'then he made him sit').

Middle Dutch lacks special forms for the reflexive pronoun, the personal pronouns are used to express reflexivity, as in Brune liet hem verdoren (677, = 'Bruun allowed himself to be fooled'). The reflexive third person pronoun sich/sick is first found in the eastern dialects in the fourteenth century, from which it later spread to other dialects.

3.1.2 Plural formation - The commonest plural endings in Middle Dutch are: $-e$ for nouns which use the strong declension, $-n$ for those with the weak declension, and $-s$ 
for many words ending in -el, -en and -er (as in duvels, tekens, cloosters = 'devils', 'signs', 'monasteries'), for loan words (pelgrims) and for some monosyllables (as in wijfs, mans $=$ 'women, men'). A limited number of words can form their plural with -er (as in kintkinder, ei - eier = 'children', 'eggs'). There is also the possibility of the singular and plural forms being identical for some neuter monosyllabic words with a long stem syllable, for example when a word with either a long vowel or with a short vowel is followed by two consonants (as in dat been - die been, dat dinc - die dinc = 'leg(s)', thing(s)'). However, these words are also found with a plural ending -e.

A separate category is formed by the cumulative plurals which we can find in nouns with a 'normal' -er plural. In addition to -er, there is another common plural morpheme attached to these words (as in kint - kind-er / kind-er-e / kind-er-en / kind-er-s - the same phenomenon as in English 'children'). Cumulative plurals are sometimes the result of a morphological reinterpretation, when a plural form is interpreted as a singular. This is most likely to happen with words which generally refer to plurals, for example, scoe (= 'shoe' sg.) - scoen (pl.) > scoen (sg.) - scoene / scoenen / scoens (pl.). This phenomenon can also occur in the other direction, if a word in the singular is interpreted as a plural form and loses its ending. This occurs mostly with words ending in -en in the singular, as in raven ('raven' (sg.))- ravens ( $\mathrm{pl}$.) > raaf (sg.) - raven ( $\mathrm{pl}$.).

3.1.3 Conjugation - There are, just as in Modern Dutch, three different types of verbs in Middle Dutch: strong, weak, and irregular verbs. The strong verbs change the vowel in the verb stem to form their preterite and past participle, as the forms in the Glossary clearly show. This phenomenon - indicated by the German term Ablaut - follows a fixed pattern. This means that we can divide the strong verbs into seven classes.

\begin{tabular}{|l|l|l|l|l|}
\hline & Infinitive & Preterite sg. & Preterite pl. & Past participle \\
\hline I. & biten (= 'to bite') & beet & beten & gebeten \\
2a. & bedriegen (= 'to betray') & bedroog & bedrogen & bedrogen \\
2b. & crupen (= 'to crawl') & croop & cropen & gecropen \\
3a. & vinden (= 'to find') & vant & vonden & gevonden \\
3b. & werpen (= 'to throw') & warp & worpen & geworpen \\
4. & nemen (= 'to take') & nam & namen & genomen \\
5. & geven (= 'to give) & gaf & gaven & gegeven \\
6. & varen (= 'to go') & voer & voeren & gevaren \\
7. & laten (= 'to let') & liet & lieten & gelaten \\
\hline
\end{tabular}

Table 3: Division of strong verbs into seven classes 
Weak verbs form the past participle and the preterite by adding a dental suffix to the verbal stem, $-d(e)$ or $-t(e)$. The third group, the irregular verbs, comprises verbs which change the vowel in the present tense (ic can - wi connen ='I can, we can; I am/we are able'), or weak verbs with a divergent preterite (denken - dacht; brengen - bracht = 'to think - thought; to bring - brought').

In the following table we present the paradigm for the indicative forms of a weak verb $($ keren $=$ 'to turn') and a strong verb (nemen $=$ 'to take'). The infinitive form is in both cases marked by the ending -en, the past participles are formed by adding a prefix ghe- and a suffix: - $t$ for the weak verbs, -en for the strong verbs: ghekeert and ghenomen. The forms of the present participle are kerende and nemende. There are different forms for the singular and the plural imperative: sg. keer/kere and neem/neme, pl. keert/keret and neemt/nemet.

\begin{tabular}{|l|l|l|l|l|}
\hline \multicolumn{3}{|l|}{ Weak verb: keren } & \multicolumn{2}{l|}{ Strong verb: nemen } \\
\hline & Present & Preterite & Present & Preterite \\
\hline Isg & ic kere & ic keerde & ic neme & ic nam \\
$2 s g$ & du keers & du keerdes & du neems & du naems \\
3 sg & hi keert & hi keerde & hi neemt & hi nam \\
ipl & wi keren & wi keerden & wi nemen & wi namen \\
$2 \mathrm{pl}$ & ghi keert & ghi keerdet & ghi neemt & ghi naemt \\
$3 \mathrm{pl}$ & si keren & si keerden & si nemen & si namen \\
\hline
\end{tabular}

Table 4: Conjugation: indicative forms of a weak and a strong verb in Middle Dutch

Middle Dutch uses the subjunctive in indirect speech or to express, for example, a wish or a supposition. The only differences in verb endings between indicative and subjunctive are found in the 3 rd person singular present tense (subjunctive: hi kere, hi neme), and, for strong verbs, also in the 1st and 3 rd person singular preterite (ic name, hi name). In all other instances the subjunctive forms are identical to the indicative.

\subsection{Syntax}

At the syntactic level the differences between the Middle Dutch dialects are smaller than, for example, in vocabulary or phonology. We will present some general aspects of Middle Dutch syntax.

3.2.1 Word order - The positioning of the finite verb plays an important role in the description of primary and subordinate clauses. Main clauses in Middle Dutch use the 
same word order as modern Dutch (or English): mostly SVO, i.e. Subject - (finite) Verb - Object, as in Hi stal tgroete (2105, = 'He stole the big ones'). In declarative sentences the finite verb usually takes the second position, preceded by the subject on the first position. The fact that main clauses have the verb in the second position leads to inversion whenever the first position is taken, not by the subject but by another element: the subject then follows the finite verb. This may, for example, occur in questions where the first position is filled with an interrogative pronoun: Wat sechdi van [...] $(135,=$ 'What do you say of [...]?'), or when the first position is taken by an object or an adverbial: Doe leide men Coppen in dat graf (451, = '[Then] they laid C. in the grave'). The translation of the last example shows that English differs from (Middle) Dutch in that it allows two syntactic units ('Then' and 'they') to precede the finite verb, whereas in Dutch the subject needs to be moved in such cases: 'men leide' > 'Doe leide men'.

In subordinate clauses, word order is not as fixed as in modern Dutch (where we usually find SOV). In Middle Dutch subordinate clauses the finite verb can take almost every position, except the first one which is normally reserved for the subject.

The following example shows the normal word order for main clause and subordinate clause: Hi hadde te hove so vele mesdaen, dat hire niet dorste gaen $(51-52,=$ ' He had behaved so badly at court, that he did not dare go'). In the main clause the finite verb (hadde) takes the second position and the subject is found on the first position, while in the subordinate clause the finite verb dorste together with the infinitive gaen appears in final position. Compare this with the sentence where the finite verb takes the second position in the subordinate clause (which would not be possible in modern Dutch): Alse die coninc dit versach, Dat hi hadde dat hoege verloren (1324-25, ="When the king noticed that he had lost an eye').

The word order in the nominal group shows some peculiarities when compared to modern Dutch (or English). Usually we find a pattern such as 'article/demonstrative pronoun - adjective - noun'. However, in Middle Dutch the adjective can also follow the noun (= die ridder goet: 'the good knight'), and a possessive pronoun, too, is sometimes found after the noun it belongs to (die boeke sijn = 'his books'). In this case adjective and pronoun remain uninflected.

Genitives, too, can appear before or after the noun. This sometimes leads to very complicated structures as in the following phrase: sijn neve Jan, sGraven zone van Henegouwen (= 'his nephew Jan, the son of the Count of Henegouwen'). This kind of extrapositioning is no longer possible in modern Dutch because of the absence of case endings.

3.2.2 Passive voice and impersonal constructions - A passive construction is used to accentuate the role of some participant other than the agent in an event. While in the active voice the agent usually is syntactically realised as subject (as in ic screef desen brief 
$=$ 'I wrote this letter'), the passive voice shifts the focus of attention to the object or person undergoing the action by making it the subject of the sentence, or it emphasizes the action itself (desen brief wart gescreven bi mi = 'this letter was written by me'). Passive constructions in Middle Dutch are expressed analytically by an auxiliary (sijn or wer$d e n)$ and the past participle of the main verb. The agent of the action can be expressed by using the prepositions van or $b i{ }^{8}$ The passive voice is also used in $V d v R$, for example in hi seide dat desen brief bi hem alleene ware ghescreven (3287-88, = 'he had to say (lit.: said) that this letter had been written by himself alone').

Impersonal constructions, hardly ever found in Modern Dutch, are relatively frequent in Middle Dutch. They are characterised by the absence of a nominative subject. A number of verbs occur in both personal and impersonal constructions. Originally the impersonal construction consisted of a verb form in the 3 rd person singular, a dative element and a genitive element: mi lanct waters (= 'I long for water'), where the personal pronoun $m i$ is a dative form and waters is a genitive. Later on, the genitive object could be replaced by a prepositional phrase (mi lanct na di = 'I long for you'), an infinitive (mi lanct te comene = 'I long to come'), or a dat-clause (mi lanct dat ghi comt $=$ 'I long for you to come']). ${ }^{\text {' }}$

3.2.3 Negation - The most common negation in Middle Dutch consists of the elements en or ne and another negating word such as niet, niemant and geen ['not, nobody, none'], with the first element always immediately preceding the finite verb form. Two examples: Dat ics vergheten niet ne mach (2666, = 'That I cannot forget it'); Doe ne conste Reynaert niet bejaghen (3351, = 'Then Reynaert was unable to find anything'). However, it is also possible for a sentence to be negated with just one of these elements: Dinen aerbeit wert niet cleene $(2871,=$ 'Your work is not light'). Negation with just the single particle en or ne before the finite verb occurs in Middle Dutch only in specific circumstances but is actually the more original form, and was the major option in Old Dutch. However, this negating particle gradually lost its force and acquired an accompanying negative adverb or noun to reinforce itself, which subsequently took over the negative function entirely. A similar development can, in fact, also be seen in other Indogermanic languages. We can sum up the development of negation in Dutch as follows:

$\begin{array}{ll}\text { Old Dutch } & \text { en } / \text { ne } \\ \text { Middle Dutch } & \text { en } / \text { ne }+ \text { niet, geen, niemand,... } \\ \text { Modern Dutch } & \text { niet, geen, niemand,... }\end{array}$

8 The preposition door, which is the standard means of introducing the agent in passive sentences in modern Dutch, only arises after the Middle Ages.

9 Examples are taken from Van der Wal \& Quak (1994: 84). 
Note that many negative adverbs and pronouns which are used in Dutch to express negation, arose through a proclitic binding with the negating word $n e(n e+i e t>n i e t$, ne +ooit $>$ nooit).

In addition to clearly negative words like niet or geen, other words such as maer (= 'only'), cume and nauwe (both mean 'scarcely') also have a negative value. These can also occur in connection with en or ne (Die ne had mer één coe = 'Who only had one cow'). Moreover, a negating word can also appear in subordinate clauses beginning with eer (Eer ic noit dit werc bestont = 'before I (n)ever started this work'), clauses which are dependent on a comparative or superlative (as in Die scoonste die nie men sach = 'The finest that was (n)ever seen'), or in sentences which have a negative implication (as in Hoe dul es hi ende wel sot die mannen geloeft nembermere, where the negative implication is 'you must never believe men').

To avoid confusion with negation using two elements it seems sensible to reserve the term double negation for sentences in which two or more negative adverbs or pronouns are used alongside each other, as in Daerne quam oec nie geen man, ... or dan [ $<$ dat en] was niewerinc noit vernomen ... which mean literally 'there came also never no man' and 'that was seen nowhere never'. Against the rules of logic these negative elements do not cancel each other out but reinforce each other. Unlike modern Dutch, where such constructions are only tolerated in the spoken language, this double negation also occurs in the written forms of Middle Dutch dialects. 


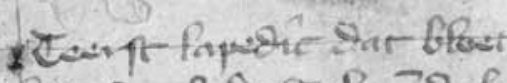

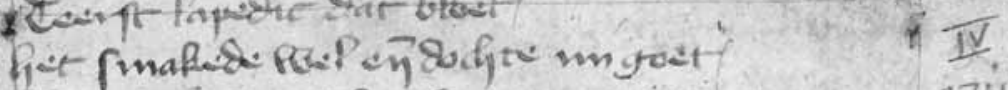

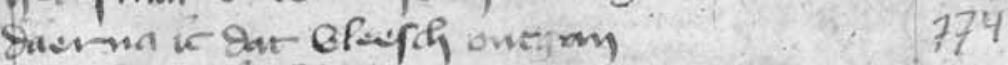

Saen Pousir Peckermic an

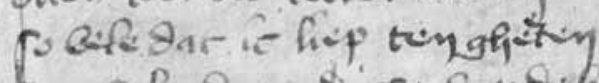

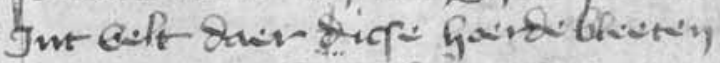

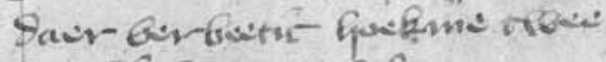

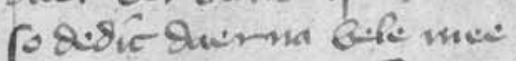

afe is ansir-bab in comen

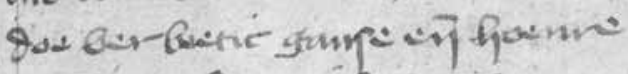

Jo cmif: Sicr iff:- onnt

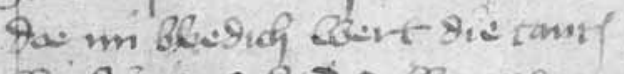

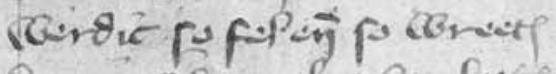

Oar te pain al of berbert

al sut is busnt in to bermatge

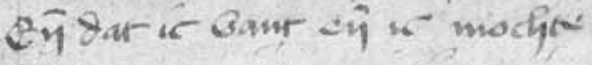

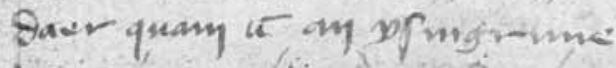

to bontor min cond mme

Gi freffer misntindina borm

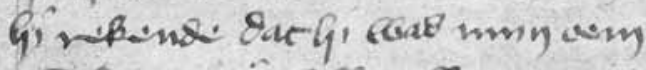

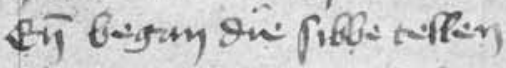

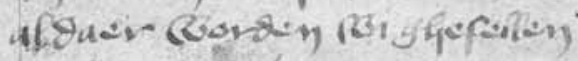

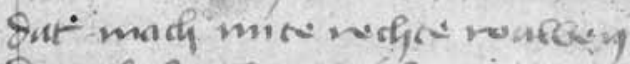

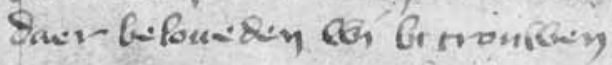

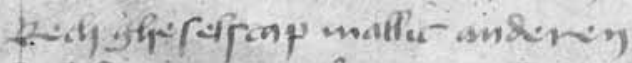

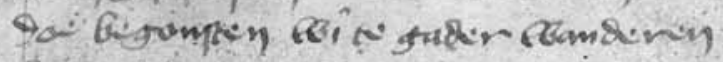

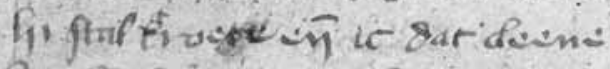

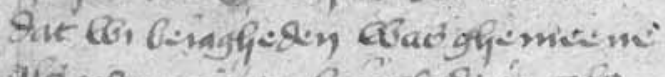

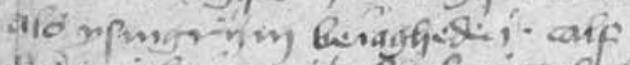

10. mochtic min di.

A. 


\section{Further reading}

\section{Editions}

Although reference is often made to 'the' Reynaert, the work's transmission shows that there is not one 'Reynaert'. First of all, there are two, not just one, Middle Dutch poems about the fox: Van den vos Reynaerde and Reynaerts historie (sometimes referred to as Reynaert I and Reynaert II). But even if we limit ourselves here to Van den vos Reynaerde, it must be stressed that there is no single, unequivocal text. There are five manuscripts, the oldest of which dates from the end of the thirteenth century and the youngest from the beginning of the fifteenth century. These five copies or redactions - although all based on a common original - display mutual textual deviations. Not only does the text of redaction A have an extra 76 lines as compared to redaction $\mathrm{F}$, the redactions also differ considerably as to the content and the order of the lines. This is not surprising taking into account a process of transmission stretching across a century and a half, as scribes will always introduce textual variants when copying texts. These do not only consist of accidental mistakes, different spellings or the intrusion of dialects (which in rhymed position often induced scribes in a later phase of the work's transmission to make 'corrections'), but also of consciously introduced adaptations of the content and modernizations of the work's linguistic forms.

When redactions are published, various approaches are possible, depending on the intended use of the edition. The manuscript text may be published photographically in a facsimile edition, for example. In this form the following are available: redaction A (Janssens a.o. 1991) and redaction J (Klitzing 1989). However, for scholars it is at least as important that the manuscript text is accessible in a transliteration which may be cited. One option in that case is a diplomatic edition, that is, the publication of an accurate transcription of the signs that constitute the text, including all mistakes and peculiarities. Redactions A, F, E, G, H, L, Pg have been published in diplomatic editions by Wytze Hellinga (1952). His synoptic standard edition replaced a number of older diplomatic editions, especially the work of Foeke Buitenrust Hettema (A: Buitenrust Hettema \& Muller 1903; A, F, E: Buitenrust Hettema \& Degering 1921). However, Buitenrust Hettema's introduction, notes and glossary - intended as a sequel to the publication of 
1903 - remain an inexhaustible source of information (Buitenrust Hettema 1910). Hegman (1989) published a diplomatic edition of redaction J.

A critical edition is another option. In that case a transcription is made, with corrections (emendations) of obvious errors. Often punctuation, spelling, rhymes etc. have also been normalized. Most Reynaert editions are critical editions of redaction A. Important among them are Jonckbloet (1856), Martin (1874), Van Dis (1972), Lulofs (1983) and Bouwman \& Besamusca (2002). The older editions remain of great value on account of their introductions and critical apparatus.

A special form of critical edition is the reconstruction of the lost original on the basis of all surviving sources. A general introduction on how to deal with textual variants and textual criticism when editing Middle Dutch texts may be found in De Haan (1973) and Salemans (2000). Once the relationship between the sources has been established, variant readings within and between families of the stemma - the 'family tree' - are compared in order to find the 'oldest', or, when this is impossible, the 'best' reading. As the selected readings in this approach derive from different sources, normalization of the linguistic forms is necessary before the text can be published. Among Reynaert scholars it is especially Jacob Wybrand Muller who has been engaged with this type of textual criticism (Muller 1917 and 1940). The third revised edition of his critical edition (Muller 1944) is, together with the second revised edition of his exegetical commentary (Muller 1942), a philological monument, but as a reconstruction of the original poem it is not undisputed nowadays.

A number of modern translations of Van den vos Reynaerde are available: into English verse: Colledge 1967; into French prose: Wouters 1974; into German prose: Berteloot \& Worm 1982; into German verse: Poeth 2005; into Dutch prose: Bouwman \& Besamusca 2007; into Dutch verse for example: Van Altena 1979, Eykman 2008, Posthuma 2008.

\section{Research}

Van den vos Reynaerde has been subjected to intensive research by philologists for more than two centuries. This edition is indebted to their contributions, as is evident from the footnotes to the Introduction and other chapters. It is quite impossible to discuss in depth the secondary literature on Van den vos Reynaerde here. We shall limit ourselves to some trends from the last few decades, paying particular attention to a number of contributions in English.

Gerhard Arendt (1965) was the first to examine Van den vos Reynaerde systematically as a literary text, focusing on the importance of literary space and the consistent structure of Reynaert's tricks. The poet contrasts the orderly world of the court with the wilderness, where Reynaert rules and his opponents lose their way, also in a moral 
sense. As the court animals pretend to be better than they are, they can be unmasked: confronted with the wily fox, the court animals are each time deceived and punished according to a fixed pattern. A similar approach of the literary space was applied by Van Daele (1994), albeit with different interpretative results.

Like Arendt, Frank Lulofs (1975) concentrated on the text itself, but did so from a completely different angle: not, like Arendt, interpreting deductively (from general ideas to the actual poem), but inductively: from the details in all available sources to cautious generalisations. On the basis of A 1885-2017, for example, Lulofs demonstrated not only the exhaustive degree to which, in his view, a continuous literary and cultural-historical commentary should be conducted, but also how research into variants may use the sources as valuable witnesses for the later reception of the text, rather than as mere stepping stones on the way to a reconstruction of a lost original. His findings were summarized in the hundred pages of commentary in his edition (Lulofs 1983).

From the outset, research into Van den vos Reynaerde concentrated on the poem's relationship with the Old French source text(s). The emphasis lay especially on textual agreements, for one reason because it was at one time argued - wrongly - that Van den vos Reynaerde was the original text, and the Old French Le Plaid its adaptation. The original status of Van den vos Reynaerde was defended primarily by Willems (1836) and - as regards the first part of the work that was supposed to have been written by Arnout - by Van Mierlo (1927). These views came under attack from Jonckbloet (1856), Delbouille (1929) and others. D.C. Tinbergen collected the agreements with Old French source texts known from older Reynaert research (Muller 1942, Concordantiën III). Only relatively recently were the differences with the Roman de Renart studied, at first by Heeroma (1970) and later by Bouwman (1991). They charted and analysed all the interpolations, omissions, and transpositions that provide an insight into Willem's method of composition and views on literature.

The meaning that is assigned to the story is intimately connected with the way the main protagonist is regarded. For most of the older philologists the fox is a positive character. Arendt sees the fox as the only animal who acts true to its nature, while Lulofs regards him as the leader who acts in the interests of his clan; the fox may not always be flawless from a moral point of view, he is nevertheless legally innocent. Heeroma sees the fox as the alter ego of Willem, a poète maudit who takes revenge on his critics at court through the fox. In these interpretations it is the corrupt legal procedure and the court where appearances count for everything that are denounced, rather than the fox who by the clever use of his tricks successfully defends himself against his opponents.

A very different view has been put forward by Van Oostrom (1983), who regards Reynaert as fundamentally malevolent, which is in accordance with the negative 
image that the fox has in other Middle Dutch works and with the epithet which the poet and fellow animals use repeatedly to characterize Reynaert as diefelle: that is, the scoundrel or villain. This opinion, which holds the fox responsible in part for the disintegration of the court community, was confirmed by Wackers (1986), elaborated by Bouwman (1991) and particularly by Van Daele (1994), but was also modified by Reynaert (1996).

It should be noted, however, that a rejection of the fox's behaviour does not mean that the work's audience may not at the same time admire his verbal ingenuity or laugh at the disasters that befall his opponents. There is much in favour of assuming a multiple attitude towards the text among the implied audience, which on the one hand is concentrated on the narrative action (sharing the fiction), and on the other hand on a process of reflection on the action, at a certain remove from the text, assisted by the narrator's asides and the effective use of certain forms of dramatic irony.

To conclude, it seems useful to mention some publications in English that provide information about areas of research devoted to Van den vos Reynaerde. Most of these contributions are of a comparative nature, as they have been written for medievalists outside the Netherlands who are specialists in other medieval literatures. According to Bouwman (1990), Willem used two Old French versions of Le Plaid (branch I) for his reworked text. Bouwman (1992a) demonstrates that Willem also derived material from other branches of the Roman de Renart, in particular motifs and lines from Le Pèlerinage de Renart (branch VIII). Bouwman (1992b) compares the texts of Le Plaid and Van den vos Reynaerde to show how Willem shifts the emphasis in his poem, balancing between tradition and originality. Besamusca (1996) discusses Willem's adaptation of the macrostructure of Le Plaid, the way older stories are repeated by the characters themselves and the interventions of the narrator. Wackers (1994) concentrates on the relationship between words and deeds in Middle Dutch Reynaert stories. Wackers (2000a) investigates the literary context of the Roman de Renart, Van den vos Reynaerde and Reynaerts historie and its implications for the implied audience. He also points (as does Meuwese 2006) to marginal decorations in contemporary Flemish manuscripts alluding to the Cuwaert-episode (lines 135-164), which might help to identify the cultural context of Van den vos Reynaerde. The interpretation of Wackers (2006) tries to harmonize the negative character of Reynaert with the comical effect that the tricks he plays on his opponents have on the audience. Jacoby (1970) concentrates on the legal elements in Van den vos Reynaerde (although some of his interpretations are now disputed; cf. Bouwman 1991). Finally, every reader of this edition who has developed an appetite for Middle Dutch texts will benefit from Kooper (1994). This collection of essays about medieval Dutch literature in its European context includes a bibliography of translations and a chronological table. 


\section{Middle Dutch (by Matthias Hüning \& Ulrike Vogl)}

The chapter 'Middle Dutch - A short introduction' (see above pp. 257-271) is mainly based on the online publication Geschiedenis van het Nederlands / History of the Dutch language (Hüning a.o. 1999).' The online text has been modified and updated to fit the context of this edition.

Middle Dutch is, of course, also treated in textbooks on the history of the Dutch language, like De Vries a.o. (1995), Van den Toorn a.o. (1997) or Van der Sijs (2005). Janssens \& Marynissen (2005) focus on the external history of Dutch, while Van der Wal \& Van Bree (1992) present a very good overview of the linguistic structure of Middle Dutch (especially in the chapters 5 and 6). Van der Wal \& Van Bree (1992) has been used extensively when preparing the chapter in this volume; many of its examples and especially the tables are based on the rich material in this book. A textbook (with text fragments and exercises) dedicated solely to Middle Dutch is Hogenhout-Mulder (1985). Mooijaart \& Van der Wal (2008) presents a course in Middle Dutch and Early Modern Dutch (which also includes text fragments and exercises). All these textbooks are written in Dutch. An overview of the history of Dutch in German is presented by Vekeman \& Ecke (1992).

For English-language readers a number of texts are available. Wim Daniëls (2005) presents a (very) short history of the Dutch language. Earlier, Colette van Kerckvoorde wrote an excellent introduction to Middle Dutch (1993). It is much more detailed than the chapter in this edition can be, and it contains many text fragments, used mainly for illustration purposes. An introduction to the structure of Middle Dutch can also be found in Van der Wal \& Quak (1994), embedded in a broader overview of Old and Middle Continental West Germanic.

Middle Dutch syntax is the subject of several studies, such as Duinhoven (1988 and 1997), Van Gestel a.o. (1992), or Burridge (1993). An old standard work on this topic is Stoett (1923). A short, but informative, overview of Middle Dutch syntax can be found in Van der Horst (1984). Van der Horst (2008), a new two-volume history of Dutch syntax, devotes several hundred pages to Middle Dutch. Van Loey's studies (1970, 1976 and 1980) are standard reference works on Middle Dutch phonology and morphology. Although not very easily readable, they contain a great deal of information, also on dialect diversity. An overview of Old Dutch can be found in Quak \& Van der Horst (2002).

The most comprehensive dictionary of Middle Dutch is the Middelnederlandsch woordenboek (MNW), a dictionary with illustrative citations and references for the different meanings of a word. Derived from this dictionary is a concise dictionary, the

1 The Dutch version has been translated into English by Dr John Gledhill, who kindly gave permission to use his translation. 
Middelnederlandsch handwoordenboek (MNHW), which contains the same entries, with equivalents and paraphrases for the different meanings in modern Dutch. It formed the basis of the Retrograad woordenboek van het Middelnederlands, the retrograde dictionary of Middle Dutch (Van den Berg 1972). A supplement to the MNHW became available in 1983 (Van der Voort van der Kleij 1983). Another concise dictionary was published by Pijnenburg \& Schoonheim (1997). While the MNW is a result of the philological tradition of the nineteenth century, we have a very modern lexicographical product for Early Middle Dutch (13th century), the Vroegmiddelnederlands Woordenboek (VMNW), compiled by the Institute for Dutch Lexicology, Leiden. It is this institute that has recently begun to make the historical dictionaries of Dutch available online (cf. http://gtb.inl.nl/). 


\section{Index of proper names}

In the list below the proper names of animals, persons and places have been listed and arranged alphabetically according to their most frequently found non-declined forms. Other instances of the name have been added between round brackets, again in alphabetical order. If only declined forms are found, the declension has been put between round brackets in the entry, as in Alente(n). Emendated proper names have been italicized (see also Editorial principles).

Line numbers have been contracted in all cases where, after a minimum of three references, a character plays a role across a larger number of lines, or is addressed by another character. The line numbers are followed by a concise explanation, while in cases where names denote a particular feature, the literal sense of the name is also given.

$$
\text { Abelquac } 790 \text { - Villager: 'smooth talker' }
$$

Abstale 802 - Village southwest of Hulst, in the medieval county of Flanders, now in Zeeuws-

Vlaanderen, part of the province of Zeeland in The Netherlands

Aken 2270c, 2630 - German town, residence of Charlemagne, town where the Holy Roman Emperors were crowned

Alente(n) 297 - Noble lady, not further specified

Arnout 6 - Author of an earlier (probably Old French) story about Reynaert

Artinnen 2249 - Ardennes, in Van den vos Reynaerde characterised as a wild region; south-eastern part of Belgium

Babilonie(n) 23-Distant country or town (Babylon) in the Orient

Bave 790 - Village woman

Belin (Belijn, Belijns, Beline, Belins) 1847, 1850, 2942-76, 3056-83, 3122, 3200-3316, 3330-3368, $3417,3441,3442$ - Ram, court chaplain
Belsele 2097 - Village south-west of SintNiklaas, in the eastern part of (the medieval county of) Flanders

Bloys 1509 - Unknown village in the 'lant van Vermendoys' (see note to line 1510)

Botsaert (Botsaerde) 3362-75 - Unspecified animal (monkey, boar?); King Nobel's clerk

Bruneel 1857, 3367 - Unspecified animal (ass?); 'little brown one'

Bruun (Brune, Brunen, Bruuns) 476-988, 1028, $1088,1463,1815,1821,1822 d, 1852,1904,1942-$ 2022, 2169, 2250, 2251, 2254, 2270b, 2329, 2425, $2433,2449,2459,2464,2470,2484,2487,2810-$ 2918, 2980, 2993, 3014, 3103, 3195, 3335, 3406, 3463 - Bear, named after the colour of his fur: 'brown one'

Cantaert 295 - Cockerel, son of Canticleer; 'singer'

Canticleer (Cantecleer, Canteclere, Canticler) $285,291,315,375,425,1469,1807,1809,1861$ Cock; 'clear singer' 
Christus (christum filye) 1820 - Jesus Christ, the Lord's anointed, God's son (Matth. 1)

Cleenebejach 1863 - Ferret: 'small catch'

Colne 2639 - Cologne; German town

Coppe (Coppen) 287, 305, 307, 417, 451, 461, 465 - Hen, Canticleer's murdered daughter: 'crested head' (?), named after the body part that is missing because it had been bitten off

Cortoys 99, 114, 122, 125, 253 - Small dog: 'courtly one'

Crayant 299 - Cockerel, Canticleer's son: 'crower'

Cuwaert (Coewaerde, Coewaert, Cuaerde, Cuwaerde, Cuaert, Cuwaerts, Cuwart) $138,158,164,247,2644-88,2738,3053-3132,3201$, $3204,3211,3214,3224,3235,3242,3247,3275$, 3307, 3313, 3378, 3419 - Hare: 'coward'

Doringhen 2466 - Thuringia, medieval landgraviate, now in Central Germany

Elmare (Elmaren) 373, 1483, 1493 - Benedictine grange between Aardenburg and Biervliet in the medieval county of Flanders, founded as a priory by St Pieter's Abbey, Ghent (located approximately near present-day WaterlandOudeman on the border between Belgium and the Netherlands)

Elve 2442 - Elbe, river separating the Lower German area (in particular the duchy of Saxony and the landgraviate of Thuringia) from more easterly regions that were added to the medieval German Empire at a later date

Ermelinc (Ermelijnc, Hermeliken) 2241, 2564, 2613 - Ermanric, king of the East Goths (fourth century), famous in Germanic heroic poetry as the owner of huge treasures

Fine 1860 - Female weasel

Fortadent 1855 - Boar: 'strongtooth'
Fyrapeel (Fierapeel) 3390, 3399, 3411, 3426, 3429, 3431, 3468 - Leopard: 'fineskin'

Gente(n) 2654 - Lioness, King Nobel's wife: 'of noble birth'

Ghent (Ghend) 92, 2263 - Ghent, town in the eastern part of Flanders, an important economic power in the thirteenth century due to its flourishing manufacture of woollen cloth

Grimbeert (Grimbeerde, Grimbeerte, Grimbeerts, Grimbert, Grimberte, Grinbert) 177, 283, 421, 1335-1762, 1887, 1897, 2231, 2259, 2286 - Badger, Reynaert's nephew

Haersint (Arsenden, Haersenden, Harsenden, Hersenden, Hersvinden, Hersvint, Yswenden) 242, 1651, 1977, 2123, 2861, 2892, 2913, 2930, 3414 - She-wolf, Ysingrijn's wife. The numerous forms of the name seem to allude to varying obscene meanings: 'she can't get enough of it'; 'arse end'; 'arse wind'

Hawy 1849 - Ewe, Belin's wife: 'oh yes!' (from French 'ah oui!')

Herman(ne) 2733 - Deacon, chairman of the ecclesiastical synod which is purported to have excommunicated Reynaert; probably a historical person

Hermeline (Ermelijnen, Ermeline, Hermelijne, Hermelinen) 1361, 1407, 1425, 2282, 2415, 3080, 3092-3166, 3218, 3231, 3321, 3327 - Vixen, Reynaert's wife

Hijfte 2262, 2263-Village north-east of Ghent in the medieval county of Flanders, approximately near present-day Lochristi

Hughelijn metten crommen beene $800-$ Villager ('little Hugh with the crooked legs')

Hulsterloe 2575, 2660 - Place (of pilgrimage) in the wooded region east of Hulst, in the medieval county of Flanders (approximately near present-day Nieuw-Namen) 
Jordane 2641 - River in the Holy Land

Jufroet 2952 - Theologian with easy-going ideas about the remission of sins without the Church's intercession; probably a historical person

Julocke (Julocken) 731, 831, 1246, 1289, 1298 Priest's wife: 'you I tempt'

Kriekeputte (Kriekepit, Kriekenputte) 2578, 2596, 2634, 2657, 2665 - Spring ('creek pit') just south of Hulsterloe

Lamfroyt (Lamfreyde, Lamfreits, Lamfroit, Lamfroits, Lamfroy, Lamfroyt, Lamfroyts) 602, 646, 647, 699-815, 860, 879, 901, 917-25, $1822 b$ - Villager

Leye 2640 - Leie, river which flows from a westerly direction into the river Scheldt in Ghent

Lonnen 2438 - London, town in England with which the county of Flanders, and especially the merchants from Ghent, had close commercial ties

Lottram Lancvoet 785 - Villager ('L. with the long feet')

Ludmoer metter langher nese 793 - Villager ('L. with the long nose')

Ludolf metten crommen vingheren 796 Villager ('L. with the crooked fingers')

Madocke 1 - Title of an earlier story written by Willem

Malcroys 273 - One of Reynaert's dens: 'wicked hole'

Manpertuus (Manpertus) 512, 514, 519, 1064, 1359, 1377, 1427, 3073 - Reynaert's strongest fortress: 'wicked hole' (in French: Malpertuis, Maupertuis)

Martinet 1171, 1212, 1217, 1227, 1228, 1242, 1256, 1278 - Priest's son
Mompelier 1156 - Montpellier, city in distant southern France

Nobel (Nobele) 44, 1769, 2752 - King Lion: 'noble'

Ogerne(n) 803 - Village woman: 'Oh, yes please!'

Pancer 126, 170, 1857 - Beaver

Parijs 2631 - Paris, capital of France, residence of the French kings

Pinte 309 - Hen, Canticleer's daughter, probably named after the colour of her feathers: 'spotted one'

Polane (Pollanen) 301, 3018 - Probably Poland, distant land east of the German empire

Portaengen 301 - Probably Brittany, the French duchy (in French: Bretagne); alternatively: England (Britain)

Portegale 599 - Probably Portugal, a distant land

Reynaerdin(e) 1411 - Young fox, Reynaert's son: 'little Reynaert'

Reynaert (Reynaerd, Reynaerde, Reynaert, Reynaerts, Reynart) passim - Fox

Reynout 2668 - Unspecified animal (dog?), counterfeiter

Rijn (Rijne) 2672, 2675 - Small dog

Roede 331 - Chicken, Canticleer's wife; named after the colour of her feathers: 'red and white one'

Roeme (Rome) 2718, 2719, 2744, 2791, 2792 Holy City, residence of the pope and major place of pilgrimage

Rosseel 1859 - Squirrel, named after the colour of his fur: 'little red one' 
Rossel 1415 - Young fox, Reynaert's son; named after the colour of his fur: 'little red one'

Rume(n) 1924 - Wolf, one of Ysingrijn's executed brothers: 'big stomach'

Sassen 2453, 2466 - Saxony in North-Germany, west of the river Elbe

Scouden 3018 - Probably the island of Schouwen in the medieval county of Zeeland; no longer an island, it is now part of the province of Zeeland in The Netherlands

Sproete 309 - Hen, Canticleer's daughter, named after the colour of her feathers: 'freckled one'

Tiecelin(e) (Ticelin, Tyecelijn) 1856, 2796, 2807 - Raven

Tybeert (Tybeerde, Tybeerte, Tybeerts, Tyberte) 107, 127, 1011-1321, 1465, 1815, 1826, 1853, 1918-2023, 2248, 2261, 2813, 2922 - Tomcat

Vermendoys 1510 - Vermendois, county in the north of France

Vlaendren 2252, 2256, 2574 - County of Flanders, in the Middle Ages a fief of the
French king, with the exception of the areas known as the 'Vier Ambachten' ('Four Shires') and the 'Land van Aalst' ('Land of Aalst'), which belonged to the German empire

Vulmaerte 788 - Village woman: 'dirty maid'

Waes 2257 - Waasland, area in the eastern part of the medieval county of Flanders, south of the area of the 'Vier Ambachten' ('Four Shires')

Wijdelancke(n) 1924 - Wolf, one of Ysingrijn's executed brothers: 'wide flank'

Willem (Willeme) 1, 3463-69 (acrostic) Author of Van den vos Reynaerde

Ysingrijn (Isingrijn, Ysegrims, Ysengrijn, Ysengrijne, Ysingrijns, Ysingrine)

62-98, 171-203, 231, 1222, 1481, 1517, 1555, 1565, 1570, 1580, 1616, 1854, 1904-2022, 2095, 2110, 2169, 2260, 2270a, 2461, 2487, 2706, 2806, 2825-2917, 2929, 2993, 3013, 3103, 3406, 3462 - Wolf

Zomme 2442 - The river Somme in Northern France; it flows in a westerly direction passing through the city of St.-Quentin. It roughly marks the south-western border of the Lower German area 


\section{Glossary}

This glossary contains the complete lexical richness of Van den vos Reynaerde. All word forms found in the text have been listed and referenced, with a maximum of five line-numbers; further occurrences are indicated by 'etc.' $(+)$ All headwords are printed in bold face type. In addition the headword of each article is in upper case, while references to headwords are in lower case.

Articles - The headwords have been derived from the Middelnederlandsch handwoordenboek (barring a few exceptions, marked ${ }^{*}$ ) and appear therefore in their normalized form. Every article states word class, main meanings in modern English, word forms found and their line numbers, and, where applicable, references to further articles. In a number of cases word forms have been subdivided further: verbs according to tense, person and number (mood: only imperative forms have been marked, and conjunctive forms insofar as they deviate from the indicative forms), nouns according to singular and plural, some indefinite and demonstrative pronouns according to attributive and independent usage. When two or more words have been collapsed into one word as a result of clisis, this form occurs in two or more articles, with the indication (clis.). For example 'souddi (clis.)' is found under SULLEN as well as GI; 'tfolc (clis.)' under DAT (I) and VOLC. In most articles these clitic forms are listed together at the end of the article (see, for example, HI), except in cases where the word forms have been further subdivided (for an example see WILLEN). In the article the word class indication is followed by one or more meanings (in italics). Meanings have been limited to indications of the general, neutral meaning (or meanings) of a particular word, as the English translation in this edition offers readers the opportunity to study the Middle Dutch word in context. In many cases the articles provide more meanings than used in Van den vos Reynaerde, making this glossary also useful for the study of other Middle Dutch texts. Standard combinations of words with their often specific meanings (like 'leet hebben', 'aflaet doen') are not listed separately (cf. the articles LEET and HEBBEN, AFLAET and DOEN).

References - If the word forms differ from the normalized form in their first three letters, they are listed as a reference to the corresponding article. This means that there are references for words like anscoen | HANTSCHOE; blauwen | BLOUWEN and boem | BOOM, but that no references have been provided in cases like broet | BROOT or bloume | BLOEME. However, exhaustive referencing has been aimed at in two specific categories. All clitic word forms have been separately referenced in the glossary (for example, comdi | COMEN + GI; buter | BUTEN (I) + DIER (II)). This also applies to identical word forms that belong to different articles (for example, baerde | BAERT, BARDE; wilde | WILLEN, WILT (I)). In addition (representative) inflected verb forms with a vowel change in their stems have been referenced, even when the variations from the (normalized) infinitive only occur after three letters: bedrouch | BEDRAGEN; ontbant | ONTBINDEN. As it is impractical to include all the word forms that occur in the edition as separate references in the glossary's alphabet, it should be noted that users will sometimes need to consult the glossary articles creatively. Note that references to other articles may also be found at the end of a particular article; compare, for example, AEN (II) (See: DAERANE); SITTEN (See also: BESITTEN); DACH (See also: CINXENDACH, DOEMSDACH, MIDDACH). 


\section{Abbreviations}

\begin{tabular}{|c|c|c|c|}
\hline $1-3$ & 1st, 2 nd, 3 rd person singular & (m.) & masculine \\
\hline $4-6$ & 1st, 2nd, 3 rd person plural & n. & noun \\
\hline (a) & accusative & (n.) & neuter \\
\hline adj. & adjective & (n) & nominative \\
\hline adv. & adverb & num. & numeral \\
\hline art. & article & ord. & ordinal \\
\hline ass. & assimilation & o.s. & oneself \\
\hline attrib. & attributive(ly) & pers. & personal \\
\hline aux. & auxiliary & p.p. & past participle \\
\hline clis. & clisis & pl. & plural \\
\hline comp. & comparative & poss. & possessive \\
\hline conj. & conjunction & pr. & present (indicative) \\
\hline cons. & consecutive & pr.p. & present participle \\
\hline (d) & dative & prep. & preposition \\
\hline decl. & declined & pret.pres. & preterite present \\
\hline em. & demonstrative & pron. & pronoun \\
\hline determ. & determinative & red. & reduction \\
\hline dim. & diminutive & refl. & reflexive \\
\hline disjunct. & disjunctive & reinf. & reinforced \\
\hline (f.) & feminine & rel. & relative \\
\hline (g) & genitive & s. & subjunctive \\
\hline $\mathrm{mp}$. & imperative & s.o. & someone \\
\hline npers. & impersonal & sg. & singular \\
\hline impf. & imperfect (indicative) & s.th. & something \\
\hline indef. & indefinite & subord. & subordinate \\
\hline indep. & independent(ly) & superl. & superlative \\
\hline inf. & infinitive & & transitive \\
\hline ter. & interrogative & undecl. & undeclined \\
\hline terj. & interjection & vb. & verb \\
\hline ntr. & intransitive & w. & weak \\
\hline & irregular & str. & strong \\
\hline
\end{tabular}

$(\dagger)$ Readers who would like to search all occurences of a given word form may use the electronic version of the edited Middle Dutch text, which is available on the website of Amsterdam University Press (www.aup.nl). 
ABBET, n. (m.) | abbot || abd 945 abd $\mid$ ABBET

ACHTE (I), n. (f.) | attention (to detail), care || achte 685

ACHTE (II), num. | eight || achte 328. - VIII 2965

ACHTEN, w. vb. | intr. - think, consider, (achten van) care for; tr. - think, mean, consider, take note of, care \| (pr.1) hachtic (clis.) 2117 ACHTER, prep. | behind, to, along, through || achter 1726, 2427

ACHTERBLIVEN, str. vb. | intr. - stay behind, get the worst of, fail (to do, to materialize), be ignored, fail to happen, cease || (inf.) bliven achter 96. - bliven achtre 1295. - (impf.3) bleef achter 2484

ACHTERENDE, n. (n.) | back end, hind quarters, back || achterhende 1932

ACHTERST, adj. | last (in a row), furthest behind $\|$ achterste 3042

ACHTERSTEKEN, str. vb. | tr. - drive back, withhold, thwart \| (inf.) steken achtre 2275

ACHTERWAERT, adv. | at the back of, backwards || achterwaert 1746

AEN (I), prep. | on, upon, from || an 138, 184, 204, 437, 457 etc. - ant (clis.) 3363

AEN (II), adv. || See: DAERANE aenbalke | HANENBALC

AENCNOPEN, w. vb. | tr. - tie (up, on to) || (inf.) an cnoepen 2030

AENDOEN, irr. vb. | tr. - put (on), pull on, dress II (inf.) an doen 2855

AENDRAGEN, irr. vb. | tr. - wear, command, ascribe to, give \| (inf.) andraghen 2907

AENGAEN, str. vb. | intr. - go to, approach, address, attack, torment; tr. - begin, do, undertake, accept, receive, take possession of $\|$ (inf.) angaen 187. - (impf.3) ghinc an 261. ghinc ane 814

AENROEPEN, str. vb. | tr. - call s.o., shout, argue $\|$ (impf.3) riep an 1049

AENSCHIJN, adv. | apparently || anschijn 1777

AENSCHINEN, str. vb. | intr. - shine on, be apparent $\|$ (inf.) anschine 1814

AENSICHTE, n. (n.) | face, appearance, mask || aensichte 741

AENSLAEN, str. vb. | tr. - hit, fasten; intr. begin (to speak, sing) $\|$ (inf.) aneslaen 442 AENTIËN, str. vb. | tr. - accuse s.o. of, blame s.th. on, charge \| (inf.) tyen an 2237. - (impf.6)

teghen an 2060

AENVAERDEN, w. vb. | tr. - undertake a journey to, attack, take possession of, carry \| (impf.6) anevaerden 3329

aerbeit $\mid$ ARBEIT

aercheit $\mid$ ARCHEIT

aerm- $\mid$ ARM-

AES, n. (n.) |food, prey || ase 3129

AEX, n. (f.) | axe || haex 701, 735

AF, adv. \| See: DAERAF

AFBERNEN, w. vb. | tr. - burn off || (inf.) afbernen 1502

AFBITEN, str. vb. | tr. - bite off, cut off || (p.p.) afghebeten 289

AFCOMEN, str. vb. | intr. - descend (from), be freed from, lose, cease, finish (a task) || (imp.pl) comt af 1800

AFDOEN, irr. vb. | tr. - take s.th. off, remove, abolish, terminate, destroy; deprive, dismiss, release s.o.; refl. - resign, renounce $\|$ (inf.) afdoen 2894. - (p.p.) afghedaen 949

afghebeten $\mid$ AFBITEN

afghedaen $\mid$ AFDOEN

af ghenomen | AFNEMEN

afghesleghen $\mid$ AFSLAEN

af ghewonnen $\mid$ AFWINNEN

AFLAET, n. (m.n.) | omission, neglect, absolution, indulgence || aflaet 835, 1672, 2718, 2763, 2794. - aflate 2909

AFNEMEN, str. vb. | tr. - take away (from); intr. - get less, decrease \| (p.p.) af ghenomen 159 AFSLAEN, str. vb. | tr. - cut off, behead, shorten, deduct; intr. - turn off, get cheaper \| (p.p.) afghesleghen 1730

AFSNIDEN, str. vb. | tr. - cut off, mow, amputate $\|$ (impf.3) sneet af 2843-2844 AFVLOEYEN, w. vb. | intr. - run, flow (away) II (impf.3) afvloyde 2889

AFWINNEN, str. vb. | tr. - obtain, catch, deprive of $\|$ (p.p.) af ghewonnen 1744 aghedochte | HAGEDOCHTE

AL (I), indef. pron.; used attrib. + indep. | all, completely, each, every, everything $\|$ (attrib.) al $57,72,91,236,325$ etc. - alle $49,333,364,365$, 467 etc. - allen $366,716,734,844,882$ etc. tallen (clis.) 672, 2360 - alles 102. - alre 778 , $836,1343,2330,2795$. - (indep.) al 696, 738, 772, 1997, 2460. - alle 1239, 1492, 1683, 1974, 2069 etc. 
AL (II), adv. | entirely, wholly, continuously, absolutely \| al 19, 90, 391, 392, 413, 427 etc.

AL (III), prep. | through, along || al 2443

AL (IV), conj. | although, however, when, as || al $32,91,116,194,238$ etc.

ALDAER, adv. | there, where || aldaer 1531, 1580, 2100, 2250, 2406 etc. - aldaert (clis.) 1539

aldaert $\mid$ ALDAER + HET (I)

ALDUS, adv. | thus, in this way || aldus 108, 1429, 2397, 3360

ALDUSDAEN, adj. | in such a way, like this || aldusghedanen 3069. - aldustanen 862

ALGADER (I) * indef. pron. | all together, altogether || (attrib.) algader 1272, 1929, 2414, 2457, 2543 etc. - allegader 1003, 1451, 2216, 2503. - algadre 1141. - allegadre 1236. - (indep.) allegader 2227

ALGADER (II), adv. | together, entirely || algader 2116, 2571, 2884, 3168

ALINEEN, adv. | continually || alineen 1251 alle, allen, alles, alre $\mid \mathrm{AL}(\mathrm{I})$ allegader, allegadre $\mid A L G A D E R$

ALLENE (I), adj. | alone, by oneself || alleene 1209, 1305, 2754, 2953, 3076 etc.

ALLENE (II), adv. | only, exactly, except for, entirely, in the same way $\|$ alleene 50, 104, 214, 799, 1066 etc.

ALLERBEST (I), adj. (reinf. superl. of GOET) | very best || alrebeste 1534

ALLERBEST (II), adv. (reinf. superl. of WEL) | in the best possible way || alrebest 468

ALLERMEEST, adv. (reinf. superl. of VELE III) | most, more than any other || alremeest 2192

ALLERMINST, adj. (reinf. superl. of CLEINE) | smallest, least, less than any other || alremintsten 2126

ALLERSCHARPST * adv. (reinf. superl. of SCHARP) | worst, most violently, most villainously || alrescaerpst 784

ALLES, adv. | in all respects || alles 797 alre- | ALLER-

\section{alrenaest $\mid$ NAEST}

ALS, adv. | in all, (a. ende a.) entirely, certainly || als ende als 3025. - als ende hals 3279

ALSE, conj. | as, as if, when, because || alse, 83, $618,1100,1201,1260$ etc. - alsene (clis.) 346. als dat 1650. - also als 506, 2632, 2702, 3225. alsi (clis.) 2997. - alsic (clis.) 2047. - alst (clis.) 1732

alsene $\mid$ ALSE + -ENE alsi $\mid$ ALSE + SI

alsic $\mid$ ALSE + IC

ALSO (I), adv. | as, thus, so, very, provided, also || also, 54, 82, 173, 582, 617 etc. - alsoe 2831

ALSO (II), conj. | as, if, as if, when || also, 654, 1341, 2143, 2704, 3342. - also als 506, 2632, 2702, 3225. - alsoet (clis.) 1265

alsoet $\mid$ ALSO (II) + HET (I)

ALSOF, conj. | as if || alse oft 2988

alst $\mid$ ALSE + HET (I)

ALTEGADER, adv. | completely, entirely || altegader 2439

ALTEHANT, adv. | immediately, at once || altehant 539

ALTOOS, adv. | always, entirely || altoes 2962, 3001

AME, n. (f.) | barrel, measure for liquids (ca.155 liters) \| (pl.) hamen 619

AMEN, interj. | amen $\|$ amen, 2015. - ameen 2014 an, an- $\mid$ AEN, AEN-

ANDER, pron.; used attrib. + indep. | other, second, the other, the next || (attrib.) ander 276, $367,805,1438,2418$ etc. - des ander daghes 1167, 2927. - dandre (clis.) 1871 - andren 1019, 1900, 2388, 2525. - (indep.) ander 298, 782, 783 . - dandre (clis.) 72, 1410 - andren 186, 191, 192, 1710, 2738. - manlic andren 1574, 2103.

ANDERS, adv. | differently, in a different case, else $\|$ anders 2990

ANDERSINS, adv. | in a different way, in a different case $\|$ andersins 84

ANDERWERF, adv. | for the second time, once more, on another occasion $\|$ anderwaerf 2778 andwoerde $\mid$ ANTWORDE, ANTWORDEN andwoerdi $\mid$ ANTWORDEN + HI anscoen $\mid$ HANTSCHOE ant $\mid A E N+D A T(I)$

ANTWORDE, n. (f.n.) | answer, accountability II andwoerde 2140, 2947

ANTWORDEN, w. vb. | tr. - answer, reply (inf.) andwoerden 2806. - antwoerden 1810. (impf.3) andwoerde 1442, 1736, 1985, 2142, 2623, 3173, 3425. - andwoerdi (clis.) 221

ANXT, n. (m.) | fear || anxt 3199

APEERT, adv. | shamelessly, publicly || apeert 204

APRIL, n. (m.) | April $\|$ aprille 322

ARBEIT, n. (m.f.) | work, effort, trouble, labour (also when giving birth) || aerbeit 2871. aerbeide 743 
ARCH, adj. | bad, wicked || erghe 2343. - ergher 919

ARCHEIT, n. (f.) | wickedness, sin || aercheit 2955. - (pl.) eerchede 2535

arde $\mid$ HARDE

arem|ARM

ARGERTIERE, adj. | wicked || argertieren 2526

ARM, adj. | destitute, insignificant, unhappy || aerme 566, 2323, 2766. - aermen 838, 934. arem 38, 101, 564, 773, 1027 etc. - arems 1320

ARMINC, n. (m.) | wretch, fool, poor devil || aermijnc 2071, 2204

ARMOEDE, n. (m.f.n.) | poverty || aermoede 2664

ase $\mid$ AES

at ETEN

autare | OUTAER

AVENTURE, n. (f.) | story, history, happening, adventure, chance, bad luck, destiny, fate \|

avonture 624. - avontuere 31, 394, 401, 2593. avontueren 161, 349, 1349, 1389. - (pl.) avonture 4 AVONT, n. (m.f.) | evening $\|$ avont 1068. avonde 1906 || See also: TAVONT

avonture | AVENTURE

AY, interj. | oh, alas || ay 987, 1026, 1425, 1560, 1811 etc.

BACHTEN, adv. | on the other side, at the back || bachten 1286, 2896

baden | BIDDEN

baerde | BAERT, BARDE

baerken | BERKE

BAERT, n. (m.) | beard || baert 3191. - baerde $60,858,1980$

BAKE, n. (m.f.) | side of bacon || bake 217, 224, 227, 1513, 2121. - (pl.) baken 1519

BALCH, n. (m.) | belly, stomach, skin || balghe 2815

\section{balch | BELGEN}

BALLINC, n. (m.) | outlaw, exile, s.o. who has been excommunicated $\|$ ballinghe 2728

BAN, n. (m.) | (official) announcement, decree, exile, excommunication || ban 2716, 2950. banne 2742

BANDERSIDE, adv. | on the other side, on the other hand $\|$ banderzijde 1826

BANNEN, str.+w. vb. | tr. - excommunicate, ban, exile || (p.p.) tebannen 2734, 2736 || See also: VERBANNEN bantse $\mid$ BINDEN + -SE

BARAET, n. (n.f.m.) | deception, deceit, trick, cunning plan, derision || baraet, 483, 1192, 1482, 2043. - barate, 1704, 2379, 3088, 3402. - baraten 353

BARBACANE, n. (f.) | barbican, curtain wall || barbecane 522

BARDE, n. (m.) | adze, axe, battle axe || baerde 701

BARE, n. (f.) | stretcher, bier || bare 286, 291, 309, 418, 1600. - baren 293

BAREN, w. vb. | tr. - make public; refl. - appear, show o.s.; intr. - appear, turn up \| (inf.) baren 2400 || See also: MISBAREN

baren | BERE

BAROEN, n. (m.) | vassal, baron, nobleman || (pl.) baroene 1329, 1879

BASSEN, str.+w. vb. | intr. - bark, make a (loud) noise \| (inf.) bassen 1593

bat $\mid$ BET, BIDDEN

BATE, n. (f.) | advantage, profit, help, compensation || bate 2908. - baten 192

becaremde | BEKERMEN

BECLAGEN, w. vb. | tr. - regret, bemoan, feel sorry for; refl. - complain $\|$ (pr.3) beclaghet 1472. - (impf.3) beclaghede 1525. - (impf.6) beclaechden 2300. - (p.p.) beclaghet 1345, 1371 becnause | BECNAUWEN + -SE

BECNAUWEN, w. vb. | tr. - gnaw, chew on, nibble at $\|$ (imp.sg.) becnause (clis.) 225

BECOMEN, str. vb. | intr. - arrive, grow up, like, taste $\|$ (impf.3) bequam 2094. - (impf.6) bequamen 2459

BECOPEN, irr. w. vb. | tr. - bribe (s.o.), profit (from a sale), atone for, pay for $\|$ (inf.) becoepen 350, 643, 1959, 2036, 2537 etc.

BEDACHT, adj. (p.p. from BEDENKEN) | sensible || bedacht 1915

BEDDE, n. (n.) | bed || bedde 1241, 1303

BEDE, n. (f.) | prayer, request, command || bede 1738

BEDENKEN, w. irr. vb. | consider, think of, reconsider, have second thoughts $\|$ (p.p.) bedocht 84 || See also: BEDACHT

BEDI (I), adv. | for that reason, surely || bedi 2351, 2907, 2990

BEDI (II), conj. | because, as || bedi 3125 bedocht | BEDENKEN

BEDRAGEN (I), str. vb. | tr. - cover, accuse, cheat, deceive; refl. - behave o.s. || (inf.) 
bedragen 2229. - bedraghen 2194. - (p.p.)

bedreghen 2523

BEDRAGEN (II), str. (w.) vb. | tr. - feed; refl. - provide for o.s. || (impf.3) bedrouch 2670 . (impf.6) bedroughen 2710

bedreghen | BEDRAGEN (I)

BEDRIEGEN, str.+w. vb. | tr. - cheat, forge, counterfeit || (inf.) bedrieghen 486 . - (p.p.)

bedroghen 206, 692, 1479, 3184, 3401

bedrouch, bedroughen $\mid$ BEDRAGEN (II)

BEDWANC, n. (n.) | force, power, domination || bedwanc $886,1841,2301$

BEDWINGEN, str. vb. | tr. - force, control (o.s.) || (inf.) bedwinghen 1728 || See also:

BEDWONGEN

BEDWONGEN, adj. (p.p. from

BEDWINGEN) | enforced || bedwongene 3177

beede | BEIDE

BEEN, n. (n.) | bone, leg || been 2517. - (pl.)

been 1266, 2013, 3026. - beene 145, 800

beere | BERE

beet $\mid$ BITEN

begaert | BEGEREN

began | BEGINNEN

BEGEREN, w. vb. | tr. - desire, fancy, request, attack || (pr.5) begaert 2005. - begheerdijt (clis.) 1113. - (impf.1) begheerde 2374. - (p.p.) begaert 2255

BEGEVEN (I), w. vb. | tr. - leave, abandon; refl. - enter a convent, monastery $\|$ (inf.) begheven

24, 1497, 2955. - (p.p.) begheven 155, 273, 1484 \| See also: BEGEVEN (II)

BEGEVEN* (II), adj. (p.p. from BEGEVEN I) | reclusive, conventual, monastic || begheven 369

begheerdijt | BEGEREN + GI + HET

BEGIEN, w. vb. | tr. - confess, declare || (p.p.)

beghiet 2949

BEGIN, n. (n.) | beginning, entrance || beghin 12

BEGINNEN, str.+w. vb. | tr. - start, begin s.th., intend; intr. - originate (from) \| (inf.) beghinnen 443, 1030. - (pr.1) beghinne 40. - (impf.1) began 361, 2378. - (impf.3) began 108, 693, 972, 1624, 1751 etc. - begonste 64, 1319, 3386. - (impf.4) begonsten 2104. (impf.6) begonsten 146. - begonden 1709. - (p.p.) begonnen 9, 538, 1695 || See also: ONTGINNEN

BEGRAVEN, str.+w. vb. | tr. - bury, dig || (inf.) begraven 458, 461. - (p.p.) begraven 2607, 2697
BEGRIPEN, w. vb. | tr. - seize, apply, engage, blame, rebuke, disprove, comprise $\|$ (pr.1)

begripic (clis.) 32

begripic $\mid$ BEGRIPEN + IC

BEHENDELIKE, adv. | in a clever or sly way, secretively, suitably $\|$ behendelike 1685

BEHENDICHEIT, n. (f.) | cleverness, slyness. || behendichede 2485

BEHOUDEN, str. vb. | tr. - keep, protect, save, keep alive, get/keep hold of, control II (pr.s.3) behoude 173. - (impf.s.3) behilde 2350, 2352. (p.p.) behouden 768

BEIDE, num. | both || beide 700. - beede 147, $681,745,751,792$ etc. - beeden 2702 . - beeder 151, 3062. - beede ... ende ... (13), 42, 408, 832, 837 etc.

BEIDEN, w. vb. | intr. - wait, await; tr. postpone $\|$ (inf.) beiden 1183. - (pr.6) beiden 1098

BEJACH, n. (n.) | booty, advantage, possession || bejach 119, 276, 507

BEJAGEN, w. vb. | tr. - acquire, seize, catch; refl. - support, provide for o.s. || (inf.) bejaghen 2912, 3351. - (impf.3) bejaghede 1936, 2110. (impf.4) bejagheden 2120. - bejaechden 2106. (p.p.) bejaghet 2128

bekenden | BEKENNEN + -ENE

BEKENNEN, w. vb. | tr. - hear, learn, get to know, recognize, have (sexual) intercourse; refl. - repent, understand $\|$ (inf.) bekinnen 457. - (impf.3) bekinde 2824. - bekende 983. bekenden (clis.) 539

BEKERMEN, w. vb. | tr. - regret, bemoan, lament || (impf.3) becaremde 3053

bekinde, bekinnen || BEKENNEN

BELAGEN, w. vb. | tr. - ambush, attack, deceive II (inf.) belaghen 3451

BELANC, adj. (attrib.) | related $\|$ belanc sijn 2537

BELGEN, str. vb. | intr. - swell up, be angry, lose one's temper; refl. - get upset about s.th. || (inf.) belghen 2683. - (pr.5) belghedi (clis.) 3210. (impf.3) balch 1745, 2917, 2970, 3200 || See also: VERBELGEN

belghedi | BELGEN + GI

BELOKEN, adj. (p.p. from BELUKEN)| closed, gloomy, obscure || belokenre 2265

beloken | BELUKEN

BELOPEN, str. vb. | tr. - catch, catch up with, take off guard, tempt $\|$ (inf.) beloepen 2538. (p.p.) belopen 349 
BELOVEN, w. vb. | tr. - promise, announce; refl. - rejoice (in), be grateful (for) || (impf.3) beloofde 2430. - (p.p.) belovet 3182 BELUKEN, str. vb. | tr. - enclose, shut in, limit || (p.p.) beloken 335, 1165 || See also: BELOKEN bem | SIJN (I)

benden | BINDEN

BENEDEN, prep. | under, beneath || beneden 508, 777

BENEMEN, str. vb. | tr. - deprive, prevent, obstruct || (impf.1) benam 2472

BENIDEN, str.+w. vb. | tr. - resent, annoy, envy |l (impf.3) benijdde 340

bequam, bequamen $\mid$ BECOMEN

BEQUAME, adj. | agreeable, pleasant, useful, capable || bequame 620 || See also: ONBEQUAME

BEQUAMELIJC, adj. | agreeable, palatable, useful $\|$ bequamelic 1115

BERADEN (I), str. vb. | tr. - counsel, deliberate, bring about, support, be merciful (God); refl. consider, deliberate, intend to. $\|$ (inf.) beraden 435, 592, 3228. - (impf.3) beriet 551, 639, 1921. (impf.6) berieden 2192. - (p.p.) beraden $2992 \|$ See also: BERADEN (II)

BERADEN (II), adj. (p.p. from BERADEN I) | sensible, willing, determined $\|$ beraden 478, 1970 BERCH, n. (m.) | mountain, mountain range || berch 509, 552, 881. - berghe 284, 2869

BERE, n. (m.) | bear || beere, 479, 518, 710, 717, 720. - baren 2463

BEREHUUT, n. (f.) | bearskin || beerehuut 926 BEREIT, adj. (p.p. from 'bereiden') | ready, prepared, willing || bereet 617

beriet, berieden | BERADEN

BERINGEN, w. vb. | tr. - surround, encircle || (p.p.) beringhet 779

BERKE, n. (f.) | birch || berke 2696. - baerken 2606. - (pl.) baerken 2603

BEROUWEN, str.+w. vb. | intr. - regret || (pr.3) berauwet 3437

BEROUWENISSE, n. (f.) | repentance ||

berouwenisse $1434 \mathrm{~b}$

BERRENDE, adj. (pr.p. from 'bernen') |

burning || berrende 303

besat | BESITTEN

bescalt | BESCHELDEN

BESCHELDEN, str. vb. | tr. - abuse, taunt, call names, mock; intr. - mock, call names || (impf.3) bescalt 936
BESCHEREN, str. vb. | tr. - shave (esp. of the tonsure), rob || (p.p.) bescoren 947, 2708

BESCHERMEN, w. vb. | tr. - protect, defend, resist $\|$ (inf.) bescaermen 405

BESCHOUWEN, w. vb. | tr. - see, consider, inspect || (inf.) bescauwen 1579

BESCHULDICH, adj. | guilty || besculdich 53 bescoren | BESCHEREN

beseekede | BESIKEN

BESEM, n. (m.) | broom || bessem 722

BESIEN, str. vb. | tr. - see, regard, judge; intr. - take care of $\|$ (inf.) besien 3281. - (imp.pl.)

besiet 1017

BESIKEN *, str. vb. | tr. - piss upon || (impf.3) beseekede 75

BESITTEN, str. vb.| tr. - sit, occupy, possess, acquire, undergo, lay siege to $\|$ (impf.3) besat 2564

BESPIEN, w. vb. | tr. - spy on, notice, observe || (p.p.) bespiet 3164

BESPREKEN, str. vb. | tr. - discuss, declare, agree, consult; refl. || (inf.) bespreken 435. (impf.6) bespraken 467

BEST (I), adj. (superl. of GOET I) | excellent, (the) best || beste 211, 515, 1385, 1875. - (n.) die beste 86 || See also: ALLERBEST (I)

best $\|$ BEST (II), SIJN (I)

BEST (II), adv. (superl. of WEL) | (the) best, (the) most, (the) soonest, (the) most preferable, (the) easiest || best 436, 798, 969, 1005, 1330 || See also: ALLERBEST (II)

BESTAEN, str. vb. | intr. - remain, begin, undertake, have a right to, do, live, suit; tr. attack, undertake, accept $\|$ (inf.) bestaen 553, 1040, 1354, 2624. - (pr.3) bestaet 970, 1822a. - (impf.3) bestoet 1898. - (p.p.) bestaen 1092, 1692

besteecse | BESTEKEN + -SE

BESTEKEN, str. vb. | tr. - sting, prick, attack, arouse, enclose $\|$ (pr.1) besteecse (clis.) 1193 BESTELEN, str. vb. | tr. - steal, hide away || (p.p.) bestolen 2146

bestoet $\mid$ BESTAEN

bestolen | BESTELEN

BESTORMEN, w. vb. | tr. - storm || (inf.) bestormen 1377 bestu | SIJN (I) + DU

BET, adv. (comp. of WEL) | better, rather, sooner, further, later \| bet 226, 255, 540, 1062, 1087 etc. - bat 2234,3180 
BETAMEN, w. vb. | intr. - be becoming/fitting/ suitable $\|$ (pr.3) betaemt 1782

beteghen | BETIËN

BETER, adj. (comp. of GOET I) | better, more, more considerable, other \| beter 1096, 1102, 1399, 2057. - beteren 1095. - betren 3356

BETEREN, w. vb. | tr. - repair, make amends, pay a penalty, reconcile; refl. - be reconciled with s.o. who has done penance || (inf.) betren 3415 , 2770, 2788. - (pr.s.3) betere 2729

BETIËN, str. vb. | tr. - accuse, rebuke || (p.p.) beteghen 2524

BEVAEN, str. vb. | tr. - catch, acquire, undertake, cover, be absorbed by, associate with \| (p.p.) bevaen 43, 517, 899, 2747

beval | BEVELEN

BEVELEN, str. vb. | tr. - summon, command, recommend, entrust $\|$ (inf.) bevelen 382. - (pr.1) bevele 1408. - bevelic (clis.) 1410. - (impf.3)

beval 439, 1978, 3279

bevelic | BEVELEN + IC

BEVEN, w. vb. | intr. - shiver, tremble || (pr.1) beve 1434. - (pr.5) bevet 2651. - (impf.3) beefde 1749, 2972

BEVER, n. (m.) | beaver || bever 126, 1857

BEWACHTEN, w. vb. | tr. - guard, keep secure II (inf.) bewachten 405

BEWANEN, w. vb. | tr. - think, mean, suspect || (pr.3) bewaent 176. - (imp.pl.) bewaent 2203

BEWANT, adj. (p.p. from 'bewenden') | in a particular state/position || bewant 1626

BEWERVEN, str. vb. | tr. - acquire, cause || (inf.) bewerven 2166. - (p.p.) beworven 2881 BEYAERT, n. (m.) | chimes, ringing of (church) bells, carillon || beyaert 1268

BI (I), prep. | at, near, together with, at the time of, through, at the loss of, through forfeit of $\|$ bi $117,118,123,158,161$ etc.

BI (II), adv. | near | bi 602, 1123, 1438, 1615, 1916 etc. || See also: DAERBI

BIDDEN, str. vb. | tr. - pray, insist on, request, beg for || || (inf.) bidden 2966, 2996. - (pr.1) bidde 12. - biddic (clis.) 482, 1672. - bids (clis.) 3083. - (imp.pl.) bidt 1462, 1722, 2760, 3079. - (impf.1) bat 2968. - badic (clis.) 2348. (impf.3) bat 30, 852, 2995, 3135, 3347. - (impf.6) baden 2306, 2494, 3044. - (impf.s.3) bade 2998. - (p.p.) ghebeden 27, 2772 || See also: GEBIDDEN

biddic | BIDDEN + IC bids | BIDDEN + -ES

BIECHTE, n. (f.) | confession || biechte 1439, 1691, 2055 - biechten 1437, 1443, 1456, 1657, 1718 etc.

BIEDEN, str. vb. | tr. - inform, order, offer, promise, summon $\|$ (pr.3) biedt 3459. - biet 3439. - (p.p.) gheboden $265,365 \|$ See also: GEBIEDEN, ONTBIEDEN

BIER, n. (n.) | beer || bier 2174 || See also: CLOESTERBIER

bijspel | BISPEL

BILE, n. (m.) | axe $\|$ bijlen 816

BINDEN, str. vb. | tr. - bind, fetter, attach, oblige || (inf.) binden 1487. - benden 2931. (impf.3) bantse (clis.) 2837. - (impf.6) bonden 1590. - (p.p.) ghebonden 2832, 2920, 3014, 3027 || See also: ONTBINDEN, VERBINDEN

BINNEN (I), prep. | within, inside, during || binnen 140, 141, 175, 270, 988 etc.

BINNEN (II), adv. | in, inside || binnen 572, 1077, 1791, 3029 || See also: DAERBINNEN BISANT, n. (m.) | gold or silver coin || busant 1150

BISPEL, n. (n.) | parable, proverb, example || bijspel 181

BISSCHOP, n. (m.) | bishop || bisscop 2964 BITEN, str. vb. | tr. - bite || (impf.3) beet 1313, 1938. - (p.p.) ghebeten 3126 || See also: AFBITEN, ONTBITEN, VERBITEN

BLAER, adj. | with a blaze (white spot) on its forehead, scapegoat, bald, destitute $\|$ (n.) die blare 2490

BLANDEN, w.+str. vb. | tr. - mix, blend || (inf.) blanden 2177

BLASE, n. (f.) | bobble, blister, bladder || blase 248

BLASEN, str. vb. | intr. - blow, hiss, boast; tr. blow (an instrument) || (inf.) blasen 2050

blauwen | BLOUWEN

BLEEC, adj. | pale || bleec 279

bleef $\mid$ BLIVEN

blenden | BLINDEN

BLETEN, w. vb. | intr. - bleat, wail || (inf.)

bleeten 2084

bleve, bleven | BLIVEN

blever binnen | BLIVEN + DAERBINNEN

bleves | BLIVEN + -ES

BLIDE, adj. | glad, cheerful, happy || blide 389, 656, 2019, 2539, 2546 etc. - bliden 2765 || See also: ONBLIDE 
BLIKEN, str. vb. | intr. - shine, sparkle, make an appearance; refl. - show o.s. || (inf.) bliken 3373 BLINDEN, str. vb. tr. | blind, make s.o. blind, dazzle \| (inf.) blenden 1839

BLISCHAP, n. (f.) | joy, enjoyment || bliscap $826,898,908,914,1223$ etc.

BLIVEN, str. vb. | intr. - | remain, stay, fail to happen, die, give birth || (inf.) bliven 165, 546, 758, 907, 1182 etc. - dit bliven 3190. - (pr.3) blivet 1283, 2864. - (pr.4) bliven 3320. - (pr.5) bleves (clis.) 199. - (imp.pl) blivet 3315. blijft 3040. - (impf.s.1) bleve 1110. - (impf.3) bleef $683,719,1425,1604,2116$ etc. - (impf.6) bleven 5, 1974, 3262. - blever binnen (clis.) 750. - (p.p.) bleven 866, 1654, 2925 || See also: ACHTERBLIVEN

BLODE, adj. | cowardly || bloode 1194 BLOEDICH, adj. | bloody || bloedich 1464, $1816,1822,2090$

BLOEME, n. (f.) | flower, blossom, the best (of a group) \| (pl.) bloumen 324

BLOET, n. (m.) | blood, complexion, family, person || bloet 756, 808, 932, 2079, 2889 etc. bloede 868

BLOOT (I), adj. | uncovered, naked || bloeter 1258

BLOOT (II), adv. | evidently, in a straightforward way || bloot 1666

BLOUWEN, str. vb. | tr. - hit, strike || (inf.) blauwen 251. - (p.p.) teblauwen 1580, 1823

BODE, n. (m.) | messenger, servant $\|$ bode 525, 1012, 2599. - (pl.) boden 1814

bodscap | BOOTSCHAP

BOEC, n. (m.n.)| book, charter $\|$ (pl.) boucken 8

BOECSTAVE, n. (m.) | letter $\|$ (pl.) boucstave 459

boem | BOOM

boes, boes- | BOOS, BOOS-

bonden | BINDEN

BOOM, n. (m.) | tree, pole | boem 184, 660, 683, 852,2097

BOOS, adj. | wicked, malicious || boesen 857. bosen 2345

BOOSHEIT, n. (f.) | malice || boesheit 2072. (pl.) boesheden 685

BOOTSCHAP, n. (f.) | message || bodscap 477, $481,1355,2474$

BORCH, n. (m.f.n.) | fortress, town || (pl.) borghe 2452. - borghen 515
BORNE, n. (m.f.n.) | source, spring, well || borne 2578, 2586

BORSE, n. (f.) | purse || burse 1267

BOSCH, n. (m.n.) | wood, forest || bosch 42, 2362, 2575

bosen | BOOS

BOTTELGIER, n. (m.) | master butler (at a court) || bottelgier 2801

boucken | BOEC

boucstave | BOECSTAVE

BOUDELIKE, adv. | quietly, bravely ||

boudeliken 1768

BOUT, adj. | bold, fearless, imperturbable || bouden 1765. - (comp.) bouder 2087. - (n.) die boude 1262

BOVEN (I), prep. | above, more than, over, except, in spite of $\|$ boven 1548, 1952

BOVEN (II), adv. | up || boven 1617 || See also: DAERBOVEN

brac, brake | BREKEN

bracht | BRINGEN

BRADEN, str. vb. | tr. - roast, burn alive; intr. to be roasted $\|$ (inf.) braden 1838

BRAUWEN, w. vb. | tr. - hem (of an article of clothing), seel or stitch together (the eyelids of a bird of prey) || (inf.) braeuwen 2885

BREET, adj. | broad, large || breet 2846

BREKEN, str. vb. | tr. - break, demolish, conquer; refl. - force o.s.; intr. - stop, weaken, lack || (inf.) breken 531, 954. - (impf.3) brac 680, 1675. - (impf.s.3) brake 2344. - (p.p.) tebroken 166 || See also: GEBREKEN, INBREKEN, OPBREKEN

BRIEF, n. (m.) | letter, inscription, charter || brief 358, 2222, 3287, 3362. - (pl.) brieve 2433,

2459, 3349, 3352

BRIESCHEN, w. vb. | intr. - growl || (inf.)

briesschen 693

brincdi $\mid$ BRINGEN + GI

BRINGEN, w. irr. vb. | tr. - bring, bring along, bring about, bring forth, announce, spend \| (inf.) bringhen 432, 663, 2043, 2172. - bringe 2270c. - (pr.1) bringhe 528, 3435. - (pr.5) brincdi (clis.) 1989. - (impf.3) brocht 215. brochte $286,358,367,373,700$ etc. - (impf.4) brochten 2418. - (p.p.) brocht 83, 332, 651, 1646. - bracht 685 || See also: UTEBRINGEN, VOLBRINGEN, VORTBRINGEN, WEDERBRINGEN brocht(e), brochten | BRINGEN 
BROEDER, n. (m.) | brother (family), brother (monastic order), companion, fellow \| (pl.)

broeders 305, 1923

BROEDERSONE, n. (m.) | brother's son, nephew $\|$ broedersone 178, 1336

BROET, n. (n.) | brood || broede 332, 392

BROOT, n. (n.) | bread, livelihood || broet 3067

BROUWEN, str.+w. vb. | tr. - brew, plot ||

(pr.4) bruwen 1956. - (p.p.) ghebrauwen 2175

BRUGGE, n. (f.) | bridge || brugghe 1725

BRUUN, adj. | brown, shining || brunen 858 ||

See also: Bruun (proper name)

bruwen | BROUWEN

buke | BUUC

burse | BORSE

busant $\mid$ BISANT

BUTEN (I), prep. | outside, without, distant from || buten 393, 1603, 1683, 1699, 1706 etc. buter (clis.) 1694

BUTEN (II), adv. | outside, out, (know) by heart || buten 1183, 1209, 2493, 3076

buter | BUTEN (I) + DIER (II)

BUTSEEL, n. (m.) | leather bag for wine or meat || butseel 1858

BUUC, n. (m.) | belly, stomach, trunk, beehive || buuc 556, 663, 1524. - buke 1577

CAF, n. (n.) | chaff, worthless item \| caf 1799

CALF, n. (n.) | calf $\|$ calf 2110

can | CONNEN

CAPELLAEN, n. (m.) | chaplain || capelaen

143, 2942, 2976

CAPOEN, n. (m.) | capon || cappoen 1533, 1698

CAPROEN, n. (m.) | cap, hat, monk's hood || capproen 944

CARINE, n. (f.) | fast (as during Lent), pain || carine 423. - (pl.) karijnen 280

CARITATE, n. (f.) | charity, alms, Christian charity || karitate 278

carmede | KERMEN

carminghe $\mid$ KERMINGE

CARRE, n. (f.) | cart || karre 2412. - kerren 209

CASTEEL, n. (n.m.) | castle, fortress || casteel

274, 514, 1377, 1403, 3344. - casteele, 708

CASTIËN, w. vb. | tr. - rebuke, punish, goad,

preach; intr.; refl. - take as an example, better o.s.

II (inf.) hu castyen 489

CATER, n. (m.) | (male) cat, tomcat, scoundrel, devil || cater 107, 1011, 1454, 1826, 1918 etc. - kater 2248, 2261. - (pl.) catren 2463 caut | COUT

chierheit | SIERHEIT

CINXENDACH, n. (m.) | Whitsuntide ||

tsinxendaghe 41

CLAER, adj. | clear (oflight, face, sound), sharp

(of intellect), pure, obvious || claerre 1441

CLAERLIKE, adv. | clearly, entirely, truthfully

|| claerliken 1657

CLAGE, n. (f.) | complaint, lament, accusation || claghe 61, 125, 127, 248, 255 etc. - (pl.) claghen 1851,1876

CLAGEN, w. vb. | intr. - complain, feel sorry for o.s., accuse; tr. - bemoan, regret $\|$ (inf.) claghen 194, 989, 1127, 1323, 1785. - te claghene 59. een claghen 1758. - wat claghen 2899. - (pr.1) claghic (clis.) 116, 419. - (pr.3) claghet 114, 235, 253. - (impf.3) claechde 2823. - claghede 100, 2711. - (impf.6) claechden 2316 || See also: BECLAGEN

claghen | CLAGE, CLAGEN

claghic $\mid$ CLAGEN + IC

CLARE, adv. | clearly (of light, sound), purely, obviously || claer 1100

CLAREN, w. vb. | tr. - illuminate, clarify, elucidate; refl. - clear o.s.; intr. - become clear \| (inf.) claren 2959. - (pr.5) claert 2742

CLAUWE, n. (f.) | claw || (pl.) claeuwen 750, $967,1264,2462,2884$ etc.

cleene $\mid$ CLEINE

CLEET, n. (n.) | piece of material, cloth, article of clothing || cleet 1939

CLEINE, adj. | small, fine, clean, little, low || cleene 49, 826, 1027, 1426, 1843 etc. - cleenen 3081, 3093. - (n.) dat cleene 2105 || See also: MINDER (comp.), ALLERMINST (reinf. superl.)

CLEMMEN, str. vb. | intr. - climb, rise, increase II (inf.) clemmen 1617, 1946

CLEPEL, n. (m.) | clapper (of a bell), knocker (on a door) || (pl.) clippelen 1293

CLERC, n. (m.) | member of the clergy, scholar, clerk, pupil || clerc 251, 3362, 3372

CLIEVEN, str. vb. | tr. - split; intr. - (cause to) split, burst || (inf.) clieven 652

clippelen | CLEPEL

CLOCKE, n. (f.m.) | clock || clocken 1297 CLOCKENLINE, n. (f.) | bell rope || (pl.) clockelijnen 1486

CLOETE, n. (m.f.) | barge pole, ball, testicle || cloet 786. - cloete 792 
CLOOSTER, n. (n.m.) | convent, monastery || cloester 1740

CLOOSTERBIER, n. (n.) | beer brewed in a monastery || cloesterbier 1955

CLOOSTERCRUNE, n. (f.) | monk's tonsure || cloestercrune 1951

CLUSE, n. (f.) | hermitage || cluse 275

CLUSENAER, n. (m.) | hermit || clusenare 268, 369, 422, 3064

CNAGEN, str.+w. vb. | tr. - gnaw || (p.p.)

ghecnaghet 2127

CNAPE, n. (m.) | boy, servant, squire || cnape

1217

cocht $\mid$ COPEN

COENE, adj. | brave, audacious, composed, proud || coene 326, 690, 1353, 2006, 2087 etc. coenen $2444 .-$ (n.) die coene 3431

\section{coepen $\mid$ COPEN}

COEVER, n. (n.m.) | supply, abundance, power || couver 569

COKEN, w. vb. | tr. - cook, plot || (inf.) koken

789

comdi $\mid$ COMEN + GI

comedi $\mid$ COMEN + GI

COMEN, str. irr. vb. | intr. - come, rise, descend from, happen || (inf.) comen 473, 961, 979, 2339, 2376 etc. - commen $285,699,760,2252,2446$ etc. - (pr.1) comme 1394, 1450, 3198. - (pr.3) comt 194, 705, 1022, 1342, 1542 etc. - commet 2586 . - (pr.5) comt 3171. - commet 2602. comedi (clis.) 3338. - comdi (clis.) 527, 1070. (pr.6) commen 14, 2783. - (pr.s.3) come 1017. - (imp.sg.) com 3237. - (imp.pl.) comet 2645. - comt 2644. - (impf.1) quam 118, 2095, 3230. - (impf.3) quam 272, 291, 356, 503, 608 etc. (impf.6) quamen $48,725,1002,1163,1569$ etc. - (impf.s.1) quame 1398. - (impf.s.3) quame 475, 1107, 2447. - (p.p.) comen 79, 160, 519, 1754, 2797. - commen 87, 314, 1088, 2768. || See also: AFCOMEN, BECOMEN, INCOMEN, MISCOMEN, ONTCOMEN, UTECOMEN, WEDERCOMEN

COMPLETE, n. (f.) | compline (last of the daily hours) || complete 951

CONDEN, w. vb. | tr. - inform, announce ||

(inf.) conden 2055. - (pr.5) condi (clis.) $1798 \|$

See also: ORCONDEN

condi $\mid$ CONDEN / CONNEN + GI

CONFITERI*, vb. (Latin) | confess $\|$ (pr.1)

confiteor 1453
CONINC, n. (m.) | king || coninc 44, 63, 65, 100, 110 etc. - conincs 1005, 1370, 1395, 1693, 3266 etc. - conincx 1391, 1317. - coninx 141, 525, 977, 1219, 2167. - sconincx (clis.) 2272, 2689. sconinx (clis.) 48, 55, 140, 196, 1753 etc.

CONINCKLIKE, adv. | regal, powerful || coninclike 363

CONINGINNE, n. (f.) | queen || coninghinne 1475, 2151, 2165, 2180, 2491 etc.. - coninghinnen, 2209, 2851

CONNEN, irr. vb. (pret. pres.) | be able to (do), know, cope II (pr.1) can 806, 1662, 3300, 3302. - (pr.3) can 262, 687, 1034, 1799, 1913. - (pr.6) connen 1787, 1192. - (impf.1) conste 3225. (impf.3) conste 342, 404, 462, 755, 757 etc. const 953. - conde 202, 749. - condi (clis.) 1527. - (impf.6) consten 1889, 1890 conste, consten $\mid$ CONNEN

CONT, adj. | known, renowned, acquainted with || cont 716, 1905

CONVENT, n. (n.) | gathering, conventual community, agreement $\|$ convent 1608. - covent 2532

COPEN, w. irr. vb. | tr. - buy, pay for || (inf.) coepen 2439. - (impf.3) cocht (clis.) $2616 \|$ See also: BECOPEN

CORT, adj. | short, small, strong || corten 1496, $1985,2244,2807$

CORTEN, w. vb. | tr. - | make smaller, shorten; intr. - get less, decrease \| (pr.1) corte 1874. (imp.pl.) cort 1934

COSTEN, w. vb. | intr. - cost, be worth || (inf.) costen 2654d. - (impf.3) coste 1075

COSTER, n. (m.) | sacristan || coster 728, 729, 763,813

COUDE, n. (f.n.) | cold || coude 2650, 2663

COUT, adj. | cold, placid || caut 2297. - couden 2096 couver | COEVER

CRACHT, n. (f.) (en m.) | force, power, speed, violence, rape || cracht 347, 1302, 2046, 2266, 2414 etc. - crachte 686,1036

CRAEYEREN, w. vb. | intr. - call, shout; tr. announce $\|$ (inf.) crayeren 45

CRAGE, n. (m.f.) | neck || craghe 2979, 3265

CRAKEN, w. vb. | intr. - creak; tr. - break, torture $\|$ (impf.3) crakede 1287 cramp | CREMPEN

CRANC, adj. | weak, ill, poorly, insignificant, poor $\|$ cranc 1013, 1842. - crancke 563, 869, 1845. 
- crancken 56, 1757, 1994, 2132

CREATURE, n. (f.) | creature, living being, human being || creature 2588. - creatuere 1350, 1700

CREDE, n. (m.f.) | (the) creed || crede 142, 148, 388. - credo 249

CREMPEN, str. vb. | intr. - shrink, shrivel up; tr. - (cause to) shrink \| (impf.3) cramp 1503 croep | CRUPEN

CROM (I), adj. | crooked, bent, faulty, misshapen || crom 505. - crommen 633, 796, 800

CROM (II), n. (n.) | injustice || crom 2961

CRONE, n. (f.) | wreath, crown || crone 2612. cronen 1782

CROP, n. (m.) | knob, throat || crop 1931. croppe 288

CRUCESTAF, n. (m.) | staff with a crucifix attached $\|$ cruusstaf 727,811

CRUNE, n. (f.) | crown, tonsure || crune 947, 1464, 1499, 1816, 1822 etc. || See also: CLOOSTERCRUNE

CRUPEN, str. vb. | intr. - creep, bend, sneak || (inf.) crupen 859, 1619. - (imp.pl.) crupet 675, 1177. - cruupter in (clis.) 1629. - (impf.3) croep 871, 1623. - (p.p.) ghecropen 396 || See also: INCRUPEN

cruupter in | CRUPEN + DAERINNE

CRUUT, n. (n.) | herb, medicinal plant || cruut 2590

CUME, adv. | with difficulty, hardly, almost || cume 611, 768, 2125, 2137, 2914

CUPE, n. (f.) | barrel, tub || (pl.) cupen 1518

DACH, n. (m.) | day, daylight, time, session (of a court of law), term $\|$ dach $80,834,1100,1318$, 1373 etc. - dages 1104 . - daghes 1167,2086 , 2927. - daghe $136,385,408,905,1083$ etc. - (pl.) daghe 1684, 2455. - daghen 1786, 2469, $3148 \|$ See also: CINXENDACH, DOEMSDACH, MIDDACH

dade, daden, | DOEN

DAER, adv. | there, in that direction, then, where II (dem.) daer 58, 154, 349, 394, 448 etc. - (rel.) daer 14, 75, 118, 171, 275 etc. || See also: -ER DAERAF, adv. | from/of/about that/which/ whom, as a result, for that/which reason $\|$ (dem.) daeraf 1456, 2957. - datter af (clis.) 80. - ghevere af (clis.) 1042. - hebbicker af (clis.) 573. - sulter af (clis.) 3267. - (rel.) daer af 70, 1344, 1718. daer of 21 .
DAERANE, adv. | upon that/which, to him/her/ them, thereto, next, afterwards \| (dem.) daeran 93, 205, 362, 455, 1884. - deran 923. - daer an 2082. - hadder an (clis.) 122. - mochtire an (clis.) 133. - (rel.) daer an 224, 2053. - daert an (clis.) 2762. - daer ane 212, 360 .

DAERBI, adv. | with it/him/her/them, with which/whom, as a result, moreover, about that/ which $\|$ (dem.) daerbi 2982, 3188. - daer bi 2148. - (rel.) daer bi 2710

DAERBINNEN, adv. | within, in there, meanwhile || (dem.) daerbinnen 2054. - daer binnen 458. - siere binnen (clis.) 341. - blever binnen (clis.) 750

DAERBOVEN, adv. | up there, above, contrary to $\|$ daerboven 1636

DAERINNE, adv. | inside, in him/her/them/it, in whom, in which \| (dem.) daerin 653, 675, 1623, 2594, 3266 etc. - (rel.) daer in 56, 120, 854, 1052, 1125 etc. - cruupter in (clis.) 1629

DAERMEDE, adv. | with him/her/them/it, with whom, with which, also, in addition $\|$ (dem.) daermede 1120, 1139. - daermet 594, 2115. gaffer mede (clis.) 1676. - ghincker met (clis.) 795. - hadder met (clis.) 2438. - hebber met (clis.) 1230. - (rel.) daer mede 544-545, 1268, 2670, 2682, 2879.

DAERNA, adv. | after which, later, afterwards II (dem.) daerna 432, 761, 763, 764, 766 etc. daernare 2371. - (rel.) daer na 296

DAEROMME, adv. $\mid$ for that/which reason, therefore, why, about then/there \| (dem.) daeromme $246,583,896,1111,1385$ etc. - stonder omme (clis.) 2185. - (rel.) daer omme 2, 733, 3335-3336.

DAEROMTRENT, adv. | approximately, roughly $\|$ (dem.) daeromtrent 810

DAERONDER, adv. | under which || (dem.) daeronder 374. - daer onder 2607. - (rel.) daer onder 2697

DAEROPPE, adv. | on/upon which, to him/her/ them/whom, thereupon, after $\|$ (dem.) daerup 456. - (rel.) daer up 2754, 3292

DAEROVER, adv. | about which/whom, above, present, contrary to, in defiance of $\|$ (dem.) daer over 510-511

daert an | DAERANE + HET (I)

DAERTEVOREN, adv. | previously || (dem.)

daertevoren 682, 1167

DAERTOE, adv. |for/to that/which || (dem.) 
daertoe 11, 36, 189, 445, 996 etc. - doere toe (clis.) 2961. - hiere toe (clis.) 3289. - sauder toe (clis.) 1216. - sechdire toe (clis.) 3463. - wilre toe (clis.) 2873. - (rel.) daer toe 337.

DAERWAERT, adv. | to, there, where || (dem.) daerwaert 152, 2032

DAET, n. (f.) | deed, action, matter, force ||daet 836, 1004, 1991, 2795, 2897 || See also: MISDAET, ONDAET, OVERDAET, WELDAET

\section{daet, daedt $\mid$ DOEN}

daet $\mid$ DOEN + HET (I)

DAGEN, w. vb. | intr. - dawn, stay, linger; tr. - give respite, postpone, summon, summon to a court of law \| (inf.) daghen 1007, 1023, 1340. zijn daghen 3149. - (pr.3) daghet 1346. - (p.p.) ghedaghet 1372

DAGERAET, n. (f.) | dawn || dagheraet 1094, 2044

\section{daghe, daghes, daghen $\mid \mathrm{DACH}$}

DAL, n. (n.) | valley, depth, hole || dale 284, 540, 890, 910,958

DAME, n. (f.) | lady || dame 1849

DAN (I), adv. | then, next, at least || dan 346, 434, 472, 975, 1157 etc. - danne 2145

DAN (II), conj. | than, except, only, but, except/ but only, or || dan 22, 104, 123, 232, 240 etc. danne 2040. - dant 411, 1655

dan | DAT (I) + EN (I)

DANC, n. (m.) | thought, desire, thanks, reward, price \| danc 548, 1228, 3105, 3268, 3290

dancti $\mid$ DANKEN + GI

dandre $\mid$ DIE (I) + ANDER

DANEN, adv. | from there, there ... where ||

danen $272,880,1398,1563,1605$ etc. - danen dat 2797

DANKEN, w. vb. | intr. - thank, reward, get even $\|$ (inf.) dancken 876, 1925. - (pr.5) dancti (clis.) 2328. - (imp.pl.) danct 2472. - (impf.3) dancte 2566

dannes $\mid$ DAT (I) + EN (I) + SIJN (I)

dant $\mid$ DAN (II) + HET (I)

dar|DORREN

dart | DORREN + HET (I)

DAREN, w. vb. | tr. - hurt (also feelings); intr. harm \| (inf.) daren 904

DAS (I), dem. pron. (n. sg. g) | that $\|$ (indep.)

das 3108

DAS (II), n. (m.) | badger || das 58, 177, 421, 1335, 1755 etc. - (pl.) dassen 2465
DAT (I), dem. pron. + art. (n. sg. n/a); used attrib. + indep. | the, that || (attrib.) dat 57, $88,444,451,715$ etc. - ant (clis.) 3363. - dort (clis.) 502. - int (clis.) 314, 475, 719, 1467, 1529 etc. - tfolc (clis.) 2057. - tgat (clis.) 1284. tghetal (clis.) 410. - tgoet (clis.) 2859. - tgraf (clis.) 457. - tgroete (clis.) 2105. - theeren (clis.) 2340. - thijs (clis.) 1505. - thoeft (clis.) 159, 678, 748, 1730. - thof (clis.) 1321. - thonich (clis.) 598. - tlaken (clis.) 91. - tleven (clis.) 1498. - tlijf (clis.) 3132. - tloepen (clis.) 755. - tmijn (clis.) 3150. - tsout (clis.) 2429. - twoeste (clis.) 2268. - upt (clis.) 848. (indep.) dat $25,180,188,252,260$ etc. - dan (clis.) 123. - dannes (clis.) 564. - dats (clis.) 115, 1949, 2582, 2903, 2908.

DAT (II), rel. pron. (n. sg. n/a) | that, what, which, who \| dat 92, 114, 215, 304, 335 etc.

DAT (III), conj. | that, if, as, because, so that, insofar as, until \| dat 4, 7, 12, 17, 30 etc. - dat (clis.) $34,102,240,1208,1263$ etc. - als dat 1650. - danen dat 2797. - die wijle dat 842. - hoe dat 22. - indien dat 2187, 2468, 2507, 2820. - nadien dat 2221, 2758. - sint dat 264, 402. - teerst dat 1431, 2400. - ten eersten dat 1364, 2288. - tote dien dat 2214. - dats (clis.) 1962, 2712. - dattene (clis.) 228, 354, 1346. - datter (clis.) 76. - datter af (clis.) 8o. - dattu (clis.) 2872

dat 1 DAT (III) + HET (I)

dattene $\mid$ DAT (III) + -ENE

datter | DAT (III) + DAER

datter af $\mid$ DAT (III) + DAERAF

dats $\mid$ DAT (I) + SIJN (I) / DAT (III) + -ES

dattu | DAT (III) + DU

DE, art. || See: DIE (I)

DECKEN, w. vb. | tr. - cover, hide, cover up, keep secret || (impf.1) decte 2372. - (impf.3) decte 2393 || See also: ONTDECKEN dede, deden $\mid$ DOEN

dedi $\mid$ DOEN + HI

dedic $\mid$ DOEN + IC

dedine $\mid \mathrm{DOEN}+\mathrm{HI}+-\mathrm{ENE}$

DEEL, n. (n.) | part, partly, a short while, share, place || deel 222, 350, 1262, 2068, 2109 etc. deele 220

deene $\mid$ DIE (I) + EEN (I)

DEGENE, dem. + determ. pron. | the one who || (determ.) denghenen 1871a, 2428. - (dem.) denghenen 2275

DEKEN, n. (m.) | deacon || deken 2733, 2964 
DELEN, w. vb. | tr. - part, divorce; intr. separate || (inf.) delen 2107, 2910

DELIJT, n. (n.) | enjoyment, joy || delijt 1224

DELVEN, str. vb. | intr. - dig; tr. - dig, bury ||

(inf.) delven 2608 || See also: ONTDELVEN

den | DIEN (I)

denghenen | DEGENE

DERDE, ord. | third || derde 2779. - derden

1376. - derdes 2086

der $\mid$ DIER (II)

der DIE (I) + HERE (I)

deran | DAERANE

derre $\mid$ DESE

DES (I), dem. pron. || See: DIES (I)

DES (II), rel. pron. (m./n. sg. g) | of which $\|$ des 611

DESE, dem. pron.; used attrib. + indep. | this, these \| (attrib.) dese 15, 31, 230, 283, 418 etc. desen $270,282,302,434,551$ etc. - derre 979. (indep.) dese 2567, 3329. - desen 596, 988, 1011, 1080, 1233 etc.

DEUS, n. (m.); (Latin) | God || deus 2034

dheerde $\mid$ DIE (I) + ERDE

dher | DIE (I) + HERE (I)

dhuwe | DIE (I) + UWE

DI, pers. pron. (2 d/a) | you || di 921, 922, 928,

1437,1478 etc.

DICHTEN, w. vb. | tr. - dictate, compile, invent

II (inf.) dichten 3300. - mijns dichtens 26. -

(impf.1) dichte 3357,3359

DICHTERE, n. (m.) | poet, author || dichtre

3356

DICKE, adv. | frequently, often || dicke 207, 2823, 2875, 3135. - dicken 2, 70, 343, 1127, 1388 etc.

DICWILE, adv. | frequently, often || dicwile 201

DIE (I), dem. pron. + art. (m. sg. $\mathrm{n}-\mathrm{f}$. sg. n/a - pl. n/a); used attrib. + indep. | the, this, that, these, those || (attrib.) die 4, 7, 32, 33, 44 etc. entie (clis.) 1871b, 2165, 2186, 2306, 2449 etc . - (art.) de 126, 290, 291, 348, 396 etc. dandre (clis.) 72, 1410, 1871. - deene (clis.) 2125, 2609. - der (clis.) 1968. - dher (clis.) 2881. - dheerde (clis.) 2373. - dhuwe (clis.) 1843. - dysere (clis.) 3465. - (indep.) die 107, 306, 526, 570, 850 etc. ॥ See also: DIEN (I), DIER (II), DIES (I)

DIE (II), rel. pron. (m. sg. $\mathrm{n}-$ f. sg. $\mathrm{n} / \mathrm{a}-\mathrm{pl}$. $\mathrm{n} / \mathrm{a})$ | that, who, which || die 1, 6, 16, 19, 23 etc. diene (clis.) 858,1593 . - diere (clis.) 1631. - dies (clis.) 176, 2409, 2436. - diese (clis.) 2305, 2311. - diet (clis.) 39, 1921, 2192. - entie (clis.) 191
DIEDEN, w. vb. | tr. - explain; intr. - be valid, benefit || (pr.3) diet 1446. - diedet 3177

DIEF, n. (m.) | thief, criminal, miscreant || dief 129, 185, 357, 1327, 1415 etc. - (pl.) dieve 2434 ॥ See also: HOENDERDIEF

DIEFTE, n. (f.) | theft, offence, crime || diefte $351,1445,2058$

DIEGENE, dem. + determ. pron.| he, she, the one, those, the people who \| (determ.) dieghene 34,2041

DIEN* (I), dem. pron. (m. sg. d/a - pl. d of

DIE I - n. sg. d of DAT I); used attrib. + indep. | the, that, this || (attrib.) dien 149, 161, 387, 476, 982 etc. - mettien (clis.) 1917, 2018, 2809. den $8,13,18,60,63$ etc. - enten (clis.) 13, 3413. - huten (clis.) 399, 506, 651, 1128, 1392 etc. metten (clis.) 60, 416, 765, 796, 800 etc. - toten (clis.) $888,1233,2586,2739,2882$ etc. - tote dien dat 2214. - (indep.) dien 1537, 1790, 2117, 2214 ॥ See also: TEN

DIEN* (II), rel. pron. (m. sg. d/a - pl. d of DIE II - n. sg. d of DAT II) | who (m), which, that || dien 219, 330, 942, 1695, 1827 etc.

diene $\mid$ DIE (II) + -ENE

DIENEN, w. vb. | intr. - serve, be of use, (d. met/van) serve with, provide with; tr. - deserve, serve $\|$ (inf.) dienen 2429. - (pr.5) dient 942. (impf.3) diende 157, 1594. - (p.p.) ghedient 550, 1802 || See also: VERDIENEN

DIEP, adj. | deep, wet, thick || diep 824, 2366. diepen, 2356, 2462

DIEPE, adv. | deep || diepe 859

DIER (I), n. (n.m.) | animal || dier 88, 139, 338, 746,856 etc. - diere 956. - (pl.) dier 1871, 2246. - diere 49, 778, 1455, 1461, 1841 etc. - dieren 365 , 1019, 1869, 1876, 2336 etc.

DIER (II), dem. pron. (f. sg. g/d - pl.g); used attrib. + indep. | the, that || (attrib.) dier 934, 1598, 2442, 2606. - entier (clis.) 2442. - (art.) der 35, 158, 209, 293, 373 etc. - buter (clis.) 1694. - enter (clis.) 820. - metter (clis.) 713, 763, 793, 813,1094 etc. - toter (clis.) 986, 1536, 1645, 2851. - uter (clis.) 681, 1523, 1908. - (indep.) dier 1786 || See also: TER

diere $\mid$ DIE (II) + -ER

DIES * (I), dem. pron. (m. sg. g of DIE I - n. sg. $g$ of DAT I); used attrib. and indep. | of the || (attrib.) - des 141, 525, 731, 825, 1167 etc. sconincx (clis.) 2272, 2689. - sconinx (clis.) 48, 55, 140, 196, 1753 etc. - sduvels (clis.) 2266, 2267, 
2706. - sheere (clis.) 2461, 3442. - shonichs (clis.) 1116. - sleets (clis.) 1276. - snachts (clis.) 1107. - spaeus (clis.) 2716, 2950. - spapen (clis.) $826,1575,2819$. - (indep.) dies 72, 769, 1059, 1133, 2238 etc. - des 656, 775, 826, 876, 1219 etc. || See also: TES

DIES (II), adv. | that is why, for that reason || dies 94, 339, 478, 2306

dies $\mid$ DIE (II) + -ES

diese $\mid$ DIE (II) + -SE

DIESGELIKE, adv. | also, too, as well as ||

diesghelike 2324

diet $\mid$ DIE (II) + HET (I)

DIETSCH, n. | Dutch || dietsche 5, 9, 1459 DIEU *, n. (m.); (French) | God || dieu 937 DIJN, poss. pron. (2) | your || dijn 917, 2872. dine 1960. - dinen 1049a, 2871. - dijnre 2621 DINC, n. (n.f.) | thing, action, lawsuit, story || dinc $267,1269,1343,1770,2484$ etc. - dinghe 476, 2755. - (pl.) dinghen 2337, 2747, 2786, 3305, 3469 || See also: SOENDINC

DINGEN, w. vb. | intr. - sit (of a court of law), plead, speak, strive; tr. - urge, plead, pillage, ravage II (inf.) dinghen 607. - (p.p.) ghedinghet 780 dincken $\mid$ DUNKEN

dine, dinen $\mid \mathrm{DIJN}$

dinghen | DINC, DINGEN

DIT, dem. pron.; used attrib. + indep. | this, these || (attrib.) dit 12, 230, 618, 627, 929 etc. (indep.) dit 86, 98, 165, 174, 233 etc. - ditte 2595 doch $\mid \mathrm{TOCH}$

\section{dochte | DUNKEN}

DOCHTER, n. (f.) | daughter || dochter 427. (pl.) dochtren 329

DODEN, w. vb. | tr. - kill, invalidate || (inf.)

dooden 1942 || See also: DOOT (II)

doe $\mid$ DOE (I) (II), DOEN

DOE (I), adv. | then || doe 48, 144, 146, 151, 154 etc. - doe so 1159,1488

DOE (II), conj. | when, while || doe 57, 98, 210, 220, 283 etc.

doedi $\mid$ DOEN + GI

DOEMSDACH, n. (m.) | doomsday ||

domsdaghe 3443

DOEN, irr. vb. | aux.; tr. - do, make, bring, accomplish, give; intr. - act; refl. - go to, position o.s. || (inf.) doen $943,1043,1137,1715,1834$ etc.

- te doene $383,689,1354,1655,1878$ etc. - (pr.1) doe $22,586,1148,2134$ etc. - doere toe (clis.) 2961. - (pr.3) doet 125, 237, 531, 1021, 1041 etc. - (pr.5) doet 197, 481, 1736, 2498, 2553 etc. - doedi (clis.) 280o. - (pr.6) doen 1792. - (pr.s.3) doe 2763. - (imp.pl.) doet 532, 1037, 1133, 1945, 2861 etc. - (impf.1) dede 1463, 1465, 1466, 1486, 1502 etc. - dedic (clis.) 1499, 1504, 1517, 1616, 1654 etc. - (impf.3) dede 7, 244, 266, 553, 716 etc. - dedi (clis.) 136, 1262, 1265, 1520, 1608 etc. - dedine (clis.) 144. - (impf.4) daden 3229. - (impf.5) daedt 3057. - (impf.6) daden 24, 621, 807, 1724, 1867 etc. - deden 457 . - (impf.s.3) dade 1036, 1106, 1330, 1992, 2494. - daet (clis.) 2195. - (p.p.) gedaen 1434c. - ghedaen 44, 69, 81, 89, 186 etc.

|| See also: AENDOEN, AFDOEN, GEDOEN, MISDOEN, ONTDOEN, VOLDOEN

doere toe $\mid$ DOEN + DAERTOE

doet $\mid$ DOEN, DOOT

DOGEN, w. vb. | tr. - suffer || (pr.3) doghet 281. - (impf.4) dogheden 2416. || See also: GEDOGEN

DOGET, n. (f.) | virtue, honour, generosity, strength, good deed || doghet 3136

doghet | DOGEN, DOGET

DOL, adj. | stupid, foolish || (comp.) dulre 918

DOLE, n. (f.) | uncertainty, unconsciousness, confusion || dole 2402

DOMINUS *, n. (m.); (Latin) | Lord ||

dominus 2065 .

DOMPHEIT, n. (f.) | stupidity, folly || dompheit 3369

domsdaghe | DOEMSDACH

DONKER(I), n. (n.) | darkness || doncker 502

DONKER (II), adj. | dark, obscure, secret, severe || (superl.) donckerste 541

dooden | DODEN

DOOT (I), n. (f.m.) | death || doot 307, 986, 1307, 1645, 1984 etc. - doet 1434a

DOOT (II), adj. (p.p. from DODEN) | dead, invalid || doot 172, 839, 905, 1141, 1844 etc. doode 287 || See also: STEENDOOT

DORDAT, conj. | because, so that || dordat 111, 216, 885, 897, 3030

DORE (I), n. (m.) | fool || (pl.) doren 13, 33

DORE (II), prep. | through, in spite of, for the benefit of, because of $\|$ dor 25, 66, 67, 231, 243 etc. - dort (clis.) 502

DORP, n. (n.) | village, field || dorp 715, 719, 1529. - dorpe 1584, 1603, 2262, 2398

DORPER, n. (m.) | villager, lout, scoundrel || dorper 602, 779, 1822c, 2346. - (pl.) dorperen 845 . - dorpren 13, 33. - dorpers 866 
DORPERHEIT, n. (f.) | lack of manners, insolence, wickedness, disgraceful action \| dorperheit 1669

DORREN, irr. str. vb. (pret. pres.) | dare, need, must, may, can \| (pr.1) dar 1354, 2007, 2923, 2948. - dart (clis.) 239, 3461. - (pr.5) dorret 2530. (impf.1) durste 2400. - (impf.3) dorste 52, 758 dorst $\mid$ DORST, DORVEN

DORST, n. (m.) | thirst $\mid$ dorst 280

dorste | DORREN, DORVEN

dort | DORE (II) + DAT (I)

DORVEN, irr. str. vb. (pret. pres.) | need, may, must, dare || (impf.3) dorste 887. - (impf.5)

dorst 2580

DOVEN, w. vb. | intr. - be out of one's mind, rampage, become deaf $\|$ (inf.) doven 1714

DRAGEN, str. vb. | tr. - carry, contain, take, bring, lead, support, commit, inform, receive; refl. - join, go to, behave o.s.; intr. - amount to, move quickly, be aimed at, concern, benefit, help \| (inf.) draghen 2411, 3253, 3350, 3352. - (pr.1) draghe 3264. - (pr.3) draghet 2876, 3340. - draecht 269. - (pr.5) draghet 944. - (impf.1) droughic (clis.) 2326. - (impf.3) drouch 303, 729, 786, 794, 2025 etc. - drouchene (clis.) 1303. - (impf.4) droughene (clis.) 2420. - (impf.6) droughen 309. - droughene (clis.) 1601. - (impf.s.1) droughe 3259, 3348. - (p.p.) ghedreghen 881, 902, 3275 || See also: AENDRAGEN, BEDRAGEN, GEDRAGEN, OPDRAGEN, OVEREENDRAGEN, VERDRAGEN, VORTDRAGEN

dranc|DRINKEN

dreechdem | DREIGEN + HEM (I) dreecht, dreeghen | DREIGEN

dreef, dreven | DRIVEN

DREIGEN, w. vb. | tr. - threaten || (inf.)

dreeghen 1327. - (pr.3) dreecht 1069. - (impf.3) dreechdem (clis.) 774

DRIE, num. | three || drie 1023, 1340, 1966, 1997, 2003. - III 1372, 1908, 2732, 2798, 2805 || See also: DERDE

drijfdi | DRIVEN + GI

DRINGEN, str. vb. | tr. - push, harass; intr. force one's way through || (p.p.) ghedronghen 2826 DRINKEN, str. vb. | tr. - drink, experience (distress), drown; intr. || (inf.) drincken 706, 2178. - (impf.3) dranc 3134 || See also: DRONKEN

DRIVEN, str. vb. | tr. - hunt, drive, do, work, express; intr. - move, drive, approach, come \| (inf.) driven 545, 908. - dryven 959, 2380. (pr.5) drijfdi (clis.) 3394. - (pr.6) dryven 1128. - (impf.3) dreef 976, 1879, 3242. - (impf.6) dreven 308. - (pr.p.) dryvende 852. - (p.p.) ghedreven 865,1554 || See also: VERDRIVEN DROEFLIKE, adv. | sadly, miserably || drouvelic 3051

DROEVE, adj. | sad, gloomy, miserable, dark, turbid || drouve 1044, 1425, 2062, 3381. - drouven 2179, 2893, 2898, 3383. - (comp.) droever 872

DROGE, adj. | dry, withered, feeble || droghe 2366

DRONKEN, adj. (p.p. from DRINKEN) | drunk $\|$ droncken 2280

drouch, droughen | DRAGEN

drouchene, droughene $\mid$ DRAGEN + -ENE

droughic | DRAGEN + IC

DRUUT, n. (m.) | friend, mate \| druut 925

dryven | DRIVEN

DU, pers. pron. (2 n) | you || du 918, 1958, 2622. bestu (clis.) 920. - dattu (clis.) 2872. - haetstu (clis.) 562. - heefstu (clis.) 927. - sechstu (clis.) 2200. - weetstu (clis.) 2657

DULDE, adj. | insignificant, low, mean ||

(superl.) dulsten 493

DULEN, w. vb. | intr. - cry, weep, howl || (inf.)

dulen 693

dulre $\mid \mathrm{DOL}$

DUNKEN, irr. w. vb. | intr. - appear, mean || (inf.) dincken 198. - (pr.3) dinct 126, 233, 1014, 1096, 1399 etc. - dincket 665, 1368. - (impf.3)

dochte 362, 499, 954, 1055, 1090 etc.

durste | DORREN

DUS, adv. | thus, so || dus 9, 166, 204, 314, 340 etc.

DUSDAEN, dem. pron. | in such a way || (attrib.) dusdanen 1704

DUSENT, num. | thousand || dusent 1091, 2616 DUVEL, n. (m.) | devil || duvel 1494, 3204. duvels 1276. - sduvels (clis.) 2266, 2267, 2706 DWAEN, irr. str. vb. | tr. - wash, clean, cleanse || (inf.) dwaen 1456

DWINGEN, str. vb. | tr. - push, subject, force (o.s.); intr. - have trouble breathing, feel oppressed || (inf.) dwinghen 664. - (impf.s.3) dwonghe 2305 || See also: BEDWINGEN dwonghe | DWINGEN dysere | DIE (I) + ISER 
ECHT, adv. | then, next, again, before long || echt 1644, 2960, 3411, 3425

EDEL, adj. | noble, distinguished, excellent || edel 991, 2203, 2551. - edele 581, 830, 2180, 2615, 2760

EDELHEIT, n. (f.) | nobility, aristocracy ||

edelheit 66

eecke | EIKE

eede $\mid$ EET

EEN (I), num. | one || een 295, 399, 782, 783, 785 etc. - eene $137,745,825,976,2007$ etc. - deene (clis.) 2125, 2609. - eenen 1273, 1293, 1612, 2230. - teenen (clis.) 60o. - tenen (clis.) 332 || See also: EERSTE

EEN (II), art. | a, an || een 26, 99, 128, 129, 134 etc. - eens 804, 1320, 2278. - teenen (clis.) 2262, 2309, 2756, 3282. - eere 134, 135, 153, 175, 179 etc. - teer (clis.) 2239. - teere (clis.) 1615, 2845

EEN (III), indef. pron. | someone, something, a certain $\|$ een 2182. - eene 27

EENCOREN, n. (m.n.) | squirrel || eencoren

1859

eenich, eeneghe $\mid \mathrm{ENICH}$

EENLIJC, adj. | lonely || eenlic 883

EENT, n. (m.) |duck $\|$ (pl.) haenden 2088

EER (I), adv. | earlier, before, first, rather, sooner || eer 3039. - eere 3187. - wijlen eere 101. - eer ... eer 3262-3263 || See also: WILENEERE

EER (II), conj. | before || eer 749, 880, 977, 1016, 1079 etc.

\section{eerchede $\mid$ ARCHEIT \\ eerden $\mid$ ERDE \\ eere | EEN (I) (II), ERE}

EERSTE (I), ord. | first || eerste 3109

EERSTE (II), adv. | first, before, in the first place, for the first time $\|$ eerst 2072. - ten eersten 1364, 2079, 2288, 3233. - enten eersten 912. - teerst

(clis.) 1431, 2052, 2400, 3433

EET, n. (m.) | oath, curse $\|$ eede 1805

eewelike | EWELIJC

EI, n. (n.) | egg || ey 3180

EIGEN, n. (m.n.) | property, proprietor, serfdom

|l eyghin 2320

EIKE, n. (f.m.) | oak || eecke 651, 655, 859, 965.

- eecken 681

EISCH, n. (m.) | request, desire, command || heesch 3066

EISCHEN, w.+str. vb. | tr. - request, ask, claim || (impf.3) heesschede 220

eist | SIJN (I) + HET

EL, pron. | other, else || hel 571, 3240
ELC, indef. pron.; used attrib. + indep. | each, everyone || (indep.) elc 810, 2758

ELKERLIJC, indef. pron. | everyman, every one || elkerlijc 302, 2878

ELWAER, adv. | elsewhere || elwaer 2592

EMMER, adv. | ever, always, forever, in any case, after all $\|$ emmer 19, 409, 787, 1261, 1489 etc.

EMMERMERE, adv. | henceforth, from now on, forever, in any case, certainly $\|$ emmermeer 1281, 2320

EN (I), adv. | not || en 25, 102, 112, 116, 136 etc. - ne 21, 27, 76, 96, 130 etc. - dan (clis.) 123. dannes (clis.) 564. - in (clis.) 205, 559, 586, 1085, 1148 etc. - inne (clis.) 93, 492, 560, 1605. - men (clis.) 2616. - nes (clis.) 1438, 2408, 2521, 2557, 3155

EN (II), conj. | if, but || en 2411. - ne 59, 113, 132, 475, 1329 etc.

ENDE (I), conj. | and, but, while, if, when, although, in order that, so that $\|$ ende 8, 15, 33, 36, 42 etc. - enten (clis.) 13, 3413. - enten (clis.) 912. - enter (clis.) 820. - entie (clis.) 191, 1871b, 2165, 2186, 2306 etc. - entier (clis.) 2442

ENDE (II), n. (n.m.) | end, conclusion, edge || hende 1080 || See also: ACHTERENDE, OOSTENDE

ENDEN, w. vb. | tr. - stop, end; intr. - stop, end || (p.p.) ghehent 450

-ENE, enclitic pers. (and refl.) pron. (3 m.d/a $-6 \mathrm{~d}) \mid$ him, them, himself, themselves || (-en, -ene, -ne) alsene (clis.) 346. - bekenden (clis.) 539. - dattene (clis.) 228, 354, 1346. - dedine (clis.) 144. - diene (clis.) 858, 1593. - drouchene (clis.) 1303. - droughene (clis.) 1601, 2420. ghegreepene (clis.) 3119. - ghincken (clis.) 1249. - ghinckene (clis.) 789. - ghine (clis.) 216. - hanghene (clis.) 1961. - hebben (clis.) 1646. - heeftene (clis.) 987, 2803. - hiefsene (clis.) 1302. - hine (clis.) 472, 902, 912, 932, 936, 2477. - hoendine (clis.) 217. - hortene (clis.) 1635. - icken (clis.) 1505, 1609, 1634. - ickene (clis.) 1466. - leeddickene (clis.) 1508, 1610. leidene (clis.) 1600. - lietene (clis.) 1591, 1592. maectene (clis.) 1483. - men (clis.) 1912, 2888. - menne (clis.) 1007. - mesleettene (clis.) 208. - namene (clis.) 1600. - salne (clis.) 1023, 1340. - siettene (clis.) 939. - sine (clis.) 1128, 1588, 1644. - slouchene (clis.) 817. - soene (clis.) 1980. - soudene (clis.) 143. - spaerdene (clis.) 1255. - stacken (clis.) 787. - sulne (clis.) 3422. - 
warpene (clis.) 229, 1567. - wildine (clis.) 610, 939

ENGIEN, n. (n.) | ingenuity, trick, means || engiene 452

ENICH, indef. pron.; used attrib. | some, any, something, anything || eeneghe 1669, 2681, 3259, 3448. - eeneghen 2059. - eenegher 2160. eenich 139, 1136, 2583, 2591. - enich 2654e. enige $2654 \mathrm{f}$

enten | ENDE (I) + DIEN (I) / TEN

enter | ENDE (I) + DIER (II)

entie | ENDE (I) + DIE (I) / DIE (II)

entier | ENDE (I) + DIER (II)

ENTROUWEN, adv. | truly, surely ||

entrauwen 252, 2208, 3241

-ER, adv. (enclitic form of DAER) | there, then, where || (-er, -ere, -re). - diere 1631. - gheraecter (clis.) 2403. - hebber (clis.) 2662. - hire (clis.) $52,342,1360,1545,1620$. - ontfincker (clis.) 1507, 1582. - soutter (clis.) 1145. - vinder (clis.) 1627. - warper (clis.) 822. - wasser (clis.) 825. zijter (clis.) 2638 || See also: DAER, DAERAF, DAERANE, DAERBINNEN, DAERINNE, DAERMEDE, DAERTOE (clis.)

ERDE, n. (f.n.) | earth, soil || eerden 433. dheerde 2373

ERDIJN, adj. | earthen || erdinen 1164

ERDSCH, adj. | earthly, part of/belonging to the earth $\|$ erdschen 2228

ERE, n. (f.) | honour || eere 66, 132, 992, 1005, 1073 etc. - eeren $35,433,546,920,1188$ etc. - theeren (clis.) 2340 || See also: ONERE, WERELTERE

\section{erghe, ergher $\mid \mathrm{ARCH}$}

ERRE, adj. | confused, angry, furious, distressed || erre 2829, 3371, 3381, 3401

ERREN, w. vb. | tr. - lead astray, hinder, infuriate; intr. - go astray, err; refl. - lose one's temper, get/be annoyed \|| (impf.3) errede 3203 es $\mid$ SIJN (I)

-ES, enclitic pers. pron. ( $3 \mathrm{~m} . \mathrm{g} / \mathrm{a}-3 \mathrm{n} . \mathrm{g}) \mid \mathrm{him}$, it || (-es, -s) bids (clis.) 3083. - bleves (clis.) 199. - dats (clis.) 1962, 2712. - dies (clis.) 176, 2226, 2409, 2436. - ghijs (clis.) 662. - haddics (clis.) 2714. - hads (clis.) 27, 1721. - heves (clis.) 1963. - hijs (clis.) 46, 493, 913. - ics (clis.) 580, 584, 1030, 2666, 3302, 3401. - jans (clis.) 3139. - lates (clis.) 3204. - maechs (clis.) 1500. - mochtes (clis.) 2866. - mochtijs (clis.) 588, 591. - roukes (clis.) 1117. - saels (clis.) 592, 3299. - scaems (clis.) 2226. - sijs (clis.) 2276. - sijts (clis.) 597. soudens (clis.) 24. - souts (clis.) 591, 1668, 2736, 3290. - waers (clis.) 2679, 2699, 2925, 3180. waes (clis.) 226. - wancons (clis.) 1920. - wats (clis.) 2951. - wijs (clis.) 567. - wildijs (clis.) 619, 1925. - willics (clis.) 1785. - zwijghics (clis.) 94 ETEN, str. vb. | tr. - eat, devour || (inf.) heten $566,570,589,1113,1187$ etc. - eten 1110. - tetene 2133. - (pr.3) hetet 924. - (imp.pl.) hetet 666. - (impf.1) hat 563. - (impf.2) haetstu (clis.) 562. - (impf.3) at 1822b. - hat 271, 1532, 3134. - (impf.4) haten 567. - (impf.5) hatet 1214. hatet (clis.) 593, 604. - (p.p.) gheten $706 \|$ See also: OPETEN

EVEL, adj. | evil, angry, disagreeable || evelen 2503

EVENE, adv. | equally, even, as ... as || even 19 EVERSWIJN, n. (n.) | boar || everzwijn 1855 EWELIJC, adv. | eternally, everlasting, never ending || eewelike 1794, 2321, 3454 ey $\mid$ EI eyghin | EIGEN

FEL (I), adj. | cruel, wicked, irascible, malicious, dangerous, difficult, felonious, treacherous $\|$ fel $484,1019,1077,1089,2091$ etc. - felle 88, 105, $344,395,856$ etc. - fellen 60, 544, 940, 956, 1783 etc. - (n.) die felle 614,1853

FEL (II), adv. | cruelly, maliciously || fel 338

FIERE, adj. | wild, fierce, proud, bold, fair || fier $326,1028,2173,2245$

FILIUS *, n. (m.); (Latin) | son || filye 1820

FLUME, n. (m.) | river $\|$ flume 2641

FORET, n. (n.) | ferret || foret 1863

FRANSOYS, adj. | French || francsoys 100

\section{ga | GAEN}

gaefse | GEVEN + -SE

GAEN, irr. str. vb. $\mid$ go, walk, come $\|$ (inf.) gaen $52,144,559,632,635$ etc. - te gane, 1695. - te ghane 3010. - (pr.1) ga 383, 1434a, 2744. - (pr.3) gaet 969, 1359, 2162 2753. - gaet (clis.) 1885, 2745, 3358. - (pr.4) gaen 1097, 1157, 1185, 1956, 3127. - (pr.5) gaet 1386, 2695, 3034. - (pr.s.4) ghawi (clis.) 1961, 1963. - (imp.pl.) gaet 533, 704, 1025, 1037, 1151 etc. - (impf.1) ghinc 390, $393,1562,2076,2083$ etc. - (impf.3) ghinc 294, $343,388,522,608$ etc. - ghincken (clis.) 1249. - ghinckene (clis.) 789. - ghincker met (clis.) 795. - ghinct (clis.) 1868. - (impf.6) ghinghen 
63, 334, 840, 849, 1492 etc. - (impf.s.1) ghinghe 1156. - (impf.s.3) ghinghe 963. - (pr.p.) gaende 291. - (p.p.) ghegaen 518, 554, 1718 || See also: AENGAEN, HENENGAEN, INGAEN, MEDEGAEN, NAGAEN, NEDERGAEN, OMMEGAEN, ONDERGAEN, ONTGAEN, OPGAEN, TOEGAEN, UTEGAEN, VERGAEN, VOREGAEN, VORTGAEN, WECHGAEN, WEDERGAEN

GAERNE, n. (m.) | whisker, hair (of beard) $\|$ (pl. + dimin.) gaerdeline $1412 \|$ See also: GRANE gaet | GAEN + HET (I)

gaf $\mid$ GEVEN

gaffer mede $\mid$ GEVEN + DAERMEDE

GALGE, n. (f.) | gallows || galghe 1379, 1882, 1914, 1916, 2010 etc.

GANC, n. (m.) | journey, way || ganc 152, 510, 551,885

\section{gane | GAEN}

GANGEN, w. vb. | intr. $-g o||$ (p.p.)

gheganghen 3230

GANS, n. (f.) | goose || gans 1697. - (pl.) gansen 1741, 2089

GAST, n. (m.) | stranger, foreigner, guest, enemy, person || gast 1200, 1883. - (pl.) gaste 1975, 2836

GAT, n. (n.) | opening, passage, hole || gat 1172, $1177,1182,1515,1577$ etc. - gate 1190, 1315, 1522, 1588. - tgat (clis.) 1284 || See also: VUURGAT

gavedi $\mid$ GEVEN + GI

gawi voert | VORTGAAN

GEANDEN, w. vb. | tr. - avenge, take revenge || (inf.) ghehanden 202

GEBARE, n. (f.) | attitude, outward appearance, clamour || ghebare 1765

GEBEDE, n. (f.n.) | request, prayer $\|$ (pl.)

ghebede 862,3048

GEBIDDEN, str. vb. | intr. - beg; tr. - relent, persuade \| (inf.) ghebidden 3258

GEBIEDEN, str. vb. | tr. - announce, summon, order, desire, offer; intr. - command, rule \|

(pr.1) ghebiede 2780. - ghebiedic (clis.) 2777, 2778. - (pr.5) ghebiet 1835. - ghebiedijt (clis.)

1355. - (impf.3) gheboet 441, 1771, 2211, 3009. gheboot 840

GEBLEET, n. (n.) | bleating || ghebleet 2077

GEBODE, n. (f.) | message, command $\mid$ ghebod 1037. - ghebode 2304, 2471

GEBOREN, p.p. (from 'beren') | born || gheboren 798, 802, 1791, 2517, 2758 || See also: WELGEBOREN
GEBREKEN, str. vb. | tr. - break, subdue, control; refl. - force oneself; intr. - break, lack, be necessary, be insufficient \| (inf.) ghebreken 3261. - (pr.s.3) ghebreke 2038. - (impf.s.3) ghebrake 1930

GEBUUR, n. (m.) | neighbour, friend, enemy, citizen, villager, farmer, peasant || ghebuere 344. - (pl.) ghebuere 1572, 1578, 1975

GECRAEY, n. (n.) | noise, uproar, din || ghecray 2303. - ghecraye 2307

GEDACHTE, n. (n.f.) | intellect, mind, thought, plan $\|$ ghedochte 542

gedaen || DOEN

GEDENKEN, w. vb. | intr. - think, remember; impers. - remember; tr. - think of, remember; refl. - remember $\|$ (inf.) ghedincken 1500, 1671, 1991, 3048. - (pr.3) ghedincket 2858

GEDICHTE (I), adv. | near, incessantly || ghedichte 812

GEDICHTE (II), n. (n.) | text, writing || ghedichte 3256

GEDIËN, w.+str. vb. | intr. - grow, increase, lead to, result in $\|$ (p.p.) ghedeghen 413

GEDINGE, n. (n.) | session (of a court of law), treaty, crowd, throng $\|$ ghedinghe 314, 475, 527 GEDOEN, str. irr. vb. | aux.; tr. - do, cause; intr. - act, have to do \| (pr.1) ghedoe 3192 (2x). (impf.3) ghedede 139

GEDOGEN, w. vb. | tr. - suffer, endure, allow; intr.; refl. - restrain o.s. \| (inf.) ghedoghen 755, 1586, 1890. - (impf.3) ghedoghede 2342. - ghedoghedi (clis.) 1589. - (p.p.) ghedoghet 2662

GEDRAGEN, str. vb. | tr. - carry, bear, endure, contain; intr. - be aimed at, directed at; refl. || (inf.) ghedraghen 637, 2138. - (impf.s.3) ghedroughe 1126

GEEN, indef. pron.; used attrib. | no, not one II gheen 564, 631, 712, 1296, 1511 etc. - gheene 2687, 2785, 3006. - gheenen 873. - gheere 687 GEENREHANDE, adj. | no || gheenrande 2839

GEESTELIJC, adj. | spiritual, religious, pious || gheesteliker 2962

GEGRIPEN, str. vb. | tr. - grab, assault || (impf.3) ghegreep 1245, 1256. - ghegreepene (clis.) 3119

GEHELPEN, str. vb. | tr. - help, avail; refl. take care of o.s., look after o.s. || (inf.) ghehelpen 691, 1799 
GEHOORSAM, adj. | obedient, subservient || gheorsam 2570

GEHOREN, w. vb. | tr. - hear, listen to; intr. obey || (impf.3) ghehoerde 2308

GEHUUC, n. (n.) | shouting $\|$ ghehuke 1601

GEIT, n. (f.) | goat || (pl.) gheeten 2083

GELACH, n. (n.) | position, cover, help, ambush, food and drink || ghelach 1514. - ghelaghe 2419

GELAET, n. (n.) | appearance, behaviour || ghelaet 1089, 1733, 1798, 2113. - ghelate 1207,

1764, 2179

GELATEN, str. vb. | intr. - allow, neglect; refl. behave, pretend || (impf.3) gheliet 1061, 3051

gelaten | LATEN

GELDEN, str. vb. | tr. - pay, refund, take revenge, repay; intr. - cost $\|$ (pr.4) ghelden 1232

GELEERT, adj. (p.p. from LEREN) |

experienced, learned || gheleert 1032

GELEIDE, n. (n.f.) | guidance, accompaniment, safe conduct, protection $\|$ gheleede 141, 1155, 3435

GELEIDEN, w. vb. | tr. - see off, take somewhere II (inf.) gheleeden 3055

GELES, n. (n.) | gospel text || gheles 2945

GELIDEN, str. vb. | intr. - go, glide; tr. - pass || (inf.) gheliden 1521

GELIGGEN, str. vb. | intr. - lie, give birth, lead II (impf.3) ghelach 1317

GELIKE, adv. | in the same way, in the manner of, at the same time \| ghelijc 1766, 2388

GELLEN, str.+w. vb. | intr. - scream, shout, yell II (impf.3) ghal 1226

GELOVE, adj. | exhausted || ghelove 1595

GELOVEN (I), w. vb. | intr. - trust (s.o.); tr. believe || (inf.) gheloven 1780, 1790, 2515, 2519. gheloeven 2235. - (pr.3) gheloevet 1020. - (pr.6) gheloven 1784. - (imp.pl.) ghelovet 2905. (impf.1) gheloofdic (clis.) 2541.

GELOVEN (II), w. vb. | tr. - praise, assure || (inf.) gheloven 608, 1618. - (pr.s.3) ghelove 2508. - (impf.3) ghelovede 142. - (impf.6) gheloofden 2102

GELUCKE, n. (n.) | happiness || gheluc 1832 GELUUT, n. (n.f.) | sound, noise, (bell) ringing, rumour || gheluut 1528, 1571, 3387. - ghelude 2307 GEMAC, $\mathrm{n}$. (n.) | peace, peaceful circumstances, advantage, calm, need || ghemac 2864. ghemaex 736. - ghemake 2122, 2214, 3312 || See also: ONGEMAC

GEMACKELIKE, adv. | calm, suitable || ghemackelic 3023
GEMANC, n. (m.n.) | mixture, stock, gathering II ghemanc 2302

GEMEEN, adj. | common, general, ordinary, friendly $\|$ ghemeene 2106, 3130

GEMIC, adj. | fitting, ready || ghemicke 2874 GEMOET, n. (n.m.) | meeting, gathering || ghemoet 1054, 1107, 2783

GEMOETEN, w. vb. | tr. - meet, concede || (inf.) ghemoeten 1104

GENADE, n. (f.) | quiet, benevolence, mercy (God's), help, power, humility, gratitude \| ghenade $67,317,1375,1690,1987$ etc. - ghenaden 1450, 1741, 2189, 3460 || See also: ONGENADE GENADICH, adj. | merciful, benevolent || ghenadich 2336

GENADELIKE, adv. | appealingly, pitifully, compassionately || ghenadelike 3121

GENAKEN, w. vb. | intr. - | approach, touch, learn, find out $\|$ (pr.3) ghenaket 2000

GENE, dem. pron. | this, that || (attrib.) ghene 2684, 3389. - ghenen 1702

GENENDE, n. (f.) | boldness, responsibility || ghenent 2531. - gheninde 2825

GENEREN, w. vb. | tr. - save, keep, feed; refl. feed o.s.; intr. - earn a living $\|$ (inf.) gheneeren 1685

GENESEN, str. vb. | intr. - stay alive, cure, give birth; tr. - save \| (inf.) ghenesen 1400. - (pr.3) gheneset 1296. - (pr.1) ghenese 1400. - (impf.s.3) ghenase 1282. - (p.p.) ghenesen 245, 2548

GENOECH (I), indef. num. | enough || ghenouch 233, 2614, 2643, 3099

GENOECH (II), adv. | sufficiently, to a large extent || ghenouch 2026, 3028, 3395

GENOEGEN, w. vb. | refl. - be content;

impers.; intr. - be sufficient; tr. - approve \| (inf.) ghenoughen 2709

GENOEMEN, w. vb. | tr. - name, enumerate, list || (inf.) ghenomen 806

GENOOT, n. (m.) | equal, companion $\|$ (pl.) ghenote 2247

GENTEL, adj. | noble || gentel 2528

GEPENS, n. (n.) | thought, deliberation || ghepeinse 2356

GEPENSEN, w. vb. | intr. - think, reflect; tr. think $\|$ (inf.) ghepeinsen 968

GEQUITEN, w. vb. | tr. - free, pay, redeem || (impf.3) ghequijtte 2674

GERADEN, str. vb. | tr. - advise, counsel, plan; intr. - consult, succeed || (inf.) gheraden 1449 
GERAKEN, w. vb. | tr. - touch, acquire; intr. - succeed, arrive, begin $\|$ (inf.) gheraken 512, 2629. - (impf.1) gheraecter (clis.) 2403. - (p.p.) gheraect 1242, 2435

GERECHT, adj. | right, good, correct, just, legal || gherecht 263. - gherechten 1678

GERECHTE, n. (n.) | (from RECHTEN I) court of law, tool; (from RECHT II) law, verdict, court of law $\|$ (pl.) gherechten 578, 579

GEREET, adj. | ready, prepared, easy, clear || ghereet 1948, 1966, 2847, 2984, 3254 etc. || See also: ONGEREET

GEREIDEN, w. vb. | tr. - prepare, get ready, repair; refl. intr. - get ready \| (inf.) ghereeden 1913, 2052, 2973. - (imp.pl.) ghereet 2010, 3321. (impf.3) ghereedde 1758

GERNE, adv. | gladly, willingly, easily, usually || gherne 29, 35, 189, 222, 924 etc.

GEROEP, n. (n.) | shouting || gheroup 1206

GERUCHTE, n. (n.)| shouting, announcement, commotion, trouble || gherochte 1529, 3319. gheruchte 739

GESCHEIT, n. (n.) | removal, separation, farewell || ghesceede 387

GESCHIEN, w. vb. | intr. - occur, happen || (inf.) ghescien 1375, 3020, 3117, 3427. - (pr.3) ghesciet 1723. - (pr.s.3) ghescie 2004. - (p.p.) ghesciet 54, 115, 1628, 1723, 2148 etc.

GESCHRIVEN, str. vb. | tr. - write down, describe \| (impf.1) ghescreeft (clis.) 93

GESEGGEN, w. vb. | tr. - say, describe || (inf.) ghesegghen 1480, 1647

GESELLE, n. (m.) | friend, companion (on a journey), brother in arms, equal, young person || gheselle 613, 629, 645, 1854, 2676 etc. - (pl.) ghesellen 2100, 2449, 2671, 2798

GESELSCHAP, n. (f.n.) | friendship, alliance, society, companion || gheselscap 2103, 2673

GESIEN, str. irr. vb. | tr. - see, remark, understand; intr. - look || (inf.) ghesien 757. (impf.3) ghesach 1260, 3235, 3333

GESINDE, n. (n.) | company, court $\|$ ghesinde 1395 GESLACHTE, n. (n.) | dynasty, family, descendants, offspring || gheslachte 327, 464, 1141 GESMIDE, n. (n.) | (suit of) armour, saddle, jewel $\|$ ghesmide 2610

GESONT, adj. | alive, healthy || ghesont 3040 || See also: ONGESONT

GESPELE, n. (m.f.) | playmate, friend $\|$ (pl.) ghespelen 2354
GESPREKEN, str. vb. | intr. - speak; tr. - say, pronounce, agree || (inf.). ghespreken 1497. (impf.3) ghesprac 438

GESTADE, adj. | firm, reliable, loyal, calm || ghestade 613,3062

GESTAEN, str. irr. vb. | intr. - stand, persist; tr. - allow, help || (inf.) ghestaen 560, 1301

GESTILLE, n. (n.) | silence || ghestille 26, 1133, 2188

GESTOLEN, adj. (p.p. from STELEN) | stolen || ghestolen 261

GESTRECKET, adj. (p.p. from 'strecken') | stretched $\|$ ghestrect 2373

gesweghen $\mid$ SWIGEN

GETAL, n. (n.) | number, amount || ghetal 822. - ghetale 399. - tghetal 410

GETELEN, w. vb. | tr. - succeed, execute || (inf.) ghetelen 2353

GETEMEN, str. vb. | intr. - be proper, consider acceptable, bear \| (inf.) ghetemen 2205

GETIDE, n. (n.) | time, hour, one of the prayers to be said at fixed times of the day || ghetijde 951, 2978

GETROUWE, adj. | honest, loyal, reliable, married || ghetrauwe 1775, 2505, 2598, 2619, 3257 || See also: ONGETROUWE

GETROUWELIKE, adv. | truthfully, accurately $\|$ ghetrauwelike 2997

GETROUWEN, w. vb. | intr. - trust; tr. - entrust; refl. - risk, undertake || (impf. 5) ghetrauwet 3380 gevaen | VAEN

GEVAL, n. (n.) | fate, chance, luck, misfortune, profit || gheval 46, 617, 1058, 1398, 2219 || See also: MISGEVAL, ONGEVAL

GEVALLEN, str. vb. | intr. - fall, occur, happen, please || (inf.) ghevallen 1387, 2325, 2994. (pr.3) ghevalt (clis.) 3037. - (impf.3) gheviel 149, 394, 2279, 2371. - (impf.s.3) gheviele 2184. (p.p.) ghevallen 1274, 1389

GEVANE, n. | prisoner || (pl.) ghevane 3011. ghevanghene 3432

GEVEN, str. vb. | tr. - give, present, occur, bring, have; refl. - care for, sacrifice o.s., go to, devote o.s. to, behave; intr. - be of use II (inf.) gheven 222, $605,1068,1499,1794$ etc. - te ghevene 529, 2431. - (pr.1) gheve 834. - (pr.3) ghevet 278, 1954. - (pr.s.3) gheve 1073, 1771, 2509, 2622, 2936. ghevere af (clis.) 1042. - (imp.pl.) ghevet 2946. - gheeft 1672. - (impf.3) gaf 728, 810, 1637, 1712, 
2140 etc. - gaffer mede (clis.) 1676. - (impf.5.) gaeft 213. - gavedi (clis.) 1119. - (impf.s.1) gave 3150. - gaefse (clis.) 1150. - (impf.s.3) ghave 2469. - gave 2304. - (p.p.) ghegheven 2775, 3106, 3289 || See also: BEGEVEN, OPGEVEN, VERGEVEN

GEVENST, adj. (p.p. from 'vensen') | fictitious, false $\|$ gheveinsde 2635, 2986

GEVOECH, n. (n.)| need, advantage, wish, correct way $\|$ ghevouch $658,884,1621$. ghevoughe 2983 || See also: ONGEVOECH GEVREESCHEN, w.+str. vb. | tr. - ask, hear, trace \| (impf.6) ghevreescheden 1578

GEWAERLIKE, adv. | really, in truth || ghewaerlike 2584

GEWAERT, adj. (p.p. from 'gewaren') | justified, convinced, satisfied, guaranteed \| ghewaert 1120

GEWANT, n. (n.) | fabric, clothing, outfit, merchandise || ghewande 1279

GEWARE, adj. | attentive, benevolent, energetic || gheware (werden) 1201, 1708

GEWELDICH, adj. | powerful, forceful, violent || geweldich 2270d. - gheweldich 1220

GEWELT, n. (n.m.f.) | power, force, violence || ghewelt 2267, 2314

GEWERKEN, w. irr. vb. | tr. - make, accomplish || (impf.1) ghewrochte 1648

GEWILLELIKE, adv. | voluntarily, diligently, forcefully $\|$ ghewilleghelike 3446

GEWIN, n. (n.) | advantage, profit, income || ghewin 276, 676, 1525, 1630, 2406 etc. ghewinne 2492

GEWINNEN, str. vb. | tr. - acquire, conquer, get, reach, cause || (inf.) ghewinnen 342, 571, $585,749,1029$ etc. - (pr.1) ghewinne 580,584 . (impf.3) ghewan 227

GEWIS, adj. | certain || ghewes 597

GEWONE, adj. | ordinary, usual || ghewone 411, 920

GEWOUDEN, str. vb. | intr. tr. - decide, allow, persevere $\|$ (inf.) ghewouden 430

GEWOUT, n. (n.f.) | power, (free) disposal, force, will, violence, reach, hiding place $\|$ ghewout $605,2136,2470,2868,3445$

GEWREKEN, str. vb. | tr. - avenge; refl. avenge o.s., take revenge $\|$ (inf.) ghewreken 953. - (pr.s.4) ghewreken 436. - (impf.s.6) ghewraken 468. - (p.p.) ghewroken 1824 ghal | GELLEN

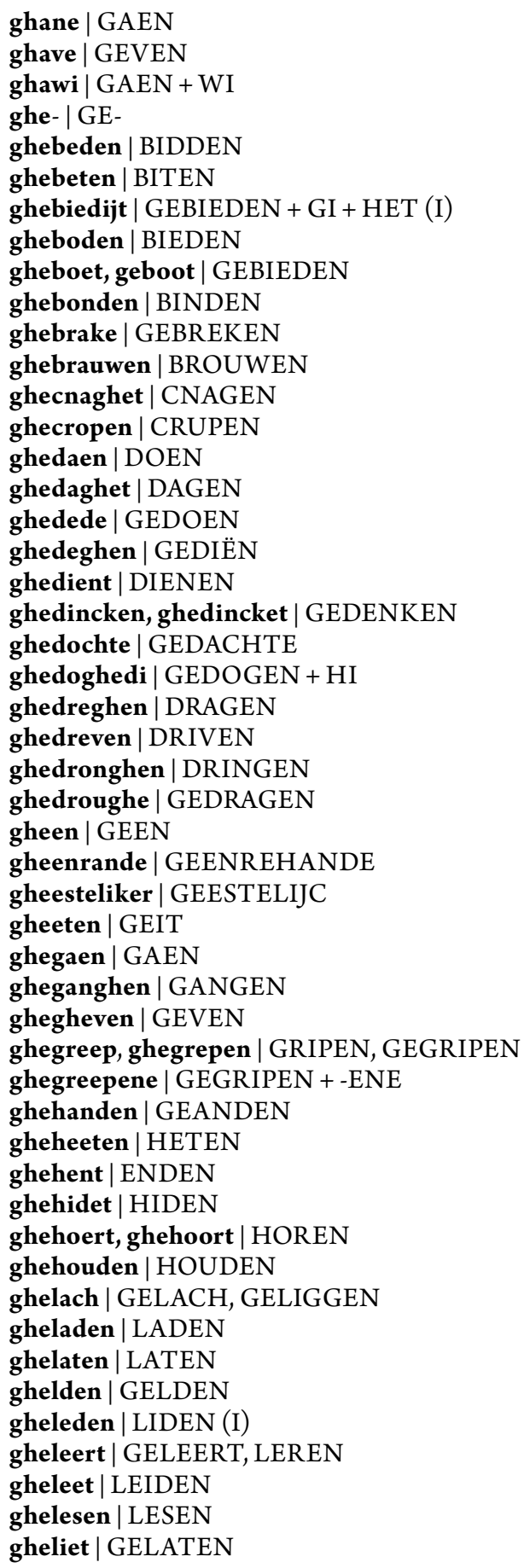




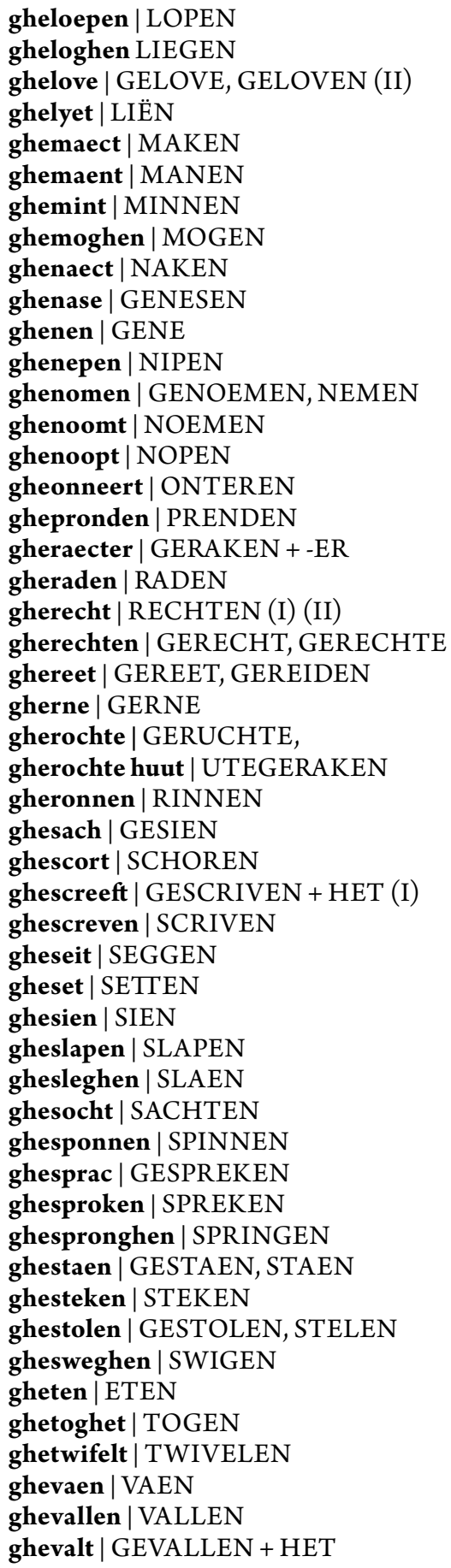

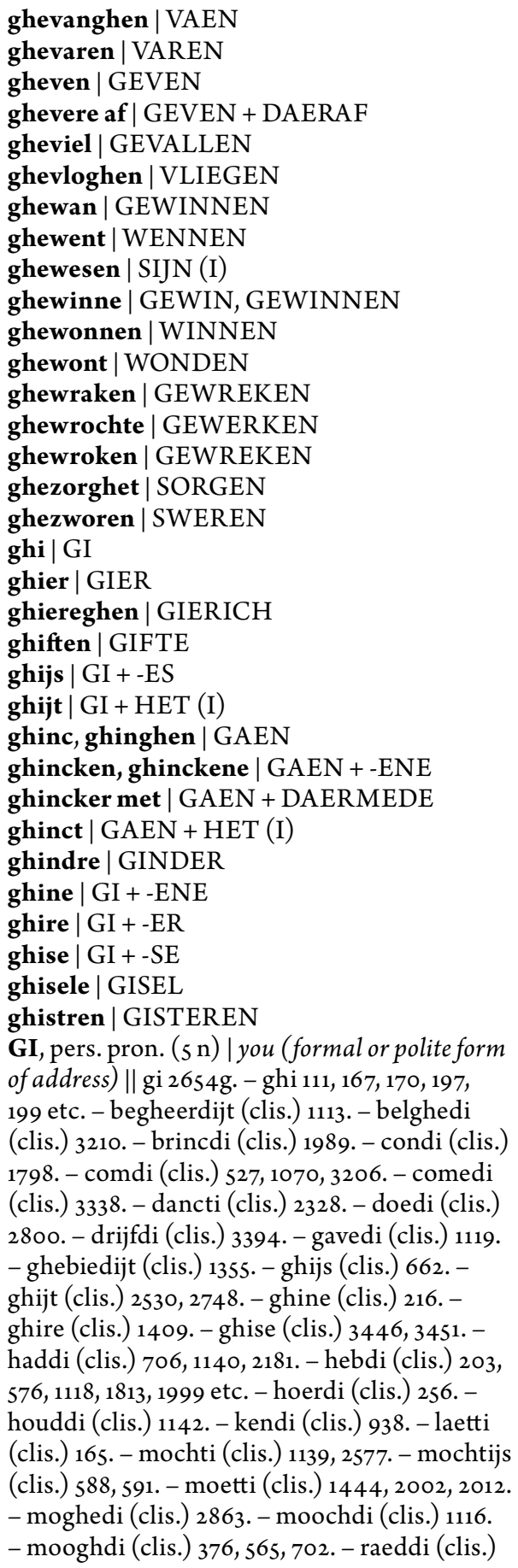


689. - sechdi (clis.) 135, 601, 1116, 1122, 1131 etc. - sechdire (clis.) 3463. - sidi (clis.) 524, 945, 1033, 1194, 1903 etc. - slouchdi (clis.) 1844. smeekedi (clis.) 2633. - souddi (clis.) 706, 2726. - suldi (clis.) 630, 664, 1659, 2604, 2608 etc. suldijt (clis.) 3253. - vermerrendi (clis.) 1373. - vernaemdi (clis.) 3248. - vindise (clis.) 1210. - vraechdi (clis.) 2201. - waendi (clis.) 671, 2206, 2640, 2699. - waerdi (clis.) 1926, 2677. - walschedi (clis.) 1457. - weetti (clis.) 1135. wildi (clis.) 187, 606, 647, 943, 1132 etc. - wijldijt (clis.) 2143. - wildijs (clis.) 619, 1925. - wildijt (clis.) 3439. - wildine (clis.) 939. - zidi 2730 GIER, n. (m.) | greedy person, glutton || ghier 940 GIERICH, adj. | greedy, grasping, gluttonous || ghiereghen 403

GIFTE, n. (f.) | present, offering || ghiften 3141, 3144

GINDER, adv. | there, that way, after || ghindre $831,1332,1599,1868$

GISEL, n. (m.) | hostage || (pl.) ghisele 3104 GISTEREN, adv. | yesterday || ghistren 136, 272, 416, 3249

GOD, n. (m.) | God || $\operatorname{god} 10,173,317,354,428$ etc. - gode 170, 382, 488, 526, 1074 etc.

GODSAT, n. (m.) | God's wrath || godsat 3191 GOEDERTIERE, adj. | noble, friendly, mild || goedertiere 2335. - goedertieren 3060 goem | GOME

GOET (I), adj. | good, brave, reliable, great, useful, distinguished || goet 126, 172, 198, 613, 617 etc. - goede 299, 423, 2027, 2694. - goeden $39,227,297,649,1035$ etc. - goeder 218,568 , 1229. - goets 548 || See also: BEST (I, superl.), ALLERBEST (I, reinf. superl.)

GOET (II), n. (n.) | that which is morally good, happiness, blessing, property || goet 213, 261, 1042, 1106, 1982 etc. - tgoet 2859. - goeds 102, 3135. - goede 3358

GOME, n. (m.) | attention || goem (nemen) 183, 659, 1994, 2132

GONNEN, irr. vb. (pret. pres.) | tr. - grant, allow; intr. - be inclined $\|$ (inf.) jonnen 10. (pr.1) jonne 2558. - jan 1074. - jans (clis.) 3139. (pr.s.1) jonne 2748. - (impf.3) jonste 3304 GOUDIJN, adj. | gold, golden || guldin 2615 GOUT, n. (n.) | gold $\|$ gout 2135, 2430. - goud 2407. - goude 2274, 2445, 2611, 3143 GRACHT, n. (f.n.) | moat, canal, ditch, grave || gracht 348,1603
GRAF, n. (n.) | grave || graf 451. - grave 460. tgraf (clis.) 457

GRAM, adj. | angry || gram 107, 845, 1170, 2112, 2482 etc.

GRANE, n. (f.) | hair (of beard or moustache), whisker || (pl.) granen 2987 || See also:

GAERNE

GRAS, n. (n.) | grass, grassland, blade of grass || gras 453, 1596, 2757, 2891, 3065

GRAVE, n. (m.) | count $\|$ grave 564

GRAVEN, str. vb. | tr. - dig, bury || (impf.2)

grouves 2620|| See also: BEGRAVEN

GRIEF, n. (n.m.) | grief, derision, taunts,

disadvantage $\|$ grief 186

GRIJS, adj. | grey || grijsen 6o. - (n.) den grijsen 2260

GRIPEN, str. vb. | tr. - seize, take, understand || (inf.) gripen 1179. - (p.p.) ghegrepen $694 \|$ See also: BEGRIPEN, GEGRIPEN

GROEN, adj. | green || groene 325. - groenen 43 groet $\mid$ GROETEN, GROOT

groeten | GROETEN, GROOT

GROETEN, w. vb. | tr. - invite, greet, attack || (inf.) groeten 1105. - (pr.1) groet 1773. - (pr.3) groet 3436. - (impf.3) groette 1365

GRONGAERT, n. (m.) | a grumbler $\|$ (pl.)

grongaerde 32

GRONGEREN, w. vb. | intr. - growl, howl ||

(impf.3) grongierdi (clis.) 2112

grongierdi | GRONGEREN + GI

GROOT, adj. I great, powerful, fat, numerous, old, costly, distinguished || groet 49, 569, 771, 781, 807 etc. - groot 308, 1206, 1224, 1598, 1665 etc. - groete $469,1583,1599,1717,2119$ etc. - grote $658,1566,1573,1822$ d, 1988 etc. - groeten 47 , $71,419,1259,1569$ etc. - groten $327,638,1594$, 1601,1862 etc. - groeter 28,3239 . - groter 972 , 2045, 2170, 3031. - (n.) tgroete (clis.) 2105 ॥ See also: MEERE (comp.), MEEST (superl.), OVERGROOT

grouves | GRAVEN

guldin | GOUDIJN

HA, interj. | ha || ha 1228

hachtic $\|$ ACHTEN

hadde, hadden || HEBBEN

hadder an $\mid$ HEBBEN + DAERANE

hadder met $\mid$ HEBBEN + DAERMEDE

haddet $\mid$ HEBBEN + HET (I)

haddi | HEBBEN + GI / HI 
haddic $\mid$ HEBBEN + IC

haddics $\mid$ HEBBEN + IC + -ES

hads $\mid$ HEBBEN + -ES

hadse $\mid$ HEBBEN + -SE

hadsi $\mid$ HEBBEN + SI

hadt $\mid$ HEBBEN + HET (I)

HAER (I), n. (n.) | hair, wool || haer 1502, 2294

HAER * (II), pers. pron. ( 3 f. g/d/a $-6 \mathrm{~g}) \mid$ her, them $\|$ (3) haer 833, 1654, 3099, 3233. - hare 237. - (6) haer 1255. - datter (clis.) 76. - ghire (clis.) 1409. - icker (clis.) 1153. - moeter (clis.) 430

HAER * (III), refl. pron. | herself || haer 1299, 2894

haer, haerre $\mid$ HARE

haerde $\mid$ HARDE

haerwaert | HAREWAERT

haest | HAESTE, HAESTEN

HAESTE, n. (m.f.) | haste, speed || haest 713, 1247

HAESTELIKE, adv. | hastily, speedily ||

haestelic 2685

HAESTEN, w. vb. | intr. - hurry; tr. - further, speed up; refl. - hurry $\|$ (inf.) haesten 2941. (pr.5) haest 2004. - (pr.4) haesten 2017

HAESTICH, adj. | hurried, hasty, quick ||

haestich 3004

haet up | OPETEN + HET (I)

haetstu | ETEN + DU

haex $\mid$ AEX

HAGE, n. (m.f.) | bush, hedge || haghe 42, 386, $396,820,1052$ etc. - haghen 2362. - (pl.) haghen 3154

HAGEDOCHTE, n. (f.) | vault, cave, lair || haghedochte $541,1363,3089,3318$. - aghedochte 3272

HAKE, n. (m.) | hook || (pl.) haken 841

HALF (I), adj. | half || half 1987, 2585. - halve 864. - halven 3293

HALF (II), adv. | half || half 2109

halp | HELPEN

HALS, n. (m.) | neck || hals 289, 700, 817, 1199, 1590 etc. - halse 3368

hals $\mid$ ALS

HAME, n. (f.) | bottom, backside || hamen 971 hamen | AME, HAME

HANE, n. (m.) | rooster || hane 294, 295, 297, 299, 300 etc. - hanen 302, 2398

HANENBALC, n. (m.) | roof beam || aenbalke 1614

HANGEN, str. vb. | tr. - hang, hang up; intr. hang || (inf.) hanghen, 1839, 1892, 1912, 2053,
2498 etc. - hanghense (clis.) 3265. - (pr.4)

hanghene (clis.) 1961. - (impf.3) hinc 224, 360, 1923, 2483, 2979 etc. - (impf.s.3) hinghe 184, 1884, 2968. - (pr.p.) hanghende 1519 || See also: VERHANGEN

hanghene | HANGEN + -ENE

hanghense $\mid$ HANGEN + -SE

HANT, n. (f.) | hand, representative, side, force || hant 1050, 1536, 1788, 2431, 2982

HANTSCHOE, n. (m.) | glove $\|$ (pl.) anscoen 751, 949

HARDE, adv. | very || arde 153, 207, 312, 569, 656 etc. - harde 443, 1416, 1966a, 3270. - haerde 3

HARE (I), n. (f.) | (penitential) hair shirt || hare 269, 374

HARE (II), poss. pron. (3 f. -6$) \mid$ her, their $\mid$ (3) haer 236, 2864. - haerre 428, 1302. - hare 29, 241, 1426, 2286. - haren 464, 464, 732, 1271, 1978 etc. - (6) haer 1382, 1793, 2264, 2469, 2766 etc. - haerre 151, 307, 311, 313, 347 etc. - hare 2037, 2811, 3328, 3415, 3416. - haren 36, 321, 725, 766,1362 etc

HARE (III), adv. | this way, here, up till now ||

hare 2644,3237

hare | HAER (II)

HARENTARE, adv. | here and there, everywhere || harenthare 1624, 1707, 2063

HAREWAERT, adv. | in this direction, so far || haerwaert 1448. - herwaert 1049a

HASE, n. (m.) | hare || hase 138, 247, 3128. -

haze 3053

hat, haten | ETEN

HATEN, w. vb. | tr. - hate || (inf.) haten 3186. (impf.1) hate 3403

HAVE, n. (f.) | property, money, cattle || have 563 haze $\mid$ HASE

HEBBEN, w. vb. | tr. - have, possess, keep, hold prisoner; refl. - behave, behave o.s.; intr. - have to, must; impers.; aux. \| (inf.) hebben 81, 159, 619, 630, 636 etc. - (pr.1) hebbe 70, 205, 378, 383,384 etc. - hebben (clis.) 1646. - hebber (clis.) 2662. - hebber met (clis.) 1230. - hebbic (clis.) 569, 905, 1439, 1478, 1670 etc. - hebbicker af (clis.) 573. - hebse (clis.) 1631. - (pr.2) hebs 2872. - - heefstu (clis.) 927. - (pr.3) heeft 69, $186,191,319,538$ etc. - hevet $6,9,73,88,231$ etc. - heft 1822d. - heefse (clis.) 414. - heeftene (clis.) 987, 2803. - heves (clis.) 1963. - (pr.5) hebt 200, 206, 948, 949, 1082 etc. - hebbet 548 , 1997. - hebdi (clis.) 203, 576, 1118, 1813, 1999 etc. 
- (pr.5) hebse (clis.) 3445. - (pr.6) hebben 321, 1692, 1788, 1962, 2488. - (pr.s.3) hebbe 113, 3105, 3191. - (impf.1) hadde 120, 328, 1092, 1556, 1805 etc. - haddic (clis.) 598, 1149, 1514, 1515, 2967 etc. - haddics (clis.) 2714. - hads (clis.) 1721. (impf.3) hadde 44, 46, 51, 56, 59 etc. - hadder an (clis.) 122. - hadder met (clis.) 2438. - haddet (clis.) 2994. - haddi (clis.) 748, 1553, 2848. hads (clis.) 27. - hadse (clis.) 2931. - hadt (clis.) 881, 2255. - (impf.5) haddet 363, 555. - hadt 212, 3039. - haddi (clis.) 706, 1140, 2181. - hadse (clis.) 117. - (impf.6) hadden 311, 567, 1695, 1748, 1966a etc. - hadsi (clis.) 1498. || See also: LIEFHEBBEN, WAERTHEBBEN

hebben | HEBBEN + -ENE

hebber | HEBBEN + -ER

hebber met $\mid$ HEBBEN + DAERMEDE

hebbic $\mid$ HEBBEN + IC

hebbicker af $\mid$ HEBBEN + IC + DAERAF

hebdi | HEBBEN + GI

hebse $\mid$ HEBBEN + -SE

hecht $\mid$ ECHT

HEDEN, adv. | at present, today, nowadays || heden 199, 625, 634, 636, 927 etc.

heede | HEIDE

heefse $\mid$ HEBBEN + -SE

heefstu | HEBBEN + DU

heeft | HEBBEN

heeftene $\mid$ HEBBEN + -ENE

heelt | HELET

heere | HERE

heesch $\mid \mathrm{EISCH}$

heesschede | EISCHEN

HEET, adj. | hot, passionate, quick tempered || heet 893

\section{heeten | HETEN}

HEIDE, n. (f.) | heath, field || heede 3154. heyde 2284. - heiden 1099. - heyden 879, 1431 HEILICH, adj. | happy, holy, pious || heleghen 1743

HEILIGE, n. (m.) | saint, relic || (pl.) heleghe 83 hel | EL

heleghe(n) || HEILICH, HEILIGE

HELET, n. (m.) | hero || heelt 615. - helet 1071, 3236

HELLE, n. (f.) | hell, grave || helle 2185. - hellen 2195

helpe | HELPE (II), HELPEN

HELPE (I), n. (f.) | help, helper, device || hulpe 714, 3226. - hulp 1843. - hulpen 10, 160, 2446
HELPE (II), interj. (= pr.s.3 from: so helpe mi God) | help || helpe 575, 1541, 2065, 3376

HELPEN, str. vb. | tr. - help, repair; intr. avail || (inf.) helpen 189, 833, 2627. - (pr.3) helpt 2926. - (pr.s.3) helpe 1038, 1143, 1352, 1544, 1951. - (imp.pl.) helpt 580, 584, 2855, 3122, 3237. (impf.3) halp 2415. - (impf.s.3) holpe 2480, 3179 II See also: GEHELPEN

HEM* $(\mathrm{I})$, pers. pron. $(3 \mathrm{~m} . \mathrm{d} / \mathrm{a}-3 \mathrm{n} . \mathrm{d}-6 \mathrm{~d} / \mathrm{a})$ | him, them, themselves, herself || (3) hem 3, 105, 140, 159, 160 etc. - heme 3083. - (6) hem 16, 310, 716, 734, 797 etc. - dreechdem (clis.) $774 \|$ See also: -ENE

HEM * (II), refl. pron. | himself || (3) hem 11, 53, $190,677,769$ etc. $-(6)$ hem $2020,2300,2710$, 3052, 3326 || See also: -ENE

hende || ENDE (II)

HENENGAEN, str. irr. vb. | intr. - go away || (impf. 3) henenghinc 3022

HENENLOPEN, str. vb. | intr. - walk away || (impf.3) henenliep 2365. - liep henen 1063

HENENTRECKEN, str. vb. | intr. - move away $\|$ (impf.3) henentrac 2365

HENNE, n. (f.) | hen || hinne 287, 1698. hinnen 134. - (pl.) hinnen 1612, 2399

HERBERGE, n. (f.) | place to spend the night, house, inn || herberghe 1082. - herberghen 1188, 1305

HERBERGEN, w. vb. | intr. - find shelter, lodge, stay; tr. - house s.o. || (inf.) herberghen 1108. (impf.1) herberghede 1827

herberghen | HERBERGE, HERBERGEN HERE (I), n. (m.) | lord || heere 65, 86, 110, 131, 163 etc. - her 1822a, 1940, 1993. - der (clis.) 1968. - dher (clis.) 2881. - sheere (clis.) 2461, 3442. (pl.) heeren 233, 434, 1006, 1018, 1337 etc. || See also: JONCHERE

HERE (II), n. (n.) | army, crowd || heere 48o, 718

HEREMITE, n. (m.) | hermit || hermite 268. hermijte 356

HERTE, n. (n.f.) | heart || herte 899, 917, 954, 982, 1077 etc. - herten 498, 1195, 2232, 3408 herwaert | HAREWAERT

HET (I), pers. pron. (3 n. n/a) | it || het 41, 79, 172, 424, 499 etc. - aldaert (clis.) 1539. - alsoet (clis.) 1265. - alst (clis.) 1732. - begheerdijt (clis.) 1113. - cocht (clis.) 2616. - daert an (clis.) 2762. - daet (clis.) 2195. - dant (clis.) 411, 1655 . - dart (clis.) 239, 3461. - dat (clis.) 34, 102, 240, 
1208, 1263 etc. - diet (clis.) 39, 1446, 1921, 2192. - eist (clis.) 648, 1191, 1418, 1914, 2530 etc. - gaet (clis.) $1885,2745,3358$. - ghebiedijt (clis.) 1355.ghescreeft (clis.) 93. - ghevalt (clis.) 3037. - ghijt (clis.) 2530, 2748. - ghinct (clis.) 1868. - haddet 2994. - haet up (clis.) 600. - hadt (clis.) 881, 2255. - hatet (clis.). - hets (clis.) 124, 181, 903, 1022, 1034 etc. - hijt (clis.) 1198, 1462, 1489, 1722, 3385 . - hoet (clis.) 101, 931, 1387, 2202. - ict (clis.) 1459, 2143, 2293, 2658, 2705 etc. - jaet (clis.) 2691, 3429. - laet (clis.) 590. - liept (clis.) 721. lyet (clis.) 2281. - maectet (clis.) 2388. - maghet (clis.) 3341. - ment (clis.) 1912, 2569. - mochtet (clis.) 3257. - neent (clis.) 2704, 3244. - oft (clis.) 2700. - saelt (clis.) 168, 190, 492, 635, 3412. - salt (clis.) 1419, 1959. - secht (clis.) 2317, 2554, 3152. - seit (clis.) 446. - sijt (clis.) 2784. - sodat (clis.) 1581. - sout (clis.) 2659, 2877. - suldijt (clis.) 3253. - sullent (clis.) 2036, 2537. - waent (clis.) 1818. - waert (clis.) 2184, 2654 f. - waest (clis.) 1318, 1559, 1893, 2367, 2369. - wijldijt (clis.) 2143. - wildijt (clis.) 3439. - willict (clis.) 2531. zijt (clis.) 238, 2784. - zoet (clis.) 2290, 2292

HET (II), art. || See: DAT (I)

HETEN, str.+w. vb. | tr. - declare, call, name, command, promise; intr. - be called $\|$ (pr.3) heet $602,2575,2578$. - heetet 2596. - (pr.6) heeten 22. - hiet 99, 287, 295, 298, 785, 1482, 2051, 2217, 2262, 2830, 3249, 3361. - (p.p.) gheheeten 296

heten | ETEN

hets $\mid$ HET (I) + SIJN (I)

heves $\mid$ HEBBEN + -ES

hevet | HEBBEN

heyde | HEIDE

HI, pers. pron. (3 m. n) | he $\|$ hi 2, 7, 46, 51, 56 etc. - andwoerdi (clis.) 221. - condi (clis.) 1527. - dedi (clis.) 136, 1262, 1265, 1520, 1608 etc. dedine (clis.) 144. - ghedoghedi (clis.) 1589. - grongierdi (clis.) 2112. - haddi (clis.) 748, 1553, 2848. - hiere toe (clis.) 3289. - hijs (clis.) 46, 493, 913, 1243. - hijt (clis.) 1198, 1462, 1489, 1722, 3385. - hine (clis.) 472, 902, 912, 932, 936 etc. - hire (clis.) 52, 342, 1360, 1545, 1620. - hise (clis.) 8, 75, 402, 1309, 2312 etc. - hoendi (clis.) 78. - hoendine (clis.) 217. - keerdi (clis.) 3116. - merkedi (clis.) 2383. - mochtire (clis.) 133. - peinsdi (clis.) 1899. - queddi (clis.) 2386. - scuwedi (clis.) 55. - seidi (clis.) 272. - teldi (clis.) 2450. - wildi (clis.) 1314, 2526, 2955. wildine (clis.) 610
HIDEN, w. vb. | tr. - hide || (p.p.) ghehidet 2594 HIE, n. (f.) | ewe || hye 1848

hief up | OPHEFFEN

hiefsene up | OPHEFFEN + -SE * + -ENE

HIER, adv. | here, now || hier 40, 61, 87, 112, 138 etc.

HIERAF, adv. | about this || hieraf 2480

HIERBINNEN, adv. | meanwhile || hierbinnen 336, 1304, 2423, 3455

hiere $\mid \mathrm{HI}+$-ER

hiere toe $\mid$ HIER + DAERTOE

HIERNA, adv. | after this, then || hierna 1000, 1686, 3306. - hiernaer 169

HIEROMME, adv. | because of, for this reason, as a result of $\|$ hieromme $55,614,1170,2341$ HIERTOE, adv. | to this end, for this purpose, moreover $\|$ hiertoe 3370

HIERVORE, adv. | before, before this (time) || hiervoren 2787

hiet $\mid$ HETEN

hijs | HI + -ES / SIJN (I)

hijs | IJS

hijt $\mid \mathrm{HI}+\mathrm{HET}$ (I)

hilt, hilden | HOUDEN

hinc, hinghe $\mid$ HANGEN

HINDERWAERT, adv. | backwards, towards hell || hinderwaert 2015. - inderwaert 2012

hine $\mid \mathrm{HI}+$-ENE

hinnen | HENNE

hire $\mid \mathrm{HI}+$-ER

hise $\mid \mathrm{HI}+-\mathrm{SE}$

ho | HOGE (II)

hodevare | ODEVARE

HOE (I), adv. | how, why || hoe 40, 343, 436, 468, 543 etc. - hoe dat 22. - hoe so 1440,1761 . - hoet (clis.) 101, 931, 1387, 2202

HOE (II), conj. | as, however much, although || hoe 3192

hoech | HOGE (II)

hoechste, hoeghe $\mid \mathrm{HOOCH}$

HOEDE, n. (f.) | surveillance, protection, prevention || hoede 377,391

HOEKIJN, n. (n.) | young male goat, kid || (pl.) hoekine 2085

hoeft | HOVET

hoeghe $\mid \mathrm{HOOCH}$, OGE

HOEN, n. (n.) | hen, chicken || hoen 878,888 , $1534,1556,1565$ etc. - (pl.) hoene 2088. - hoenre $1609,1633,1706,1708,1727$ etc. - hoenren 1621, 1731 
HOENDERDIEF, n. (m.) | chicken thief ||

hoenredief 1231

hoendi | HONEN + HI
hoendine | HONEN + HI + -ENE
hoenen | HONEN
hoerdi | HOREN + GI
hoere | HOREN, ORE
hoeren | HOREN
hoet | HOE (I) + HET (I)
hoever | OEVER

HOF, n. (n.m.) | fenced off area, yard, house, castle, garden, court day \| hof 45, 55, 57, 1424, 1428 etc. - thof 1321 . - hove $48,51,87,195,473$ etc. - thof (clis.) 1321. - (pl.) hove 1789

HOGE (I), n. (f.m.) | thought, memory, cheerfulness || in hoghen 1048. - in hueghen 2108 HOGE (II), adv. | high, very, far, difficult || ho 443. - hoech 1548. - hoghe 1961

hoghe $\mid$ HOGE (II), HOOCH, OGE hoghen | HOGE (I), HOOCH, OGE

HOL, n. (n.) | cavity, hole, cave || hol 2387, 2421, 2479, 3090, 3202. - hole 2377, 2401. - holle 2381 holpe | HELPEN

HONDERT, num. | hundred || ondert 232 HONEN, w. vb. | tr. - dishonour, mislead, cheat, harm || (inf.) hoenen 175, 501, 1634. - honen 488, 491. - (impf.3) hoende 1200. - hoendi (clis.) 78. - hoendine (clis.) 217

HONGER, n. (m.) | hunger || hongher 280, 2663. - honghere 2711

HONGERICH, adj. | hungry, eager || ongherich 1526

HONICH, n. (m.n.) | honey || honich 576, 577, $589,603,618$ etc. - honichs 610, 661. - thonich (clis.) 598. - shonichs (clis.) 1116

HONICHRATE, n. (f.m.n.) | honeycomb || (pl.) honichraten $568,665,1114$

HONT, n. (m.) | dog, miserable creature $\|$ hont 404. - (pl.) honde 346. - honden 337, 416, 1592, 2455, 2833. - hondekijn 99, 2676

HOOCH, adj. | high, great, loud, distinguished, noble || oech 509. - hoeghe 1879, 3250. - hoghe 2452, 2753. - hoghen 2909. - (superl.) hoechste 1763. - (n.) die hoechste 1001

hoofschen | HOVESCH

HOPEN, w. vb. | tr. - hope, expect; intr. trust $\|$ (inf.) hopen 2378. - (pr.1) hope 1414, 2047. - hopic (clis.) 3148. - (impf.3) hopede 900. - (impf.6) hopeden 2492|| See also: ONTHOPEN hore | ORE

horen | HOREN, HORN, ORE

HOREN, w. vb. | tr. - hear, interrogate, follow, obey; intr. - belong to; impers. - be appropriate, suit || (inf.) hoeren 957. - horen 312, 442, 647, 702, 1009 etc. - te hoerne 2077. - (pr.1) hoere 1127. - (pr.5) horet 2069, 3355. - (pr.6) horen 14, 34, 445. - (imp.pl.) hoert 40, 425, 877, 970, 1180 etc. - (impf.1) hoerde 1953, 2084. - hoerdic (clis.) 151. - (impf.3) hoerde 574, 952, 1208, 1285, 1869 etc. - hoorde 739. - horde 2496. - (impf.5) hoerdi (clis.) 256. - (impf.6) hoerden 1495. - hoorden 337. - horden 1871a, 1986. - (p.p.) ghehoort 16, 2630, 3388. - ghehoert $2522 \|$ See also: GEHOREN, VERHOREN

HORN, n. (m.) | horn, corner, angle || horen 2050

HORTEN, w. vb. | tr. - push; intr. - struggle, wriggle $\|$ (impf.3) hortene (clis.) 1635

hortene | HORTEN + -ENE

houddi $\mid$ HOUDEN + GI

HOUDE, n. (f.) | affection, favour, mercy, protection, loyalty $\|$ houde 2251. - hulde 594, 1139, 1607, 2167, 2509 etc. - hulden 1780 houde | HOUDE, OUDE (II), OUT houden | HOUDEN, OUDE (I) (II), OUT HOUDEN, str. vb. | tr. - hold, guard, protect, treat, preserve, rule, possess, see; refl. - beware of, behave o.s.; intr. - stand still, find o.s. || (inf.) houden 47, 429, 3205. - (pr.4) houden 633. (pr.5) hout 585. - (pr.5) houddi (clis.) 1142. - (imp.pl.) hout 596, 1808. - (impf.1) hildic (clis.) 587. - (impf.3) hilt 2886. - (impf.6) hilden 1976, 2264. - (p.p.) ghehouden 1804 |l See also: BEHOUDEN, ONTHOUDEN, OPHOUDEN

\section{hout | HOUDEN, HOUT, OUT}

HOUT, adj. | benevolent, sympathetic, loyal || hout 606, 2232 || See also: ONHOUT houtmakigghe | OUTMAKIGGE hove $\mid \mathrm{HOF}$

HOVESCH, adj. | courtly, courteous, civilised || hovesch 1217, 2074. - hoofschen 1422

HOVESCHEIT, n. (f.n.) | courtliness, civility || hoofschede 1665. - hovesscheden 28 HOVESCHLIKE, adv. | courtly, courteously || hoofschelike 37

HOVET, n. (n.) | head || hoeft 289, 742, 817, 985, 1952 etc. - hoefde 688. - thoeft (clis.) 159, 678, 748,1730 
hu | UWE, U

hueghen | HOGE (I)

hulde, hulden | HOUDE

hule | ULE

hulp, hulpe(n) | HELPE (I)

huse | HUUS

hute, hute- | UTE, UTE-

huten, huter | UTE + der

HUUS, n. (n.) | house || huus 513, 524, 1065,

1118,1124 etc. - huse 1639. - huuse 1128. - thuus

(clis.) 2864

huut | HUUT, UTE (I)

HUUT, n. (f.) | skin, bark || huut 269, 741, 1258 ||

See also: BEREHUUT

huutlac | UTELEKEN

huut traken | UTETRECKEN

huwe | UWE

hye $\mid \mathrm{HIE}$

IC, pers. pron. (1 n) $|I| \mid$ ic 12, 22, 30, 34, 40 etc. - ik 1434c. - alsic (clis.) 2047. - badic (clis.) 2348. - begripic (clis.) 32. - bevelic (clis.) 1410. - biddic (clis.) 482, 1672. - claghic (clis.) 116, 419. - dedic (clis.) 1499, 1504, 1517, 1616, 1654 etc. - droughic (clis.) 2326. - ghebiedic (clis.) 2777, 2778. - gheloofdic (clis.) 2541. - hachtic (clis.) 2117. - haddic (clis.) 598, 1149, 1514, 1515, 2967 etc. - haddics (red+clis.) 2714. - hebbic (clis.) 569, 905, 1416, 1439, 1478 etc. - hebbicker (clis.) 573. - hildic (clis.) 587. - hoerdic (clis.) 151. - hopic (clis.) 3148. - icken (clis.) 1505, 1609, 1634. - ickene (clis.) 1466. - icker (clis.) 1153. -ics (clis.) 580, 584, 1030, 2666, 3302, 3401. icse (clis.) 572, 1132, 2084, 2089, 2855 etc. - ict (clis.) $1459,2143,2293,2658,2705$ etc. - in (clis.) $205,559,586,1085,1148$ etc. - inne (clis.) 93 , 492, 560, 1605. - keeric (clis.) 2720. - lapedic (clis.) 2079. - leeddickene (red+clis.) 1508, 1610. - leerdic (clis.) 2082, 2394. - levic (clis.) 424, 2036. - lietic (clis.) 1120. - maghic (clis.) 3147. - makedicse (red+clis.) 1471. - manic (clis.) 2653. - mochtic (clis.) 1832, 2109, 2125, 2205. moestic (clis.) 1558. - moetic (clis.) 999, $2654 \mathrm{c}$. - oftic (clis.) 2654e. - ontvruchtic (clis.) 2332. - peinsdic (clis.) 2341 peinsic (clis.) 3188. prandic (clis.) 1537. - saghic (clis.) 2376, 2390. scraefdic (clis.) 2404. - segghic (clis.) 25, 480, 1380, 1478. - seidic (clis.) 1669, 3165. - soudic (clis.) 605, 1831, 1871b, 2497, 3350. - spaerdic (clis.) 2410. - suchtic (clis.) 1434. - vandic (clis.) 154, 2406, 2407. - verwervic (clis.) 1606. - waendic (clis.) 594, 2529. - wanic (clis.) 277, 906, 2635. - wildic (clis.) 2515. - willic (clis.) 189, 222, 382, 583, 1190, 1406, 1456, 2042, 2512, 2718, 2719. - willics (clis.) 1785. - willict (clis.) 2531. - wistic (clis.) 3256. - zorghic (clis.) 1374. zwijghics (clis.) 94

icken, ickene $\mid \mathrm{IC}+$-ENE

icker | IC + HAER (II)

ics $\mid \mathrm{IC}+-\mathrm{ES}$

icse $\mid \mathrm{IC}+-\mathrm{SE}$

ict | IC + HET (I)

IE, adv. | ever, always, continually || ye 2824

IEMAN, pron. | someone || yement 500, 1417, 2272, 3364. - yemene 2384

IET (I), pron. | something || yet 588, 591, 669, 1116, 1458, 3243, 3245. - yewet 122

IET (II), adv. | somewhat, possibly, ever || yet 1949, 2213, 2581, 2631, 2693, 2731, 3248

IEWAER, adv. | somewhere, to some extent || yewer 2375

IJS, n. (n.) | ice || hijs 2297. - thijs (clis.) 1505 IN (I), prep. | in, within, inside, against || in 5, 9, 12, 23, 28 etc. - int (clis.) 314, 475, 719, 1467, 1529 etc.

IN (II), adv. | in, inside, within || in 1218, 2196 || See also: DAERINNE

in, inne $\mid \mathrm{IC}+\mathrm{EN}(\mathrm{I})$

INBREKEN, str. vb. | tr. - break in, burgle, destroy; intr. - break $\|$ (p.p.) in tebroken 1166 INCOMEN, str. irr. vb. | intr. - enter, begin || (p.p.) commen in 1526

INCRUPEN, str. vb. | intr. - creep into || (inf.) incrupen 1517. - (impf.3) croep in 2405 inderwaert $\mid$ HINDERWAERT

INDIEN, conj. | if, while, because, as, so that || indien dat 2187, 2468, 2507, 2820

INGAEN, irr. str. vb. | intr. - enter, begin, break; tr. - enter into || (inf.) ingaen 1190, 3078. - ten ingane 322

INLIGGEN, str. vb. | intr. - stay || (pr.3) leghet in 275

INLOPEN, str. vb. | intr. - enter (a fight or battle), break (of dykes) || (inf.) inloepen 1900 INSTEKEN, str. vb. | tr. - insert, stick in, attack || (impf.3) instac 679

instac | INSTEKEN

int $\mid \mathrm{IN}+\mathrm{DAT}(\mathrm{I})$

INTRECKEN, w.+str. vb. | tr. intr. - retract || (impf.3) trac in 516 
is $\mid$ SIJN (I)

ISER, n. (n.) | iron, fetters, armour, arrow, nail || (pl.) dysere (clis.) 3465

JA, adv. + interj. | yes, undoubtedly, although || ja 1155, 1417, 2202, 2548, 2637 etc. - jaet (clis.) 2691, 3429

JAER, n. (n.) | year || jaer 115, 169, 240, 424, 834 etc. - jare 270, 1273, 2309. - (pl.) jaren 604 jaet $\mid$ JA + HET (I)

JAGEN, w. vb. | tr. - hunt, shoot, chase, aim to; intr. - strive for, make haste || (inf.) jaghen 1593 || See also: BEJAGEN, ONTJAGEN

JAGER, n. (m.) | hunter || (pl.) jagheren 2454 JAMER, n. (m.n.) | wailing, mourning || jammer 308

JAMERLIJC, adj. | pitiful, moving || jammerliken 1207

JAMERLIKE, adv. | pitifully, movingly || jammerlic 874. - jammerlike 2190, 2888, 2988 jan | GONNEN

jans | GONNEN + -ES

jare, jaren $\mid$ JAER

JEGHEN (I), prep. | against, opposite, coming towards, contra || jeghen 113, 738, 1331, 1357, 1458 etc.

JEGHEN (II), adv. | opposite, coming towards, at present $\|$ jeghen 3274 . - te jeghen 215

JONC, adj. | young || jonc 112, 1711. - jonghe 439, $2306,2603,3328$. - jonghen 765 . - jongher 328 , 329

JONCHERE, n. (m.) | young nobleman || (pl.) joncheeren 2034

JONGELINC, n. (m.) | young man || jonghelinc 223, 1896

jonnen | GONNEN

k- $\mid \mathrm{C}-$

keer | KEER, KEREN

KEER, n. (m.) | turn, direction, fate, journey, opportunity, trick, conversion \| keer 1910 || See also: WEDERKEER

keerdi omme | OMMEKEREN + HI keeren | KEREN

KEITIJF, n. (m.) | prisoner, wretch, fool || keytijf 640,838 . - (pl.) keytive 2800

KELE, n. (m.f.) | throat, maw || kele 662, 1520, 1818, 1936, 2967 etc. - kelen 158, 185, 1884, 3120 kendi $\mid$ KENNEN + GI

KENNEN, w. vb. | tr. - know, understand, recognize; refl. - be humble, be meek $\|$ (pr.1) kenne 2329, 2351. - (pr.3) kent 53. - (pr.5) kendi (clis.) 938. - (pr.6) kennen 86. - (impf.1) kende 2293, 2334 || See also: BEKENNEN

KEREN, w. vb. | tr. - turn, translate, explain, send; refl. - turn around, behave o.s.; intr. turn around, turn back \| (inf.) keren 1187 , 1523. - (pr.1) keeric (clis.) 2720. - (pr.3) keert 11, 29. - (pr.5) keert 1663. - (pr.6) keeren 36, 2033. - (imp.sg.) keer 1049a. - (impf.3) keerde 641, 1304, 2448, 3318. - (impf.6) keerde 1750 |l See also: OMMEKEREN, UTEKEREN, WEDERKEREN

KERKE, n. (f.) | church || kerke 726

KERMEN, w. vb. | intr. - groan, lament || (impf.3) carmede 2711, 2713

KERMINGE * n. (f.) | groaning $\|$ carminghe 313 kerren | CARRE

keytijf, keytive $\|$ KEITIJF

KINT, n. (n.) | child, prince, (male) servant || kint 2074. - (pl.) kindre 74, 339, 398, 409, 412 etc. - kindren 168, 390, 2124, 2782, 3246. kinderen 320

KNECHT, n. (m.) | boy, (male) servant, subordinate || knecht 1774. - knechte 2939. (pl.) knechte 2684

KNIE, n. (n.f.) | knee, bend || (pl.) knien 2882

\section{lach | LIGGEN}

LACHEN, str.+w. vb. | intr. - laugh, smile || (inf.) lachen 626. - van lachene 3019. - (impf.3) louch 614, 622, 657, 1286, 1622 etc.

LACHTER, n. (m.n.)| disgrace, defamation, jeering || lachter 71, 95, 1962, 2226. - lachters 2834. - lachtre 1024, 1296, 2175, 2276 || See also: LASTER

LACHTERLIKE, adv. | disgracefully || lachterlike 1383

LADEN, str. vb. | tr. - load, fill, order; intr.; refl. - take s.th. upon oneself II (inf.) laden 477. (p.p.) gheladen 556

laet | LATEN + HET (I)

laetse | LATEN + -SE

laetti | LATEN + GI

LAGE, n. (f.) | position, opportunity, lodging, ambush || laghe 135, 407, 2368. - (pl.) laghen 345, 2361

LAGEN, w. vb. | tr. - lie in wait for || (impf.4) lagheden 2119 || See also: BELAGEN

laghen | LAGE, LIGGEN 
LAKEN, n. (n.) | sheet, (woollen or linen) cloth || tlaken (clis.) 91

LAM, n. (n.) (en m.) | lamb || (pl.) lammen 2076 lanc $\mid$ LANC, LANGE

LANC, adj. | long, lengthy, limp, slow || lanc 304, 447, 509, 552, 2846. - langhe 1772, 2207. langhen 3154. - (comp.) langher 240, 631, 712, 793, 3325

LANCVOET, n. (m.) | large foot || lancvoet 785 LANGE, adv. | long, for a long time, continually || langhe $355,582,863,1158,1323$ etc. - lanc 1218, 2926. - (comp.) langher 429, 828, 1300, 1328, 2011 etc. - (superl.) lancst 3198

LANGEN, w. vb. | intr. - become longer; tr. longfor, lengthen; impers. || (pr.3) langhet 1955 langhe(r) | LANC, LANGE

LANKE, n. (f.) | side, underbelly || (pl.) lancken 875

LANT, n. (n.) | land || lant 1510, 1535, 2249, 2257, 2432 etc. - lande 870, 2388, 2427, 2724, 2868 etc. - (pl.) landen 2312

LANTERNE, n. (f.m.) | lantern, candle || (pl.) lanternen 804

LAPEN, w. vb. | tr. - lick, slurp || (impf.1)

lapedic (clis.) 2079

las | LESEN

LASTER, n. (m.) | disgrace, defamation, jeering || laster 1822c || See also: LACHTER

LAT, adj. | slow, lazy || lat 1178

LATEN, str. vb. | tr. - let, do, fail to do, leave behind, allow, let blood; refl. - behave o.s., subject o.s.; intr. - show o.s., let go of; aux. || (inf.) laten $625,1558,1561,1814,1972$ etc. - (pr.1) laet 2183. - (pr.5) laet 2742. - laetti (clis.) 165. - (pr.6) laten 17. - (imp.pl.) laet 406, 489, 1187, 1290, 1291 etc. - laet (clis.) 590. - laetse (clis.) 2035. - lates (clis.) 3204. - (impf.1) liet 1120, 2737. lietic (clis.) 1120. - (impf.3) liet 677, 744, 811, 1306, 1428 etc. - lijt 3101b. - (impf.6) lieten 838 . - lietene (clis.) 1591, 1592. - (p.p.) gelaten 1748. - ghelaten 854, 929, 2477, 2549, 2803 || See also: GELATEN, MISLATEN, NEDERLATEN, VERLATEN

lates | LATEN + -ES

LAVEN, w. vb. | tr. - refresh, comfort || (inf.)

laven 3238

lecht | LICHT (II)

LECKERNIE, n. (f.) | titbit, lust || leckernie 2082

lede | LIT leden | LIDEN (II), LIT

leeden | LEET (I), LEIDEN

leeddickene | LEIDEN + IC + -ENE

leeft | LEVEN (I)

leelic | LELIJC

leeren | LEREN

LEEN, n. (n.m.) | fief, (official) post, authority, power, possession || leene 3454

leet $\mid$ LEET (I), LEIDEN

LEET (I), adj. | disagreeable, horrible, sad || leet 1559, 1949, 2001, 2144, 2903 etc. - leit 1966a. leede 2836. - leeden 1524. - sleets (clis.) 1276 LEET (II), n. (n.) | sorrow, grief, unhappiness, loss, discomfort, pain || leede 89, 752, 861, 3224 LEGGEN, w. vb. | tr. - lay, place, make, stop || (impf.3) leide 345, 400, 407, 451, 2361. - (impf.5) leit 219. - (impf.6) leidene (clis.) 1600

\section{leghet | LIGGEN}

leide, leidene | LEGGEN

LEIDEN, w. vb. | tr. - lead, escort, spend || (inf.) leeden 2051. - (pr.5) leet 1138. - (imp.pl.) leedet 1763. - (impf.1) leede 1152. - leeddickene (clis.) 1508, 1610. - (impf.3) leedde 1705. - (impf.6) leedden 2493. - (p.p.) gheleit 889. - gheleet 3402. || See also: GELEIDEN, MISLEIDEN leidene | LEGGEN + -ENE

leit | LEET (I), LEGGEN

LELIJC, adj. | ugly, unpleasant, disgraceful || leelic 746

LEREN, w. vb. | tr. - teach, tell, learn, hear || (inf.) leeren 1489, 2070. - te leerne 142. - (pr.5) leert 1929. - (impf.1) leerde 1505. - leerdic (clis.) 2082, 2394. - (impf.3) leerde 642. - (p.p.) gheleert 203, 1968 || See also: GELEERT LESEN, str. vb. | tr. - read, read out, collect, recite, teach, declare, learn $\|$ (inf.) lesen 147, 361, 388, 1739, 2222 etc. - te lesene 359, 1680. - (imp. pl.) leest 2945. - (impf.3) las 249, 449, 3365. (p.p.) ghelesen 1079 || See also: OPLESEN LESSE, n. (f.n.) | recitation, lesson, declaration, story || lesse 449. - lessen 155 || See also:

GELES, SIELELESSE

let | LETTEN, LIT

lettel | LUTTEL

LETTEN, w. vb. | tr. - prevent, delay, harm; intr. - retard, wait || (inf.) letten 1314. - (pr.5) let 1949. - (pr.s.3) lette 475

LETTERE, n. (f.) | (single) letter, caption, letter, book || (pl.) letteren 361, 455. - lettren 3252, $3262,3266,3280,3283$ etc. 
LEVEN (I), w. vb. | intr. - live, act; tr. experience || (inf.) leven 377, 582, 2321, 2501, 3140. - te levene 330. - (pr.1) levic (clis.) 424, 2036. - (pr.6) leven 23, 37, 1461, 2954. - (pr.s.1) leve 3198. - (imp.pl.) leeft 346o \| See also: VORTLEVEN

LEVEN (II), n. (n.) | life, way of life, pleasure, period || leven 173, 1069, 1500, 1793, 3410. tleven (clis.) 1498

LICHAME, n. (m.n.) | body, person || lichame 433

LICHT (I), adj. | light, quick, easy, obvious, slight || lichten 3301

LICHT (II), n. (n.f.) | light || lecht 1643 || See also: STALLICHT

LICHTE, adv. | lightly, easily, possibly, lightheartedly || licht 3028. - lichte 1784, 3257

LIDEN (I), str. vb. | intr. - go, pass, happen; tr. - endure, excel || (inf.) lijden 150, 1052, 1056. (pr.3) lijdet 2593. - (pr.6) lijden 3148. - (p.p.) gheleden 2454 || See also: GELIDEN

LIDEN (II), str. vb. | tr. - bear, long for, endure; intr. - resign o.s. to; refl. - have patience || (p.p.) leden 231, 2453, 3199

LIEBAERT, n. (m.) | leopard, lion || lubaert 3391

LIEDE, n. (m.pl.) | people, the population, subjects || liede 566, 1479, 3250. - lieden 765, 1792, 2191

LIEF (I), adj. | dear, popular, beloved, agreeable, in a good mood, in good health, safe || lief 1559, 1893, 1988, 2221, 2904. - lieve 575, 1103, 1111, 1278, 1435 etc. - liever 2654 h. - (comp.) liever 1652 , 3245. - (superl.) liefsten 2193, 2230. - (superl., n.) die liefste 2906

LIEF (II), n. (n.) | joy, pleasure, (met l.) in a cheerful mood, safe, in good health || lief 2144; met lieve 2761

LIEFHEBBEN, w. vb. | tr. - love || (pr.1) hebbic lief (clis.) 1416. - (pr.3) heeft lief 130. - (pr.5) lief hebt 1812. - (impf.3) hadde lief 3286

LIEGEN, str. vb. | intr. - lie, mislead; tr. - deny, harm || (inf.) lieghen 204, 485. - dat lieghen 2517. - (pr.1) liege 2654e. - (pr.5) lieghet 2808. (impf.s.1) loghe 3165. - (p.p.) gheloghen 205, 3185 LIËN, w. vb. | tr. - confess, admit, approve; intr. - plead, agree $\|$ (pr.3) lyet (clis.) 2281. - (impf.3) lyede 3108 . - (p.p.) ghelyet 3418

liep, liepen | LOPEN

liept $\mid$ LOPEN + HET (I)
LIER, n. (n.) | cheek || lier 1348. - (pl.) lier 745, 855, 994. - liere 895, 1960

liet, lieten | LATEN

lietene | LATEN + -ENE

lieve | LIEF (I), LIEF (II), LIEVE (I)

LIEVE (I), n. (f.) | pleasure, affection, love ||

lieve 2131,3348

LIEVE (II), adv. | in a pleasant way, (comp.) sooner || (comp.) liever 1654, 2040, 2967, 3464 liever | LIEF (I), LIEVE (II)

LIGGEN, str. vb. | intr. - lie, be, stay, happen, be situated, be advantageous || (inf.) ligghen 839, $871,932,960,2183$ etc. - te ligghene 536. - van ligghene 3156. - (pr.3) leghet 418, 427, 461, 465, 923 etc. - (pr.6) ligghen 3014. - (impf.3) lach $456,458,508,535,850$ etc. - (impf.6) laghen 75 , 791, 1363, 1640, 2920. - (pr.p.) ligghende 1604 II See also: GELIGGEN, INLIGGEN

LIJCTEKEN, n. (n.) | scar, mark, proof ||

lijcteekine 2292

lijden | LIDEN (I)

LIJF, n. (n.m.) | life, livelihood, body, person || lijf 132, 236, 720, 1382, 1404 etc. - live 1978, 2780, 3247. - tlijf (clis.) 3132

\section{lijne | LINE}

LINDE, n. (f.) | lime tree || linde 453

LINE, n. (f.) | rope, cord || lijne 1079, 1935, 1946, 1958, 1964 etc. - lijnen 2025 || See also:

\section{CLOCKENLINE}

LIOEN, n. (m.) | lion || lyoen 1833, 3393, 3459 LIST, n. (f.m.) | knowledge, skill, trick || lust 117, 995, 1744, 1909, 2046 etc. - luste 1034. - liste 686,2395

LISTICH, adj. | clever, agile || lustich 2048. lusteghe 2364

LIT, n. (n.) | limb, member, part || let 2840. - lede 2536. - (pl.) lede 1822d, 2776, 2811. - leden 2886

live $\mid$ LIJF

loedwapper | LOOTWAPPER

loef $\mid \mathrm{LOOF}$

loen $\mid \mathrm{LOON}$

loepen | LOOPEN

LOF, n. (m.n.) | praise, honour, favour, consent || lof 56, 3299. - love 47, 196, 649

LOGE, n. (f.) | lye || loghe 788

LOGENE, n. (f.) | lie || loghene 2207

loghe | LIEGEN, LOGE

LONEN, w. vb. | tr. - pay, reward, repay, avenge, serve; intr. - be revenged $\|$ (inf.) loenen 2552. lonen 1421, 1781 || See also: WEDERLONEN 
LOOF, n. (n.) | foliage, leaves || loef 1446. - (pl.) lovere 3065. - loveren 43

loofde | LOVEN

LOON, n. (m.n.) | payment, reward, price, repayment, retribution || loen 1795

LOOTWAPPER, n. (m.) | leaden ball ||

loedwapper 794

LOPEN, str. vb. | intr. - go, walk, run, flow, extend, amount to; tr. - kick; impers. || (inf.) loepen 721, 1161, 2029, 2035, 3420. - tloepen (clis.) 755. - (impf.1) liep 1528, 1531, 2401. (impf.3) liep 756, 823, 896, 1248, 2432. - liept (clis.) 721. - (impf.6) liepen 1161, 1495, 1579, 1864, 2019 etc. - (p.p.) gheloepen 503, 507, 644, 724, 732 etc. - (pr.p.) loepende 2812 || See also: BELOPEN, HENENLOPEN, INLOPEN, MEDELOPEN, NALOPEN, NEDERLOPEN, OMMELOPEN, OVERLOPEN, TOELOPEN, VORTLOPEN, WECHLOPEN LOS, adj. | loose, free, robbed of, remote from || $\operatorname{los} 1471$

LOSENGIEREN, w. vb. | intr. - flatter, cajole || (inf.) losengieren 3086

louch | LACHEN

love | LOF, LOVEN

LOVEN, w. vb. | tr. - praise, approve, promise; intr. - trust \| (pr.1) love 2769. - (impf.3) loofde 3271 || See also: BELOVEN, GELOVEN,

\section{VERLOVEN}

lovere | LOOF

lubaert | LIEBAERT

LUCHT, adj. | left || luchter 1053

LUDE, adv. | hard, loud || lude 148, 1227, 1551, 2644 || See also: OVERLUDE

LUDEN, w. vb. | intr. - sound, sing, ring; tr. - cause to sound, announce $\|$ (inf.) luden 1495. - dat luden 1488. - (pr.3) ludet 1297. - (impf.3) luudde 1491 lust $\mid$ LIST

luste | LIST, LUSTEN

LUSTEN, w. vb. | impers. - fancy; intr. - please |l (pr.3) luste 828. - (pr.6) lusten 330

lustich | LISTICH

LUTTEL (I), adj. | small, little || lettel 736, 920 || See also: ALLERMINST (reinf. superl.)

LUTTEL (II), adv. | little, not often, seldom || lettel 226, 780, 2129, 2328, 2434 etc. || See also: MIN (comp.)

LUTTEL (III), n. (m.n.) | little, little bit || lettel 1629, 2024, 2280, 2395, 2609 etc. - (dimin.) lettelkijn 3217

\author{
luudde | LUDEN \\ lyede | LIËN \\ lyet | LIËN + HET (I) \\ lyoen | LIOEN
}

\section{mach | MOGEN}

MACHT, n. (f.m.) | force, power, violence || macht 2873 || See also: ONMACHT

MAECH, n. (m.) | relative $\|$ maech 1668,1902 , 2714, 3392. - (pl.) maghe 62, 1085, 2461, 3442. maghen 1024, 1757, 1852, 1888, 2193 etc.

maechs | MOGEN + -ES

maect, maecten $\mid$ MAKEN

maectene | MAKEN + -ENE

maectet $\mid$ MAKEN + HET (I)

MAEL, n. (m. f. n.) | sign, time of day, meal ||

male 6oo, 3138

maende $\mid$ MANEN

MAENT, n. (f. m.) | month, moon || maent 175

MAER, conj. | unless, if not, except that, but ||

maer 514, 556, 1781, 1993, 2031 etc. - mar 3101b

maerbersteene |MARBERSTEEN

maerc|MARC

maerghin |MORGEN (II)

maerken | MERKEN

MAGER, adj. | thin, poor, meagre || magher 279

maghe $\mid \mathrm{MAECH}$

maghet $\mid$ MOGEN + HET (I)

maghic $\mid$ MOGEN + IC

MAKEN, w. vb. | tr. - prepare, make, cause, repair; refl. - get ready, go to, pretend; intr. undertake, make a lot of fuss and noise; impers. II (inf.) maken 30, 143, 511, 610, 1153 etc. - (pr.3) maect 2567. - maket 92, 247. - (pr.6) maken 20. - (imp.pl.) maect 1940, 1948. - (impf.1) maecte $152,1528,1529,2926$. - maectene (clis.) 1483. - (impf.3) maecte 1, 746, 1060, 2112, 2256. - makede 1206, 2673. - maectet (clis.) 2388. - (impf.6) maecten 1571, 1573, 2302, 3469. makeden 238, 1862. - makedicse (clis.) 1471. - (p.p.) ghemaect 452, 997, 1516, 2436, 3360. ghemaket 1999. || See also: MISMAKEN MALC, pron. | every, each || manlic andren 1574, 2103 male | MAEL, MALE (I) (II) *

MALE (I), n. (f.) | stomach, bag $\|$ male 400, 889 MALE* (II), adv. (Latin) | wicked, evil $\|$ male 257

MALSCH, adj. | overconfident, arrogant || malsch 19 
MAMME, n. (f.) | breast, udder || mammen 2075

MAN, n. (m.) | human being, man, vassal, servant $\|$ man 105, 228, 263, 564, 719 etc. (pl.) mannen 167|| See also: MOLENMAN, TIMMERMAN

\section{mane | MANE, MANEN}

MANE, n. (f.) | moon || mane 1099

MANEN, w. vb. | tr. - remind, urge, beg, summon, warn || (pr.1) mane 2155. - manic (clis.) 2653. - (pr.5) manet 2654g. - (impf.1) maende 2348. - (impf.3) maende 3043. - (p.p.) ghemaent 2181 || See also: VERMANEN

MANGELINGE, n. (f.) | exchange, contract, dispute || manghelinghe 2338

MANIERE, n. (f.) | manner, custom, habit, nature $\|$ manieren 3087

manlic|MALC

mar $\|$ MAER

MARBERSTEEN * n. (m.) | marble || maerbersteene 454

MARC, n. (f. n. m.) | mark (coin) || maerc 1091, 2616, 3143

MARE, adj. | famous, prestigious || mare 238, 294, 417, 615

MAT, adj. | powerless || mat 1283

MATE, n. (f.) | measure, moderation || mate 672. - maten 626, 666

MATER, n. (f.); (Latin) | mother || mater 1453 me | MEER (II)

MEDE (I), adv. | with which, also, as well || mede 366, 730, 996, 1173, 2081 etc. || See also:

DAERMEDE

MEDE (II), n. (m.) | mead $\|$ mede 2177

MEDEGAEN, str. irr. vb. | intr. - accompany

|| (inf.) mede gaen 1945, 2391. - (impf.3)

medeghinc 1922

MEDELOPEN, str. vb. | intr. - walk, go along with || (inf.) mede lopen 1958

mee |MEER

meende $\mid$ MENEN

meer $\mid$ MEER (I) (II), MERE

MEER (I), indef. num. (comp. of VELE I) |

more $\|$ meer 21, 232, 426, 753, 806 etc. - meere 102, 3186. - mee 1479

MEER (II), adv. (comp. of VELE III) | more, henceforth, moreover $\|$ meer 2504, 2526, 2687, 2785. - me 1375. - mee 2086, 3149, 3193

meer | MERE

meerct $\mid$ MERKEN
meerre(n)|MERE

meest | MEEST, MEESTE

MEEST, indef. num. (superl. of MEER) | most

|| meest 191, 904, 2041

MEESTE, adj. (comp. of GROOT, VELE II)

| largest, greatest, highest, oldest || meeste 137,

1006, 2582. - meesten 851. - meest 186

MEESTER, n. (m.) | master, boss $\|$ meester 154, 250, 2801, 2952

MEESTERLIJC, adj. | masterly, as done by a master $\|$ meesterlike 2395

MEKEL, adj. | great, large || mekel 718

MEN, indef. pron. | they, people in general || men $92,127,168,180,258$ etc. - men (clis.) 1912, 2616, 1888. - menne (clis.) 1007. - ment (clis.) 1912,

2569

men | MEN + -ENE / EN (I)

MENEN, w. vb. | tr. - mean, think, suspect || (impf.3) meende 638

MENICH, indef. pron.; used attrib. + indep. | much, many, many people $\|$ (attrib.) menich 115, 169, 338, 513, 923 etc. - menigh 2663. - meneghe $371,1125,1697,1698$, 2362. - meneghen 779, 1251, $1337,1507,1902$ etc. - menegher 207, 1646, 3087. - (indep.) menich 1034, 1061

MENICHVOUDICH, adj. | frequent, different || menichfoudeghe 2451

MENICHVOUT, adj. | manifold, different, very || menichfout 542. - menichfoude 505, 898, 2664

MENIGERHANDE, adj. | various ||

menegherande 3158

menne $\mid$ MEN + -ENE

ment $\mid$ MEN + HET (I)

MERE, adj. (comp. of GROOT, VELE II) | greater, more, older $\|$ meer 234, 737, 2535, 2834, 3349. - meerre 1470. - meerren 1504 merkedi $\mid$ MERKEN + HI

MERKEN, w. vb. | tr. - signal, investigate, mark, understand, become aware of; intr. - signal, give signs || (inf.) maerken 2604. - (imp.pl.) meerct 2486. - merket 2573. - (impf.3) mercte 1895. merkedi (clis.) 2383

MERREN, w. vb. | tr. - hinder; intr. - delay, remain, stay away, stand still $\|$ (inf.) merren 3217. - (impf.3) merrede 3202 || See also: VERMERREN

MES, n. (n.) | knife || messe 1567 || See also: TAFELMES

mes- | MIS- 


\section{mesdaen | MISDOEN \\ mesleettene | MISLEIDEN + -ENE \\ mesliet | MISLATEN \\ mesquame | MISCOMEN \\ mesrocht $\mid$ MISRAKEN \\ messe | MES, MISSEN}

MET, prep. | with, at, by || met 39, 43, 153, 179, 201 etc. - metten (clis.) 60, 416, 765, 796, 800 etc. - metter (clis.) 713, 763, 793, 813, 1094 etc. - mettien (clis.) 1917, 2018, 2809 || See also:

DAERMEDE

metten | MET + DIEN (I)

metter $\mid$ MET + DIER (II)

METIEN, adv. | at the same time, at that moment $\|$ mettien 709

mettien $\mid$ MET + DIEN (I)

MEYE, n. (m.f.) | May $\|$ meye 2639

MI, pers. pron. (1 d/a) $\mid m e \| \mathrm{mi} \mathrm{27,30,69,} \mathrm{78,}$ 88 etc.

MICKE, n. (f.) I gaff shaped pole, pole used for gallows $\|$ micke 2822. - (pl.) micken 3146

MIDDACH, n. (m.) | afternoon || middach 384 , 3332

MIDDEN, adv. | in the middle of || midden 109, 1313

MIDDEWAERT, n. (f.n.) | middle ||

middewaerde 511. - middenwaerde 1549

MIEDE, n. (f.) | pay, present, ransom, money ||

miede 1982

mier, miere $\mid$ MIJN

MIJN, poss. pron. (1) | my || mijn 11, 73, 173, 190, 195 etc. - mine $74,116,339,409,412$ etc. minen $25,131,152,193,206$ etc. - mijns 26,95 , 1404, 2345, 2559 etc. - mier 2136, 2937. - miere $68,117,183,318,381$ etc. - mire 1451 . - tmijn (clis.) 3150

\section{mijns | MIJN, MIJNS}

MIJNS, pers. pron. (2 g) | (on/for etc.) me || mijns 420, 2132

MILDE, adj. | benevolent, mild, generous || milde 2187. - milder 2431

MILE, n. (f.) | mile || mile 864, 976

MIN, adv. (comp. of LUTTEL II) | less || min 1294

mine, minen $\mid \mathrm{MIJN}$

MINDER, adj. (comp. of CLEINE) | smaller, lesser $\|$ mindre 410,1470

MINEREN, w. vb. | intr. - eat greedily, stuff o.s.; tr. - undermine, digest $\|$ (inf.) mineeren 704 minne MINNE, MINNEN
MINNE, n. (f.) | love, beloved, warm-

heartedness, peace $\|$ minne 243

MINNEN, w. vb. | tr. - love, desire || (inf.)

minnen 583. - mynnen 2759a. - (pr.1) minne

579, 1134. - (p.p.) ghemint 237

mire $\mid \mathrm{MIJN}$

MISBARE, n. (n.f.m.) | clamour, noise, mourning $\|$ mesbare 3242

MISBAREN, w. vb. | intr. - rant, lament; refl. || (pr.6) mesbaren 3220

MISCOMEN, w. vb. | intr. - experience, prevent; impers. . - displease $\|$ (impf.s.3)

mesquame 669, 3245

MISDADICH, adj. | criminal, sinful ||

mesdadich 2068

MISDAET, n. (f.) | crime, oversight, injustice || mesdaet 1451, 2545, 3412, 3415, 3448. - (pl.) mesdaden 1677, 2804

MISDOEN, irr. str. vb. | intr. - act wrongly, harm, sin $\|$ (inf.) mesdoen 3458. - (p.p.) mesdaen 51, 191, 1455, 1460, 1661 etc.

MISLATEN, str. vb. | refl. intr. - rant, lament, act strangely || (impf.3) mesliet 1299. - (pr.5) mesliet 3395

MISLEIDEN, w. vb. | tr. - mislead, harm; refl. - misbehave \| (pr.5) mesleettene (clis.) 208 MISMAKEN, w. vb. | tr. - maim, torture || (p.p.) mesmaect 987

MISPRIJS, n. (m.) | disgrace, contempt || mesprijs 1475

MISPRISEN, w.+str. vb. | tr. - disapprove, hold in contempt, reproach $\|$ (inf.) mesprijsen 168

MISRAKEN, irr. w. vb. | intr. - lose one's way, be unhappy, fail || (inf.) mesraken 496, 1752. (p.p.) mesrocht 747

MISSELIJC, adj. | various, precarious, uncertain || messelic 1387

MISSEN, w. vb. | intr. - miss, be mistaken, fall short; tr. \| (pr.1) messe 2581

MISTROUWEN, w. vb. | intr. - mistrust, become disloyal || (impf.1) mestroude 2693 MISVAL, n. (n.) | disaster, defeat, ailment, insult, error $\|$ mesval 1357

MISVALLEN, str. vb. | intr. - experience misfortune, stumble $\|$ (p.p.) mesvallen 3243 MISVOEREN, w. vb. | tr. - maltreat, make unhappy $\|$ (p.p.) mesvoert 74 mochte, mochten $\mid$ MOGEN mochtes $\mid$ MOGEN + -ES 


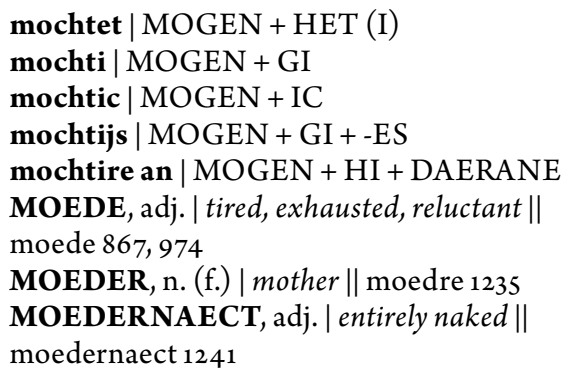

MOER, n. (n.m.) | mud, marsh || moer 2661 moert $\mid$ MORT

MOET, n. (m.)| (quick) temper, mood, disposition, sense, mind, opinion, agreement $\|$ moet 1041, 1060, 1899, 2503, 2539 etc. - te moede 310, 1062, 1761, 2919

MOETEN, irr. vb. (pret. pres.) | must, may, cannot fail to, shall, can, be possible, need || (pr.1) moet 381, 570, 999, 1418, 2654c, 3077. - moetic (clis.) 999, 2654c. - (pr.3) moet 428, 917, 1043, 1421,1630 , etc. - (pr.4) moeten 566. - (pr.5) moet 1108, 1561, 2625, 2626, 3058 etc. - moetet 2867. - moetti (clis.) 1444, 2002, 2012. - (pr.s.3) moete 10, 354, 490, 1039, 1068 etc. - moeter (clis.) 430. - (impf.1) moestic (clis.) 1558. (impf.3) moest 1586. - moeste 290, 510, 853, 1204, 1250,1729 etc.

moestic $\mid$ MOETEN + IC

moeter $\mid$ MOETEN + HAER (II)

moetic $\mid$ MOETEN + IC

moetti | MOETEN + GI

MOEYE, n. (f.) | aunt || moye 1990, 2900, 2911. - moyen 1365, 1667, 2861, 3212, 3218 etc.

MOGEN, irr. vb. (pret. pres.) | may, be in a position to, be allowed, must, shall, need, dare, like, bear || (inf.) moghen 559, 691, 1480, 2439, 2994. - (pr.1) mach 560, 571, 908, 1400, 1405 etc. - maghet (clis.) 3341. - maghic (clis.) 3147. - (pr.3) mach 96, 246, 486, 488, 595 etc. maechs (clis.) 1500. - (pr.4) moghen 1184, 3161. - moghense (clis.) 429. - (pr.5) moghet 589, $637,663,1384,1834$ etc. - moghedi (clis.) 2863. moochdi (clis.) 1116. - mooghdi (clis.) 376,565 , 702. - (impf.1) mochte 1634, 1647, 2667, 2682, 2701 etc. - mochtic (clis.) 1832, 2109, 2125, 2205. - (impf.3) mocht 312, 962, 3392. - mochte 251, $442,545,622,721$ etc. - (impf.5) mocht 216, 1113. - mochtes (clis.) 2866. - mochtet (clis.) 3257. - mochti (clis.) 1139, 2577. - mochtijs (clis.) 588,591 - - mochtire an (clis.) 133. - (impf.6) mochten $847,2840$. - (p.p.) ghemoghen $1732 \|$ See also: VERMOGEN

MOGENDE, adj. | strong, powerful, rich || moghende 2802

moghedi | MOGEN + GI

moghense $\mid$ MOGEN + -SE

MOLENE, n. (f.) | mill || molen 119

MOLENMAN, n. (m.) | miller $\|$ molenman 121

MONIC, n. (m.) | monk || moonc 1483. moonke 2708, 2710

MONT, n. (m.f.) | mouth (also of an animal) || mont $182,403,415,596,1537$ etc. - (pl.) monden 2462

moochdi $\mid$ MOGEN + GI

mooghdi $\mid$ MOGEN + GI

moonc $\mid$ MONIC

moort $\mid$ MORT

MORDDADELIKE, adv. | murderous, criminal || mordadelike 3120

MORDDADICH, adj. | with murderous intent, criminally $\|$ mordadeghe 357

MORDELIJC, adj. | treacherous, criminal, murderous $\|$ mordeliken 2161

MORDEN, w. vb. | tr. intr. - murder, kill || (inf.) te mordene 2191

MORDENARE, n. (m.) | murderer, criminal, villain || mordenare 1222. - mordeneere 128. (pl.) mordenaren 3036

MORGEN (I), n. (m.) | morning || morghins 2278

MORGEN (II), adv. | tomorrow || maerghin 1094, 1373, 1392, 2717, 2789. - morghen 1083. morghin 1098, 1185, 2744

MORSEEL, n. (n.) | bite, piece, morsel || morseel 923. - morzeel 134 MORT, n. (f.) | death, murder, murder plan, shameful act || moert 2148, 2205. - moort 437, 2160, 2197. - morde 2524. - mort $2654 \mathrm{f}$ MOS, n. (n.) | moss, pool || mos 2609, 2620 MOUDE, n. (f.) | earth, soil || mouden 465, 2393 moye $\mid$ MOEYE

MUER, n. (f.m.) | wall || muere 335, 343, 393, 1164, 1699, 1706

MULE, n. (f.m.) | maw || mulen 694. - (dimin.) muulkine 1413

MUSEEL, n. (m.n.) | muzzle, snout || muzeele 219

muse | MUUS

muulkine | MULE 
MUUS, n. (f.m.) | mouse || muus 1119, 1121, 1125, 1149. - muse 1129, 1132, 1134, 1135, 118 o etc. muzeele | MUSEEL mynnen | MINNEN

NA (I), prep. | after, to, behind, according to || na $8,296,298,627,635$ etc.

NA (II), adv. | near, almost, behind, following, next, later, after || na 1419, 1498, 1552, 1898, 2569 etc. || See also: DAERNA

NACHT, n. (f.m.) | night || nacht 1604, 1914, 2045, 2265, 2410 etc. - nachte 118, 408, 2367, 2369, 2784. - snachts (clis.) 1107

NADAT, conj. | after, as || nadat 2735, 3418 NADIEN, conj. | after, when, as, like || nadien dat 2221, 2758

naect | NAECT, NAKEN

NAECT, adj. | naked || naect 1253 || See also: MOEDERNAECT

NAER, adv. | after which, last, later || naer 2023 NAEST (I), adv. | nearest, recently, soon || naest 269, 714, 1248. - (superl.) alrenaest 2605

NAEST (II), adj. | near, next, first || naeste 715, 1888. - naesten 270

NAET, n. (f.m.) | seam || naet 1267

NAGAEN, str. irr. vb. | intr. - attack, torment || (pr.3) gaet na 3408

NAKEN, w. vb. | intr. - approach, threaten, happen, touch; impers. || (inf.) naken 495, 1751. (pr.3) naect 3319. - naket 3113. - (impf.3) naecte 781, 1566. - nakede 401. - (p.p.) ghenaect $988 \|$ See also: GENAKEN

NALOPEN, str. vb. | intr. - follow, pursue || (pr.6) liepen na 347

nam | NEMEN

NAMAELS, adv. | later || namaels 2059 name | NAME, NEMEN

NAME, n. (m.f.) | name, title, fame, meaning || name 1276, 2635, 2706. - namen 1001, 2460

namen | NAME, NEMEN

namene | NEMEN + -ENE

NAUWE (I), adj. | narrow, cramped, accurate, familiar || nauwen 2488

NAUWE (II), adv. | narrowly, dangerously, accurately, sparsely || nauwe 2128, 2360 ne $\mid$ EN

NEDERGAEN, str. irr. vb. | intr. - come down, decrease \| (impf.3) ghinc neder 890, 930

NEDERLATEN, str. vb. | tr. refl. - cause to come down, let down || (impf.3) liet neder 958
NEDERLOPEN, str. vb. | intr. - walk down, stream, glide down || (impf.3) nederliep 895. (impf.6) liepen neder 2986-2987

NEDERSLAEN, str. vb. | tr. - knock down, kill, keep down; refl. - establish o.s.; intr. - knock down, hang down, collapse $\|$ (impf.3) slouch neder 3384

NEDERVALLEN, str. vb. | intr. - fall down, deteriorate, die, cease || (impf.3) viel neder 1269, 1596

NEDERWAERT, adv. | down, below ||

nederwaert 910

neemt | NEMEN

NEEN, adv. | no || neen 587, 1103, 1143, 1781, 2208 etc. - neent (clis.) 2704, 3244

neent $\mid$ NEEN + HET (I)

NEGEEN, indef. pron.; used attrib. + indep. | no, no one, none || (attrib.) negheene 267,1375 , 3311. - negheenen 3066. - (indep.) negheen 342, 1255

NEMEN, str. vb. | tr. - take, grab, get, marry, demand, receive, take away, determine; refl. ॥ (inf.) nemen 1419, 2206, 3046. - te nemene 529, 720. - dat orlof nemen 2999. - (pr.1) neme 2856, 3082. - (pr.3) neemt 495. - nemet 2132. - (pr.5) neemt 1994. - (imp.pl.) neemt 183, 3460. - nem 1957, 2562. - nemet 659. - (impf.3) nam 106, 386, 1169, 1246, 1423 etc. - (impf.6) namen 3367. - namene (clis.) 1600. - (impf.s.3) name 1980. - (p.p.) ghenomen 8o, 1498 || See also: AFNEMEN, BENEMEN, OPNEMEN, VERNEMEN

NEMMEE, adv. | not anymore, no longer, never again || nemmee 622, 1314. - nemmeer 957

NEMMERMEE, adv. | never again, never, by no means, definitely not $\|$ nemmermee 1106, 2720, 2793, 3170. - nemmermeer 697, 1154, 1723, 1992, 2629 etc.

nes $\mid \mathrm{EN}(\mathrm{I})+\mathrm{SIJN}(\mathrm{I})$

NESE, n. (f.) | nose || nese 793

NESTELEN, w. vb. | intr. - nestle || (pr.6) nestelen 2590

NEVE, n. (m.) | nephew, grandson, cousin, friend || neve 581, 684, 1072, 1081, 1103 etc. - neven 1994, 3247. - (pl.) neven 1973

neven | NEVE, NEVEN

NEVEN, prep. | next to, along || neven 386, 895, 2373, 2987

NEWARE, conj. | but || newaer 1745, 2291, 2534. - neware 95, 174, 2918 
NICHTE, n. (f.) | niece, granddaughter || (pl.) nichten 1973

NIE, adv. | never, not in any case || nye 746, 1162, $1541,1648,1774$ etc.

NIEMAN, pron. | no one || niemen 58, 262, 1101, 2066, 2212 etc. - niemene 123, 130, 1351, 1756, 2224 etc. - niemens 885, 886. - niement 1086, 3017

NIENE, adv. | never || niene 1506

NIET (I), adv. | not, definitely not || niet 6, 21, 25, 27,52 etc.

NIET (II), pron. | nothing || niet 1118, 1625, 1627, 1649, 2117 etc.

NIET (III), n. (m.n.) | desire, affection || niet 1983

NIEUMARE, n. (f.) | news, rumour, fame ||

niemare $367,1573,1599$

NIEUWE, adj. | new, strange || niewer 558

NIJT, n. (m.) | effort, fury, malevolence, regret || nijt 915

NIPEN, str. vb. | tr. - pinch, tear up || (p.p.) ghenepen 200

NO, conj. | neither, nor || no 112, 131, 276, 404, 560 etc. - no ... no ... 97, 213, 271, 405, 474 etc. noch ... no ... 3067. - no weder ... no 2587-2588.

NOCH (I), adv. | yet, still, all the time, once, moreover, even || noch 86, 162, 175, 353, 416 etc.

NOCH (II), conj. | neither || noch ... noch ...

2340. - noch ... no ... 3067.

NOCHTAN, adv. | also, in addition, at that time, moreover, at least, however || nochtan 78 , 94, 234, 572, 664 etc. - nochtanne 2039

NODE, adv. | forced, reluctantly, seldom, fearfully || node 567. - noede 728, 2194. - noode 1193

noede $\mid$ NODE, NOOT

NOEMEN, w. vb. | tr. - call, praise || (inf.) nomen 2630. - (pr.5) noomt 2634. - (p.p.) ghenoomt 1000 || See also: GENOEMEN NOENE, n. (f.m.) | noon || noene 384 noet $\mid$ NOOT

NOMEN ${ }^{*}$, n. (n.); (Latin) | name $\|$ nomine 1820

\section{nomen | NOEMEN}

NONNE, n. (f.) | nun || (pl.) nonnen 1696, 1743 noode $\mid$ NODE

NOOIT, adv. | never, absolutely not, ever || noint $76,872,1825,2680,2885$ etc. - noyt 139, 2859

noomt | NOEMEN

NOOT, n. (f.m.) | compulsion, adversity, danger, shortage || noet 570, 1523, 1983, 2872. - noede 517. - noot 1205, 1646, 1908, 2129

\section{noyt $\mid$ NOOIT}

NOPEN, w. vb. | tr. - sting, hurt, pinch, hit; intr. || (p.p.) ghenoopt 964

NU, adv. | now || nu 11, 23, 40, 61, 92 etc.

NUTTE, adj. | useful, advantageous || nutte 2595, 2750 || See also: ONNUTTE

nye $\mid$ NIE

O, interj. | oh || o 306, 925, 1194, 1796, 1797 etc.

ODEVARE, n. (m.) | stork || hodevare 2310, 2322 och $\mid$ OOC

oec $\mid$ OOC

oech $\mid \mathrm{HOOCH}$

oeghe $\mid$ OGE

oem $\mid$ OOM

oemoedelike | OOTMOEDELIKE

oere | ORE

oesthende | OOSTENDE

OEVER, n. (n.) | bank, beach || hoever 871. ouver (clis.) 848

of $\mid$ OF, OFTE

OF, subord. conj. | when, if, as if, or || of 249, 261, 267, 491, 589 etc. - oft (clis.) 2700. - alse oft 2988. - ofte 14. - oftic (clis.) 2654e

OFFERANDE, n. (f.) | alms, gift || offerande

1273

OFFERKERSE, n. (f.) | church candle ||

offerkeersse 1246

oft $\mid$ OF + HET (I)

ofte | OF, OFTE

OFTE, disjunct. conj. | or, unless || ofte 268 , $1348,1379,1470,1559$ etc. - of 770, 1823, 2001, 2010, 2012 etc.

ofte $\mid \mathrm{OF}$

OGE, n. (n.f.) | eye, eyelet || hoeghe 1325, 1348, 1567. - hoghe $787,1257,1735$, 1960. - oeghe 2818.

- (pl.) hoghen 756, 1585. - oghen 1709, 1746, 1891

omb- | ONB-, ONTB-

omdat | OMMEDAT (II)

ommacht | ONMACHT

OMME (I), prep. | at, about, against, before, past, because of, by $\|$ omme 119, 1091, 1150, 1199, 1350 etc. - om 234, 235, 253, 307, 343 etc.

OMME (II), adv. | round about, everywhere, near, thereabout, past || al omme ende omme 1165, 1179, 2441, 2757 || See also: DAEROMME OMMEDAT (I), adv. | because, as a result || ommedat 2233, 2511

OMMEDAT (II), conj. | so that, because, provided || omdat 242, 3221 
OMMEGAEN, str. vb. | intr. - go round, turn around, move this way and that $\|$ (inf.) omme te ghane 1709. - (pr.3) ommegaet 1735

OMMEKEREN, w. vb. | tr. - turn round, turn away; refl. - turn round; intr. - turn round and round, spin || (impf.3) keerdi omme (clis.) 3116 OMMELOPEN, str. vb. | intr. - walk around || (inf.) sijn ommeloepen 2440

OMMESIEN, str. vb. | intr. - look around, look round $\|$ (impf.3) ommesach 2383. - sach omme 2063

OMMESWINGEN, str. vb. | intr. - swing

around $\|$ (inf.) ommezwinghen 795

OMMETRENT, adv. | around, everywhere,

about || omtrent 1607

omtrent | OMMETRENT

onbaren | ONTBEREN

ONBECLAGET, adj. | without having been

accused $\|$ ombeclaghet 3061

ONBEDECT, adj. | uncovered, evident ||

ombedect 1659

ONBEGREPEN, adj. | unpunished, unblemished || onbegrepen 199

ONBEQUAME, adj. | disagreeable, unseemly || ombequame 2636

ONBERADEN, adj. | unprotected, rash ||

omberaden 1429

ONBERECHT, adj. | unattended, untreated,

not yet dealt with $\|$ omberecht 124

ONBEROEPEN, adj. | impeccable ||

onberoupen 3060

ONBESCHAVEN, adj. | intact, untouched ||

onbescaven 17

ONBLIDE, adj. | sad || omblijde 952

ONDAET, n. (f.) | crime, infamous deed ||

ondaet 2058

ONDER (I), prep. | under, in, below || onder 453, $465,759,791,1085$ etc.

ONDER (II), adv. || See: DAERONDER

ONDERCOMEN*, adj. (p.p. from 'ondercomen') | weakened || ondercommen 868 ONDERGAEN, str. irr. vb. | intr. - head s.o. off, prevent || (p.p.) ondergaen 397, 3118

ondert | HONDERT

ONERE, n. (f.) | dishonour, disgrace ||

tonneeren (clis.) 1490

ONGEHIER, adj. | horrible, cruel, malevolent || onghiere 414

ONGEMAC, n. (n.) | suffering, pain, burden, danger $\|$ onghemac 230, 573, 781, 807
ONGEMAECT, adj. | not (yet) made, not repaired, ugly $\|$ onghemaket 5

ONGENADE, n. (f.) | bad feeling, cruelty || onghenade 2315

ONGEREC, n. (n.) | misery, disaster ||

ongherec 1197, 1468

ONGEREDE, n. (n.) | lack, want, problem || onghereede 2170

ONGEREET, adj. | not ready, not available, lost, difficult $\|$ onghereet 3182. - onghereede 3155 ONGESONT, adj. | ill, weak, in bad health || onghesont 933

ONGETROUWE, adj. | disloyal, unreliable ||

onghetrauwe 1701, 2527

ONGEVAL, n. (n.) | mishap, fate, damage, crime || ongheval 737, 771, 1225, 2171, 2486. onghevals 1589

ONGEVOECH, n. (n.) | scandal, distress, suffering || onghevouch 234, 3394

ONGEWROKEN, adj. | unpunished ||

onghewroken 97,165

onghereede | ONGEREDE, ONGEREET

ongherich | HONGERICH

ONHOUT, adj. | antagonistic || onhout 111

ONLEDICH, adj. | busy, engaged || onledich 1309

ONMACHT, n. (f.) | powerlessness, exhaustion

|| ommacht 1301, 3234, 3238

onneert | ONTEREN

ONNUTTE, adj. | harmful, shameless, wrong, useless || onnutte 16

ONRECHT, n. (n.) | injustice, lawlessness ||

onrecht 252, 1367

ONREINE, adj. | dirty, mean, lewd || onreyne

1734, 1797

ONS, pers. pron. (4 d/a) | us || ons 10, 85, 172,

345, 397 etc.

ONSACHTE, adv. | hard, loud || onsochte 3335.

- onzochte 990

ONSALICH, adj. | disastrous, poor || onsalich 1715. - onsalichst 778

ONSCHONE, adj. | ugly, unclean, disgraceful || onscone 2725

ONSCHOUT, n. (f.) | innocence, plea to prove innocence $\|$ onsculde 82

ONSE, poss. pron. (4) | our || onse 404, 431, 1703, 2331. - onsen 1786, 3107. - onser 1102, 1851. - tonsen (clis.) 2419

ONSOETE, adv. | hard, cruel || onsoete 964 ONSPELLIJC, adj. | serious || onspellic 3017 


\section{ontbant | ONTBINDEN}

ONTBEREN, str.+w. vb. | intr. tr. - leave, miss; refl. - shirk, neglect || (inf.) onbaren 2866. (pr.s.3) ombeere 127

ONTBIEDEN, str. vb. | intr. tr. - inform, order, send for, offer $\|$ (inf.) ombieden 472. - ontbiet 3447. - (impf.3) ontboet 1002, 2251, 2259. omboet 2427

ONTBINDEN, str. vb. | tr. - loosen, acquit, make known; intr. - come loose II (impf.3) ontbant 3433. - (impf.6) ontbonden 1876 ontboet | ONTBIEDEN

\section{ontbonden | ONTBINDEN}

ONTBITEN, str. vb. | tr. intr. - eat, taste ||

(inf.) ombiten 611

ONTCOMEN, str. vb. | intr. - escape || (impf.3) ontquam 353

ONTDECKEN, w. vb. | tr. - reveal, disclose; intr. - be revealed, become visible $\|$ (inf.)

ontdecken 3314

ONTDELVEN, str. vb. | tr. - dig up, steal ||

(inf.) ontdelven 2627

ONTDOEN, irr. vb. | tr. - loosen, open, declare; refl. -open, dawn; intr. - let loose, open || (p.p.) ontdaen 655

ONTEREN, w. vb. | tr. - dishonour, destroy II (p.p.) ontheert 668, 753. - onneert 1996. gheonneert 2003

ONTERVEN, w. vb. | tr. - rob, ruin; intr. disinherit || (p.p.) onthervet 668

ONTFARMEN, w. vb. | impers. intr. refl.

- have pity; tr. - move, feel sorry for $\|$ (inf.) ontfaermen 406. - (imp.sg.) ontfaerme 68, 72. - ontfaermet 318. - ontfaremt 420. - (impf.3) ontfaermede 2712. - ontfaremde 3052

ontfinc| ONTVAEN

ontfincker | ONTVAEN + -ER

ontfoer | ONTVAREN

ONTGAEN, str. irr. vb. | go away, escape, commit, stop \| (inf.) ontgaen 687, 697, 1384, 1405. - (pr.1)

ontga 1420. - (p.p.) ontgaen 921, 1473, 3101

ONTGELDEN, str. vb. | tr. - pay, suffer, undergo $\|$ (inf.) ontghelden 1818, 1831

ontghan | ONTGINNEN

ONTGINNEN, str. vb. | tr. - begin, taste, dig || (impf.p.p.) ontghan 2081. - (p.p.) ontgonnen 2437 || See also: BEGINNEN ontgonnen | ONTGINNEN ONTHOPEN, w. vb. | intr. - despair || (impf.3) onthopet 1059
ONTHOUDEN, str. vb. | tr. - keep behind, keep, remember; refl. intr. - control o.s., be somewhere, sojourn || (inf.) onthouden 2577. (p.p.) onthouden 3019

ONTJAGEN, w. vb. | tr. - chase away, take away \| (p.p.) ontjaghet 417

ONTLIVEN, w. vb. | tr. - kill; intr. - be killed || (inf.) ontliven 1998 ontquam | ONTCOMEN ontran | ONTRINNEN

ONTRINNEN, str. vb. | intr. - run away, fail || (impf.3) ontran 2715

ontsach | ONTSIEN

ONTSCHOEYEN, w. vb. | tr. - take s.o.'s shoes off $\|$ (impf.3) ontscoyde 2888. - (p.p.)

ontschoyt 2890

ONTSCHRICKEN, w. vb. | intr. - get away, escape || (inf.) ontscricken 3147

ONTSIEN, str. vb. | tr. - fear, stand in awe of; refl. intr. - be afraid, be apprehensive || (impf.3) ontsach 737, 2041, 2210

ontspranc| ONTSPRINGEN

ONTSPRINGEN, str. vb. | intr. - escape, wake up, jump away \| (pr.3) ontsprinct 1907. - (impf.3) ontspranc 1227. - (impf.6) ontspronghen 1638

ontspronghen | ONTSPRINGEN ontstac, ontstaken | ONTSTEKEN ontstacse | ONTSTEKEN + -SE ONTSTEKEN, str. vb. | tr. - rob, light; intr. burn || (impf.3) ontstac 1234. - ontstacse (clis.) 1247. - (impf.6) ontstaken 1643 ontswam | ONTSWEMMEN ONTSWEMMEN, w. vb. | tr. - escape by swimming || (impf.3) ontswam 844, 846 ONTVAEN, str. vb. | tr. - accept, get, undergo, catch; intr. - begin || (inf.) ontfaen 188, 1189, 1250, 2790, 2957 etc. - (impf.1) ontfinc 1827. - (impf.3) ontfinc 164, 809, 2565, 3372. ontfincker (clis.) 1507, 1582. - (p.p.) ontfaen 70, 3172

ONTVAREN, str. vb. | intr. - go away, escape II (inf.) ontvaren 3037. - ontfaren 3221, 3324. (impf.3) ontfoer 85

ONTVRUCHTEN, w. vb. | refl. intr. tr. - be afraid of $\|$ (pr.1) ontvruchtic (clis.) 2332 ONTWEE, adv. | in two (parts) || ontwee 652, 1313, 3126

ONTWEGET, adj. | confused, lost || ontweghet 2514 
ONTWENDEN, w. vb. | tr. - keep at a

distance, disregard; intr. - get lost, escape \| (inf.) ontwenden 1840

ONTWISSCHEN, w. vb. | tr. - escape || (inf.) ontwisschen 1506

ONVERDAEN, adj. | still alive, untouched ||

onverdaen 1927

ONVERSWEGEN, adj. | unremarked, not

mentioned || onversweghen 97

ONVERVAERT, adj. | fearless || onvervaert

339, 389. - (n.) die onvervaerde 1760

ONVRO, adj. | sad, bitter || onvroe 982

ONVROET, adj. | foolish, insane, furious ||

onvroet 671,2540

ONWERDE, n. (f.) | contempt, slander,

indignation, disgrace $\|$ onwaert 498, 576

ONWILLE, n. (m.) | reluctance, sadness ||

onwille 321

onzochte | ONSACHTE

OOC, conjunctive adv. | also, moreover, on the other hand || och 1857. - oec 130, 190, 366, 367,

446 etc

OOIT, adv. | always, at some time || oyt 1776

OOM, n. (m.) | uncle, grandfather || oem 190,

193, 195, 204, 206 etc.

OOSTENDE, n. (n.) | east side || oesthende 2574 OOTMOEDELIKE, adv. | merciful, respectful,

friendly || oemoedelike 2977

OP (I), prep. | up, on top of, in, over, on, against || up 286, 348, 418, 460, 497 etc. - op 2770a. - upt (clis.) 848

OP (II), adv. | up, straight, open || up 2092 || See also: DAEROPPE

OPBREKEN, str. vb. | tr. - break off, break open; intr. - open || (p.p.) uptebroken 2479

OPDAT, conj. | provided, if, so that || updat 1420

OPDRAGEN, str. vb. | tr. - carry up, clear up;

intr. - rise || (inf.) updraghen 1947

OPENBARE, adv. | openly, clearly,

emphatically, certainly || openbare 1865, 2064,

2159, 2163, 2211 etc.

OPETEN, str. vb. | tr. - eat || (impf.s.1) haet up (clis.) 600

OPGAEN, str. vb. | intr. - rise, begin || (pr.3)

gaet up 61. - upgaet 2717

OPGEVEN, str. vb. | tr. - hand, inform; refl. yield $\|$ (pr.1) gheve up 2563

OPHEFFEN, str. vb. | tr. - lift, rise, strike up, start, accept, further; refl. - rise; intr. - come into flower, come into being || (inf.) upheffen 1564. - (impf.3) hief up 1259, 3385-3386. - uphief 2170. - hiefsene up (clis.) 1302. - (p.p.) up gheheven 156. - upheven 274

OPHOUDEN, str. vb. | tr. - stop, keep, keep in; refl. - restrain o.s.; intr. - end $\|$ (impf.6) uphilden 1162

OPLESEN, str. vb. | tr. - pick up, read, recite || (impf.5) uplaset 211

OPNEMEN, str. vb. | tr. - pick up, raid, undertake \| (impf.3) upnam 1546. - (impf.6) namen up 1159

OPSCHRAVEN, w. vb. | tr. - uncover, cratch away \| (impf.1) scraefdic up (clis.) 2404

OPSPRINGEN, str. vb. | intr. - jump up, jump open || (impf.1) spranc up 2401. - (impf.3)

spranc up 177, 740, 1847, 1852

OPSTAEN, str. vb. | intr. - get up, arise; tr. || (impf.3) stont up 99

OPWAERT, adv. | upwards, straight, forwards || upwaert 2295

OPWERDEN, str. vb. | intr. - get up quickly, arise || (impf.6) worden up 1643

orconde $\mid$ ORCONDE (I), ORCONDEN

ORCONDE (I), n. (f.n.) | evidence, proof,

message || orconde 1871a, 2643

ORCONDE (II), n. (m.) | witness || (pl.)

orconden 1877

ORCONDEN, w. vb. | tr. - give evidence,

declare, tell || (pr.1) orconde 2704

ORDENE, n. (f.m.) | (monastic) order, rank, rule || ordine 2707. - ordinen 943

ORE, n. (n.) | ear || hoere 854, 996. - hore 946. - oere 745. - (pl.) horen 678

ORLOF, n. (m.) | leave, approval, promise || orlof 495, 709, 1423, 1887, 2999 etc. - orlove 1391 OSSE, n. (m.) | ox, bull $\|$ osse 2121

OTTER, n. (m.) | otter $\|$ otter 1454 OUDE (I), n. (f.) | age, old age || houden 767 OUDE (II), n. (m.) | old man || houde 2306, 2364. - (pl.) houden 439, 466

OUT, adj. | old, historic || hout 112, 181, 380. houd 2408. - houde 765. - houden 157, 157, 821. ouder 1991. - (n.) den houden 2394

OUTAER, n. (n.m.) | altar || autare 2973

OUTMAKIGGE, n. (f.) | a woman who repairs particular objects || houtmakigghe 804 ouver| OEVER

OVER, prep. | over, above, opposite, during, because of, for $\|$ over 59, 115, 169, 239, 258 etc. OVERAL, adv. | everywhere, completely, 
especially || overal 45, 612, 1413, 1638, 1789 etc.

OVERDADICH, adj. | bold, violent, criminal || overdadich 2245

OVERDAET, n. (f.m.) | rashness, act of

violence, crime, disgrace || overdaet 137, 499, 1331,

1334, 2037 etc. - overdade 469

OVEREEN, adv. | in a heap, together, completely || overeene 146

OVEREENDRAGEN, str. vb. | intr. - agree ||

(pr.6) overeendraghen 2271

OVERGROOT, adj. | enormous || overgroeten 2417

OVERLANGE, adv. | in due course, after some time $\|$ overlanc 547,3385

OVERLOPEN, str. vb. | intr. - go, walk across; tr. - hit upon, attack \| (inf.) over te loepene 553 OVERLUUT, adv. | aloud, loudly, clearly, definitely || overluut 628

OVERSEE, adv. | on the other side of the sea (esp. the Mediterranean), to/in the Holy Land \| overzee 2719, 2792, 2912, 2958, 3171 etc.

OVERSTARC, adj. | enormously strong || overstaerc 1090

oyt | OOIT

pade $\mid$ PAT

PAER, n. (n.f.) | equal, pair || paer lettren 3252, 3346

paerc | PARC

paerkement | PARCAMENT

paerlement | PARLEMENT

PAEYEMENT, n. (n.) | payment, revenge || payment 809

PAIS, n. (m.) | peace, reconciliation || pays 3467 , 3469

PALSTER, n. (m.) | walking stick, pilgrim's staff II palster 372, 2790, 2940, 2982, 3024 etc.

PANT, n. (n.m.) | pawn, agony, injury $\mid$ pant 1265 PAPE, n. (m.) | priest, cleric, clergyman $\|$ pape $726,811,840,1123,1127$ etc. - papen 825,1163 , $1171,1192,1322$ etc. - spapen (clis.) 731, 826, 1575, 2819

PARC, n. (n.) | fence, garden, battleground, fenced off area for tournaments or games, enclosure || paerc 334

PARCAMENT, n. (n.) | parchment || paerkement 91

PARDOEN, n. (n.) | mercy, pardon || pardoen 835. - perdoen 2910

PARLEMENT, n. (n.) | discussion, meeting, session of a court of law $\|$ paerlement 2264 PAROCHIAEN, n. (m.) | parishioner || (pl.) prochiane 764,830

PARTRISE, n. (f.) | partridge || (pl.) pertrijsen 3157

PAS, n. (m.n.) | step, way, passage || pas 1063

PASTE, n. (f.m.n.) | dough, school fee $\|$ past 2674

PAT, n. (m.n.) | path, track || pat 633, 891. - pade 3310. - (pl.) pade 504

PATER, n. (m.); (Latin) | pater, father $\|$ pater 1453. - patrum 1820

PATERNOSTER, n. (n.m.) | Lord's Prayer || paternoster 1739

PAVES, n. (m.) | pope || spaeus (clis.) 2716, 2950 payment | PAEYEMENT

pays | PAIS

peelgrijn | PELGRIJM

peinsdi $\mid$ PENSEN + HI

peinsen | PENSEN

PELGRIJM, n. (m.) | pilgrim, stranger ||

peelgrijn 2852, 2880, 2945, 3012, 3028 etc. -

peelgrins 2857

PELSE, n. (f.) | pelt || pelse 352

PENITENCIE, n. (f.) | penitence, punishment || penitencie 2957

PENNINC, n. (m.) | coin $\|$ (pl.) penninghe 2669

PENSEN, w. vb. | intr. - think of, beware of, consider, reflect; tr. - think, mean, think up, invent $\|$ (inf.) peinsen 2618. - dit peinsen 627. - (pr.1) peinsic (clis.) 3188. - (impf.1) peinsde 2331. - peinsdic (clis.) 2341. - (impf.3) peinsde 623, 676, 2034. - peinsdi (clis.) 1899 || See also: GEPENSEN

PERDITUM *, n. (n.); (Latin) | lost object || (pl.) perdite 257

perdoen | PARDOEN

pertrijsen | PARTRISE

PESE, n. (f.) | rope, cord || pese 794, 1313

pijne $\mid$ PINE

pijnen | PINEN

PIJNLIJC, adj. | difficult, disagreeable, cruel || pijnlic 1873

PINE, n. (f.) | punishment, burden, misery, suffering, trouble || pine 230, 371, 573, 1566, 1813 etc. - pijne 1947. - pinen 279, 743, 1485 pinen | PINE, PINEN

PINEN, w. vb. | tr. - punish, torment, exert; intr. - exert oneself, dare; intr. - suffer pain || (inf.) 
pinen 1294, 1311. - pijnen 1630. - (pr.s.4) pinen 3324. - (impf.3) pijnde 696. - (impf.6) pijnden 2020

PIPEN, w.+str. vb. | intr. - squeak, scream || pipen (pr.6) 1180

PLACEBO DOMINO *, n. (n.) | prayer sung during the office for the dead $\|$ dat placebo domino 444 plach, plaghen | PLEGEN

PLADIJS, n. (f.m.) | plaice || (pl.) pladijse 208, 211

PLADISENGRAET, n. (m.) | fish bone ||

pladijsengraet 214

playdieren | PLEIDEREN

plecht $\mid$ PLICHT

pleecht $\mid$ PLEGEN

PLEGEN, str.+w. vb. | intr. tr. - be surety for, pledge, do as promised, look after, do, associate with, be in the habit of; impers. II (inf.) pleghen 428, 1688, 1729. - (pr.3) pleecht 1219. - (pr.6) pleghen $35,654 .-$ (pr.5) pleghet 1409. (impf.3) plach 521, 536, 2754, 3365. - (impf.6) plaghen 1699

PLEIDEREN, w. vb. | intr. - plead, go to court || (inf.) een playdieren 1868

PLICHT, n. (f.) | responsibility, protection, power $\|$ plecht 2856

PLUME, n. (f.) | feather $\|$ (pl.) plumen 888, 1713 POENT, n. (n.m.f.) | point, lesson, the right moment $\|$ pointe 2283

poerte | PORTE

POGEN, w. vb. | tr. - force, bring to a standstill; intr. refl. - make an effort, do one's best $\|$ (impf.1) poghede 2341. - (impf.3) poghede 680 pointe $\mid$ POENT

PORREN, w. vb. | tr. - encourage, move; refl. intr. - begin, go \|| (inf.) porren 1238

PORTE, n. (f.) | gate, door || porte 397, 520, 3073, 3074, 3119. - poerte 535

prandic $\mid$ PRENDEN

PRENDEN, w.+str. vb. | tr. - grab, take away $\|$ (impf.1) prandic (clis.) 1537. - (p.p.) ghepronden 399

priemen | PRIME

PRIESTER, n. (m.) | priest || priester 761, 937, 941

PRIJS, n. (m.) | value, honour, praise || prijs 2938. - prijse 3069 || See also: MISPRIJS

prijse | PRIJS, PRISEN

PRIME, n. (f.) | prime, early morning || priemen
385

PRIOR, n. (m.) | prior || pryhore 945

PRIOREIT, n. (n.) | priory || pryoreit 1696

PRISEN, w.+str. vb. | tr. - estimate, praise ||

(pr.1) prijse $578 \|$ See also: MISPRISEN

prochiane | PAROCHIAEN

PROEVEN, w. vb. | tr. - prove, try, experience; intr. - exert o.s.; refl. - prove, compete with $\|$ (inf.) prouven 2042. - (impf.6) proufden 1877. (imp.pl.) prouft 662

PROOYE, n. (f.) | prey, loot, gang || proye 887,

2119

PROVENDE, n. (f.) | ration, prebend ||

provende 2709

proye $\mid$ PROOYE

pryhore $\mid$ PRIOR

pryoreit|PRIOREIT

pude $\mid$ PUUT

PUT, n. (m.) | well, pool, hole || putte 2602, 2605, 2696 || See also: Kriekeputte (proper name)

PUTENSONE, n. (m.) | son of a whore || putensone 919

PUUT, n. (m.) | frog || (pl.) pude 2299, 2308

QUAESITUM *, n. (n.); (Latin) | acquisition, acquired object $\|$ (pl.) quesite 257

QUAET (I), adj. | bad, criminal, insignificant, unhappy, harmful, difficult, angry || quaet 484, $500,1022,1338,1901$ etc. - quade 243, 394, 401, 2338. - quaden 1112, 3277

QUAET (II), n. (n.) | evil, villainy, injury, misfortune || quaet 213, 1736, 1830, 1992, 2692 etc. - quade 3358

QUAET (III), n. (m. n.) | villain || quaet 1797 QUALIKE, adv. | bad, unlawful, unhappy || qualike 258. - qualic 259, 550, 1804 quam, quamen | COMEN, UTECOMEN QUANS, adv. | as if || quansijs 2567 QUEDDEN, w. vb. | tr. - address, greet || (inf.) quedden 1105. - (impf.3) queddi (clis.) 2386 queddi | QUEDDEN + HI

QUELLEN, w. vb. | tr. - torture; refl. - make an effort, exert o.s.; intr. - suffer $\|$ (pr.6) quellen 2196

QUENE, n. (f.) | old woman || quene 767 quesite | QUAESITUS

QUITE, adj. | paid, levelled, away, null and void, free || quite 258, 1390, 2436, 2549, 2803. - quijte 355

QUITEN, w. vb. | tr. refl. - free o.s., redeem, 
acquit, pay || (inf.) quiten 2963 || See also:

GEQUITEN

rade $\mid R A D E N(I)$, RAET

raden | RADEN (I) (II), RAET

RADEN (I), str. vb. | intr. - give advice, recommend; tr. - plot, cause $\|$ (inf.) raden 2530 , 3461. - (pr.1) rade 532, 2740. - (pr.5) raeddi (clis.) 689. - (impf.3) riet 1679, 3176. - (impf.6) rieden 471,1004 , 1006. - (p.p.) gheraden 555 || See also: BERADEN, GERADEN, VERRADEN

RADEN (II), w. vb. | tr. - break on the wheel || (inf.) raden 531

raeddi $\mid$ RADEN (I) + GI

RAET, n. (m.) | support, advice, ruse, plan, meeting, judgement $\|$ raet 543, 567, 1003, 1014, 1021 etc. - raets 548, 2353. - rade 470, 1035, 1329, 1689, 2209 etc. - raden 1678

RAKE, n. (m.) | rake $\|$ rake 723

RAM, n. (m.) | ram, battering ram || ram 1847, 2111, 2942, 3056, 3075 etc.

RAMPENEREN, w. vb. | tr. intr. - shout abuse, mock || (inf.) rampineeren 703. - rampineren 849

RASCH, adj. | quick, lively, strong || rasch 2026 RAT, n. (n.) | wheel || rat 1379

rauwe | ROUWE

rauwen | ROUWE, ROUWEN

RAVEN, n. (m.) | raven $\|$ raven 18, 1856, 2808 rebben $\mid \mathrm{RIBBE}$

recht $\mid$ RECHT (I) (II), RECHTE

RECHT (I), adj. | right, real, just, righteous, lawful, reasonable, right (side) || recht 128, 2103, 2961, 3046, 3410 etc. - richt 304. - rechte 1316, 1703. - rechter 1050, 1057, 1694, 1720, 1747 etc. RECHT (II), n. (n.m.) | straight line, orderly circumstances, law, rule, duty, righteousness, the law, lawsuit || recht 67, 124, 258, 262, 529 etc. rechte 908, 1991, 2101, 2683, 2938 etc. || See also: ONRECHT

rechte $\mathrm{RECHT}$ (I) (II)

RECHTE, adv. | up straight, directly, precisely, completely, very, doubtlessly $\|$ recht 282, 1303, $1615,1846,3403$

RECHTEN (I), w. vb. (from adj. RECHT I) | tr. refl. - straighten o.s., erect, make ready; intr. stand up, be extended $\|$ (p.p.) gherecht 1378 RECHTEN (II), w. vb. (from n. RECHT I) | intr. - go to court; tr. - sentence, punish || (p.p.) gherecht 1005
RECKEN, w. vb. | tr. - stretch; refl. - hurry; intr. - reach $\|$ (inf.) recken 2811

REDENE, n. (f.) | reason, sense, expression, evidence || redene 2573. - redenen 1333. - (pl.) redenen 1875

REINAERDIE, n. (f.) | trick, cunning, mean tricks || reynaerdye 2038

REKENEN, w. vb. | tr. - pay, calculate; intr. pay attention to || (impf.3) rekende 2098

rentvleesch | RINTVLEESCH

reynaerdye $\mid$ REINAERDIE

RIBAUT, n. (m.) | tramp, villain || rybaut 938

RIBBE, n. (f.) | rib, beam $\|$ (pl.) rebben 2126

richt $\mid \mathrm{RECHT}$

riep, riepen $\mid$ ROEPEN

RIES, n. (m.) | daredevil, rogue || ries 2668

riet, rieden $\mid \mathrm{RADEN}$

RIJCHEIT, n. (f.) | power, riches || rijcheit

2428

rijkelijc $\mid$ RIKELIJC

RIJM, n. (m.) | rime, frosted dew || rijme 2096

rijme | RIJM, RIME, RIMEN

rijnc $\mid R I N C$

RIJS, n. (n.) | branch || rijs 1675. - (pl.) rijsere

3464

rijsen | RISEN

RIKE (I), n. (n.) | realm || rike 364, 2583

RIKE (II), adj. | powerful, rich, strong, foremost || rike 38, 1067, 1789, 2323, 2422 etc. - (comp.) riker 1511

RIKELIJC, adj. | powerful, rich, costly || rijkelijc 2611. - rikelike 926

RIME, n. (f.) | line of verse, poem, rhyme || (pl.) rijme 15, 20, 2679

RIMEN, w. vb. | tr. - rhyme, put in words; intr. rhyme, write poems $\|$ (pr.1) rijme 232

RINC, n. (m.) | ring, circle, company || rinc 109.

- rijnc 315. - ringhe 2756

RINNEN, str. vb. | intr. - stream, run, go ||

(p.p.) gheronnen 118, 734, 760, 1321 || See also:

ONTRINNEN

RINTVLEESCH, n. (n.) | beef $\|$ rentvleesch 1518

RISEN, str. vb. | intr. tr. - (make) appear, rise, arise from $\|$ (inf.) rijsen 1319

RIVIERE, n. (f.m.) | river, brook, bank || riviere $777,820,823,843,896$ etc. - ryviere 850

ROCKE, n. (m.) | distaff || rocke 732, 832, 1245, 1249

rode, roden $\mid$ ROOT 
roef $\mid \mathrm{ROOF}$

roeft, roefde $\mid$ ROVEN

ROEKELOOS, adj. | careless, unscrupulous || rouckeloes 2787

ROEKEN, w. vb. | intr. impers. - pay attention to, care for $\|$ (pr.1) roucke 1649. - (pr.3) roukes (clis.) 1117

ROEMEN, w. vb. | intr. - bluff || (pr.5) roomt 2633

ROEPEN, str. vb. | intr. - call, shout; tr. summon, announce, invoke $\|$ (inf.) roupen 1204. - dat roupen 3124. - (impf.3) riep 830, 1210, 1228, 1237, 1243 etc. - (impf.6) riepen 306, 1640 |l See also: AENROEPEN

ROEREN, w. vb. | tr. - move, touch, treat; refl. intr. - move $\|$ (inf.) roeren 2840

roet, roeden $\mid R O O T$

ROOF, n. (m.n.) | robbery, loot || roef 351, 1445, 1561

\section{roomt $\mid$ ROEMEN}

ROOT, adj. | red || roet 985. - rode 3191. - roden 940, 1943. - roeden 944 || See also: Roede (proper name)

roucke $\mid$ ROEKEN

rouckeloes $\mid$ ROEKELOOS

roukes $\mid$ ROEKEN + -ES

roupen $\mid R O E P E N$

ROUWE, n. (f.m.) | sorrow, lamentation, regret || rauwe 913, 1290, 2714, 3020, 3131 etc. - rauwen 2989

ROUWEN, w.+str. vb. | impers. intr. - mourn, regret $\|$ (inf.) rauwen 1719, 2101, 2150

ROVEN, w. vb. | intr. - rob; tr. - steal, rob II (inf.) roven $1687,1779$. - dat roven 2516. - (pr.3) roeft 1543. - rovet 3407. - (impf.3) roefde 409

RU, adj. | hairy, rough || ruwen 2815

RUGGE, n. (m.) | back || rugghe 1726, 2844 RUMEN, w. vb. | tr. - extend, clear up, leave; refl. - move away; intr. - extend, depart $\|$ (inf.) rumen 887, 3344. - (impf.3) ruumde 1424 RUNEN, w. vb. | intr. - whisper, flatter; tr. whisper in s.o.'s ear, suggest $\|$ (impf.3) ruunde 2851 RUTSEN, w. vb. | intr. - slide, glide || (inf.) rutsen 973

ruumde | RUMEN

ruunde | RUNEN

ruwen | RU

rybaut $\mid$ RIBAUT

ryviere | RIVIERE $-\mathbf{s} \mid \mathrm{Z}$ -

SAC, n. (m.) | bag || zac 229

sach $\mid$ SIEN

SACHTE, adv. | softly, pleasantly, slowly

|| sachte 3215. - sochte 621 || See also:

ONSACHTE

SACHTEN, w. vb. | tr. - soften, alleviate, calm down; intr. - turn soft, recover; impers. || (p.p.) ghesocht 3428

SADEN, w. vb. | tr. - satisfy; refl. intr. satify o.s., enjoy || (inf.) saden 591 || See also:

VERSADEN

saecht $\mid$ SIEN

saels | SULLEN + -ES

saelt | SULLEN + HET (I)

SAEN, adv. | soon, quickly, at once, suddenly || saen $64,398,1238,1444,1592$ etc. - also saen 82. - alsoe saen 2831

saerc|SARC

SAERMEER, adv. | in the future, now ||

tsjaermeer 1911

saeuse | SAUSE

SAGE (I), n. (f.) | expression, story, lie || saghe 1084

SAGE (II), n. (m.) | coward, wretch $\|$ saghe 395

saghe | SAGE (I) (II), SIEN

saghen | SIEN

SAKE, n. (f.) | affair, matter, cause, action || sake 1836, 2687, 3313. - zake 2343. - saken 1803. -

(pl.) saken 29, 1134, 1440, 1880, 2681

sal, salt | SULLEN

salics | SULLEN + IC + -ES

SALUUT, n. (m.) | greeting, letter, compliment || saluut 2426

SAMENINGE, n. (f.) | gathering, company || zameninghen 3031

salne | SULLEN + -ENE

salt | SULLEN (+ HET I)

SANC, n. (m.) | hymn, song $\|$ sanc 151

SANCTUS *, adj. (Latin) | holy || sancta 1544

SANT (I), n. (n.m.) | sand, bank, field || zant

960, 2404. - sande 2387

SANT (II), n. (m.) | holy || sente 1047, 1049

SARC, n. (m.n.) | rock, tomb, grave \| saerc 456.

- zaerc 460

sat $\mid$ SAT, SITTEN

SAT, adj. | full, satisfied || sat 1145, 1146, 1181, 1527, 1609. - zat 561, 610, 634, 892, 1153

saten | SITTEN

sauder toe | SULLEN + DAERTOE 
SAUSE, n. (f.) | sauce || saeuse 1216

SAUVER *, vb. (French) | save $\|$ (pr.s.3) saut 937

sc- $\mid \mathrm{SCH}-$

scaden | SCHADE (I), SCHADEN

scaems | SCHAMEN + -ES

scaerpe | SCHARP, SCHARPE

scauwen | SCHOUWEN

sceen | SCHINEN

scerpe(n) | SCHARP, SCHARPE

SCHADE (I), n. (m.f.) | harm, damage, injury, disadvantage || scade 68, 770, 1280, 1988, 2210 etc. - scaden 318, 474, 1969

SCHADE (II), n. (f.n.) | shadow || scade 3162

SCHADELOOS, adj. | harmless,

disadvantageous || scadeloes 2963

SCHADEN, w. vb. | intr. tr. - damage, harm || (inf.) scaden 1837,2529

SCHALC, n. (m.) | servant, villain || scalc 940. - scalken 1783. - (pl.) scalke 1787

SCHALCHEIT, n. (f.) | servility, perversity || scalcheit 1791

SCHAME, n. (f.) | shame, disgrace || scame

1275, 2705. - scamen 972

SCHAMEN, w. vb. | refl. intr. - feel

embarrassed, be ashamed, be disgraced, be made to feel ashamed or embarrassed; impers.

|l (impf.3) scaemde 1196. - (imp.sg.) scaems (clis.) 2226

SCHAMP, n. (m.) | derision, disgrace, deception || scamp 1504 || See also: SCHAMPIE

SCHAMPIE, n. (f.) | derision, disgrace, deception || scampye 2037 || See also: SCHAMP SCHANDE, n. (f.m.) | derision, disgrace, offence || scande 1280. - scanden 1263, 2178

SCHARE, n. (f.) | company, gang || scare 1864 SCHARP, adj. | sharp, rough, hard, wicked, intelligent || scaerpe 701. - scerpe 280, 374, 788. - scerpen 201, 2462. - scerper 735, 816 || See also: ALLERSCHARPST (reinf. superl.)

SCHARPE, n. (f.) | bag carried by pilgrims and travellers || scaerpe 2946, 2980, 3024. - scerpe 2790, 2940, 3098, 3172, 3263 etc. - scerpen 2845 SCHAT, n. (m.) | treasure || scat 2141, 2146, 2241, 2244, 2352 etc. - scats 2559. - scatte 2374, 2378, 2422, 2435, 2739

SCHAVEN, str.+w. vb. | tr. - plane, smooth; intr. - run away \| (inf.) scaven 2809

SCHEIDEN, str.+w. vb. | tr. - divide, separate, end; refl. intr. - divide, separate, go away, end
II (inf.) sceiden 1184. - sceeden 3054. - (pr.1) sceede 1154. - (pr.3) sciet 1392. - (impf.3) sciet 1427, 1971, 2390, 3050. - (impf.s.1) sciede 3251- (impf.s.3) sciede 1981 || See also: VERSCHEIDEN

SCHELDEN, str. vb. | tr. - abuse, insult, scold, disapprove; intr. - rail at, quarrel || (inf.) scelden 929, 1817, 1832. - (pr.3) sceldet 2001 || See also: BESCHELDEN

SCHENKEN, w.+str. vb. | tr. - pour, do s.o. an evil turn \| (inf.) scijncken 705

SCHEREN, n. (n.m.) | joke, folly, lie || scerne 221. - scherne 545, 936, 1288

SCHIERE, adv. | quickly, hastily, suddenly, nearly || sciere 245, 441, 478, 844, 1037, 1234,

2404, 3124

SCHINEN, str.+w. vb. | intr. - emanate light, look like, notice, appear \| (inf.) scinen 424. - (pr.3) scijnet 1099. - (impf.3) sceen 773, 1252, 3027. - scheen 1265 || See also: AENSCHINEN

SCHOE, n. (m.) | shoe $\|$ (pl.) scoen 2848, 2850, 2854, 2862, 2867 etc || See also: HANTSCHOE SCHOEYEN, w. vb. | tr. - provide with shoes \| (inf.) scoyen 2860 \| See also: ONTSCHOEYEN

SCHONE (I), adj. | bright, pure, beautiful, attractive, pleasant || scone 223, 242, 334, 893, 994 etc. - sconen 487, 1422, 2386, 3301. scoenre 3085. - (superl.) scoenste $300 \|$ See also: ONSCHONE

SCHONE (II), adv. | brightly, beautifully, well, already || schone 1057

SCHOREN, w. vb. | tr. - tear, maim, end; refl.; intr. - tear, wear, end || (impf.3) scorde 740, 1286. - (impf.6) scoorden 338. - (p.p.) ghescort 2344 SCHOUT, n. (f. m.) | duty, debt || sculde 2168, 2510, 3457 || See also: ONSCHOUT SCHOUWEN, w. vb. | tr. - see, watch, consider; intr. || (inf.) scauwen 939, 2475. - (impf.3) scauwet 2032. - (imp.pl.) scouwet 1433 || See also: BESCHOUWEN, WEDERSCHOUWEN

SCHOVUUT, n. (m.) | negatively connotated bird, jay, owl, tramp || scuvuut 2589

SCHRAVEN, w. vb. | intr. - root, turn up the ground; tr. - scratch \| (inf.) scraven 462, 2608 \| See also: OPSCHRAVEN

SCHRIVEN, str. vb. | tr. - write, describe, depict || (impf.s.1) screve 3252. - (p.p.) 
ghescreven 362, 3254, 3288, 3360 || See also:

\section{GESCHRIVEN, VOLSCHRIVEN}

SCHULDICH, adj. | compulsory, indebted, guilty || sculdich 1343, 1878, 2225, 2654a, 2655 etc.

SCHURE, n. (f.) | barn, shed || scuere 336, 1124, 1163, 2819. - scueren 1705

SCHUWEN, w. vb. | intr. - be or become shy, recoil; tr. - fear, avoid; refl. || (impf.3) scuwedi (clis.) 55

sciet, sciede | SCHEIDEN

scijncken | SCHENKEN

sconincx, sconinx $\mid$ DIES (I) + CONINC

screve | SCHRIVEN

sculde $\mid$ SCHOUT

scuvuut $\mid$ SCHOVUUT

scuwedi | SCHUWEN + HI

sduvels $\mid$ DIES (I) + DUVEL

-SE ${ }^{*}$, enclitic pers. pron. ( $3 \mathrm{f}$. n/a $-6 \mathrm{n} / \mathrm{a}$ )

| she, her, them || (3) becnause (clis.) 225. bringhense voort (clis.) 2198. - hadse (clis.) 117. - hanghense (clis.) 3265. - hise (clis.) 8. - icse (clis.) 3260. - moghense (clis.) 429. - (6) bantse (clis.) 2837. - besteecse (clis.) 1193. - diese (clis.) 2305, 2311. - gaefse (clis.) 1150. - ghise (clis.) 3446, 3451. - hadse (clis.) 2931. - hebse (clis.) 1631, 3445. - heefse (clis.) 414. - hiefsene (clis.) 1302. - hise (clis.) 75, 402, 1309, 2312, 2314 etc. - icse (clis.) 572, 1132, 2084, 2089, 2855 etc. - laetse 2035 (clis.). - makedicse (clis.) 1471. ontstacse (clis.) 1247. - sise (clis.) 17. - vindise (clis.) 1210. - voerese (clis.) 2836. - waense (clis.) 1126. - wise (clis.) 432

sechdi | SEGGEN + GI

sechdire toe | SEGGEN + GI + DAERTOE sechstu | SEGGEN + DU

secht $\mid$ SEGGEN + HET (I)

SEDE, n. (m.f.) | habit, custom, nature || zede

243, 3062. - zeden 666, 1729

SEENT, n. (m.) | synod, church council || zeinde 2734

SEER (I), adj. | painful, ill, wailing || zeer 754. zeeren 3015

SEER (II), n. (n.m.) | pain, grief, lamentation || zeere 419

seere | SERE

SEGEL, n. (m.n.) | seal || seghele 360. - zeghele 358

SEGGEN, w. vb. | tr. - say, speak, tell, call, declare; intr. || (inf.) segghen 239, 2189, 2380,
2923, 3342. - te segghene 385. - (pr.1) segghe $2277,2534,2584,2705,2788$ etc. - secht 2317 , 2554,3152 . - segghic (clis.) 25, 480, 1380, 1478. - segghu (clis.) 2142. - (pr.2) sechstu (clis.) 2200. - (pr.3) seghet 1076. - seit 182, 2196, 3303. - (pr.5) secht 170, 673, 1393, 2156, 2158 etc. - sechdi (clis.) 135, 601, 1116, 1122, 1131 etc. - sechdire toe (clis.) 3463. - (pr.6) segghen 1018. - (imp.pl.) secht 1025, 2652, 2656, 3222. - segghet 2061. - seght 941. - (impf.1) seide 1618, 2691, 3349. - seidic (clis.) 1669, 3165. seit (clis.) 446. - (impf.3) seide 110, 316, 368 , 648, 984 etc. - zeide 1432. - seidi (clis.) 272. - seit 489, 1131, 1407, 2065, 2900. - (impf.6) seiden 1010, 3047. - (p.p.) gheseit 1666, 1670, 3370 || See also: GESEGGEN, VOLSEGGEN, WEDERSEGGEN

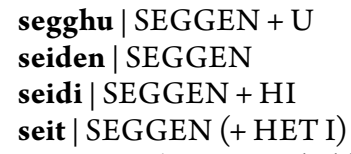

SEKER, adj. | quiet, reliable, guaranteed || seker $597,2298,2471$

SEKEREN, w. vb. | tr. - promise, assure, compel; intr. || (impf.3) sekerde 609

SELDEN, adv. | seldom || selden 182

SELVE, indef. pron. | self, the very, even, the same \| (without predeterminer) selve $546,726,1240,1384,1901$ etc. - selfs 1652 . selven 664, 667, 1060, 1205, 1576 etc. - (with predeterminer). (attrib.) selve 106, 1177, 1512, 1846. - selven 282, 660, 2602, 3310. - selver 150, $815,1152,2155,2476$ etc. - selves 992, 1404, 1424, 2545

\section{selver | SELVE, SILVER}

SENDEN, w.+str. vb. | tr. - send, command || (inf.) senden 3347. - (impf.3) sende $2310 \|$ See also: UTESENDEN

\section{sent $\mid$ SINT}

SERE, adv. | painful, to a large extent, hard, quickly || seere 321, 643, 1752, 3220. - zeere 292, 352, 496, 762, 818 etc. - (comp.) zeerre 747 SERIANT, n. (m.) | servant, warrior, man || serjant 984, 2444

SERICH, adj. | painful, sad || zeerich 1270, 2482 SESSE, num. | six || zesse 1568, VI 2710

SETTEN, w. vb. | tr. - place, prescribe, set up, begin, write; refl.; intr. || (inf.) setten 1349. (imp.pl.) settet 1673. - (impf.3) sette 738. (p.p.) gheset 1172, 1277 
SEVEN, num. | seven || zevene 329. - VII 240, $604,619,2124,2138$ etc.

sheere | DIES (I) + HERE (I)

shonichs $\mid$ des + HONICH

si | SI, SIJN (I)

SI, pers. pron. (3 f. $\mathrm{n}-6 \mathrm{n}) \mid$ she, it || (3) so 225 , $245,256,733,1149$ etc. - soe $30,2762,3151$. - (6) si 14, 18, 20, 21, 22 etc. - zi 2018. - sij 2318. - zij 2300. - alsi (clis.) 2997. - hadsi (clis.) 1498. siere binnen (clis.) 341. - sine (clis.) 1128, 1272, 1588, 1644. - sijs (clis.) 2276. - sise (clis.) 17. slouchsi (clis.) 1587. - soene (clis.) 1980. - zijt (clis.) 238. - zoet (clis.) 2290, 2292

SIBBE, n. (f.m.) | relationship, family || sibbe 2099

SIDE, n. (f.) | side || zijde 2609. - zijden 1053, 1057 || See also: BANDERSIDE, WEDERSIDE sidi $\mid$ SIJN (I) + GI

siere | SIJN (II), SIRE *

siere binnen | SI + DAERBINNEN

SIEC (I), adj. | ill, weak || ziec 933, 3015

SIEC (II), n. (m.) | sick person, leper || ziecs 1320

SIEDEN, str. vb. | tr. intr. - cook, burn || (inf.) zieden 1838

SIELE, n. (f.) | soul || ziele 1441, 2157, 2183, 2856, 2860. - zielen 381, 428, 448, 1271. - sielen 1688. (pl.) zielen 1740

SIELELESSE, $\mathrm{n}$. (f) | reading of a passage from the Bible during the office of the dead || zielenlesse 449

SIEN, str. vb. | tr. - see, notice, admire; intr. - look, resemble || (inf.) sien 1238, 1376, 1378, 3381. - te siene 931. - (pr.3) siet 324. - (pr.5) 997, 2916. - (imp.pl.) siet 162, 658, 830, 1186, 1278 etc. - siettene (clis.) 939. - (impf.1) sach $350,1634,2379,2382,2389$. - saghic (clis.) 2376, 2390. - (impf.3) sach 455, 692, 699, 759, 827 etc. - (impf.5) saecht 2885 . - saghet 872 , 2833. - (impf.6) saghen 76, 284, 346, 846, 1644 etc. - (impf.s.3.) saghe 1683. - (p.p.) ghesien 1056, 3021 || See also: BESIEN, GESIEN, OMMESIEN, ONTSIEN, TOESIEN, VERSIEN

\section{siere binnen | SI + DAERBINNEN}

SIERHEIT, n. (f.) | beauty, treasure || chierheit 2614

siettene | SIEN + -ENE

sij $\mid$ SI

SIJN (I), irr. vb. | intr. - be, exist, happen || (inf.) sijn 500, 554, 747, 917, 1145 etc. - zijn 631,
$753,999,1658,2402$ etc. - wesen $246,595,606$, 612,618 etc. - te sine 2185 . - te zine 411 . - te wesene 1679. - (pr.1) bem 380, 525, 561, 671, 674 etc. - (pr.2) best 918, 2622. - bestu (clis.) 920. - (pr.3) es 19, 112, 128, 166, 225 etc. - is 1434b. - eist (clis.) 648, 1191, 1418, 1914, 2530 etc. - dannes (clis.) 564. - hets (clis.) 124, 181, $903,1022,1034$ etc. - dats (clis.) 115, 1949, 2582, 2903, 2908. - hijs (clis.) 1243. - nes (clis.) 1438, $2408,2521,2557,3155$. - wats (clis.) 1628, 3307. - (pr.4). sijn 1157. - (pr.5) sijt 2654a. - zijt 482. - sidi (clis.) 524, 945, 1033, 1194, 1903 etc. - zijt 111, 1032, 1072, 1181, 1223 etc. - zidi (clis.) 2730. - zijter (clis.) 2638. - (pr.6) sijn 16, 38, 314, 413, 620 etc. - zijn $87,1129,1138,1778,1795$ etc. -

(pr.s.3) si 3302, 3440. - zi 124, 493, 1836, 2750. sijt (clis.) 2784. - zijt (clis.) 2784. - (imp.pl.) zijt 1356, 2298, 2651. - sijts (clis.) 597. - weset 1178. - (impf.1) was 326, 1776, 2074, 2091, 2108 etc. (impf.3) was 41, 54, 57, 58, 79 etc. - waes 226. waest (clis.) 1318, 1559, 1893, 2367, 2369. - wasser (clis.) 825. - (impf.4) waerwi (clis.) 355. (impf.5) waert 2703. - waerdi (clis.) 1926, 2677. - waren 1484, 2333. - (impf.6) waren 43, 83, 305, 333,339 etc. - (impf.s.1) ware $668,2514,2540$. waer 160, 586, 1130, 2499. - waers (clis.) 2699, 318 o. - (impf.s.3) ware $26,91,195,252$, 255 etc. waer 172, 1149, 1824, 2130, 2147. - waers (clis.) 2679, 2925. - waert (clis.) 2184, 2654f. - (p.p.) ghewesen 2902, 2922

SIJN (II), poss. pron. (3 m.) | his (sometimes: her, their) || sijn 45, 200, 235, 507, 720 etc. zinen $744,1293,1969,1977,2191$ etc. - siere 269 , 1688, 3218. - ziere 10, 155, 185, 498, 546 etc. - zier 694. - tsinen (clis.) 466, 776, 2471

SIJNS, pers. pron. (3 m.g) | him || sijns 3048. zijns 355

sijs $\mid S I+-E S$

sijt | SIJN (I) (+ HET I)

sijts | SIJN (I) + -ES

SILVER, n. (n.) | silver || selver 2135, 2407, 2430. - selvere 2274

SIN, n. (m.) | direction, intelligence, mood, desire, meaning || zin 11, 36, 2130. - sinne 39. - zinne 2166, 2179, 2499, 2765, 2827 etc. $-(\mathrm{pl}$.) zinnen 2770 sine $\mid \mathrm{SI}+-\mathrm{ENE}$ sine, sinen | SIJN (II)

SINGEN, str. vb. | intr. tr. - sing, shout, preach || (inf.) zinghen 431, 440, 950, 2974. - te zinghene 148. - (pr.5) singhet 1218. - (impf.3) zanc 448 
SINKEN, str. vb. | intr. - sink, drop, calm (down) \| (inf.) zijncken 1290

SINT (I), adv. | since, later, afterwards || sint 79, 217, 356, 1499, 1504 etc. - sent 78

SINT (II), conj. | after, as, from the time that || sint dat 264, 402

SIRE *, n. (m.); (French) | lord || siere 937 sise $\mid S I+-S E$

SITTEN, str. vb. | intr. | sit, lie, find o.s.; tr. || (inf.) sitten 144, 523, 560, 2122, 2822. - (pr.5) satet 1213. - (impf.3) sat 2755. - zat 971, 1531. (impf.6) saten 1614, 1631, 2756. - (pr.p.) sittende 2814 || See also: BESITTEN

slach | SLACH, SLAEN

SLACH, n. (m.n.) | blow, trouble, misfortune || slach 812, 1251, 1253, 1259, 1507. - (pl.) slaghe 819, 1583, 1676. - slachen 638, 1594 || See also: VEDERSLACH

SLACHTEN, w. vb. | tr. - kill, slaughter; intr. resemble $\|$ (inf.) slachten 18,1414

SLAEN, str. vb. | tr. - strike, hit, defeat, aim; refl. - go to, direct one's steps towards \| (inf.) slaen $812,1249,1466,1717$. - te slane 730,829 . (pr.3) slaet 1268, 3428. - (imp.sg.) slach 1540, 1551. - (impf.3) slouch 782, 783, 875, 955, 1253 etc. - slouchene (clis.) 817. - (impf.5) slouchdi (clis.) 1843. - (impf.6) slouchsi (clis.) 1587. (p.p.) ghesleghen 505, 653. - (pr.p.) slaende 292 || See also: AENSLAEN, AFSLAEN, NEDERSLAEN, VERSLAEN

SLAKEN, w. vb. | tr. - decrease, let go; intr. come undone, decrease \| (imp.pl.) slaect 3398 SLAPEN, str. vb. | intr. - sleep, doze, linger; impers. || (impf.6) sliepen 1639. - (p.p.) gheslapen 1667 || See also: SLAPEND

SLAPEND, adj. (pr.p. from SLAPEN) | sleeping || slapenden 121

SLAVINE, n. (f.) | pilgrim's mantle, cape or coat for travelling || slavine 372

SLECHT, adj. | level, smooth, simple || slecht 454 sleets | DIES (I) + LEET (I)

sliepen | SLAPEN

slouch | SLAEN

slouchdi | SLAEN + GI

slouchene | SLAEN + -ENE

slouchsi | SLAEN + SI

SMAKE, n. (m.f.) | taste, smell || smake 218

SMAKEN, w. vb. | intr. tr. - taste, smell, notice || (pr.6) smaken 1135. - (impf.3) smaecte 2080. smakede 402
SMAL, adj. | small, thin || smale 1725 smaren | SMEREN

SMARTE, n. (f.) | sorrow, pain || smerte 2989 smeekedi $\mid$ SMEKEN + GI

SMEKEN, w. vb. | intr. tr. - flatter, cherish || (inf.) smeeken $485,682,3086$. - smeekene 1801. - smeekens 180o. - (pr.5) smeekedi (clis.) 2633 SMEREN, w. vb. | tr. - rub, anoint, flatter || (inf.) smaren 2928 smerte | SMARTE snachts $\mid$ DIES (I) + NACHT sneet af $\mid$ AFSNIDEN

SNEL, adj. | quick, fast, nimble || snelre 153

SNELLE, adv. | fast, quickly || snel 3415

SNIEMEN, adv. | soon, suddenly || snieme 3371 so | SI, SO (I) (II)

SO (I), adv. | so, so much that, also, very, definitely || so $3,51,74,79,89$ etc. - soe 2659 , 3331. - zoe 981, 2566

SO (II), conj. | as, because, while, when || so 725, 945,3440

sochte | SACHTE, SOEKEN

SODAT, consec. conj. | so that, when, while, because, until || sodat 740, 808, 869, 1503, 1581, etc. sodat $\mid$ SODAT + HET (I)

soe $\mid$ SI, SO (I)

SOEKEN, w. vb. | tr. - seek, look for, invent, visit, attack \| (inf.) soucken 7. - (impf.3) sochte 1633

SOENDINC, n. (n.f.) | reconciliation, compensation || soendinc 188

SOENE, n. (f.m.) | reconciliation, compensation || soene 3439. - zoene 3106, 3430

soene $\mid$ SI + -ENE

SOENEN, w. vb. | tr. intr. - settle (a dispute), compensate, be reconciled || (inf.) zoenen 3412 \| See also: VERSOENEN

soeten | SOETE, SOETEN

SOETE, adj. | sweet, dear, soft || soete 420, 549, $577,581,669$ etc. - soeten 1283, 2935. - zoeter 3059 soeten | SOETE, SOETEN

SOETEN, w. vb. | tr. - sweeten, soften, soothe; intr. - become sweet/soft/calm \| (inf.) soeten 2897

SOM, indef. pron.; decl. + undecl. | some, any || (decl.) some 1018. - somen 1893, 3052. - zomen 980. - (undecl.) som 2193

SOMER, n. (m.) | summer || zomer 2447 SOMWILEN, adv. | sometimes, often || somwijlen 2585 
SONDE, n. (f.) | $\sin ||$ zonde 2703. - (pl.)

zonden $281,371,1658,1717,2009$ etc. - sonden $1434 \mathrm{C}$

SONDELIJC, adj. | sinful || sondeliker 836. zondeliker 2795

SONDER (I), prep. | without, except || sonder 50, 58, 90, 214, 377 etc.

SONDER (II), conj. | but, except || sonder 2589, 2903

SONDERLINC, adj. | separate, special ||

sonderlinghe 3068

SONE, n. (m.) | son || sone 803, 1171, 1766.

- zone 1411. - (pl.) zonen 328 || See also:

BROEDERSONE, PUTENSONE

SONNE, n. (f.m.) | sun, sunshine || zonne 759,

1319, 2557, 2717. - zonnen 537

SONNENOPGANC, n. (m.) | dawn, sunrise || zonneupganc 2927

SORGE, n. (f.) | sorrow, fear, danger, trouble, distress || zorghe 393, 1308, 1984, 2195, 2326 etc. zorghen 228, 516, 1307, 1434, 1627 etc.

SORGEN, w. vb. | intr. tr. - fear, worry, be concerned with, look after $\|$ (pr.1) zorghe 1111. zorghic (clis.) 1374. - (imp.pl.) sorghet 670. zorghet 494. - (p.p.) ghezorghet 2327

SOT, adj. | stupid, foolish || zot 586, 1351

soucken | SOEKEN

souddi | SULLEN + GI

soude | SOUT, SULLEN

souden | SULLEN

soudene | SULLEN + -ENE

soudens $\mid$ SULLEN + -ES

soudic | SULLEN + IC

SOUT, n. (n.m.) | pay, wages || soude 2469. -

tsout (clis.) 2429

sout | SULLEN + HET (I)

soutter | SULLEN + -ER

souts | SULLEN + -ES

SOWIE, indef. pron. | whoever || sowie 2000

SPADE (I), adj. | late, lengthy || spade 2316, 2317, 2999

SPADE (II), adv. | late || spade 1476, 2073

spaerdene | SPAREN + -ENE

spaeus $\mid$ DIES (I) + PAVES

SPANEN, w. vb. | tr. - wean || (impf.3) spaende 2075

spapen $\mid$ DIES (I) + PAPE

SPAREN, w. vb. | tr. - save, spare, avoid, neglect, delay; refl. - spare o.s.; intr. - delay, linger \| (inf.) sparen 1240, 3006. - (gheen langher) sparen 3325. - (pr.1) spare 2224. - (pr.3) spaert 1328, 2016. - (pr.5) spaert 1186.- (imp.pl.) spaert 2011. - (impf.1) spaerdic (clis.) 2410. - (impf.3) spaerdene (clis.) 1255

SPEL, n. (n.) | game, entertainment, joke, behaviour || spele $672,1147,1283,1581,1885$ etc. spelen 157

spelen | SPEL, SPELEN

SPELEN, w. vb. | intr. - play, amuse o.s., act; tr. II (inf.) spelen 2076

SPELLEN, w. vb. | tr. - spell, explain || (inf.) spellen 147

SPIKER, n. (m.n.) | larder, barn || spijker 1512, 1515,1575

SPILLE, n. (f.) | spindle || spillen 832

SPINNEN, str.+w. vb. | intr. - spin; tr. - spin, plan, plot || (p.p.) ghesponnen 733

SPIRITUS *, n. (Latin) | ghost, spirit || spiritus 1544

SPISE, n. (f.) | food, victuals || spise 558. - spijse 577, 3068. - spijsen 1112, 3156

SPOR, n. (n.m.) | footprint, track, path, step || spore 2393

SPOT, n. (n.m.) | jest, scorn $\|$ spot 585, 587, 1142

sprac, spraken | SPREKEN

sprake | SPRAKE, SPREKEN

SPRAKE, n. (f. m.) | speech, language, conversation \| sprake 1846

spranc|SPRINGEN

SPREKEN, str. vb. | intr. - speak; tr. announce || (inf.) spreken 1659, 1809, 2217, 2914, 3299 etc. - te sprekene 2687. - (imp.pl.) spreect 1458. - (impf.1) sprac 1628. - (impf.3) sprac 65, 126, 171, 203, 375 etc. - (impf.6) spraken 459. - (impf.s.3) sprake 2213. - (p.p.) ghesproken 98, 2480. - (pr.p.) sprekende 644 || See also: BESPREKEN, GESPREKEN, VERSPREKEN

SPRINGEN, str. vb. | intr. - jump, escape, originate; tr. - pounce \| (inf.) springhen 2035. - te springhene 2021. - (pr.6) springhen 2033. - (impf.3) spranc 109, 315, 1196, 1244, 1266 etc. - (impf.6) spronghen 2018. - (p.p.) ghespronghen $766 \|$ See also: ONTSPRINGEN, OPSPRINGEN, UTESPRINGEN, VERSPRINGEN, VORTSPRINGEN

SPRONC, n. (m.) | jump, origin, moment || spronc 1712

spronghen | SPRINGEN 
stac, staken | STEKEN

stacken | STEKEN + -ENE

STADE, n. (f. $\mathrm{m}$ ) | right place, right time, help || stade 3311

STAEN, str. irr. vb. | intr. - stand, be, remain, exist, belong with, suit; tr. || (inf.) staen 63, 192, $324,1066,1429$ etc. - te stane 2754. - (gheen langher) staen 631, 712. - (pr.3) staet 138, 630, $688,1124,1952$ etc. - steet $2657 .-$ (pr.6) staen 320, 1412. - (impf.3) stont 283, 715, 717, 1226, 1252 etc. - stoet 171, 336, 623, 931, 1209 etc. (impf.6) stonden 848, 2295, 2461. - (impf.s.3) stonde 196, 1979, 2700. - stonder omme (clis.) 2185. - (p.p.) ghestaen 698, 776, 1229, 2392 \| See also: BESTAEN, GESTAEN, OPSTAEN, VERSTAEN

STAERBLINT, adj. | completely blind, blind as a bat || staerblent 77

staerc|STARC

staerf | STERVEN

staert | STERT

STAF, n. (m.) | stick, staff, cudgel || staf 2946. - stave 789. - (pl.) staven 1569 || See also: CRUCESTAF

STAGE, n. (f.m.) | platform, upper floor, height || stage 2753

STAKE, n. (m.f.) | stick, baton, stem || stake 724 stal | STELEN

STALLICHT, n. (n.) | (large) candle || stallicht 303

\section{stan | STENEN}

STAP, n. (m.) | step, doorstep, stick || stap 766 STARC, adj. | forceful, powerful, brave, great || staerc 333, 1028. - sterc 690, 1882 || See also: OVERSTARC

STAT, n. (f.m.n.) | place, position, moment, town || stat 1152, 1610, 2242, 2438, 2476 || See also: STEDE

STEDE, n. (f.m.n.) | place, opportunity, town, moment || stede 150, 865, 2596, 3292 || See also: STAT

STEEN, n. (m.) | stone, rock, fortress || steen 1256, 1591. - steene 2753. - (pl.) steene 1602, 2615, 2870 || See also: MAERBERSTEEN STEENDOOT, adj. | dead, dead as a doornail || steendoot 1597

steet | STAEN

STEKEN, str. vb. | tr. - stick, hit, place; refl. - bump, knock o.s. against; intr. - be in || (inf.) steken 3260. - te stekene 730, 829. - (impf.3) stac $782,1547$. - stacken 787. - (impf.6) staken 1587, 3283. - (p.p.) ghesteken 3276, $3354 \|$ See also: ACHTERSTEKEN, BESTEKEN, INSTEKEN, ONTSTEKEN

STELEN, str. vb. | tr. - steal, rob, burgle; refl. steal away; intr. - act secretly, steal away II (inf.) stelen 642, 1828, 1969. - (dat) stelen 1687, 2516. - (impf.3) stal 106, 2105. - (p.p.) ghestolen 120, 256, 2147 || See also: BESTELEN, GESTOLEN STENEN, str.+w. vb. | intr. - groan, complain || (impf.3) stan 874, 990

sterc|STARC

STERT, n. (m.) | tail, backside || staert 523, 973. - steert 2391

STERVEN, str. vb. | intr. - die, be killed || (inf.) sterven 1261, 2007, 2182. - sterven (weten) 2197. - (impf.3) staerf 2008

stic | STUC

stierne | STUREN

STILLE, adj. | silent, quiet, secret || (comp.) stilre 2886

STILLEKINE, adv. | silently, quietly, secretly || stillekine 2291, 3209

STILLESWIGEN, str. vb. | intr. - soothe, calm down, be silent || (imp.pl.) zwighet stille 2572. - (impf.3) zweech stille 2028, 2917. - (impf.6) zweghen stille 2216. - (p.p.) ghesweghen stille 775

stoef $\mid$ STUVEN

STOEL, n. (m.) | chair, throne || stoel $2270 \mathrm{cc}$ stoet $\mid$ STAEN

STOLE, n. (m.) | mantle, stole || stolen 378 stonde $\mid$ STONDE, STAEN

STONDE, n. (f.m.) | time, time of day, opportunity || stonden 161, 282, 2239, 2456. - stont 934, 2371, 2921. - (pl.) stonden 1281, 2244, 2360 stonden | STAEN, STONDE stonder omme | STAEN + DAEROMME stont | STAEN, STONDE

STOPPEN, w. vb. | tr. - seal, close, stop; rel.; intr. - stop \| (impf.3) stoppede 2387

STOUT, adj. | brave, cruel, proud || stoute 3406 stoven | STUVEN

STRATE, n. (f.) | street, way || strate 1208, 1316, 1703, 1763. - straten 930, 1492, 1562, 1613, 1747 streden | STRIDEN

STRENGE, n. (m.f.n.) | rope, strip || (pl.) stringhen 841

STRIC, n. (n.m.) | bow, snare || strec 1173, 1198, 1203, 1230, 1277 etc. - strecs 1202 
STRIDEN, str. vb. | intr. - fight, dispute; tr. fight || (impf.6) streden 792

STRIJT, n. (m.n.) | fight, single combat || strijde 2020

\section{stringhen | STRENGE}

STRO, n. (n.) | straw, stalk or piece of straw ||

stro 2542. - stroe 2561, 2565

STROOM, n. (m.n.) | stream || stroem 851. strome 959

STROP, n. (m.n.) | noose, snare || strop 1930 STROWISCH, n. (m.) | wisp of straw ||

stroewisch 1234

STRUUC, n. (m.)|bush, (tree) stump $\|$ (pl.)

struke 1602,2870

STUC, n. (n.) | piece, chunk, a short time \| stic

1114

STUPE, n. (f.) | convulsion, pillory, the stocks || stupen 860

STUREN, w. vb. | tr. - aim, send || (inf.) te

stierne 1682

STUVEN, str. vb. | intr. - disperse, disappear suddenly \| (impf.3) stoef 352. - (impf.6) stoven 1713

SUCHTEN, w. vb. | intr. - sigh, complain || (pr.1) suchtic (clis.) 1434 || See also: VERSUCHTEN

SULC (I), dem. pron. | such, such a one, as such || (attrib.) sulc 809, 1608. - sulke 20, 767, 2046, 2205, 2992 etc. - sulker 228, 685, 1223. - sulken 543, 1795, 2292. - (indep.) die sulke 1778

SULC (II), indef. pron. | someone, many, some || sulc $722,723,724,774,1104$. - sulken 176 suldi | SULLEN + GI

\section{suldijt | SULLEN + GI + HET (I)}

SULLEN, irr. vb. (pret. pres.) | must, shall, want to $\|$ (pr.1) sal 632, 1030, 1040, 1153, 1182, 1183 etc. - saels (clis.) 592. - saelt (clis.) 492. - salt (clis.) 1419. - (pr.2) salt 1958. - (pr.3) sal 175, 192, 260, 424, 426 etc. - saels (clis.) 3299. - saelt (clis.) 168, 190, 492, 635, 3412. - salne (clis.) 1023, 1340. - salt (clis.) 1959, 2145. - (pr.4) sullen $431,432,434,3054,3420$ etc. - sulne (clis.) 3422. - (pr.5) sult 626, 634, 636, 1376, 1378 etc. - suldi (clis.) 630, 664, 1659, 2604, 2608 etc. - suldijt (clis.) 3253. - sulter af (clis.) 3267. - (pr.6) sullen 1382, 1476, 2178, 2319. - sullent (clis.) 2036, 2537. - (impf.1) soude 30, 554, 1480, 1609, 2189 etc. - soudic (clis.) 605, 1831, 1871b, 2497, 3350. - souts (clis.) 591. - (impf.3) soude $81,150,159,198,472$ etc. - soudene (clis.) 143. - sauder toe (clis.) 1216. - sout (clis.) 2659, 2877. souts (clis.) 2736, 3290. - (impf.4) souden 1109, 2107. - (impf.5) souddi (clis.) 706, 2726. - sout 1802, 2678. - souts (clis.) 1668. - soutter (clis.) 1145. - (impf.6) souden 440, 1779, 2270c, 227od, 2276 etc. - soudens (clis.) 24

sullent | SULLEN + HET (I)

sulne | SULLEN + -ENE sulter af $\mid$ SULLEN + DAERAF

SUSTER, n. (f.) | sister $\|$ suster 311. - sustre 307 SUUR, adj. | sour, disagreeable || zuer 2114 SUUT, adv. | south || suut 759

SUUTWEST, adv. | southwest || zuutwest 2579 SUVER, adj. | pure, clean, chaste || zuver 414, 2092

SWAER, adj. | heavy, ill, difficult || zwaer 1557, 1873, 2024, 2199

SWAERDE, n. (f.) | head, scalp || zwaerde 1503 SWARE (I), adv. | heavy, difficult, very || zwaer 1041. - zware 310, 2919

SWARE (II), n. (f.) | heaviness || zware 370 SWART, adj. | black || zwarten 1696 SWEET, n. (n.m.) | sweat || zweet 894 SWEMMEN, str.+w. vb. | intr. - swim, float || (impf.3) zwam 870 || See also: ONTSWEMMEN

SWEREN, w. vb. | intr. - swear, conspire, curse; tr. - swear, take/swear an oath, solemnly seal an agreement with s.o., allay, ward off $\|$ (pr.5) zweert 3456. - (impf.3) zwoer 1270, 1550, 1606. - (impf.6) swoeren 2270a. - zwoeren 2268. (p.p.) ghezworen 526, 1805, 2467, 3174 || See also: VERSWEREN

SWIGEN, str. vb. | intr. - be silent; tr. - be silent about, conceal || (pr.1) zwijghics (clis.) 94.(imp.pl.) swijghet 1289. - zwighet 2220. - (p.p.) gesweghen 1933 || See also: STILLESWIGEN SWIJN, n. (m.) | swine, pig || zwijn 918 || See also: EVERSWIJN

swoeren | SWEREN

TAFEL, n. (f.m.) | table, table of contents, painting || tafle 1538, 1547. - taflen 1213, 1532 TAFELMES, n. (n.) | table knife $\|$ tafelmes 1546,1553

taken | TE (I) + Aken (proper name)

TALE, n. (f.) | speech (speaking), words, story, speech (address) || tale 108, 179, 283, 538, 641 etc. - talen 183, 246, 426, 707 || See also: WEDERTALE 
tallen | TE (I) + AL (I)

TAM, n. (n.) | tame animal || tam 271

TANT, n. (m.) | tooth || tant 768, 2090. - (pl.)

tanden 201, 1264, 1312

tart | TREDEN

TASTEN, w. vb. | tr. - feel, touch; intr. || (inf.)

tasten 1624. - (impf.3) taste 1625

TAVERNE, n. (f.) | tavern, inn || taverne 1287

TAVONT, adv. | tonight || tavont 1082, 1097,

1108, 1145, 1184

TE (I), prep. | at, in, on, with, to, until, according to $\|$ te 51, 59, 87, 89, 92 etc. - taken (clis.) $2270 \mathrm{c}$.

- tallen (clis.) 672, 2360. - teenen (clis.) 600,

2262, 2309, 2756, 3282. - tenen (clis.) 332. - teer

(clis.) 2239. - teere (clis.) 1615, 2845. - teerst

(dat) (clis.) 1431, 2052, 2400, 3433. - tetene

(clis.) 2133. - thuus (clis.) 2864. - thuwaert

(clis.) 2686. - thuwen (clis.) 1147. - thuwer

(clis.) 2723. - tonneeren (clis.) 1490. - tonsen

(clis.) 2419. - tsinen (clis.) 466, 776, $2471 \|$ See

also: TEGADER, TEHANT, TEN, TER, TES, TESAMEN, TEVOREN, TEWAREN

TE (II), adv. | too || te 18, 226, 447, 464, 1158

etc.

tebannen | BANNEN

teblauwen | BLOUWEN

tebroken | BREKEN

TEE $\|$ n. (m.f.) | toe $\|$ (pl.) teen 2889

teekin(e)|TEKEN

teenen | TE (I) + EEN (I) / EEN (II)

teer, teere $\mid \mathrm{TE}(\mathrm{I})+\mathrm{EEN}$ (II)

teerst $\mid$ TE (I) + EERST

TEGADER, adv. | together || tegader 2104, 2409

teghen an $\mid$ AENTIËN

TEHANDE, adv. | immediately, quickly,

already, yet || tehant 959, 983, 1151, 2290, 2403

TEKEN, n. (n.f.) | sign, token, omen, evidence

|| teekin 1054. - (pl.) teekine 163 || See also:

LIJCTEKEN

teldi | TELLEN + HI

TELEN, w. vb. | tr. - produce, take care of ||

(inf.) telen $381 \|$ See also: GETELEN

TELLEN, w. vb. | tr. intr. - count, tell || (inf.)

tellen 2099, 2799. - (impf.3) telde 2290, 2457. teldi (clis.) $2450 \|$ See also: VERTELLEN

TEN, prep. (from TE (I) + den < DIEN I) $\|$ ten $47,322,527,969,1080$ etc. - enten (clis.) 912, 3413

temmerman | TIMMERMAN

tenen $\mid \mathrm{TE}(\mathrm{I})+\mathrm{EEN}$
TER, prep. (from TE (I) + der < DIER II) $\|$ ter 150, 433, 815, 896, 1053 etc.

terden | TREDEN

TES, prep. (from TE (I) + des < DIES I) $\|$ tes $48,977,1005,1064,1163$ etc.

TESAMEN, adv. | together || tsamen 3091

tetene $\mid$ TE (I) + ETEN

TEVOREN, adv. | earlier, previously, moreover || tevoren 156, 797, 914, 922, 928 etc.

TEWAREN, adv. | actually, truly || tewaren 603 tfolc | DAT (I) + VOLC

tgat $\mid \mathrm{DAT}(\mathrm{I})+\mathrm{GAT}$

tghetal | DAT (I) + GETAL

tgoet $\mid$ DAT (I) + GOET (II)

tgraf $\mid$ DAT (I) + GRAF

tgroete $\mid \mathrm{DAT}(\mathrm{I})+$ GROOT

theeren $\mid \mathrm{TE}(\mathrm{I})+\mathrm{ERE}$

thijs | DAT (I) + IJS

thoeft | DAT (I) + HOVET

thof $\mid$ DAT (I) + HOF

thonich | DAT (I) + HONICH

thoren | TOREN

thuus | TE (I) + HUUS

THUUSWAERT, adv. | home, homewards ||

thuuswaert 902, 3097

thuwaert $\mid$ TE (I) + UWAERT

thuwen, thuwer $\mid \mathrm{TE}(\mathrm{I})+\mathrm{UWE}$

TIEN, num. | ten || tienen 593, 595 || See also:

TIENDE

TIENDE, ord.| tenth || tienden 2536

TIJT, n. (f.m.) | time, moment, weather, life || tijt 1102, 1112, 1229, 1368, 1925, 3005. - tijde 2309. -

tijden 149, 3063. - (pl.) tijden 2073

TIMMERMAN, n. (m.) | carpenter $\|$

temmerman 649. - (pl.) temmermans 654

tlaken | DAT (I) + LAKEN

tleven $\mid$ DAT (I) + LEVEN (II)

tlijf | DAT (I) + LIJF

tloepen | DAT (I) + LOPEN

tmijn | DAT (I) + MIJN

TOCH, adv. | nevertheless || doch 1739

TOE, adv. | there, as well, further, near || toe 833, 1232, 1237, 2545 || See also: DAERTOE

TOEBRENGEN, w. irr. vb. | tr. - bring, bring about, spend $\|$ (impf.1) toebrochte 1530

toechde | TOGEN

TOEGAEN, str. irr. vb. | intr. - approach, continue, close || (imp.pl.) gaet toe 675

TOELOPEN, str. vb. | intr. - approach, gather || (impf.3) liep toe 1203 


\section{toerne | TOREN}

TOESIEN, str. vb. | intr. - look, watch; tr. attend, look after $\|$ (pr.1) toezye 1542. - (impf.3.) toesach 1539

TOGEL, n. (m.) | bridle || toghel 1162

TOGEN, w. vb. | tr. - show, declare; refl. intr. appear, show o.s. || (inf.) toghen 2642, 2678. (impf.3) toechde $372,1089,2113$. - toghede 2458. - (p.p.) ghetoghet 1078

TONGE, n. (f.) | tongue, language || tonghe 1076 tonneeren $\mid \mathrm{TE}(\mathrm{I})+$ ONERE

tonsen | TE (I) + ONSE

TOP, $\mathrm{n}$. (m.) | crown || top 948

TOREN, $\mathrm{n} .(\mathrm{m}) \mid$. anger, regret, sorrow, suffering || toren 913, 1291, 1474, 1792, 2925 etc. - thoren

915. - torne 2483. - toerne 3295

TORMENT, n. (m.n.) | torment || torment 2186

TORNICH, adj. | angry, furious || tornich 1170 TOTE (I), prep. | till, at, to, in || tote 413,646 , $1012,1098,1102$, etc. - toten $888,1233,2586,2739$, 2882 etc. - toter (clis.) 986, 1536, 1645, 2851

TOTE (II), conj. | until, while, before || tote dien dat 2214

TOTEDAT, conj. | until || totedat 3072 trac in | INTRECKEN

TRAECH, adj. | slow, lazy, weak || traech 1903, 2713. - traghe 1178

TRAEN, n. (m.) | drop, tear $\|$ (pl.) tranen 2986 trauwe | TROUWE

TRECKEN, w.+str. vb. | tr. - pull, drag, stand; refl. - go, resemble; intr. || (inf.) trecken 2411. (pr.5) trect 1369, 1660. - (impf.6) traken 1588 See also: HENENTRECKEN, INTRECKEN, VORTTRECKEN

TREDEN, str. vb. | intr. - step; tr. - enter, trample (down, underfoot) || (inf.) terden 2870. (impf.3) tart 540

TREKE, n. (f.m.) | trick, ruse, prank || treken 1810, 2218, 3277

TREKER, n. (m.) | cheat, trickster $\|$ trekere 129 TROOSTEN, w. vb. | tr. - console, encourage; refl. - trust in, put one's trust in; intr. || (pr.3) troestet 3193. - (impf.3) troeste 1298. (impf.s.3) troeste 3080,3084 TROP, n. (m.) | mass, heap || trop 821 TROUWE, n. (f.) | loyalty, (solemn) promise, word of honour, trust \| trauwe 241, 2286, 2533, 2554, 3177. - trauwen 590, 1720, 2102, 2149, 2176 etc. - trouwen $2654 \mathrm{~g}$

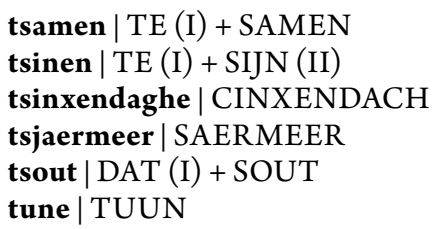
tusschen 145, 301, 599, 817, 820 etc.

TUUN, n. (m.) | fence, hedge || tuun 1905, 2021. - tune 646

TWAELFHONDERT, num. | twelve hundred II XIIC 2460

TWEE, num. | two || twee 76, 305, 653, 679, 751 etc. - II 1739, 3036, 3042, 3070. - tween 966. tweer 313

TWI, adv. | why || twi 1194, 1903, 1912, 2904, 3206 etc. - twy 2317

TWINT, n. (m.) | blink of an eye, short moment, trifle, a bit, (niet een t.) not one bit, absolutely not || twint 2011

TWINTICH, num. | twenty || XX 2469

TWIVELEN, w. vb. | intr. impers. - doubt, be unsure, hesitate || (pr.3) twifelt 1834. - (p.p.) ghetwifelt 980

twoeste | DAT (I) + WOEST twy $\mid$ TWI

U, pers. pron. (5 d/a) | you || hu 68, 72, 113, 126, 193 etc. - segghu (clis.) 2142

ULE, n. (m.f.) | owl $\|$ hule 2589

up, up- | OP, OP-

uphief | OPHEFFEN

uphilden | OPHOUDEN

uplaset | OPLESEN

upnam | OPNEMEN

upt $\mid$ OP (I) + DAT (I)

UTE (I), prep. | out, outside, from || hute 1241, 2377. - huut 882, 1427, 2499. - huten (clis.) 399, $506,651,1128,1392$ etc. - huter (clis.) 681, 1523, 1908. - uter (clis.) 681, 1523, 1908 UTE (II), adv. | out, outside || hute 1828 UTEBRINGEN, w. vb. | tr. - produce, show || (impf.3) brochte huut 742. - (p.p.) hutebrocht 748

UTECOMEN, str. vb. | intr. - appear || (inf.) commen huut 1527. - (pr.5) comdi huut 3206. (impf.6) quamen huut 1572

UTEGAEN, str. vb. | intr. - go outside, end; tr. - leave || (inf.) hute te gane 521. - (impf.3) ghinc hute 3208. - ghinc huut 627 
UTEGERAKEN, w. vb. | intr. - escape || (impf.3) gherochte huut 752

UTEKEREN, w. vb. | tr. - stop (s.o.), destroy (s.th.); refl. - go outside; intr. - leave, return \| (imp.pl.) keert hute 1181

UTELEKEN, str.+w. vb. - intr. | leak, drip || (impf.3) huutlac 808

uter | UTE (I) + der

UTERMATEN (I), adj. | extraordinary ||

utermaten 557

UTERMATEN (II), adv. | extraordinarily, excessively || utermaten 561, 661, 892, 1115, 1491 etc.

UTESENDEN, w.+str. vb. | tr. - despatch, send, delegate $\|$ (impf.3) sendde huut 2425

UTESPRINGEN, str. vb. | intr. - jump out, escape || (impf.3) spranc hute 1315

UTETREKKEN, str.+w. vb. | tr. - pull out, translate; intr. - go out $\|$ (impf.6) huut traken

842

UTEWAERT, adv. | outside || huutwaert 2051, 3010

UTEWERPEN, str. vb. | tr. - throw out, stick out; refl. || (inf.) werpen huut 3386. - (impf.3) warp huut 1257

UWAERT, adv. | in your direction, against you || thuwaert (clis.) 2686

UWE, poss. pron. (5) | your $\|$ hu 66, 166, 222, 360,422 etc. - huwe 167, 662, 1813, 1923, 1947 etc. - huwen 168, 201, 204, 219, 364 etc. - huwes $548,1279,1800$, 1994. - huwer 590, 1195, 1780, 3062. - dhuwe (clis.) 1843. - thuwen (clis.) 1147. - thuwer (clis.) 2723

\section{va |VAEN}

VADER, n. (m.) | father || vader 8o1, 1271, 1279, 2008, 2228 etc. - vaders 2345. - vadre 1140, 1235 VAEN, str. vb. | tr. - catch, take, capture, take prisoner; intr. || (inf.) vaen 1465, 1867, 2830. vanghen 3422. - te vane 1173 . - (imp.sg.) va 1551. - vanc 1540. - (impf.1) vinc 2072. - (impf.2) vinc 229. - (p.p.) gevaen 3101a. - ghevaen 688, $711,717,878$, 922 etc. - ghevanghen 683,1911 , 2832 || See also: BEVAEN, ONTVAEN

VAER, n. (m.f.) | fear, danger $\|$ vaer 2651. - vare 1623, 2295, 2321, 2372, 2648 etc.

vaert | VAERT, VAREN

VAERT, n. (m.f.) | journey, speed || vaert 497, 869, 970, 1040, 1043 etc. - vaerde 153

VAL, n. (m.) | fall || val 1637
VALDORE, n. (f.) | trapdoor || valdore 1615, 1619, 1622

VALLEN, str. vb. | intr. - fall, happen || (impf.3) viel 1301. - (p.p.) ghevallen 1642 |l See also: GEVALLEN, MISVALLEN, NEDERVALLEN

VALSCH (I), adj. | unreliable, false, unreal || valsch 2329, 3407. - valsche 2669, 2880. valschen 487

VALSCH (II), adv. | by false or fraudulent means, false $\|$ valsch 20

VAN, prep. | of, from, made of, by, as a result of, as regards || van 4, 31, 134, 135, 157 etc.

vanc, vanghen | VAEN

VANDEN, w. vb. | tr. intr. - visit, try || (imp.pl.)

vandet 1449

VANE, n. (f.m.) | banner || vane 729, 763, 813

vane | VAEN

vant | VINDEN

vare |VAER, VAREN

VAREN, str. vb. | intr. - go, travel, act; tr. move by ship or cart || (inf.) varen 2012, 2016, 2157, 2248, 2818 etc. - dat varen 3189. - (pr.1) vare 1401. - (pr.5) vaert 2741. - (impf.3) voer 1605, 1635. - (p.p.) ghevaren 285, 903 \| See also: ONTVAREN

VAST, adj. | firm, strong, determined || vast 1882, 1935, 2854, 2875, 3456

VASTE, adv. | firmly, strongly, forcefully, soon || vast 1199, 2673. - vaste 145, 341, 695, 704, 1976 etc. VASTELIKE, adv. | firmly, strongly, forcefully, soon $\|$ vastelike 814

VASTEN, w. vb. | intr. - fast || (inf.) te vastene 1681

VEDERE, n. (f.) | feather, wing $\|$ (pl.) vederen 292

VEDERSLACH, n. (m.n.) | beating of the wings || vederslach 1862

veeten | VETE

VEL, n. (n.) | skin || vel 200, 774, 967, 2654d, 2884 etc. - velle 2980

VELE (I), indep. indef. num. | many, much || vele 51, 89, 592, 603, 637 etc. || See also: MEER (comp.), MEEST (I, superl.)

VELE (II), adj. | many, much || vele 337, 370, 1192, 1477, 2555 etc. || See also: MERE (comp.), MEESTE (superl.)

VELE (III), adv. | much, very, often || vele 18, 410, 536, 762, 1519 etc. || See also: MEER II (comp.), ALLERMEEST (reinf. superl.) 
VELSPOT, n. (n.) | piece of skin || velspot 2844

VELT, n. (n.) | field, meadow, plain, land || velt 2268, 2313, 3444. - (pl.) velde 325, 2363

VENISOEN, n. (f.) | venison, game || venisoen 1136

VER, n. (f.) | lady || ver 2654

verbalch | VERBELGEN

VERBANNEN, str.+w. vb. | tr. - ban, expel || (p.p.) verbannen 2731

VERBELGEN, str.+w. vb. | tr. - cause to swell up, make angry; refl. intr. - become angry, get annoyed || (impf.3) verbalch 2637 || See also:

\section{VERBOLGEN}

VERBINDEN, str. vb. | tr. - bind, blindfold; refl. intr. - conclude a treaty $\|$ (impf.6)

verbonden 1585

VERBITEN, str. vb. | tr. - bite to death, tear, restrain; intr. - restrain o.s. || (pr.3) verbijt 3123 . - (pr.5) verbit 3446. - (impf.1) verbeet 2078, 2085, 2088, 2092. - (impf.3) verbeet 463, 2311 VERBOLGEN, adj. (p.p. from VERBELGEN) | angry, dismayed || verbolghen 848, 1397

VERBOLGENLIJC, adj. | angry, dismayed || verbolghenlike 179

verbonden | VERBINDEN

VERCIESEN, w. vb. | tr. - experience, prefer || (p.p.) vercoren 1941

VERCOELEN, w. vb. | tr. - cool down, cool off; refl. - cool off; intr. - become cooler, cool off II

(inf.) vercoelen 897

vercoren | VERCIESEN

verde |VREDE

VERDERVEN, str.+w. vb. | tr. - bring ruin upon, destroy; intr. - become unhappy \| (pr.5) verdervet 667

VERDIENEN, w. vb. | tr. - deserve, achieve; intr. || (inf.) verdienen 594. - (p.p.) verdient 1963

VERDOEMT, adj. (p.p. from 'verdoemen' | damned || verdoomt 999

VERDOREN, w. vb. | tr. - confuse, madden, cheat; intr. - become mad, confused $\|$ (inf.) verdoren $677,1632,2049,2164$. - (p.p.) verdoort 3070

VERDOVET, adj. (p.p. from 'verdoven')| stunned, dazed, frenzied $\|$ verdoeft 818 VERDRAGEN, str. vb. | tr. - transport, lift up, endure, bear; refl. - abstain from; intr. - agree \| (inf.) verdraghen 1889

\section{verdreef | VERDRIVEN}

VERDRIVEN, str. vb. | tr. - expel, ruin; intr. disappear $\|$ (impf.3) verdreef 2115

VERDROEVEN, w. vb. | tr. - distress, curse; refl.; intr. - sadden $\|$ (inf.) verdrouven 853 VERGAEN, str. vb. | intr. - end, die; tr. - pass; refl. || (inf.) vergaen 1039. - (impf.3) verghinc 1263, 1490, 3295. - (p.p.) vergaen 323, 1440 VERGETEN, str. vb. | tr. intr. - forget, neglect, leave behind; impers.; refl. - relax \| (inf.) vergheten 2666, 2667. - (p.p.) vergheten 1721 VERGEVEN, str. vb. | tr. - give, give away, forgive || (inf.) vergheven 1462, 1653, 2502, 2511. - (pr.5) verghevet 2692. - (pr.s.3) vergheve 1722. - (impf.3) vergaf 2543. - (impf.s.3) vergave 2677 - verghave $616,1130,1220$. - (p.p.) vergheven 174,378

verghinc|VERGAEN

VERHANGEN, str. vb. | tr. - hang (also: elsewhere or differently); refl. - hang o.s.; intr. hang $\|$ (p.p.) verhanghen 3096

VERHEFFEN, str. vb. | tr. - lift up, praise; refl. intr. - rise, increase in force or power $\|$ (p.p.) verheven 1553

VERHELEN, str. vb. - tr. refl. | hide || (p.p.) verholen 255 || See also: VERHOLEN

VERHOEREN, w. vb. | tr. - dishonour; intr. commit adultery $\|$ (p.p.) verhoert 73

VERHOGEN, w. vb. | tr. - please; refl. intr. rejoice || (p.p.) verhoghet 3137

verholen | VERHELEN, VERHOLEN VERHOLEN, adj. (p.p. from VERHELEN)

| hidden, secret || verholen 2145, 2287, 3314. verholnen 2242, 2281

verholen | VERHELEN

VERHOLENLIJC, adj. | hidden, secret || verholenliken 891

VERHOLENLIKE, adv. | hidden, secret || verholenlike 1516, 2421, 2426, 3284

VERHOREN, w. vb. | tr. - hear, listen to, interrogate, ignore; intr. || (impf.3) verhoerde 534, 2139.

VERHORNT, adj. | covered in horn || verhoernden 786 VERJONNEN, irr. w. vb. | tr. - envy, resent || (inf.) verjonnen 260

VERLATEN, str.+w. vb. | tr. refl. intr. - leave, trust in, cease || (pr.1) verlate 1087

VERLATENISSE n. (f.) | forgiveness, absence || verlanessen 2056 
VERLIES, n. (n.m.) | loss, damage, accident || verlies 71,770

VERLIESEN, str. vb. | tr. - lose, destroy; refl. - ruin o.s. || (inf.) verliesen 995, 1382. - (impf.3) verloes 254. - (impf.s.3) verlore 133. - (p.p.) verloren 311, 696, 927, 948, 966 etc. verloes, verlore, verloren | VERLIESEN VERLOVEN, w. vb. | tr. - promise, abjure; refl. - commit o.s. || (inf.) verloven 1444

VERMALEDIËN, w. vb. | tr. - curse || (inf.) vermalendyen 490 . - (p.p.) vermaledijt 2654 b. - vermalendijt 916

VERMANEN, w. vb.| tr. - rebuke, encourage, explain; refl. - remember \| (impf.s.3) vermaende 1973

VERMERREN, w. vb. | tr. - neglect, prevent; intr. - linger, hesitate \| (pr.5) vermerrendi (clis.)

1373

vermerrendi | VERMERREN + GI

VERMOGEN, irr. vb. | intr. - be capable of, be powerful; tr. - can, be able; refl. || (impf.1) vermochte 2094

vernaemdi | VERNEMEN + GI vernam, vernamen, vernomen | VERNEMEN

VERNEMEN, str. vb. | tr. - take, see, hear, understand; intr.; refl. || (imp.pl.) verneemt 2227. - (impf.1) vernam 2382. - (impf.3) vernam 711, 911, 978, 1046, 2481 etc. - (impf.5) vernaemdi (clis.) 3248. - (impf.6) vernamen 1570. - (p.p.) vernomen 520, 1753, 2375, 2796 VERNOOY, n. (n.f.) | distress, sorrow, pain || vernoy 1275. - vernoys 1937. - vernoye 1989, 2901

VERNOOYEN, w. vb. | impers. intr. - distress, find unpleasant $\|$ (inf.) vernoyen 1366, 1668, 3213. - (impf.3) vernoyde 3

VERONWERDEN, w. vb. | tr. - hold in contempt; refl. intr. impers. - be angry $\|$ (impf.3) veronweerde 2246

VERORDELEN, w. vb. | tr. - judge || (inf.) verordeelt 1886

VERPINET * adj. (p.p. from 'verpinen') | exhausted || verpijnet 867

VERRADEN, str. vb. | tr. - betray, mislead, betray someone's trust, trap \| (impf.1) verriet 1650. - (impf.3) verriet 3110, 3419. - (p.p.) verraden 1742, 2190, 2424, 2805 VERRADENISSE, n. (f.) | betrayal, conspiracy || verradenessen 2229. - verranesse 2237
VERRADER, n. (m.) | traitor, hypocrite, false counsellor || (pl.) verraderen 2223

VERRE, adv. | far, far away, by far || verre 79, $312,882,1548$ etc. - van verren 210, 698, 979,

1046

verriet | VERRADEN

VERS, n. (n.) | verse, poem, song || vers 448. (pl.) verse 445

versach | VERSIEN

VERSADEN, w. vb. | tr. - satisfy (with food); intr. - be satisfied \| (p.p.) versadet 212

VERSAMENEN, w. vb. | tr. - collect; refl. intr. - gather $\|$ (p.p.) versamet 57

VERSCH, adj. | fresh, new, sweet || verssche 162, 2848. - versscher 568

VERSCHEIDEN, str.+w. vb. | tr. - separate, distinguish; refl.; intr. - separate, go away \| (inf.) versceeden 262. - versceiden 880

VERSCHROVEN, adj. (p.p. from 'verschruven') | contemptible, wicked || verscroven 925

VERSEREN, w. vb. | tr. - hurt (also offeelings); intr. - suffer pain or distress $\|$ (pr.5) verseert 1737. - (p.p.) verzeert 1919

VERSIEN, str. vb. | tr. - see, notice, check, provide, take care of; refl.; intr. || (impf.3) versach 1324. - (p.p.) versien 710, 2118 versleghen | VERSLAEN

VERSLAEN, str. vb. | tr. - knock down, kill, inform; refl.; intr. - knock down || (p.p.) versleghen 427, 901

verslant | VERSLINDEN

VERSLINDEN, str.+w. vb. | tr. - devour, swallow up; intr. || (impf.3) verslant 2311. - (p.p.) verslonden 415

VERSOENEN, w. vb. | tr. - reconcile, make up; intr. - be reconciled || (inf.) versoenen 3417. (p.p.) versoent 2774. - verzoent 2820

VERSPREKEN, w. vb. | tr. refl. - abuse, curse || (p.p.) versproken 1823

versproken | VERSPREKEN

verspranc|VERSPRINGEN

VERSPRINGEN, str. vb. | intr. - jump up/ away $\|$ (impf.3) verspranc 819

VERSTAEN, str. vb. | intr. - startle, listen; tr. - hear, understand, know, listen to, tell; refl. be knowledgeable about || (inf.) verstaen 1459, 1662, 2952, 3214, 3225. - te verstane 1611. (pr.1) versta 2632. - (pr.6) verstaen 39. - (pr.3) verstaet 2057. - (imp.pl.) verstaet 183, 1452, 1481, 
2595, 2600. - (impf.1) verstont 3241. - (impf.3) verstoet $1895 .-$ (p.p.) verstaen 3207

verstoet, verstont | VERSTAEN

VERSTORBEREN, w. vb. | tr. - confuse, anger; refl.; intr. - get confused/angry $\|$ (pr.5) verstorbeert 1738

VERSTOTEN, str.+w. vb. | tr. - hit and break, drive away; intr. - knock against || (p.p.) verstoten 2355

VERSUCHTEN, w. vb. | intr. refl. - sigh || (impf.3) versuchte 990, 1917

VERSWEREN, str. vb. | intr. refl. - swear; tr. - abjure \| (inf.) verzweeren 1686. - (p.p.) verzworen 3169

VERTELLEN, w. vb. | tr. - tell, explain || (inf.) vertellen 1784

VERTEREN, w. vb. | tr. refl. - digest; intr. consume $\|$ (pr.5) verteert 1215

VERVAERT, adj. (p.p. from VERVAREN)

frightened, fearful || vervaert 674, 1044, 1202, 1306, 2151 etc.

VERVAREN, w. vb. | tr. - frighten; intr. become frightened || (impf.6) vervaerden $2456 \|$ See also: VERVAERT

VERWATEN (I), str. vb. | tr. - damn, loathe || (inf.) verwaten 354,853 || See also:

VERWATEN (II)

VERWATEN (II), adj. (p.p. from

VERWATEN) | banned, cursed || verwatenen 2728

VERWEENDELIKE, adv. | costly, proud || verweendelike 1066

VERWERVEN, str.+w.vb.|tr. - acquire, achieve; refl.; intr. || (impf.1) verwervic (clis.) 1606

VERWIJT, n. (n.m.) | reproach, jeering, revenge || verwijt 2736

VERWINNEN, str. vb. | tr. - conquer, acquire; refl. || (inf.) verwinnen 1476

VERWOET, adj. | insane, infuriated, mad || verwoedde 2833

verzworen | VERSWEREN

VESTE, n. (f.) | castle, fortress, moat || veste 85, 3077

VET, adj. | fat || vet 134, 218, 225, 333, 878 etc. vette 1119, 1121, 1125, 1129, 2399. - vetten 1621, 3128 VETE, n. (f.) | feud, enmity || veeten 2171 VIANT, n. (m.) | enemy, devil || viant 2067. viants 182. - viande 2029. - (pl.) vianden 2236 VIER, num. | four || vieren 413, IV 2848, 2850, 2854 viel| VALLEN

vier|VUUR

VIEREN, w. vb. | intr. - celebrate a feast day, rest, postpone; tr. - celebrate, postpone, let rest $\|$ (inf.) te vierne 1681

VIERTICH, num. | forty || XL 1676

VIGILIE, n. (f.) | vigil || vygelye 450. - (pl.)

vygelyen 431,440

VIJF, num. | five || vive 2269, 227ob. - viven 822

|| See also: VIJFSTE

VIJFSTE, ord. | fifth || vijfste 2261

VIJFTIEN, num. | fifteen ||$X_{412}$

vijte | VITE

vinc | VAEN

VINDEN, str. vb. | tr. - find, meet, conclude, judge, examine, consider; refl. || (inf.) vinden 1620, 2358, 2603, 2610, 2612. - (pr.1) vinde 1396. - vinder (clis.) 1627. - (pr.5) vindise (clis.) 1210.- (impf.1) vant 2093. - vandic (clis.) 154, 2406, 2407. - (impf.3) vant 300, 851, 1051, 1065, 1197 etc. - (impf.6) vonden 3092. - (impf.s.3) vonde 543. - (p.p.) vonden 2240, 2243, 2359 vinder | VINDEN + -ER vindise $\mid$ VINDEN + GI + -SE

VINGER, n. (m.) | finger $\|$ (pl.) vingheren 796 VISSCHEN, w. vb. | tr. - fish $\|$ (inf.) visschen 1505

VITE, n. (f.) | vita, life, biography || vijte 7

VLEESCH, n. (n.) | meat || vleesch 271, 379, 1520, 2081, 3067 etc. || See also:

RINTVLEESCH

VLEESCHSMOUT * , n. (n.) | fat, dripping || vleeschsmout 379

VLEGEL, n. (m.) | flail || vleghel 723

VLIEGEN, str. vb. | intr. - fly, move rapidly || (imp.sg.) vliech 1050. - (impf.3) vloech 1051, 1053, 1547, 2797. - (p.p.) ghevloghen 1047, 1731 VLIEN, str.+w. vb. | intr. - fly; tr. - flee || (inf.) vlien 758 , 3116. - (impf.3) vloe 1825

VLIET, n. (m.) | pool, ditch, canal || vliet 827 vloe | VLIEN

vloech | VLIEGEN

VLOEKEN, w.+str. vb. | tr. - curse, insult; intr. - curse \| (impf.3) vloucte 856, 1550

VLOER, n. (m.f.) |floor, bottom || vloer 1269, 1549, 1636

VLOGEL, n. (m.) | wing || vlogel 1049a

VLOTEN, w. vb. | intr. - flow, drift, swim; tr. cause to flow $\|$ (pr.3) vloot 831

voer | VAREN, VORE 


\section{voerdere | VORDER}

VOEREN, w. vb. | tr. - take, carry, treat; refl.; intr. || (inf.) voeren 2841. - (impf.3) voerese (clis.) 2836 || See also: MISVOEREN voeren | VOEREN, VOREN voerese | VOEREN + -SE

voert | VORT

VOET, n. (m.f.) | foot, paw, base, foot (ca. 30 cm) 2024, 3293. - voets 2846 . - (pl.) voete 679, 749, 754, 791, 963 etc. - vote 2392 . - voeten $695,966,2405,2883,2896$ etc. || See also:

\section{LANCVOET}

VOGEL, n. (m.) | bird || voghel, 1051, 1056, 2885. - Sente Martins voghel 1047, 1049 - (pl.) voghelen $366 .-$ (dimin.) vogheline 3158 VOL, adj. | full, complete, abundant || vul 835, 2330, 2763, 2794. - vullen 2734, 2777

VOLBRINGEN, w. irr. vb. | tr. - achieve, make || (inf.) vulbringhen 2748

VOLC, n. (n.) | folk, people || volcke 2055. - tfolc (clis.) 2057

VOLDOEN, irr. str. vb. | tr. - complete, execute; intr. - pay, settle || (impf.s.1) vuldade 3178

VOLEN, p.p. (of VELEN) | recommended || volen 3315

VOLGEN, w. vb. | intr. - follow; tr. - follow, chase, agree with $\|$ (inf.) volghen $847,3310 .-$ (pr.5) volghet 210. - (imp.pl.) volghet 632, 3323. - (impf.3) volchde 718, 2023, 2810. - (impf.6) volchden 1568

VOLSCHRIVEN, str. vb. | tr. - describe completely $\|$ (p.p.) vulscreven 6

VOLSEGGEN, w. vb. | tr. - tell completely ||

(p.p.) vulseit 2215

vonde, vonden | VINDEN

VONNISSE, n. (f.n.) | decision, judgement, verdict || vonnesse 3424

VONNISSEN, w. vb. | intr. - return/deliver a verdict; tr. - pronounce a verdict, explain \| (inf.) te vonnesse 1880

VORDER, adj. | front || voerdere 679

VORE, prep. | for, by, in front of, against, because of, above \| voer 63, 72, 281, 291, 371 etc. - vor 2678 VOREGAEN, str. vb. | intr. - precede; tr. excel || (imp.pl.) gaet voren 1948, 3312 VOREN, adv. | at the front, forward, first, in the past || voeren 632, 1552, 1956, 3215. - vore 1620. voren $695,1631,1940,2318,2883$

VOREWAERDE, n. (f.) | agreement, treaty, limitation || vorworde 2532
VORST (I), n. (m.f.) | cold, frosty spell || vorst 103, 254

VORST (II), n. (m.f.) | ridge (of roof) || vorst 3146 VORT, adv. | forward, further, henceforth, at once || voert 856, 1281, 1684, 1833, 2504 etc. VORTBRINGEN, w. irr. vb. | tr. - produce, further, tell || (inf.) voertbringhen 1872, 3058. - (pr.5) brinct voort 2159. - (pr.6) bringhense voort 2198

VORTDRAGEN, str. vb. | tr. - continue carrying, promote; intr. - proceed $\|$ (inf.) voertdraghen 1339

VORTGAEN, str. vb. | intr. - go on, keep going, become known || (pr.s.4) gawy voert (clis.) 18501851. - (impf.6) ghinghen voort 1875, 3071

VORTLEVEN ${ }^{*}$, w. vb. | intr. tr. - live on || (inf.) voert te levene 530

VORTLOPEN, str. vb. | intr. - run away || (impf.6) liepen voert 2019

VORTMEER, adv. | henceforth, also, besides || voertmeer 380

VORTSPRINGEN, str. vb. | intr. - jump forward || (impf.3) spranc voert 1203, 3390 VORTTRECKEN, str.+w. vb. | tr. - favour, produce; intr. - come forward $\|$ (impf.3)

voerttrac 3374

VORWAERTMEE, adv. | forwards, henceforth || vorwaertmeer 376

VOS *, pers. pron. (French) | you || vo 937

VOS, n. (m.) | fox $\|$ vos 50, 463, 575, 857, 1173 etc.

vote | VOET

vraechdi $\mid$ VRAGEN + GI

VRAET, n. (m.) | glutton || vraet 544, 1088, 1734, 2346,2487

vrauwe | VROUWE

VRAGEN, w. vb. | tr. - ask, interrogate; intr. ask a question || (impf.3) vraechde 1330. - (pr.5) vraechdi (clis.) 2201

VREDE, n. (m.f.) | treaty ensuring safety and legal security, peace, truce \| vrede 140, 265, 365, 2777, 2778 etc. - verde 166 . - vreden 530

VREMT, adj. | strange, rare || vremde 2285. vremder 558,1389

VRESE, n. (f.) | danger, fear || vresen 1434a

VRESELIJC, adj. | dangerous, terrible || (superl.) vreeselicste 3387

VRESELIKE, adv. | dangerously, terribly || vreeselike 1326

VRI, adj. | free, noble, excellent || vry 1071, 1339, 1658, 2009, 2299, 2318 etc. - vryen 1341, 3454 
VRIENDELIKE, adv. | friendly, benevolent || vriendelike 2502, 2767

VRIENT, n. (m.) | friend, relative, beloved || vrient 549, 613, 941, 1801, 1962 etc. - (pl.) vriende 3405. - vrienden 2150, 3282

VRIENTSCHAP, n. (f.) | friendship, affection || vrienscap 2167

VRIHEIT, n. (f.) | freedom, privilege $\|$ (pl.) vriheden 3452

VRO, adj. | glad, cheerful, joyful || vro 2254, 2699. - vroe 1048, 2108, 2576 || See also:

ONVRO

vroe | VRO, VROE

VROE, adv. | early || vroe 2073, 2278, 2789

VROET, adj. | wise, sensible, prudent, clever || vroet 482, 1013, 1357, 1674, 1894 etc. vroeden 2394. - (n.) die vroede 331 || See also: ONVROET

VROME, n. (f.m.) | advantage, profit || vrome 630, 1073. - vromen 474, 2340, 2723

vromen | VROME, VROMEN

VROMEN, w. vb. | intr. - avail, help; tr. strengthen || (inf.) vromen 962, 1837

VROUWE, n. (f.) | lady || vrauwe 297, 731, $788,790,803$ etc. - vrouwe $242,1246,1289$, 2285, 2415. - vrauwen 2282, 2560, 2654, 2937. vrouwen $2654 \mathrm{~h}$

VRUCHTEN, w. vb. | intr. refl. - be afraid; tr. - fear, be afraid of $\|$ (pr.1) vruchte 559, 3035. - (impf.1) vruchte 2324 || See also: ONTVRUCHTEN

vry|VRI

vul, vul- | VOL, VOL-

vuldade | VOLDOEN

vulscreven | VOLSCHRIVEN

vulseit | VOLSEGGEN

VUUR, n. (n.) | fire || vier 1244. - viere 1233, 1640

VUURGAT * ${ }^{*}$ n. (n.) | fireplace || vyergat 1642 vygelye | VIGILIE

vyergat |VUURGAT

WACH, interj. | woe, alas || wach 3379 wachte | WACHTE, WACHTEN

WACHTE, n. (f.) | guard || wachte 2370 WACHTEN, w. vb. | tr. - guard, spy on, expect, wait; refl. - beware of; intr. - beware of, wait || (inf.) te wachtene 3038. - (pr.5) wacht $483 .-$ (pr.s.3) wachte 769.- (imp.pl.) wacht 1357. - (impf.1) wachte $2360 \|$ See also: BEWACHTEN
WACHTER, n. (m.) | guard $\|$ wachtre 404 WAEN, n. (m.) | expectation, opinion, doubt || waen $90,636,900,1093,1383$ etc. - wane 298 , 1231 waendi | WANEN (I) + GI waendic | WANEN (I) + IC waende, waenden | WANEN (I)

waense | WANEN (I) + -SE

waent | WANEN (I) (+ HET I)

waer | WAER (I) (II) (III), SIJN (I)

WAER (I), adj. | true || waer 648, 1802, 2293, 2690. - waren 446

WAER(II), n. (n.) | truth || waer 170, 239, 673, 1131, 1380 etc.

WAER (III), inter. pron. | where, how, where to || waer (inter.) 2657, 3122, 3339

WAER (IV) rel. pron. | what, where, wherever || $641,1663,2358,2364,2573$ etc.

waer | SIJN (I)

waerc|WERC

waerdi $\mid$ SIJN (I) + GI

waerf $\mid$ WERF

WAERHEIT, n. (f.) | truth, word of honour, testimony || waerheit 2158, 2581, 3183

WAEROMME, adv. (inter.+rel.) | why ||

(inter.) waeromme 674, 3213

waers $\mid$ SIJN (I) + -ES

waert | SIJN (I), WERDEN, WERT (I) (II)

waert (clis.) | SIJN (I) + -HET (I)

waerven | WERF

WAERWERT, adv. | where to, where ||

waerwaert 1660

waerwi | SIJN (I) + WI

waes $\mid$ SIJN (I) + -ES

waest $\mid$ SIJN (I) + HET (I)

WAGEN, n. (m.) | cart || waghen 1126, 2137, 2412

WAKEN, w. vb. | intr. - watch, lie awake; tr. guard $\|$ (inf.) te wakene 1680. - (impf.3) waecte 2

wale $\mid \mathrm{WEL}$

WALSCH, adj. | French || walschen 8

walschedi | WALSCHEN + GI

WALSCHEN, w. vb. | intr. - speak French ||

(pr.5) walschedi (clis.) 1457

wan | WINNEN

WANC, n. (m.) | doubt, vacillation $\|$ wanc 1195 wancons | WANCONNEN + -ES

WANCONNEN, irr. vb. | intr. - take amiss, resent $\|$ (pr.1) wancons (clis.) 1920 
WANCONSTE, n. (f.m.) | antagonism, suspicion || wanconst 907, 2544

WANDELEN, w. vb. | intr. - walk, travel, ramble; tr. - change; refl. - adopt a disguise, change one's appearance || (inf.) wandelen 2104, 2701, 2737, 3162

WANDELINGE, n. (f.) | journey (on foot), company \| wandelinghe 2727. - wandelinghen 3059

wane | WAEN, WANEN (I)

WANEN (I), w. vb. | tr. - expect, mean, think; intr. - doubt || (inf.) wanen 2580 . - (pr.1) wane 625, 950, 1101, 1351, 1756 etc. - wanic (clis.) 277, 906, 2635. - waense (clis.) 1126. - waent (clis.) 1818. - (pr.3) waent 2182, 3095. - (pr.5) waendi (clis.) 671, 2206, 2640, 2699. - (impf.1) waende 3243. - waendic (clis.) 594, 2529. (impf.3) waende $46,697,1058,1523,1752$ etc. (impf.6) waenden 1494, 2030, 2174 || See also: BEWANEN

WANEN (II), adv. (inter.+rel.) | from where || (inter.) wanen 1195, 2141, 3338

WANT, conj. | because, so that || want 140, 395, 402, 798, 953 etc.

ware $\mid$ SIJN (I)

warelteere | WERELTERE

waren | SIJN (I), WAER (I)

WARMHEIT, n. (f.) | warmth || waremhede 537 warp | WERPEN

warpene $\mid$ WERPEN + -ENE

warper | WERPEN + -ER

wart | WERDEN

was $\mid$ SIJN (I)

wasser | SIJN (I) + -ER

WAT (I), inter. pron. | what, which || wat 135, 246, 426, 562, 601 etc. - wats (clis.) 1628, 2951, 3307

WAT (II), rel. pron. | what || (rel.) wat 877,981 , 1430, 1530, 1932 etc.

WAT (III), indef. pron. | what || wat 1806, 2093

WAT (IV), adv. | what, why, how || wat 1075,

1798, 1929, 2034, 2480 etc.

WATER, n. (n.) | water, river, fountain || water 1825,2313

WATERVAR, n. (m.) | bittern || watervar 1858

WATTAN, adv. | so what, what does it matter || wattan 245, 1292

wats $\mid$ WAT + SIJN (I) / -ES

WECH (I), n. (f.m.) | way, trip, manner || wech $387,1045,1092,1692$. - weghe 1682,1683 . - (pl.) weghen 882
WECH (II), adv. | gone, disappeared, away || wech 1631

WECHGAEN, str. vb. | intr. - leave || (imp.pl.) gaet wech 1016, 1356

WECHLOPEN, str. vb. | intr. - run away || (impf.3) liep wech 713

WECKEN, w. vb. | tr. - wake up, spur on || (impf.3) wecte 1235

WEDER (I), prep. | against, inconsistent with, of || weder 1727

WEDER (II), adv. | again, once more, back || weder $708,955,1181,1315,1522$ etc.

WEDER (III), indef. pron. | neither || weder 2587

WEDER (IV), conj. | if, unless || weder 945 WEDER(V), n. (n.) | weather, thunderstorm || weder 893

WEDER (VI), n. (m.) | ram, wether $\|$ weder 2111

WEDERBRINGEN, w. irr. vb. | tr. - bring back, return || (impf.3) wederbrochte 3334

WEDERCOMEN, str. vb. | intr. - come back, return $\|$ (pr.s.1) wedercome 2724

WEDERGAEN, str. vb. | intr. - return || (imp.

pl.) gaet weder 2684

WEDERKEER, n. (m.) | return, turn ||

wederkeer 1724, 2319, 2688

WEDERKEREN, w. vb. | tr. - cause to turn back, give back, avenge; intr. - return \| (pr.5) wederkeert 1016. - (impf.3) keerde weder 3273 WEDERLONEN, w. vb. | intr. - reward, requite || (inf.) wederlonen 492

WEDERSCHOUWEN, w. vb. | tr. - meet (again) || (pr.1) wederscauwe 2761

WEDERSEGGEN, w. irr. vb. | tr. - revoke, contradict, refuse \| (inf.) wedersegghen 2273 WEDERSIDE, n. (f.) | opposite side, two (opposite) sides || wederzijden 293

WEDERTALE, n. (f.) | contradiction, answer || wedertale 1009

WEE (I), adj. | very, unpleasant || wee 2913, 3233

WEE (II), interj. | oh dear, alas || wee 306 weeden | WEIDEN

weenen | WENEN

weerelt | WERELT

weet | WETEN

weetstu | WETEN + DU

weetti | WETEN + GI

WEGEN, str.+w. vb. | tr. - weigh; intr. - be heavy || (inf.) weghen 1932 
WEGGE, n. (m.) | wedge || (pl.) wegghen 653, 681

weghe $\mid$ WECH (I)

weghen | WECH (I), WEGEN

WEIDEN, w. vb. | tr. - put out to pasture; intr. go into the field, graze $\|$ (inf.) weeden 1707. - te weedene 1699

WEKE, n. (f.m.) | week || (pl.) weken 2965 WEL, adv. | well, kindly, very || wale 180, 462, 801, 1010, 1074 etc. - wel 24, 47, 90, 169, 182 etc. II See also: BET (comp.), BEST (II, superl.), ALLERBEST (II, reinf. superl.)

WELC, inter. pron. | who, which || welker 1030 WELDAET, n. (f.) | good deed, virtue $\|$ weldaet 3006. - (pl.) weldaden 3045

WELGEBOREN, adj. (p.p.) | noble, of high birth || welgheboren 2334

WELLECOME, adj. | welcome || willecome 629, 1072. - willecomme 3270

WELP, n. (m.n.)| whelp || (pl.) (dimin.) welpekine 1426. - welpkine 3137, 3328. welpine 3129. - welpekijnen 1362. - welpkinen 3081, 3093, 3219

WENEN, w. vb. | tr. - cry, weep for; intr. - cry, weep \| (pr.6) weenen 3220

WENNEN, w. vb. | tr. - get used to, tame; intr. refl. - get used to $\|$ (p.p.) ghewent 1536

WENTELEN, w. vb. | tr. intr. - revolve, roll; refl. || (impf.3) wentelde 975. - (p.p.) ghewentelt 981

WERC, n. (n.) | work, artefact, act || werc 3363, 3373. - waerc 2615. - werke 725

WERDEN, str. vb. | intr. - become, originate, happen, shall, be $\|$ (inf.) werden 634, 2003, 2654c, 3371. - (pr.1) werde 1801. - (pr.3) wert 174, 258, 1078, 1079, 1911 etc. - (impf.1) wart $389,2087,2680$, 2732. - (impf.3) wart 107, 348, $398,416,818$ etc. - waert $296,974,3388$. - wert 2090. - (impf.4) worden 2100, 3164. - (impf.6) worden 77, 2832. - (impf.s.3) werde 1005. worde 2331, 2344, 2355. - (p.p.) worden 1777, 2773, 3102, 3104 || See also: OPWERDEN WERELT, n. (f.m.) | world || weerelt 962 WERELTERE, n. (f.) | honour, respect,(royal) dignity || warelteere 2350

WEREN, w. vb. | tr. - fend off, prevent; refl. intr. - defend, resist $\|$ (inf.) wernen 190

WERF, n. (f.) | yard, gathering, instance || waerf 348 , 2007. - waerven 232, 1007, 1023, 1340, 1372 etc.
WERKEN, w. vb. | intr. - work, act; tr. - make || (inf.) werken 1035. - (impf.3) wrochte 1334 || See also: GEWERKEN

WERPEN, str. vb. | tr. - throw, hit; refl. || (impf.3) warp 209, 783. - warpene (clis.) 229, 1567. - warper (clis.) 822 || See also: UTEWERPEN

WERS, adv. (comp.) | worse || wers 1545 WERT (I), adj. | worth, worthy, dear || waert 1795, 1812

WERT (II), adv. | to, towards || waert 390, 533, 540, 708, 870 etc. || See also: ACHTERWAERT, DAERWAERT, HAREWAERT, HINDERWAERT, NEDERWAERT, OPWAERT, THUUSWAERT, UTEWAERT, UWAERT, WAERWERT

WESEL, n. (m.f.n.) | weasel || wesel 1860 wesen, wesene $\mid$ SIJN (I)

WET, n. (f.m.) | law, verdict, faith || wet 1148. wit 3377

WETEN, vb. (pret. pres.) | tr. - know, suspect, care for, acknowledge \| (inf.) weten 290, 565, 590, 2143, 3290. - te wetene 2134. - (pr.1) weet 90, 266, 1215, 1447, 1501 etc. - ( pr.2) weetstu (clis.) 2657. - (pr.3) weet 180, 801, 1144, 910 etc. - (pr.5) weet 2160, 2202. - weetti (clis.) 1135. (pr.6) weten 21, 2198. - (imp.pl.) wetet 2598. (impf.1) wiste 2396. - wistic (clis.) 1144, 2654c, 3256. - (impf.3) wiste 640, 714, 1175, 1198, 1212 etc. - wist 1931. - (pr.6) wisten 1641

WI (I), pers. pron. (4 n) | we || wi 429, 434, 436, 566,567 etc. - wij 2420. - wy 1109, 2017. - gawy voert (clis.) 1850. - ghawi (clis.) 1961, 1963.

- waerwi (clis.) 355. - wijs (clis.) 567. - wise (clis.) 432

WI (II), interj. | alas || wy 306, 925, 1194, 1796, 1797 etc.

WICHT, n. (n.) | creature, child || wicht 1027, 3400

WIDE, adv. | wide, far || wijde 294, 655

WIE (I), inter. pron. | who || (inter.) wie 260, 448, 449, 458, 987 etc. - wien 1834

WIE (II), rel. pron. | who, whoever, he who || (rel.) wie 769, 3440

wij | WI

wijde | WIDE

WIJF, n. (n.) | woman, wife || wijf 73, 235, 719, 731,805 , etc. - wijfs 1245,2930 . - wives 95. wive 1977, 2123, 2282, 2781, 3246. - wiven 821 


\author{
wijldijt | WILLEN + GI + HET (I) \\ wijle | WILE \\ wijlen | WILE, WILEN \\ wijleneere | WILENEERE \\ WIJN, n. (m. n.) | wine || wine 2280 \\ wijs $\mid W I+-E S$ \\ wijs | WIJS, WISE
}

WIJS, adj. | wise, experienced, learned || wijs 1032, 1674, 2298. - (n.) den wysen 2259

wijse | WISE

wijsen | WISE, WISEN

WIJSHEIT, n. (f.n.) | wisdom || wijsheit 3397

WIJT, adj. | wide, broad, roomy || wijt 824

wilde | WILLEN, WILT (I)

WILDERNISSE, n. (f.n.) | uncultivated

area, wilderness $\|$ wildernesse 3153. - (pl.)

wildernesse 2582

wildi | WILLEN + GI / HI

wildic | WILLEN + IC

wildijs | WILLEN + GI + -ES

wildijt | WILLEN + GI + HET (I)

wildine | WILLEN + GI / HI + -ENE

WILE, n. (f.m.) | hour, time, moment || wijle

842, 863, 1819. - wijlen 815. - wile 975

WILEN, adv. | previously, in the past || wijlen

296, 2299, 2564. - wilen 2239

WILENEERE, adv. | previously, in the past ||

wijleneere 101

\section{wille | WILLE, WILLEN}

WILLE, n. (m.f.) | will, wish || wille 25, 244, 635,

776,1137 etc. || See also: ONWILLE

willecome $\mid$ WELLECOME

willic | WILLEN + IC

willics | WILLEN + IC + -ES

willict | WILLEN + IC + HET (I)

WILLEN, w.+irr. vb. | intr. tr. - want to, prefer, will \| (pr.1) wille 34, 1081, 1132, 1435, 1497 etc.

- willic (clis.) 189, 222, 382, 583, 1190 etc. - wilt 3055, 3455. - willics (clis.) 1785. - willict (clis.) 2531. - wilre toe (clis.) 2873. - (pr.3) wille 769, 1349, 2511, 2769, 2788 etc. - wildi (clis.) 1314. willet 772. - (pr.4) willen 1083, 3162. - (pr.5) wilt 950, 1406, 1458, 1656, 2963 etc. - wildi (clis.) $187,606,647,943,1132$ etc. - wijldijt (clis.) 2143. - wildijs (clis.) 619, 1925. - wildijt (clis.) 3439. - wildine (clis.) 939. - (impf.1) wilde 184, 1618, 2402, 3232. - wildic (clis.) 2515. - wildine (clis.) 610. - woude 1563. - (impf.3) wilde 132,612 , 956, 1052, 1240 etc. - woude 1008 , 2236, 2649, 3142, 3281 etc. - (impf.5) wilde 1780.
- (impf.6) wilden 1010, 1161, 2429. - wouden 2997, 3046

wilre toe | WILLEN + DAERTOE

wilt | WILLEN, WILT (II)

WILT (I), adj. | wild, ferocious || wilde 2249

WILT (II), n. (n.) | game $\|$ wilt 271

WILTBRAET, n. (n.) | game \| wiltbraet 1214

WINNEN, str. vb. | tr. - get, acquire, cultivate || (inf.) winnen 133. - (impf.3) wan 2440. -

(p.p.) ghewonnen 117, 259, 928, 1322, 1788 etc.

|l See also: AFWINNEN, GEWINNEN, VERWINNEN

WINTER, n. (m.) | winter || winter 103, 323. wintre 2096

WISE, n. (f.) | manner || wijs 687 , 979, 1030. wijse 557. - wijsen 207, 1320

WISEN, w.+str. vb. | intr. - indicate, teach, sentence; tr. - sentence, pass judgement; refl. II (inf.) wijsen 2070, 2497, 2512, 2641. - (pr.6) wijsen 167. - (impf.3) wijsde 2495. - (impf.6) wijsden 1881

wiste, wisten | WETEN

wit | WET

WISSE, n. (f.) | rope, noose || wisse 224

woent, woende I WONEN

woerde, woerden | WORT

WOEST, adj. | wild, empty || twoeste (clis.) 2268

WOESTINE, n. (f.n.) | wasteland, wilderness || woestine 3329. - wostine 503, 2661. - woestinen 508

WOLF, n. (m.) | wolf $\|$ wulf $1575,1967,3413$ WOLVINNE, n. (f.) | she-wolf || wulfinne 2892

WONDE, n. (f.) | wound || wonden 1282. - (pl.) wonden 162, 3015

WONDEN, w. vb. | tr. - wound, injure, maim || (p.p.) ghewont 986, 1311, 1645, 2920

WONDER, n. (n.) | surprise, astonishment, curiosity || wonder 1541, 1579, 2270, 2547, 2698. wonders 3099

WONDEREN, w. vb. | intr. - surprise, be surprised; refl. impers. - wonder, ask o.s. II (impf.3) wonderde 2647, 2649

WONDERLIKE, adv. | curious, strange || wonderlic 3022

WONEN, w. vb. | intr. - live, dwell, remain; tr. get used to $\|$ (inf.) wonen 3161. - te wonen 3170. - (pr.3) woent 602, 1123. - (pr.6) wonen 3157. (impf.3) woende 1511

woort, woorden $\mid$ WORT 
worde | WERDEN

worden | WERDEN, WORT

WORP, n. (m.n.) | throw $\|$ (pl.) worpe 1583

WORST, n. (f.) | sausage || worst 104, 106, 116,

120, 253

WORT, n. (n.f.) | word, promise, name || wort 2654e. - (dimin.) wordekijn 2213. - (pl.) woort 15, 438, 620, 1874. - woerde 1917, 2018, 2809, 3240 . - woorden $487,1422,1985$. - woerden 1496, 2235, 2807, 3301. - worden 446, 1871 b wostine | WOESTINE

woude | WILLEN, WOUT

wouden | WILLEN, WOUDEN

WOUDEN, w. vb. | tr. - direct, govern || (inf.) wouden 3204 || See also: GEWOUDEN

WOUT, n. (n.) | wood, forest || wout 2084, 2869, 3444. - woude 502, 506, 651, 1803, 2288 etc.

wrake | WRAKE, WREKEN

WRAKE, n. (f.) | revenge, punishment, penance || wrake 1845

WREET, adj. | harsh, antagonistic, cruel, aggressive || wreet 464, 2091, 2842, 3032

WREKEN, str. vb. | tr. - avenge, revenge, punish; refl. || (inf.) wreken 2915. - (pr.1) wreke 999. - (pr.5) wreket 167. - (pr.s.3) wreke 1793. (imp.pl.) wreket 992. - (impf.s.3) wrake 1174 II See also: GEWREKEN

wrochte | WERKEN

WROEGEN, w. vb. | tr. - tell, betray, accuse; refl. || (inf.) wroughen 1787. - te wroughene 113, 2225. - (impf.3) wroughede 1205

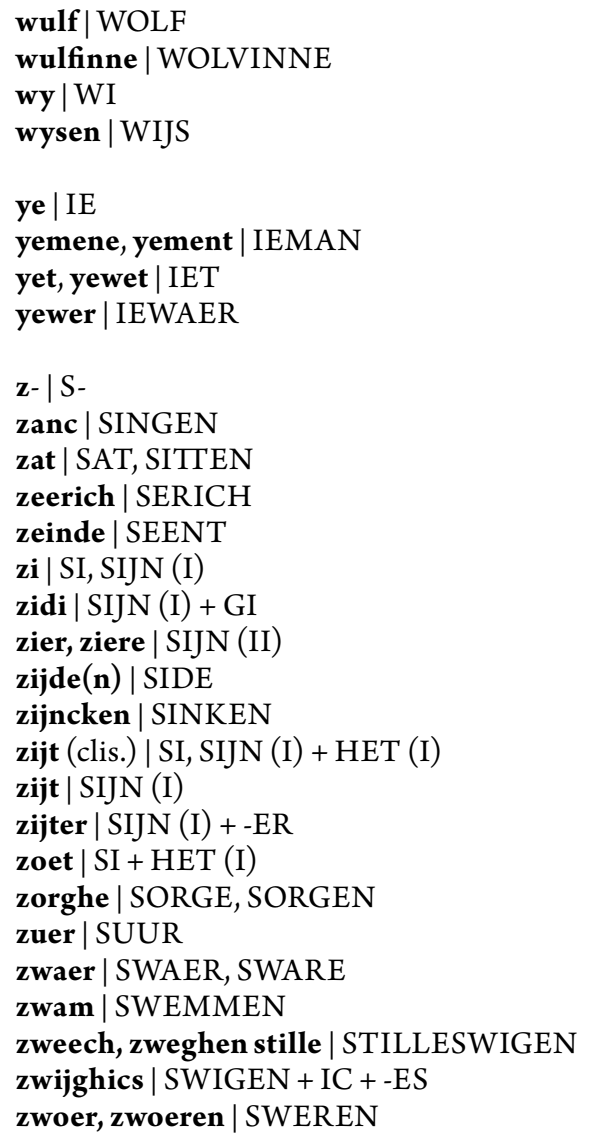




\section{Word index (semantic fields)}

In this index the normalized words from the glossary have been arranged into semantic fields derived from a Dutch thesaurus (Brouwers 1991). The procedure was as follows. The Dutch meanings of words selected for the glossary (from the Middelnederlandsch handwoordenboek) were compared with semantic fields in Brouwers' thesaurus. Only those meanings of words that actually occur in Van den vos Reynaerde have been assigned to one or more semantic fields. Within each semantic field words are listed strictly alphabetically.

Brouwers' thesaurus refers by means of an alphabetical register to (numbered) lists containing tens of thousands of modern Dutch words, expressions and proverbs according to their semantic affinity. In our index the principle is applied to the Middle Dutch vocabulary of just one text. Here the two thousand or so normalized words from the glossary are listed according to their semantic affinity. In this way the index refers to the entries of the glossary in which all word forms used in Van den vos Reynaerde are listed with a selection of line-numbers and meanings. The concepts of the semantic fields and the structure in which they are arranged have been derived from the thesaurus; headwords have been translated into English. In a number of cases cross-references between related semantic fields have been added.

It should be stressed that we have compiled an index, not a thesaurus. It does not in any way aim at an exhaustive presentation. The wide mesh used for the net of concepts spread over the Middle Dutch of one single text here allows all kinds of linguistic fish to escape. As was mentioned earlier, meanings listed in the glossary that do not occur in Van den vos Reynaerde are not found in this index. For example, AFSLAEN has been listed only under 1.9.1 Cut on the basis of the meanings cut off, behead. The other meanings (shorten, deduct, etc.) are not found in Van den vos Reynaerde, and have been ignored for that reason. Finally the index, like the glossary, is limited to single words. The meanings of more or less fixed expressions and compounds have not been included ('guldijn waerc', 'ontweghet sijn', 'mate es tallen spelen goet' etc.) In spite of all these restrictions we hope that users will appreciate this index for one important advantage: as a result of their assignment to broad semantic fields words elucidate each other. This may enable us to develop new insights into the language used by Willem.

\section{GENERAL RELATIONS}

1.1 Existence - Being: DINC, SIJN (I). - Nonbeing: SCHINEN (see also 9.1 Deceive). - Way of being: DUSDAEN, SULC (I). - Incidental circumstance: BEWANT.

1.2 Relativity - Relation: DAERMEDE, DAEROVER, HIERAF, JEGHEN (I),
JEGHEN (II), OVER. - Similarity: ALSE, ALSO (I), ALSO (II), ALSOF, DIESGELIKE, EVENE, GELIKE, QUANS, SLACHTEN, SO (II). - Difference: ANDER, EL. - Variety: MENIGERHANDE. - The same: HAER* (III), HEM* (II), SELVE. - Compare: SO (I). Distinguish: VERSCHEIDEN.

- Weigh: WEGEN. - Count: REKENEN, TELLEN. - Geometrical measurements: AME, 
MILE, VOET. - Chronology: APRIL, AVONT, DACH, DAGERAET, JAER, MAENT, MEYE, MIDDACH, MORGEN (I), NACHT, WEKE (see also 1.5). - Coins: BISANT, MARC, PENNINC (see also 6.2 Pay). - Numbers: ACHTE (II), DERDE, DRIE, DUSENT, EEN (I), EERSTE (I), GETAL, HALF (I), HONDERT, SESSE, SEVEN, TIEN, TIENDE, TWAELFHONDERT, TWEE, TWINTICH, VIER, VIERTICH, VIJF, VIJFSTE, VIJFTIEN.

- Determinate: DAS (I), DAT (I), DEGENE, DESE, DI, DIE (I), DIEGENE, DIEN * (I), DIER (II), DIES (I), DIT, DU, GI, HAER * (II), HEM * (I), HI, IC, MI, RECHTE, SI, U, UWAERT, VOS *, WI (I). - Indeterminate: EEN (III), ENICH, IEMAN, IET (I), MEN, NA (II), SOWIE, SULC (II), WEDER (III), WELC, WIE (I), WIE (II).

1.3 Causality - Cause: BEDI (I), BEDI (II), BEWERVEN, BI (I), DAEROMME, DIES (II), DORDAT, DORE (II), HIEROMME, OMME (I), OMMEDAT (I), OMMEDAT (II), TWI, VOREN, WAEROMME, WANT. Result: DAERTOE, DUS, HIERTOE, SODAT. - Coincidence: GEVAL.

1.4 Order-Sequence: ANDER. - Continuity: GEDICHTE (II). - Precede: VOREGAEN. - Follow: NA (I), NALOPEN, VOLGEN. - Accompany: GELEIDEN, GEMEEN, GESELLE, GESELSCHAP, GESINDE, MEDE (I), MEDEGAEN, MEDELOPEN, MET, OVEREEN (see also 8.1 Sociable civilised). - Beginning: BEGIN, SINT (I), SINT (II) (see also 5.4.2.1 Begin). - End: TOTE (II), TOTEDAT, VERGAEN (see also 5.4.2.1 End). - Middle: MIDDEN, MIDDEWAERT (I), MIDDEWAERT (II). - Single: AL (I), ELC, ELKERLIJC, MALC. - Exceptional: OFTE, SO (II), SONDER (I), WEDER (IV). - Irregularity: DAN (II), SONDER(II), SONDERLINC, VREMT.

1.5 Time - Chronology (see 1.2). - Space of time: AL (IV), ALSE, ALSO (II), DOE (I), DOE (II), LIDEN (I), TIJT, WILE. - Lengthy: AL (II), ALINEEN, BEIDEN, LANC, LANGE, OVERLANGE. - Briefly: ALTEHANT,
TWINT. - Always: ALTOOS, EMMER, EMMERMERE, EWELIJC. - Never:

NEMMEE, NEMMERMEE, NIE, NIENE, NOOIT.

- Events: AVENTURE, BLIVEN, GESCHIEN, GEVALLEN, MISCOMEN, SIJN (I). - Before: DAERTEVOREN, EER (I), EER (II), EERSTE (II), HIERVORE, TEVOREN, VOREN. - After: DAERNA, DAEROPPE, DAN (I), ECHT, HIERNA, NA (I), NA (II), NADAT, NADIEN, NAMAELS. - Simultaneously: BI (I), BINNEN (I), HIERBINNEN. - In the present: HEDEN, NU, TAVONT. - In the past: GISTEREN, WILEN, WILENEERE. - In the future: MEER (II), METTIEN, MORGEN (II), NAEST (I), NAEST (II), OVER, SAERMEER, VORT, VORTBRINGEN, VORTMEER, VORWAERTMEE. - New: JONC, JONCHERE, JONGELINC, NIEUWE, VERSCH. - Old: OUDE (I), OUDE (II), OUT, QUENE.

- Frequently: ANDERWERF, DICKE, DICWILE, NOCH (I), WERF. - Seldom: IE, OOIT, SELDEN, SOMWILEN.

- Early: VROE. - Late: SPADE (I), SPADE (II). - Timely: STADE, STONDE.

1.6 Quantity - Quantity: BEIDE, IET (II), IEWAER, MENICH, PAER, SO (I), SOM. - Little: ALLENE (I), CAF, CLEINE, CRANC, CUME, DULDE, EI, LUTTEL (I), LUTTEL (II), LUTTEL (III), MATE, MIN, MINDER, NAUWE (II). - Much: ALSO (I), COEVER, HARDE, MENICHVOUDICH, MENICHVOUT, SERE, VELE (I), VELE (II), VELE (III).

- More: ALLERMEEST, DAERBI, GEDIEN, HOUDEN, MEER (I), MEEST, MEESTE, MERE, OOC. - Less: ALLERMINST, SACHTEN, SINKEN, SLAKEN.

- Everything: AL (I), ALGADER (I), ALLES, ALTEGADER, LADEN, STOPPEN, VOL.

- Nothing: GEEN, GEENREHANDE, NEGEEN, NIEMAN, NIET (II). - The whole: AL (I), AL (II), ALGADER (II), ALLENE (II), ALS, OVERAL, SUVER. - The part: BANDERSIDE, DEEL, DELEN, HALF (II), MORSEEL, POENT, STUC. - Enough: GENOECH (I), GENOECH 
(II), GENOEGEN. - Too much: TE (I), UTERMATEN (I), UTERMATEN (II).

1.7 Space - Place: ALDAER, DAER, ELWAER, ER, GINDER, HARE (III), HIER, LANT, STAT, STEDE, WAER (III). - Extensive: HARENTARE, OVER, OVERAL. Present: BLIVEN, GELACH, GELIGGEN, INLIGGEN, SETTEN, WONEN. - Absent: GEBREKEN, ONGEREET. - To place: LEGGEN, STEKEN. - Cosmos (see 2.2.1). Plants (see 2.2.3). - Road (see 1.9.1). - Abode: HERBERGE, HERBERGEN. - Community: DORP, CLOOSTER, HOF, STAT, PRIOREIT. - Building: BORCH, CASTEEL, CLOOSTER, CLUSE, HUUS, MOLENE, VESTE. - Parts of the building: BARBACANE, HAGEDOCHTE, HANENBALC, HOF, MUER, PARC, PORTE, SCHURE, SPIKER, STAGE, TUUN, VALDORE, VLOER, VUURGAT. - Furniture: STOEL, TAFEL, TAFELMES. - Place to sleep: BEDDE. - Build: RECHTEN (I). - Place where animals live: HAGEDOCHTE, HOL, NESTELEN. - Far: VERRE. - Near: BI (I), BI (II), DAEROMTRENT, GEBUUR, NA (II), NAER, NAEST (I), NAEST (II), TE (II), TEN, TER, TES, TOTE (I). Upright: GESTAEN, OPSTAEN, RECHTE, STAEN. - Flat: LIGGEN, SLECHT. Sloping: NEDERGAEN, NEDERLATEN, NEDERLOPEN, NEDERSLAEN. - On: OP (I), OP (II), OVER, SITTEN. - Under: BARE, DAERONDER, DRAGEN, GEDRAGEN, ONDER (I). - Above: BOVEN (I), BOVEN (II), DAERBOVEN, HANGEN. - Below: BENEDEN. - Parallel: NEVEN. - Outside: BUTEN (I), BUTEN (II), UTE (I), UTE (II). - Inside: BINNEN (I), BINNEN (II), DAERBINNEN, DAERINNE, HERTE, IN (I), IN (II), TUSSCHEN. - Container: AME, BUTSEEL, CUPE, SAC, SCHARPE, SLAVINE. - In front: VORDER, VORE. - Behind: ACHTER, ACHTERST, BACHTEN, NA (II), LUCHT, SIDE. - Beside: WEDERSIDE. - Orientation: OOSTENDE, SUUT, SUUTWEST.

1.8 Change - Change: KEER, KEREN, WERDEN. - Changeable: MISSELIJC.
- Constant: GESTADE. - Instead of: MANGELINGE.

1.9.1 Movement (general) - Movement: DRIVEN, LOPEN, PORREN, ROEREN, TRECKEN. - Absence of movement: STILLE. - Direction: DAERTOE, DAERWAERT, DANEN, HAREWAERT, LEIDEN, NA (I), THUUSWAERT, TOE, TOTE (I), WAER (III), WAERWERT, WEDER (I), WERT (II). - Deviation: OMMEKEREN. Road: PAT, STRATE, WECH (I). - Forward movement: VORT. - Backward movement: ACHTERWAERT, HINDERWAERT, WEDER (II). - Move along something: GELIDEN, NEVEN, RUTSEN. - Move through something: AL (III), DORE (II). $-R u b$ : BECNAUWEN, CNAGEN, SCHRAVEN. - Run through: STEKEN. - Rise up: CLEMMEN, OPDRAGEN, OPGAEN, OPHEFFEN, OPLESEN, OPWAERT, VERHEFFEN. - Fall down: NEDERVALLEN, NEDERWAERT, VAL, VALLEN. - Surround: BELUKEN, BERINGEN, OMME (I), OMME (II), OMMETRENT. - Cover: BEVAEN, DECKEN. - Uncover: BLOOT (I), BLOOT (II), ONBEDECT, ONTDECKEN, OPSCHRAVEN. - Turn: WENTELEN. Regular movement: OMMESWINGEN. Irregular movement: STUVEN. - Approach: GEMOET, GEMOETEN, GENAKEN, NAKEN, TOEGAEN, TOELOPEN. Deviate: DAERAF, WANEN (II). - Congregate: DAERANE, GEMANC, SAMENINGE, SCHARE, TEGADER, TESAMEN, TROP, VERSAMENEN, VOLC. - Separate: SCHEIDEN. - Remove: LOS. - Fasten: AENCNOPEN, BINDEN. - Loosen: ONTBINDEN. - Mix: BLANDEN. - Insert: INSTEKEN. - Extricate: UTETREKKEN, UTEWERPEN. - Open: GAT, ONTDOEN, OPBREKEN. - Enclosed: TUUN. - Knock against: DAEROPPE, DRINGEN, HORTEN. - Hit: BLOUWEN, SLACH, SLAEN, WORP (see also 2.2.8 and 6.2 Pay). - Grab: GEGRIPEN, GRIPEN, HAKE, NEMEN, NIPEN, PRENDEN, VAEN (see also 6.2 Take). - Break off: BREKEN, CRAKEN, ONTWEE, SCHOREN. - Cut: AEX, AFBITEN, AFNEMEN, AFSLAEN, AFSNIDEN, 
BARDE, BESCHEREN, BILE, CLIEVEN, MES, TAFELMES. - Mill: MOLENE, MOLENMAN.

- Journey: VAERT, VAREN. - Arrive: COMEN, GERAKEN, WEDERCOMEN, WEDERGAEN, WEDERKEER, WEDERKEREN. - Stay behind: ACHTERBLIVEN. - Leave: ONTRINNEN, RUMEN, SCHAVEN, SCHEIDEN, WECHGAEN, WECHLOPEN. - Send away: BALLINC, BAN, BANNEN, VERBANNEN, VERDRIVEN. - Bring: BRINGEN, WEDERBRINGEN. - Go: CRUPEN, GAEN, GANC, GANGEN, LOPEN, PALSTER, PAS, STAF, STAKE, STAP, TREDEN, WANDELEN, WANDELINGE, WERT (II). - Jump: OPSPRINGEN, OPWERDEN, SPRINGEN, SPRONC, UTESPRINGEN, VERSPRINGEN, VORTSPRINGEN. - Advance: VORTGAEN. - Go towards: AENVAERDEN. - Go away from: HENENGAEN, HENENLOPEN, HENENTRECKEN, VERSCHEIDEN. Enter: INCOMEN, INCRUPEN, INGAEN, INLOPEN, INTRECKEN. - Leave: UTEGAEN, UTEKEREN, UTEWAERT. Pass: LIDEN (I). - Cross: OVERLOPEN. Go round: OMMEGAEN, OMMELOPEN. - Ride: OPHOUDEN, TOGEL. - Float: VLOTEN. - Swim: SWEMMEN. - Fly: VLIEGEN.

1.9.2 Motion (modality) - Fast movement: HAESTE, HAESTELIKE, HAESTEN, HAESTICH, RASCH, SAEN, SCHIERE, SNEL, SNELLE, SNIEMEN, TEHANT. Slow movement: LAT, LETTEN, MERREN, SACHTE, SPAREN, TRAECH. - Throw: WERPEN. - Go fast: RECKEN, RINNEN, VLIEN, VORTLOPEN.

1.9.3 Motion (vehicle, dress, cover) Carriage: CARRE, WAGEN. - Clothing: CLEET. - Outer clothing: HARE (I).Shoes: SCHOE, SCHOEYEN. - Headdress: CAPPROEN. - Glove: HANTSCHOE. Dress: AENDOEN, AENDRAGEN. - Undress: AFDOEN, MOEDERNAECT, NAECT, ONTSCHOEYEN. - Sew: BRAUWEN, NAET.

\section{THE MATERIAL WORLD}

2.1 Creation, life (incl. relationships), death-Produce: CREATURE, MAKEN, WERC, WERKEN. - Destroy: BREKEN, VERDERVEN, VERLOVEN, VERSTOTEN. - Reproduce: BROET, EI. - Genealogy: GESLACHTE, SIBBE. - Family: BELANC, BESTAEN, MAECH. MATER, MOEDER, VADER. - Children: DOCHTER, KINT, SONE. - Brothers: BROEDER. - Sisters: SUSTER. - Uncle, aunt: MOEYE, OOM. Nephew, niece: BROEDERSONE, NEVE, NICHTE. - Cousin: NEVE, NICHTE. - Life: LEVEN (I), LEVEN (II), LIJF, ONVERDAEN, VORTLEVEN *. - Death: DOOT (I), DOOT (II), STEENDOOT, STERVEN, VERSLAEN. - Kill: DODEN, MORDEN, MORDENARE, MORT, ONTLIVEN, VERBITEN, VERHANGEN. Funeral: BEGRAVEN, 355 GRAF, 355 SARC.

2.2.1 Cosmos - Celestial bodies: MANE, RISEN, SONNE, SONNENOPGANC. Earth: ERDSCH, WERELT. - Mountain: BERCH. - Valley: DAL. - Swamp: MOER. - Desert: HEIDE. - Spring: BORNE, PUT. - Lake: WATER. - Stream: DIEP, FLUME, GRACHT, OEVER, RIVIERE, VLIET, WATER. - Sea: OVERSEE. - Flow away: AFVLOEYEN, UTELEKEN. - Stream: STROOM. - Bridge: BRUGGE. - Atmosphere: SOMER, WEDER (V). - Cloud: BELOKEN.

2.2.2 Inanimate matter-Metals: GOUDIJN, GOUT, ISER, SILVER (see also 7.3 Jewelry). - Different kinds of stone: ERDE, ERDIJN, MARBERSTEEN *, MOUDE, SANT (I), STEEN. - Gold and silversmiths' work: GESMIDE, WAERC (see also 7.3 Jewelry). - Working the soil: DELVEN, GRAVEN, ONTDELVEN, SCRAVEN. - Ropes: LINE, PESE, STRENGE, STROP, WISSE. - Woven material: LAKEN. - Spinning: ROCKE, SPILLE, SPINNEN. - Woodworking: CLIEVEN, TIMMERMAN, WEGGE.Wooden articles: CLOETE, MICKE, VORST.

2.2.3 Plants - Plant: BOOM, BOSCH, CRUUT, HAGE, STRUUC, WOUT. - Trunk: RIJS. - 
Leaf: LOOF. - Flower: BLOEME. - Moss: MOS. - Dicotyle trees: BERKE, EIKE, LINDE. - Plant growing: WILT (I), WOEST. - Uncultivated land: GRAS, VELT, WILDERNISSE, WOESTINE. - Grain and hay harvest: CAF, STRO, STROWISCH. - Farmhouse: SCHURE, SPIKER, RAKE, VLEGEL.

2.2.4Animals-Animal: DIER(I). - Fish: PLADIJS.-Amphibians: PUUT.-Birds: CAPOEN,EENT, GANS, HANE, HENNE, HOEN, ODEVARE, PARTRISE, RAVEN, SCHOVUUT, ULE, VOGEL, WATERVAR. - Mammals: BERE, BEVER, CALF, CATER, DAS (II), EENCOREN, EVERSWIJN, FORET, GEIT, HASE, HIE, HOEKIJN, HONT, LAM, LIEBAERT, LIOEN, MUUS, OSSE, OTTER, RAM, SWIJN, VOS, WEDER (VI), WELP, WESEL, WOLF, WOLVINNE.Keepinganimals: TAM, WENNEN.-Keeping bees: HONICH,HONICHRATE. - Fishing: VISSCHEN. - Hunting and shooting: BELAGEN, JAGEN,JAGER, LAGEN, PROOIJE, STRIC.

2.2.5 Mankind - Human being: DRUUT, JONGELINC, LIEDE, MAN, WICHT. - Man: MAN. - Woman: QUENE, VER, VROUWE, WIJF (see also 8. Society).

2.2.6 Parts of the body-Body: LICHAME, LIJF. - Blood: BLOEDICH, BLOET. - Bones: BEEN, PLADISENGRAET. - Skin: BALCH, BEREHUUT, HUUT, PELSE, SWEET, VEL, VELSPOT, VERHORNT. - Hair: CRUNE, GRIJS, HAER (I), PLUME, TOP, VEDERE, VEDERSLACH. - Head: HOVET. - SWAERDE. - Face: AENSICHTE, LIER. - Eye: OGE. - Ear: ORE. - Nose: NESE. Mouth: MONT, MULE, MUSEEL, TONGE. - Teeth: TANT. - Chin: BAERT, GRANE. Neck and shoulders: CRAGE, CROP, HALS, KELE. - Breast: MAMME, RIBBE. - Stomach: BUUC, LANKE. - Back: ACHTERENDE, HAME, RUGGE, STERT. - Limbs: LIT. Arm: HANT, VINGER, VLOGEL. - Leg: CLAUWE, KNIE, LANCVOET, TEE, VOET.

2.2.7 Workings of the body-Digestive organs: MALE (I). - Organs of the excretory system: CLOETE.
2.2.8 Food and drink - Eat: BITEN, ETEN, HONGER, HONGERICH, LUSTEN, MINEREN, ONTBITEN, OPETEN, SADEN, SAT, SPANEN, VERSADEN, VERSLINDEN, VRAET, WEIDEN. - Drink: DORST, DRINKEN, DRONKEN, LAPEN, SCHENKEN. - Digestion: VERTEREN. - Excretion: BESIKEN*, SWEET. - Sleep: SLAPEN, SLAPEND, WAKEN, WECKEN. - Meal: GELACH, MAEL. - Victuals: AES, GERECHTE, SPISE, VET. - Meat: BAKE, RINTVLEESCH, VENISOEN, VLEESCH, VLEESCHSMOUT *, WILT (II), WILTBRAET, WORST. - Bread: BROOT. Other foods: SAUSE, HONICH. - Alcoholic drinks: BIER, CLOOSTERBIER, MEDE (II), WIJN. - Preparation of spirits: BLANDEN, BROUWEN. - Hostelry: TAVERNE.

2.2.9 Physical health - Healthy: GESONT. Ill: BLEEC, GENESEN, ONDERCOMEN, ONGESONT, ONMACHT, SIEC (I), SIEC (II), VERDOVET. - Injuries: LIJCTEKEN, MISMAKEN, PANT, WONDE, WONDEN.

2.3.1 Properties of matter (size, shape) - Large: GESTRECKET, GROOT, LANC, LANGE, MEKEL, OVERGROOT. - Small: CLEINE, CORT, CORTEN, CREMPEN. - Broad: BREET, WIDE, WIJT. - Thin: MAGER, SMAL. - High: HOGE (II). - Low: DIEP, DIEPE. - Point: WEGGE. - Sharp: SCHARP. - Crooked: CROM (I), CROM (II). - Uneven: SCHARP, RU. - Heavy: SWAER.

\subsubsection{Properties of substances (physical,} chemical) - Gaseous state: BLASE. - Semiliquid state: SMEREN. - Aridity: DROGE. - Warmth: COKEN, HEET, WARMHEIT. - Cold: COUDE, COUT, IJS, RIJM, VERCOELEN, VORST, WINTER. - Light: AFBERNEN. - Heating appliance: VUUR, VUURGAT * . Taste: SMAKE. - Tasty sweet: LECKERNIE. - Unsavoury - sour: SCHARP. - Sound: GECRAEY, GEHUUC, GELUUT, GERUCHTE, LUDE, MISBARE, MISBAREN, MISLATEN, OVERLUUT. - Silence: GESTILLE, STILLEKINE. Dull sound: GRONGEREN. - Sharp sound: HOGE (II). - Sound made by humans: 
DULEN, GELLEN, ROEPEN, SUCHTEN, VERSUCHTEN. - Sound made by other animals: BASSEN, BLETEN, BRIESCHEN, GEBLEET, PIPEN. - Light: CLAER, CLARE, LICHT (II), ONTSTEKEN, SCHINEN. Darkness: DONKER (I), DONKER(II).Source of light: BERRENDE, LANTERNE, OFFERKERSE, STALLICHT. - Colours: BRUUN, GRIJS, GROEN, ROOT, SWART.

2.4 Physical sensations - Touch: TASTEN. Taste: SMAKEN. - Hear: GEVREESCHEN, HOREN, VERHOREN, VERNEMEN, VERSTAEN. - See: BESCHOUWEN, BESIEN, GESIEN, GEWARE, OMMESIEN, SCHOUWEN, SIEN, TOESIEN, VERSIEN, WEDERSCHOUWEN. - Impaired sight: BLINDEN, STAERBLINT, VERBINDEN. Visibility: BAREN.

\section{THE INTELLECT}

3.1 Intellectual powers - Attention: ACHTE (I), ACHTEN, BESIEN, BESPIEN, GOME, MERKEN, WACHTE, WACHTEN, WACHTER. - Remember: GEDENKEN, ONTHOUDEN. - Forget: VERGETEN. Imagination: WAEN, WANEN (I). - Sensible: BEDACHT, VROET, WIJS, WIJSHEIT. Cunning: BEHENDICHEIT, ENGIEN, LIST, LISTICH, REINAERDIE (see also 9.1 Deceive). - Stupid: DOL, DOMPHEIT, DORE (I), ONVROET, SOT. - Mental health: REDENE. - Insanity: DOVEN, ONTWEGET.

3.2 Intellectual activity - Thought: BEVAEN, GEDACHTE, GEPENS, GEPENSEN, PENSEN, SIN. - Seek: SOEKEN. - Find: VINDEN. - Believe: BEWANEN. - Doubt: TWIVELEN. - Be surprised: HA, WONDER, WONDEREN, WONDERLIKE. - Reason illogically: SAGHE (I). - Prove: PROUVEN, ORCONDE (I) (see also 8.3 Trial). - Judge: BEDENKEN, DUNKEN, MENEN. - Confirm: BEGIEN, EET, JA, LIËN, SEKEREN. - Deny: EN (I), NEEN, NIET (I), NO, NOCH (II). - Agree conditionally: INDIEN, OF. - Agree: AMEN * - Understand: VERSTAEN. - Know: BEKENNEN, CLERC,
GELEERT, KENNEN, LEREN, WETEN. - Truth: ENTROUWEN, GEWAERLIKE, GEWIS, TEWAREN, WAER (I), WAER (II), WAERHEIT. - Fallacy: DOLE, MISSEN.

\subsection{Expression and communication of $a$}

thought - Announce: BAN, CONDEN, CONT, CRAEYEREN, NIEUMARE, OPENBARE, TOGEN, UTEBRINGEN, UTECOMEN, VORTTRECKEN, WROEGEN. - Keep secret: HIDEN, ONVERSWEGEN, SCHUWEN, VERHELEN, VERHOLEN, VERHOLENLIJC, VERHOLENLIKE. - Clear: AENSCHIJN, AENSCHINEN, ALSO (II), APEERT, BLIKEN, DIEDEN, SCHINEN. - Natural sign: GEBARE, GELATE, GELATEN, SPOR, TEKEN (see also 9.1 Deceive). - Artificial sign: SEGELE, VANE. - Speak: SEGGEN, SPRAKE, SPREKEN, VOLSEGGEN. Be silent: STILLESWIGEN, SWIGEN. Speak loudly: AENROEPEN, GEROEP.Speak softly: RUNEN. - Say: GESEGGEN, GESPREKEN, TALE, WORT. - Determine: GENOEMEN, HETEN, NAME, NOEMEN, NOMEN *. - Inform: BOOTSCHAP. - Tell: AVENTURE, TELLEN, VERTELLEN. - Ask: VRAGEN, WATTAN. - Answer: ANTWORDE, ANTWORDEN. - Discussion: BESPREKEN, VORTGAEN. - Speech: PLEIDEREN, TALE, WOORT. - Education: CLERC, LESSE, MEESTER, WISEN. - Go to school: PASTE. - Read: LESEN. - Write: GESCHRIVEN, SCHRIVEN (see also 7.3 Literature - art of poetry). - Stationery: BRIEF, LETTERE, PARCAMENT. - Art of writing: BOECSTAVE, LETTERE. - Book: BOEC. - Language: DIETSCH, FRANSOYS, WALSCH, WALSCHEN. - Alphabet: SPELLEN. - Word formation: BISPEL.

\section{VOLITION}

4.1 Aspects of the will-Voluntarily: GEWILLELIKE. - Forced: MOETEN. Eagerness: GAERNE, GERNE, LIEVE (II). - Reluctance: NODE. - Willpower: BEDWINGEN, BEDWONGEN. - Lack of willpower: WANC. 
4.2 Actions of the will - Choose: VANDEN, VERCIESEN, WILLEN. - Decide: BERADEN (II).

4.3 Will imposed on others - Have authority: BEDWANC, DWINGEN, EIGEN, MACHT, SENDEN, STUREN, UTESENDEN. Serve: DIENEN. - Govern: GEWOUDEN, GEWOUT, WOUDEN. - Authority: CONINC, CONINCKLIKE, CONINGINNE, CRONE, HOF. - Subject: BODE, BOTTELGIER, CNAPE, KNECHT, SERIANT. Freedom: ONTCOMEN, ONTGAEN, ONTSCHRICKEN, ONTSPRINGEN, ONTSWEMMEN, ONTVAREN, ONTWENDEN, ONTWISSCHEN, QUITE, UTEGERAKEN, VRI. - Captivity: GEVANE, GISEL, VAEN. - Obedient: GEHOORSAM, OOTMOEDELIKE. - Exercise authority: BEVELEN, BIEDEN, GEBIEDEN, GEBODE, LADEN, ONTBIEDEN, VORTDRAGEN. Allow: GETEMEN, GONNEN, MOETEN, ORLOF.

4.4 Reciprocal desire - Propose and request: BEDE, BIDDEN, EISCH, EISCHEN, GEBIDDEN. - Accept: AENGAEN, GEHOREN. - Promise: BELOVEN, COVENT, OVEREENDRAGEN, SWEREN, VERSWEREN, VOREWAERDE.

\section{THE ACTION}

5.1 Aspect of a subject orobject-Lazy: LAT, TRAECH.-Careful: NAUWE(II), SORGE, SORGEN.-Carefree: ROEKELOOS, ROEKEN. - Competent: BEHENDELIKE. -Incompetent: MAT.-Powerful: CONNEN, CRACHT, GEWELDICH, GEWELT, MEESTE, MOGEN, MOGENDE, RIKE(I), RIKE(II), VERMOGEN. - Vehement: FEL. - Easy going: GEMAC, GEMACKELIKE, SPAREN.-Important: COSTEN, RIKELIJC, SAKE, SIERHEIT. - Unimportant: ONWERDE, VERONWERDEN.Good:ALLERBEST (I),ALLERBEST (II), BECOMEN, BEHENDELIKE, BET, BETERBEST (I), BEST (II), EDEL, EDELHEIT,LAVEN, MEESTERLIJC,
ONBESCHAVEN, OUTMAKIGGE, WEL.-Bad:ALLERSCHARPST *,BOOS, BOOSHEIT, QUAET (I), QUALIKE, WERS. -Strong: OVERSTARC, STARC, VAST, VASTE, VASTELIKE.-Weak: CRANC. - Pure: DWAEN.-Cleaning implements: BESEM,LOGE.

5.2 Means - Necessary: DORVEN, GEWANT. - Superfluous: ONNUTTE. - Useful: BATE, GEMIC, NUTTE, VROME, VROMEN. Harmful: DAREN, GRIEF, SCHADE (I), SCHADELOOS, SCHADEN, VERLIES. Aim: DORDAT, OPDAT.

5.3 Aim - Recommend: BERADEN (I), GERADEN, MANEN, RADEN, RAET, VERMANEN.

5.4.1 Preparation - Prepared: BEREIT, GEREET, GEREIDEN. - Attempt: POGEN, PROEVEN.

5.4.2.1 Action (general) - Action: ALDUS, ALDUSDAEN, ALSO (I), ANDERS, ANDERSINS, GELAET, GELATEN, HOE (I), MANIERE, SEDE, WISE. - Act: ARBEIT, DAET, DOEN, GEDOEN, GEWERKEN, MAKEN, ONLEDICH, PLEGEN, VOEREN, WERC. - Do nothing: LATEN, ONTBEREN. - Interrupt: AFCOMEN, BEGEVEN (I), BEGEVEN* (II). - Begin: AENSLAEN, BEGINNEN, BESTAEN, ONTGINNEN, OPGAEN, OPGEVEN, OPNEMEN (see also 1.4 Beginning). - Complete: ENDEN, GETELEN, TOEBRENGEN, VOLBRINGEN, VOLDOEN, VOLSCHRIVEN, WERKEN (see also 1.4 End). - Take care of: TELEN. - Neglect: VERMERREN. - Easy work: LICHT (I), LICHTE. - Hard work: ARBEIT, GERUCHTE, ONGEREDE, PIJNLIJC, PINEN, SWAER, SWARE (I), SWARE (II). - Safety: BEHOUDEN, BESCHERMEN, BEWACHTEN, HOEDE, HOUDEN, SCHADE (II). - Danger: DREIGEN, NOOT, ONBERADEN. - Repeat: GEWONE, PLEGEN. - Fatigue: GELOVE, MOEDE, VERPINET *.

5.4.2.2 Reciprocal action-Cooperate: BERADEN (I), GEHELPEN, GESPELE, 
HELPE (I), HELPE (II), HELPEN, SAUVER * - Refrain from: ONTHOUDEN. - Thwart: ACHTERSTEKEN, AL (IV), BENEMEN, MAER, NEWARE, NOCHTAN, ONDERGAEN, TOCH, VERSTORBEREN, WEDERSEGGEN, WEREN. - Association: HERE (II), PARLEMENT.

- Struggle: STRIDEN, STRIJT. - Peace: GELEIDE, PAIS, VERSOENEN, VREDE. - Attack: AENGAEN, BELOPEN, BESTORMEN. - Means of defence: BARBACANE, BORCH, CASTEEL, VESTE. - Men: SOUT. - Weapons: BARDE, LOOTWAPPER (see also 1.9.1 Cut).

5.4.3 Result - Succeed: GELUCKE, GOET (II). - Fail: MISRAKEN, MISVAL, MISVALLEN, ONGEREC, ONGEVAL, ONSALICH.

\section{ASPECTS OF THE ECONOMY}

6.1 Acquisition and possession - Acquire: BEJAGEN, GEWIN, GEWINNEN, QUAESITUS *, VERDIENEN, VERWERVEN, VERWINNEN, WINNEN. - Lose: PERDITUS *, QUITE, VERLIESEN, WECH (II). - Possess: BESITTEN, BORSE, DIJN, GOET (II), HARE (II), HAVE, HEBBEN, MIJN, MIJNS, ONS, ONSE, SCHAT, SIJN (II), SIJNS, UWE. - Rich: BEDRAGEN (II), GENEREN, RIJCHEIT. Poor: ARM, ARMOEDE.

6.2 Use - Save: GIER, GIERICH. - Give: BIEDEN, DIENEN, GEVEN, GIFTE, GONNEN, MILDE, OPGEVEN. -

Receive: ONTVAEN. - Take: AENGAEN, AFWINNEN, BEJACH, NEMEN, ONTJAGEN, PRENDEN, PROOYE (see also 1.9.1 Grab). - Steal: BESTELEN, GESTOLEN, HOENDERDIEF, INBREKEN, ROOF, ROVEN, STELEN. - Buy: COPEN. - Pay: PAEYEMENT, GEQUITEN (see also 1.2 Coins).

\section{EMOTION}

7.1 In general - Feeling: MOET, SIN.
7.2 Joy, distress - Enjoy: BEQUAME, BEQUAMELIJC, SACHTE, SOETEN, TROOSTEN. - Suffer: DOGEN, GEDOGEN, GEDRAGEN, LEET (I), LEET (II), LIDEN

(II), NAGAEN, NOPEN, ONGEMAC, ONSACHTE, ONSOETE, PINE, PINEN, SEER (I), SEER (II), SMARTE, VERDRAGEN, VERNOOY, VERNOOYEN, VERSEREN, WEE (I). - Happy: BLIDE, BLISCHAP, DELIJT, HOGE (I), LIEF (II), VERHOGEN, VRO. - Sad: ARM, ARMINC, DROEFLIKE, DROEVE, GENADELIKE, JAMER, JAMERLIJC, JAMERLIKE, ONBLIDE, ONVRO, ONWILLE, SERICH, VERDROEVEN. - Content: GENOEGEN, GEWAERT. - Dissatisfied: BECLAGEN, GRONGAERT, ONBEQUAME, ROUWE, ROUWEN. - Serious: ONSPELLIJC. Laugh: LACHEN. - Weep: AY, BEKERMEN, CLAGE, CLAGEN, KERMEN, KERMINGE *, O, STENEN, TRAEN, WACH, WEE (II), WENEN, WI (II). - Game: SPEL, SPELEN.

7.3 Sense of beauty (incl. jewelry, literature, music) - Beautiful: SCHONE (I), SCHONE (II). - Ugly: LELIJC. - Jewelry: CRONE, SCHAT, STEEN (see also 2.2.2 Metals, Gold and silversmith's work). - Literature - art of poetry: DICHTEN, DICHTERE, GEDICHTE (II), MAKEN, ONGEMAKET, RIME, RIMEN, VERS, VITE, VOLSCHRIVEN (see also 3.3 Write). - Perform music: AENSLAEN. - Musical instruments: BEYAERT, BLASEN, CLEPEL, CLOCKE, CLOCKENLINE, HORN, LUDEN. - Singing: SANC, SINGEN.

7.4 Hope-despair-Hope: HOPEN. - Despair: ONTHOPEN.

7.5 Daring - fear - Courage: BOUDELIKE, BOUT, COENE, DORREN, GENENDE, GOET (I), HELET, ONVERVAERT, STOUT. - Fear: ANXT, BEVEN, BLODE, ONTSIEN, ONTVRUCHTEN, SORGE, SORGEN, VAER, VERVAERT, VERVAREN, VRESE, VRESELIJC, VRUCHTEN. - Trust: BEVELEN, GELOVEN, GETROUWEN, NAUWE (I), SEKER, VERLATEN. Mistrust: MISTROUWEN. 
7.6 Wrath - meekness - Wrath: BELGEN, BESTEKEN, ERRE, ERREN, GRAM, NIJT, ONWERDE, TOREN, TORNICH, VERBELGEN, VERBOLGEN, VERBOLGENLIJC, VERWOET.

7.7 Desire - revulsion - Desire: BEGEREN, GEVOECH, LANGEN, NIET (III), WILLE. - Love - friendship: GESELLE, GESELSCHAP, HOUDE, HOUT, LIEF (I), LIEFHEBBEN, LIEVE (I), MINNE, MINNEN, NEVE, SOETE, TROUWE, VRIENDELIKE, VRIENT, VRIENTSCHAP. - Hate: HATEN, ONHOUT, SUUR, VETE, VIANT. - Benevolence: CARITATE, GENADE, GENADICH, GOEDERTIERE, GOET (I), ONTFARMEN, WELDAET. Malice: ARCH, ARGERTIERE, BENIDEN, EVEL, FEL (I), FEL (II), MISVOEREN, MORDDADELIKE, MORDDADICH, ONGEHIER, ONGENADE, TORMENT, VERDOEMT, VERJONNEN, VERMALEDIËN, VERWATEN (I), VERWATEN (II), VLOEKEN, WANCONSTE, WANGONNEN, WREET (see also 10.2 Godlessness, swear ). Gratitude: DANC, DANKEN. - Forgiveness: VERGEVEN (see also 10.2 Sacraments). - Revenge: GEANDEN, GELDEN, GEWREKEN, WEDERLONEN, WRAKE, WREKEN (see also 9.2 Punish). - Arrogance: FIERE, MALSCH, OVERDADICH, ROEMEN, VERWEENDELIKE. - Humility: SCHAME, SCHAMEN.

\section{SOCIETY}

8.1 Social interaction - Rudeness Loneliness: EENLIJC. - Social relationships: GAST, GESCHEIT, GROETEN, ONTVAEN, ORLOF, QUEDDEN, SALUUT, WELLECOME. - Sociable civilised: HOVESCH, HOVESCHEIT, HOVESCHLIKE (see also 1.4 Accompany). - Unsociable - uncivil: DORPER, DORPERHEIT. - Social institutions - Feudal society: FEL (I), HOUDE, LEEN, MAN.
8.2 Social status - Status: GENOOT. - Nobility: BAROEN, DAME, EDEL, GEBOREN, GENTEL, GRAVE, HERE (I), HOOCH, VRIHEIT, WELGEBOREN. Peasantry: DORPER. - Renowned: ERE, LOF, MARE, PRIJS, SIRE *, VRI.

8.3 Social legislation - Just: RECHT (I). Unjust: MALE * (II), ONRECHT. - Legal: RECHT (II). - Illegal: QUALIKE. - Insult: SCHELDEN. - Legal system: STRO. - Trial: CLAGE, CLAGEN, DAGEN, DINGEN, GEDINGE, HEILIGE, ONBECLAGET, ONBERECHT, ONSCHOUT, ORCONDE (I), ORCONDE (II), ORCONDEN, PLEIDEREN, PROEVEN, QUITEN, RECHTEN (II), REDENE, RINC, SCHULDICH, SOENDINC, SOENE, SOENEN, STAGE, TALE, VERORDELEN, VONNISSE, VONNISSEN, WEDERTALE, WISEN, WROEGEN (see also 3.2 Prove).

\section{MORAL}

9.1 Duty - behaviour - Duty: PLICHT, SULLEN. - Good behaviour: DOGET, GERECHT. - Bad behaviour: ARCHEIT, DIEF, DIEFTE, MISDOEN, ONREINE, QUAET (II), QUAET (III), RIBAUT, RIES, SAGHE (II), SCHALC, SCHALCHEIT. Honest: CLAERLIKE, GETROUWELIKE. - Dishonest: VALSCH (I), VALSCH (II). - Loyalty: GETROUWE, TROUWE. Disloyalty: ONGETROUWE, VERRADEN, VERRADENISSE, VERRADER. - Deceive: BARAET, BEDRIEGEN, BELOPEN, GEVENST, LAGE, LIEGEN, LOGENE, MISLEIDEN, TREKE, TREKER, VERDOREN (see also 1.1 Non-being, 3.1 Cunning). - Honourable: BETAMEN. - Dishonourable: ONGEVOECH, PUTENSONE, VERHOREN (see also 7.3 Music instruments, Singing). - Guilty: BESCHULDICH, MISDADICH, MISDAET, MORDELIJC, ONDAET, OVERDAET, SCHOUT, SCHULDICH, SONDE, SONDELIJC. - Repentance: BEROUWEN, BEROUWENISSE, BETEREN, CARINE, CLAREN, VASTEN. 
9.2 Assessment of behaviour-Approve: LOVEN. - Disapprove: BEGRIPEN, CASTIËN, SCHELDEN, VERWIJT. - Flatter: LOSENGIEREN, SMEKEN. - Honour: ONBEROEPEN, PRISEN, WERELTERE, WERT (I). - Mock, dishonour: BESCHELDEN, HONEN, LACHTER, LACHTERLIKE, LASTER, MISPRIJS, MISPRISEN, ONERE, ONSCHONE, ONTEREN, ONTERVEN, RAMPENEREN, SCHAMP, SCHAMPIE, SCHANDE, SCHEREN, SPOT, VERSCHROVEN, VERSPREKEN. - Accuse: AENTÏEN, BEDRAGEN (I), BETIËN, BLAER. Justify: GENENDE. - Reward: LONEN, LOON, MIEDE. - Punish: BECOPEN, BRADEN, GALGE, ONBEGREPEN, ONGEWROKEN, ONTGELDEN, QUELLEN, RAT, SIEDEN, STUPE (see also 7.7 Revenge, 10.2 Sacraments).

\section{RELIGION}

10.1 Supernatural world - Supernatural: CHRISTUS, DEUS, DIEU *, DOEMSDACH, DOMINUS *, DUVEL, FILIUS, GOD, HELLE, PATER, SIELE, SPIRITUS.
10.2 Christian religion - Catholicism: PAROCHIAEN. - Faith: WET. - Superstition: TEKEN. - Devotion: GEESTELIJC, HEILICH, PALSTER, PELGRIJM, SANT (II), SCHARPE, SLAVINE. - Godlessness, swear: DUVEL, GODSAT, HINDERWAERT, VERDOEMT (see also 7.7 Malice). - Prayer: BEVELEN, BIDDEN, COMPLETE, FILIUS *, GEBEDE, GETIDE, HEILIGE, NOENE, PATER, PATERNOSTER, PLACEBO DOMINO, PRIME, SANCTUS *, SPIRITUS *, VOLEN. - Religious service: GELES, SIELELESSE, VIEREN, VIGILIE. - Offering and Eucharist: CREDE, OFFERANDE, OFFERKERSE. - Sacraments: AFLAET, BIECHTE, CONFITERI *, PARDOEN, PATER, PENITENCIE, SETTEN, VERLATENISSE (see also 7.7 Forgiveness). - Christian festivals: CINXENDACH. Clergy: BISSCHOP, CAPELLAEN, DEKEN, MATER, PAPE, PATER, PAVES, PRIESTER, SEENT. - Monastic: ABBET, CLOOSTER, CLUSE, CLUSENAER, CONVENT, HEREMITE, MONIC, NONNE, PRIOR, PRIOREIT, PROVENDE, ORDENE. Clothing: CLOOSTERCRUNE, CRUNE, STOLE. - Church building: CRUCESTAF, COSTER, KERKE, OUTAER, VANE. 


\section{Bibliography}

Only articles, studies and editions referred to in this book have been listed. Other publications may be found relatively easily. For publications in the nineteenth century, see Petit 1888-1910; Teirlinck 19101912. For the first part of the twentieth century, see Muller 1942; Muller 1944. For later publications see the bibliographical surveys by R.M.T. Zemel (in Bosch 1972) and by L. Geeraedts (Geeraedts 1980), and the bibliographies of two dissertations (Bouwman 1991; Van Daele 1994). The journal Tiecelijn has been published in Flanders since 1988 (from 2008 as a yearbook). It is devoted to recent rewritings, verse adaptations, iconography and ex-libris art as well as scholarly publications on Reynaert material. International scholarship on European Reynaert texts may be followed through Reinardus. Yearbook of the International Reynard Society, which has also appeared since 1988.

Altena, E. van (transl.), Reinaert de vos. De middeleeuwse satire hertaald. Amsterdam 1979.

Arendt, G.-H., Die satirische Struktur des mittelniederländischen Tierepos 'Van den vos Reynaerde'. Köln 1965. - [Ph.D. Köln; chapter 'Die Struktur des Geschehens' (pp. 149-176) reprinted in Van Dijk \& Wackers 1999, pp. 51-69]

Barnouw, A.J. (ed.), Beatrijs. A Middle Dutch legend. Edited from the Only Existing Manuscript in the Royal Library at The Hague, with a Grammatical Introduction, Notes and a Glossary. London [etc.] [1914]. (Publications of the Philological Society, 3)

Bartelinck, G.J.M., 'Een thema uit de fabelliteratuur en het dierenepos in de middeleeuwen. De hofdag van de zieke leeuw en de gevilde wolf', in: Lampas 10 (1977), pp. 283-301.

Berg, B. van den (ed.), Retrograad woordenboek van het Middelnederlands. 's-Gravenhage 1992.

Berg, E. van den, Middelnederlandse versbouw en syntaxis. Ontwikkelingen in de versifikatie van verhalende poëzie ca.1220 - ca.140o. Utrecht 1983. - [Ph.D. Utrecht]

Berteloot, A. and H.-L Worm (eds.), Van den vos Reynaerde = Reinart Fuchs. Mittelniederländischer Text und deutsche Übertragung. Marburg 1982. (Marburger Studien zur Germanistik, 2).

Besamusca, B., 'Opmaak en voordracht. De Rotterdamse fragmenten van Van den Vos Reinaerde', in: E. Cockx-Indestege and F. Hendrickx (eds.), Miscellanea Neerlandica. Opstellen voor dr. Jan Deschamps ter gelegenheid van zijn zeventigste verjaardag. Leuven 1987, vol. II (Miscellanea Neerlandica, 2), pp. 123-131.

Besamusca, B., 'Rewriting the Roman de Renart. The Middle Dutch Beast Epic Van den vos Reynaerde', in: D. Kelly (ed.), The Medieval Opus. Imitation, Rewriting, and Transmission in the French Tradition. Proceedings of the Symposium Held at the Institute for Research in Humanities, October 5-7 1995, the University of Wisconsin-Madison. Amsterdam [etc.] 1996, pp. 387-404.

Besamusca, B. 'Het publiek van de Middelnederlandse Arturromans', in: J.D. Janssens [a.o.], $O p$ avontuur. Middeleeuwse epiek in de Lage Landen. Amsterdam 1998. (Nederlandse Literatuur en Cultuur in de Middeleeuwen, 18), pp. 145-157, 327-329.

Bibliografievan de Nederlandsetaal-enliteratuurwetenschap (BNTL) - [URL: http://www.bntl.nl/bntl/]

Bosch, J., Reinaert-perspectief. Kampen 1972. - [Inaugural lecture Amsterdam VU; bibliography, compiled by R.M.T. Zemel, on pp. 43-51] 
Bossuat, R., Le Roman de Renard. Nouvelle édition, revue et mise à jour. Paris 1967. (Connaissances des Lettres, 49).

Bouwman, A., 'On the Place of Van den vos Reynaerde in the Old French Roman de Renart Tradition'. In: Reinaerdus, Yearbook of the International Reynard Society 3 (1990), pp. 15-24.

Bouwman, A.Th., Reinaert en Renart. Het dierenepos Van den vos Reynaerde vergeleken met de Oudfranse Roman de Renart. Amsterdam 1991. 2 vols. (Nederlandse Literatuur en Cultuur in de Middeleeuwen, 3). - [Ph.D. Leiden]

Bouwman, A., 'Van den vos Reynaerde and Branch VIII of the Roman de Renart', in: Reinardus. Yearbook of the International Reynard Society 5 (1992), pp. 35-45. - [1992a]

Bouwman, A.Th., 'Van den vos Reynaerde and Branch I of the Roman de Renart. Tradition and Originality in a Middle Dutch Beast Epic, in: Neophilologus 76 (1992), pp. 482-501. - [1992b]

Bouwman, A.Th., 'Omstreeks 1275: Van den vos Reynaerde in het Latijn vertaald. Virtuoze woordkunst', in: M.A. Schenkeveld-Van der Dussen (ed.) Nederlandse literatuur, een geschiedenis. Groningen 1993, pp. 36-40. - [1993a]

Bouwman, A.Th., 'Het dier in de Middelnederlandse letterkunde', in: W.L. Idema, M. Schipper and P.H. Schrijvers (eds.), Mijn naam is haas. Dierenverhalen in verschillende culturen. Baarn 1993, pp. 57-65. - [1993b]

Bouwman, A.Th., [Review of Van Daele 1994], in: Tijdschrift voor Nederlandse taal-en letterkunde 112 (1996), pp. 276-280.

Bouwman, A.Th., 'Taaldaden. Over intertekstualiteit in Van den vos Reynaerde', in: J.D. Janssens [a.o.], Op avontuur. Middeleeuwse epiek in de Lage Landen. Amsterdam 1998. (Nederlandse Literatuur en Cultuur in de Middeleeuwen, 18), pp.125-143, 322-327. - [URL: http://www.dbnl.org/ tekst/bouwoo8taalo1/]

Bouwman, A.Th. and B. Besamusca (eds.), Reynaert in tweevoud. Vol. I: Van den vos Reynaerde (Amsterdam 2002).

Bouwman, A.Th. and B. Besamusca (transl.), 'Over de vos Reynaert. Een prozavertaling van Van den vos Reynaerde', in: Tiecelijn 20 (2007), pp. 106-141.

Breul, K. (ed.), The Cambridge Reinaert Fragments (Culemann Fragments). Cambridge 1927.

Brink, H. van den and J. van Herwaarden, 'Van den vos Reynaerde. Recht en macht', in: H. van den Brink [a.o.] (eds.), Samenwinninge. Tien opstellen over rechtsgeschiedenis geschreven ter gelegenheid van het tienjarig bestaan van het interuniversitair instituut Nederlands Centrum voor Rechtshistorische Documentatie. Zwolle 1977, pp. 75-91. - [Reprinted in Van Dijk and Wackers 1999, pp. 179-196]

Brinkman, H. and J. Schenkel (eds.), Het Comburgse handschrift. Hs. Stuttgart, Württembergische Landesbibliothek, Cod. poet. et phil. $2^{\circ}$ 22. Diplomatische editie. Hilversum 1997. 2 bdn. (Middeleeuwse verzamelhandschriften uit de Nederlanden, 4)

Brouwers, L., Het juiste woord. Standaard betekeniswoordenboek der Nederlandse taal. 11th ed. Compiled by F. Claes. Antwerpen 1991.

Bruin, C.C. de (ed.), Het oude testament. Eerste Stuk. Genesis - II Koningen. Leiden 1977. (Corpus Sacrae Scripturae Neerlandicae Medii Aevi; Series Maior, 1)

Buitenrust Hettema, F. (ed.), Van den vos Reynaerde. Vol. II: Inleiding - Aantekeningen - Glossarium. Zwolle [1910]. (Zwolsche herdrukken, 19/20)

Buitenrust Hettema, F. and H. Degering (eds.) - Van den vos Reynaerde. Uitgegeven naar het Comburgsche en Darmstadse handschrift door F. Buitenrust Hettema, naar het Dyckse handschrift door H. Degering. 2nd ed. Zwolle 1921. 2 vols. (Zwolsche herdrukken, 18-19/20). - [Vol. I. Tekst; Vol. II. Inleiding, aanteekeningen, Glossarium]

Buitenrust Hettema. F. and J.W. Muller (eds.), Van den vos Reynaerde. Opnieuw naar het het Comburgsche handschrift uitgegeven. Zwolle 1903. (Zwolsche herdrukken, 18)

Burger, P. (transl.), Jacob van Maerlant, Het boek der natuur. Amsterdam 1989. (Griffioen)

Burridge, K., Syntactic Change in Germanic. Aspects of Language Change in Germanic with Particular Reference to Middle Dutch. Amsterdam 1993. (Current Issues in Linguistic Theory, 89). 
Caenegem, R.C. van, Geschiedenis van het strafrecht in Vlaanderen van de XIe tot de XIVe eeuw. Brussel 1954. (Verhandelingen van de Koninklijke Vlaamse Academie voor Wetenschappen, Letteren en Schone Kunsten van België, Klasse der Letteren, 19).

Caenegem, R.C. van, Geschiedenis van het strafprocesrecht in Vlaanderen van de XIe tot de XIVe eeuw. Brussel 1956. (Verhandelingen van de Koninklijke Vlaamse Academie voor Wetenschappen, Letteren en Schone Kunsten van België, Klasse der Letteren, 24).

Campbell, M.F.A.G., Annales de la typographie néerlandaise au XVe siècle. La Haye 1874. - [With supplements I-IV: La Haye 1874-1890]

Colledge, E. (ed.), Reynard the Fox and Other Mediaeval Netherlands Secular Literature. With an Introduction by E. Colledge and Translations by E. Colledge and A.J. Barnouw. Leyden [etc.] 1967. (Bibliotheca Neerlandica).

Combarieu, M. de and J. Subrenat, Le Roman de Renart. Index des thèmes et des personnages. Aix-enProvence 1987. (Senefiance, 22)

Cummins, J., The Hound and the Hawk. The Art of Medieval Hunting. New York, 1988.

Daele, R. van, 'Quelques aspects de la réception renardienne en Flandre aux dix-neuvième et vingtième siècles', in: Reinardus. Yearbook of the International Reynard Society 3 (1990), pp. 173-183.

Daele, R. van, Ruimte en naamgeving in 'Van den vos Reynaerde'. Gent 1994. (Koninklijke Academie voor Nederlandse taal- en letterkunde, Reeks III, 42). - [Ph.D. Leuven]

Daele, R. van , 'Het laatste woord is aan Willem. Over het slot van Van den vos Reynaerde (A $3390-$ 3469)', in: K. Porteman, W. Verbeke and F. Willaert (eds.), Tegendraads genot. Opstellen over de kwaliteit van middeleeuwse teksten. Leuven 1996, pp. 63-72.

Daele, R. van, 'De robotfoto van de Reynaertdichter. Bricoleren met de overgeleverde wrakstukken: 'cisterciënzers', 'grafelijk hof' en 'Reynaertmaterie', in: Tiecelijn 18 (2005), pp. 179-205.

Daniëls, W., Talking Dutch. Rekkem 2005.

Delbouille, M., 'La composition du “Reinaert I”. Arnout, Willem et le Roman de Renart français', in: Revue belge de philologie et d'histoire 8 (1929), pp. 19-52.

Derolez, A., The Palaeography of Gothic Manuscript Books From the Twelfth to the Early Sixteenth Century. Cambridge 2006. (Cambridge Studies in Palaeography and Codicology, 9).

Deschamps, J., Middelnederlandse handschriften uit Europese en Amerikaanse bibliotheken. Tentoonstelling t.g.v. het honderdjarig bestaan van de Koninklijke Zuidnederlandse Maatschappij voor taalen letterkunde en geschiedenis. Brussel, Koninklijke Bibliotheek Albert I, 24 okt.-24 dec. 1970. Catalogus. 2nd herz. dr. Leiden 1972.

Deschamps, J., 'Nieuwe fragmenten van Van den vos Reynaerde', in: E. Rombauts and A. Welkenhuysen (eds.), Aspects of the Medieval Animal Epic. Proceedings of the International Conference Louvain, May 15-17, 1972. Leuven [etc.] 1975. (Mediaevalia Lovaniensia, Series 1: Studia, 3), pp. 199-206.

Deschamps, J. and H. Mulder, Inventaris van de Middelnederlandse handschriften van de Koninklijke Bibliotheek van België (voorlopige uitgave). Eerste aflevering. Brussel 1998.

Dievoet, G. van, 'Le Roman de Renart et Van den vos Reynaerde témoins fidèles de la procédure pénale aux XIIe et XIIIe siècles?', in: E. Rombauts and A. Welkenhuysen (eds.), Aspects of the Medieval Animal Epic. Proceedings of the International Conference Louvain, May 15-17, 1972. Leuven [etc.] 1975. (Mediaevalia Lovaniensia, Series 1: Studia, 3), pp. 43-52.

Dijk, H. van and P. Wackers (eds.), Pade crom ende menichfoude. Het Reynaert-onderzoek in de tweede helft van de twintigste eeuw. Hilversum 1999. (Middeleeuwse studies en bronnen, 67)

Dis, L.M. van (ed.), Van den vos Reinaerde. $20 e$ dr. Groningen 1972. (Van alle Tijden)

Dufournet, J. and A. Méline (transl.) - Le Roman de Renart. Paris 1985. 2 vols.

Duinhoven, A.M., Bijdragen tot reconstructie van de Karel ende Elegast. Vol. 1 (Assen 1975). - [Ph.D. Utrecht]

Duinhoven, A.M., Middelnederlandse syntaxis synchroon en diachroon. Vol. I: De naamwoordgroep. Leiden 1988. 
Duinhoven, A. M., Middelnederlandse syntaxis synchroon en diachroon. Vol. II: De werkwoordgroep. Groningen 1997.

Engels, L.J., 'Reynardus vulpes als bewerking van de Reinaert', in: P. Wackers [a.o.]: Verraders en bruggenbouwers. Verkenningen naar de relatie tussen Latinitas en de Middelnederlandse letterkunde. Amsterdam 1996, pp. 63-84, 282-291. - [1996a]

Engels, L.J., 'Van den vos Reynaerde and Reynardus vulpes: A Middle Dutch Source Text and Its Latin Version, and Vice Versa', in: Media Latinitas. A Collection of Essays to Mark the Occasion of the Retirement of L.J. Engels. Steenbrugis 1996. (Instrumenta Patristica, 28), pp. 1-28. - [1996b]

Eykman, K. (transl.), Reinaert de vos. Met een nawoord van R. van Daele. Amsterdam 2008.

Flinn, J., Le Roman de Renart dans la littérature française et dans les littératures étrangères au Moyen Age. [Toronto] 1963. (University of Toronto Romance Series, 4). - [Ph.D. Paris]

Foulet, L., Le Roman de Renard. Paris 1914. (Bibliothèque de l’École des Hautes Études, Sciences Historiques et Philologiques, 211). - [Reprint: Paris, 1968]

Fukumoto N., N. Harano and S. Suzuki (eds.), Le Roman de Renart. Édité d'après les manuscrits C et M. Tokyo 1983-1985. 2 vols. [Reprint, with French prose translation by G. Bianciotto: Paris, 2005, Livre de poche]

Gasse, B. van, 'Antropomorfisme en ander ongedierte', in: R.van Daele [a.o.] (eds.), Reynaert bloemleest Tiecelijn. Sint-Niklaas 1993, pp. 89-90.

Geeraedts, L., 'Van den vos Reynaerde. Eine beschreibende Bibliographie der Sekundärliteratur zwischen 1944 und 1976', in: J. Goossens and T. Sodmann (eds.), Reynaert Reynard Reynke. Studien zu einem mittelalterlichen Tierepos. Köln [etc.] 1980. (Niederdeutsche Studien, 27), pp. 282-323.

Gestel, F. van [a.o.], Oude zinnen. Grammaticale analyse van het Nederlands tussen 1200-1700. Leiden 1992.

Goossens, J., 'Over het begin van de volksboekoverlevering van de Reinaert', in: De nieuwe taalgids 74 (1981), pp. 45-47.

Goossens, J. (ed.), Reynaerts historie, Reynke de Vos. Gegenüberstellung einer Auswahl aus den niederländischen Fassungen und des niederdeutschen Textes von 1498. Darmstadt 1983. (Texte zur Forschung, 42). - [1983a]

Goossens, J., Die Reynaert-Ikonographie. Darmstadt, 1983. (Texte zur Forschung, 47). - [1983b]

Goossens, J., De gecastreerde neus. Taboes en hun verwerking in de geschiedenis van de Reinaert. Leuven [etc.] 1988. (Leuvense Studiën en Tekstuitgaven, Nieuwe Reeks, 8).

Goossens, J., 'De moderne Nederlandse Reinaert-bewerkingen', in: Verslagen en mededelingen van de Koninklijke Academie voor Nederlandse taal-en letterkunde 1996, pp. 17-39. - [1996a]

Goossens, J., 'Von kranken Löwen und Rahmenerzählungen, Hoftagen und Strafprozessen. Bemerkungen zur Erzählstruktur des mittelalterlichen Tierepos', in: H. Höfinghoff [a.o.] (eds.), Alles was Recht war: Rechtsliteratur und literarisches Recht: Festschrift für Ruth Schmidt-Wiegand zum 70. Geburtstag. Essen 1996, pp. 217-226. - [1996b]

Graf, A., Die Grundlagen des Reineke Fuchs. Eine vergleichende Studie. Helsinki 1920. (Folklore Fellows Communications, 38 ).

Greetham, D.H., Textual Scholarship. An Introduction. New York [etc.] 1994, p. 279-283 ('Scribal Variants').

Grimm, J., Reinhart Fuchs. Berlin 1834 .

Gumbert, J.P., 'La page intelligible: quelques remarques', in: O. Weijers (ed.). Vocabulaire du livre et de l'écriture au moyen âge. Actes de la table ronde Paris, 24-26 septembre 1987. Turnhout 1989. (Civicima. Études sur le vocabulaire intellectuel du moyen âge, 2), pp. 111-119.

Gysseling, M., 'Speurtocht naar de Reinaert-dichter', in: Jaarboek Oudheidkundige Kring 'De vier ambachten'. Hulst 1966/67, pp. 9-20.

Gysseling, M., 'Datering en localisering van Reinaert I', in: E. Rombauts and A. Welkenhuysen (eds.), Aspects of the Medieval Animal Epic. Proceedings of the International Conference Louvain, May 15-17, 1972. Leuven [etc.] 1975. (Mediaevalia Lovaniensia, Series 1, Studia, 3), pp. 165- 186. 
Gysseling, M., Corpus van Middelnederlandse teksten (tot en met het jaar 130o). Reeks II. Literaire handschriften. Vol. 1 Fragmenten. ('s-Gravenhage 1980). Vol. 3 Rijmbijbel/Tekst (Leiden 1983).

Haan, M.J.M. de, Enige aspecten van de tekstkritiek van Middelnederlandse teksten. Leiden 1973. [Ph.D. Leiden]

Heeroma, K., 'De eerste Reinaert en zijn voorbeeld', in: idem, De andere Reinaert. Den Haag 1970, pp. 10-114.

Heeroma, K., 'De Reinaert en het recht', in: Tijdschrift voor Nederlandse taal-en letterkunde 87 (1971), pp. 260-274.

Hegman, W.E., 'De "Brusselse fragmenten” van Reynaert I', in: P.M. Gilhuys [a.o.] (eds.), Zestigjaar Oudheidkundige Kring 'De Vier Ambachten'. Jubileumboek 1988-1989. Hulst 1989, pp. 14-37.

Hellinga, W. Gs (ed.), Van den vos Reynaerde. Dl. I Teksten. Diplomatisch uitgegeven naar de bronnen vóór het jaar 1500 (Zwolle 1952). - [Corrections in Spiegel der Letteren 8 (1964/65), pp. 3137]

Hellinga, W. Gs, 'Wie was Willem die de Reynaert schreef?', in: Jaarboek Oudheidkundige Kring 'De vier ambachten'. Hulst 1957, pp. 11-23.

Hellinga, W. Gs, 'De betekenis van de incunabelkunde voor de neerlandistiek', in: E. Lindenberg, E. Raidt and J.A. Verhage (eds.), Dietse studies. Bundel aangebied aan Prof. Dr. J. Du P. Scholtz. Kaapstad/Pretoria 1965, pp. 52-76.

Hermesdorf, B.H.D., 'Van den vos Reynaerde. Rechtshistorische aantekeningen', in: B.H.D. Hermesdorf: Recht en taal te hoofde. Opstellen over de ontmoeting tussen Middelnederlandse letteren en Oudvaderlands recht. Zwolle 1955. (Zwolse Reeks van Taal- en Letterkundige Studies, 1), pp. 106-161.

Hoecke, W. van, 'La littérature française d'inspiration arthurienne dans les anciens Pays-Bas'. In: W. Verbeke, J. Janssens and M. Smeyers (eds), Arturus Rex. Vol. I. Catalogus. Koning Artur en de Nederlanden. La matière de Brétagne et les anciens Pays-Bas (Leuven 1987). (Mediaevalia Lovaniensia, Series 1, Studia 16), pp. 189-260.

Hogenhout-Mulder, M., Cursus Middelnederlands. 2nd ed. Groningen 1985.

Huygens, R.B.C. (ed./ transl.), Reynardus vulpes. De Latijnse Reinaert-vertaling van Balduinus Iuvenis. Critisch uitgegeven en vertaald. Zwolle 1968. (Zwolse Drukken en Herdrukken voor de Maatschappij der Nederlandse Letterkunde, 66).

Horst, J. M. van der, Kleine Middelnederlandse syntaxis. 2nd rev. ed. Amsterdam 1984.

Horst, J.M. van der, Geschiedenis van de Nederlandse syntaxis. Leuven 2008. 2 vols.

ILC - Van Thienen and Goldfinch 1999

Hüning, M. [a.o.] (1999/2008), Geschiedenis van het Nederlands / Geschichte des Niederländischen / History of the Dutch language. - [URL: http://neon.niederlandistik.fu.berlin.de/taalgeschiedenis/]

Jacoby, F.R., Van den vos Reinaerde. Legal Elements in a Netherlands Epic of the Thirteenth Century. München 1970. - [Ph.D. New York]

Janssens, G. and A. Marynissen, Het Nederlands vroeger en nu. 2nd. rev. ed. Leuven 2005.

Janssens, J., 'Een meesterwerk van dubbelzinnigheid'. In: Janssens [a.o.] 1991, pp. 173-187.

Janssens, J. and R. van Daele, Reinaerts streken: van 2000 voor tot 2000 na Christus. Leuven 2001.

Janssens, J. [a.o.] (ed.), Van den vos Reynaerde. Het Comburgse handschrift. Leuven 1991.

Jauss, H.R., Untersuchungen zur mittelalterlichen Tierdichtung. Tübingen 1959. (Beihefte zur Zeitschrift für Romanische Philologie, 100). - [Habilitationsschrift Heidelberg]

Jauss-Meyer, H. (transl.), Le Roman de Renart. München 1965. (Klassische Texte des Romanischen Mittelalters in Zweisprachigen Ausgaben, 5).

Jonckbloet, W.J.A., Geschiedenis der Middennederlandsche dichtkunst. Vol. II (Amsterdam 1852).

Jonckbloet, W.J.A. (ed.), Vanden vos Reinaerde. Groningen 1856.

Jonkers, M.C.J.M., Reynardus en Reynaert. Verkenningen rond de Reynaert-receptie in de Reynaerdus Vulpes van Balduinus, nomine Iuvenis. [Z.pl.] 1985. - [Ph.D. Groningen] 
Keyser, P. de (ed.), Reinaerts historie (Hs. Koninklijke Bibliotheek 14601). Antwerpen 1938. (Rijksuniversiteit te Gent. Werken uitgegeven door de faculteit van de Wijsbegeerte en Letteren. Extra serie: Facsimiles, 1).

Kerckvoorde, C.M.van, An Introduction to Middle Dutch. Berlin [etc.] 1993.

Klitzing, H., Reineke Fuchs. Ein europäisches Epos. Eine Ausstellung des Goethe-Museums Düsseldorf, Anton-und-Katharina-Kippenberg-Stiftung, Arbeitsstelle Reineke Fuchs. Düsseldorf 1989.

Knapp, F.P., Das lateinische Tierepos. Darmstadt 1979. (Erträge der Forschung, 121)

Kooper, E. (ed.), Medieval Dutch Literature in Its European Context. Cambridge 1994. (Cambridge Studies in Medieval Literature, 21)

Lodge, R.A. and K. Varty (eds.), The Earliest Branches of the Roman the Renart. Louvain [etc.] 2001. (Synthema, 1).

Loey, A. van, Schönfelds historische grammatica van het Nederlands. Klankleer, vormleer, woordvorming. 8th ed. Zutphen 1970.

Loey, A. van, Middelnederlandse spraakkunst. Vol. II. Klankleer. 7 th. rev. ed. Groningen 1976.

Loey, A. van, Middelnederlandse spraakkunst. Vol. I. Vormleer. 9th ed. Groningen 1980.

Lulofs, F., Nu gaet reynaerde al huten spele. Over commentaar en interpretatie. Amsterdam 1975. (Amsterdamse smaldelen, 3). - [Chapter 'Nu gaet reynaerde al huten spele (A 1885)' (pp. 18-31) reprinted in Van Dijk \& Wackers 1999, pp. 167-177]

Lulofs, F. (ed.), Van den vos Reynaerde. De tekst kritisch uitgegeven met woordverklaring, commentaar en tekstkritische aantekeningen. Groningen [1983]. - [2nd, improved impr.]. Groningen 1985]

Lulofs, F., Ik lees, ik lees, wat jij niet leest. Of boosaardig is ook aardig. Groningen 1984. - [Valedictory lecture Groningen]

Mann, J. (transl.), Ysengrimus. Leiden [etc.] 1987. (Mittellateinische Studien und Texte, 12)

Mann, J., 'The Roman de Renart and the Ysengrimus', in: Varty 1988-1991, Vol. I, pp. 135-162.

Martin, E. (ed.), Reinaert. Willems Gedicht Van den vos Reinaerde und die Umarbeitung und Fortsetzung Reinaerts Historie. Paderborn 1874.

Martin, E. (ed.), Das niederländische Volksbuch Reynaert de Vos nach der Antwerpener Ausgabe von 1564. Paderborn 1876.

Martin, E. (ed.), Le Roman de Renart. Strasbourg [etc.] 1882-1887. 3 vols. - [Photomech. repr.: Berlin [etc.] 1973]

Martin, E. (ed.), Neue Fragmente des Gedichtes Van den vos Reinaerde und das Bruchstück Van bere Wisselauwe. Strassburg [etc.] 1889. (Quellen und Forschungen zur Sprach- und Culturgeschichte der germanischen Völker, 65).

Menke, H., Bibliotheca Reinaerdiana. Vol. I. Die europäischen Reineke Fuchs-Drucke bis zum Jahre 1800 (Stuttgart 1992).

Merlijn 1975 - Een zeer genoeglyke en vermaaklyke Historie van Reynaert de Vos. Amsterdam: de Erve de Wed.Jacobus van Egmont, [ca. 1780]. Hulst 1975. - [Facsimile edition by Antiquariaat Merlijn]

Meuwese, M., 'The Secret History of the Fox and the Hare in Trinity B.11.22', in: G.H.M. Claassens and W. Verbeke (eds.), Medieval Manuscripts in Transition. Tradition and Creative Recycling. Leuven 2006, pp. 179-195.

Middelnederlandsch woordenboek (MNW) - Verwijs and Verdam 1885-1971

Middelnederlandsch handwoordenboek (MNHW) - Verdam 1932; Van der Voort van der Kleij 1983

Mierlo, J. van, 'Voor Arnout's oorspronkelijkheid', in: Verslagen en mededeelingen der Koninklijke Vlaamsche Academie 1927, pp. 1071-1118.

Mierlo, J. van, 'De definitieve oplossing in zake den Reinaert-proloog', in: Verslagen en mededeelingen der Koninklijke Vlaamsche Academie 1942, pp. 563-595.

Mierlo, J. van (transl.), Magister Nivardus' Isengrimus. Het vroegste dierenepos in de letterkunde der Nederlanden. Utrecht 1946.

Mooijaart, M. and M. van der Wal, Nederlands van Middeleeuwen tot Gouden Eeuw. Cursus Middelnederlands en Vroegnieuwnederlands. Nijmegen 2008. 
Muller, J.W., 'Een nieuw handschrift van den Reinaert', Verslagen en mededeelingen der Koninklijke Vlaamsche Academie 1908, pp. 109-188.

Muller, J.W., Critische commentaar op Van den vos Reinaerde naar de thans bekende handschriften en bewerkingen. Utrecht 1917.

Muller, J.W., 'Reinaert-studiën, I. De slotverzen van Reinaert I', in: Tijdschrift voor Nederlandsche taal-en letterkunde 46 (1927), pp. 52-64.

Muller, J.W., 'Reinaert-studiën, V. Tekstcritiek', in: Tijdschrift voor Nederlandsche taal- en letterkunde 59 (1940), pp. 159-210.

Muller, J.W., Van den vos Reinaerde. Exegetische commentaar. 2nd ed. Leiden 1942. (Leidsche Drukken en Herdrukken, Groote Reeks, 2)

Muller, J.W. (ed.), Van den vos Reinaerde, Inleiding met aanteekeningen, lijst van eigennamen, tekst. Critisch uitgegeven. 3 rd, newly rev. en augm. ed. Leiden 1944. (Leidsche Drukken en Herdrukken, Groote Reeks, 1).

Naar de letter 1972 - Reinaert de Vos. Tentoonstelling (29 sept. $1972-28$ febr. 1973) Instituut De Vooys, Utrecht. [Compiled by the working group 'Textus sub tecto']. Utrecht 1972. (Naar de letter, 5)

Nieboer, E. and J.Th. Verhulsdonck, 'Lais, fabliau's, Roman de Renart', in: R.E.V. Stuip (ed.), Franse literatuur van de Middeleeuwen. Muiderberg 1988, pp. 121-139.

Nieuwenhuis, M. (transl.), Ysengrimus. Amsterdam 1997. (Griffioen)

Oostrom, F.P. van, Reinaert primair. Over het geïntendeerde publiek en de oorspronkelijke functie van Van den vos Reinaerde. Utrecht 1983. (Kwarto-reeks, 4). - [Reprinted, without appendices, in Van Dijk \& Wackers 1999, pp. 197-213]

Oostrom, F.P. van, 'Mr. Willem', in: idem, Stemmen op schrift. Geschiedenis van de Nederlandse literatuur vanaf het begin tot 1300. Amsterdam 2006, pp. 464-502, 584-585.

Overgaauw, E.A., 'Die Dycksche Handschrift. Ihre Entdeckung, Herkunft, Datierung und früheren Besitzer', in: B. Haller and H. Mühl (eds.), Die Dycksche Handschrift. Berlin 1992, pp. 40-58.

Overgaauw, E., Die mittelalterlichen Handschriften der Universitäts- und Landesbibliothek Münster. Wiesbaden, 1996.

Owen, D.D.R. (transl.), The Romance of Reynard the Fox. Oxford [etc.] 1994. (World's classics)

Peeters, L., 'Historiciteit en chronologie in Van den Vos Reynaerde', in: Spektator 3 (1973/74), pp. 157179, 347-369. - [Reprinted in Van Dijk \& Wackers 1999, pp. 125-165]

Perry, B.E. (ed.), Aesopica. A Series of Texts Relating to Aesop or Ascribed to Him or Closely Connected With the Literary Tradition That Bears His Name. Vol. I Greek and Latin Texts. (Urbana, Ill. 1952).

Petit, L.D., Bibliographie der Middelnederlandsche taal-en letterkunde. Leiden 1888-1910. 2 vols.

Pijnenburg, W.J.J. [a.o.], (eds.), Vroegmiddelnederlands Woordenboek. Woordenboek van het Nederlands van de dertiende eeuw in hoofdzaak op basis van het Corpus-Gysseling. Leiden 2001. 4 vols.

Pijnenburg, W.J.J. and T.H. Schoonheim (eds.), Middelnederlands lexicon. 2nd rev. and augm. ed. Amsterdam 1997.

Pleij, H., '[Review of Van Oostrom 1983], in: Forum der Letteren 24 (1983), pp. 233-237.

Poeth, Ph., Von dem Fuchs Reinaert. Deutsche Reimfassung der Dichtung 'Van den vos Reynaerde' (= Reynaert I) aus dem 13. jahhundert von 'Willem, der den Madock machte'. Münster 2005.

Posthuma, A. (transl.), Reynaert de Vos. Amsterdam 2008.

Prevenier, W., 'Court and City Culture in the Low Countries from 1100 to 1530', in: Kooper 1994, pp. 11-29.

Quak, A. and J.M. van der Horst, Inleiding Oudnederlands. Leuven 2002.

Rey-Flaud, H. and A. Eskénazi (transl.), Le Roman de Renart, Branche I. Traduit d'après l'édition de M. Roques. 2 me éd. revue et corrigée. Paris 1982. (Traductions des Classiques Français du Moyen Age, 8)

Reynaert, J., 'Botsaerts verbijstering. Over de interpretatie van Van den vos Reynaerde', in: Spiegel der Letteren 38 (1996), pp. 44-61. - [Reprinted in Van Dijk \& Wackers 1999, pp. 267-283; URL: http://www.dbnl.org/tekst/reynoo1botso1/] 
Rijns, H. (ed.), De gedrukte Nederlandse Reynaerttraditie. Een diplomatische en synoptische uitgave naar de bronnen vanaf 1479 tot 1700 . Hilversum 2007.

Rituale Romanum Pauli V pontificis maximi. Jussu editum aliorumque pontificum cura recognitum atque auctoritae ssmi d.n. Pii papae xi ad normam codicis juris canonici accomodatum. Editio juxta typicam Vaticanam. Mechliniae 1926.

Roques, M. (ed.), Le Roman de Renart. Edité d'après le manuscrit de Cangé par M. Roques. Paris 1948-1963. 6 vols. (Classiques Français du Moyen Age, 78, 79, 81, 85, 88, 90)

Sabbe, M. and L. Willems (eds.), Reynaert de vos, Reynier le renard. Herdruk van de Plantijnsche uitgave van 1566. Antwerpen 1924.

Salemans, B.J.P., Building Stemmas With the Computer in a Cladistic, Neo-Lachmannian Way: The Case of Fourteen Text Versions of Lanseloet van Denemerken. [z.pl.] 2000. - [Ph.D. Nijmegen]

Scheidegger, J.R., Le Roman de Renart. Ou le texte de la dérision. Genève 1989. (Publications Romanes et Françaises, 188).

Schippers, A., Middelnederlandse fabels: genre, collecties, catalogus. Nijmegen 1995. [Ph.D. Nijmegen]

Schippers, A., 'The Fable Is Dead; Long Live the Fable! Is There Any Life After Genre? A Personal Essay and a Plea', in: B. Roest and H. Vanstiphout (eds.), Aspects of Genre and Type in Pre-Modern Literary Cultures. Groningen 1999, pp. 71-78

Schlusemann, R., Die hystorie van reynaert die vos und The history of reynard the fox. Die spätmittelalterlichen Prosabearbeitungen des Reynaert-Stoffes. Frankfurt a.M. 1991. (Europäische Hochschulschriften Reihe 1, 1248). - [Ph.D. Münster]

Schlusemann, R. \& P. Wackers (eds./transl.), Reynaerts historie (Mittelniederländisch-Neuhochdeutsch). Münster, 2005. (Bibliothek mittelniederländischer Literatur, 2).

Schnur, H. (transl.), Fabeln der Antike. Griechisch - Lateinisch - Deutsch. Überarbeitet von E. Keller. 2nd. corr. and augm. ed. München/Zürich 1985.

Segre, C. (ed.), La chanson de Roland. Transl. M. Tyssens. Genève 2003.

$\mathrm{Sijs}, \mathrm{N}$. van der, De geschiedenis van het Nederlands in een notendop. Amsterdam 2005.

Sodmann, T. (ed.), Reynke de vos. Lübeck 1498. Nachdruck des einzig vollständig erhaltenen Exemplars in Wolfenbüttel (32.14 Poet.). Hamburg 1976.

Sonnemans, G.H.P., Functionele aspecten van Middelnederlandse versprologen. Boxmeer 1995. 2 vols. - [Ph.D. Nijmegen]

Staub, K.H. and Th. Sänger, Die handschriften der Hessischen Landes- und Hochschulbibliothek Darmstadt. Bd. 6 Deutsche und Niederländische Handschriften mit Ausnahme der Gebetbuchhandschriften. Wiesbaden 1991.

Stoett, F.A., Middelnederlandsche spraakkunst. Syntaxis. 3 d rev. ed. 's-Gravenhage 1923.

Stoetzer, W., 'Aesopus en Lokman. Aantekeningen over de integratie van Aesopus in de Arabische cultuur', in: W.L. Idema, M. Schipper and P.H. Schrijvers (eds.), Mijn naam is haas. Dierenverhalen in verschillende culturen. Baarn 1993, pp. 158-168.

Stuiveling, G. (ed.), Esopet. Facsimile-uitgave naar het enig bewaard gebleven handschrift. Amsterdam $[1965] .2$ vols. (Ad Fontes).

Sudre, L., Les sources du Roman de Renart. Paris 1893.

Teirlinck, I., De toponymie van den Reinaert. Gent 1910-1912. - [Additions and corrections from Teirlinck's own copy published in Taal en tongval 20 (1968), pp. 142-165]

Thienen, G. van and J. Goldfinch (eds.), Incunabula Printed in the Low Countries. A Census. Nieuwkoop 1999. (Bibliotheca bibliographica Neerlandica, 36 )

Toesca, M. (transl.), Le Roman de Renart. Paris [1979].

Toorn, M.C. van den [a.o.] (eds.), Geschiedenis van de Nederlandse taal. Amsterdam 1997.

Varty, K., 'The Earliest Illustrated English Editions of Reynard the Fox and Their Links With the Earliest Illustrated Continental Editions', in: J. Goossens and T. Sodmann (eds.), Reynaert Reynard Reynke. Studien zu einem mittelalterlichen Tierepos. Köln [etc.] 1980. (Niederdeutsche Studien, 27), pp. 160-195. 
Varty, K. (ed.), A la recherche du Roman de Renart. New Alyth 1988-1991. 2 vols.

Varty, K., 'Les anthologies dans le Roman de Renart. Le rôle de l'anthologiste-conteur dans la "matière de Renart”', in: Varty 1988-1991, vol. I, pp. 51-77.

Varty, K., The Roman de Renart. A Guide to Scholarly Work. Lanham, Md. [etc.] 1998.

Varty, K. (ed.), Reynard the Fox. Social Engagement and Cultural Metamorphoses in the Beast Epic from the Middle Ages to the Present. New York [etc.] 2000. (Polygons. Cultural Diversities and Intersections, 1)

Verdam, J. (ed.), Middelnederlandsch handwoordenboek. Rev. from the word 'sterne' by C.H. Ebbinge Wubben. 's-Gravenhage 1932. - [Photomech. reprints. - Supplement: Van der Voort van der Kleij 1983].

Vekeman, H. and A. Ecke, Geschichte der niederländischen Sprache. Bern [etc.] 1992. (Germanistische Lehrbuchsammlung, 83).

Verwijs, E. and J. Verdam (eds.), Middelnederlandsch woordenboek. 's-Gravenhage 1885-1952. 11 vols. - [Vol. 9 compl. by F.A. Stoett. - Vol. 10: Tekstcritiek (by J. Verdam); Bouwstoffen I: A-F (by W. de Vreese), II: G-Z (by G.I. Lieftinck). - Vol. 11: Aanvullingen en verbeteringen op het gebied van dijken waterschapsrecht, bodem en water, aardrijkskunde, enz. (by A.A. Beekman). - Reprint of vols. 1-9: 's-Gravenhage 1969-1971].

Verzandvoort, E. and P. Wackers, 'Bibliografie van Reinaertvolksboeken', in: Dokumentaal 12 (1983), pp. 7-21.

Verzandvoort, E. and P. Wackers (eds), Reynaert den Vos oft Der dieren oordeel. Facsimile van het rond 1700 in de drukkerij van Hieronymus Verdussen vervaardigde volksboek. Antwerpen [etc.] 1988. (Gloriant, 2)

Vinaver, E., 'Principles of Textual Emendation', in: Studies in French Language and Mediaeval Literature presented to Professor Mildred K. Pope by Pupils, Colleagues and Friends. Manchester 1939. (Publications of the University of Manchester, 268), pp. 351-369.

Voort van der Kleij, J.J. van der (ed.), Verdam - Middelnederlands Handwoordenboek. Supplement. Leiden [etc.] 1983.

Vos, J. de: 'Een Gentse codex in Stuttgart'. In: Janssens [a.o.] 1991, pp. 133-153.

Vries, J.W. de, R. Willemyns and P. Burger, Het verhaal van een taal. Negen eeuwen Nederlands. 5 th ed. Amsterdam 1995.

Vriesema, P., 'Gheraert Leeu en Die hystorie van Reynaert die vos. De Reynaert als prozaroman', in: De letter doet de geest leven. Bundel opstellen aangeboden aan Max de Haan bij zijn afscheid van de Rijksuniversiteit te Leiden. Leiden 1980 (Publicaties van de vakgroep Nederlandse taal- en letterkunde, 9), pp. 73-84.

Vroegmiddelnederlands woordenboek (VMNW) - Pijnenburg [a.o.] 2001.

Wackers, P.W.M., De waarheid als leugen. Een interpretatie van Reynaerts historie. Utrecht 1986. [Ph.D. Nijmegen].

Wackers, P., 'Middle Dutch Fables', in: Reinardus. Yearbook of the International Reynard Society 6 (1993), pag. 203-216.

Wackers, P., 'Words and Deeds in the Middle Dutch Reynaert Stories', in: Kooper 1994, pp. 131- 147.

Wackers, P., 'Medieval French and Dutch Renardian Epics: Between Literature and Society', in: Varty 2000, pp. 55-72. - [2002a]

Wackers, P., 'The Printed Dutch Reynaert Tradition. From the Fifteenth to the Nineteenth Century', in: Varty 2000, pp. 73-103. - [2002b]

Wackers, P., 'Die mittelniederländische enzyklopädische Tradition', in: A. Berteloot and D. Hellfaier (eds.), Jacob van Maerlants "Der naturen bloeme" und das Umfeld: Vorläufer - Redaktionen Rezeption. Münster [etc.] 2001, pp.11-27.

Wackers, P. (ed.), Reynaert in tweevoud. Vol. II: Reynaerts historie (Amsterdam 2002).

Wackers, P., 'The Middle Dutch Bestiary Tradition', in: B. Van den Abeele (ed.), Bestiaires mediévaux. Nouvelles perspectives sur les manuscrits et les traditions textuelles. Turnhout 2005. (Publications de 
l'Institut d'Études médiévales, Université Catholique de Louvain. Textes, études, congrès, 21), pp. 249-64.

Wackers, P., 'Reynaert the Fox: Evil, Comic, or Both?', in: A.P. Tudor and A. Hindley (eds) Grant Risee? The Medieval Comic Presence. Essays in Memory of Brian J. Levy. Turnhout 2006, pp. 305-318.

Wackers, P. and E. Verzandvoort, 'Bewerkingstechniek in de Reynaerttraditie', in: Tijdschrift voor Nederlandse taal-en letterkunde 105 (1989), pp. 152-181.

Wal, M. van der and C. van Bree, Geschiedenis van het Nederlands. Utrecht 1992. (Aula. Het wetenschappelijke boek)

Wal, M.J. van der and A. Quak (1994): 'Old and Middle Continental West Germanic', in: E. König and J. Van der Auwera (eds.), The Germanic Languages. London 1994. (Routledge Language Family Descriptions), p. 72-109.

White, T.H. (transl.), Bestiary. A Book of Beasts. New York, 1980. - [1st ed. 1954]

Willems, J.F. (ed.), Reinaert de Vos. Episch fabeldicht van de twaelfde en dertiende eeuw. Met aenmerkingen en ophelderingen van J.F. Willems. Gent 1836. - [Repr. by F.A. Snellaert, Gent 1850]

Witton, N., 'Die Vorlage des Reinke de Vos', in: J. Goossens and T. Sodmann (eds.) Reynaert Reynard Reynke. Studien zu einem mittelalterlichen Tierepos. Köln [etc.] 1980. (Niederdeutsche Studien, 27), pp. 1-159.

Wouters, L. (transl.), Van den Vos Reynaerde, Reynaert le Goupil. Introduction de E. Rombauts. Bruxelles 1974 .

Ziolkowski, J.M., Talking Animals. Medieval Latin Beast Poetry, 750-115o. Philadelphia 1993. (Middle Ages series) 


\section{List of illustrations}

Frontispiece - Comburg manuscript (A)

Stuttgart, Württembergische Landesbibliothek, Cod. poet. et phil. $2^{\circ} 22$

F. 205 recto (cf. lines 2081-2164)

- First lines: Uuillem die vele bouke maecte

Daar hi dicken omme waecte

Hem vernoyde so haerde

p. 8 - Rotterdam fragments $(\mathrm{G})$

Rotterdam, City Library (Gemeente Bibliotheek), 96 B 5

Recto and verso of fragment 1 (cf. 11. 2186-94, 2209-17)

- First lines: Jn groter torment in groter pine

Jndien dat die Coninc milde

Een gestille maken wilde

p. 40 - Darmstadt fragments (E)

Darmstadt, Universitäts- und Landesbibliothek, Hs. 3321

Parts of ff. 1 verso and 2 recto (cf. 11. 2687-2722, 3017-3052)

- First lines: Ne sake te sprekene meer.

Cohart dede enen wederkeer

Ende ginc vans conincs rade dar.

p. 246 - Dyck manuscript (F)

Münster, University and Regional Library, Ms. N.R. 381

Part of f. 118v (cf.11. 2670-91)

- First lines: Dar hi hem scone mede bedroech

Ende die gesellen sine

Dat was eer ic mit rime

p. 272 - Brussels fragments $(\mathrm{J})$

Brussel, Koninklijke Bibliotheek van België/Bibliothèque Royale de Belgique, MS. IV 774

F. 6 recto (cf. 2079-2110)

- First lines: Teerst lapedic dat bloet

het smakede wel ende dochte mi goet

daerna ic dat vleesch ontgan 


\section{Contributors}

André Bouwman is Keeper of Western Manuscripts at Leiden University Library.

Bart Besamusca is Senior Lecturer in Medieval Dutch Literature at Utrecht University.

Thea Summerfield was Lecturer in Old and Middle English Literature at Utrecht University until 1 January 2007. Currently she works as a translator specialised in medieval literature and as a researcher of Middle English and related literatures.

Matthias Hüning is Professor of Dutch Linguistics at the Freie Universität Berlin.

Ulrike Vogl is Postdoctoral Researcher in Dutch Linguistics at the Freie Universität Berlin. 